UNIVERSIDADE DE SÃO PAULO

ESCOLA DE COMUNICAÇÕES E ARTES

MARGARIDA MARIA ADAMATTI

A crítica cinematográfica no jornal alternativo Opinião: frentismo, estética e política nos anos setenta 



\section{A crítica cinematográfica no jornal alternativo Opinião: frentismo, estética e política nos anos setenta}

Tese apresentada ao Programa de PósGraduação em Meios e Processos Audiovisuais, Linha de Pesquisa História, Teoria e Crítica, da Escola de Comunicações e Artes da Universidade de São Paulo, como exigência parcial para a obtenção do Título de Doutora em Meios e Processos Audiovisuais, sob a orientação do Prof. Dr. Eduardo Victorio Morettin. 
Adamatti, Margarida Maria

A crítica cinematográfica no jornal alternativo Opinião: frentismo, estética e política nos anos setenta/ Margarida Maria Adamatti. -- São Paulo: M. M. Adamatti, 2015.

$437 \mathrm{p}$.

Tese (Doutorado) - Programa de Pós-Graduação em Meios e Processos Audiovisuais - Escola de Comunicações e Artes/Universidade de São Paulo.

Orientador: Prof. Dr. Eduardo Victorio Morettin.

Bibliografia:

1. Crítica cinematográfica 2. História do Cinema Brasileiro 3. Imprensa alternativa. I. Morettin, Eduardo Victorio II. Título.

CDD 21. ed. - 791.43 


\section{Comissão Julgadora}

Margarida Maria Adamatti

A crítica cinematográfica no jornal alternativo Opinião:

frentismo, estética e política nos anos setenta

Tese apresentada à Escola de Comunicações e Artes da Universidade de São Paulo para a obtenção do título de doutora em Meios e Processos Audiovisuais

Presidente e orientador: Prof. Dr. Eduardo Victorio Morettin (ECA-USP) Assinatura:

Banca examinadora:

Prof. (a). Dr(a.):

Instituição:

Assinatura:

Prof. (a). Dr(a.):

Instituição:

Assinatura:

Prof. (a). Dr(a):

Instituição:

Assinatura:

Prof. (a). Dr(a.):

Instituição:

Assinatura:

São Paulo, de de 2015 

A Júlio César Montenegro Bastos e a Jean-Claude Bernardet

A Fábio Raddi Uchôa

Aos meus pais, Gentil Adamatti e

Maria Aparecida Andrade

Bastos Adamatti

E a Justina Adamatti

[in memoriam] 

Agradeço à FAPESP (Fundação de Amparo à Pesquisa do Estado de São Paulo) pelo apoio financeiro e institucional à pesquisa, através do processo número 2013/09201-9. 



\section{Agradecimentos}

Agradeço à FAPESP (Fundação de Amparo à Pesquisa do Estado de São Paulo) pelo apoio financeiro e institucional à pesquisa, através do processo número 2013/09201-9. Agradeço a acolhida, a confiança, a enorme simpatia dos funcionários e a motivação ao receber os comentários e o aceite da pesquisa.

Meu agradecimento especial ao Prof. Dr. Eduardo Victorio Morettin que sugeriu a pesquisa sobre a crítica de cinema na imprensa alternativa e pela orientação desde o mestrado. Pela amizade em todo esse tempo e pelos vários conselhos acadêmicos e pessoais. Agradeço não só os mais de mil comentários meticulosos nesses últimos meses, revisando literalmente cada vírgula do texto, mas também pela minha formação como pesquisadora. Pelas inúmeras aulas de cinema, pela indicação de livros, pela presença indispensável, pela dedicação integral a todos os seus orientandos, pelas reuniões de orientação que tanto me ajudaram.

Agradeço também à Profa. Dra. Rosana de Lima Soares e ao Prof. Dr. Marcos Francisco Napolitano de Eugenio pela leitura cuidadosa e pelas sugestões fundamentais na banca da qualificação, quando o trabalho tomou corpo numa hipótese conjunta de pesquisa. Agradeço demais pela disponibilidade dos dois para reavaliar as mudanças na estrutura da tese.

Meu agradecimento especial a todos os entrevistados: Clóvis Marques, Júlio César Montenegro Bastos, Jean-Claude Bernardet, Marcos Ribas de Farias, Sérgio Augusto, José Carlos Avellar e José Arrabal. Pelo enorme tempo que tomei deles para responder às infinitas perguntas e dúvidas. Pela simpatia de todos eles ao me receber, recontando em detalhes histórias, trajetórias, repensando sentidos. Pelas conversas sempre animadas horas a fio. Sem a ajuda de todos eles, esse trabalho teria ficado incompleto. Foi um enorme prazer poder conversar com tantas pessoas que eu já admirava de tantos anos e de tantos textos.

A Clóvis Marques pela disponibilidade em conversar tão prontamente sobre a crítica de cinema, não só tirando minhas dúvidas, mas me abrindo a agenda de contatos da equipe do jornal. A Marcos Ribas de Farias pelo relato sincero e alegre, pela vibração apaixonada pelo cinema e pelas trocas de ideias e inúmeras perguntas feitas, respondidas sempre com muita paciência. Ao José Carlos Avellar pela disponibilidade de conversar comigo por tantas horas, enriquecendo outras maneiras de pensar a crítica de cinema e o período. Agradeço a Sérgio Augusto pela conversa alegre e pela paciência de contar duas histórias ao mesmo tempo, o seu percurso como crítico de 
Opinião e como editor do jornal. Agradeço a José Arrabal pelo tratamento afetuoso, pela generosidade e pelas muitas horas de bate papo que passaram num minuto. Arrabal é um grande contador de histórias. Foi um prazer ouvir sua trajetória de vida. Nessa tese, apresentamos apenas o começo desse trabalho sobre a crítica de teatro dele em Opinião. Agradeço a Jean-Claude Bernardet pela acolhida, a paciência em explicar em detalhes seu pensamento e especialmente o debate de ideias enriquecedor durante a entrevista sobre minhas hipóteses de pesquisa. Os artigos e livros de Bernardet foram fundamentais para esta tese e para a minha trajetória todos esses anos.

A participação de Júlio César Montenegro nesta tese é fundamental. Ele é o elo da seção de cultura de Opinião. Com imensa paciência e generosidade, Montenegro me concedeu inúmeras entrevistas, que já nos primeiros contatos tornaram-se parte do dia a dia em conversas animadas durante o último ano inteiro. Montenegro explicou em detalhes o dia a dia do jornal. Montenegro ensina uma nova maneira de ver a todos que se deixam modificar. $\mathrm{O}$ tom afetuoso dele não invade só o estilo desse agradecimento, mas até a relação estabelecida com os críticos de cinema. Todos falaram dele com especial carinho e não é para menos. Montenegro surgiu num momento muito difícil para mim e irradiou sua alegria contagiante no meu dia a dia. Ele contou e recontou histórias em disponibilidade total e me enviou vários materiais do Ceará. A afetividade dele abriu caminhos até no processo de entrevista com os críticos. Montenegro tem uma incrível capacidade de multiplicar afetos e compartilhar conhecimentos. Fiz um amigo nesse percurso, mais do que um entrevistado. De nossas muitas conversas aprendo sempre com sua inteligência aguçadíssima, sua paixão, irreverência, doçura e enorme cultura. Ao poeta, meu muito obrigada.

Meu agradecimento muito especial ao Fábio Raddi Uchôa por todos esses anos. Pela companhia em todas as horas, pelas conversas infinitas e animadíssimas que são meu porto seguro. Agradeço demais pela leitura atenta, pela revisão da tese com inúmeros comentários, pelas ótimas ideias e sugestões, pela indicação de livros e pela paciência nesses últimos tempos. Aos nossos embates teóricos e ao muito que aprendi e aprendo com ele todo esse tempo sobre cinema, análise de filmes, política, arquivos. Pela força em todas as horas nesta união de sentimentos.

Aos meus pais, Gentil Amabilino Adamatti e Maria Aparecida Andrade Bastos Adamatti pelo amor incondicional. Pelo estímulo à pesquisa e ao estudo desde o primeiro caderninho vermelho para escrever. Pela leitura atenta e pela revisão do texto até nos pontos e vírgulas. Pela paciência em me ouvir falar tantas vezes sobre crítica de cinema, frentismo, nacional popular, até que o assunto se tornou parte do dia a dia. Pela 
disponibilidade em fazer o possível e o impossível para me ajudar e pelo apoio nas pequenas e grandes coisas em todo esse trajeto.

Agradeço especialmente à amiga de todas as horas Cristiane Oliveira Reimberg. Começamos juntas esse percurso acadêmico na faculdade até o doutorado. Aos infinitos emails, telefonemas e ideias trocadas todos esses anos, pelas conversas sobre a pesquisa. A essa amizade fundamental em todos esses anos, minha eterna gratidão.

Ao diálogo aberto e às sugestões do Prof. Dr. Rubens Luís Ribeiro Machado Júnior e o Prof. Dr. Arthur Autran Franco de Sá Neto que me motivaram a procurar novas metodologias de pesquisa desde o tempo da dissertação. Nessa tese, tentei responder a algumas das indagações propostas por eles no mestrado. À Profa. Dra. Margarethe Born-Steinberger Elias pelas aulas de Epistemologia da Comunicação e à orientação do Prof. Dr. Josias Abdalla Duarte, quando todo esse percurso começou.

Ao grupo de pesquisa e às reuniões de orientação, especialmente a Reinaldo Cardenutto com quem conversei muitas vezes sobre a Frente Cultural, sobre Gramsci e sobre Cinema Novo. Agradeço também a Pedro Plaza Pinto, Rodrigo Archangelo e Marina Takami pelas trocas de ideias sobre cinema nos congressos e encontros. Ao Bruno Brasil da Biblioteca Nacional pelas conversas via email sobre a imprensa alternativa.

Aos funcionários da ECA, especialmente à Márcia Rangel e à Rosely. Agradeço também a equipe da biblioteca que me ajudou tantas vezes, como o Paulo. Agradeço demais ao Bill e João não só pelo apoio técnico, mas pela amizade.

À Cinemateca Brasileira, especialmente a Gabriela Souza de Queiroz e ao Alexandre Miyazato, mas também ao Ricardo Arantes e ao Daniel pela incansável ajuda nas minhas inúmeras solicitações e dúvidas. À Gabriela pelas tantas informações sobre o acervo do Gustavo Dahl. Agradeço também ao Prof. Dr. Antonio Carlos Amancio, ao Prof. Dr. André Gatti, a Rodrigo Saturnino, a Roberto Farias, a Thiago de André, a Alessandra Castañeda e especialmente ao Luiz Gonzaga de Luca pelas informações sobre o Gustavo Dahl.

Meu agradecimento especial a Fátima, Rita, Tatiana, Daniela, Bianca, Nídia Luiza, Ana Maria, Leiliane, Thaís, Paula por todos esses anos de amizade fundamental em minha vida. 

Vingança, Não é arma

Forjada quente Ou prato comido frio Pra mim é sentimento Sisgueriando por dentro Até sair sem grito Por escrito

Como escrevo isso mais velho $\mathrm{Ou}+$ pessoalmente histórico acho que toda Batalha pro anti-ditatorial Opinião Foi vingança de quem não tinha força suficiente Prum corpo a corpo + eficiente.

Júlio César Montenegro Bastos 29 jul. 2014 

Tornar verdadeiro consiste em dar a ilusão completa da verdade, segundo a lógica ordinária dos fatos, e não em os transcrever servilmente na desordem de sua sucessão. Concluo daí que os realistas de talento antes deveriam chamar-se ilusionistas (...). Cada um de nós tem, portanto, simplesmente uma ilusão do mundo, ilusão poética, sentimental, alegre, melancólica, suja ou lúgubre segundo sua natureza. E o escritor não tem outra missão que não a de reproduzir fielmente essa ilusão com todos os procedimentos de arte que aprendeu e de que pode dispor Guy de Maupassant citado por Pierre Bourdieu in As regras da arte

O espaço dos pontos de vista - significa dizer que só se pode esperar sair do círculo das relativizações que se relativizam mutuamente, como reflexos refletindo-se indefinidamente, com a condição de colocar em prática a máxima da reflexividade e de tentar construir metodicamente o espaço dos pontos de vista possíveis sobre o fato literário (ou artístico) com relação ao qual se definiu o método de análise que se pretende propor. A história da crítica da qual desejaria apresentar aqui um pequeno esboço não tem outro fim que não o de tentar levar à consciência daquele que escreve e de seus leitores os princípios de visão e de divisão que estão no princípio dos problemas que eles se colocam, e das soluções que lhes dão. Ela faz descobrir de imediato que as tomadas de posição sobre a arte e a literatura, assim como as posições nas quais elas se engendram, organizam-se por pares de oposição, frequentemente herdadas de um passado de polêmica, e concebidas como antinomias insuperáveis, alternativas absolutas, em termos de tudo ou nada, que estruturam um pensamento, mas também o aprisionam em uma serie de falsos dilemas. Pierre Bourdieu in As regras da arte 



\title{
Resumo
}

Opinião (1972-1977) é um dos mais importantes jornais da imprensa alternativa. O semanário nasceu para fazer a oposição ao regime militar através da união entre várias tendências políticas, na chamada Frente Ampla. Mesmo com forte censura, surgiu um tipo de crítica progressista caracterizada pelo profundo debate político e estético. A discussão do cinema não era feita só do ponto de vista da estética, mas também como imperativo político contra o regime militar. Analisamos as metodologias dos críticos Jean-Claude Bernardet, Sérgio Augusto, Marcos Ribas de Farias, Gustavo Dahl, José Carlos Avellar e Clóvis Marques para observar como cada um deles articula nos textos os imperativos da estética e da política. Na recepção aos filmes, algumas temáticas estão sempre presentes: o papel do intelectual, a discussão sobre a cultura popular e a linguagem cinematográfica mais adequada para conquistar o público brasileiro. $\mathrm{O}$ objetivo da tese é avaliar como os críticos reelaboram e reconstroem um projeto político e estético para o cinema brasileiro nos anos setenta. Nas disputas internas do jornal, é possível também acompanhar como as questões da resistência cultural se fazem presentes no cotidiano dos críticos de cinema.

Palavras-chave: imprensa alternativa, jornal Opinião, crítica cinematográfica, história da imprensa, história do cinema brasileiro.

\begin{abstract}
Opinião (1972-1977) is one of the most important newspapers of the underground press. The weekly was born to do the opposition to the military regime through the union of many political tendencies, the so-called Broad Front. Even with strong censorship it came's a kind of progressive criticism characterized by deep political and aesthetic debate. The film discussion was made not only from de aesthetic point of view, but also as a political imperative against the military regime. We analyze the methodologies of film critics Jean-Claude Bernardet, Sérgio Augusto, Marcos Ribas de Farias, Gustavo Dahl, José Carlos Avellar and Clóvis Marques to observe how each one articulated in the texts the aesthetics and politics imperatives. At the reception of movies, some issues are always present: the role of the intellectual, the discussion about popular culture and the most appropriate language film to win the Brazilian public. The aim of this thesis is to assess how critics reconstruct and rebuild a political and aesthetic project for the Brazilian cinema in the seventies. In the internal disputes of the newspaper, we can also follow how the cultural resistance matters are present in the routine of film critics.
\end{abstract}

Keywords: underground press, Opinião newspaper, film critic, history of the press, history of Brazilian cinema. 


\section{Sumário}

\section{Introdução I}

Parte I - Opinião e a Crítica de Cinema 01

Capítulo 1 - A seção de cinema de Opinião 05

1.1. O dia a dia da seção de cinema 05

1.2. A estética do silêncio e a escrita do crítico censurado 17

Capítulo 2 - Matrizes Teóricas da Crítica de Cinema de Opinião 41

2.1. A crítica participativa 44

2.2. Um ethos revolucionário em busca do específico de Opinião 50

2.3. A presença diária de Brasil em Tempo de Cinema 66

\section{Capítulo 3 - Os críticos de cinema do jornal 89}

3.1. Jean-Claude Bernardet e o caso Lição de amor 89

3.2. Sérgio Augusto e Os Boas Vidas 107

3.3. Gustavo Dahl. Política e emoção em Uirá 128

3.4. Marcos Ribas de Farias e Clóvis Marques: 153 a meio campo entre a cinefilia e a política

3.5. José Carlos Avellar e a materialidade do cinema

Capítulo 4 - Os embates com os leitores

4.1. Lacombe Lucien e a metodologia da nova crítica francesa

4.2. Sacco e Vanzetti: cinema político ou melodrama de tribunal? 
Parte II - Crítica de Cinema e Frente Cultural: 217 concordâncias e conflitos no campo cinematográfico

Capítulo 5 - Por Dentro do Cinema Novo:

Conceitos Movediços sobre o Intelectual em Opinião

5.1. A função dos cinemanovistas na resistência: entre $\mathrm{o}$ arauto e $\mathrm{o}$ mediador neutro

5.2. Dez anos de Cinema Nacional: o discurso cinemanovista nos novos tempos

5.3. O Novo Cinema Novo: as mortes e ressurreições do movimento na imprensa

5.4. Intelectuais Cinemanovistas e o Estado autoritário.

260 A tensão entre os gêneros jornalísticos

5.5. Crise ou reelaboração do papel do intelectual?

Capítulo 6 - A cultura popular em cena no cinema: entre atritos e silêncios

6.1. Nelson Pereira dos Santos: "Amuleto de Ogum é a gente na tela"

6.2. Nordeste Congelado: cultura popular em frasco 335 6.3. Xica da Silva: a luta pelo poder 345 6.4. Júlio César Montenegro: a Frente do Atrito 358

José Arrabal e a oposição ao nacional popular na seção de teatro de Opinião 


\section{Citação no caso das Entrevistas}

Entrevistamos os críticos de cinema de Opinião Jean-Claude Bernardet, Sérgio Augusto, Marcos Ribas de Farias, José Carlos Avellar e Clóvis Marques, além dos editores da seção Tendências e Cultura: Júlio César Montenegro e o já citado Sérgio Augusto. Entrevistamos também o crítico de teatro de Opinião José Arrabal, cujo depoimento encontra-se no Anexo desta tese.

Quando citamos as declarações dos entrevistados, seja em frases com aspas ou sem aspas, trata-se das entrevistas que realizamos. Nesses casos, a fonte da informação é esta tese. [exemplo: Jean-Claude Bernardet conta que (...)]. Por isso não mencionamos a cada nova frase que se trata de nossas entrevistas, nem abrimos uma nova nota de rodapé para mencionar como fonte esta tese. $\mathrm{O}$ padrão que se segue nestes casos é o do Jornalismo, como o de um livro reportagem, cujo objetivo é não perder a fluência do texto, nem obrigar o leitor a percorrer mais notas de rodapé.

Em casos de livros, artigos ou entrevistas feitas por terceiros, logicamente sempre mencionamos a referência no corpo do texto ou em nota de rodapé.

\section{Citação de artigos da imprensa}

Logo na primeira frase que citamos um artigo da imprensa, a referência completa do texto aparece em nota de rodapé. Não colocamos dezenas de vezes a mesma nota de rodapé a cada nova citação com aspas do mesmo texto na sequência, porque se trata da mesma referência. Obviamente, quando mudamos de assunto ou de artigo, citamos a nova fonte em nota de rodapé.

Eis um exemplo:

A ligação entre autoria e "diário sentimental" é a chave do artigo de Sérgio Augusto sobre Os Boas-Vidas (1953) de Federico Fellini ${ }^{1}$. (...) Para Augusto, o cineasta faz uma sátira de costumes e aborda os desocupados fora do viés marxista:

"Ao contrário do que disseram alguns críticos marxistas, Vitelloni não é 'uma sátira (ou uma crítica) de costumes' nem uma descrição da agonia de uma classe decadente. Os decadentes e nostálgicos desocupados de Fellini não são produtos de uma categoria, de uma classe social. Fellini é a negativa mais talentosa do ideal marxista de cinema. Em vez de desemprego e reforma agrária, ele discute problemas de caridade, amor e solidão".

\footnotetext{
${ }^{1}$ Augusto, Sérgio. A maioridade de Os Boas Vidas. Opinião. n. 76. p. 20, 22 abr. 1974.
} 


\section{Introdução}

A crítica de cinema dos anos setenta no Brasil, tendo como ponto de partida o jornal alternativo Opinião (1972-1977). Esse é o primeiro objeto de pesquisa desta tese. Objeto construído quase de forma empírica, porque o estudo sobre a crítica brasileira de cinema da década de setenta carece não só de trabalhos descritivos, mas de reflexões em torno de seus métodos de análise. A grande referência continua a ser o auto-estudo de Jean-Claude Bernardet no livro Trajetória Crítica (1978), obra que inclui parâmetros vitais para entender os pressupostos críticos daqueles anos.

O estudo panorâmico e metodológico sobre a crítica de cinema nos anos setenta permanece quase inexplorado, assim como o nicho da crítica realizada na imprensa alternativa ${ }^{1}$, que nasceu para fazer a oposição ao regime militar brasileiro. O jornal alternativo Opinião (1972-1977) ${ }^{2}$ é um dos mais importantes veículos da resistência. Mas mesmo com a presença de críticos renomados e com uma análise de peso sobre os filmes brasileiros, o semanário não foi objeto de pesquisa na área de cinema. Em suas páginas censuradas, surgiu um tipo de crítica de cinema progressista que marcou o período pela profundidade do debate político e estético. Dois críticos colaboravam com frequência: Jean-Claude Bernardet e Sérgio Augusto. Cada um deles escreveu por volta de sessenta artigos. Além deles, participaram da seção Gustavo Dahl, José Carlos Avellar, Marcos Ribas de Farias, Clóvis Marques e Carlos Frederico. Opinião foi importante tribuna de discussão do campo cinematográfico e cultural. Cineastas brasileiros e produtores escreviam com frequência tanto para apoiar quanto para discordar das matérias.

Nacionalista e engajado pela cinematografia brasileira, Opinião não foi só espaço de discussão de cinema. Trata-se do jornal alternativo de base política mais importante da imprensa alternativa (Kucinski, 1991). O número zero do semanário foi lançado no Rio de Janeiro em 23 de outubro de 1972. O veículo pertencia a Fernando

\footnotetext{
${ }^{1}$ Por causa do acirramento da censura prévia e do AI-5 (Ato Institucional n. 5 - dez. 1968), jornalistas e intelectuais reúnem-se em torno da imprensa alternativa, em jornais como $O$ Pasquim, Opinião, Movimento, Bondinho, Versus, Amanhã, Politika, Crítica, Em Tempo, etc. A imprensa alternativa caracterizou-se como instrumento de resistência, fazendo o combate ao regime militar em mais de 150 jornais. Kucinski (1991) vê o papel deste segmento como jornalismo engajado, de importância indiscutível por causa da oposição ao discurso oficial. Sofrendo com intensa censura, repressão e atentados à bomba nas redações e nas bancas de jornais, os periódicos alternativos formaram espaços de reorganização política e ideológica da esquerda. Sobre a imprensa alternativa ver Bernardo Kucinski (1991).

${ }^{2}$ A coleção completa de Opinião está disponível para consulta on line na Hemeroteca da Biblioteca Nacional.
} 
Gasparian, professor de economia do Mackenzie e diretor das fábricas de sua família, tradicional no ramo têxtil. Gasparian era dono da Editora Paz e Terra e da Editora Inúbia, onde editou Opinião, Cadernos de Opinião e a Revista Argumento. Aliado do governo de João Goulart, ele era representante de entidades empresariais ${ }^{3}$ e fazia parte do Conselho Nacional de Economia (entre 1963-1967), até ser destituído do cargo pelo governo militar. Nesse contexto, ele partiu para o exílio no início de 1970 e atuou como professor convidado em Oxford e na Universidade de Nova Iorque. O assassinato do amigo deputado Rubens Paiva pelos órgãos de repressão em 1971 provocou nele o impulso final para criar um jornal de oposição ao regime militar. Foi Bernardo Kucinski, também em "exílio voluntário" em Londres, quem indicou o nome de Raimundo Rodrigues Pereira para ser o editor do futuro jornal. Os dois eram amigos desde o curso de Física da USP. Raimundo Pereira era o segundo jornalista mais importante em Veja, depois de Mino Carta. Expulso do curso de engenharia do Instituto Tecnológico da Aeronáutica (ITA), ele tinha sido editor da Folha da Tarde, repórter policial de $O$ Dia, redator de revistas técnicas, além de participar da revista Realidade 4 . Foi do núcleo de Realidade que surgiu a união entre um grupo de jornalistas de esquerda, dando início à imprensa alternativa de base política sob o comando de Raimundo Pereira.

O que unia Fernando Gasparian e Raimundo Pereira era a ideia de criar um jornal de oposição contra o governo militar, portador de um projeto nacional. Houve alguns desentendimentos durante a elaboração do acordo. Gasparian queria criar um periódico de intelectuais para a elite do país, enquanto Pereira queria um semanário de propriedade coletiva de jornalistas com viés popular. A ideia de um jornal de Frente Política de Oposição nascia da vontade de lutar contra o regime repressivo por meio de uma aliança entre várias tendências políticas de esquerda, passando por intelectuais, jornalistas, políticos e perseguidos pelo regime que escreviam com pseudônimos ${ }^{5}$. Gasparian conseguiu aglutinar muitos intelectuais de renome em torno de Opinião.

\footnotetext{
${ }^{3}$ Foi presidente do Sindicato da Indústria Têxtil de São Paulo e do Rio de Janeiro e presidente da Federação Nacional da Indústria Têxtil. Exerceu também o cargo de diretor da Companhia Paulista de Estradas de Ferro no governo Carvalho Pinto.

${ }^{4}$ Sobre a Realidade, ver Revista Realidade, 1966-1968: tempo de reportagem na imprensa brasileira de José Salvador Faro. Porto Alegre: Editora da ULBRA, 1999.

${ }^{5}$ A ideia de criar uma aliança entre a esquerda para fazer a oposição ao regime militar remonta indiretamente à proposta da Frente Única do PCB. A linha frentista e democrática contra a ditadura foi reiterada pelo partido em vários documentos a partir de 1965. O projeto era defendido pelo PC muito antes do regime militar e nasceu da ideia de promover a revolução por etapas. A proposta previa a aliança entre todos os setores da sociedade para garantir primeiro o fortalecimento da democracia em direção à implantação futura da revolução. Ver Segatto (1981) e Lima (1995).
} 
Assim o jornal acabou funcionando como ponto de encontro da esquerda e como canal de comunicação de intelectuais com seu público.

O semanário nasceu com três editorias principais: Economia, Política, Tendências e Cultura. Havia também um encarte com a tradução do Le Monde, além da publicação de uma seleção de textos do The Guardian, The Washington Post, The New York Review of Book e New Statesman. A ideia era autenticar o jornal em termos de qualidade internacional e causar alarde em caso de censura aos periódicos estrangeiros.

Opinião sofreu um processo de censura virulento. Nasceu e morreu censurado, enquanto a intervenção aos demais veículos da grande imprensa diminuiu a partir de janeiro de 1975, por causa da abertura política. O semanário enfrentou um atentado a bomba em 1976, a prisão de seus dirigentes por desobediência à censura várias vezes, além de ameaças de violência e de morte. Mesmo com todos esses percalços, em pouco tempo, Opinião tornou-se um jornal de prestígio. Ele era uma referência obrigatória junto aos deputados de oposição em Brasília. Muitos deles faziam questão de aparecer em público com o jornal debaixo do braço. O periódico foi ponto de encontro e de debate da oposição, antecipando a discussão da dívida externa, dos direitos dos consumidores e das questões ambientais.

A aliança entre liberais e a esquerda em Opinião funcionou num primeiro momento. Mas com o passar do tempo, as tensões envolvendo o controle do jornal e as formas de fazer a resistência tornaram-se mais fortes. A tese é dedicada especialmente a essas disputas internas entre as alas do jornal que tomaram diferentes proporções e incidiram na seção cultural. Um dos conflitos residia no fato de que Fernando Gasparian pagava salários muito abaixo do mercado. Na verdade, a questão salarial foi decidida durante a elaboração do projeto junto com o editor chefe. O proprietário de Opinião queria compor uma equipe pequena dentro do piso da categoria. Enquanto isso, Raimundo Pereira quis incorporar uma grande quantidade de colaboradores engajados que aceitaram receber pouco, porque queriam fazer a luta contra a ditadura na imprensa. Como os salários eram baixos, a redação conseguiu o direito de comandar o jornal. Mas os atritos de poder entre a equipe e o proprietário causaram indiretamente a dissolução do acordo com Raimundo Pereira. A questão também era política. Gasparian apoiava a proposta de abertura do general Ernesto Geisel, enquanto a equipe se opunha ferozmente não só ao presidente, mas à forma de conduzir a abertura.

Para enfrentar o dono do jornal, a redação compôs matérias em torno do tema da abertura que causaram a demissão de Raimundo Pereira em 1975. Ele levou consigo 40 
colaboradores para Movimento (1975-1981), tornando real o sonho de criar um periódico de propriedade coletiva de jornalistas. Depois do racha na redação, Opinião permaneceu no mercado por mais dois anos e meio. A censura era cada vez mais feroz com o semanário, causando uma crise financeira. Além disso, os jornalistas reclamavam por aumento salarial. Havia ainda confrontos diretos com Gasparian porque os colaboradores da seção cultural exigiam liberdade total de crítica. Em meio a todos esses problemas, o jornal fechou em 1977.

A tese analisa não só a crítica de cinema, mas também a seção cultural de Opinião. A trajetória do jornal é muito rica na seção Tendências e Cultura e permite compor variados ângulos de pesquisa. Concentramos nosso foco no estudo da crítica de cinema enquanto parte da intelectualidade cinematográfica de esquerda. Procuramos avaliar como os críticos reelaboram e reconstroem um projeto político e estético para o cinema brasileiro dos anos setenta. O viés nos permite conectar os temas específicos do campo do cinema com os da historiografia cultural da resistência, com especial atenção ao local onde ocorre este debate: o Jornalismo.

No número zero, Opinião apresenta-se como jornal sem vínculos partidários, voltado à defesa dos direitos dos cidadãos e das liberdades democráticas ${ }^{6}$. O projeto original de Fernando Gasparian previa um caráter de Frente Ampla ${ }^{7}$. O conceito significava a união entre várias tendências políticas de esquerda no combate ao regime militar.

Há muitas Frentes em Opinião. Bernardo Kucinski (1991: 83) observa o surgimento de um espírito de Frente e de convívio entre diversas correntes de oposição, desde a burguesia nacional até a extrema esquerda, como reflexo da solidariedade e sentimento de derrota que predominava nos jornais alternativos. Historicamente, a ideia da Frente em prol da democracia vinha das Frentes Populares e das Frentes Nacionais contra os regimes fascistas na luta pelos direitos dos cidadãos ${ }^{8}$. Se a união entre a

\footnotetext{
${ }^{6}$ Opinião. n. zero, p.1-2, 23 out. 1972.

${ }^{7}$ Faremos referência ao termo Frente Ampla ao longo da tese porque ele era utilizado por Opinião. O termo Frente Ampla também designava o movimento de 1966, que reuniu Juscelino Kubitscheck, João Goulart e Carlos Lacerda para lutar pela redemocratização do país. Ver Marchi (2001).

${ }^{8}$ Historicamente o conceito de Frente tem mais de uma variável. A proposta da Frente Única pretendia criar uma unidade de ação da classe operária, mas manter a fisionomia de cada partido. Com o contexto do fascismo mundial, surgiram as Frentes Populares e depois as Frentes Nacionais. Nos dois casos se retomava a ideia de Frente Única como uma aliança centrada na ação dos partidos de esquerda, democráticos e antifascistas. Trata-se de uma coalizão de partidos de esquerda em torno de objetivos comuns, quando o fascismo era visto como o principal inimigo. Enquanto a frente única é uma aliança proletária e anticapitalista, a frente popular é democrática e antifascista. Há nas frentes desde reivindicações políticas e econômicas até a defesa da paz e das liberdades democráticas. Depois da
} 
esquerda era necessária para enfrentar o regime militar, a divergência entre suas alas também era grande em Opinião. O termo Frente Ampla era muito usado no período e estará presente nos capítulos com algumas subdivisões. Trata-se de conectar a Frente de tendências de esquerdas com a seção de cinema. Entre as Frentes desenvolvidas nesta tese, a primeira delas explica a especificidade da Frente no Jornalismo. Na sequência, o comparativo é feito com as principais bandeiras para fazer a resistência na área da cultura, na chamada Frente Cultural. Por último, adequamos os valores da Frente Cultural defendidos na seção de cinema, compondo a Frente Cinematográfica de Opinião.

Foi em 1967, no periódico Amanhã ${ }^{9}$, liderado por Raimundo Pereira, que se colocou em prática pela primeira vez o mecanismo das Frentes Jornalísticas (Kucinski, 1991) ${ }^{10}$. Trata-se da união entre várias tendências e partidos políticos de esquerda num jornal voltado ao mercado, cujo objetivo é lutar pelas liberdades democráticas. Essa união entre os diversos atores sociais contra o regime militar tinha alguns pontos consensuais sobre como fazer a resistência na área cultural. Esta tese dedica-se a relacionar as bandeiras defendidas pelos críticos de cinema com os pontos de consenso e dissenso no campo cultural. O trabalho é feito através de um parâmetro comparativo maior. Marcos Napolitano (2011) delineou os pontos comuns de articulação da esquerda para a resistência cultural. Antes dele, Antonio Rubim (1987, 1988, 1988 a) traçou o nascimento e a evolução nos anos cinquenta de algumas diretrizes culturais autônomas criadas pelos intelectuais comunistas, que muitas vezes estão na origem da discussão nos anos sessenta e setenta. O conceito de Frente Cultural desenvolvido por Napolitano

derrota do fascismo, houve uma nova fase de frentes em países europeus e ao redor do mundo que procuraram dar vida à ideia de aliança e de frente popular. Ver Bobbio (1998). O ponto de contato da ideia de frente durante o regime militar brasileiro retomava um conceito próximo ao da frente popular ou o da frente nacional, no sentido de união entre tendências políticas de oposição para combater o governo totalitário.

${ }^{9}$ Amanhã é o primeiro jornal na linha da imprensa alternativa de base política, criada por Raimundo Pereira. Dessa linhagem, surgiram oito jornais: Opinião, Movimento, Assuntos, Um Novo Amanhã, Em Tempo, Bloco, Brasil Extra, Retrato do Brasil.

${ }^{10}$ Segundo Kucinski (1991), não havia divergências táticas entre as alas dos jornais nos primeiros anos da imprensa alternativa, porque não havia definições e propostas precisas. Contudo, no final dos anos setenta, as frentes jornalísticas portadoras de projetos nacionais começaram a romper, antecipando a fragmentação da esquerda. O processo começou a partir de 1977, um ano antes da eclosão das greves operárias, por causa de profundas divergências entre seus integrantes. Para Kucinski, o sentido de condomínio forçado das frentes jornalísticas perdia sentido à medida que se abria espaço para a rearticulação partidária. Por causa do contexto político, a imprensa alternativa funcionava como um substituto dos partidos, com assembleias, reuniões, campanhas de assinaturas e debates. A sustentação da imprensa alternativa vinha também de partidos de esquerda, que se uniam em jornais produzidos com os padrões técnicos de mercado. A partir de 1979, os partidos podiam se reorganizar sem precisar conviver com outras facções na imprensa alternativa, lançando seus próprios jornais. Era o começo do fim das frentes jornalísticas. 
fornece sustentação teórica para analisar as disputas internas da seção cultural de Opinião. Através deste conceito, conectamos a recepção dos filmes no jornal com a temática da resistência cultural. O Frentismo Cultural surgiu de uma série de pontos comuns delineados pelos principais atores da resistência: os liberais, os comunistas, a contracultura e a Nova Esquerda. Trata-se de um pacto político que marcou lutas e processos de transição para a democracia, amenizando as diferenças até a derrota do inimigo. $\mathrm{O}$ frentismo cultural caracterizava-se por alguns pilares centrais: a ocupação dos circuitos comerciais através de linguagem acessível, a busca por uma estética nacional popular e a afirmação do intelectual como arauto da sociedade. No final da década de sessenta, as bases de sustentação do frentismo começaram a se fragmentar. A cada ano surgiam divergências maiores entre os atores sociais. Esse processo de afastamento seguiu nos anos setenta até a dissolução completa nos anos oitenta. Opinião acompanhou o debate e essas divergências no seu dia a dia. Grande parte da riqueza da seção Tendências e Cultura vem desses choques e de um pensamento progressista em relação às bases comuns do Frentismo. Os pontos convergentes giravam em torno de três propostas principais na seção de cinema: a discussão estética sobre o cinema, o debate sobre a cultura popular a partir do Cinema Novo e o papel dos intelectuais na resistência. Esses três temas são recorrentes em todo o percurso crítico do semanário e dizem respeito ao debate interno da esquerda. A oposição utilizava a cultura como estratégia principal porque a conexão entre política e cultura parecia o terreno menos perigoso para afirmar uma estratégia contra a ditadura. A escolha da cultura levava vantagem porque ela era instrumento de grandeza nacional e reunia os diversos agrupamentos da esquerda em torno de temas comuns. Foi assim que a cultura tornou-se o mote para a reconfiguração da crítica política naqueles anos.

Se o regime era de direita e ditatorial, em contrapartida, a esquerda tinha relativa hegemonia do ponto de vista cultural (Schwarz, 2009). Porém, no percurso do golpe militar até a abertura, a esquerda fragmentou-se e rachou sobre as formas de realizar a resistência cultural. Essas disputas internas, aplicadas ao cinema, fazem parte do nosso objeto de pesquisa.

Na crítica de Opinião, por exemplo, um dos debates mais intensos recaía sobre a linguagem utilizada. Se o Cinema Novo tinha conquistado prêmios internacionais e criado uma linguagem original, ele falhava no contato com o público. Esse debate começou ainda na metade dos anos sessenta e se prolongou em toda a história do jornal. Preocupados com a conquista do público e do mercado, ante ao inimigo maior do 
imperialismo hollywoodiano, os críticos de Opinião dividem-se entre as preferências estéticas pelo cinema moderno e pela experimentação, ou pelo cinema clássico com seu maior poder de penetração no público. Esse debate fazia parte do campo do cinema e ao mesmo tempo das discussões sobre a arte engajada ${ }^{11}$, que queria conquistar o público para conscientizá-lo da situação brasileira.

A discussão sobre a linguagem cinematográfica será abordada na tese junto com outros pilares da resistência na crítica de cinema de Opinião. Esses pontos são um desdobramento da Frente Cultural. Por isso usamos o termo Frente Cinematográfica de Opinião porque há variações em alguns pontos do Frentismo. Com esse recorte, procuramos explicar quais são os conceitos desenvolvidos pelo jornal, além de revelar os valores conjuntos e os pontos de tensão com a Frente Cultural. A Frente Cinematográfica de Opinião resume e abrange os temas tratados nesta tese. Ela possibilita conectar o campo específico da crítica de cinema de Opinião com as discussões da esquerda. Através dela, é possível acompanhar se os questionamentos internos do campo cultural de esquerda estão presentes no cotidiano dos críticos de cinema. Nosso objetivo é observar se Opinião participou deste debate ou se aprofundou o questionamento da cultura política ${ }^{12}$ engajada.

Se os valores da Frente Cultural eram consensuais logo após o golpe militar ${ }^{13}$, por volta de 1968-69, eles passaram a ser cada vez mais questionados no interior da

\footnotetext{
${ }^{11}$ O engajamento é tomado por Marcos Napolitano (2001) como a atuação do intelectual numa esfera pública, em defesa das causas humanitárias, libertárias e de interesse coletivo. O termo arte engajada era utilizado como todo tipo de manifestação artístico-cultural de esquerda, empenhada em fazer críticas ao poder ou denunciar a desigualdade. A arte engajada brasileira buscava uma estética nacionalista e antiimperialista, mas ao mesmo tempo tentava adentrar nas artes de espetáculo para colocar em prática seus objetivos. Houve, segundo o autor, a tentativa de conciliar a cultura popular, a cultura culta com as premissas da vanguarda.

${ }^{12}$ Norberto Bobbio (1998: 306-7) define a cultura política como o "conjunto de atitudes, normas, crenças, mais ou menos largamente compartilhadas pelos membros de uma determinada unidade social e tendo como objetivo fenômenos políticos". Este conjunto de crenças, ideias, linguagens, símbolos, normas, doutrinas e tradições formalizados tanto em partidos, quanto em instituições ou organizações políticas, dão um significado à vida política num determinado contexto. Importa aqui pensar como a cultura política de esquerda agia enquanto formação cultural nos críticos de Opinião.

${ }^{13}$ Uma boa parte do núcleo da Frente Cultural é devedora do Partido Comunista, que teve ao longo das décadas importância premente na formação cultural da esquerda e de muitos intelectuais. A influência não nascia só através dos filiados e simpatizantes do partido, mas incluía os intelectuais que gravitavam em torno da cultura nacionalista de esquerda. Assim as bandeiras do partido para a área cultural, propagadas geralmente por artistas e intelectuais, alastraram-se por amplos setores da sociedade ao longo das décadas. Até mais ou menos o final dos anos sessenta, a linha cultural do partido teve sucesso majoritário, porque os artistas comunistas e simpatizantes constituíram um núcleo pensante e criador que conseguiu traduzir com sucesso algumas ideias conjuntas: a opção pelo nacionalismo, o realismo, uma linguagem simples para garantir a comunicação com o público, a defesa da cultura nacional popular, a luta contra o imperialismo, a atenção aos problemas da sociedade por meio do caráter social da arte, o papel mediador do artista-intelectual e a política de ocupação dos espaços culturais. Portanto, se havia uma perda
} 
esquerda ${ }^{14}$, seja pelos movimentos políticos dissidentes do PCB (Partido Comunista Brasileiro), seja pelos movimentos artísticos de vanguarda ou pelos estudos acadêmicos. Assim a emergência de dissensos internos da esquerda gerou a dissolução cada vez maior da Frente Cultural e dos consensos em torno da realização da resistência. Esse processo foi acompanhado do declínio gradativo da cultura política comunista. O PCB perdia sua influência por causa de seu afastamento gradual dos movimentos sociais ${ }^{15}$, como o movimento operário e o estudantil, que se tornaram uma oposição importante ao regime.

Logo após o golpe militar, os valores da Frente Cultural eram ainda homogêneos no interior da esquerda. Em primeiro lugar, havia consenso entre a intelectualidade engajada de esquerda sobre a necessidade de ocupar o mercado cultural ${ }^{16}$, utilizando uma linguagem acessível à compreensão popular. A cultura nacional popular ${ }^{17}$

progressiva na política, o partido continuava forte do ponto de vista cultural. Ver Rubim, (1987, 1988, 1988 a) e Napolitano (2001, 2001 a, 2011).

${ }^{14}$ A partir de 1967-68, o campo artístico passou a sofrer com cisões e rupturas sobre questões ligadas à linguagem utilizada e sua eficiência para atingir o público. Os debates em torno do nacional e a relação conflituosa entre ocupar o mercado e se relacionar com a indústria cultural estavam em discussão no interior do campo. O consenso estético e ideológico inicial entre 1964-67 não conseguia se sustentar mais na segunda metade dos anos setenta. Além disso, um debate intelectual de grande vigor começou a acontecer entre 1964-68 e conduziu à revisão da perspectiva do nacional popular como eixo de ação cultural da esquerda. Nesse contexto, a influência cultural do PCB, marcada pelo nacional popular, sofreu um grande abalo. Como consequência, os projetos culturais não eram mais convergentes e se estilhaçavam em vários grupos antagônicos da resistência. Ver Napolitano (2001, 2001 a, 2011).

${ }^{15}$ Ao longo do processo, o PCB perdeu sua vitalidade com a evasão de quadros e por causa das baixas dos militantes. A participação nos movimentos sociais era pequena. Tomado de imobilismo e prudência excessiva, o PCB era o partido do não enfrentamento ao regime para poder acumular forças no futuro. Ele protelava as ações em torno da Frente Ampla, com receio de atrapalhar a união entre a esquerda. Por causa da opção de desencorajar as greves, o PCB não acompanhou o desabrochar dos movimentos sociais, especialmente o movimento operário. A postura acabou isolando o partido. Ver Lima (1995).

${ }^{16}$ A ida ao mercado já fazia parte da estratégia dos artistas engajados antes do golpe militar. Ela não parecia incompatível com a vontade de atuar politicamente. Nesse sentido, a arte de espetáculo parecia o caminho natural para popularizar a cultura engajada. Antes de 1967, o artista engajado tinha uma visão mais neutra do mercado, como canal de distribuição de suas ideias sob a forma de bens culturais (Napolitano, 2011).

${ }^{17}$ Tomamos aqui o conceito desenvolvido por Marcos Napolitano (2001a) do nacional popular, entendido como cultura política engajada que pressupõe um movimento intelectual de "ida ao povo". Na busca por uma cultura brasileira, o sentido da cultura nacional popular poderia ser traduzido na busca da expressão simbólica da nacionalidade, de tal forma que o nacional e o popular se refletissem e dessem sentido um ao outro. Assim a cultura nacional popular seria a síntese de uma cultura entre o nacional e o popular ou entre o povo e a nação. Trata-se ao mesmo tempo de uma cultura política e uma política cultural das esquerdas, cujo sentido poderia ser traduzido na busca da expressão simbólica da nacionalidade. Napolitano mostra como o nacional popular transformou-se numa cultura política engajada e no projeto identitário, não só dos artistas e intelectuais ligados ao partido comunista, mas do setor nacionalista e de esquerda. Todos esses agentes culturais incorporaram a tarefa de ir ao povo e de articular esta consciência. Essa vontade de se aproximar do povo muitas vezes norteava a ação dos artistas e dos intelectuais tanto no cinema, na música, quanto no teatro, na literatura e nas artes plásticas. Por exemplo, o Cinema Novo teve uma inspiração política fundada em alguma medida também no nacional popular. Ele tentava articular a expressão de uma consciência nacional orientada para a emancipação da nação, cujo sujeito político seria o povo. Depois do golpe militar, o nacional popular tornou-se o núcleo ético e político de construção de uma consciência de resistência. 
significava a preferência por uma arte que deveria ter caráter social e nacional, com interesse pelos problemas populares. O trabalho ficaria a cargo de uma intelectualidade que vai ao povo e cumpre o papel de arauto da transformação social do país. Sempre à frente como vanguarda, a intelligentsia ajudaria no processo de elaboração da consciência popular (Napolitano 2001, 2001 a, 2011).

Se estes valores eram consensuais, Opinião está inserido num processo de progressiva fragmentação da Frente Cultural. A ida ao povo era questionada como forma de ambição do intelectual de se ver como porta-voz ${ }^{18}$ do povo. Enquanto isso, os valores do nacionalismo e da cultura brasileira passaram a ser vistos, grosso modo, como uma forma de ideologia pelos novos pensadores no campo acadêmico (entre eles, Roberto Schwarz e Carlos Guilherme Mota). Com isso, a cultura do nacional popular começava a ruir ${ }^{19}$. Frente à indústria cultural que transformava a produção engajada em mercadoria, os artistas e intelectuais se perguntavam se a ida ao povo e a ocupação do mercado eram suficientes para atingir realmente o público.

A imprensa alternativa fazia parte do espaço de discussão e de disputas acirradas entre a cultura política engajada e os dissensos da esquerda. Entre os críticos de cinema de Opinião, esse debate estava longe do consenso e narramos qual o caminho era trilhado por cada um deles. Os questionamentos e debates sobre o Frentismo atravessaram Opinião na análise fílmica e no debate sobre a política cinematográfica. É quase impossível falar dos filmes no jornal sem passar por estes temas. Portanto, Opinião é um espaço privilegiado para estudar estas divergências. Analisamos o pensamento cinematográfico dos críticos na intersecção entre estas concordâncias e dissensos. Além desses temas, existia na crítica de Opinião uma tensão entre os valores da esquerda engajada e os conceitos do campo cinematográfico. O objetivo é observar se o jornal permanecia atrelado aos valores do nacional popular ou se fornecia espaço ao mesmo tempo ao debate estético.

\footnotetext{
${ }^{18}$ Os debates entre os intelectuais conduziram à revisão da perspectiva do nacional popular como eixo de articulação da esquerda. A tentativa do artista de construir uma temática popular na ida ao povo não experimentava o mesmo consenso de antes. No novo contexto, o modelo de intelectual engajado que se representava como porta voz das classes populares e dos interesses nacionais foi colocado em xeque. Ver Napolitano (2011), Hermeto (2010), Mota (2008).

${ }^{19}$ A cultura nacional popular, típica da cultura política de esquerda, era cada vez mais criticada. A crise começou por volta de 1968-69 com o surgimento das vanguardas de experimentalismo estético, mas se aprofundou mesmo no final dos anos setenta. Os pontos de atrito giravam em torno da pretensão de buscar a nacionalidade e da absorção da cultura nacional popular pela indústria cultural e pelo regime militar através de sua política cultural.
} 
O estudo sobre as disputas internas do jornal tornou-se central para entender o andamento da Frente Cultural em Opinião e dos rachas internos da esquerda. O trabalho foi feito pela análise das matérias do jornal, pelas cartas de época e através dos depoimentos dos entrevistados. Deixamos de lado um tipo de construção da história que exclui o dissenso de opiniões entre os entrevistados. Longe de procurar uma visão consensual e linear sobre o jornal, trouxemos as razões da disputa interna porque o tema é a própria dissolução da Frente Jornalística. O trabalho foi também de resgate da memória, trazendo os relatos dos críticos de cinema e dos editores de cultura. Entrevistamos Jean-Claude Bernardet, Sérgio Augusto, Marcos Ribas de Farias, Clóvis Marques e José Carlos Avellar, além dos editores da seção cultural, Júlio César Montenegro Bastos e o já citado Sérgio Augusto. O depoimento do crítico de teatro José Arrabal encontra-se no Anexo desta tese ${ }^{20}$. Infelizmente não pudemos trazer todos os lados dessa história. Fernando Gasparian, Gustavo Dahl, Fernando Peixoto, Carlos Frederico e Beatriz Nascimento faleceram. Tentamos diversos contatos com Raimundo Pereira, mas não obtivemos resposta.

Os críticos de cinema de Opinião dispuseram de enorme tempo e generosidade para responder a todas as perguntas em detalhes. Eles contaram minuciosamente suas histórias, suas influências teóricas, assim como a trajetória no jornal. Narraram também o dia a dia do trabalho da crítica de cinema nos anos setenta. Além deles, sem a ajuda de Júlio César Montenegro não teria sido possível recontar com tantos detalhes a história de Tendências e Cultura, especialmente no capítulo 6. Afinal os críticos de cinema nem sempre estiveram presentes no dia a dia do jornal. Montenegro é uma figura central não só da seção cultural, mas da história da dissolução da Frente de Opinião. Ele comentou os bastidores das matérias e até ajudou a desvendar um mistério sobre a autoria de um artigo. Fez conosco um trabalho contínuo de puxar diversos fios da memória. Sempre disponível e solícito, expôs sua vida em livro aberto. Contou e recontou histórias ao vivo, por telefone, por emails e em forma de poesia. Enviou matérias e documentos do Ceará. Explicou em pormenores o dia a dia da seção Tendências e Cultura e da Frente Ampla no jornal. Sem a participação de Montenegro e dos críticos de cinema, o resultado final dessa história teria perdido muita riqueza.

\footnotetext{
${ }^{20}$ O crítico de teatro de Opinião José Arrabal foi citado mais de uma vez nas entrevistas de Júlio César Montenegro e de Jean-Claude Bernardet como parte da discussão que envolveu o jornal na fase final (ver Capítulo 6). O depoimento de José Arrabal esclarece o dia a dia e as polêmicas da seção de teatro de Opinião (ver Anexo).
} 
A tese está dividida em duas partes e em cada tópico fazemos a discussão concomitante do campo do cinema e da questão da Frente Cultural. A primeira parte concentra-se no estudo geral da crítica de cinema de Opinião. O Capítulo 1 é introdutório e apresenta os editores da seção Tendências e Cultura e os críticos de cinema de modo panorâmico. A descrição inclui detalhes do dia a dia do jornal em busca de um projeto editorial. O primeiro capítulo antecipa algumas das polêmicas que envolveram a editoria. Na sequência, detalhamos as estratégias dos críticos de cinema para comentar os filmes censurados, num jornal também sob censura prévia. O padrão textual criado incide na forma do texto jornalístico, e cria o que chamamos de uma estética do silêncio. Muitos pesquisadores consultaram o jornal, mas não pensaram na forma do texto. $O$ que Opinião diz é importante, mas o estudo sobre o como se impõe neste trabalho. Por isso a análise da forma do texto é vital para analisar o discurso do jornal.

O capítulo 2 insere o debate da crítica de cinema na discussão do campo intelectual através do conceito de crítica participativa. Analisamos o que havia de comum entre os críticos do jornal em busca de um projeto editorial. Afinal o semanário não é somente o local onde os críticos escrevem, porque ele também é determinante de um tipo de crítica de cinema que possui um específico. Além disso, buscamos localizar pela análise vertical o paralelo entre o texto padrão do semanário e alguns antecedentes diretos da década anterior, como, por exemplo, Brasil em Tempo de Cinema de JeanClaude Bernardet, publicado pela primeira vez em 1967.

O capítulo seguinte é dedicado aos críticos de cinema do jornal. Detalhamos a composição principal do ato crítico de cada articulista e decompomos um ou dois textos mais característicos deles. Jogamos luz no trabalho de críticos de cinema, que ainda não tinham sido objeto de pesquisa acadêmica. Para exemplificar as diferenças entre eles, dividimos os colaboradores a partir da tensão entre crítica estética e crítica política. Optamos por um texto o mais simples possível para tornar claro o processo de confecção de sentido. Neste capítulo, damos mais destaque à citação direta dos artigos para possibilitar ao leitor o contato com o pensamento dos críticos.

A seção de cartas é o objeto do Capítulo 4. Trata-se de um espaço privilegiado para comparar a recepção dos críticos e a do público sobre os mesmos filmes. Pontuamos como os leitores se apropriam das obras e dos conceitos estéticos dos críticos, refazendo sentidos que não estavam previstos no ato de enunciação. Uma das partes mais interessantes do jornal é a discussão com o público, seja ele composto por 
leitores anônimos ou por personalidades, no que chamamos de uma Tribuna da Opinião. Nesses espaços as divergências estéticas e políticas explodem em interessantes debates sobre a autonomia da arte e a submissão à política.

A segunda parte da tese é dedicada a analisar a relação entre a crítica de cinema e os conflitos internos, seja da esquerda ou do campo do cinema. Aqui a discussão da Frente Ampla ganha contornos mais nítidos, especialmente sobre o papel da intelectualidade e da cultura popular. Interessa-nos também analisar as divergências de pensamento dos críticos de Opinião com os cineastas dentro da estrutura do texto jornalístico. Os debates passam principalmente pela discussão da política cinematográfica e pela presença dos cinemanovistas neste campo.

No Capítulo 5 adentramos nas discussões teóricas sobre a função do intelectual. Isso inclui um debate sobre a transição da noção de intelectual arauto, para aquela de intelectual porta voz neutro que traduz os anseios populares como uma correia de transmissão. Não se trata de um tema apenas local. Ao longo do século XX, reafirmavase a noção de engajamento do intelectual em prol da democracia e da libertação nacional, empurrando a intelligentsia para a esquerda. Essa discussão está calcada na noção do intelectual engajado, inaugurada por Jean-Paul Sartre (1945). Para esse debate partimos de Antonio Gramsci (1968) para explicar não somente o primeiro sentido de intelectual em pauta em Opinião, como também o projeto da imprensa alternativa. A discussão prossegue com o tema do engajamento através de Jean-Paul Sartre (1994) e a partir dos conceitos de Pierre Bourdieu $(1996,2007)$ sobre a distinção simbólica e sobre o paradoxo entre a autonomia da arte e a política. Não se trata de enfatizar as motivações políticas desses intelectuais, como fez Daniel Pécaut (1990). A proposta é revelar a construção desse discurso e a reconstrução do intelectual como alguém "neutro". O mapeamento dos temas do jornal em relação ao cinema brasileiro tem por objetivo entender como certos cineastas alcançavam a legitimação de seu discurso e sua distinção simbólica.

O último capítulo é dedicado às discussões sobre a cultura popular na última fase do jornal, quando o nacional popular é posto à prova. Revelamos nessa parte da tese como os atritos com o nacional popular aparecem na crítica de cinema de Opinião e qual era a reação do campo a esses questionamentos. O estudo não é feito somente através dos filmes, mas explica em detalhes o dia a dia da seção cultural e a razão das disputas internas entre as alas do jornal. Esses atritos motivaram o confronto final do jornal e anteciparam o caminho de dissolução da Frente Jornalística. 
Nos dois últimos capítulos, aprofundamos o tema do intelectual e da cultura popular a partir do eixo comum do Cinema Novo. Indiretamente não avaliamos só o jornal, mas também o discurso dos cineastas sobre si mesmos. O estudo permite observar se o semanário endossou ou questionou os diretores do Cinema Novo. Opinião é um local privilegiado para pesquisar o entrelaçamento ou as tensões entre o discurso dos cineastas e dos críticos, porque se concede um espaço muito grande para os entrevistados. Os capítulos 5 e 6 observam a evolução do pensamento cinemanovista nos anos setenta e o seu processo de legitimação perante o público. Algumas indagações iniciais norteiam a segunda parte da tese: a aproximação com o Estado em torno da política cinematográfica gerava reações negativas na imprensa e no jornal Opinião? Como o grupo se afirmava perante a sociedade naquele momento de crise do nacional popular? Que imagem o Cinema Novo construía de si mesmo? Eles foram questionados enquanto grupo no semanário em algum momento?

O diálogo de Opinião com o Cinema Novo sintetiza o percurso de uma geração de críticos de cinema que se formou sob o impacto deste movimento. Os três colunistas do jornal mais frequentes já atuavam como críticos durante a eclosão do Cinema Novo. São eles: Jean-Claude Bernardet, Sérgio Augusto e Gustavo Dahl. O primeiro tornou-se o maior pensador do Cinema Novo entre os críticos. Bernardet escreveu ainda em 1965 a primeira análise consistente sobre o movimento, publicada dois anos depois no livro Brasil em tempo de cinema (2007). Sérgio Augusto era colega de redação dos cinemanovistas no jornal Metropolitano ainda na eclosão do movimento. Gustavo Dahl atuava como crítico de cinema do Estado de S. Paulo quando o movimento surgiu, mas pouco tempo depois ele se tornou cinemanovista, misturando as fronteiras entre a realização cinematográfica e a crítica de cinema. Desde o início do movimento, os três debateram em alguma medida o Cinema Novo. Dez anos depois, em Opinião, esses críticos fecham o ciclo e discutem não só estética, mas a política e a função do cinema dentro de um contexto autoritário.

Nesse percurso de dez anos do Cinema Novo, dois componentes entraram em cena, imprimindo um novo rumo à discussão. $\mathrm{O}$ peso cada vez maior do mercado e o regime ditatorial com sua política de cinema alteraram o pensamento cinematográfico não só dos cinemanovistas, mas também dos críticos aqui estudados. Por causa desses dois componentes, a discussão do cinema brasileiro em Opinião vai passar quase que obrigatoriamente pelo extra-fílmico, pela política, pelo mercado. O cinema autoral é repensado sempre em função desses imperativos. Jean-Claude Bernardet fez esse 
reconhecimento logo na primeira vez que escreveu em Opinião ${ }^{21}$. Nesse primeiro texto, ele explicava que os tempos eram outros. Não se tratava mais de cineastas, mas de empresários. A luta dos cinemanovistas nos anos setenta tentava inserir o cinema no campo do mercado, da ocupação e da resistência ao regime. Esses dois inimigosparceiros exigiam um viés de análise eminentemente político que imprimiu uma marca ao jornal: o cinema brasileiro não é mais visto enquanto arte isolada, mas faz parte do contexto político e cultural. Assim os filmes brasileiros em Opinião, via de regra, não são pensados como estética e enveredam pela discussão política.

Muitos cânones de Opinião não eram somente consensuais no campo da esquerda engajada. Se alguns desses temas eram bandeiras da luta da esquerda cinematográfica desde os primeiros congressos do cinema brasileiro nos anos cinquenta, eles tinham se tornado uma proposta conjunta do campo cinematográfico. Geralmente essas influências eram também implícitas e funcionavam como uma tradição e um repertório comum, às vezes de forma não consciente e secundária. Funcionavam como uma espécie de homologia das estruturas significativas goldmanianas (Ver Capítulo 2). É inegável que a cultura política engajada estava presente em Opinião. Mas na prática não há culturas políticas puras; só há culturas políticas de tipo misto, resultante da combinação de variadas tendências. (Bobbio, 1998). Entre uma cultura política engajada e a cultura cinematográfica voltada à estética do cinema, analisamos se Opinião foi refém do engajamento, se ampliou a discussão estética ou se balanceou os dois lados. A cultura política de esquerda pode até ter grande peso sobre essas formulações, mas jamais é o único fator sobre os críticos.

O mais interessante deste debate é estudar como Opinião trouxe os principais pontos de atrito da Frente Cultural. Muitos textos são problematizantes e cheios de nuances que misturam o debate do cinema com a tensão entre política e estética. A tese não se concentra somente na análise histórica sobre o papel do intelectual, da cultura popular e das balizas estéticas defendidas pelos críticos. Chegamos a esses conceitos através do estudo específico sobre as críticas de cinema e sobre a recepção dos filmes brasileiros. Esses dois aspectos têm papel central no trabalho.

Procuramos adequar alguns parâmetros de outras áreas para observar os matizes de pensamento da crítica voltada à arte ou ao imperativo político. Nesse percurso, adaptamos conceitos de outros campos para aplicar na crítica de cinema. Transitando

\footnotetext{
${ }^{21}$ Bernardet, Jean-Claude. O empresário substitui o gênio? Opinião. n. 1, p. 24, 06 a 13 nov. 1972.
} 
pelo universo do jornalismo, da história da resistência e do cinema, a tese não segue a risca um único modelo. Pegamos de empréstimo paradigmas de diferentes campos para tentar construir alguns aportes metodológicos para a crítica de cinema neste intercâmbio entre os três universos.

Contudo, isso não significa um abandono de outras preocupações teóricas. Afinal a análise histórica não deve prescindir da reflexão estética, fornecendo ao cinema autonomia de discussão por sua condição de campo independente. Fugimos da perspectiva de ver o cinema somente como ilustração de uma possível participação política dos críticos, porque esse viés reduziria o jornal a uma elucidação da linha política dos seus atores sociais. Pensamos os críticos de Opinião na articulação complexa entre seus parâmetros estéticos e políticos. Estes são também fruto do imaginário e de condicionantes culturais através da cultura política, mas sozinhos eles não explicariam a totalidade do ato crítico. Portanto, o estudo dos parâmetros estéticos conectados ao estudo político dos críticos de Opinião fica aqui realçado em primeiro plano.

Tomamos também alguma inspiração da história cultural, que é o estudo dos processos e práticas, através dos quais se constroem sentidos, identidades e significados no mundo social. A cultura é sua fonte de compreensão e de problematização. Nascida da crise de paradigmas, a história cultural é difícil de classificar do ponto de vista metodológico. Não há uma postura teórica clara, partindo de uma subjetividade epistemológica e uma objetividade metodológica, ou seja, o objeto se define pelo método, sem se apoiar numa teoria pronta. Ela se caracteriza pela heterogeneidade das referências, gerada no fim das discussões das grandes utopias. Trata-se do desafio de ao mesmo tempo estudar o particular e o geral, buscando delinear os parâmetros do imaginário do período. Lynn Hunt (1992) revela como pouco a pouco, os historiadores de 1960-70 abandonaram os relatos tradicionais de instituições políticas e se direcionaram para a compreensão social da vida das minorias. Até os estudos marxistas se aproximaram do que os franceses denominam de mentalité, mostrando que as relações econômicas e sociais não determinam as relações culturais. Assim, a história cultural deve ir além das mentalidades, num estudo minucioso de textos, imagens e ações. Trata-se de uma ciência interpretativa, cuja tarefa fundamental é a decifração de significados. Partimos, portanto, de um estudo sem um modelo teórico pré-definido, através do imaginário dos intelectuais atuantes na crítica de cinema de Opinião. Buscamos adentrar no pensamento político e nas linhas de atuação destes críticos, 
trilhando uma história de como esta intelectualidade se debruçou sobre si mesma para avaliação. A pesquisa tenta ir além de um relato parcial da representação do cinema brasileiro no pensamento dos cronistas de Opinião. Pretende apresentar as ambiguidades da visão dos críticos sobre o cinema brasileiro, visto ao mesmo tempo como subdesenvolvido, autêntico, ideológico, atrasado, nacional, artificial, cosmopolita, popular, popularesco, burguês, porque todas essas nuances refletem um pouco do pensamento da época.

Conectamos nesse trabalho a análise interna e a externa, com o primado da primeira, porque a forma e o como são muito importantes para pensar Opinião. Nesse sentido, tomamos como princípio norteador de nosso trabalho o conceito de estrutura explicado por Antonio Candido (2011 a), porque reconhecemos que os textos críticos são obras autônomas. Mas essa autonomia é formada por elementos externos e pela cultura política, por influências da sociedade, pela ideologia de seu tempo, etc. Esse cotejo com a análise externa é, portanto, vital, mas faz parte também da estrutura interna da obra. Não se trata jamais de afirmar sem dados suficientes que um texto crítico possui um ponto de vista determinado, porque é um reflexo de seu tempo e de suas instituições políticas. Só o estudo da estrutura externa ou do contexto não dá conta de explicar a crítica de cinema sem passar pelo estudo da forma, ou do estudo de como os textos constituem as mensagens políticas vinculadas. Mais do que explicar o conteúdo de Opinião, através dos princípios da Frente Cultural, procuramos conectar este estudo com a forma do texto. Pretendemos observar quais são os elementos externos (da realidade social ou os conceitos teóricos) que se transformam em estrutura interna para os artigos. Nesse sentido, procuramos proceder conforme a natureza da obra analisada. Isto é, pensar os textos pelo que eles nos falam e pelos referenciais que eles solicitam, mais do que tentar encaixar um modelo de análise, a partir das considerações políticas daquele momento. Trata-se de uma análise do particular sem pretensões totalizantes sobre os críticos de cinema.

Nosso objetivo é auxiliar a desenvolver dispositivos críticos a partir do estudo das particularidades, sem nos afastar da totalidade do fenômeno da crítica da imprensa alternativa. Quando observa uma fragilidade na reflexão acadêmica sobre teorias e procedimentos para realizar a crítica de mídia, Rosana de Lima Soares (Soares; Silva, 2013) lembra que a crítica ainda reclama ser tratada como campo particular de pesquisa. Afinal, os estudos da particularidade vão auxiliar a compor dispositivos críticos porque 
eles dialogam com a totalidade, terminando por configurar o campo teórico e geral sobre o assunto. Opinião tem um debate muito rico exatamente porque muitas vezes se nega ao universal e parte do particular e do ensaístico. O campo da crítica de cinema ainda não dispõe de um dispositivo crítico com pretensões à universalidade, sendo que as maneiras de criticar a mídia vêm dos produtos específicos. E provavelmente nunca o terá, segundo Rosana Soares, porque a maneira de se fazer crítica é plural por diferentes vias de acesso à obra, com variada gama de métodos analíticos e de procedimentos explicativos. Logo a crítica resulta "inacabável” em seu gênero e "infinita em número", explica Soares, como "infinito é o processo interpretativo" do qual participa. 
Parte I

Opinião e a Crítica de Cinema

Um jornal que não defende interesses pessoais, não pertence a nenhum partido, não é porta-voz de qualquer ideologia e se recusa a aceitar um volume de publicidade que ultrapasse a 20 por cento de sua receita. Esses são os princípios básicos de OPINIÃO, semanário que começa a circular no próximo dia 6 de novembro, segunda-feira". (...)

Um jornal de oposição?

- OPINIÃO não vai fazer 'política' na medida em que não vai fazer propaganda de movimentos políticos ou preservar a imunidade de grupos ou igrejinhas - garante Raimundo.

“(...) temos como compromisso a defesa dos direitos do cidadão e das liberdades democráticas.

Número Zero de Opinião 23 out. 1972 

Capítulo 1

A seção de cinema de Opinião

O gesto de criação hoje, aqui e agora, tem de ser igual ao da liberdade do menino que entra no playground para brincar. Cercam-no de grades, a pretexto de protegê-lo, para que se possa mantê-lo debaixo dos olhos vigilantes. Mas a grade acaba sendo um obstáculo apenas para aqueles que não conseguem entrar lá. A cerca acaba determinando um território livre do menino e ali ninguém pode com ele. Digam ao menino: 'Zézinho, não vá pro balanço que você cai'. Ele resmunga e descobre a gangorra. Proíbam-no a gangorra e ele encontrará o escorregador. E assim proíbam-lhe tudo, todos os brinquedos. Que o menino, ainda assim, saberá achar três pedrinhas no chão e com elas construir seu mundo mágico. Paulo Afonso Grisolli em depoimento à revista Visão. A crise da cultura brasileira. v. 39, n. 1, p. 55,05 jul. 1971 



\section{Capítulo 1 - A seção de cinema de Opinião}

Este capítulo reconta o cotidiano e as polêmicas da seção de cinema de Opinião, abrigada na rubrica Tendências e Cultura. Em seguida, explicamos as estratégias para lidar com a censura e o quanto ela altera o texto jornalístico do semanário, criando o que chamamos de uma estética do silêncio. O trabalho é feito com duas fontes de informação principais: a bibliografia sobre o jornal ${ }^{1} \mathrm{e}$ as entrevistas que fizemos com os críticos de cinema. Quando usamos ao longo desta tese as declarações coletadas através de nossas entrevistas, não indicamos a fonte em nota de rodapé. Entrevistamos os críticos de cinema Jean-Claude Bernardet, Sérgio Augusto, Marcos Ribas de Farias, Clóvis Marques e José Carlos Avellar, além dos dois editores de cultura do jornal: Júlio César Montenegro e o já citado Sérgio Augusto. Infelizmente Fernando Gasparian, Gustavo Dahl e Carlos Frederico faleceram. Fizemos diversos contatos com Raimundo Pereira por email e por telefone, mas não obtivemos resposta.

\subsection{O dia a dia da seção de cinema}

O jornal carioca Opinião (1972-1977) foi comandado de 1972 a 1975 pelo editor-chefe Raimundo Rodrigues Pereira. A seção cultural chamada Tendências $e$ Cultura teve mais de um editor. No começo ninguém ficava no cargo muito tempo. Passaram por ela tanto os jornalistas Flávio Pinheiro ${ }^{2}$ quanto Abel Silva ${ }^{3}$. Outros ajudaram interinamente, como Tárik de Souza ${ }^{4}$ até a entrada de Júlio César Montenegro Bastos. Ele seguiu no comando até a demissão de Raimundo Pereira em fevereiro de

\footnotetext{
${ }^{1}$ Afora a obra de referência de Bernardo Kucinski, o colaborador de Opinião José Antonio Pinheiro Machado (1978) escreveu um relato em primeira pessoa sobre as pressões e ameaças, inclusive de morte, sofridas pelos dirigentes. Vani Kenski (1990) defendeu uma tese voltada à área de psicologia sobre os motivos do "fascínio" dos leitores por Opinião. Ela analisou as estratégias imagéticas utilizadas pelo jornal para transmitir significados proibidos. José Antonio Spinelli Lindoso (1997) realizou na Faculdade de Educação uma análise dos artigos de alguns intelectuais, geralmente ligados ao Cebrap, que escreveram na seção de política de Opinião sobre o processo de abertura, a sucessão presidencial e as eleições. A dissertação de Eduard Marquardt (2003) procurou criar um retrato panorâmico sobre a seção cultural do jornal, além de catalogar os artigos publicados nesta editoria. Da área de Letras, o autor iniciou um debate sobre a relação tensa entre mercado e crítica cultural em Opinião e observou uma inclinação pela crítica mais erudita, voltada à apreciação de obras de arte. Além desses trabalhos, o jornalista Carlos Azevedo (2011) publicou um livro-reportagem sobre a história de Movimento. O autor escrevia em Opinião e em Movimento e era dirigente da AP (Ação Popular) e do PC do B (Partido Comunista do Brasil). É possível encontrar neste livro algumas informações e depoimentos sobre o dia a dia de Opinião.

${ }^{2} \mathrm{Na}$ época era sub-editor do jornal Correio da Manhã. Tinha sido repórter da sucursal da Folha de S.Paulo no Rio de Janeiro e redator de Visão.

${ }^{3}$ Quando Abel Silva foi editor de Opinião, ele já era poeta, escritor e compositor.

${ }^{4}$ Jornalista e crítico musical de Veja, Folha de S.Paulo, Estado de S. Paulo.
} 
1975, quando grande parte da equipe abandonou Opinião para apoiar o editor-chefe. Nessa época, Raimundo Pereira fundou com parte desse grupo o seminário alternativo Movimento (1975-1981), jornal de propriedade coletiva de jornalistas.

Com a perda de tantos colaboradores, Opinião enfrentou uma queda nas vendas. Para reverter o quadro, Fernando Gasparian contratou uma equipe de jornalistas "profissionais" que permaneceram no jornal por um ano (1975-1976). O escolhido para substituir Raimundo Pereira foi Argemiro Ferreira, editor de internacional do Jornal do Brasil, que trouxe vários colegas junto com ele. Antes de assumir o cargo, Ferreira publicou quatro artigos na seção de cinema durante o segundo semestre de 1974. Para comandar a equipe de cultura, Argemiro convidou Sérgio Augusto, que já era crítico de Opinião, do JB e do jornal $O$ Pasquim.

Em meio à forte censura, depois de um ano, Fernando Gasparian estava sem recursos para pagar os salários da equipe. Foi quando se dissolveu o acordo com Argemiro Ferreira. Então o proprietário do jornal chamou de volta os "engajados", que aceitavam receber salários irrisórios, porque viam o jornal como parte da luta contra a ditadura. Montenegro conta que nessa época foi fazer uma entrevista com Gasparian para $O$ Globo. Foi quando ele recebeu um convite para retornar à Editora Inúbia ${ }^{5}$. Primeiro Montenegro comandou o Jornal de Debates ${ }^{6}$ como redator-chefe, mas ele publicou tantas cartas de leitores sobre homossexualismo e racismo que Gasparian o mandou de volta para Opinião. Montenegro esclarece que o dono do jornal não tinha total confiança nele, por isso o colocou na editoria de cultura. Ele aceitou voltar quando soube que seu amigo Genilson César estaria no comando do jornal, dando total liberdade a todos. Durante 1976-1977, Montenegro mudou a cara da seção cultural. Trouxe vários colaboradores, deu dinâmica aos textos, abriu espaço para debater a própria função do jornalismo cultural. Ele é, em síntese, a figura chave de Tendências $e$ Cultura (Ver Capítulo 6).

Os críticos de cinema eram "editores contribuintes". O termo foi cunhado no jornal por Sérgio Augusto e tomado de empréstimo do jornalismo americano. Cada um

\footnotetext{
${ }^{5}$ Quando citamos as declarações de Júlio César Montenegro, Jean-Claude Bernardet, Sérgio Augusto, Marcos Ribas de Farias, José Carlos Avellar e Clóvis Marques, trata-se das entrevistas que realizamos com os autores. Nos casos de exceção, mencionamos as fontes.

${ }^{6}$ O semanário Jornal de Debates circulou de abril de 1972 a 1976, com algumas interrupções. A linha editorial defendia o desenvolvimento do mercado interno e o nacionalismo de esquerda. Na última fase, o jornal concedeu grande espaço aos leitores, através da temática da liberdade. O título retomava a trajetória do famoso Jornal de Debates, fundado por Mattos Pimenta e Plínio Catanhede em 1946, que foi o principal veículo da campanha pelo monopólio estatal do petróleo nos anos cinquenta (Kucinski, 1991: 90).
} 
sugeria suas pautas, discutia as ideias com o editor, escrevia as matérias, mas não precisava ficar na redação. Geralmente os críticos só passavam pelo jornal para entregar os textos ${ }^{7}$. Esse regime explica porque os articulistas de cinema acompanharam pouco as reuniões de pauta. A separação dos críticos do restante da equipe era também física. A editoria de cultura funciona nos fundos de uma "enorme casa de burguês", no Jardim Botânico, como conta Jean-Claude Bernardet. O contato com as demais editorias era reduzido porque os críticos de cinema ficavam na edícula.

O regime colaborativo de trabalho não tem relação alguma com a quantidade de artigos publicados. O jornal tinha um time de críticos de cinema de peso com uma carreira consolidada na função desde os anos sessenta ${ }^{8}$. Jean-Claude Bernardet e Sérgio Augusto escreveram mais de sessenta artigos cada um para Opinião. Bernardet começou a exercer a crítica no Suplemento Literário do jornal O Estado de S. Paulo. Perseguido político, ele já era professor e teórico de cinema. Naquela época, Sérgio Augusto era crítico de cinema do Jornal do Brasil. Logo na primeira edição, Bernardet publicou um texto no jornal. O nome de Sérgio Augusto surgiu em Opinião um mês depois. Os dois escreveram com maior frequência até 1976. De outubro de 1973 até dezembro de 1974, Bernardet recorreu ao pseudônimo Carlos Murao para poder publicar artigos em Opinião por causa da censura. Gustavo Dahl participou do projeto entre 1974-1975, antes de entrar para a Embrafilme. Ao lado de Bernardet, ele também começou a carreira de crítico de cinema no Suplemento Literário, antes de se tornar cinemanovista. Durante sua gestão, Sérgio Augusto trouxe para o jornal um novo time de críticos: José Carlos Avellar, Marcos Ribas de Farias e o então novato Clóvis Marques. Tanto Avellar quanto Ribas de Farias eram críticos de cinema de longa data do Jornal do Brasil. Entre o final de 1976 e o início de 1977, a equipe mudou ${ }^{9}$. Entraram novos atores sociais, como o cineasta marginal Carlos Frederico ${ }^{10}$, mas geralmente os convidados escreveram poucos artigos. Não eram só os críticos de cinema que participavam do

\footnotetext{
${ }^{7}$ Sergio Augusto explica que Jean-Claude Bernardet era o editor de cinema de São Paulo, e ele do Rio de Janeiro. Às vezes os dois preparavam textos para o mesmo número, às vezes revezavam. $\mathrm{O}$ trabalho era feito por intermédio do editor Júlio César Montenegro. "Era uma coisa de trabalho separado, mas em dupla", explica Sérgio Augusto. Jean-Claude Bernardet chegou a enviar alguns textos de São Paulo para Opinião, mas mudou para o Rio de Janeiro por causa do jornal. Ao mesmo tempo, viajava com grande frequência pelo Brasil, ministrando seminários para o Instituto Goethe (Ver Capítulo 3).

${ }^{8}$ Apresentamos o histórico dos críticos de cinema no capítulo 3.

${ }^{9}$ Não há datas precisas de entrada e saída dos críticos em Opinião. A equipe era muito extensa, compondo um tipo de trabalho freelancer. Mesmo na gestão de Argemiro Ferreira, Bernardet publicou artigos. Sobre a fase final do jornal, ver Capítulo 6.

${ }^{10}$ Autor de A possuída dos mil demônios (1970) e de Lerfa-mu (1979), Carlos Frederico é autor de muitos curtas e médias metragens. Foi produtor de Os homens que eu tive (1973) de Tereza Trautman e de alguns filmes da Boca do Lixo.
} 
jornal. Diversos cineastas, produtores e renomados intelectuais faziam parte do debate nas seções de cartas ao longo de todos os anos.

Abaixo reproduzimos a lista dos editores de cultura de Eduard Marquard (2003), feito a partir do quadro de colaboradores publicado em Opinião:

\begin{tabular}{l|l|l|l}
\hline \multicolumn{2}{l}{ Opinião } & \multicolumn{2}{|l}{ Tendências e Cultura } \\
\hline $\begin{array}{l}\text { Raimundo } \begin{array}{l}\text { Pereira } \\
\text { Podrigues }\end{array} \\
\text { out. 1972- } \\
\text { fev. 1975 }\end{array}$ & Flávio Pinheiro & $\begin{array}{l}\text { out. 1972- } \\
\text { fev. 1973 }\end{array}$ \\
\cline { 3 - 4 } & & Abel Silva & $\begin{array}{l}\text { fev. 1973- } \\
\text { set. 1973 }\end{array}$ \\
\cline { 3 - 4 } & Julio César Montenegro & $\begin{array}{l}\text { set. 1973- } \\
\text { mar. 1975 }\end{array}$ \\
\hline Argemiro Ferreira & $\begin{array}{l}\text { mar. 1975- } \\
\text { jun. 1976 }\end{array}$ & sem editor & $\begin{array}{l}\text { mar. 1975- } \\
\text { maio 1975 }\end{array}$ \\
\cline { 3 - 4 } & & Sérgio Augusto & $\begin{array}{l}\text { maio 1975- } \\
\text { jun. 1976 }\end{array}$ \\
\hline sem editor ${ }^{11}$ & $\begin{array}{l}\text { jun. 1976- } \\
\text { abr. 1977 }\end{array}$ & Julio César Montenegro & $\begin{array}{l}\text { jun. 1976- } \\
\text { abr. 1977 12 }\end{array}$ \\
\hline
\end{tabular}

Montenegro explica que a editoria cultural era chamada de bólide porque ninguém ficava muito tempo nela. A seção dava errado sucessivamente; os editores se envolviam em outros projetos e abandonavam o barco. Não parava de entrar e sair gente. Interinamente, Montenegro foi ajudar Tárik de Souza na cobertura da morte de Pablo Picasso, em abril de $1973^{13}$. Ele estava voltando para o Rio de Janeiro depois de trabalhar como correspondente em Brasília, enquanto o antecessor deixava a seção. Foi Tárik quem sugeriu o nome de Montenegro a Raimundo Pereira para substituí-lo e comandar Tendências e Cultura. Ele foi chamado literamente para "apagar o fogo", porque muitas pessoas estavam saindo da editoria. Portanto, Montenegro assumiu o cargo oficialmente sete meses após o nascimento do jornal, em setembro de 1973.

\footnotetext{
${ }^{11}$ Marquardt explica que na última fase, o jornal não publicava o nome do editor-chefe. Há três versões sobre quem foi o editor geral nos últimos anos: 1. Gasparian assumiu o controle, 2. uma equipe se revezou no cargo de editor chefe ou 3. apenas Ozéas Carvalho e Genilson César cumpriram essa função específica. Este último era dissidente do PCdoB. Em entrevista, Montenegro refere-se a Genilson César como o escolhido por Gasparian para ser representante da redação. Não havia mais o termo editor-chefe. Genilson César era uma espécie de secretário de redação, cargo ocupado antes por Tonico Ferreira durante a gestão de Raimundo Pereira. No dia a dia, cada editor mandava sua parte organizada para Genilson César que organizava todo o material e diagramava os textos. A diferença é que ele não fazia o trabalho de copydesk de Raimundo Pereira. De acordo com Montenegro, Ozéas Carvalho ficava encarregado da parte gráfica e da impressão.

${ }^{12}$ Tomamos o quadro de Marquardt como modelo, embora saibamos que os dados publicados no jornal não são completamente confiáveis. Afinal Opinião tinha o hábito de incluir nomes de colaborares que já não participavam mais da equipe.

${ }^{13} \mathrm{O}$ nome de Montenegro aparece como correspondente em Brasília no quadro de colaboradores do jornal até março de 1973 (n. 18). Em julho de 1973 (n. 35), ele publica um artigo na seção cultural. Em setembro do mesmo ano, Montenegro é apresentado oficialmente como editor da seção.
} 
Se a seção propiciou a Montenegro um "cartaz brutal", como ele diz, o espaço não era considerado pela chefia o carro chefe da casa. $O$ forte do jornal era a parte de política, enquanto a cultura era vista como "de segunda", como "frescura" ou "perfumaria”, resumem tanto Júlio César Montenegro ${ }^{14}$ quanto Jean-Claude Bernardet. A seção cultural, assim como todo o jornal, fornecia espaço para diversas tendências políticas. O proprietário de Opinião era um liberal progressista, enquanto Raimundo Pereira representava o universo de matizes comunistas no jornal. $\mathrm{O}$ editor-chefe tomou cuidado para compor uma equipe com diversas tendências políticas entre seus colegas de Realidade, Veja e Amanhã. Amigo de Raimundo Pereira desde a época do ITA, Júlio César Montenegro Bastos é trotskista até hoje, mas nunca se filiou a nenhum partido. Motivado pelo ódio à ditadura e às instituições, ele abandonou uma carreira de sucesso. Antes de ir trabalhar no Rio de Janeiro como jornalista no começo dos anos setenta, ele atuava como engenheiro e administrador de empresas. Quando decidiu se engajar na resistência, ele era Diretor Administrativo da Telefônica de Fortaleza ${ }^{15}$. Antes disso, foi engenheiro do Departamento de Estradas do Ceará e administrou as frentes de emergência para os agricultores sem safra na Sudene, cujo objetivo era evitar o êxodo rural durante a seca de 1966. Na época da Telefônica, ele ajudava o "pessoal subversivo" da cidade, como gosta de dizer. Distribuía panfletos à noite, mesmo sob o risco de prisão. Montenegro dava consultoria aos bancários que queriam fazer greve. Além disso, incentivava a associação dos funcionários da telefônica, quando o movimento sindical era quase proibido. Começou como administrador de Opinião e de tanto dar "palpite" foi logo convidado a compor a equipe. Primeiro trabalhou como correspondente de política em Brasília por seis meses, mas estava triste de ficar sozinho na cidade e longe da esposa. Voltou para o Rio de Janeiro e assumiu o trabalho interno do jornal.

Os liberais, comunistas e os trotskistas não eram as únicas tendências políticas do jornal. Havia também os independentes da esquerda. Eles quase compõem uma subcategoria, a dos jornalistas “profissionais”. Sérgio Augusto, Marcos Ribas de Farias

\footnotetext{
${ }^{14}$ Júlio César Montenegro escreveu um artigo sobre esse assunto. Ver: $O$ refresco da cultura. Opinião. n. 219, p. 21, 14 jan. 1977.

${ }^{15}$ Montenegro foi emprestado do Departamento de Estradas do Ceará para assumir a administração da Telefônica e apurar as inúmeras irregularidades, denunciadas numa comissão de inquérito. Ele era também o encarregado de substituir a equipe de apadrinhados por pessoas especializadas, investigar os casos internos de corrupção e fazer as cobranças dos inúmeros casos de uso indevido de linhas telefônicas dos clientes famosos, alguns deles militares graúdos. O autor narra essas histórias no depoimento Júlio César Montenegro - "Meus (poucos) anos de Telefonia". Edição de 100 anos da Telefonia no Ceará. Linha Direta - TeleCeará. ano 12, n. 134, p. 4-5, ago./set. 1991.
} 
e Clóvis Marques definem o interesse pelo semanário alternativo Opinião como um "projeto interessante de jornalismo". Para eles, a experiência foi maravilhosa porque o jornal era aberto, democrático e não faltava espaço para escrever. Sérgio Augusto achava importante existir um veículo para afrontar o regime militar de alguma forma, mas para ele o trabalho não tinha o sentido de resistência. É muito "sadio" ter um jornal "independente ou sem patrão", como foi o caso de Movimento, completa ele. Augusto só saiu de Opinião porque Gasparian iria diminuir ainda mais os salários, já muito inferiores em relação ao mercado. "Abaixo disso não havia condições", afirmou Augusto ${ }^{16}$.

Montenegro incorporava cada vez mais colaboradores na seção. "Vinha gente diferente", da universidade, "de toda parte". "O pessoal me adorou”, relembra. A seção funcionava de maneira bem aberta, sem uma estrutura rígida. As pessoas ofereciam os textos, Montenegro discutia o assunto e os artigos eram publicados. Por exemplo, um dia chegou Heloisa Buarque de Hollanda e sugeriu dois textos sobre Cinema Novo (Ver Capítulo 5). Era assim que o processo funcionava em Opinião. Se alguém ia a algum festival de cinema, aproveitava para combinar com Montenegro o envio de um artigo antes de partir. Raimundo Pereira ficava muito satisfeito com esse esquema todo.

A seção Tendências e Cultura era vista como "estratégia de combate" contra a ditadura. Esse tom combativo aparecia na reunião de pauta. Toda a equipe discutia o que ia sair na próxima edição, até o pessoal de São Paulo. Porém os críticos de cinema nem sempre tomavam parte no processo, com exceção de Marcos Ribas de Farias, que também era editor da seção internacional. Os críticos de cinema não identificam hoje um projeto editorial para a seção de cultura de Opinião, mas observam a preferência na reunião de pauta pela visão política contrária à ditadura ou pelos filmes estrangeiros que incomodavam naquele momento ${ }^{17}$. Uma das muitas variáveis disponíveis era comentar um lançamento estrondoso, como fez Júlio César Montenegro com O Exorcista (1973) de William Friedkin ${ }^{18}$. Repensando o assunto na entrevista, Jean-Claude Bernardet

\footnotetext{
${ }^{16}$ Os principais editores do jornal, (Herzog, 2011) relembram que durante a experiência na imprensa alternativa as contas da casa ficavam por conta das esposas, porque o salário de Opinião era insuficiente para viver. Montenegro, por exemplo, usou seus fundos guardados durante anos para se dedicar ao projeto e ainda contou com a colaboração da esposa. Sérgio Augusto nos explicou que não continuou no jornal pelo mesmo motivo, porque como qualquer pessoa "tinha contas a pagar".

${ }^{17}$ Bernardet conta que não havia reuniões de caráter político ou ideológico na seção de cultura, embora a ideologia estivesse com certeza por baixo das pautas sobre os filmes e peças de teatro.
} 
conclui que talvez o projeto do jornal fosse mesmo abordar filmes com problemas com a ditadura ou que dissessem algo sobre ela.

Talvez nesses breves relatos, relampejos de memória motivados pelas entrevistas, tenhamos aqui e acolá um pequeno indício de dois projetos editoriais diferentes para a seção de cinema. De um lado o viés político da resistência presente nas reuniões de pauta e de outro lado o dia a dia com a liberdade de pontos de vista de Tendências e Cultura. Raimundo Pereira lia e comentava todas as matérias. Não ficava preso ao texto inteiro, mas ao assunto e à forma de exposição, explica Júlio César Montenegro. Outras vezes o critério dependia da ação da censura. Se houvesse grande interdição ao conteúdo da editoria de política, a equipe aumentava o volume de matérias de cultura, e vice versa.

Nenhum dos críticos de cinema lembra-se da existência de um projeto editorial para a seção cultural. Mas todos relatam em coro a imensa liberdade e autonomia que Júlio César Montenegro dava a todos eles. A lembrança sobre a seção cultural do jornal está centrada na figura, realmente irradiadora de alegria, de Montenegro. Para Sérgio Augusto, Montenegro é muito simpático, inteligente, engraçado e leve. "Só tenho boas lembranças dele. Não tenho nenhuma queixa dele, muito pelo contrário. Montenegro era totalmente aberto, não tinha nenhum tipo de dogmatismo. Anti extremo. Ele era o oposto do Partidão; era a esquerda libertária”.

A chave do que era publicado ou não em Opinião na seção de cinema gira em torno de Júlio César Montenegro. Tudo era discutido com ele. Segundo Bernardet, ele realmente exerceu muito bem a função de editor; era excelente. "Tudo era muito maleável com o Júlio, não tinha diretriz, era tudo muito livre. Sempre tive super apoio do Júlio. Confiava totalmente nele. Não tinha essa conexão com o Raimundo.”

O contato com os críticos era feito através do editor de cultura, sem nenhum tipo de interferência superior. Havia liberdade total para escrever sobre o que cada um queria. Por exemplo, Bernardet declara que não estava interessado em fazer exatamente crítica de cinema. Ele queria abordar "questões mais amplas" [de política cultural]. Para Montenegro, Bernardet gostava mesmo era de discutir o cinema nacional e conversar com os realizadores. Essa total abertura parece ser uma das maiores saudades deixadas em quem conhecia de perto o ambiente das redações dos grandes jornais. Marcos Ribas de Farias relata que usava seus critérios como espectador para escolher as pautas. Nem

\footnotetext{
${ }^{18}$ Montenegro, Júlio César. O exorcista - um diabo de sucesso. Opinião. n. 107, p. 23,22 nov. 1974. O autor relata a reação do público e analisa o filme.
} 
sequer havia uma obrigação em comentar a produção em cartaz, isso nem na gestão de Montenegro, nem na de Sérgio Augusto. Às vezes Montenegro pedia um artigo sobre um filme considerado importante ou respondia que determinado lançamento não merecia aparecer no jornal.

A gestão de Sérgio Augusto seguiu a mesma trilha do antecessor. Era totalmente livre, tão livre que havia espaço até para discordar dele nas seções de cartas (Ver Capítulo 4). Talvez uma das diferenças seja a preocupação jornalística forte de Augusto com o gancho, com o acontecimento. As pautas vinham do que estava acontecendo no momento, sem nada programado. "Era tudo muito democrático e aberto", explica o exeditor.

Os comentários atuais dos críticos de cinema sobre a total autonomia diferem das descrições do passado sobre a seção cultural de Opinião. Vani Kenski (1990) e Bernardo Kucinski (1991) relataram o quanto a editoria de cultura foi palco de várias divergências. As polêmicas passavam por questões de ordem política. São elas:

1. a tentativa de cada colaborador de demarcar território com suas tendência ou orientação política;

2. o conflito entre uma área nacionalista e outra internacionalista. A primeira era adepta a divulgar questões ligadas à cultura nacional, enquanto a segunda defendia uma concepção ampla da cultura;

3. as reclamações de episódios de censura interna ${ }^{19}$ : manipulação de títulos, supressão de matérias e cortes sob pretexto técnico, feitos por Raimundo Pereira, sem autorização prévia ${ }^{20}$. Raimundo acusava o grupo dos "intelectuais" de desconhecer os procedimentos de edição do Jornalismo. Qualquer acusação recebia o fardo da censura política, convertendo o processo de edição numa saia justa ${ }^{21}$. Para a equipe um

\footnotetext{
${ }^{19}$ Censura interna é um termo utilizado para caracterizar a presença do censor da polícia federal dentro das redações. A palavra foi incorporada pelos jornalistas para se referir ao poder de veto às matérias de Raimundo Pereira e de Fernando Gasparian.

${ }^{20}$ Paulo Francis foi o primeiro a acusar Raimundo Pereira de censura interna. Ele queria por escrito a quantidade exata de laudas disponíveis e o estilo de redação do jornal para evitar novos episódios de censura (Kucinski, 1991). A lista incluiu também Washington Novaes e os "amigos" de Gasparian. Depois de cortar partes do artigo de Franklin de Oliveira e colocá-lo nas seções de cartas, o ato político de Raimundo serviu como um ingrediente a mais para sua demissão. O procedimento seria uma forma de manifestar seu desagrado e discordar da linha defendida pelo autor (Lindoso, 1997).

${ }^{21}$ Às vezes as declarações são conflitantes, por exemplo, o editor Sérgio Buarque (Azevedo, 2011) relata que Jean-Claude Bernardet ia até Raimundo acusá-lo de censura interna. Buarque explica que jornalismo é mexer, cortar, reescrever, mas logo em seguida também acusa Raimundo de cortar a segunda parte de uma entrevista com Florestan Fernandes, sem conversar com ele. "Era tudo uma saia muito justa. Ali qualquer coisinha que você fazia tinha uma discussão. Ai, fui aprender: toda vez que você corta o texto de alguém, você cortou o 'essencial', você 'mutilou', e tal... Agora, você turbina isso com questões políticas, vira um problemão” (Azevedo, 2011: 109-110).
} 
semanário de Frente Ampla deveria agregar todas as tendências políticas, sem dar espaço somente a uma delas. Raimundo Pereira defendia o lado oposto; para ele um jornal deveria ter uma coordenação política. $\mathrm{Na}$ época, o próprio Montenegro chegou a reclamar de censura interna em carta ao próprio Raimundo Pereira ${ }^{22}$. Na missiva, o editor de cultura defendia que toda redação discutisse abertamente qual matéria seria publicada ou vetada. Montenegro conta que Raimundo Pereira editava jornalisticamente todos os textos, vírgula por vírgula, até de madrugada ${ }^{23}$. Mas desde aquela época, o editor de cultura já tinha "horror a copydesk".

4. o controle secreto do jornal pelos partidos clandestinos através da figura de Raimundo Pereira. Ele teria submetido o projeto do jornal somente aos dirigentes do PCdoB (Partido Comunista do Brasil) ${ }^{24}$ e da AP (Ação Popular) ${ }^{25}$.

Parte destas indagações fogem ao nosso recorte sobre os críticos de cinema, apontando para a existência de maiores disputas na relação com a direção do jornal. De qualquer modo, o termo censura interna implica projetar o censor no colega jornalista.

\footnotetext{
${ }^{22}$ Bernardo Kucinski (2003: 323) transcreve uma carta de Júlio César Montenegro de 12 de janeiro de 1973 enviada a Raimundo Pereira, do acervo do próprio editor-chefe: "Como é que um jornal que se propõe a abrir o debate com o mundo exterior fecha o debate entre seus colaboradores [...] nesses dias que passei aí notei que as discussões são poucas, as reuniões de pauta são uma listagem de assuntos... sei que a situação, as dificuldades de tempo e gente, forçam a tomada de resoluções sem ouvir ninguém, mas estou preocupado com a transformação disso em hábito. Só para exemplificar: quando estávamos lendo as matérias para escolher o que iria no Nacional, você vetou tão sumariamente a notícia da greve de Minas, que eu quase nem tentei argumentar [...]. Certo, alguém tem que tomar todas as resoluções, enquanto os menos experientes aprendem. Só que o mesmíssimo argumento é usado para afastar o povo das decisões do governo [...] é por tudo isso que eu acho desagradável e em choque com o que Opinião representa, que você tenha dito 'não quero discutir mais esse assunto'. Por quê? Se a minha posição é fácil de ser contestada, porquê se recusar ao pequeno trabalho?"

${ }^{23}$ Júlio César Montenegro explica que não desempenhava a função de copydesk. Quando escolhia as cartas dos leitores para diagramar, ele não alterava nada e publicava os textos na íntegra. Mas Raimundo Pereira editava o texto de todos. Certa vez, houve um problema na gráfica, que inverteu o sentido de uma manchete de Montenegro. Quando soube do problema, Raimundo teria exclamado algo do tipo 'precisa acontecer isso justo com o texto do Montenegro?', prevendo que haveria confusão porque Montenegro se irritaria com o erro.

${ }^{24}$ O PCdoB (Partido Comunista do Brasil) surgiu do racha do PCB (Partido Comunista Brasileiro) em 1962. Enquanto o PCB defendia a revolução etapista e a aliança entre diversos setores da sociedade para reconquistar as liberdades democráticas, as dissidências do partido, como o PCdoB, defendiam a luta armada contra o regime militar. Ver Aarão; Sá (2006); Segatto (1981).

${ }^{25}$ Formada em 1963, a partir dos quadros da Juventude Universitária Católica (JUC), a Ação Popular (AP) teve forte presença no meio estudantil até 1964. A opção socialista se confirmou em 1965 com a definição de luta armada pela libertação nacional. A Ação Popular acabou se fundindo com o PCdoB em 1973 (Aarão; Sá, 2006). O partido tinha um contato secreto com Opinião através do jornalista Carlos Azevedo, que mesmo na clandestinidade sugeria pautas e enviava textos em segredo para Raimundo Pereira. Sobre esse assunto ver os dois lados do debate: Kucinski e a defesa de Carlos Azevedo (2011), contato da AP com Raimundo Pereira. Segundo Azevedo, a AP teria muitas divergências com Opinião por ser um Jornal de Frente. Portanto, o contato com figuras dos partidos não significaria exercer o controle do jornal. O discurso de Raimundo traz versões flutuantes sobre a influência dos partidos clandestinos nos jornais conduzidos por ele. Por exemplo, em Movimento, Raimundo era o responsável pela coluna Ensaios Populares, mas os textos eram escritos em segredo por um dos líderes da AP, Duarte Brasil Lago Pacheco Pereira.
} 
Para Montenegro, não é pertinente tentar "traçar uma linha torcendo numa direção, o que na época, fluía com fusões. Eram muitas trajetórias para entrelaçar histórias”. Se todos os editores confessam num depoimento ou noutro que foram um pouco radicais ${ }^{26}$, quem resume bem a questão é Tônico Ferreira (Herzog, 2011), ao lembrar que "todos nós" éramos um pouco autoritários no período, com pouco jogo de cintura. Havia briga para tudo na redação, até para demitir um motoboy.

Um pouco do clima daquele período pode ser sentido numa breve história contada em separado tanto por Montenegro, quanto por Bernardet. Ela ilustra uma diferença de pensamento entre as tendências políticas. Raimundo é descrito como um "xiita" que trabalhava "o tempo inteiro". Certo dia, Bernardet e Montenegro resolveram ir à praia e voltaram queimados de sol. Na volta, Raimundo os repreendeu: "como vocês podem ficar na praia, quando o mais importante é a luta contra a ditadura?" Se a história pode parecer inocente à primeira vista, ela revela o quanto a maior parte dos editores do jornal incorporou a ideia de missão e sacrifício à causa. Raimundo fazia parte desta forma de pensar, Montenegro não. A descrição de Raimundo assemelha-se de alguma forma ao ideal do militante do então PC [Partido Comunista] (Sá Motta, 1997). Observamos nos depoimentos dos entrevistados (ver Herzog, 2011) que Opinião substitui o partido e se torna o depositário de todas as energias, como uma forma de renúncia total. A vida toda era dedicada a trabalhar, a varar madrugadas e madrugadas, dormindo às vezes na redação, como fazia Raimundo Pereira. Eles chegavam até a compartilhar as casas com os amigos menos favorecidos, num ideal de solidariedade com alguns pontos em comum com as regras éticas do PC das décadas anteriores (Sá Motta, 1997). Embora os jornalistas da imprensa alternativa pertencessem às dissidências do PCB, eles ainda estavam atrelados à figura do militante estoico, que trabalha sem parar em nome de uma causa política, no caso a resistência.

Se estas discussões correm o risco de enveredar por um viés personalista, interessa aqui relacionar a trajetória pessoal com as tendências políticas internas da esquerda. O relato na primeira pessoa da poetisa Ana Cristina César, através do biógrafo Ítalo Moriconi (1996), refaz esse percurso sobre o dia a dia da seção cultural de

\footnotetext{
${ }^{26}$ Montenegro confessa que não tem distância suficiente para avaliar a questão porque sempre foi amigo de Raimundo e não tinha uma relação de chefe com ele. De certa maneira também teria sido radical. Nesse sentido, ele relembra a frase de Raimundo: "Montenegro, você não pode chegar aqui e querer tudo do seu jeito". Para ele, Raimundo só poderia ser visto como autoritário no sentido de burocrático. Queria um único comando para o jornal, mas o risco dessa postura é o autoritarismo. Afinal um jornal contra a censura deve ter o mesmo critério interno, explica.
} 
Opinião. No relato é possível observar a representação feita das alas da resistência. Nas cartas, Ana Cristina frisava os conflitos e tensões internos entre o nacional popular e a “esquerda libertária” (oposição ao nacional popular). Por motivos diferentes, Raimundo Pereira e Fernando Gasparian encontravam-se na cultura do nacional popular. Isso é explicado por Ana Cristina César da seguinte maneira: o "liberal conservadorista" Gasparian não tinha coragem de ir contra os "medalhões da política" [leia-se o polo nacional popular consagrado na imprensa $\left.{ }^{27}\right]$. O proprietário do veículo queria fazer um “jornalismo cultural de esclarecimento humanista", baseado na ideia de "cultura universal". Para Ana Cristina César, Raimundo representava um "autoritário a serviço da política nacionalista", "populista" e "stalinista do PCdoB". Era comprometido com a "denúncia social" e com uma perspectiva "realista socialista". Como editor-chefe, cabia a ele administrar tensões com três atores sociais: com Fernando Gasparian, com os grandes medalhões da política e com os partidos clandestinos. Esse é o sentido da "Frente Ampla Cultural" para Ana Cristina. Esta descrição de época revela o imaginário de uma parte dos colaboradores de Tendências e Cultura. Para Ana Cristina, o dono do jornal e o editor-chefe privilegiavam a arte engajada, mas deixavam de lado a politização das questões subjetivas. A descrição de Ana Cristina serve para pensarmos a razão da preferência da chefia pelos filmes engajados, narrada pelos críticos de cinema nas entrevistas.

Por fim, Ana Cristina César descreve a seção cultural como vanguarda de pensamento, como uma esquerda autêntica contra a política cultural da Frente Ampla. A atitude dos colegas descrita por ela é a de tentar barrar as influências dos liberais conservadores, dos sociais democratas e do Partidão. Com Montenegro à frente e Ronaldo Brito ao lado, o sonho da equipe era o da auto-gestão. Trazendo temas comuns à contracultura, Ana Cristina César narra que a seção diversificou a pauta em torno do rock, do corpo, da TV e dos debates sobre Jornalismo Cultural entre 1976-1977. O objetivo era discutir o próprio circuito cultural e procurar uma terceira via, longe da mitificação da grande imprensa. Segundo Ana Cristina, a recepção do público foi boa, isto é, a redação recebia longas cartas comentando os artigos. Montenegro conseguia "envolver" os leitores no debate ao publicar as cartas com destaque.

\footnotetext{
${ }^{27}$ Para maiores detalhes, ver o capítulo 6. O nacional popular é entendido aqui como uma cultura política engajada que pressupõe um movimento intelectual de "ida ao povo" para encontrar a expressão da nacionalidade (Napolitano, 2001 a). A cultura do nacional popular alastrou-se pelos artistas engajados. No caso do cinema, por exemplo, o Cinema Novo teve uma inspiração política no nacional popular. Para a definição do termo, ver a introdução desta tese.
} 
Após uma pausa para pensar durante as entrevistas, os críticos afirmam em coro que a censura interna não existia. Jean-Claude Bernardet relembra que jamais Raimundo Pereira nem Fernando Gasparian se envolveram ou intrometeram na área cultural. Nunca vieram comentar nada sobre os textos dele. Caso houvesse algum tipo de pressão, "Montenegro nos protegeria". O "bom humor" dele e a "ironia" aliviavam as tensões, explica. Contudo, Bernardet não nega que ante à tranquilidade da seção de cinema, a de música e teatro eram mais turbulentas. Ele se refere à presença "isolada" do crítico teatral Fernando Peixoto, do PCB. Existiria uma tensão entre o projeto do nacional popular em Peixoto e sua oposição na figura de Montenegro. A disputa seria em torno do imperativo do engajamento, enquanto Montenegro lutava para fazer no jornal a própria crítica da esquerda.

Com mais conhecimento de causa sobre o assunto, Júlio César Montenegro nega a existência de um controle dos textos e o comando único por um partido no semanário. Segundo ele, só no final do jornal, Fernando Gasparian teria exercido a censura interna, imitando a "hegemonia" de Raimundo em Movimento (Ver Capítulo 6). Essa polêmica interna ficou famosa na seção Tendências e Cultura por causa do grupo dos "Dissidentes da Cultural". Na disputa entre os atores sociais de Opinião, o grupo era comandado por Montenegro e lutava contra o controle interno do proprietário do jornal. A disputa se dava em torno da autonomia total de criticar quem se quisesse na área cultural, enquanto Gasparian não admitia a crítica aos artistas consagrados no campo ou aos seus amigos pessoais. Segundo Kucinski (1991), Montenegro permanecia impaciente com a corrente do nacional popular, comandada pelo crítico de teatro Fernando Peixoto. Do outro lado, os dissidentes da cultura exigiam autonomia e liberdade total para a seção de cultura e contavam com o apoio de Luís Renato Martins, Genilson César e Jean-Claude Bernardet. Comentaremos os episódios de "censura interna" através dos relatos dos entrevistados e da documentação encontrada: 1. a polêmica em torno do artigo de Gustavo Dahl sobre o filme Delito Matteoti (1973) de Florestano Vancini ${ }^{28} ; 2$. o caso de Xica da Silva e de Gota d'água ${ }^{29}$.

\footnotetext{
${ }^{28}$ Ver o item sobre Gustavo Dahl no Capítulo 3.

${ }^{29}$ Ver o Capítulo 6 e a Conclusão da tese.
} 


\subsection{A estética do silêncio e a escrita do crítico censurado}

Opinião foi mutilado pela censura do início ao fim. Nasceu e morreu sobre intensa repressão. Um mês após o lançamento, na edição número 8, a situação piorou quando se instituiu a censura prévia ${ }^{30}$. Três dias antes do fechamento, o jornal era obrigado a arcar com os custos do envio de todas as matérias à sede da Polícia Federal em Brasília. O processo atrasava o fechamento do jornal. Por isso quando a edição ia para as bancas, ela já estava desatualizada. A consequência foi uma queda crescente nas tiragens. Para enfrentar a tesoura, a equipe produzia em média uma quantidade suficiente para preencher duas edições na esperança de ver publicadas as tradicionais 24 páginas do semanário. A censura em Opinião acabava por incidir em toda a imprensa. Os jornais eram proibidos de noticiar as apreensões e cortes ao semanário de Fernando Gasparian. Para comprovar é só ler a lista de ordens de censura à imprensa (Marconi, 1980) e observar quantas vezes os jornais não podiam citar a apreensão de Opinião ou a prisão de seus dirigentes ${ }^{31}$.

Enquanto a censura à imprensa diminuía por volta de 1975, quando os censores deixaram a redação do jornal $O$ Estado de S. Paulo, já no contexto de abertura política, a repressão tornava-se cada vez mais feroz em Opinião $^{32}$. Das dez mil páginas escritas, os leitores só tiveram contato com seis mil ${ }^{33}$.

\footnotetext{
${ }^{30}$ Quando Gasparian conseguiu vencer um processo no Supremo Tribunal Federal provando que a censura à imprensa era inconstitucional, o presidente Emilio Garrastazu Médici institucionalizou a censura prévia ao jornal Opinião como "decreto legal" baseado no AI-5. A partir desse momento, a censura foi transferida para Brasília. A edição zero do jornal é de 06 a 13 de nov. 1972. A censura prévia foi instituída na edição n. 8 de 25 dez. 1972 a 01 jan. 1973.

${ }^{31}$ Gasparian e Pereira foram presos, por exemplo, por causa da primeira edição censurada em Brasília. Como os originais atrasaram, a equipe imprimiu o número sem os cortes. Na edição n. 26 , sem maiores explicações para os cortes, Gasparian reclamou das arbitrariedades e foi preso na presença dos deputados Chico Pinto, Lysaneas Maciel e Marcos Freire (Machado, 1978). Maciel contou na tribuna do plenário que o coronel prometeu matar Gasparian, com o dedo em riste. Ele solicitou um projeto de lei tentando limitar os abusos da repressão e também acabou preso, junto com Chico Pinto. Uma entrevista com Dom Helder Câmara rendeu a Gasparian outra prisão. Os chefes do Rio de Janeiro e das sucursais eram regularmente chamados à polícia. Os diretores ou editores do jornal foram detidos por algumas horas mais de uma vez por causa dos textos. Além deles, o diretor de arte, Elifas Andreatto (Herzog, 2011) contou que apanhou na gráfica e teve que sair correndo do censor por causa de uma foto de Dom Paulo Evaristo Arns. Depois de aprovada a imagem, ele usou o vermelho para criar impacto e aproveitar o convênio com a gráfica que garantia o uso de uma cor. O censor saiu batendo nele, porque achou que o vermelho tinha valorizado a imagem e indicava algo agressivo.

${ }^{32}$ Se os censores deixaram a redação do Estadão em janeiro de 1975, a imprensa alternativa só ficou livre da censura prévia em 1978, junto com alguns órgãos da grande imprensa, como a Tribuna da Imprensa. Sobre um histórico da censura à imprensa ver Marconi (1980), Lins da Silva; Festa (1986).

${ }^{33}$ Em números exatos, calcula-se que 100 mil laudas de Opinião não chegaram a ser impressas. Fim de uma etapa (editorial). Opinião. n. 230, p. 6, 01 abr. 1977.
} 
Opinião já era vigiado pelo Departamento de Segurança e Informação (DSI) desde o lançamento, quando os colaboradores são acusados de possuir "vínculos" com o Partido Comunista Brasileiro e de divulgar propaganda subversiva” ${ }^{34}$. A lista não poupava nomes; passava não só pelo dono do jornal e pelo editor-chefe, mas também por Jean-Claude Bernardet, os três com "antecedentes". Nem Paulo Francis e Washington Novaes escaparam à listagem, que incluía também Antonio Carlos Callado, Fernando Henrique Cardoso, Millôr Fernandes, Celso Furtado, Hélio Jaguaribe e Otto Maria Carpeaux. O jornal é denunciado por ser veículo de difusão do pensamento das organizações de esquerda e de "outros notórios comunistas não estruturados".

Algumas palavras como exílio, censura, ditadura, golpe, revolução, tortura, ou temas de natureza social, como assembleias, debates ou reivindicações estavam sempre na mira da censura, segundo Flavio Aguiar (Carneiro, 2002). Podiam ser vetadas com a menor suspeita de que fossem uma alusão ao Brasil, mesmo que remota. O jargão marxista era recebido com tremenda fúria, sobretudo se relacionado aos itens anteriores, ou se descrevesse algo do Brasil. Parágrafos com palavras como classe, burguesia, proletariado, luta de classe eram passiveis de sumir, especialmente se o contexto sugerisse confronto. Outras vezes os censores transformavam frases afirmativas em negativas e vice-versa para alterar o sentido dos textos. Algumas personalidades, como Nelson Werneck Sodré, raramente poderiam ser citadas ou escrever para o jornal. Às vezes não se admitia a menção aos cassados ou intelectuais exilados nos textos. Marcos Gomes (Herzog, 2011) lembra que os intelectuais famosos, como Celso Furtado, se arriscavam ao conceder entrevistas ao Opinião.

Para Tonico Ferreira (Azevedo, 2011), os censores internos na redação durante as primeiras edições duraram pouco porque se percebeu que o editor-chefe, Raimundo Pereira, conseguia convencer os censores através do contato pessoal. Para tentar enfrentar a censura, valia tudo. Como o nome de Ferreira Gullar estava proibido, o editor de cultura, Sérgio Augusto, alterava a grafia para Frederico Gullar. Depois, na gráfica, ele voltava a colocar Ferreira Gullar. A estratégia nunca foi descoberta. Mesmo exilado e "vetado", Gullar podia contribuir escrevendo textos de reflexões sobre arte. Só não podia compor artigos provocadores para não chamar a atenção. "Era assim que a gente conseguia driblar aqui e ali”, conta Augusto. Os censores tinham cismas e

\footnotetext{
${ }^{34}$ Há vários processos internos da censura contra Opinião no site Memórias Reveladas do Arquivo Nacional. Os processos citados aqui são os seguintes: Processo DSI/MJ n. 01.022 e Processo Secom n. 54.414.Disponível em: <http:na.gov.br/mr/Multinivel?Exibe_Pesquisa.asp?v_CodReferencia_ID=41201> Acesso em 09 abr. 2014.
} 
cortavam os textos ${ }^{35}$, mas a equipe tentava enganá-los o tempo todo. Por exemplo, Raimundo fazia o papel de irritado, enquanto Tônico encarnava o de apaziguador, que conversa com os censores. Às vezes a dupla ficava sabendo dos fatos exatamente pelas proibições da censura. Não era também raro uma matéria censurada numa semana ser liberada na semana seguinte. É consensual entre os críticos entrevistados que a crítica de cinema era pouco censurada, seja na imprensa alternativa ou na grande imprensa ${ }^{36}$.

A equipe utilizava algumas estratégias para evitar os cortes: baixar as matérias apenas de madrugada ou tentar vencer os censores pelo cansaço. Os espaços criados pelos cortes eram preenchidos com desenhos, frases ou com uma tarja negra, onde se lia “Assine e Leia Opinião.” O semanário alterava a grafia típica do jornal ou errava de propósito o número das páginas para causar estranheza no leitor. Algumas vezes se utilizou também uma ilustração estilizada de Caetano Veloso e Chico Buarque. Se os espaços em branco eram proibidos, às vezes alguns deles bem pequenos apareciam.

A censura em Brasília, segundo Kenski (1990), era feita em diferentes níveis. O primeiro grupo do Centro de Informações do Exército (CIE) fazia a leitura "crítica" do jornal, para identificar a transmissão de "mensagens". Depois, eles orientavam o trabalho dos censores da Polícia Federal. Um terceiro grupo verificava na gráfica se a impressão correspondia aos cortes estabelecidos. Para agilizar o processo, Opinião contratou um responsável para retirar em Brasília o material censurado e transmitir os cortes por telefone à redação. Tônico Ferreira (Azevedo, 2011) e Flavio Aguiar (Carneiro, 2002) detalham como esse processo de leitura era tenso tanto em Opinião quanto em Movimento. Depois de diagramar todo o jornal com lápis e régua, toda a redação acompanhava por duas a quatro horas a leitura da lista de cortes, linha a linha, não só do texto, mas das ilustrações, charges e manchetes. Até a coluna de xadrez não escapava ${ }^{37}$. A responsabilidade era muito grande, porque ao menor erro, toda a edição poderia ser apreendida (Azevedo, 2011).

\footnotetext{
${ }^{35}$ Júlio César Montenegro conta que tudo era passível de censura. Certa vez o jornal traduziu uma matéria sobre a homossexualidade de Leonardo da Vinci. Por azar, o nome do censor também era Leonardo. Vendo na coincidência uma alusão a sua pessoa, ele vetou o texto.

${ }^{36}$ Maria Rita Aquino (1999) provou quantitativamente que o jornal alternativo Movimento era muito mais censurado do que $O$ Estado de S.Paulo nas seções culturais.

${ }^{37}$ Sérgio Augusto contou que a coluna de xadrez era traduzida. Quando ela foi censurada, estava escrito algo como "peão derruba o rei". Segundo ele, o clima era muito complicado para trabalhar, porque o mundo da censura é o mundo da "paranoia". Uma das saídas contra a censura em $O$ Pasquim era o humor, fazendo brincadeira em tom surrealista. Assim era mais fácil para driblar a tesoura e mandar recados políticos. Mas Opinião era um jornal voltado ao texto, o que dificultava essas estratégias de humor através das imagens caricatas.
} 
Bernardet era muito consciente de fazer no jornal uma "cultura de resistência" dentro de "limites viáveis". A luta dependia do que era possível escrever, "evitando qualquer tipo de provocação”. Mesmo respeitando esses limites, a partir de outubro de 1973, os textos dele foram totalmente vetados pelo censor. Nada no conteúdo justificava a proibição. A solução foi procurar um tom mais ameno ainda. Mas isso não adiantou porque a interdição dos artigos era total. Montenegro, Raimundo Pereira e Bernardet levaram três semanas para concluir que a censura não era ao conteúdo, mas ao nome dele. A partir daquele momento, Bernardet passou a usar o pseudônimo Carlos Murao ${ }^{38}$. O nome falso possibilitava até escrever textos mais "duros", totalmente liberados.

A censura estava presente no cotidiano do trabalho de todos os críticos de cinema de Opinião. Clóvis Marques ficava mais preocupado com a interdição ao próprio texto do que com a censura aos filmes. Qualquer texto dele era escrito na forma de um diálogo com um "militar fantasmagórico de direita. Escrevíamos sabendo que estávamos sendo observados", explica. Por isso os textos são "tão cheios de alusões e metáforas". Se os críticos de Opinião internalizavam o diálogo com a censura nos artigos, na grande imprensa, José Carlos Avellar não levava em conta a censura como critério para escrever no Jornal do Brasil. Para Avellar, ela nunca foi um fator impeditivo do seu trabalho e não interferia no processo de criação. Mas foi por um caso de censura que Avellar passou a escrever em Opinião, como veremos mais à frente. José Carlos Avellar explica que não havia uma grande preocupação com a forma do texto, porque todos os jornalistas sabiam muito bem em que contexto estavam inseridos. Além disso, qualquer repórter teve artigos vetados em algum momento. Repensando hoje o caso, ele acredita que a postura era quase uma irresponsabilidade, porque a responsabilidade legal dos textos ficava nas mãos dos editores.

Alguns percalços relatados acima também existiam nas redações dos grandes veículos. As proibições aos nomes dos diretores e dos filmes chegavam aos jornais por ordem de censura, seja por telefone ou pessoalmente. José Carlos Avellar (Novaes, 2005) relata alguns destes casos na edição revisada do texto A teoria da relatividade. Os exemplos citados pelo crítico do $J B$ não são os mesmos das ordens de censura de vários jornais, transcritas por Paolo Marconi (1980). Afinal a censura dependia do censor, do jornal e do momento político, como relatou Maria Aparecida de Aquino (1999).

\footnotetext{
${ }^{38}$ A autoria dos artigos de Bernardet permaneceu algum tempo em sigilo até mesmo na redação, mas o nome de um colaborador desconhecido gerou muitos comentários na equipe sobre quem poderia ser o tal crítico.
} 
Vários textos de José Carlos Avellar no Jornal do Brasil foram motivo de queixa direta da censura. Foi por um desses atritos que ele passou a escrever no jornal Opinião. Avellar não se recorda de todos os seus problemas com o órgão censório, mas cita alguns: A classe operária vai ao paraíso (1971) de Elio Petri, O processo (1962) de Orson Welles e A queda (1978) de Ruy Guerra. A relação com a censura era de extrema ambivalência. Certa vez enquanto fazia parte do júri do Festival de Brasília, o censor responsável pela fiscalização da programação convidou os jornalistas a uma sessão privada na cabine da censura de filmes proibidos, entre eles Emmanuelle (1974) de Just Jaeckin. Por outro lado, as brechas à censura existiam. Avellar tentava levantar questões políticas através de algum aspecto do filme. A questão era saber qual brecha abrir. Certa vez ele aproveitou o ensejo da tradicional lista dos "melhores filmes do ano" para incluir um filme censurado. O eleito por ele foi $O$ último tango em Paris (1972) de Bernardo Bertolucci. Segundo o texto, a equipe não pôde ver o filme, mas mesmo assim ele tinha sido realizado. Enfim, o filme "existia" mesmo com a ação da censura. Além de tudo, era o melhor do ano. Era lamentável não poder assistir ao melhor filme do ano, escreveu Avellar. O crítico conta que o texto era absolutamente provocativo, mas saiu assim mesmo, provando como não havia uma regra única para escrever sobre filmes censurados. O texto rendeu reclamações à direção do jornal, e Avellar foi chamado para uma conversa com a chefia. Para o jornal, a questão estava bem argumentada. Eles não fariam nada a respeito, mas Avellar não deveria repetir esse tipo de coisa. Sérgio Augusto também aproveitou uma brecha dessas e publicou um texto exatamente sobre O último tango em Paris no Opinião ${ }^{39}$, comentando diretamente a censura.

O Último tango não foi a única estratégia usada por José Carlos Avellar para driblar a tesoura. Noutro momento, o $J B$ estava proibido pela censura de citar os contratos de risco da Petrobrás, mas o crítico aproveitou o lançamento de um filme estrangeiro para estabelecer comparações entre a história e a situação daquele momento. A trama girava em torno de um contrato feito com um assassino. Sem entrar no mérito político, Avellar estabelecia um paralelo entre o significado de um contrato de risco no filme e nas operações econômicas da estatal brasileira. A linha política permanecia subentendida, mas conseguia encaminhar uma leitura sobre a situação.

O texto foi a porta de entrada para Avellar escrever em Opinião. A crítica provocou reações externas e internas. Não agradou aos chefes do $J B$ e causou um

\footnotetext{
${ }^{39}$ Augusto, Sérgio. O tango de Bertolucci: arte ou pornografia? Opinião. n. 15, p 17, 12 a 19 fev. 1973.
} 
desentendimento. Ele continuava em funções internas, mas parou de escrever crítica de cinema por alguns meses. Nesse período, Avellar procurou outros veículos para publicar, seja no Rio de Janeiro ou mesmo em outros estados. Foi assim que ele passou a colaborar em Opinião. Um contexto muito parecido o levou ao Movimento em outro momento.

A estratégia de Avellar não era uma novidade entre os jornalistas, porque a ditadura impedia a expressão natural de pensamento das pessoas. Para Avellar, atos como este dele não significaram "heroísmo". Afinal ser um "falso herói" não adianta. Segundo o crítico, era preciso fazer o "essencial" e isso significava estabelecer reflexões e formas de pensamento nos textos. Ao fornecer informações cinematográficas, o leitor poderia compor suas próprias estratégias de enfrentamento da situação e fazer uma oposição ao estado de coisas. Era assim que Avellar tentava fazer o público perceber o impedimento de dizer algo ou mesmo chamar a atenção para algum aspecto. Dessa forma, ele procurava colocar em xeque o poder. A estratégia era convidar o leitor a compor uma reflexão ou simplesmente a pensar, porque na época o simples ato de insistir num pensamento já era considerado absolutamente subversivo.

A descrição de José Carlos Avellar sobre o dia a dia da crítica de cinema na grande imprensa esclarece porque os críticos deram tanto destaque nas entrevistas à enorme liberdade que existia na seção cultural de Opinião. A censura não era o único problema para comentar os filmes. Os conflitos na grande imprensa passavam longe das acusações de "censura interna" de Opinião. Mas o dia a dia dos críticos era regido tanto por conflitos com os leitores ${ }^{40}$, quanto com os editores. Os desentendimentos eram motivados pela questão do gosto do crítico. Às vezes os editores mandavam parar de escrever, porque o filme ou o tema "não interessavam". Às vezes eles simplesmente implicavam com o tipo de escrita do colaborador. Na outra ponta, os críticos também revidavam e retalhavam os editores, mas sempre numa relação de igual para igual. Afinal todos eram jornalistas da mesma equipe.

Avellar explica que esse contexto faz parte do trabalho normal dos críticos. Segundo ele, até hoje nas redações o tema gira em torno do estilo de narração do cinema hegemônico. As reações negativas por parte dos editores e dos leitores aparecem quando o crítico deixa de apreciar, se entusiasmar e admirar os filmes preferidos do

\footnotetext{
${ }^{40}$ Enquanto trabalhou no $J B$, Avellar recebeu invariavelmente cartões postais de um leitor que distribuía xingamentos a ele e a toda sua família, porque o crítico gostava dos filmes de Luís Buñuel. Avellar declara que nunca se importou com essas histórias, que são simplesmente parte da "excentricidade" dos leitores.
} 
público. Os conflitos são maiores quando o cronista não gosta de um produto ou de um realizador caro. Ou quando estão em jogo produções de grande bilheteria. O cinema brasileiro também causava desconforto na redação, se um articulista defendesse um tipo filme longe do gosto do público. Caso alguém fizesse, por exemplo, a defesa intransigente do Cinema Marginal, poderia causar um confronto não só dentro da redação, mas também com os leitores. Para Avellar, todos esses casos são anedotários porque têm pouca importância na discussão dos filmes. De qualquer forma eles revelam as diferenças no dia a dia do jornal Opinião, onde não havia esse tipo de pressão.

O breve resumo acima exposto não tem a intenção de encerrar o tema. Os casos servem como referência para analisar na sequência as estratégias textuais que os críticos de Opinião usam para denunciar a interdição dos artigos ou para transmitir significados políticos indiretamente. O foco do estudo é observar a forma do texto de Opinião porque o entendimento dos artigos do jornal ao longo desta tese passa por essa relação. A historiografia às vezes cita alguns artigos de Opinião, mas em alguns casos há perdas em termos de interpretação, porque a análise da forma do texto censurado permanece em segundo plano (Ver Capítulo 5). Afinal a censura é um dado determinante sobre o conteúdo e a apresentação dos textos. Para destrinchar as características da crítica espiral-lacunar de Opinião, tomamos como princípio de análise as estratégias do jornal contra o silêncio imposto pelo censor. Está em curso pensar não só o conteúdo da mensagem, mas também a construção do texto censurado.

Se o nosso foco principal é analisar estas estratégias na seção de cinema, alternamos aqui alguns exemplos das demais editorias do jornal, quando os procedimentos adotados chamam a atenção pela originalidade ou relevância do tema. Procuramos enfatizar, quando possível, o critério temporal para revelar o quanto a censura gerou uma linguagem cada vez mais codificada.

Opinião criou uma metalinguagem na qual o leitor deveria compreender o conteúdo extrapolando o sentido linear do texto (Kenski, 1990). Com o passar do tempo, a compreensão do jornal tornou-se cada vez mais ambivalente, por causa da instauração da censura prévia. O processo gerou um tipo de linguagem codificada, de difícil entendimento que foi analisada na pesquisa de Vani Kenski (1990). Segundo ela, a maior parte dos leitores de Opinião não compreendia as estratégias utilizadas para explicitar a intervenção. Muitos deles nem percebiam os espaços em branco ou o excesso de publicidade do próprio jornal, como formas de demonstrar a censura. Alguns chegaram a cancelar as assinaturas, irritados com esse "excesso" na publicidade. 
Não era para esse público que Montenegro dava preferência quando escrevia. Num artigo para a Revista de Cultura Vozes (Montenegro, 1976), ele declarou que o público de Opinião era em sua maior parte universitário e provavelmente entendia o trabalho dele de transmitir significados no texto e nas ilustrações. Esse público descrito por Montenegro foi estudado por Vani Kenski (1990). "Fascinados" pelo jornal, eles tinham o hábito de reler diversas vezes as matérias em busca dos sinais da censura. Estes leitores estavam atentos às tarjas negras. Para eles, o lado hermético do jornal justificava-se pela necessidade de enfrentar a censura. $\mathrm{O}$ simples ato de comprar Opinião representava um ato de resistência, engajamento e coragem. A simples participação na lista de assinantes ou o deslocamento até a banca de jornal significava para esse grupo de leitores um risco, próximo ao da ilegalidade (Kenski, 1990).

Para os que liam o jornal como um grande quebra-cabeças, e como um enigma a desvendar, parece ter sido feita a primeira edição de Opinião. Nela, já existia uma menção indireta à censura. A primeira delas tomou a forma de um debate sobre a função da imprensa ${ }^{41}$ com declarações de jornalistas famosos de grandes veículos. O artigo é uma aula aos leitores de como o jornal deve ser lido. O conteúdo da enquete já passa pelo subentendido, pelo implícito e pela metáfora. Há declarações como: jornais "transformaram-se" em auxiliares da propaganda do governo, ou "todos os governos gostariam de mandar os jornalistas para a masmorra", mas alguns "realmente mandam". Dentre os depoimentos, dois deles chamam mais a atenção para uma leitura do implícito. No primeiro deles, José Hamilton Ribeiro usa o recurso de falar de países estrangeiros para poder transmitir um recado: [A função da imprensa] "nessas circunstâncias, e aqui estou falando da Rússia e de Portugal, deve ser o de preservar a independência, a dignidade de homens livres (ou o que deles ainda resta)". A mensagem segue explicitando a necessidade de se ler nas entrelinhas:

\footnotetext{
"A propaganda (para ficar numa área refrescante) está na sua quando diz que certo dentifrício destrói o mau hálito sem dizer que um de seus componentes é agente do câncer. A imprensa, não. Seja com dentifrício. Seja com... Bem, talvez a maior função da imprensa no Brasil, hoje, seja dizer mais do que vai escrito [grifo nosso]".
}

"Dizer mais do que vai escrito": eis o princípio para se ler Opinião. E logo nesse primeiro número, isso é revelado na matéria. O jornal era obrigado a trabalhar no regime da política do silêncio, isto é, se a censura determina o limite do dizer, o

\footnotetext{
${ }^{41}$ Qual a função da imprensa? Opinião. n. 1, p. 22, 6 a 13 nov. 1972.
} 
jornalista tenta encontrar as formas de dizer algo, mediante o apagamento de outros sentidos possíveis. O texto tem de lidar com a censura que instaura a interdição do dizível para poder dizer, sem dar declarações explícitas. Assim o jornalista procura revelar o que do dizível não se pode dizer e o que é preciso não dizer para poder dizer.

O segundo depoimento é ainda mais explícito, o que não era comum, e fornece um exemplo à declaração de José Hamilton. Pompeu de Souza faz um paralelo com a censura durante o governo Getúlio Vargas para explicar a função da imprensa. O DIP (Departamento de Imprensa e Propaganda) suspendeu três ou quatro vezes $O$ Diário Carioca por causa da coluna A guerra dia a dia, composta por telegramas internacionais. Pompeu explica sem maiores rodeios, e numa linguagem bastante clara, que o DIP praticava uma arbitrariedade, mas não um disparate. O Diário Carioca não tinha reportagem sobre política, apenas notícias oficiais:

"o único jeito de fazer notícia era transformar uma notícia sobre a guerra na Europa em apólogo de política brasileira. Lembro esse remoto episódio apenas para repetir o que é preciso fazer no jornalismo. Sempre, de qualquer maneira".

A base informativa deste texto está nas elipses. O trecho revela as formas de produção de sentido utilizadas pelo silêncio para agir através do não-dito e das significações implícitas. "O silêncio não fala. O silêncio é. Ele significa. Ou melhor: no silêncio, o sentido é". (Orlandi, 1997: 31). Se o objetivo da censura é silenciar e limitar o sujeito no seu percurso de produção de sentido, a forma desse texto revela as estratégias discursivas encontradas para significar em outros locais. O sentido não está alocado em um único lugar, mas se produz na relação entre os sujeitos. Isso porque o sentido não pára, ele só muda de caminho.

Outras estratégias também eram comuns no jornal, com a utilização do fait divers no sentido bartheano ${ }^{42}$. Em 1975, a chamada de capa era a seguinte: "A resistência contra a ditadura". Ao abrir a edição, o leitor encontrava no conteúdo uma descrição do historiador Edgard Carone sobre o funcionamento não da Ditadura Militar, mas do Estado Novo ${ }^{43}$. Internamente, as informações metafóricas sobre 1937 também diziam respeito ao regime de 1964. Para analisar o trecho, adaptamos o conceito de fait

\footnotetext{
42 A definição dada aqui ao fait divers é de Roland Barthes (2003 a) e explica algumas estratégias adotadas em Opinião. Não se trata do sentido clássico de fait divers como notícia extraordinária transmitida em forma romanceada num registro dramático (Meyer, 1996). Usamos Barthes porque ele explica a forma de funcionamento do mecanismo do fait divers ao leitor.

${ }^{43}$ Carone, Edgard. A resistência contra a ditadura. Opinião. n. 162, p. 12-3, 12 dez. 1975.
} 
divers de Roland Barthes (2003 a). Para o autor, o fait divers é fechado em si mesmo. A explicação é dada sem remeter a outros conhecimentos prévios do leitor. Trata-se de uma informação total, imanente que contém em si todo o seu saber. Em Opinião, dá-se o encontro do fait divers censurado com o implícito, porque o entendimento depende do conhecimento de outros significados.

A forma de ação do fait divers implícito de Opinião segue a descrição bartheana. Ele age por espanto a partir de um conteúdo incerto ou pela imprecisão entre causa e efeito. Ao ler a manchete e a capa, o leitor cria uma expectativa de encontrar informações contrárias à ditadura. Logo em seguida vem a decepção com o conteúdo, porque o público percebe que as informações são relativas ao Estado Novo. Assim o fait divers de causalidade decepcionada funciona porque a causa revelada é sempre mais pobre do que a prometida. A partir do espetáculo da decepção bartheano, a notícia censurada pode adquirir novos significados para o leitor, porque a causalidade é tanto mais notável quanto mais é decepcionada. Esse mecanismo propicia ao fait divers realizar-se em toda a sua forma. A decepção converte-se exatamente na força do relato, dando luz às outras significações. $O$ espanto tenta acender no leitor novos entendimentos do texto, que não estão explicitados. Através do espanto se dá o entendimento do sentido outro.

O fait divers sempre trabalha mantendo no público o hábito da intervenção (Meyer, 1996). Barthes também esclarece que o fait divers tudo explica, mas algo foge do leitor. Há forças que constantemente lhe escapam. As causas parecem penetradas pelo acaso ou pela coincidência. No caso de um jornal censurado, a resposta está logicamente ao lado da coincidência. Se algo foge ao entendimento do leitor, ele consegue gerar uma significação outra, ao instaurar o mecanismo da dúvida. A partir da repetição dos fatos, se gera, portanto, outra significação.

$\mathrm{O}$ encontro do fait divers com o implícito é em Opinião uma estratégia de migração de sentido através da utilização de fatos históricos do passado para reinterpretação através de metáforas. Constrói-se aqui um outro sentido que não é exatamente um sentido contrário ou uma denegação, mas o sentido a que o autor faz referência (Orlandi, 1997). Através da alusão, se diz outra coisa. Assim o texto passa a significar pelo avesso, pelo seu duplo.

Outras formas também eram comuns em Opinião, tais como noticiar o aniversário da Declaração de Direitos Humanos ou do Ato Institucional Número 5 (AI5), ou ainda citar a missa de Dom Paulo Evaristo Arns como brecha para abordar um 
caso proibido: o assassinato do estudante Alexandre Vannucchi pela repressão ${ }^{44}$. Este último caso é interessante para apontar a utilização da composição visual e da forma textual do jornalismo informativo como recurso frente à censura. Como a imprensa foi proibida de publicar notícia sobre a missa de sétimo dia de Vannucchi, Opinião teve de inovar para informar. No alto da página se lê a manchete: Missa para um estudante morto. Logo abaixo há uma tarja negra, com a inscrição: "Leia e Assine Opinião". A tarja negra reveste-se aqui de novo significado: o luto. Descendo mais os olhos, o leitor encontra uma segunda matéria: Nota oficial sobre a morte do estudante Vannucchi.

A primeira matéria inicia com o sermão do padre durante a missa de sétimo dia do estudante da USP. Esse último dado aparece em itálico e se converte na chave explicativa que liga as duas notícias. A missa recebeu "três mil pessoas", com um número "inusitado" de estudantes universitários. O celebrante, Dom José Melhado Campos, rezou "pelo nosso irmão", "para que sua vida e morte não tenham sido em vão". No segundo parágrafo a mensagem é um pouco mais clara: Dom Paulo Evaristo Arns, co-celebrante, declara: "Cristo, mesmo depois de morto foi devolvido aos familiares e amigos: essa justiça fez o representante do poder romano".

A manchete do segundo artigo procura esclarecer que seu conteúdo é uma versão oficial. Portanto, a estratégia é tentar se eximir da responsabilidade pelos fatos descritos. Não se trata de matéria jornalística, mas da versão do governo. Para não deixar dúvidas, a única descrição dada é a do delegado sobre "os fatos que culminaram com a morte de Alexandre Vannucchi Leme, estudante do $4^{\circ}$ ano de Geologia da USP”. Preso por pertencer a uma "organização subversiva", "autodenominada" Ação Libertadora Nacional, ele "foi levado" à rua para encontrar dois companheiros. Tentou fugir e foi atropelado por um caminhão. Esta segunda matéria com a versão da ditadura completa a declaração lacunar de Dom Paulo Evaristo Arns sobre o corpo de Cristo, quando o general explica que o corpo não foi "reclamado", e por isso, foi enterrado. Na verdade, Vannucchi foi sepultado como indigente. Assim, através da estrutura do texto jornalístico, Opinião traz a informação faltante através do não-dito.

O funcionamento da matéria parece agir por uma sensação de estranhamento. Estranhamento porque as informações básicas do jornalismo não estão no primeiro texto, nem no primeiro parágrafo, como manda o lead: falta o nome do estudante e a causa da morte. Desta "falha" e da insistência no tema, que ocupa metade da página, se

\footnotetext{
${ }^{44}$ Há duas matérias sobre o caso: Missa para um estudante morto e Nota oficial sobre a morte do estudante Vannuchi. Opinião. n. 22, p. 5, 2 a 9 abr. 1973.
} 
tenta levar o receptor a "completar" os dados faltantes. Aqui o "dizer" precisa da falta. Assim, o leitor mais atento é levado a reconstruir os fatos, através da "costura" das notícias fragmentadas ${ }^{45}$. Através do preenchimento das lacunas, o público encontra as informações suprimidas do primeiro texto.

O mecanismo pressupõe ainda uma ordem de leitura. Para alcançar a significação implícita, o leitor deve passar primeiro pela significação literal (Ducrot, 1977). Contudo, o processo pressupõe uma escolha. Cabe ao ouvinte responder com a significação escolhida. Esse tipo de transmissão de sentido descrito acima faz uso do texto jornalístico informativo. Trata-se da forma mais simples e mais comum presente em Opinião. O número de matérias com este formato é muito maior do que o uso do tom opinativo, provavelmente para evitar a interdição dos textos. Um dos exemplos é a discussão sobre a criação do Conselho Superior de Censura (CSC). No segundo semestre de 1975, é divulgado na imprensa a disposição do governo de regulamentar o Conselho como uma instância para os artistas recorrerem. Naquela época, Opinião publicou dois artigos sobre o tema. No primeiro, o tom é informativo. O jornal apenas declarou ser cedo para avaliar a iniciativa do governo, sem se posicionar diretamente. ${ }^{46}$ No segundo, apresenta-se um material opinativo, mas com o cuidado de designar as informações como versões de terceiros, para evitar a responsabilidade. O semanário toma o cuidado de colher e balancear informações de artistas e intelectuais contrários e a favor da criação do Conselho. Enquanto Nelson Werneck Sodré declara não admitir "em hipótese alguma" a censura, Arnaldo Jabor toma outro rumo. Não responde à pergunta feita, e inverte o alvo. Segundo ele, a censura deveria existir para reprimir a "desconfiguração cultural e moral causada no público brasileiro pelos filmes estrangeiros". Assim, sem precisar explicitar sua opinião, o jornal transmite mais de uma forma de refletir sobre a notícia.

Outra estratégia encontrada pelo semanário para transmitir informações era a publicação de artigos de periódicos estrangeiros. Opinião conseguiu um acordo para publicar artigos de importantes jornais estrangeiros, como o Le Monde, The Guardian, The Washington Post, The New York Review of Book e New Statesman. Através das matérias traduzidas, o jornal abordava indiretamente a censura e a ditadura, por intermédio da comparação com outros países, como por exemplo, relatar o

\footnotetext{
${ }^{45}$ Sobre a forma fragmentada do jornalismo diário, ver Ciro Marcondes Filho, O Capital da Notícia. São Paulo: Editora Ática, 1989.

${ }^{46}$ A criação do conselho superior de censura. Opinião. n. 118, p. 4, 07 fev. 1974.
} 
desaparecimento de jornalistas da imprensa alternativa soviética pelo Kremlin ${ }^{47}$. A estratégia não durou muito tempo, porque em 25 de outubro de 1972 a censura proibiu qualquer informação sobre medidas impostas a jornais vindos de agências de notícias estrangeiras (Marconi, 1980). Essa ordem de censura parece criada para Opinião tal a proximidade temporal entre sua publicação e a estratégia utilizada. Com cada vez mais cerceamentos, o semanário tinha que criar subterfúgios cada vez menos evidentes.

Às vezes a mensagem era dirigida a um público mais restrito ainda. Nestes casos as lacunas do texto pressupõem um conhecedor da história do cinema. Num desses casos, o autor anônimo ${ }^{48}$ cita uma declaração de Roberto Farias sobre a importância do filme histórico como forma de estimular o sentimento nacionalista do povo. A conclusão aparece em forma lacunar. "Como nos tempos da UFA?”. A frase não faz referência só à tradicional empresa cinematográfica alemã (Universum Film AG), mas a sua existência durante o regime nazista. A comparação entre os dois regimes autoritários ficava a cargo de um leitor proficiente.

Certa vez Opinião virou o feitiço contra o feiticeiro. O jornal publicou na íntegra o próprio documento oficial do regime militar, contendo as proibições da censura. A matéria em questão chamava-se Documento - A advertência do Ministério da Educação com os temas interditos para a área cultural ${ }^{49}$. Segundo o material, o cinema é uma das mais poderosas armas de subversivos para facilitar a divulgação de mensagens. Os "comunistas" usam este meio para "difundir mensagens", explorando temas como a política, a violência e a pornografia. De maneira concreta, o parecer cita nomes:

\begin{abstract}
"No Brasil essa forma vem sendo paulatinamente difundida e desenvolvida, encabeçada por alguns cineastas como Glauber Rocha, Rui Guerra, discípulos e seguidores de Godard. (...) Sob o rótulo de Cinema Novo, eles usam temas regionais para insuflar a luta armada contra o poder opressor, mostrando a violência policial de uma forma exagerada, gerando uma animosidade do povo em relação ao poder constituído. $\mathrm{O}$ próprio Glauber diz que o Cinema Novo no Brasil só terá sentido se estiver na vanguarda da mais agressiva e imediata luta sem reconciliação. 'Temos de fazer o cinema da miséria, na cultura da fome"”.
\end{abstract}

\footnotetext{
${ }^{47}$ Seeger, Murray. A caça ao underground soviético. Opinião. n. 2, p. 22, 13 a 20 nov. 1972. Artigo traduzido do The Guardian.

${ }^{48}$ Um cinema edificante. Opinião. n. 161, p. 23, 05 dez. 1975. Pelo estilo e construção, o texto parece ter sido escrito por Jean-Claude Bernardet.

${ }^{49}$ Documento - A advertência do Ministério da Educação. Opinião. n. 66, p. 5, 11 fev. 1974. O material cita o igual trecho do folheto produzido no final do governo Geisel, chamado Como eles agem, citado por Marcos Napolitano (2011: 197).
} 
A publicação deste documento oficial na íntegra permitia expor a proibição aos leitores. Além disso, o teor de "absurdo" do comunicado tornava mais fácil o entendimento da mensagem, sem que o jornal tivesse de enumerar os nomes dos diretores censurados e "subversivos". Com esse subterfúgio, Opinião faz do documento oficial uma arma contra a censura. A afirmação de Glauber Rocha no final do texto torna possível a existência de duas zonas de significação. Se o objetivo do órgão oficial era destacar seu caráter "subversivo", a frase com aspas permitia realizar uma "propaganda" das ideias do cineasta: "Temos de fazer o cinema da miséria". Chama a atenção também o uso polissêmico da palavra "poder opressor" no próprio texto oficial. Trata-se, portanto, de uma forma clássica de migração de sentido do discurso da opressão com o mesmo enunciado deslocado para o sentido da resistência.

O trecho revela o quanto o discurso da censura e o discurso da resistência coexistem no mesmo sistema discursivo (Orlandi, 1997). A retórica da dominação caminha lado a lado à retórica da resistência. Ao silêncio imposto pela censura, a resistência responde com o silêncio de outros significados constituídos numa outra área, onde é preciso não dizer para poder dizer. Assim o silêncio pode significar de outros modos. Enquanto o autoritarismo procura impor um entendimento único para toda a sociedade, a resistência diz "o mesmo", através do que é permitido declarar. No entanto, ela relata outra coisa, quando revela o proibido. Como as duas formas coexistem, não há censura completamente eficaz, porque os sentidos sempre escapam. É por isso que Opinião consegue denunciar a censura aos diretores de cinema brasileiros ao transcrever o discurso oficial.

Os dois críticos de cinema de Opinião responsáveis por discutir mais de perto a censura são Sérgio Augusto e Gustavo Dahl. O primeiro artigo do jornal a comentar a interdição ao cinema é de Augusto ${ }^{50}$. Em tom de contestação, ele enfrenta a censura textualmente: "Nada de corte ou interdições. Cabe ao público decidir o que vai assistir". E o espectador "quer ver a versão integral", declara. Se este texto é anterior à instituição da censura prévia, depois dela, Sérgio Augusto vai ainda mais longe. Ele chega a declarar: "Estaremos cobrando junto ao INC e o Ministro Jarbas Passarinho uma alteração na legislação cinematográfica, e lembrando ao Ministro da Justiça que num Brasil em ritmo de país grande não faz sentido uma censura tão retrógrada como a nossa" 51 . Esse tom contestador à censura de Sérgio Augusto foi corajoso e inédito em

\footnotetext{
${ }^{50}$ Augusto, Sérgio. O que se pode ver. Opinião. n. 6, p. 19, 11 a 18 dez. 1972.

${ }^{51}$ Augusto, Sérgio. Ajuste de contas. Opinião. n. 10, p. 21, 8 a 15 jan. 1973.
} 
Opinião, porque a Polícia Federal passou a proibir a publicação de críticas ao sistema de censura ou a qualquer notícia contra o órgão censor desde 4 de junho de $1972^{52}$. É por esse motivo que nas primeiras edições há mais declarações claras contra a censura no jornal, indicando uma "liberdade" um pouco maior. Na comparação com outros jornais, é possível observar o quanto o ato de citar o nome dos filmes censurados sem rodeios, como fez Sérgio Augusto nas duas matérias citadas acima, não era muito comum. O colega de redação do $J B$, José Carlos Avellar relata como era difícil escrever sobre os filmes de Glauber Rocha ou de Costa-Gravas. Existia uma proibição de falar qualquer coisa sobre $Z$ (1969). A equipe do $J B$ tentava fazer uma menção aqui e acolá, indicando quais os filmes passavam no exterior, mas não no Brasil. Opinião usava o mesmo critério.

Enquanto Augusto recorre ao gênero informativo, inserindo opinião no meio das notícias, Gustavo Dahl utiliza a estratégia do ensaio para falar da censura em tom analítico e opinativo. Nos seus dois artigos sobre esse assunto, ele não contesta o direito de o Estado exercer a censura. Para permitir a publicação, o autor destaca logo no subtítulo que não se quer discutir a existência da censura, mas sua relação com a cultura 53. Nesta mesma linha, o articulista aproveita para fazer elogios a Geisel. Mas logo em seguida, Dahl comenta a "decepção" com a distensão lenta e gradual do presidente, que teve o "mérito" de ter ferido questões totalmente fechadas, dentre elas a censura ${ }^{54}$.

Se num primeiro momento, Dahl parece não contestar a censura ao declarar: [ela é] "antes de tudo policial naquilo que a palavra tem de mais indiscutível, isto é, se refere à ordem pública, preocupação e função do Estado", a continuação prevê uma leitura irônica. "Quando proíbe ou corta, baseada na mesma fonte de direito que permite o uso de armas pelos policiais ou fecha com grades as prisões: a meta é a defesa da sociedade como um todo, a repressão: aos que estejam fora da lei”. O trecho é tipicamente uma zona discursiva mista. O crítico incorpora o argumento da necessidade da Lei de Segurança Nacional, mas não se furta a fazer a resistência na mesma zona discursiva, através do implícito da afirmação. Indo de encontro aos temas polêmicos, ele diferencia no artigo a censura contra o crime comum e a aplicada aos meios de comunicação de massa. Não se trata de lidar com assaltantes, mas com a população. Portanto, a censura acaba produzindo cultura. A crítica mais forte do texto é feita de maneira

\footnotetext{
${ }^{52}$ Para consultar a lista das ordens de censura, ver Marconi (1980).

${ }^{53}$ Dahl, Gustavo. Censura e cultura II. Opinião. n. 125, p. 24, 28 mar. 1975.

${ }^{54}$ Dahl, Gustavo. Censura e Cultura I. Opinião. n. 124, p. 22, 21 mar. 1975.
} 
individualizada. Ao comentar o componente de auto-agressão dos censores, Dahl os toma como casos isolados e individuais. Mas ele aproveita para lembrar que eles acabam censurando a si mesmos, porque também fazem parte da cultura brasileira.

Quando Dahl elogia o Estado, ele está utilizando a língua-de-espuma (Orlandi, 1997). Trata-se de uma língua de uso imediato, que historicamente é falada pelos militares durante a ditadura de 1964. Por meio do senso comum e do sentido de fôlego curto, ela tenta silenciar os desdobramentos do sentido, evitando repercussões. Através da língua-de-espuma, o crítico faz sua manifestação da resistência. Ele age na mesma região estabelecida pelos militares, mas produz desdobramentos em seu significado. Ao simular o senso comum, ele revela o proibido para o dizer.

O segundo artigo de Gustavo Dahl ${ }^{55}$ traz como ilustração um olho rodeado por uma mão de animal com enormes unhas. $O$ artigo pode ser lido como uma zona interdiscursiva. Ao mesmo tempo Dahl traz um discurso conciliador, mas expressa um viés irônico de resistência. $\mathrm{O}$ trecho final reserva uma crítica indireta à censura: como a cultura aceita a censura, esta última também deveria encarar a cultura e a renovação de valores como necessidade da população. Se todos têm a "utopia de um Brasil melhor", resta definir, "se do ponto de vista da censura, do poder, do estado, a cultura tem alguma contribuição a dar para tornar esta utopia possível”. A indagação deste trecho procura fazer o público preencher os espaços e impor ao destinatário (tanto o leitor quanto o censor) esta dúvida. Ducrot (1977) mostra como o ato indireto de interrogar o leitor tem a função de afirmar de modo implícito um direito a interrogar, tal qual Dahl fez. Depois da publicação deste artigo, Dahl parou de escrever em Opinião. Logo depois, ele tornou-se assessor de Roberto Farias e diretor da Distribuição da Embrafilme.

O filme censurado que recebe maior espaço em Opinião é de longe São Bernardo (1972) de Leon Hirszman. O lançamento só ocorreu um ano e meio depois, porque a obra ficou retida na censura por sete meses, gerando a falência da empresa Saga, de propriedade do diretor (Simões, 1999). Opinião publicou dois artigos sobre ele. O primeiro deles, de autoria de Jean-Claude Bernardet ${ }^{56}$, considera o filme uma produção inesperada e uma interrogação lançada ao público culto. $\mathrm{O}$ enredo nasce de uma "análise da sociedade", explica o crítico. As situações apresentadas pelos personagens são também uma "síntese das contradições sociais brasileiras", mas o autor

\footnotetext{
${ }^{55}$ Dahl, Gustavo. Censura e cultura II. Opinião. n. 125, p. 24, 28 mar. 1975.

${ }^{56}$ Bernardet, Jean-Claude. Uma voz inesperada. Opinião. n. 7, p. 22, 18 a 25 dez. 1972.
} 
não explica como. Só lança indagações. Neste texto, ele não analisa as cenas, como costumava fazer, talvez para evitar transmitir informações aos censores ${ }^{57}$.

Dois anos depois, Jean-Claude Bernardet voltou ao tema, quando o filme foi lançado numa entrevista com Leon Hirzsman. O artigo foi escrito com o pseudônimo de Carlos Murao. Mesmo num jornal censurado, o entrevistador pergunta se o livro dialoga com o presente e com a realidade atual ${ }^{58}$ : “A adaptação de um livro antigo para falar do presente foi apenas uma opção de criação ou a busca de um amparo numa obra clássica embora polêmica?" Depois Bernardet questiona se a adaptação de livros "não corre o risco de afastar o cineasta de uma análise da realidade atual", falando só "através de alusões" ao passado.

A única informação dada por Hirszman é a de que o filme tem relação com o país, mas ele não confirma se a ligação é com o presente ou com o passado. Ele foge literalmente da resposta. Muda de assunto e sai pela tangente. Antes o cineasta tinha explicado que os filmes importantes revelam a realidade brasileira. Portanto, a construção do sentido depende, na verdade, da reelaboração e repetição do conteúdo da pergunta anterior.

O trecho revela a função da incompletude (Orlandi, 1997) que é fundamental no dizer e produz a possibilidade do múltiplo. É exatamente o silêncio discursivo de Hirzsman na entrevista quem preside essa possibilidade. Ele significa o nada se multiplicando em sentidos. Quanto maior o silêncio de Hirszman, maior será o espaço para outras significações. A falta de resposta do cineasta e o caráter incompleto da linguagem utilizada por ele fundamentam o movimento de interpretação do leitor e propiciam a condição de pluralidade da língua.

Este silêncio do diretor se caracteriza como uma deixa para o leitor refletir sobre as cenas do filme. São Bernardo conta a trajetória do comerciante Paulo Honório até conseguir a posse de uma fazenda. Em meio à história de ciúme doentio por Madalena, sua esposa, a trama revela a situação social dos agricultores porque o fazendeiro coloca em prática a ideia de "coisificação do homem" pelo sistema econômico.

\footnotetext{
57 São Bernardo ficou pronto em março de 1972. A censura reteve o filme por sete meses, liberando-o com muitos cortes (15 min.) e restrições em novembro de 1972. O filme podia ser exibido, mas o diretor não aceitou os cortes. Após o prêmio Margarida de Prata da CNBB (Conferência Nacional dos Bispos do Brasil), começou o processo de liberação do filme sem os cortes. São Bernardo só foi liberado mesmo e lançado em outubro de 1973. Simões (1999), Ramos (2000). Os certificados da censura estão disponíveis no site do Memória da Censura no Cinema brasileiro 1964-1988. w.w.w.memoriacinebr.com.br

${ }_{58}$ Ninguém vai sozinho ao paraíso. Entrevista concedida a Carlos Murao (pseudônimo de Jean-Claude Bernardet). Opinião. n. 87, p. 16, 08 jul. 1974.
} 
Após meses de luta para liberar a obra, Hirszman não iria explicar como São Bernardo revelava o presente, nem iria detalhar as sequências onde realizou uma forma de denúncia social mais clara. Da mesma forma, Bernardet também não o faria. Porém, ele deixou a comparação, a partir do preenchimento de lacunas. Assim, o cineasta declara: "Brecht disse que num tempo em que o artista não consegue dizer tudo aquilo que quer", ainda assim ele "deve continuar trabalhando para que quando mudarem as condições o que for dito possa ser dito melhor". A frase segue à risca a análise de Eni Orlandi sobre o implícito.

A pergunta de Bernardet e o silêncio de Hirszman permitem a compreensão do sentido, sem incorrer na responsabilidade do dizer. Quem explica esse mecanismo é Oswald Ducrot: "Tem-se frequentemente a necessidade de dizer certas coisas e ao mesmo tempo de poder fazer como se não as tivéssemos dito, de dizê-las mas de modo tal que se possa recusar a sua responsabilidade" (Ducrot 1977: 13).

O mecanismo evita que uma informação explicitada torne-se tema de discussão. Se o subentendido tem a vantagem de poder sempre se retratar, como fica a responsabilidade do dizer nesta entrevista? A resposta está na descrição das manobras estilísticas de Oswald Ducrot. A responsabilidade do locutor está restrita à significação literal. Ele sabe que o destinatário vai procurar as motivações possíveis do ato de enunciação, além de se interrogar sobre as consequências dos fatos enunciados. $\mathrm{O}$ destinador procura trazer o destinatário para seu jogo e dirige seu raciocínio à distância. Para tal, ele fornece os dados suscetíveis de levar o leitor a esta ou aquela conclusão. Nesse jogo, o autor pode suscitar certas opiniões no destinatário, sem correr risco. Ao mostrar-se como uma interpretação do público, a significação implícita não parece prevista pelo locutor. Ao contrário, apresenta-se como uma reflexão crítica do destinatário, muito mais do que uma decifração. A estratégia pressupõe duas ações, segundo Ducrot (1977: 24): 1. "Queremos que o ouvinte saiba que quisemos fazer que ele soubesse alguma coisa"; 2. "Garantimos, apesar de tudo, o poder de negar tal intenção". Portanto, a manobra estilística só surte efeito se fundada numa condição de segredo. O sucesso dela depende do não-reconhecimento. Assim o locutor só pode negar ter dito, porque, de fato, ele não disse. Como consequência, a significação implícita é posta sob a responsabilidade do ouvinte. É ele quem tira as conclusões e arca com os riscos da interpretação literal e implícita.

O que não se podia dizer neste artigo? Não se deveria revelar que a forma encontrada para analisar a sociedade atual, a crítica implícita à exploração do trabalho, 
estava não só na história do fazendeiro, mas também na parte final do filme. Bernardet só faz menção à ideia de "coisificação do homem pelo processo econômico" para perguntar como esse processo se reflete nos dias atuais. Nas cenas finais do filme, as cenas documentais revelam camponeses em condições de vida precárias. As imagens completam as sequências apresentadas durante a trama e tem um caráter de denúncia: são imagens "atuais" da pobreza no campo. Essa foi a forma encontrada para mostrar a situação social "do presente" por Hirszman, de que tanto fala Jean-Claude Bernardet, sem explicar como.

A matéria abre uma pergunta: era possível escrever sobre filmes censurados em Opinião? Sérgio Augusto explica em entrevista que não tinha como escrever, porque era uma luta inglória, afinal os textos "não saíam". Escrever um texto sobre algo que vai ser censurado ou considerado provocador era para ele perda de tempo e uma espécie de "autocensura". Para escrever sobre filmes recém-liberados, como São Bernardo, era preciso ter "muita cautela". Só era possível transmitir mensagens na entrelinha se fosse "bem indireto".

Para comentar os filmes realizados no exterior por Glauber Rocha, Opinião citava a crítica internacional e terminava com um comentário do tipo "infelizmente a obra não chegará ao Brasil ${ }^{59}$. Sem comentar o porquê, os leitores teriam de costurar o nome de Glauber Rocha como diretor taxado de "subversivo" pelo documento oficial publicado antes em Opinião ${ }^{60}$, como vimos. Assim era possível entender a razão da não-importação. O processo de preenchimento das lacunas ficava por conta do público. Se Glauber Rocha não recebeu uma matéria sequer em Opinião, só pequenas notas, o silêncio tentava significar mais que a aparição do nome dele.

$$
* * *
$$

É possível adentrar mais no processo de confecção do jornalismo mediante a censura, a partir do material não publicado do jornal. O estudo permite observar a transformação interna do texto, a partir dos rascunhos disponíveis de Bernardet ${ }^{61}$. Analisamos o processo de confecção crítica dele a partir de um trabalho comparativo.

\footnotetext{
${ }^{59}$ A clareza de Glauber. Opinião. n. 143, p. 23, 01 ago. 1975.

${ }^{60}$ Documento - A advertência do Ministério da Educação. Opinião. n. 66, p. 5, 11 fev. 1974.

${ }^{61}$ Publicamos na revista Rebeca uma parte do estudo sobre o processo de confecção crítica de Bernardet no comparativo entre o caderno de anotação de filme e o artigo publicado em Opinião. Ver Adamatti, Margarida Maria. Jean-Claude Bernardet assiste a Os Mansos (1973): anotações para estudo de filme. Rebeca. Ano 3, Edição 5, jan. jun. 2014.
} 
Para o número zero, o crítico preparou um artigo sobre os filmes históricos, analisando especialmente Os inconfidentes de Joaquim Pedro de Andrade (1972) ${ }^{62}$ :

"Os Inconfidentes tem uma certa aspiração popular, mas não passa de aspiração, pois eles estão estruturalmente ligados, não ao povo, mas sim à aristocracia local, à futura classe dirigente brasileira. (...) Os Inconfidentes é um filme mais interessado no intelectual de hoje no Brasil do que na inconfidência mineira."

Esse artigo não saiu em Opinião. Contudo, o crítico publicou mais de uma análise deste filme na imprensa e o rascunho pode ter sido uma pesquisa para escrever as demais matérias ou um texto censurado. Quase três anos depois, por causa do lançamento de Guerra Conjugal (1974), Bernardet retomou a análise da obra de Joaquim Pedro de Andrade em Opinião ${ }^{63}$. A ligação entre os dois filmes para Bernardet faz parte da estratégia do autor de aceitar as armas do inimigo, seja a fórmula da comédia erótica ditada pelo mercado (Guerra Conjugal) ou usando o incentivo do governo ao filme histórico (Os inconfidentes):

"Em 1972, (...) Joaquim Pedro realiza um filme histórico sobre a Inconfidência Mineira, aparentemente entrando na onda e atendendo às expectativas expressas pelo governo. Em realidade, ele aceita as armas propostas pelo parceiro, mas é para voltá-las contra os objetivos almejados por esse parceiro.

Joaquim Pedro finge aceitar a regra do jogo, penetra e mina por dentro. Os Inconfidentes não apresentou uma concepção gloriosa e heróica, e no fundo marcada e ingênua, da história do Brasil. Os Inconfidentes representa o mais alto grau de contradições a que chegaram os intelectuais-cineastas na época, e o grande valor do filme é justamente o de ter feito aflorar claramente estas contradições."

A análise ampliada do filme foi publicada no livro Piranha no mar de rosas no texto $O$ caso Tiradentes, notas (Bernardet, 1982: 69-84). Ela foi feita a partir das conclusões dos Seminários sobre História do Brasil e Cinema de Jean-Claude Bernardet realizados no Instituto Goethe. O texto descreve o mecanismo da quebra da quarta parede, quando os atores se dirigem ao público, rompendo com o espaço ficcional. Primeiro Bernardet explica ao público como o filme histórico só significa para o presente. Depois, ele analisa Os Inconfidentes à luz da política cinematográfica para mostrar como o incentivo a esse tipo de produção tem fins ideológicos. Como no caso de São Bernardo, Jean-Claude Bernardet tinha um motivo para não completar a análise

\footnotetext{
62 Acervo Jean-Claude Bernardet. Cinemateca Brasileira. Pasta DJ/13. Anotações, rascunhos e textos originais publicados em Opinião 1972-1973.

${ }^{63}$ Bernardet, Jean-Claude. Com as armas do inimigo. Opinião. n. 127, p. 20, 11 abr. 1975.
} 
fílmica em Opinião. Os censores liberaram o filme, mas ficaram intrigados com algo que não sabiam determinar (Simões, 1999). Não seria Jean-Claude Bernardet quem explicaria isso aos censores através da imprensa alternativa. Portanto, em casos como este, o próprio estilo textual de Bernardet muda para evitar dar informações à censura.

Estamos aqui numa área fronteiriça entre a censura, a auto-censura $\mathrm{e}$ as estratégias de resistência na mesma zona discursiva. A maior parte dos rascunhos tem o estilo geral dos artigos de Bernardet: o texto é claro, direto, objetivo. No rascunho para Opinião, o crítico explicita com todas as letras a relação com a política atual e a crítica ao intelectual "de hoje". No texto publicado, há frases indiretas, supressão de sentidos e lacunas para evitar a interdição dos filmes.

É possível também fazer um estudo intermediário sobre o processo de edição jornalístico dos entrevistados do semanário. O caso prova o quanto Opinião era mais censurado e o quanto essa forma espiral-lacunar incidia até nas declarações dos entrevistados. Tomamos como exemplo o mesmo filme. Em Opinião, Joaquim Pedro de Andrade apenas comentou que não teria feito Os Inconfidentes sem o apoio da TV italiana. Em Opinião, o diretor usa de eufemismos para explicar que o filme fala do presente ${ }^{64}$. Mas não há maiores informações sobre como isso é feito:

"O cinema que se faz hoje no Brasil reflete muito de perto as diversas contingências políticas e sociais que o país vai atravessando. De um lado, notamos a forte pressão que se exerce através da seleção de financiamentos (roteiros aprovados) e também através de cortes e proibições. (...) O que observamos é o surgimento de uma espécie de hipocrisia, isto é, as pessoas em cinema estão proibidas de tratar com verdade uma série de temas."

Os comentários discorrem sobre a censura. Isso fica claro se comparamos a entrevista em Opinião com o material publicado na revista Visão ${ }^{65}$. Nela, Joaquim Pedro fala abertamente de como Os Inconfidentes dialoga com a realidade:

"Para fazer bom cinema hoje no Brasil é preciso, em primeiro lugar, resistir ao suborno e, em segundo lugar, sobreviver ao castigo. O suborno ocorre logo na primeira fase da produção de um filme: os produtores particulares e as instituições governamentais financiam generosamente aqueles que por aplauso ou omissão se alinham com a ideologia dominante, enquanto negam qualquer recurso ao que possam, mesmo que apenas por originalidade, destoar dela. Quando, apesar disso, se consegue filmar, o castigo vem com os cortes ou a interdição da censura, segue com o boicote dos

\footnotetext{
${ }^{64}$ Holanda, Heloisa B. de; Brito, Antonio Carlos de. Dez anos de cinema nacional. Opinião. n. 32, p. $17-$ 19, 11 a 18 jun. 1973.

${ }^{65}$ Ventura, Zuenir. Os impasses da cultura. Visão. v. 43, n. 6, ago. 1973.
} 
exibidores e termina com a recusa do público, treinado para a passividade do consumidor conservador.

O resultado é a liquidação do cinema que procura enfrentar de alguma maneira problemas que tenham importância maior para o país. Estamos proibidos de tratar dos assuntos [grifo nosso] que interessam e excluídos da discussão e da experimentação criativa. (...)

As possibilidades de fazer um filme como o que eu fiz, Os inconfidentes, de crítica política, com um espírito independente em relação às fórmulas aprovadas e toleradas, são raras. (...). O filme só foi liberado, depois de muito tempo na censura, porque escolheu um caminho que tornava possível sua liberação: eu me abriguei sob a veracidade histórica dos ataques da censura. E consegui um filme que podia discutir, ainda que indiretamente, problemas atuais brasileiros, principalmente os da resistência [grifo nosso] das ideias políticas de um homem, das ideias maiores que uma pessoa pode ter debaixo de uma repressão forte e concreta - um problema bastante atual".

Um depoimento assim explícito é inimaginável em Opinião. Na entrevista à Visão, Joaquim Pedro continua a fazer críticas a governo. Embora não seja nosso objetivo aqui comparar a censura com toda a imprensa, fica evidente que na área de cinema a censura em Opinião era muito mais forte e impedia um tratamento mais direto não só dos temas, mas com os leitores.

De tantas polissemias, a forma do texto censurado de Opinião constitui quase uma obra aberta, extrapolando os significados mais imediatos. Não quisemos aqui frisar à mutilação aos textos, mas o quanto a censura gerou no jornal um texto problematizante, aberto, dialético e múltiplo em significações. Se os censores tentaram impedir o acesso à informação, não impediram a elaboração histórica de sentido.

Não resta dúvida quanto ao déficit entre as propostas criadas pelo jornal e o entendimento geral do público. Afinal os processos descritos aqui apontaram para a necessidade de conectar constantemente as informações, com outras fontes de informação. Nessa briga entre os espaços da opressão e da resistência, a censura parece sair ganhando. Ela conseguia mutilar e frear mais sentidos que os jornalistas conseguem construir. O próprio ato de informar sai constantemente prejudicado. Por outro lado, as zonas discursivas entre resistência e opressão coexistem e funcionam para um público outro. É visando esse público que as estratégias do jornal foram feitas. Para os "fascinados" por Opinião. Para os fascinados pelo ato de comunicar e desvendar os segredos do processo informativo. Se o silêncio tentava multiplicar sentidos, para o bem e para o mal a ação depende sempre da construção do leitor. 


\section{Capítulo 2}

Matrizes Teóricas da Crítica de Cinema de Opinião

Se a ciência das obras de arte ainda está na infância é porque os encarregados dela estão comprometidos sem o saber e sem tirar disso todas as consequências: nas lutas em que se produzem o sentido e o valor da obra: são enredados pelo objeto que acreditam tomar como objeto. Conceitos utilizados para pensar a obra de arte caracterizam-se pela mais extrema indeterminação para tentar classificar gêneros, movimentos ou formas. Confusão não é menor para caracterizar a obra de arte. Essas categorias do julgamento do gosto são comuns a todos. São marcadas sempre por uma incerteza e flexibilidade extremas que as tornam refratárias à definição essencial. Isso porque o uso que é feito delas e o sentido dado depende de pontos de vista muito particulares, situados historicamente, mas irreconhecíveis dos usuários.

Pierre Bourdieu in A Distinção 



\section{Capítulo 2 - Matrizes Teóricas da Crítica de Cinema de Opinião}

Neste capítulo analisamos os parâmetros conceituais da crítica de Opinião. Passamos em revista o estudo das tensões entre modelos teóricos divergentes e procuramos localizar o específico do semanário no que era comum a todos os críticos. A apresentação detalhada e o histórico dos críticos de cinema do jornal encontram-se no capítulo 3. Não procuramos por totalizações ou pelo estilo de cada articulista. A forma escolhida é decompor os artigos mais característicos de cada crítico. A diferença entre os pressupostos teóricos entre eles revela o debate do campo do cinema no período. $\mathrm{O}$ objetivo aqui é compreender a constituição do campo da crítica de cinema nos anos setenta e suas disputas internas sobre as formas de analisar um filme.

Naquele período, a crítica de cinema voltada à produção artística sedimentava as novas formas de análise cunhadas nos anos sessenta. Depois de uma busca inicial pelo específico do cinema e pela autoria, ela passava a privilegiar seu trabalho como uma ferramenta de mudanças sociais, encarando os vínculos entre cinema e ação política. No contexto do Pós-68, a crítica de cinema incorporava as discussões de outros campos, como a ciência da linguagem, a psicanálise, a crítica marxista, etc. No caso específico de Opinião, são representantes dessa preocupação com o vínculo da política tanto JeanClaude Bernardet quanto Gustavo Dahl.

A crítica brasileira engajada acompanhava a crise da ferramenta conceitual da mise en scène. A abordagem era questionada por causa das exigências dos elementos políticos externos ao filme. A miséria deveria determinar uma estética revolucionária para os realizadores. Críticos como Jean-Claude Bernardet e Gustavo Dahl aproximaram-se gradualmente da definição de autoria do Cinema Novo e ocuparam cada vez menos espaço em seus textos nos anos sessenta com o tema. Para Glauber Rocha, a política do autor moderno é uma política revolucionária. Há nessa frase um desvio do conceito do autorismo de diário íntimo para o aspecto ético. Dizia Glauber: "o autor é o maior responsável pela verdade, sua estética é uma ética, sua mise en scène é uma política". Os dois tipos de abordagem, engajada e estética, coexistiam em Opinião, compondo num jornal de resistência uma abertura ao fator artístico por si só. 
A crítica voltada ao específico do cinema ou à política não é de forma alguma estanque em Opinião. Ao contrário, a riqueza do jornal está exatamente no entrelaçamento e tensão entre estes dois polos em cada articulista. A oposição é reelaborada aqui partindo da divisão da crítica literária proposta por Afrânio Coutinho (1975) entre a matriz platônica e a aristotélica. Embora Platão ou Aristóteles não tenham se dedicado à crítica literária, eles deram inspiração a modelos diferentes para analisar a produção cultural. A crítica platônica deu origem aos estudos interessados em ver as obras como parte do contexto. Partindo da perspectiva dos Diálogos de Platão, a obra artística é vista apenas como um veículo de transmissão de mensagens ou de valores, sejam eles políticos, econômicos, éticos, etc. O interesse recai num documento como tradutor de uma época; como uma forma de expressar uma mensagem ou como instrumento para atingir um objetivo extra-artístico. Busca-se algo fora da arte. A crítica platônica (Coutinho, 1975) foi matriz de formas de análise numerosas: a crítica sociológica, a crítica histórica, a crítica política, a crítica atrelada à psicologia, o biografismo, a crítica marxista, a crítica voltada à ética ou a moralista como forma de ensinamento e guia. Enquanto a matriz da crítica sociológica geralmente pensa a sociedade e os fatores extra-literários como nexos de determinação e como explicação para o fenômeno literário, a crítica política vê a arte como forma de ação e participação. Enquanto isso, a crítica marxista procura o valor da obra não nela mesma, mas na ação sobre o público. Ela geralmente aplica a classe social do artista para analisar o fenômeno literário.

Do lado oposto, a matriz aristotélica preocupa-se com o específico da arte. A metodologia de Poética trouxe o estudo formal como a única finalidade da mensagem estética. Aristóteles teria sido o primeiro, segundo Coutinho, a ver a experiência estética como valor e finalidade em si mesma. Nesse sentido, o objetivo da obra de arte é o prazer estético, sem nenhum tipo de preocupação ou interesse de ordem moral ou política. O viés foge de ver a arte como instrumento de outros valores, como a política. O método de trabalho é indutivo e parte da observação empírica dos elementos, da classificação em gêneros, da divisão entre as partes e das qualidades intrínsecas para atingir uma concepção geral e formular os princípios da composição interna. Pensa-se a obra como coisa autônoma, fugindo de relações mecânicas entre a obra, o autor e o meio social. O valor advém dela mesma, conforme a presença de elementos específicos 
(narrativa, enredo, personagem), deixando de lado os demais fatores não artísticos, subordinados ao ponto de vista formal e interno.

A função da crítica de matriz aristotélica é auxiliar a atingir a beleza e o significado da obra, despreocupada com os fins elaborados fora de si. Há um caráter purista e um investimento no efeito emocional das obras. Procurando pelos aspectos estéticos, a finalidade é despertar o leitor para um tipo especial de prazer, o sentimento estético. Há um esforço grande para manter as obras distantes da realidade e dos conflitos sociais. Portanto, trata-se de uma fuga dos objetivos políticos porque a autonomia do campo estético em relação ao contexto histórico-social está em jogo.

A crítica de cinema seguiu de perto esse embate que não é nada linear. Se por um bom tempo prevaleceu a ilustração de fatores extra-cinematográficos nos textos, a reversão desse processo atinge seu ápice com o estudo sobre a mise en scène, a partir da caméra-stylo de Alexandre Astruc e da Política dos Autores, levada a cabo pela equipe de Cahiers du Cinéma. Com a abertura do campo do cinema às discussões de cunho mais político, a crítica também mudou e se viu como parte de um instrumento de transformação social. Interessa-nos aqui observar o quanto Opinião reconstrói os conceitos estéticos e políticos ao mesmo tempo.

A oposição entre a matriz da crítica aristotélica e da platônica possibilita pensar em dois núcleos dentro do jornal. Grosso modo, o primeiro é o da crítica voltada à estética ${ }^{1}$, que trabalha com a questão da mise en scène, do específico do cinema através da análise imanente. O segundo é o da política que nem sempre passa através destes dados para discutir a sociedade brasileira. A divisão proposta aqui não é estanque. É apenas didática e permite ao leitor vislumbrar as variações entre os dois tipos. Muitas vezes os críticos voltados à análise da sociedade centram seus artigos no específico do cinema. Outras vezes, os articulistas mais atrelados à estética esbarram nos imperativos políticos da resistência e da Frente Cinematográfica de Opinião ${ }^{2}$. Mais do que buscar uma disputa entre os modelos, o mais interessante é observar a integração entre os dois momentos em cada crítico.

\footnotetext{
${ }^{1}$ Da Filosofia da Arte, apreendemos aqui a estética como ferramenta possível para o trabalho da crítica de cinema. Trata-se de um recorte adaptado ao nosso objeto. Não ampliaremos a teorização sobre a reflexão filosófica da arte, com suas regras, códigos e leis do gosto e do belo. A estética (Aisthesis) é vista em seu sentido ampliado, o da sensibilidade ou aspecto sensível da afetividade do crítico (Huisman, 2013), no caso centrada sobre o específico do cinema.

${ }^{2}$ Sobre as Frentes de Opinião ver a introdução.
} 
Portanto, norteia este capítulo entender como os críticos apontam para a matriz estética e/ou política como metodologia de análise. Cada núcleo tem um peso diferente e variável conforme o crítico ou o filme analisado, e procuramos demonstrar como cada um deles resolve esta questão na composição de seu ato crítico ${ }^{3}$. Por exemplo, Sérgio Augusto pensa muito mais o específico do cinema do que a política. No outro polo, Jean-Claude Bernardet afastou-se em meados de sessenta da discussão da mise en scène. Por estas vias, ele procura encontrar as obras que revelam na forma a problematização da sociedade brasileira. Bernardet está longe de desprezar o específico do cinema. Ao contrário, seu objetivo é analisar a forma como política.

\subsection{A crítica participativa}

Crítica de cinema como crítica de intervenção, afinal todo trabalho crítico, como apontou Ciro Marcondes Filho (Aidar, 2002) é uma forma de marcar posições, confrontar, entrar num campo discursivo cheio de posições conquistadas num campo de forças. Da estética em direção à política. Eis o percurso que caracteriza o histórico da crítica de artes que desemboca em Opinião. O ápice deste processo ocorre com a politização crescente do campo cinematográfico em meados dos anos cinquenta e sessenta, num contexto de grande efervescência artística. Na I Convenção Nacional da Crítica Cinematográfica em 1960, boa parte deles pensava seu papel como uma forma de intervenção necessária ao cinema nacional. Uma dessas formulações marcou a década. Foi a análise de Paulo Emilio Salles Gomes. Durante a Convenção, ele apresenta a tese Uma situação colonial? (Gomes, 1981: 286-291), publicada com algumas alterações no Suplemento Literário em 19 de novembro daquele mesmo ano. O artigo alterou de maneira definitiva a forma de pensar o cinema brasileiro. Especificadamente sobre a crítica, Paulo Emilio mostrava como a situação de

\footnotetext{
${ }^{3} \mathrm{O}$ ato crítico é descrito por Antonio Cândido (2011: 156) como a "disposição de empenhar a personalidade, por meio da inteligência e da sensibilidade, através da interpretação das obras, vistas sobretudo como mensagens de homem a homem." O crítico o atinge através da harmonia entre dois momentos importantes: o racional e o sensível; o esforço da razão e a participação afetiva do crítico, entre o momento intuitivo de percepção sensorial e o conhecimento racional. Esta operação não deixa de lado a sistematização teórica, a personalidade do crítico como forma de entender os problemas artísticos de seu tempo. Se o momento racional é decisivo, o processo começa com o sensível. É nesse sentido que entram em cena não só a cultura do crítico, seus julgamentos e escolhas, mas também sua participação afetiva no texto. Há intuição e sensibilidade para aproximar-se da revelação.
} 
subdesenvolvimento econômico do cinema atingia o olhar do crítico sobre a produção local. Ele tomava as obras nacionais como inferiores, desprezando o cinema brasileiro por suas características incipientes, mas essa relação mudava totalmente com o filme estrangeiro, visto como uma obra de arte. Por desconhecimento do contexto de produção, o analista mantinha uma postura de passividade para com os autores das obras importadas.

Repensando constantemente seu ato crítico nos anos sessenta, Jean-Claude Bernardet faz parte dos que reformulavam sua postura em relação ao cinema brasileiro como consequência deste debate. Além dele, outros colaboradores de Opinião, tais como Gustavo Dahl e Sérgio Augusto, também deram início à carreira em meio a esse debate.

Alinhado ao pensamento do mestre Paulo Emilio Salles Gomes ${ }^{4}$, Bernardet repensava a função de sua crítica no mesmo período (Bernardet, 1978), quando escreveu o artigo sobre $A$ doce vida (1960) de Federico Fellini. Esta foi sua linha divisória. O artigo ficou famoso nos meios cinematográficos brasileiros, mas ele sentiu muito a falta de um leitor: o próprio Fellini. Naquele momento, Bernardet teve um insight de que cabia ao crítico participar da produção e circulação de ideias. Assim nasceu nele a vontade de realizar uma crítica de intervenção com a possibilidade de influenciar o campo cinematográfico, que só seria possível se o objeto de estudo fosse o cinema brasileiro. Bernardet relaciona esse momento de sua constituição crítica com a eclosão do Cinema Novo, que exigia do crítico uma postura participativa, num período de grande efervescência cultural. Essa nova crítica defendia um cinema de transformação social em perspectiva política. Se o cinema mudava, a crítica tinha de mudar também. Não era mais possível analisar em separado a direção, a fotografia, a atuação dos atores

\footnotetext{
${ }^{4}$ Em entrevista, Bernardet afirma que não consegue explicar o quanto Paulo Emilio o influenciou. "Deve ter tido, foi inseparável dele como intelectual. Como pesquisador, como cinema brasileiro, foi uma relação vital". O crítico sentiu que Paulo Emilio foi a primeira pessoa a acreditar nele, abrindo perspectivas gigantescas. Paulo Emilio o desafiava, provocava; era fundamental. Até mesmo na composição do texto. Ele trabalhava por paradoxo e Bernardet retirou dele não só o pensamento, mas a forma de escrita por paradoxos. Bernardet contou que antes estava ao lado de Rubem Biáfora e de Walter Hugo Khouri. Ele pedia para Biáfora ler e comentar os textos deles de Suplemento. Os dois diziam que o cinema deles era o verdadeiro, e o dos outros, o falso. A afirmação de Paulo Emilio era vista como o fim de um sectarismo, que impunha uma estética cinematográfica como a verdadeira estética. Bernardet explicou que quando Paulo Emilio disse que existiam os filmes, não o cinema brasileiro, a frase teve forte impacto ideológico nele, marcando toda sua evolução intelectual. A mudança significava encarar cada filme individualmente. A afirmação abriu nele um gosto de libertação, que o marcou muito. Paulo Emilio o ensinou a ter o pensamento livre e isso foi fundamental, completa Bernardet.
} 
(Bernardet, 1979). A crítica era vista como uma ferramenta de mudanças sociais e o crítico-intelectual queria participar do processo de modificação da realidade. Sua responsabilidade não era somente com os filmes, mas com a realidade brasileira, com o público e com os cineastas. Da solicitação de uma atitude ativa em relação ao cinema brasileiro institui-se a defesa da crítica participativa.

Para o ideário do período, cabe ao crítico ser um agente social e contribuir para a democracia, transformando a sociedade. A discussão sobre o intelectual engajado fazia parte da ordem do dia. A alteração da conjuntura do país juntamente com a mudança no papel do crítico é vital para acompanhar a trajetória de Jean-Claude Bernardet. Contudo, a ideia de intelectual participativo não era apresentada apenas por ele, mas também estava presente naquele período na obra de Florestan Fernandes e de Antonio Candido. Preocupados com o problema da dependência cultural, ambos discutiam a superação do atraso a partir da capacidade de produzir obras de primeira ordem. Não era somente a crítica que deveria ser participativa, mas o intelectual, num conceito caro não só ao campo do cinema, mas presente, por exemplo, na obra de Antonio Candido. O crítico quer dialogar com o contexto brasileiro para modificá-lo. Essa atitude nasce do sentimento de missão do intelectual diante da necessidade de alterar a realidade.

Em 1973, na revista Argumento ${ }^{5}$, Antonio Candido apresentou o texto Literatura e Subdesenvolvimento, no qual comentava a mudança em relação ao intelectual, passando da passividade à participação. $O$ pressuposto é de ruptura na consciência intelectual. Num primeiro momento, de "consciência amena do atraso", o intelectual não possuía uma atitude participativa em relação à cultura. O progresso ainda parecia uma solução acertada ao país. Excluindo-se da relação com o povo, a intelligentsia construía para si uma posição deformada diante da cultura. O que desejava era fazer desaparecer a deficiência cultural do povo para a realização do progresso. A exclusão do contexto fez com que a intelectualidade brasileira tomasse como ponto de referência o elemento estrangeiro. Sem encarar criticamente a si mesmo, ela se dissociou de sua terra.

Após os anos cinquenta, parte da intelectualidade saiu da postura passiva. Já na fase da "consciência catastrófica do atraso", alguns dirigiam-se à luta e à reformulação

\footnotetext{
5 n. 1, out. 1973. O texto está disponível também no livro Educação pela noite (2011) de Candido. A primeira versão foi apresentada em francês ainda em 1970.
} 
política. O subdesenvolvimento não era mais visto como fator condicionante, mas acarretava numa ação propulsora, que dava novo empenho aos intelectuais para promover alterações nas estruturas internas. Naquele contexto, cabia ao intelectual a postura de "intervenção" para fugir dos valores da cultura de massa (Candido, 2011: 186).

Os ecos desse pensamento nos anos setenta se encontram também em Florestan Fernandes, que forneceu sua versão sobre o intelectual participativo no livro $A$ sociologia numa era de revolução social (1976) ${ }^{6}$. Florestan Fernandes pensa a postura do sociológico diante dos dilemas e problemas nacionais. Ele parte da análise das duas posições mais comuns do sociólogo: voltar-se às costas aos problemas práticos ou envolver-se em alternativas ideológicas reconhecidas sociologicamente como legítimas. Sem rodeios, ele condena as duas pelo extremismo. A primeira por levar ao alheamento, passividade e conivência com o status quo diante dos dilemas da vida humana. A segunda por transformar o sociólogo num adepto disfarçado ou ostensivo de ideologias. A polêmica entre o intelectual participante e os que postulam a neutralidade para Florestan Fernandes é um falso dilema, porque não existe inteligência neutra. Afinal não se pode eximir qualquer produção cultural do homem de algum estado de participação. Nesse sentido, neutralidade e participação são meros polos ideais.

Só que Florestan Fernandes não vê esse papel do intelectual como pressuposto, mas como escolha. Ele não nega, assim como viu Antonio Candido, que a emergência dos problemas, as circunstâncias e o clima de conflito tenham alterado a postura do sociólogo em relação à realidade. O sociólogo transforma-se em agente de interesses, correspondendo às aspirações sociais de certos valores da sociedade brasileira numa ânsia de "incrementar o progresso" social. Só que esse processo é uma escolha do intelectual. Não é imperativo para o intelectual se afiliar aos interesses do povo ou de

\footnotetext{
${ }^{6} \mathrm{O}$ conceito de intelectual participativo em Florestan Fernandes nos traz na outra ponta o conceito do intelectual enquanto arauto da sociedade. Em vários momentos do livro, Fernandes (1976: 86-87, 232) fala do sociólogo ou de sua função enquanto: 1) "elemento de vanguarda na consciência de problemas sociais", 2) "intérprete da consciência comum", 3) "fonte de autoconsciência da realidade", 4) "guarda avançada da consciência social", 5) "técnica de consciência social", ou de 6) sua capacidade de enxergar "melhor as coisas". Por causa dessa capacidade, pesa sobre ele incentivar os comportamentos que correspondem às exigências da situação, porque sua tarefa é fazer alcançar um novo padrão de civilização. Ou seja, o conceito de intelectual está imbricado ao de auxiliar a alavancar o progresso, mas isso não quer dizer que os intelectuais farão revoluções ou reformas sociais, mas que eles são peças importantes de qualquer processo de mudança social, porque sistematizam os conhecimentos do senso comum, aumentando o grau de penetração da consciência social às exigências da situação.
} 
uma camada específica, como comumente os intelectuais se viam no período. Tudo depende do modo pelo qual os homens definem socialmente os papéis intelectuais do cientista.

Florestan Fernandes, assim como Paulo Emilio, vê um confinamento dos intelectuais dos problemas da vida. Eles permaneceram alheios à realidade do homem, sem fazer parte dela. O sociólogo observa no livro Sociologia numa era de revolução social que a intelligentsia brasileira continuava alienada da realidade. Ela conservava seu cunho artificial que entrava em choque com a responsabilidade do intelectual. Para ele, o que há de pior na ideia de neutralidade da inteligência brasileira é fingir-se neutra e perpetuar a atitude de indiferença perante a miséria. A tarefa do intelectual para Florestan é a de se misturar com o povo e se elevar com ele a um novo padrão de civilização, sem uma relação de privilégio social. Assim eles serão não só participantes, mas ativos na reconstrução da herança social. Se Paulo Emilio também comentou a alienação do crítico de cinema em Uma situação colonial? (Gomes, 1981: 286-291), como vimos, a perspectiva se complexificou nos anos setenta. Em 1973, Paulo Emilio publicava o artigo Cinema: trajetória no subdesenvolvimento ${ }^{7}$ na revista Argumento, aprofundando como a complexa construção da identidade do cinema brasileiro é composta através da situação de subdesenvolvimento e da interação entre ocupante e ocupado através do contato com a cultura estrangeira.

Já nos anos quarenta, Antonio Candido comentava a importância da crítica participativa no trabalho desenvolvido na revista Clima. Atento às relações entre literatura e sociedade, Candido tentava relacionar as ligações profundas que todo escritor mantém com seu tempo e com seu grupo social (Pontes, 1998). Para ele, a autoria da obra não cabe só ao artista, mas sinaliza a posição do artista na cultura de sua época. No depoimento de Antonio Candido à Plataforma da nova geração, publicado no jornal $O$ Estado de S.Paulo, já estava presente um pouco da função dada à crítica de cinema de Opinião:

\footnotetext{
${ }^{7}$ Publicado pela primeira vez na Revista Argumento. n. 1, out. 1973. "Em cinema o subdesenvolvimento não é uma etapa, um estágio, mas um estado (...). Somos um prolongamento do Ocidente. (...) Nunca fomos propriamente ocupados. (...) A peculiaridade do processo, o fato de o ocupante ter criado o ocupado aproximadamente à sua imagem e semelhança, fez desse último, até certo ponto, o seu semelhante. (...) Não somos europeus nem americanos do norte, mas destituídos de cultura original, nada nos é estrangeiro, pois tudo o é. A penosa construção de nós mesmos se desenvolve na dialética rarefeita entre o não ser e o ser outro. O filme brasileiro participa do mecanismo e o altera através de nossa incompetência criativa em copiar" (Gomes, 1980: 75-77).
} 
"[uma das grandes funções do crítico é] justamente a de servir como que de agente de ligação entre uma obra e seu tempo - e não apenas entre a obra e o leitor. E esta função implica na busca dos ligamentos através dos quais uma obra se prende ao seu momento histórico e social. Somente graças à compreensão deste sistema de relações obra-momento é que se poderá ter uma noção orgânica da literatura. Ater-se à produção literária 'em si' será talvez mais interessante, mais artístico, mais especificamente literário. Mas é preciso lembrar que a crítica não pode e não deve ser puramente literária - no sentido de 'artístico' -, porque estará neste caso sacrificando uma grande parte de sua significação e limitando seu alcance” (Cf. Pontes, 1998: 100).

Aqui está em primeiro plano a função da crítica de conectar a produção com o tempo presente; conferindo a ela uma significação. O percurso crítico de Antonio Candido e de Paulo Emilio Salles Gomes acompanhou as mudanças internas do campo da crítica literária e fornece as pontes necessárias para entender as alterações da crítica de cinema da estética pura para as significações sociais. O interesse inicial deles na revista Clima sofreu uma guinada vinte anos depois. A partir do início de sessenta, segundo Heloisa Pontes, o desafio de Antonio Candido será o de revelar, através de análises circunstanciadas, a maneira pela qual os elementos externos à obra são retrabalhados como elementos internos, estruturantes do sistema literário. O ponto de inflexão é dotar os estudos literários de instrumentos analíticos mais poderosos, construídos na intersecção e no diálogo com as ciências sociais, para superar o impressionismo e amadorismo da crítica da época. Essa nova metodologia estará presente na crítica de Jean-Claude Bernardet, como veremos. 


\section{2 . Um ethos revolucionário em busca do específico de Opinião}

Dos núcleos entre estética e política que incidem em Opinião, procuramos localizar nesse tópico o que havia de comum nas formas de analisar os filmes entre os críticos de cinema do semanário. Essas preferências revelam também o percurso histórico da crítica de cinema. As transformações sociais daqueles anos refletem a vontade de participar ativamente da produção e conscientizar o público. Essa preocupação trazia junto quase uma metodologia de trabalho para a crítica de cinema. Como não há uma única formulação teórica que dê conta de explicar todo esse contexto, apresentamos alguns dos principais pressupostos antes de analisar os textos de Opinião.

Milton Lahuerta (1999) observa um deslocamento para a esquerda e um ethos revolucionarista no Brasil genericamente influenciado por referências marxistas. Tratava-se de um marxismo que se generalizava às vezes com enorme radicalização política. Segundo o autor, esse marxismo difuso permaneceu como a principal referência teórica até pelo menos a primeira metade dos anos oitenta. O ambiente cultural repressivo limitava o debate e o polarizava no campo intelectual, de modo que não havia como esse pensamento deixar de prestar tributo ao marxismo. Como consequência, havia a difusão de certa vulgata marxista (Pécaut, 1990) que conseguiu se difundir muito além dos setores do partido comunista desde o início dos anos cinquenta. Através do pensamento autônomo de seus intelectuais, o partido comunista tinha um papel crescente na elaboração de teses centrais para o debate intelectual (Rubim, 1987). As ideias tinham tanto peso no campo que formalizavam um senso comum com o qual os intelectuais progressistas reconheciam-se, independentemente se eram membros ou não do partido. Em torno dessas ideias formou-se uma cultura política fecunda que sobreviveu ao golpe militar, tornando o paradigma marxista significativo para realizar a oposição ao regime. A presença dessas ideias explica porque de uma forma ou de outra os críticos de Opinião, mesmo os contrários a essas teorias, se influenciavam por seus referenciais de análise. Afinal esse ethos revolucionário e essa vontade de mudar a sociedade estavam presentes.

Uma prova dessa enorme influência é um documento do acervo de Jean-Claude Bernardet sobre o trabalho do cineasta comunista. Indiretamente o material revela parte do trabalho da crítica engajada pelo cinema brasileiro. Denominado "O trabalho do 
cineasta comunista", o texto transmite o peso desta cultura política no imaginário do cinema ${ }^{8}$. Quando relacionamos a presença desses traços em Opinião, estamos longe de procurar localizar uma coincidência entre uma linha política do partido com os críticos. Afinal, nenhum dos críticos de cinema de Opinião naquela época era vinculado a nenhum partido. Mas se alastrou entre a crítica de cinema de diversas tendências uma inspiração da crítica marxista. De qualquer forma, a cultura política comunista dialogava direta ou indiretamente com os articulistas do semanário por causa da importância ocupada no cenário cultural brasileiro. Exemplo desse grau indireto de diálogo é a trajetória de Jean-Claude Bernardet. Ele participou de uma célula do Partido Comunista Brasileiro (PCB) até o golpe militar, mas depois se tornaria crítico ao partido 9. Embora sem data, o texto de Bernardet sobre o trabalho do cineasta comunista pertence a uma pasta com escritos dele da primeira metade dos anos sessenta ${ }^{10}$.

O documento traça diretrizes para o cineasta comunista e descreve a importância da área cultural, seguindo a política geral do Partido Comunista: "A atividade cultural não parece ser de pouca importância, e não pode ser negligenciada pelo P. [Partido]”. Um ponto importante do texto é a descrição do lugar ocupado pelo cineasta comunista. Indo contra a corrente da imersão do realizador no ambiente popular, o documento afirma que só no seu meio o diretor pode desenvolver uma atividade política e cultural propriamente dita. Se o ambiente do cineasta é vital, não há porque migrar para outros campos, que também são da maior importância. Pelo cinema, o realizador comunista age. Contudo não lhe é negado o direito de atuar no movimento operário, camponês ou bancário. Todos eles fazem parte da realidade social do diretor, mas ele as conhece muito pouco. Quando envereda por esses espaços, o cineasta deixa de ser profissional e

\footnotetext{
8 "O trabalho do cineasta comunista". Anexo do Caderno 1. Caderno de anotações de Jean-Claude Bernardet. Pasta PI $18 \mathrm{~m}$. Caderno V. Arquivo Jean-Claude Bernardet. Centro de Documentação e Pesquisa da Cinemateca Brasileira.

${ }^{9}$ Jean-Claude Bernardet declarou em entrevista que só participou de uma célula do PCB até a eclosão do golpe militar, mas nunca foi filiado ao partido. Na entrevista concedida a Musse (2004), ele enfatizou que a ligação com o PCB só foi até a época do golpe. Por outro lado, o autor completou que quando escreveu Brasil em Tempo de Cinema, ele estava distanciado, mas ainda não tinha rompido com o PC.

${ }^{10}$ Do histórico apontado por Jean-Claude Bernardet, podemos tomar algumas datas como fronteiras possíveis para tentar datar o documento, entre o período anterior ao golpe militar, a escrita de Brasil em Tempo de Cinema e a publicação do livro em 1967. O texto parece apontar para um período anterior ao golpe militar ou à luta armada. Isso fica patente quando é dito que em épocas cruciais de transformação, ser cineasta comunista "pode ter muito menos importância que o simples fato de ter dois braços e atirar granadas ou levar baldes d’água." Contudo, esse quadro está distante do "momento atual", "atravessado pelo país" e caracterizado por uma "lenta transformação" com "pequenas" e "incertas vitórias" numa "consolidação relativa". Talvez o contexto do texto seja anterior ao golpe ou à luta armada. O termo Frente Única (do PCB) utilizado pode remeter ao contexto da luta contra a ditadura militar ou ao período anterior ao golpe.
} 
realiza um trabalho que tende a ser fragmentado, superficial e marginal. Portanto, o diretor comunista deve atuar no seu meio social. O resto é utopia, divertimento, problema de consciência e populismo, mas não um trabalho comunista, porque este se fundamenta em necessidades e possibilidades que o realizador conhece por vivê-las. Transcrevemos os trechos com a descrição deste trabalho:

"No seu meio, o que pode fazer o cineasta comunista, pelo menos em São Paulo... Inicialmente deve-se dizer que os trabalhos não só devem ser feitos, não só poderão resultar, se forem levados em termo de Frente Única, não considerando a Frente Única como uma concessão feitas aos outros, muito menos como uma forma de armadilha em relação aos outros, mas como uma necessidade tão dos outros quanto nossa.

Dito isto, o trabalho do cineasta comunista pode se dividir em vários planos, que evidentemente se interpenetram:

1 - trabalho em prol da conquista dos meios de trabalho (produção e distribuição)

- atividades nas entidades de classe para as reivindicações em âmbito municipal, estadual e federal.

- promover e realizar estudos sobre a real situação econômica do cinema brasileiro, sobre os modos de distribuição, pois sabe-se muita coisa em geral, mas muito pouca coisa é fundamentada.

- examinar a política dos choques das forças econômicas (produção x distribuição); tentar uma sistematização, e para isso estudar casos significativos, tais como a Vera Cruz, o Cinema Novo, mas fazer isso com documentação.

- desenvolver a produção de longa e curta metragem. Dar particular importância à produção independente de curta metragem; tentar estudar o curso que está tomando espontaneamente e incentivá-la nesse sentido, se se julgar que é o melhor.

2 - trabalhos em prol do desenvolvimento de um cinema que podemos chamar de 'autêntico'.

- no nível da produção.

- promovendo debates na classe sobre filmes de longa e curta metragem; sobre os trabalhos em preparação, sobre filmes estrangeiros.

- promover e realizar estudos escritos (jornais ou livros) sobre qualquer aspecto do cinema.

- promover entrosamento dos grupos não só de uma mesma região, como também com os de outras regiões e países.

- desenvolver a ideia de um cinema latino-americano.

- discutir a evolução artística brasileira e latino-americana.

3 - divulgar o cinema brasileiro e sua situação, a fim de que se entrose sempre mais, na opinião pública, na cultura brasileira em geral.

4- trabalhar para a classe cinematográfica se constitua como uma efetiva classe profissional, que tome atitudes orientadas no sentido de seus interesses e se entrose cada vez mais numa problemática geral vivida pelo país - isso fundamental em relação e através de problemas cinematográficos. 
5- manter 'base de cinema' em que sejam discutidos problemas cinematográficos, profissionais e culturais, informar o P. [Partido], dos problemas e encaminhamentos dados;

- se informar sobre a situação brasileira, tentar interpretar os dados e divulgá-los.

- discutir a linha geral do P. e as suas atitudes particulares.

- lutar para uma organização interna que torne fecunda essa orientação."

O texto defende a linha da Frente Única do PCB voltada à temática nacional ${ }^{11}$. O cineasta comunista não deve se apoiar em ideias abstratas ou idealizadas. Deve se inserir no processo em curso e nas possibilidades de desenvolvimento da realidade, seguindo a linha do Partido: "pois como pessoa que vive no Brasil, todos os acontecimentos brasileiros lhe dizem respeito e o cineasta não deve somente estar enfronhado no conjunto da vida do país, como também refletir essa vida no seu trabalho particular". O texto defende a reflexão sobre a realização fílmica e dá lugar de destaque ao cinema brasileiro. Além disso, frisa a importância da discussão do cinema brasileiro na imprensa resumindo algumas das preferências de Jean-Claude Bernardet enquanto crítico. A defesa do nacional popular também está presente, quando se aborda a função de incentivar o interesse da classe cinematográfica pelos problemas do país. Portanto, é possível observar neste documento alguns itens do que se denominou mais tarde a Frente Cultural. A Frente é descrita neste texto como uma necessidade de todos, não só do partido. Estão em pauta aqui alguns pilares da Frente Cultural (Napolitano, 2011) ${ }^{12}$, tais como a conquista do mercado e dos meios de produção, uma atuação junto ao Estado em termos de política cultural, sem falar na presença do nacional popular em alguns trechos. Essas bases incidem sobre o trabalho de Bernardet em Opinião, quando ele dedica grande espaço a esses temas ou quando promove estudos sobre o cinema a partir da crítica participativa, tal qual o documento sugere. É possível também traçar um paralelo com a preferência da Frente Cultural por um realismo difuso, quando o material coloca em pauta a necessidade de criar um cinema autêntico. Contudo, a ideia de cinema autêntico não aparece em Opinião.

\footnotetext{
${ }^{11}$ A palavra Frente Única aparece em mais de um documento do PCB ao longo dos anos. Ainda no final dos anos cinquenta, ela foi idealizada como uma política de aliança de classes sociais e tendências políticas diferentes para defender a nação contra o imperialismo. A Frente faz parte do projeto etapista de revolução, colocando em primeiro lugar o fortalecimento da democracia. Esse projeto foi novamente enfatizado após o golpe militar, em mais de uma resolução, na ideia da Frente Única contra a ditadura para conquistar as liberdades democráticas. Ver Segatto (1981) e Lima (1995).

${ }^{12}$ Ver definição na introdução.
} 
O fenômeno descrito aqui não foi somente brasileiro. Os debates dos anos sessenta alteraram substancialmente a crítica de cinema ao redor do mundo. $\mathrm{O}$ ano de 1968 significou, conforme Robert Stam (2003), a diáspora do político pela teoria do cinema. A amplitude das mudanças se estende por quase duas décadas de pensamento e práticas em inúmeros países. A época foi marcada pela proliferação de periódicos marxistas de cinema ou de inflexão esquerdista, como Positif, Cinéthique, e nos recémconvertidos à esquerda, Cahiers du Cinéma e Screen. O cinema se transformava num instrumento de luta política. Um termo chave nos debates da esquerda, de acordo com Robert Stam (2003), é o da ideologia, incrustada de sentidos acumulados ao longo dos séculos. Além disso, a crítica trazia para o debate o papel ideológico dos meios de comunicação. Para os teóricos althusserianos, a câmera tinha uma espécie de defeito ideológico congênito e significava um instrumento autoritário de subjugação, cúmplice da ideologia burguesa. Como consequência desse viés determinista, a perspectiva esquerdista partia da teoria marxista e denunciava os aparelhos ideológicos de estado e do cinema dominante. Nestes casos, o cinema não era visto como parte de um continuиm discursivo mais amplo e ambivalente, mas como um bode expiatório da alienação social. O dispositivo era visto de uma forma não dialética, como uma máquina de influências poderosas, contra a qual a resistência era vã. Alguns acreditavam que todos os filmes produzissem o mesmo determinismo em todos os públicos. Uma ala esquerdista nos anos setenta influenciada por Brecht e Althusser passou a considerar a auto-reflexão do cinema uma obrigação. Do lado contrário do cinema burguês e realista estaria o cinema revolucionário e reflexivo. A solução seria trazer para o primeiro plano o trabalho de produção em textos auto-reflexivos. Em Opinião, era comum essa preocupação a alguns críticos, como veremos no próximo capítulo.

O padrão de Opinião pode ser aproximado com a ideia da crítica teórica ou ideológica (Bywater; Sobchack, 1989) que conjuga as diversas influências da semiologia, do estruturalismo, do marxismo, do neofreudianismo e dos estudos feministas. O foco é o discurso fílmico e a produção de sentido através da discussão sobre o modelo de produção e o contexto sociopolítico ideológico. Influenciada por um determinismo cultural, esse tipo de crítica analisa como o processo de significação reflete o pensamento da sociedade, através do contexto cultural dos filmes. O objetivo é localizar os valores dominantes do sistema engendrados pela ideologia e aumentar a consciência nos leitores dos efeitos inconscientes de produção de sentido na linguagem. 
Nesse período, o cinema é considerado como parte do discurso, e para a sua análise é preciso incluir o estudo da linguagem, da política e da cultura. O período de elaboração teórica e de politização de Cahiers na transição de poder no pós-68 acarretou na transferência do bazinismo modernizado para uma opção pelo cinema de montagem de Eisenstein, a partir das formulações de Louis Althusser e da revisão marxista (Xavier, 2005).

Entre os críticos brasileiros, Jean-Claude Bernardet foi o que mais comentou como a efervescência cultural dos anos sessenta incidiu no seu trabalho. Incorporando esses debates no seu processo de escrita e de pensamento, Bernardet deixava o modelo de crítica impressionista ${ }^{13}$ que imperava no Suplemento Literário do O Estado de $S$. Paulo para enveredar pela crítica participativa. Ele passava a defender os filmes politicamente corretos que revelassem nossa realidade. Este enfoque continuava presente em Opinião. Enquanto isso, o debate sobre a essência da arte ou sobre a qualidade cinematográfica era acusado de ser uma expressão da burguesia que preferia se esconder atrás de imagens decorativas para não assumir uma posição que perturbasse seu bem estar. Com uma nova função, o crítico de cinema deveria explicar ao público se o filme era uma descrição complacente, uma crítica à burguesia, se era reacionário, se analisava a miséria ou só a descrevia. Portanto o critério de análise era o social.

Para traçar a convergência crítica de Opinião, tomamos como ponto de partida alguns referenciais da crítica sociológica e da crítica voltada ao conteúdo do filme para revelar a ideologia, através do percurso de Jean-Claude Bernardet. Nos anos setenta, ele problematizou a dificuldade da crítica em articular esses elementos, sugerindo novas possibilidades de análise, como veremos.

A principal preocupação de Bernardet ainda no começo dos anos sessenta era desmistificar os filmes, longe das apreciações plásticas ${ }^{14}$. O pressuposto de revelar a ideologia por detrás da produção se agregava à ideia de conscientizar o público. Esse viés está muito presente na crítica de cinema de Opinião e gerava uma forma de analisar

\footnotetext{
${ }^{13}$ A crítica impressionista enfatiza a experiência do crítico diante da obra de arte e possibilita ao leitor aproximar-se da criação autoral (Ver Capítulo 3).

${ }^{14}$ "O que tem a 'arte' com o subdesenvolvimento? Nada. A 'poesia'? Nada. Os problemas sociais são tantos e tão urgentes que devem constituir a maior preocupação do cinema, e se não se puder fazer arte, então que a arte seja adiada. Hoje, o trabalho crítico mais urgente é desmascarar as fitas. (...). A atuação do crítico não pode ser de apreciação plástica ou técnica, mas sim de 'desmistificação (Bernardet, 1978: 56-7).
} 
os filmes atenta ao conteúdo e ao enredo. Bernardet (1978) colocou essa ideia em prática pela primeira vez no jornal Última Hora em 1963. Escrevia para o público preso ao enredo. Por isso centrava os textos no conteúdo mais imediato do filme. O objetivo era auxiliar no desenvolvimento analítico do espectador, conscientizando-o. Bernardet define essa crítica como conteudística. Por causa de todo esse contexto, era mais importante o público do que a obra. Por isso, ele deixava de lado nos artigos a forma e as discussões estéticas. A crítica de matriz conteudística ainda estava presente em Opinião, mas com diferentes gradações entre os críticos, como veremos. Dessa postura deriva um tipo de crítica praticada em Opinião: são artigos de leitura facilitada, amparados pelo entendimento sociológico do filme e de sua representação da sociedade, cujo objetivo é explicar a produção dentro do contexto político brasileiro.

O objetivo de Bernardet (2011) no Última Hora era analisar a ideologia da produção comercial importada para um público popular. Mas a empreitada não saiu totalmente a contento porque o público-alvo destes filmes não tinha o hábito de ler crítica de cinema, e quem lia a crítica da Última Hora não assistia a esse tipo de produção. Bernardet comenta que esse mesmo processo ocorreu nos artigos da imprensa alternativa. A linha dos jornais alternativos também era conteudística. Segundo Bernardet, os textos mais complexos tiveram alguma repercussão, mas provavelmente não eram lidos pela maior parte do público.

A vontade de desmascarar a ideologia dos filmes tem alguma similitude com a crítica marxista (Coutinho, 1968, Eagleton, 2011). Aplicada à arte, grosso modo, ela está mais interessada na recepção do público. Vê as obras artísticas como produto da história e procura por alguns valores e ideias que só aparecem na produção cultural. Nesse sentido, a arte é vista ao mesmo tempo como parte da superestrutura, mas com algum grau de autonomia. Encontramos em Opinião duas variações desse tipo de texto. A crítica marxista vulgar (Eagleton, 2011) vê a arte como um reflexo determinado pela base econômica e pelo modo de produção. Nesses casos, os textos costumam sair mecanicamente das relações sociais para a ideologia. O segundo tipo de texto fornece grande atenção à linguagem e à forma porque observa que a mentalidade apresentada faz parte das relações sociais de cada época histórica.

A segunda matriz comum aos textos de Opinião é a crítica sociológica que relaciona o conjunto artístico com as condições sociais. Antonio Candido (Candido, 
2011 a) explica que a maior dificuldade da crítica sociológica é vincular o político e o econômico com a obra sem um nexo causal de tipo determinista. Muitas vezes esse paralelo com a produção servia de pretexto para os críticos apontarem aspectos e problemas sociais ou verificarem se as obras espelhavam a sociedade. Ainda nos anos setenta, Antonio Candido (2011 a) demonstrava que todos esses tipos de crítica são incapazes de analisar a integridade da obra porque nascem de visões desassociadas. O tratamento externo dos fatores externos pode ser legítimo quando não se está interessado no valor da obra e quando inexiste uma preocupação estética. Embora a orientação sociológica seja possível e legítima, o risco é explicar tudo por meios de fatores sociais. Contudo essa metodologia evoluiu bastante. Trata-se dos casos em que os críticos investigam as relações entre as unidades estilísticas e o contexto como chave para conhecer o sentido do todo, compondo a chamada crítica dialética ou integral, que veremos mais à frente.

Nos anos setenta, Jean-Claude Bernardet envereda pela mesma conclusão de Antonio Candido sobre a insuficiência de análise da crítica sociológica. Ele procurava continuamente por uma metodologia de trabalho para a crítica de cinema. Certa vez ele escreveu: "Não encontrei até agora um método de trabalho que me satisfaça e que possa revelar ao máximo os filmes dos quais falo" ${ }^{15}$. Bernardet tentava conciliar nos textos a crítica sociológica e o estudo do específico do cinema. Nos anos setenta, ele questionava a junção entre a crítica conteudística, a crítica sociológica com sua preocupação em localizar a ideologia da produção. Via essa junção como necessidade daquele momento, numa época em que não havia acesso do crítico ao filme na moviola 16. Bernardet (Metz, 1972) ${ }^{17}$ explicava que a crítica de conteúdo não era defensável porque presa ao enredo mais imediato. Enquanto isso, a crítica sociológica conseguia comentar tudo de que trata o filme, mas era incapaz de falar sobre a obra propriamente. Daí sua incapacidade de atingir o específico cinematográfico. De qualquer modo, a junção entre elas ainda era a melhor opção disponível.

\footnotetext{
${ }^{15}$ Acervo Jean-Claude Bernardet. Cinemateca Brasileira. Declaração do autor. s.d. Pasta AJCB PI-1-18.

${ }^{16}$ A metodologia empregada naqueles anos tem relação com as condições de trabalho do período. Sem acesso ao filme na moviola, o crítico recorria às anotações no escuro da sala de cinema ou apelava à memória. Por causa dessa impossibilidade de ver a película na sala de montagem, Bernardet considerava a junção entre a crítica sociológica e a crítica de conteúdo a melhor opção disponível por ainda dar alguns frutos, apesar de chegar ao fim de suas possibilidades.

${ }^{17}$ Bernardet não fez só a tradução do livro A significação no cinema de Christian Metz, mas escreveu no apêndice um capítulo no qual aplicou a metodologia do autor ao filme São Paulo S.A. (1965) de Luís Sérgio Person.
} 
Após 1965, Bernardet tentava superar as análises de conteúdo mais imediatas sobre enredo e personagens, como tinha feito antes no jornal Última Hora. O caminho o levou à semiologia e às formas de significação utilizadas pelos filmes para se expressar 18 (Bernardet, 1978: 189). Esse tipo de metodologia não está presente em Opinião, dada à complexidade de análise.

No final dos anos setenta, Bernardet escreve em Trajetória Crítica (1978: 245) que a análise interna parece a mais adequada para levar em consideração o nível estético e superar as estéticas normativas ainda vigentes nos métodos impressionistas, historicistas e sociológicos. A metodologia não significava excluir as análises externas, como tipo complementar de trabalho, como a crítica sociológica dos meios de produção; “porque a obra e a análise interna remetem à sociedade global”. É esse tipo de análise que encontramos em Jean-Claude Bernardet no Opinião.

Naquele mesmo período, Bernardet (1978) também repensava a utilidade da crítica voltada à ideologia. Vista como uma forma de abstração, os críticos deixaram de se questionar a quem queriam conscientizar. O método tentava confrontar a "ideologia" do crítico e seu entendimento sobre a realidade brasileira com a compreensão mais imediata do enredo, a partir de um juízo de valores e de um sociologismo mecanicista. Para o autor, havia no período uma insuficiente compreensão dos destinatários da mensagem. Se a forma de análise era uma simplificação da teoria do distanciamento de Brecht, a consciência não se transforma somente com as informações do filme, explica. O método ainda experimental poderia ter se tornado uma ferramenta de análise muito interessante, segundo ele, se tivesse ido fundo na análise da sociedade brasileira, o que não era possível naquela época.

\section{As gradações do específico de Opinião}

O percurso histórico feito acima buscou deixar claro que muitas críticas de Opinião são o resultado da junção entre a crítica sociológica, a crítica conteudística e a crítica voltada a desmascarar a ideologia. Isso não quer dizer de forma alguma que todos os artigos do jornal sejam sempre a síntese entre esses modelos. Mas o específico

\footnotetext{
${ }^{18}$ Um exemplo disso pode ser encontrado no estudo de Bernardet sobre São Paulo Sociedade Anônima (1965) de Luís Sérgio Person publicado no livro A significação no cinema (Metz, 1972).
} 
do semanário está nessa união em busca do discurso político dos filmes. Esse tipo de texto caracteriza o jornal e é o ponto comum entre os críticos. Ele era praticado em algum momento pelos colaboradores. No capítulo 3 e 4, ampliaremos o estudo sobre cada cronista. Por hora, traçamos um panorama para demonstrar as variações deste modelo e os artigos que vão além desse padrão.

Na junção entre a crítica voltada a desmascarar a ideologia dos filmes, a crítica sociológica e a crítica de conteúdo, há diversos níveis de complexidade entre os textos. Muitas vezes se deixa de lado a profundidade analítica em prol da clareza explicativa aos leitores. O primeiro exemplo é de Argemiro Ferreira ${ }^{19}$, ainda no período sobre o comando de Raimundo Pereira:

"Indiferente aos esforços da psicanálise para livrar o homem da culpa, $O$ Exorcista teima em encarar sexo como pecado e perdição, num tipo de puritanismo repelido como fora de moda até nas facções religiosas menos conservadoras. Mas a ênfase que já se dedicou ao pecado contra a castidade, (...) dificilmente conseguiria hoje ocultar os males verdadeiros que perturbam a consciência do mundo - da fome à violência sistemática dos direitos humanos, da injustiça social às técnicas requintadas de tortura dos regimes autoritários.

A quem interessará reviver a culpa, restabelecer a ênfase na castidade em detrimento da caridade cristã, anestesiar as pessoas com o horror puritano ao sexo? Certamente não é essa uma das metas dos povos explorados, dos quais nada têm a perder na sua luta. (...)

Com sua experiência de especialista em guerra psicológica da Força Aérea dos Estados Unidos (ele chefiou um setor da Divisão de Guerra Psicológica), Blatty parece muito bem preparado para a tarefa a que se propôs em $O$ Exorcista, filme e livro, de reviver o horror ao sexo (...)."

Esse texto busca explicar ao leitor o que existe por detrás do discurso dos filmes e sua relação com a sociedade. Aqui a produção é vista quase como reflexo do modo de pensar da sociedade americana. Argemiro publica quatro artigos no jornal nos quais explica a ligação entre os filmes americanos e o pensamento capitalista. O intuito parece ser o de oferecer uma narrativa para a libertação dos homens da opressão e da exploração. Se a obra é vista como expressão dos conflitos sociais, o objetivo é contribuir para o estudo das lutas de classe no campo artístico (Eagleton, 2011). Esse tipo de crítica mantém indiretamente uma crença romântica na arte que projeta um

\footnotetext{
${ }^{19}$ Ferreira, Argemiro. A armadilha do diabo. Opinião. n. 108, p. 19, 29 nov. 1974.
} 
mundo ideal. $O$ trecho extrapola a relação entre o filme e a sociedade, forçando a comparação entre um filme de terror e a política imperialista norte-americana. Insiste na ligação entre a mensagem do filme e os interesses dos Estados Unidos. $\mathrm{O}$ artigo de Ferreira não explica como as obras podem desafiar os pressupostos ideológicos. Se o argumento estivesse certo, não existiria nenhum tipo de produção crítica de esquerda, porque a ideologia a inviabilizaria. $\mathrm{Na}$ verdade, indiretamente as obras de esquerda teriam esse papel fora do esquema hollywoodiano. O que existe, na verdade, é um apagamento do cinema enquanto forma, trazendo apenas a discussão social. Neste artigo, Argemiro Ferreira quase trata a arte como um reflexo do modo de produção, deixando de lado os fatores internos. A consequência é o silêncio sobre o estudo da forma e da linguagem, preterida pela busca do conteúdo político. Esse viés de análise aparece bastante na coluna dos leitores (ver Capítulo 4).

Na mesma edição, Júlio César Montenegro explicou com maior clareza a relação entre religião, doença e diabo no Exorcista. Mas ele se ateve à análise do filme, sem traçar paralelos entre o objetivo do diretor com a política americana ${ }^{20}$. Não se trata de um artigo, mas de uma nota, que ele escreveu, às pressas, para não deixar em branco o lançamento ${ }^{21}$. Atento à recepção do público no cinema, Montenegro explica que o filme descarta a ciência porque a cura da doença vem através da religião. No final da história, a falta de religião da família transforma-se numa inegável dívida com a fé.

Esse padrão não era usado só por Montenegro e por Argemiro Ferreira, que se tornou depois editor-chefe do jornal. Retomando o viés da crítica conteudística de Última Hora, Jean-Claude Bernardet enveredou algumas vezes pela maré do discurso em Opinião ${ }^{22}$ :

"Desejo de matar prega a formação de uma força parapolicial. O filme funciona como um teorema: a demonstração é absolutamente lógica e convence o espectador. Absolutamente lógica e absolutamente falsa.

O 'herói' é bem situado na vida (...). É como qualquer um de nós. (...) Chamado para a guerra da Coréia, não foi para a frente para não matar. É um pacifista. (...) Eis

\footnotetext{
${ }^{20}$ O exorcista - um diabo de sucesso. Opinião. n. 107, p. 23, 22 nov. 1974.

${ }^{21}$ Quando citamos ao longo desta tese as declarações de Júlio César Montenegro, Jean-Claude Bernardet, Sérgio Augusto, Marcos Ribas de Farias, José Carlos Avellar e Clóvis Marques, trata-se das entrevistas que realizamos com os autores. Nos casos de exceção, mencionamos as fontes.

${ }^{22}$ Bernardet, Jean-Claude. Viva a morte. Opinião. n. 115, p. 24, 17 jan. 1975.
} 
que a esposa desse doce homem é violentada e assassinada por jovens marginais. Mas a polícia, (...), não localiza os assassinos. Ele próprio vê os marginais atuarem na rua. Faz o que faria qualquer homem de bem: arma-se. (...) A polícia passa a procurar o assassino de marginais, mas não os marginais. Diante disso, o homem de bem continua a matar, já não mais em legítima defesa. Já se tornou uma missão.

$\mathrm{O}$ assassinato de marginais dá resultados imediatos: em uma semana, os assaltos diminuem em 50\%. Não resta dúvida que a solução está aí. Dedução lógica do espectador: o jeito é formar uma espécie de esquadrão da morte civil. (...)

Diante da ineficiência da polícia, e da inflação de criminalidade, não há outra solução senão os homens de bem, inclusive os pacifistas, se armarem e passarem a matar. E quem não fizer isso, é covarde. Insinua-se também que este tipo de covardia chama-se civilização. A demonstração é tão lógica que, quando o homem de bem começa a matar, a plateia aplaude. (...)

O filme tenta aprofundar a questão e descobre o motivo da violência dos jovens. O cinema, quem duvidava? O filme apresenta a filmagem de um bang-bang assistida por amplo público. (...)"

Contudo não era só Jean-Claude Bernardet que se dedicava a esse tipo de análise. O então novato Clóvis Marques também exercitou a análise do discurso político dos filmes de Opinião $^{23}$ :

"Um filme de antecipação política - já é um aforismo - fala do presente. Norman Jewison, diretor, e William Harrison, autor da história original e roteirista de Rollerball, sabem disso. Mas parecem ter exagerado ao pensar a melhor maneira de falar do futuro (...) seria metê-lo no escaninho apertado do senso comum americano. Daqui a 50 anos segundo o filme (...), o poder onipotente das corporações multinacionais governará um 'mundo novo' do qual terão sido banidas as fronteiras políticas nacionais, e com elas, as guerras e toda sorte de carências materiais.

Recurso preguiçoso - Excelente recurso para apagar do mapa os conflitos (atuais e virtuais) menos glamourosos e enredar-se numa complacente remastigação de preocupações das elites da sociedade pós-industrial (...)."

Até um crítico como Sérgio Augusto, mais ligado ao polo da estética do cinema, escreveu um texto para analisar o percurso histórico da figura do delinquente e o quanto Hollywood reinterpretava e se apropriava desses estereótipos ${ }^{24}$ :

\footnotetext{
${ }^{23}$ Marques, Clóvis. O futuro do supermercado. Opinião. n. 180, p. 19, 16 abr. 1976.

${ }^{24}$ Augusto, Sérgio. O grande carnaval. Opinião. n. 180, p. 19, 16 abr. 1976.
} 
“(...) pois há 20 anos até o baixo-mundo era, no cinema, menos complicado: os bandidos maus e os policiais bons. (...)

Para quem detém o poder, o cinismo torna-se uma das múltiplas formas de orgulho. Hollywood vangloria-se de sua abertura paternalista em relação aos delinquentes. Não só os defende ocasionalmente como procura justificar-lhe os atos de subversão. Ou seja: apropria-se a criminalidade sob formas aceitáveis de expressão, descobre-se e celebra-se a beleza e a grandeza do crime. Não é outra a quintaessência ideológica da literatura policial, conforme brilhante e recente diagnóstico de Michel Foucault em Surveiller et Punir (ver Opinião n. 123)."

Entre esses exemplos citados há diversos graus de complexidade. Os textos decompõem o discurso dos filmes sem estabelecer uma relação maquinal com o sistema capitalista. Assim, eles cumprem muito bem seu objetivo de crítica sociológica: tentam construir uma tese sobre a formação e funcionamento da sociedade. Contudo, nem todos eles partem da análise das imagens. É possível ver em alguns trechos traços da cultura política engajada, preocupada em conscientizar o público. Os textos estão mais próximos da crítica conteudística.

A junção entre esses parâmetros tem origem também no material fílmico. Quando se trata de cinema de gênero ou grandes lançamentos, os críticos se atêm ao conteúdo e ao discurso político dos filmes, provavelmente porque não encontrem nem maiores virtudes artísticas, nem algo de novo. Um adendo necessário. Este tipo de texto em Opinião está presente em todos os anos, mas aumenta bastante em quantidade entre 1975-1976, quando Sérgio Augusto torna-se editor de cultura. Verdade é que Augusto escreve pouquíssimos artigos com esse viés. Nestes casos, ele procura analisar o discurso dos filmes na tensão entre a estética do cinema e a política. Exatamente quando estava na chefia um crítico que se opunha à tendência da crítica ideológica, incorporase não só parte deste modelo, mas também colaboradores sintonizados com a nova fase de Cahiers du Cinéma, já no contexto de politização da crítica de cinema. Talvez até mesmo para os avessos a este padrão fosse difícil não utilizar em algum momento suas ferramentas de análise. Outra possibilidade é o crítico ter interiorizado esse modelo como forma de estabelecer um contato maior com sua equipe. Isto é, responder às demandas de um jornal de resistência. A quantidade de artigos com esse viés pode ser tomada também como uma prova da autonomia dada aos colegas para escolher o viés de análise. Vemos essa fase como um período no qual as formas de fazer a crítica de 
cinema tendem para o lado da balança da chamada crítica ideológica (Bywater; Sobchack, 1989), seja de maneira consciente ou não.

Trata-se, portanto, de um quase projeto editorial de Opinião para a área de cinema. Explicamos aqui a utilização da palavra quase. Todos os entrevistados negam veementemente a existência de um projeto editorial na seção de cinema. Todos afirmam que Júlio César Montenegro dava total autonomia aos críticos e era avesso a qualquer tipo de atitude didática. Ao observar a constância de artigos voltados a explicar o discurso dos filmes ao longo dos anos, observamos a existência de uma estrutura significativa goldmaniana ${ }^{25}$, independente do editor de cultura. Mesmo sem a intenção consciente dos críticos, estava presente a cultura política engajada e a atitude típica do intelectual preocupado em conscientizar o público ${ }^{26}$. Ou mesmo uma variação didática do tipo de crítica praticada em Cahiers du Cinéma naquele momento.

Se esse é o padrão conjunto entre os críticos, ele não era o único. Noutros momento se começava o estudo através do material fílmico, buscando uma conexão entre a obra e a situação histórica. Se os exemplos citados acima desmascaram o discurso dos filmes, outros artigos dos mesmos colaboradores avançam muitos degraus em direção à análise das imagens. Interessa-nos abordar mais de perto os níveis nos quais esse tipo de estudo conjuga as preocupações sociais e uma atenção ao específico do cinema. Eis um trecho da crítica de Sérgio Augusto ${ }^{27}$ :

"Há algo de errado no quarto onde Jack Lemmon executa seu ritual matinal, no começo de Sonhos do Passado (Save the tiger). A impressão é a de que o personagem, Harry Stoner, está numa suíte de hotel e não em sua própria casa. Os indícios de que naquele ambiente luxuosamente frio e impessoal o sr. e a sra. Stoner moram, e fazem amor, são dados pela aparição de uma parafernália eletrônica incrementada demais (tape-deck, rádio, TV com controle remoto) para fazer parte do serviço de um hotel.

De saída, possibilita a Jack Lemmon exercitar-se num solo em que se tornou mestre às custas de repetidas performances. (...) Aparentemente não há a menor necessidade de Harry acionar toda sua maquinaria eletrônica antes do breakfast, mas ele o faz porque só assim o diretor John G. Avildsen conseguirá situá-lo historicamente, topograficamente e socialmente.

\footnotetext{
${ }^{25}$ A estrutura significativa é o resultado de um complexo esforço coletivo dos grupos sociais, longe da ideia de uma estrutura mecânica fixa (ver o próximo tópico).

${ }^{26}$ Há também uma segunda possibilidade. A tendência presente nas reuniões de pauta de encontrar filmes com um viés político contrário à ditadura poderia significar uma preferência por artigos como estes que apontam o discurso autoritário dos filmes estrangeiros.

${ }^{27}$ Augusto, Sérgio. Um tigre sem salvação. Opinião. n. 70, p. 19, 11 mar. 1974.
} 
Nos velhos filmes americanos os meios de difusão viviam incrivelmente à mercê dos acontecimentos engendrados pelos atores. Se um criminoso em fuga ligasse o rádio era certo que um locutor interrompia a música para dar alguma notícia a respeito da fuga. (...) Nos anos 60, os meios de difusão passaram a ter uma nova, mas ainda subalterna, serventia cinematográfica: em vez de servir (informando) aos personagens, eles agora servem à plateia. É através deles que os cineastas reforçam artificialmente os seus recados ou situam ideologicamente os seus filmes.

Por isso é que sempre que um personagem liga a TV ou o rádio a informação vinculada (...) 'significa' alguma coisa. Nada a objetar em se tratando de um filme em que tudo está sob controle do cineasta, ou, como dirá Pasolini, em se tratando de um 'filme de poesia'. (...) Foi o Cinema de Autor soprado da Europa que alterou o modo de usar os meios de difusão no cinema americano dos anos 60. Esse novo modo, no entanto, entra quase sempre em conflito com a índole intuitiva e as tradições elípticas do cinema tradicional americano - conflito este que nenhum cineasta (...) conseguiu ainda solucionar. E não há nada mais insuportável do que as interrupções intelectuais (ou intelectualizadas) numa conversa simples (ou simplória) como de hábito costumam ser os filmes americanos."

Se o artigo analisa o discurso dos filmes, foge do viés de encontrar uma similitude com a ideologia. Ela até pode estar presente indiretamente na diferença de objetivos entre os dois tipos de cinema, mas sem infringir que o dispositivo determine a fruição do público ou auxiliar o imperialismo americano. O texto está longe de tirar conclusões deterministas sobre a diferença entre o cinema autoral e o cinema hollywoodiano ${ }^{28}$.

Sérgio Augusto decupa as cenas. Pensa o discurso fílmico através da descrição atenta dos detalhes. O texto não quer frisar a supremacia do cinema de autor, mas analisa as cenas para mostrar sua diferença. O próprio filme fala mais alto, exigindo uma metodologia adicional de trabalho, através da análise interna. Esse é o dado diferencial ao referencial geral de Opinião: a possibilidade de atrelar esse padrão com a análise interna e o específico do cinema.

Os trechos descritos acima relevam o ponto comum entre os críticos do jornal e as variações em torno deste específico em Opinião. O parâmetro serve de ilustração para o leitor acompanhar no capítulo 3 os matizes em torno desse específico em cada crítico. Às vezes os cronistas permanecem na análise do discurso político dos filmes ou apenas usam os critérios cinematográficos, como veremos. Portanto, em Opinião há

\footnotetext{
${ }^{28} \mathrm{Na}$ breve passagem por Opinião, seria possível interpretar alguns dos textos de José Carlos Avellar com essa leitura, embora esse não fosse seu intuito, como veremos. Nestes casos, o crítico analisa o mecanismo cinematográfico, desde o movimento da câmera, o enredo, até as possíveis posturas do espectador, passando pela visão de mundo do filme.
} 
duas tendências maiores: a presença desse ponto zero voltado ao discurso político dos filmes e os textos que entrelaçam os critérios do cinema com os imperativos políticos.

Subindo todos os degraus, aprofundaremos o grau máximo da junção entre estética e política em cada crítico de Opinião no Capítulo 3. Às vezes o objetivo é a estética dos filmes, outras vezes o ingrediente político aparece mais. Em outros momentos, estamos próximos do que Eagleton chama de crítica dialética. Neste caso, as obras são compreendidas como luta de classe, mas sem excluir o estudo sobre os métodos de produção. A crítica dialética para Eagleton não busca frisar somente as formas artísticas que os conflitos sociais assumem, mas indagar como se dá a luta de classe no campo estético. Sem escapar ao objeto de análise concreto, o objetivo é investigar como o estético trabalha historicamente.

Nestes casos, a análise se aproxima da fusão entre texto e contexto numa interpretação dialética, próxima também à crítica integral de Antonio Candido (2011 a). Procura-se explicar a obra artística de forma plena, com atenção às formas, estilos e significados. A crítica integral de Opinião não vai mecanicamente do texto para a ideologia, nem vê a produção cultural como reflexo passivo da base econômica. Longe de determinismos, ela entende a produção cultural como parte do amplo processo social do qual faz parte, não só nos temas, mas no estilo, no ritmo, na imagem e na forma. Pensa cada um desses itens com autonomia, ligada de forma complexa ao modo de produção. A consequência desse processo é ver a obra como uma estrutura formal que deve ser julgada conforme suas próprias leis. Ao mesmo tempo ela é uma unidade complexa moldada tanto pela história das formas relativamente autônomas, quanto pela capacidade de cristalizar certas estruturas ideológicas dominantes. A obra de peso que este tipo de crítica procura reúne dialeticamente em uma totalidade complexa o particular, o social e o individual para projetar uma imagem rica e multifacetada da sociedade e do indivíduo. 


\subsection{A presença cotidiana de Brasil em Tempo de Cinema}

Continuamos a análise do item anterior sobre a convergência de parâmetros conceituais entre os críticos de Opinião, procurando adentrar em camadas mais densas. Avaliamos se os critérios sedimentados nos anos sessenta ainda são ferramentas de análise corrente. Trata-se de pensar o ambiente cultural e como essas ideias circulavam indiretamente no jornal. Se o artigo de Paulo Emilio Salles Gomes, Uma situação colonial?, texto de 19 de novembro, apresentado durante a I Convenção Nacional da Crítica Cinematográfica em 1960, é a grande matriz de pensamento porque relaciona o cinema brasileiro com a situação de subdesenvolvimento, o diálogo com outras obras também deve ver revisto. O texto seguinte de Paulo Emilio, Cinema: Trajetória no subdesenvolvimento (1980), publicado em Argumento ${ }^{29}$, repercute pouco como forma de análise em Opinião.

Se a crítica de cinema do semanário não nasce de geração espontânea, procuramos demonstrar aqui o diálogo com obras importantes do período, tais como Brasil em Tempo de Cinema de Jean-Claude Bernardet, ou com matrizes de pensamento antecedentes, no caso a obra de Lucien Goldman e o livro Mitologias de Roland Barthes. O livro de Bernardet foi escrito como parte da dissertação de mestrado que ele iria defender na Universidade de Brasília. A pesquisa foi feita sem recuo histórico e analisava a produção brasileira do início dos anos sessenta, pouco tempo depois dos lançamentos. Bernardet relacionava a representação do povo nos filmes com a classe social dos diretores. A correlação entre os cineastas e a classe média causou muita polêmica no campo do cinema, porque muitos realizadores, especialmente os do Cinema Novo, viam-se como sujeitos responsáveis por fazer aflorar a cultura popular. Com a invasão da universidade pelos militares em 1965, Bernardet foi impedido de defender o trabalho. Só em 1967, Brasil em Tempo de Cinema ${ }^{30}$ foi lançado em livro.

O objetivo aqui é revelar as reapropriações dos conceitos no jornal, tomando o estudo comparativo com os anos anteriores para avaliar continuidades e rupturas,

\footnotetext{
${ }^{29}$ O artigo Cinema: trajetória no subdesenvolvimento foi publicado na edição n. 1 de outubro de $1973 \mathrm{em}$ Argumento. A obra foi reunida na coletânea publicada pela Paz e Terra em 1980.

${ }^{30}$ Sobre Brasil em Tempo de Cinema e a revisão da cultura do nacional popular no cinema ver o capítulo 6.
} 
especialmente no trabalho de Jean-Claude Bernardet ${ }^{31}$. Não se trata jamais de uma comparação com fins valorativos. Procuramos localizar os antecedentes teóricos e metodológicos da crítica de Opinião. Tratamos neste tópico os críticos como grupo conjunto, porque vemos estes critérios como parte do contexto social e da cultura política engajada do período.

Iniciamos a análise com a recepção de Toda nudez será castigada (1972) para entender o significado político do quase silêncio sobre o filme em Opinião. Na época do lançamento, Sérgio Augusto comparou num breve comentário $O$ último tango em Paris (1972) de Bernardo Bertolucci ${ }^{32}$ ao filme de Arnaldo Jabor. Para ele, o "pornofilme" brasileiro oferece a uma faixa do público aquilo que ela aprecia: a sordidez humana abordada com cinismo e humor de beira de calçada. Se Jabor provou que "se pode fazer um filme comunicativo, sem vulgaridade, nem apelações, com certo pudor (...), merece aplausos". Contudo, ele se preocupou demais em encher seu filme comercial de cenas artísticas e sofisticação. Sem ter um momento ridículo sequer, o cineasta incorreu num erro fatal porque levou a paródia de Nelson Rodrigues a sério. A comparação com Bertolucci não era um elogio, afinal os dois são repreendidos por flertar com o cinema tido como "erótico" na época. Além disso, os dois cineastas faziam filmes para o mercado.

A acusação de Augusto não foi única. A maior parte dos críticos viu Toda nudez como parte do gênero erótico. Jornais como Folha de S. Paulo e O Estado de S. Paulo não dedicaram artigos propriamente ao filme; fato revelador dos preconceitos sobre o uso do melodrama. Afora esse lado em comum de maior amplitude, a recepção crítica foi bastante variada. Alguns viram Toda nudez como péssimo; poucas vezes como possuidor de raro senso crítico. Outros elogiaram o nível técnico ou vislumbraram uma solução para o cinema empresarial. Os comentários negativos foram mais numerosos. Por exemplo, Jean de Baroncelli ${ }^{33}$ do Le Monde, não observou nada mais do que uma

\footnotetext{
${ }^{31}$ Nos cadernos manuscritos de Jean-Claude Bernardet, há alguns itens de análise do trabalho de Roland Barthes e de Lucien Goldman no início dos anos sessenta. Caderno de anotações de Jean-Claude Bernardet. Pasta PI 18 o. Caderno I. Arquivo Jean-Claude Bernardet. Centro de Documentação e Pesquisa da Cinemateca Brasileira. Contudo o caderno 1 desapareceu do acervo. Tivemos acesso a seu conteúdo através do sumário detalhado do caderno 1.

${ }^{32}$ Augusto, Sérgio. O último tango em Botafogo. Opinião. n. 20, p 22, 19 a 26 março 73. Em entrevista, Augusto explica que escreveu mais sobre o filme na Veja. Gostou de Toda nudez pelo tom operístico, mas fez alguma restrição ao uso do tango.

${ }^{33}$ Baroncelli, Jean de. O brilhante fórum do Festival de Berlim (tradução do Le Monde). Opinião. n. 35 , p. 22,08 a 16 jul. 1973 .
} 
curiosidade, um "melodrama que pretende fustigar o puritanismo da alta sociedade carioca." Contudo, com certo senso de "humor e de delírio", Jabor não conseguiu evitar que "essas molecagens caiam no ridículo". Baroncelli não percebeu que o ponto alto de Toda nudez é exatamente a ridicularização da chave dramática dos personagens ${ }^{34}$.

As condenações parecem indicar um preconceito em relação à utilização dos elementos do cinema tido como popular, tais como o melodrama e a comédia erótica. Jabor foi até os gêneros estigmatizados para buscar um efeito catártico e um viés crítico, conforme Ortiz Ramos (Ramos, 1987). A abordagem não foi inédita. Na mesma década, Rainer Werner Fassbinder utilizou-se do melodrama em chave conscientizadora em Lágrimas amargas de Petra Von Kant (1972) e Ali, o medo corrói a alma (1974), segundo Ismail Xavier (2005). Como no caso brasileiro, a cegueira atingiu os críticos de Cahiers du Cinéma, que demoraram para ver Fassbinder como um cineasta autoral. Isso porque nestes casos prevalecia em Opinião o imperativo político da produção, ante a discussão da autoria.

Dois anos após a estreia, Jean-Claude Bernardet publicou um artigo sobre Toda nudez em Opinião. O ano é bastante significativo do momento político de aproximação dos cinemanovistas com o Estado autoritário (Ver Capítulo 5). Os comentários do crítico fugiram totalmente da análise interna da obra e permaneceram nos fatores externos, a partir da comparação com A estrela sobe (1974) de Bruno Barreto ${ }^{35}$ :

\begin{abstract}
"Filmes como A estrela sobe e Toda nudez será castigada abrem uma nova perspectiva para o relacionamento entre o cinema brasileiro e o público: são filmes que atingem várias classes sociais e que sem apresentar nenhuma inovação são bem feitos artesanalmente, vendendo uma imagem cultural "limpa". (...) Já A estrela sobe não apresenta nenhum caráter experimental. Como também não apresentava nenhum caráter experimental outro filme muito próximo da Estrela sob este aspecto. Toda nudez Será Castigada de Arnaldo Jabor. (...) Esse cinema, para obter sucesso tanto de bilheteria como cultura, tem que recorrer a uma certa banalidade temática e dramatúrgica, bem como a um artesanato que permita dizer à média dos espectadores: 'é bem feito'. Tanto Toda nudez quanto A estrela sobe enquadram-se neste esquema. (...) A narração linear, a construção rígida das situações e personagens, sem deixar margem à ambiguidade, (...) possibilitam ao espectador se sentir seguro diante do filme. (...) O que se entende por bom acabamento - o chamado lado estético dos filmes - dá uma imagem 'digna' do Brasil (não são mais aqueles filmes que mostravam um Brasil popular e miserável). Um estilo bem comportado."
\end{abstract}

\footnotetext{
${ }^{34}$ Sobre a análise da obra de Arnaldo Jabor, ver $O$ olhar e a cena de Ismail Xavier (2003).

${ }^{35}$ Bernardet, Jean Claude. O cinema brasileiro sobe. Opinião. n. 121, p. 24, 28 fev. 1975.
} 
Se o foco do artigo é a relação entre cineasta e público, o comentário sobre os filmes que se declaram "bem feitos" esconde um critério de análise muito comum em Opinião. Com esta mesma fonte de pensamento, Marcos Ribas de Farias analisa $O$ casamento (1975) de Arnaldo Jabor ${ }^{36}$ e Gustavo Dahl vê Chinatown (1974) e A Faca na água (1962), ambos de Roman Polanski, como exemplos de um cineasta interessado pela forma porque não tem nada a dizer ${ }^{37}$. Partilhando do mesmo conceito, José Carlos Avellar trata Ovelha Negra (1974) de Haroldo Marinho Barbosa como um filme frio, bem acabado e distante de nós mesmos ${ }^{38}$. Há uma recorrência muito grande à questão do ornamento ${ }^{39}$. Este mesmo critério era utilizado para falar de algumas comédias eróticas, que usavam um “invólucro" de qualidade para atingir um público sofisticado.

É possível comparar os comentários de Opinião com o estudo de Jean-Claude Bernardet sobre Walter Hugo Khouri nos anos sessenta. No jornal alternativo, Bernardet tomou $O$ anjo da noite (1974) como um puro exercício de formalismo que demoniza o negro ${ }^{40}$. De estilo autoral e didático em seu esquematismo, o resultado seria um objeto ornamental para enfeitar residências iguais as do filme. Dez anos antes, em Brasil em Tempo de Cinema, Bernardet se referia ao cineasta como alguém dotado de uma "pretensa carga metafísica".

A terminologia era uma reapropriação de conceitos, apontando para a expressão "metafísica de Hitchcock", forjada por François Truffaut e Claude Chabrol (Baecque, 2010). Procurando pelo caráter autoral de Hitchcock, Chabrol teria aprimorado a expressão "larger than life" por metafísica. O termo "metafísica de Khouri" é uma constante em Opinião. Mas da busca inicial pela mise en scène de Cahiers, o semanário brasileiro recriou um novo sentido: a ausência de preocupações políticas. Khouri é o grande bode expiatório do cinema brasileiro. Ele é sempre lembrado como adjetivo negativo para fins de comparação por suas "convulsões metafísicas". Uma exceção

\footnotetext{
${ }^{36}$ Farias, Marcos Ribas de. O casamento, fracassado. Opinião. n. 169, p. 18, 30 jan. 1976.

${ }^{37}$ Dahl, Gustavo. Polanski - a linguagem inútil. Opinião. n. 116, p. 24, 24 jan. 1975.

${ }^{38}$ Avellar, José Carlos. Bolero Serrano. n. 180, p. 20, 16 abr. 1976.

${ }^{39} \mathrm{O}$ debate sobre o ornamento ficou famoso pelas mãos de Siegried Kracauer (2009), mas a análise feita se distancia do conceito aplicado em Opinião. No jornal, o ornamento é definido como uma beleza por si mesma que nada significa.

${ }^{40}$ Bernardet, Jean Claude. O anjo de enfeite. Opinião. n. 112, p. 21-2, 27 dez. 1974. Já nas anotações manuscritas em seu caderno, Jean-Claude Bernardet viu o filme como "puro exercício de estilo". Caderno de anotações de Jean-Claude Bernardet. Pasta PI 18 o. Caderno V. Arquivo Jean-Claude Bernardet. Centro de Documentação e Pesquisa da Cinemateca Brasileira.
} 
nesse sentido foram os artigos de Gustavo Dahl e de Paulo Emilio Salles Gomes dez anos antes. Os dois analisaram o filme e deixaram de lado os critérios ideológicos ${ }^{41}$.

Khouri não foi o único cineasta condenado em Brasil em Tempo de Cinema pela postura formalista. O mesmo critério foi utilizado para David Neves e Júlio Bressane. Nem Gustavo Dahl escapou, quando lançou Em busca do ouro (1965), considerado por Bernardet um filme ornamental, de postura contemplativa e bela fotografia. As condenações estão centradas na postura da câmera: nostálgica, ela passeia imperturbável em movimentos elegantes e gélidos. Dahl não teria contextualizado a Inconfidência Mineira porque estava preocupado em fazer uma obra de arte requintada e de bom gosto. Naquele mesmo livro, Bernardet (2007: 27) resumia as razões da condenação ao ornamento: "Uma cultura que tem como critério apenas a qualidade é uma cultura morta, ainda mais quando de boa qualidade se torna sinônimo de consumível”.

A desaprovação ao formalismo não tem como foco a questão da qualidade, mas a tentativa de excluir a miséria e as ambiguidades da representação. Trata-se de uma defesa da arte engajada e um ataque ao núcleo da arte pura. Retrospectivamente, há uma condenação à imagem positiva do Brasil como vitrine e progresso, ao contrário do que aconteceu, por exemplo, na campanha de Cinearte (Xavier, 1978). Por detrás destes comentários, os críticos de intervenção queriam revelar ao público que a forma é ideológica, e não está interessada em alterar a estrutura da sociedade. Ao contrário, ela quer vender uma imagem positiva do país, benéfica ao regime ou à indústria. Portanto, um filme brasileiro autoral de linguagem acessível, mas sem postura engajada, é desaprovado sempre em Opinião, seja pelos críticos estetas ou políticos. Afinal, não estava em pauta só a falta de originalidade, mas a fuga de sentido político.

A postura contrária ao formalismo é anterior ao livro de 1967 e tem ligação na obra de Bernardet com o surgimento do Cinema Novo. Ainda em $1961^{42}$, ele explicava que os filmes deveriam ser sempre sociais, atuando para mudar a situação brasileira.

\footnotetext{
${ }^{41}$ Dahl, Gustavo. Importância de Khouri. Suplemento Literário. O Estado de S. Paulo. 21 mai. 1960, p. 41. O crítico considera uma ingenuidade acreditar que um filme possa ser alienado. Mesmo que queira, qualquer diretor jamais se livrará da ação do meio, que sempre está filtrada nos filmes. Citado por JeanClaude Bernardet e Maria Rita Galvão (1983). A página está ilegível no acervo do jornal; por isso nos concentramos na análise feita pelos dois autores. Em Brasil Urgente em 1963, Paulo Emilio Salles Gomes (Calil, Machado, 1986) foge da discussão ideológica sobre Khouri e analisa o autor em termo de fraquezas no que tange à comunicação. Gomes, Paulo Emilio Salles. Falar bem e mal de Khouri. Brasil urgente. n. 3, mar. 1963.
} 
Não era só Jean-Claude Bernardet quem condenava o ornamento. Em 1965, um dos pontos comuns a esse discurso foi o manifesto de Glauber Rocha (2004: 63-67), Uma estética da fome. O termo ornamento é substituído por cinema digestivo, mas o sentido é o mesmo. Glauber o descreve como um cinema que não suporta as imagens da miséria e prefere filmes alegres com gente rica em casas bonitas. Embora o texto seja de 1965, vez por outra alguns críticos de Opinião incorporavam o termo glauberiano cinema digestivo.

O debate em torno do formalismo indica os dois núcleos entre os artistas voltados ao nacional popular ou à experimentação, ou entre os cinemanovistas e os marginais. Portanto, o debate em torno do formalismo dos anos sessenta mantinha-se como um critério de análise do jornal. É inegável que o termo esteja vinculado à presença da cultura política engajada, revelando como ela ainda era matriz do pensamento do jornal. A terminologia formalismo indica uma presença difusa da política cultural marxista. No geral, a crítica marxista opõe-se a todos os tipos de formalismo na arte, atacando as propriedades técnicas que reduzem a arte a um jogo estético. A postura costumava vir acompanhada de uma rejeição pelo conteúdo sem política ou o mero exercício experimental (Rubim, 1987, 1988, 1988 a).

A crítica marxista se opõe ao formalismo porque ele evita o tema político através da defesa da arte pela arte. Assim, a atenção às propriedades técnicas é vista como uma maneira de tirar a importância histórica da arte. Forma e o conteúdo são vistos numa relação dialética, mas a crítica marxista deseja afirmar em última instância a primazia do conteúdo na determinação da forma. Num viés parecido, Opinião ataca a forma e centra seus comentários no conteúdo ${ }^{43}$.

\footnotetext{
${ }^{42}$ Bernardet, Jean Claude. VI Bienal: homenagem ao cinema brasileiro. Suplemento Literário. O Estado de S.Paulo. 14 out. 1961, p. 13.

${ }^{43} \mathrm{O}$ desprezo pela forma sem conteúdo aparecia também na crítica de cinema brasileira. Desde os anos cinquenta, os exercícios formais são desprezados. Basta ver os comentários na revista Fundamentos de Alex Viany e Nelson Pereira dos Santos, ambos ligados na época ao Partido Comunista, atacando o formalismo da Vera Cruz por ignorar o homem brasileiro (Galvão, Bernardet, 1983). Se olharmos de perto estes textos, veremos a discussão sobre o ornamento sempre em relevo como princípio de análise. A discussão não estava presente só nos artigos de cinema, mas em vários campos artísticos, como na literatura, que dialogava de perto com as influências do partido comunista (Rubim, 1987). Assim um critério importante da cultura política marxista transformava-se em ferramenta de análise mesmo para os críticos de cinema externos a esse raio de influência.
} 
Voltando ao jornal, Marcos Ribas de Farias se refere a $O$ casamento (1975) de Arnaldo Jabor ${ }^{44}$ utilizando o conceito de ornamento:

"Raros filmes brasileiros conseguiram, como ele, trazer à baila este inconfessado nível ideológico que, sempre, vem agindo na formação teórica e prática do nosso cinema. Assim, ele deve ser visto como uma crônica social e seu diretor como um deslumbrado e mundano colunista entre modelos de Dior, Givenchy ou Balenciaga (...). Pois, não há dúvida de que $O$ casamento é um dos mais perfeitos exemplos do cinema burguês tentando mascarar esta condição através de uma aparente postura crítica em relação ao assunto escolhido com a qual a sua ação do espelho fica, aos seus próprios olhos, anulada.

(...) o teor burguês e de classe média da mise en scène de Arnaldo Jabor diz sempre presente. A sua revolta contra a burguesia, a sua crítica à classe média (...) usam exatamente os preconceitos burgueses e de classe média que ele busca atingir.

Pretensa vanguarda - A sua revolta e a sua crítica, portanto, são absolutamente inofensivas porque, no fundo, inexistem. A escritura adotada é burguesa na medida em que ela se inspira claramente numa distinção entre o burguês ético e o burguês político (de novo Barthes): o que ela, enquanto pretensa vanguarda, contesta é o burguesismo da arte e da moral e não o burguesismo político. Na verdade, aparentemente, o que ele critica na burguesia é a sua linguagem e não o seu estatuto. Mas, diabolicamente, a burguesia (e a ideologia e cultura que ela representa) é mais forte e a própria linguagem que ela emprega termina por ser profundamente burguesa. E qualquer movimento contestatário [grifo nosso] encontra rapidamente a sua ruína. Isto porque, como a arte burguesa tradicional, $O$ casamento pode ser medido e pesado em função de sua linguagem, que repousa na pura quantificação de seus efeitos: o luxo do cenário, a cromatização da cinegrafia, a morbidez e as taras afloradas no roteiro, as lágrimas dos atores. A classe média recebe muito bem tudo isto e, como a função do espelho foi negada sistematicamente pela escritura que lhe é proposta, sente-se muito longe daquilo que intencionalmente seria ela mesma. E acaba aplaudindo e devolvendo o dinheiro empregado para a realização do filme".

O trecho se fixa no sentido político da linguagem. O crítico prefere concentrar a análise nos dados externos ao filme, sem relacionar as afirmações na análise interna. Trata-se de um artigo teórico que repensa não só a relação com o público, mas o grau de eficiência do filme para conscientizar o espectador de sua condição burguesa.

Além da já citada semelhança com o artigo de Jean-Claude Bernardet sobre Toda nudez e sobre A estrela sobe, é possível traçar um paralelo com a análise do próprio Bernardet sobre Bahia de todos os santos (1960) de Trigueirinho Neto no livro Brasil em Tempo de Cinema de 1967. Utilizando a mesma metodologia de trabalho, o crítico também centra o estudo na questão da classe média. Como Ribas de Farias,

\footnotetext{
${ }^{44}$ Farias, Marcos Ribas de. O casamento, fracassado. Opinião. n. 169, p. 18, 30 jan. 1976.
} 
Bernardet percebe que embora o filme apresente uma oposição à burguesia, o resultado também não saiu a contento. A razão é a indefinição dos personagens. Eles não estão nem perto do povo, nem à esquerda, nem à direita. A análise é feita através do posicionamento dos personagens e de sua opção política. Bernardet observa que alguns deles demonstram repúdio às instituições, mas outros defendem os mesmos direitos. A solução proposta por Trigueirinho Neto no final é a busca por meios humanos, mas nunca políticos. Fugindo deste último viés, o desfecho opta pelo compromisso com a moral:

“(...) Trigueirinho Neto não levou às últimas consequências as contradições de sua personagem. (...) Trigueirinho Neto tem uma raiva profunda e dolorosa, mal tingida de ironia, da burguesia (...). Trigueirinho Neto quer que a sociedade mude, pois é insustentável que fique como está, mas seu antiburguesismo primário não leva a coisa alguma a não ser reforçar a moral burguesa."

A conclusão em Brasil em Tempo de Cinema é observar que Bahia de todos os santos reforça a moral burguesa, ao invés de condená-la. Trata-se de uma ilação parecida com a de Marcos Ribas de Farias. Os comentários negativos do livro não passam apenas por Trigueirinho Neto, mas atingem outros alvos, como por exemplo, o dramaturgo Nelson Rodrigues, autor da peça Toda nudez será castigada. No jornal Última Hora em 1964, Bernardet (1978: 80) fez os mesmos comentários negativos para se referir a mais uma adaptação de Rodrigues, no caso Bonitinha mas ordinária (1963) de J. P. de Carvalho. A conclusão negativa a Toda nudez em Opinião tem uma origem comum neste trecho de Brasil em Tempo de Cinema sobre Nelson Rodrigues:

"Estamos em pleno conformismo: deixemos que os ricos fiquem ricos, já sofrem bastante com sua angústia, e voltemo-nos para a comunidade extra-social. Se Nelson Rodrigues, aliás, tivesse uma compreensão mais realista e menos metafísica e moralista de seu escravo-classe média, poderia chegar a conclusões mais incisivas. Quanto ao retrato de uma alta burguesia degradada, não repercute porque as personagens são falsas e não há análise do grupo social. Nelson Rodrigues talvez tenha tido intenção de fustigar o burguês ignóbil: 'enveredei por um caminho que pode me levar a qualquer destino, menos ao êxito... estou fazendo um teatro desagradável, peças desagradáveis...'. Engano: após reticências iniciais, a burguesia fez o sucesso de Nelson Rodrigues; os ingredientes de Bonitinha mas ordinária são justamente os alimentos prediletos do masoquismo de uma burguesia que gosta de receber bofetadas na cara; ela observa, com um prazer mal disfarçado de ironia, o lixo que o autor despeja sobre ela. Mas quem justifica a adaptação cinematográfica das peças de Nelson Rodrigues não é a 
alta burguesia, e sim a classe média, que encontra na tela aquele luxo, abundância, esbanjamento que acredita serem características de uma vida a que aspire; e, por outro lado, a xingação a que são submetidos os privilegiados compensa uma eventual frustração. Boa maneira de manter cada um em seu lugar e evitar qualquer alteração de status quo" (Bernardet, 2007: 131-2).

Afora a descrição das preferências sadomasoquistas da burguesia deste trecho, os comentários de Brasil em Tempo de Cinema sobre Nelson Rodrigues caem como uma luva em Opinião na ideia de que os filmes fingem atacar a burguesia, mas a reforçam. Como consequência, o público não percebe sua situação e sua culpa. Assim, tanto o teatro desagradável de Nelson Rodrigues, quanto o sentimento de revolta dos cineastas contra sua própria classe perdem sua eficácia junto ao público, porque o espectador jamais vai conseguir se ver retratado na tela. Afinal o processo de identificação é suspenso. Mesmo com a agressão à burguesia, a finalidade acaba por ser conformista.

Como na crítica sobre $O$ casamento, os comentários sobre Nelson Rodrigues em Brasil em Tempo de Cinema também versam sobre a ineficiência do filme em alterar o status quo ou atingir o público em seu sentimento de culpa burguês. A produção do dramaturgo é vista somente como reflexo de sua classe social e de sua ligação com seu público, tão burguês quanto ele.

O comentário negativo a Toda nudez em Opinião tem uma origem comum na interlocução aberta com Nelson Rodrigues, e provavelmente advém da adaptação de um autor de linha política e moral conservadoras. É como se a acusação de conformismo contra o dramaturgo fosse transmitida instantaneamente por uma espécie de contágio a Arnaldo Jabor.

É interessante observar que o comentário negativo a Nelson Rodrigues de Brasil em Tempo de Cinema não era compartilhado pela imprensa nos anos setenta ao se referir a Toda nudez será castigada. Os jornais não questionaram a adaptação de Nelson Rodrigues como um autor reacionário. Nem mesmo um artista vinculado ao nacional popular como Glauber Rocha (2004: 446-450) abriu essa ponte. Ao contrário, ele observa uma genialidade nelsoniana nos diálogos contra a crosta moral recalcada, num mundo buñuelesco. Percebe em primeira mão as semelhanças entre $O$ casamento e o Cinema Marginal, porque Jabor desce às vísceras de Nelson Rodrigues e pega o lixo 
subjacente, a úlcera, o câncer e as zonas proibidas. Os críticos de Opinião não avaliavam esse lado do filme provavelmente por causa da ligação com um dramaturgo de direita.

Conforme a pesquisa de Terry Eagleton (2011), Marx e Engels poderiam até admirar um bom autor conscientemente reacionário com uma consciência imaginativa da história. Caberia à própria escrita do romance forçar o escritor a assumir simpatias contrárias às suas opções políticas. O simples relato realista se tornaria partidário porque dramatizaria as forças da vida social, sem precisar explicitar as tendências políticas. Nos dois autores, a influência ao leitor seria apenas indireta, mas é essa gradação indireta que Opinião não admite. Nessa mesma linha ia Leon Trotsky (Eagleton, 2011). Segundo ele, a cultura socialista deveria absorver os melhores produtos da arte burguesa. Esse tipo de comentário não era aceito em Opinião.

Também Lucien Goldman (Löwy, 2008) aceitava uma visão de mundo mística ou reacionária se as obras fossem autênticas, porque a explicação histórico-social não suprime a especificidade da obra. Se Opinião tivesse aplicado integralmente a metodologia goldmaniana a Nelson Rodrigues ou até mesmo a Walter Hugo Khouri, o jornal poderia vê-los como artistas capazes de exprimir a visão de mundo de sua classe. Assim o conceito de ornamento poderia servir para repensar outras motivações sociais, sem uma visão negativa determinada. O que Opinião não aceita em Arnaldo Jabor é fazer uma crítica à sociedade de um ponto de vista "burguês".

Os trechos de Opinião sobre Jabor e os comentários de Jean-Claude Bernardet em Brasil em Tempo de Cinema sobre Trigueirinho Neto e Nelson Rodrigues têm em comum a definição de ornamento como criação de uma imagem de luxo e abundância e a consequente exclusão da miséria brasileira. Por causa da defesa do cinema que revela a situação brasileira, se exclui por completo uma possível preferência pela forma como opção artística no jornal. Vence nestes casos a matriz da cultura engajada.

Além disso, há também um conceito em comum nos trechos citados no parágrafo anterior: o do cineasta contestatário (Amengual, 1975), citado por Ribas de Farias nominalmente e que aparece como critério para falar de Trigueirinho Neto e de Nelson Rodrigues no livro de 1967. Apresentando-se como questionadores da ideologia, esses filmes a mascaram e endossam através da fetichização e mistificação da realidade. Fingem atacar a ideologia para defendê-la, servindo aos interesses da classe dominante. 
Em Opinião, o cineasta contestatário transforma-se numa categoria de análise para os filmes que não analisam sua classe social de origem. Ribas de Farias não comenta os elementos de Cinema Marginal e de cinema de agressão de $O$ casamento (1975) como fez muito tempo depois Ismail Xavier (2003). Realça apenas um diretor contestatário. Além disso, a terminologia de Ribas de Farias demonstra sua sintonia com os debates internacionais da crítica de cinema. Neste texto, a teoria antecede ao objeto.

Este não é o único aspecto em comum entre os textos. Para provar a argumentação, Ribas de Farias vai até Roland Barthes para explicar qual é o procedimento adotado para o burguês mascarar sua condição através de uma suposta postura crítica. Esta é a chave do artigo, que retira um longo trecho de Mitologias. Quando lê uma coluna social, o anti-burguês e pretensamente intelectual se afasta dela, numa postura de recuo e recusa para sua consciência não ficar maculada. Eis mais um trecho da crítica de Marcos Ribas de Farias:

"Mas tanto o cinismo quanto a negação são reações exatamente esperáveis e dedutíveis porque encerram aquilo que Barthes, em Mithologies, chama de identificação; isto é, o pequeno-burguês é um homem incapaz de imaginar o outro (...). É que o outro constitui um escândalo, um atentado à essência. Logo, esta reação de cinismo e negação veicula perfeitamente a recusa de estabelecer como espelho de desejos secretos, pecados particulares ou fragilidades inconfessáveis. (...)

Na verdade, a coluna social é um material excelente para uma pesquisa coerente sobre o pano de fundo de nossa sociedade. (...) Cabe a cada um compreender isto e ignorar o medo de se ver espelhado (...). Nada é mais burguês e classe média do que acreditar no próprio papel que se estabeleceu para si próprio. Mas, ao mesmo tempo, nada é mais favorável à perpetuação da cultura e da ideologia burguesas do que esta atitude. Ela fica, assim, tranquilamente garantida."

A descrição acima explica que os cineastas fogem dos temas políticos e atacam somente o conteúdo moral da burguesia. A mesma argumentação foi usada no livro de Jean-Claude Bernardet para explicar como Nelson Rodrigues consegue convencer o público de que a riqueza não compensa do ponto de vista moral. Nos dois casos os filmes não alteram o status quo. Os argumentos retomam diretamente um longo trecho de Mitologias, quando Roland Barthes explica a relação da classe média com a riqueza. Num primeiro momento, a burguesia encontra nos filmes o luxo sonhado, mas depois, conclui que a riqueza não compensa exatamente por causa do cunho moral: 
"Existem, sem dúvida, certas revoltas contra a ideologia burguesa. (...) Mas tais revoltas são socialmente limitadas e permanecem recuperáveis. Para começar, porque provêm de um fragmento da própria burguesia, de um grupo minoritário de artistas e intelectuais, sem outro público senão a própria classe que contestam, e que dependem, ainda, do dinheiro dessa mesma classe para poder se exprimir. E, ademais, estas revoltas se inspiram sempre numa distinção muito nítida entre o burguês ético e o burguês político; o que a vanguarda contesta é o burguesismo da arte e da moral; (...), mas contestação política, nenhuma. $\mathrm{O}$ que a vanguarda não tolera na burguesia é a sua linguagem, não o seu estatuto. Este nem sempre ela obrigatoriamente aprova; mas o põe entre parênteses: seja qual for a violência da provocação, o que ela finalmente assume é o homem abandonado, e não o homem alienado, e o homem abandonado é ainda o homem eterno." (Barthes, 2003: 231)

Páginas depois, Roland Barthes (2003: 243-4) destrincha alguns conceitos utilizados em Opinião para entender a classe média. Parte da argumentação de Farias e de Jean-Claude Bernardet encontra-se em Mitologias. De acordo com Barthes, a burguesia "degradada" não consegue se ver refletida na tela porque os personagens são falsos. No processo de identificação, o pequeno burguês está impedido de imaginar o outro. Mesmo quando o outro se apresenta na sua frente, o pequeno burguês prefere tapar os olhos. Ou ele ignora o outro ou o nega. Outra solução é converter o outro em fonte de exotismo, em puro objeto ou espetáculo. O processo impede a análise do grupo. É a este trecho que Marcos Ribas de Farias recorre nominalmente para explicar a função do espelho em Jabor. Para Farias, os excessos na interpretação impedem o burguês de se identificar com o personagem mostrado na tela. Por esse motivo, $O$ casamento não cumpre a tarefa de conscientizar sobre a classe social do público. A atitude padrão da classe média é aplaudir o filme e devolver o dinheiro de volta para Jabor produzir outros filmes, tal qual Barthes descreveu.

O que está implícito nessa linha de raciocínio é pré-determinar a fruição. A conscientização ocorre se o público passar pelo processo de identificação autocrítica. Esta linha argumentativa não está somente nesta obra de Barthes, mas é uma constante em Opinião. Assim se excluem outras relações possíveis com a obra, como o teatro de agressão que $O$ casamento coloca em prática.

Encontramos em Mitologias a fonte histórica para esse tipo de crítica de Opinião, voltada a desmistificar a ideologia do cinema. Logo na primeira página do livro, Barthes declara: "não haverá denúncia [da norma burguesa] sem um instrumento 
de análise preciso". O estilo textual em questão de Opinião assemelha-se muito ao livro de Barthes, publicado pela primeira vez em 1957 na França. Eis, por exemplo, um trecho do artigo Um operário simpático de Roland Barthes:

"o filme de Kazan, Sur les quais [Sindicato de Ladrões], é um bom exemplo de mistificação. Trata-se, como tudo mundo certamente já sabe, de um belo estivador indolente e um tanto bruto (Marlon Brando) cuja consciência vai despertando aos poucos, graças ao Amor e à Igreja (...); houve quem pensasse que poderia tratar-se de filme corajoso, um filme de 'esquerda', destinado a mostrar ao público americano o problema do operário.

Basta, porém, descrever objetivamente os papéis do filme de Kazan para estabelecer, sem a mínima contestação, o seu poder mistificador: o proletariado é constituído por um grupo de seres apáticos, curvando-se sob o peso de uma servidão que constatam sem coragem de abalar; o Estado (capitalista) confunde-se com a Justiça absoluta; é o único recurso possível contra o crime e a exploração: se o operário consegue chegar ao Estado, à sua política e às suas comissões de inquérito, está salvo". (Barthes, 2003: 68-9)

O objetivo dos textos de Opinião é desmistificar o mito, revelando a ideologia por detrás da produção dos meios de comunicação. Um pouco da metodologia de trabalho de Opinião está na apresentação do livro de Barthes. O autor de Mitologias explica que o livro tem o propósito de "realizar uma crítica ideológica da linguagem da cultura dita de massa" para "revelar em detalhe a mistificação que transforma a cultura pequeno burguesa em natureza universal". Barthes explica que os jornais estão mergulhados na ideologia que a burguesia criou para o mundo. Este processo consegue impedir que o mecanismo pareça ideológico. A descrição de Barthes sobre o trabalho de desmistificar o mito coincide com o núcleo textual da crítica ideológica de Opinião descrito acima.

As soluções propostas tanto pelo jornal quanto pelo livro de Barthes são as mesmas. Trata-se de escolher a fala que se opõe ao mito; de permanecer no nível político. É por isso que a linguagem revolucionária não pode ser uma linguagem mítica. Para Barthes, ela é, ao contrário, um ato catártico destinado a revelar a carga política do mundo. Neste processo o mito torna-se impossível. Em muitos textos, Opinião deslocase para a mesma crença na forma revolucionária do filme moderno como forma de politização do público. Este pensamento costuma excluir as gradações possíveis de interpretação do público, conferindo aos filmes modernos um poder muito grande de 
forçar o público a refletir sobre a realidade. Nestes casos, Opinião não separava os comentários sobre as normas burguesas dos cineastas, sem personificar neles o mal de possuir uma determinada visão de mundo. Trata-se de um comentário que não diz respeito a um crítico específico, mas reflete a presença da cultura política engajada no jornal. Quando está em questão o cinema brasileiro, os críticos não consideram como positiva a capacidade do cineasta representar a visão de mundo de sua classe. $\mathrm{O}$ critério muda, por exemplo, quando Marcos Ribas de Farias se refere a Rainer Werner Fassbinder ${ }^{45}$. Neste caso, a análise sobre a própria classe reveste-se de critérios positivos.

A relação entre classe social e visão de mundo está presente não só em Opinião quanto em Brasil em Tempo de Cinema. Sobre esse parâmetro, Jean-Claude Bernardet faz uma breve referência a um autor em especial no livro Trajetória Crítica (1978): Lucien Goldman ${ }^{46}$. Trata-se do conceito de sociologia das visões de mundo. A diferença é que Goldman não pensava a relação entre classe social ${ }^{47}$ e visão de mundo como algo negativo, como os críticos de Opinião fizeram com Jabor. Busca-se compreender a obra cultural e inseri-la na totalidade histórico-social de uma determinada classe. Sem apontar nos artistas a culpa por trazer a visão de mundo da classe média, Goldman examina a estrutura do texto literário para determinar o grau em que ele incorpora a visão de mundo do grupo ou da classe social a qual o escritor pertence (Eagleton, 2011, Löwy, 2008).

Goldman busca um conjunto de relações estruturais entre o texto literário, a visão de mundo e a história. Ele quer mostrar como a situação histórica de um grupo ou classe social é transposta por meio da mediação de sua visão de mundo para a estrutura da obra literária. O interesse recai no modo com o qual as estruturas mentais são

\footnotetext{
${ }^{45}$ Farias, Marcos Ribas. Fassbinder, o cineasta anti fetichista. Opinião. n. 187, p. 23, 04 jun. 1976.

46 Não trabalhamos aqui com a totalidade da obra de Lucien Goldman. Revelamos somente a incorporação e adaptação de alguns trechos de sua obra no jornal e no livro Brasil em Tempo de Cinema. Importa entender a compreensão feita da obra. Resta pensar porque entre diversas metodologias possíveis e influências sociais, escolheu-se Goldman para debater a função do intelectual-cineasta numa época de grandes transformações culturais, artísticas e políticas. Ver Goldman (1967), Löwy (2008), Frederico (2005), Eagleton (2011).

${ }^{47}$ Goldman entende a classe social definida por três fatores interdependentes: a função na produção, as relações com as outras classes e uma visão de mundo específica. Interessa aqui esta última característica porque decorre dela pensar a classe social como infra-estrutura das correntes artísticas. A visão de mundo de uma classe é a expressão de seu máximo de consciência possível, que reúne os membros numa totalidade complexa, que vai desde aspirações e sentimento até ideias. A imaginação da obra e os conceitos filosóficos podem ser estudados por meio da visão de mundo de uma classe social. Ver Michel Löwy (2008).
} 
produzidas historicamente. Pensa-se a visão de mundo através das condições históricas que as propiciaram. A metodologia de trabalho de Goldman tenta se deslocar constantemente entre texto, visão de mundo e história, através do método dialético. Foge, portanto, de começar a analisar o texto para chegar à história ${ }^{48}$. Para ele, quanto mais um texto aproxima-se de uma elaboração completa e coerente da visão de mundo da classe social, maior é a sua validade como obra de arte. A forma de análise difere do critério de Opinião. Ao contrário, os grandes escritores são os indivíduos excepcionais que conseguem transpor para a arte a visão de mundo de classe ou do grupo ao qual pertencem. Para Goldman, o mais importante é a estrutura da obra e não seu conteúdo. Em Opinião esse trajeto é invertido; importa o conteúdo da obra, e a estrutura é vista no uso mais corrente como parte da visão de mundo do diretor.

Brasil em Tempo de Cinema aplica o conceito criado por Lucien Goldman de homologia das estruturas significativas. A estrutura significativa é o resultado de um complexo esforço coletivo dos grupos sociais, longe da ideia de uma estrutura mecânica fixa $^{49}$. O caráter coletivo da criação literária provém do fato de que as estruturas do universo da obra são homólogas às estruturas mentais de certos grupos sociais 50 (Goldman, 1967). Bernardet inicia esse percurso através da análise dos personagens e enredo de diversos filmes brasileiros daquele momento. Ele centra a análise num personagem presente e ausente ao mesmo tempo - a classe média:

\footnotetext{
${ }^{48}$ O método de Lucien Goldman (1967) pretendia realizar uma pesquisa em dois níveis: a interpretação imanente e a explicação global. Primeiro, procura-se compreender a estrutura interna da obra. Depois o trabalho recorre ao contexto para chegar à estrutura global da obra. Este significado global só é atingido no estudo entre a estrutura da forma e a microestrutura. Não se trata de comparar o contexto com as estruturas mentais e a visão de mundo das classes sociais. Deve-se evitar este método mecanicista porque a dependência da esfera ideológica nas grandes obras é extremamente complexa. Existe uma autonomia relativa no universo cultural e é impossível relacionar todos os detalhes de uma obra literária com a vida econômica. Mas em último caso, a autonomia artística é redutível à exterioridade e às condições históricas e sociais. Tanto Michel Löwy (2008), quanto Terry Eagleton (2011) quanto Antonio Candido (2011 a) admitem que na prática a metodologia de Goldman fornece muito mais espaço à estrutura externa do que à interna.

${ }^{49}$ Para Goldman, é o homem quem modifica continuamente a realidade num processo contínuo de desestruturação das antigas estruturas e criação de novas. Esse caminho é feito através do conceito de assimilação e acomodação de Jean Piaget. O indivíduo constrói estruturas mentais por meio da interação com o grupo, num processo ininterrupto de acomodações e assimilações (Frederico, 2005).

50 'La relation déjà mentionnée entre la structure de la conscience d'un groupe social et celle de l'univers constitue, (...), une homologie plus ou moins rigoureuse, mais souvent aussi une simples relation significative. Il peut donc arriver, dans cette perspective - et Il arrive meme le plus souvent - que des contenus entièrement hétérogènes et même opposés soient structurellement homologues (...) (Goldman, 1967: 533).
} 


\begin{abstract}
"Este personagem que não se fixa, que não adere a nada, que oscila entre os dois polos sociais, (...) é um dos personagens mais frequentes do Cinema Novo daquela época. Penso que se deve ver neste personagem o embaixador de uma classe média ausente do filme. É um personagem indeciso e flutuante que tem na estrutura dramática dos filmes um papel semelhante àquele que tem, na sociedade, uma camada da classe média que, também, oscila. A classe média não foi diretamente abordada num filme como $A$ grande feira; entretanto é ela e apenas ela, que lhe fornece a sua ideologia. O namoro simultâneo e indeciso com as classes superior e inferior; evitar o extremismo porque nunca se sabe aonde ele pode levar (...): são elementos fornecidos por uma camada da classe média que se pensa progressista mas que não encontra nela nenhuma força e não quer encarar de frente a sua situação problemática, preferindo se travestir numa personagem simbólica" (Bernardet, 1978: 191-2).
\end{abstract}

Essa constância entre filmes de vários autores, seja à esquerda ou à direita, serviu para Bernardet relacionar a estrutura do comportamento político da classe média com a estrutura dos filmes. Assim Bernardet aplica a homologia das estruturas de Goldman para a noção de estrutura simétrica de pares dicotômicos para o caso brasileiro. Mesmo em filmes opostos do ponto de vista ideológico ou formal existe uma tendência a polarizar o mundo entre bons e maus. A presença dessa polarização e simetria é parte da postura de hesitação e incapacidade da classe média em se decidir pela burguesia ou pelo povo. A consequência é ver o mundo de maneira polarizada. Sem um projeto político próprio, a classe média oscila entre essas duas classes. Essa bipolaridade através das estruturas simétricas no enredo dos filmes reflete-se nos personagens flutuantes que também não endossam nenhum projeto político.

Nos anos setenta, Bernardet revia a metodologia de Brasil em tempo de cinema como algo superado por causa da limitação da perspectiva sociológica menos aprofundada. Ele condenava as relações mecânicas estabelecidas porque não foram fundo na análise dramática do filme. A metodologia foi empregada dessa forma porque foi feita a partir de anotações e da memória, sem acesso a uma cópia do filme.

No livro, Bernardet aplicou com maestria o método de Lucien Goldman ao estabelecer uma comparação entre a criação artística e os sistemas conceituais da classe média. Iniciando o percurso pelo conteúdo das obras, ele reflete sobre a homologia da estrutura entre a criação artística, a realidade social e a imaginação criadora. Em alguns momentos do livro, Bernardet procura dialogar com os cineastas citados para revelar como eles reproduzem parte da estrutura significativa. Ele retirava de Goldman a busca pelas estruturas mentais que atuam em nível inconsciente enquanto virtualidade do 
grupo ${ }^{51}$ (Goldman, 1967, Frederico, 2005), através do conceito de ideologia objetiva. Ele demonstra que tanto Glauber Rocha em Barravento (1961) quanto Alex Viany em Sol sobre a lama (1963) possuem ainda um viés conservador e populista. Os filmes não dialogam com o povo, mas solicitam aos dirigentes uma solução aos problemas. Pela reconstituição do discurso do filme, Bernardet extrai a estrutura em comum para demonstrar que os autores não tem consciência da "visão ideológica objetiva" professada pelos filmes. Trata-se de revelar para a correção futura o quanto a ideologia expressa pode contradizer a intenção do diretor. A maior parte dos significados não são conscientes e passam à estrutura da obra. $\mathrm{O}$ trabalho de intervenção do crítico tanto no livro quanto no jornal é fazer o cineasta adquirir a consciência dessas estruturas sedimentadas.

O livro teve grande impacto, mas criou polêmica no campo cinematográfico por questionar a noção de cinema popular do Cinema Novo. Em alguns momentos, é verdade, o livro vê o perfil do personagem quase como um prolongamento do diretor ${ }^{52}$. Por outro lado, seria errado afiançar a existência apenas desse viés. Não é nosso objetivo analisar a obra em sua integralidade; só traçar alguns paralelos sobre as continuidades metodológicas entre o livro e Opinião. Em vários momentos, Brasil em Tempo de Cinema aproxima-se mais da interpretação íntegra entre relações sociais, forma e conteúdo exposta por Antonio Candido no artigo Crítica e Sociologia (2011 a). Afinal a análise não é feita apenas na correlação entre classe social e produção autoral, mas utiliza também a análise imanente para realizar o paralelo entre o discurso dos filmes e o momento político. Pensando como Opinião lidava com todo esse arsenal, é preciso deixar claro que o jornal não dispunha sempre de espaço e tempo suficiente para aprofundar as análises.

\footnotetext{
${ }^{51}$ Trata-se de relacionar o conteúdo das obras literárias com o conteúdo da consciência coletiva. Com as próprias palavras de Goldman (1967: 532-534) "La relation essentielle entre la vie sociale et la création littéraire ne concerne pas le contenue de ces deux secteurs de la réalité humaine, mais seulement les structures mentales, ce qu'on pourrait appeler les categories qui organisent à la fois la conscience empirique d'un certain groupe social et l'univers imaginaire créé par l'écrivain. (...) C'est dire que les structures mentales ou, pour employer un terme plus abstrait, les structures catégorielles significatives, ne sont pas des phènomènes individuals, mais des phènomènes sociaux. (...) Les structures catégorielles qui régissent la conscience collectives et sont transposes dans l'univers imaginaire créé par l'artiste ne sont ni conscientes ni inconscientes dans le sens freudien du mot".

52 Segundo Ismail Xavier (2009), o livro concentra a análise nas questões de enredo e composição dos personagens, enquanto o objetivo era intervir no debate e abordagem sociológica que levaram Bernardet a fazer correlações entre personagem e classes sociais nem sempre consistentes, como a noção de classe média como determinante da produção autoral do Cinema Novo.
} 
Na maior parte dos textos, a forma de análise de Jean-Claude Bernardet mudou bastante em dez anos, principalmente quando ele conectava a análise do filme com o complexo distribuição-exibição. Trata-se de um amplo esforço para deixar de relacionar a classe social e a produção cultural, considerando o tema datado. Opinião não tem tempo nem espaço suficiente para levar a cabo a metodologia de trabalho proposta por Lucien Goldman, mas a cada vez que retoma a sociologia das visões de mundo está dialogando com os conceitos goldmanianos aplicados por Jean-Claude Bernardet. Se o estudo feito no jornal é fragmentado, de qualquer forma tanto a sociologia das visões de mundo quanto Brasil em Tempo de Cinema são as grandes presentes-ausentes em Opinião como metodologia de trabalho aplicada à produção brasileira.

A diferença é que Goldman aplica seu método para analisar grandes obras ${ }^{53}$, sistemas filosóficos a partir da homologia das estruturas. Enquanto isso, Opinião utiliza essa metodologia para obras que não atingem a coerência máxima por causa da sobrevivência de elementos ideológicos nos autores. Trata-se de uma metodologia menos complexa usada para as obras consideradas menores, que tentam reproduzir a realidade social nos moldes do naturalismo. Ao frisar os dados negativos, o estudo de Opinião incide sobre os fatores ideológicos, deixa de lado muitas vezes a explicação do processo histórico, relacionando o autor e sua classe social. A consequência é desassociar fato e contexto. Ao contrário disso, Goldman não procurava por contradições entre o caráter individual, a obra e seu significado social como forma de expressar uma visão de mundo. Misturando alguns preceitos de Goldman com aqueles de Mitologias de Barthes, Opinião toma Jabor como um autor que repete inconscientemente a estrutura de sua classe social, sem autonomia alguma. Ele teria a postura contrária de um bom cineasta que sai de sua classe social e adota a perspectiva da classe operária.

Opinião significou muitos avanços em termos de crítica integral, mas foi também sinal de congelamento em alguns casos quando os imperativos teóricos e os critérios ideológicos imperavam ante à análise imanente. Ao sofrer com as influências

\footnotetext{
${ }^{53}$ Para Goldman, a grandeza de um gênio é sua capacidade de expressar os valores de um grupo social em nível universal. Ele é o pensador que consegue cristalizar pela primeira vez no plano conceitual os elementos esparsos de uma visão de mundo e faz deles um conjunto rigorosamente coerente. $\mathrm{O}$ escritor genial é precisamente aquele cuja sensibilidade coincide com um grande movimento social e histórico. Quando ele aborda assuntos concretos, coloca também os problemas gerais de sua classe e época (Löwy, 2008). Goldman (1967) vê a obra alienada como a que não vai além de seus desejos, leis e problemas internos, enquanto a obra de arte tem um universo coerente no qual se desenvolvem os eventos e personagens numa expressão integrada estilisticamente ao autor.
} 
do contexto político e cultural, em alguns momentos há uma diminuição da análise dos filmes. Nestes casos, amplia-se o paradoxo do intelectual entre a estética e a função de conscientizar. Sem conseguir abdicar da segunda função, as contradições entre os polos do engajamento e da estética incidiam no tipo de análise feita.

No caso de Toda nudez, foram poucos os críticos que viram no filme uma obra acima da média. Entre eles, Paulo Emilio Salles Gomes ${ }^{54}$ (1986: 284-6) no Jornal da Tarde não partilhou dos comentários negativos ao diretor. Ele não vê Nelson Rodrigues como um reacionário, mas como um moralista conservador. Consegue explicar o discurso do dramaturgo sem cair em considerações de carga ideológica, como fez Opinião. Despreocupado também com o aspecto moral do burguês, Paulo Emilio observa a existência de uma estrutura dramática tradicional e de uma encenação moderna, aberta à recepção do público. Sem desprezo pelo cinema comercial, ele alegra-se com o sucesso do filme junto ao público. Contudo os comentários não são totalmente elogiosos. Segundo ele, Jabor não teve a capacidade de misturar o sublime e o abjeto num certo tipo de pudor espiritual que toma a forma de vulgaridade.

A exceção a esse conjunto foi José Carlos Avellar, o único que incluiu a análise interna no comentário para o Jornal do Brasil ${ }^{55}$. Preocupado com seu funcionamento, o crítico começa pela descrição das cenas para concluir que Toda nudez é apresentado a partir do ponto de vista de Patrício, irmão de Herculano. Enquanto os personagens se veem como trágicos, os espectadores percebem uma comédia, porque a informação depende menos da ação e mais do modo como elas são mostradas. Assim o espectador pode apreender de uma só vez não só a tragédia que cada personagem cria para si, mas também o ridículo por detrás das convenções sociais. Patrício representa o instante de materialização das intenções do filme. Ele é o personagem mais importante e pressiona as contradições e loucuras dos outros, até elas se tornarem claras e insuportáveis. Para Avellar, o estilo de superinterpretação através do ponto de vista de Patrício é um meio eficaz para criar um duplo nível de leitura. A atitude irônica deste personagem reflete como num espelho a atitude de Jabor. É a ironia quem cria o estilo narrativo do filme, enquanto a câmera registra as atitudes com olhar de deboche. Fugindo de uma preocupação com a miséria do país ou com a visão de mundo de Jabor, José Carlos

\footnotetext{
${ }^{54}$ Gomes, Paulo Emilio Salles. Uma nudez compensada - O drama deste casamento reconciliou o público com o cinema brasileiro. Jornal da Tarde. 26 abr. 1973.

${ }^{55}$ Avellar, José Carlos. A provocação. Jornal do Brasil. 26 mar. 1973.
} 
Avellar olhou para o filme, ao invés de começar pela teoria. Se Bernardet falava da necessidade de iniciar o percurso pela análise interna, neste caso foi Avellar quem pôs em prática essa metodologia para pensar Toda nudez.

Em entrevista, Jean-Claude Bernardet explicou em entrevista que após a publicação de Brasil em Tempo de Cinema, sua grande referência foi Avellar:

"Avellar é fotógrafo; tem um olho na materialidade do filme. Ele vai buscar a tomada, a gestualidade do ator, enfim todos esses elementos que a crítica deixa de lado em função de captar as significações. As significações não existiriam sem o significante. E Avellar é muito atento a isso. Então já desde o início, os textos do Avellar tinham uma personalidade que nenhum outro crítico, isso nem eu tinha. Eu acho que isso foi muito importante".

José Carlos Avellar vê uma "complementaridade" entre a crítica dele e a de Jean-Claude Bernardet. A diferença é a "metodologia", além da "trajetória". Enquanto Bernardet comenta os "conflitos dramáticos entre os personagens e o que se passa na imagem", ele trabalha a "construção da imagem em si mesma", explica Avellar na entrevista. Ele fotografou muito antes de escrever cinema, enquanto Jean-Claude Bernardet se muniu da informação da gramática cinematográfica como crítico para começar a fazer cinema.

A crise de Bernardet após a publicação de Brasil em Tempo de Cinema foi perceber que os comentários do livro serviriam para analisar um romance, mas que havia uma "insuficiente aproximação em relação às formas e à materialidade. Faltava o olhar do Avellar", explica. Foi então que ele voltou-se à semiologia por dar a ilusão de gerar uma evolução nesse sentido. Se Bernardet acreditou nos anos seguintes que não havia aprendido muito com a semiologia, ela foi a responsável por aproximá-lo da materialidade do filme. Pela primeira vez, Bernardet teve a oportunidade de contar os planos e cortes e pensar na duração de cada um deles no laboratório de Thomaz Farkas, onde havia uma moviola. A semiologia enquanto método o aproximou do que ele "preza":

"Apesar de que eu não encampasse a semiologia como método de análise de obras, não deixou de me aproximar dessa proximidade que tanto prezo que é a questão 
da materialidade. Não me tornei um semiólogo, nem evolui nesse sentido, mas isso me aproximou da película".

Não há dúvidas que Brasil em Tempo de Cinema é a principal referência metodológica brasileira empregada como continuação do que chamamos de um quase projeto editorial para a área de cinema de Opinião. A linha é muito mais de continuidade com o trabalho dos anos sessenta. Para Sérgio Augusto, o livro foi "fundamental" para os críticos, porque foi o primeiro a refletir sobre o Cinema Novo de uma forma mais densa. É com Brasil em Tempo de Cinema que os críticos de Opinião dialogam; o que pode ser comprovado no depoimento dado por Clóvis Marques:

"Li esse livro nessa época. O Bernardet era a leitura importante na época. Esse livro foi talvez o que chamou mais a atenção na década de setenta para a contextualização sócio político-econômico-estética do cinema brasileiro. Foi assim uma espécie de um clarão para a crítica de cinema brasileira nessa época; é como se com o Bernardet, ela tivesse alcançado uma maioridade intelectual e política que não tinha ainda."

O diálogo é aberto também com os realizadores, quando em Opinião, Nelson Pereira dos Santos, Oswaldo Caldeira ou Pedro Rovai retomam conceitos teóricos de cultura popular e da função do intelectual, fazendo referência ao livro de Bernardet, especialmente ao cinema sociológico. Nas entrevistas, eles visivelmente procuram responder às indagações da obra de 1967.

Bernardet declara que só soube desse diálogo aberto entre sua obra e os realizadores quando o Festival É tudo verdade lhe fez uma homenagem. Foi quando Eduardo Coutinho declarou publicamente que fez Cabra marcado para morrer para ele. O depoimento foi parar no prefácio da reedição de Brasil em tempo de cinema. "Evidentemente tem muita ênfase e generosidade nessa fala, mas o Coutinho tinha sido abalado e preocupado com o livro". Bernardet conta ainda outra história. Algo parecido aconteceu quando Arnaldo Jabor em conversa reservada disse que Bernardet tinha visto coisas em A Opinião Pública (1966) que ele não tinha percebido. Mais adiante Bernardet comenta com tom humilde: "Para mim foi grande momento de diálogo entre a crítica e a área de produção e criação. (...) Acho que em alguns casos, com alguns filmes e diretores, eu realmente tive muita intuição". 
Capítulo 3

Os críticos de cinema do jornal

O 'como' da expressão deve salvar a precisão sacrificada pela renúncia à delimitação do objeto, sem todavia abandonar a coisa ao arbítrio de significados conceituais decretados de maneira definitiva.

Theodor Adorno in Notas de Literatura I 



\section{Capítulo 3 - Os críticos de cinema do jornal}

Depois de traçar no capítulo anterior o que há de comum na crítica de cinema de Opinião, analisamos na sequência os artigos dos seus colaboradores. Iniciamos o texto pelos dois articulistas constantes na maior parte do percurso do jornal: Jean-Claude Bernardet e Sérgio Augusto. Cada um deles escreveu por volta de 60 artigos para Opinião. Em seguida analisamos os críticos Gustavo Dahl, Marcos Ribas de Farias, Clóvis Marques e José Carlos Avellar. Esses quatro colaboradores participaram do jornal em anos específicos e compuseram por volta de dez a vinte artigos cada um. Não temos a pretensão de encerrar o trabalho sobre os colaboradores do jornal. Se os critérios não são valorativos, não há espaço para uma análise minuciosa de cada caso. Não tratamos neste capítulo dos cronistas que escrevem poucos artigos, como Carlos Frederico ou Oscar Guilherme Lopes, pela impossibilidade de localizar um modelo teórico detalhado. Muitas informações biográficas foram retiradas das entrevistas feitas por nós ${ }^{1}$. Lembramos que o jornal era semanal e esse fator temporal deve ser levado em conta, porque salienta exatamente a qualidade dos textos, escritos em pouco tempo. Se o objetivo deste capítulo é trabalhar a metodologia dos articulistas, tomamos os artigos mais representativos de cada um dos autores. Antes disso, traçamos um histórico dos colaboradores para entender como eles analisavam os filmes. Em alguns casos, a descrição inclui o papel dos críticos na resistência ao regime militar, quando esse viés tem relação com o trabalho feito em Opinião.

\subsection{Jean-Claude Bernardet e o caso Lição de amor}

Até meados dos anos cinquenta, o belga de nascimento Jean-Claude Bernardet permanecia mergulhado na cultura francesa em pleno Brasil. Falava pouco o português

\footnotetext{
${ }^{1}$ Quando citamos as declarações de Júlio César Montenegro, Jean-Claude Bernardet, Sérgio Augusto, Marcos Ribas de Farias, José Carlos Avellar e Clóvis Marques, trata-se das entrevistas que realizamos com os autores. Nos casos de exceção, mencionamos as fontes.
} 
e vivia num ambiente seleto do ponto de vista cultural. A grande mudança veio com o cinema. A inserção na cultura brasileira e a convivência com críticos e futuros cinemanovistas tem início quando ele entra para o Cineclube Dom Vital em São Paulo. Através desses contatos, Bernardet foi trabalhar na Cinemateca Brasileira. A estreia na crítica se deu com o convite para compor a equipe que cobriu as férias de Paulo Emilio Salles Gomes no Suplemento Literário do jornal $O$ Estado de S. Paulo. Naqueles primeiros anos, Bernardet (1978) exerceu a crítica impressionista ${ }^{2}$ e tinha como referencial teórico a revista Cahiers du Cinéma sob o comando de André Bazin. "Eu, Gustavo Dahl; Todo mundo lia a Cahiers du Cinéma. Acho que isso foi uma influência nítida", contou ele. Mudando de direção, nos anos setenta a preferência de Bernardet era Cinéthique por ser marxista e interessada no mecanismo de produção.

Neste período, Bernardet repensou seu ato crítico, à luz da repercussão do artigo sobre A doce vida de Federico Fellini, do impacto do Cinema Novo e do ideal do intelectual dos anos sessenta que auxilia na transformação da sociedade brasileira, como vimos. Bernardet (2011) estava interessado em problematizar a ação do intelectual. Ele procurava linhas ideológicas das obras através da análise da linguagem, em busca dos níveis menos perceptíveis ou menos intencionais das obras. A preocupação principal era com a função que o cineasta desempenhava na sociedade e como esse papel se revelava nos filmes. Assim ele escreveu textos dirigidos aos próprios intelectuais e cineastas para explicar seu relacionamento com a sociedade da qual falavam. Esse viés explica uma parte importante do trabalho semanal de Bernardet em Opinião.

Até a época do golpe militar, Bernardet participava de uma célula do PCB junto com Paulo José e pessoas ligadas ao Teatro de Arena em busca não só do envolvimento político, mas pensando numa "saída" no "sentido de outra sociedade possível". Enquanto os demais não geravam problemas, “eu e Paulo José não parávamos. A gente não queria uma igreja". Sem delongas, ele explica: "nunca me dei bem com o stalinismo" e com suas verdades universais sobre a política. Se a democracia vertical "não nos convencia", "o partido não nos suportava porque a gente questionava demais."

Nos encontros semanais (Musse, 2004), as divergências eram constantes com o responsável pela ligação com o órgão superior. Qualquer questão aberta ou objeção era

\footnotetext{
${ }^{2}$ A crítica impressionista enfatiza a experiência do crítico diante da obra de arte e possibilita ao leitor aproximar-se da criação autoral.
} 
considerada um desvio de linha. Os atritos eram constantes, até que os dois foram levados a uma espécie de julgamento na presença de Mario Shenberg. Disseram tratarse de uma conversa para esclarecer algumas questões. Mantendo "a linha stalinista", Shenberg não deu a oportunidade de resposta aos dois. Mesmo após o incidente, Bernardet continuou no partido até o golpe militar. Esperou novas ordens porque iria consolidar uma nova rede, mas percebeu que as informações eram totalmente desencontradas. "As dicas" do partido não tinham "pé nem cabeça", com informações erradas sobre a localização de Jango e a possibilidade de levante. A cultura política engajada faz parte de sua trajetória, através de leituras de Marx, Engels, Lukács ou mesmo no contato com Octavio Ianni da Escola Paulista de Sociologia ${ }^{3}$.

Com o golpe militar, a polícia procurava Bernardet na Faculdade de Filosofia da Universidade de São Paulo, no Teatro de Arena e no Última Hora. O regime deu fim a todo seu trabalho desenvolvido no jornal. Ele só não foi preso porque conseguiu escapar duas vezes. Os editores do $U H$ avisaram para Bernardet não voltar à redação, porque seria detido. O nome de origem francesa ajudou a despistar os policiais. Tudo porque um funcionário da contabilidade afirmou que se tratava de uma mulher, chamada Jeane. Na segunda visita à redação, a polícia prendeu o "informante". Não se sabe até hoje se essa pessoa anônima se enganou ou se tentou protegê-lo. A polícia acreditava que Bernardet era a ponte entre o partido comunista francês e o brasileiro. O pai dele, que tinha lutado na resistência francesa, foi avisado da prisão iminente. Assim ele conseguiu escapar, mas teve que ficar no mato por dois ou três meses. Para voltar a sua casa, Rudá de Andrade preparou um grande evento divulgando com destaque o nome de Bernardet entre as colunas sociais para observar a reação da polícia. Além do tema provocativo, um filme de Eisenstein, o crítico foi levado de carro até o prédio da Filmoteca do Museu de Arte Moderna em São Paulo. Os elevadores foram desligados por questão de segurança antes, durante e depois da palestra. No final, ele voltou para o meio do mato onde estava. Como não houve nenhuma reação da polícia, Bernardet foi para casa com algum cuidado. Organizava palestras para Rudá, mas não ousava entrar no prédio da

\footnotetext{
${ }^{3}$ Em entrevista a Ricardo Musse (2004), Bernardet comenta que entre suas leituras nesse período leu trechos de Marx e Engels. Ele leu de forma mais sistemática Lukács nos anos sessenta, sobretudo as teorias sobre o romance e o realismo crítico. Da Escola Paulista de Sociologia, quem mais conversava com ele era Octavio Ianni, que publicou alguns textos sobre cinema na Revista Civilização Brasileira. "Mas não posso dizer que tenha leituras em sociologia. Agora, se tivesse encontrado uma bibliografia sobre a classe média e a intelectualidade, com certeza teria lido. Mas mesmo sem leituras sistemáticas, a gente se informava". O conceito do intelectual orgânico de Gramsci também foi um conceito marcante. "Talvez eu tenha lido Benjamin e Gramsci num determinado momento, como se lia Frantz Fanon".
} 
Cinemateca Brasileira. Enquanto isso, ele trabalhava com João Batista de Andrade, mas o nome dele não constava nos filmes, porque muitas vezes o dinheiro vinha de comissões estaduais de cinema. Alguém recebia o dinheiro em nome dele para não despertar suspeitas. Tudo ia bem até que uma pessoa ameaçou denunciá-lo a partir da Lei de Segurança Nacional. Assim houve um novo afastamento.

Os problemas continuaram. Através do convite de Paulo Emilio Salles Gomes, Bernardet tornou-se professor assistente da então Universidade de Brasília (Souza, 2002) quando houve a invasão, expulsão e prisão dos professores em $1965^{4}$. Com a demissão coletiva dos professores, ele foi impedido de defender sua dissertação de mestrado, que estava pronta. O texto só foi publicado em 1967 na forma do livro Brasil em Tempo de Cinema. O título da obra, Bernardet pegou emprestado de Cacá Diegues.

Por decreto presidencial e em decorrência do Ato Institucional Número 5 (AI-5), Jean-Claude Bernardet é aposentado do cargo de professor da Universidade de São Paulo com mais 23 docentes, entre eles Caio Prado Jr., Octávio Ianni, José Arthur Giannotti, Mário Schenberg, Fernando Henrique Cardoso, Emilia Viotti da Costa, Paulo Singer, etc. A base foi um decreto do Ministério da Educação e Cultura assinado por Costa e Silva em 29 de abril de 1969 e publicado no dia seguinte no Diário Oficial. Todos os cassados tinham um papel importante de liderança intelectual na universidade e eram figuras que insistiam em caminhos renovadores para a USP. Bernardet dinamizara a ECA no setor de cinema e era reconhecido pelo seu profundo interesse em criar um ensino crítico (Associação dos docentes da USP, 2004: 48). Jorge Bodanski comenta que os professores ligados a Rudá de Andrade, tais como Paulo Emilio, Bernardet, Almeida Salles, Maurice Capovilla, Roberto Santos foram muito maltratados. Um pouco da razão dessa perseguição estava na linha política adotada no curso de cinema. $\mathrm{O}$ projeto inicial de Rudá privilegiava a realidade brasileira. $\mathrm{O}$ cinema era um meio de denunciar o que acontecia. Como não era possível atingir a rua, a inserção na realidade se dava pelo conhecimento dos cineastas e seus problemas. Antes de fazer cinema, os alunos tinham de observar a realidade que os cercava. Havia

\footnotetext{
${ }^{4}$ Com a demissão de dois professores, o corpo docente apostou no confronto para manter o colega. A equipe entrou em greve seguida pelos estudantes. Nesse contexto, o reitor pediu a presença de forças policiais para conter a "maré repressiva". O acirramento das posições levou à demissão coletiva de 223 professores em 1965, restando apenas 26. Todo o curso de cinema se demitiu. Ver Souza (2002) e o documentário Barra 68 - sem perder a ternura (2000) de Vladimir Carvalho.
} 
projeção, leituras e conversas com os cineastas, instigando o debate sobre a produção do período. (Souza, 2002).

Como perseguido político, o nome de Bernardet estava vetado para qualquer atividade que envolvesse dinheiro público. Toda essa série de cerceamentos levou o crítico a enfrentar muitas dificuldades financeiras. Quando possível, ele exercia a crítica de cinema, muitas vezes com pseudônimos, como, por exemplo, Álvaro Ferreira no Diário de S. Paulo entre 1968-69 ou Carlos Murao em Opinião entre 1973-74 ${ }^{5}$. Antes do lançamento do semanário, ele era taxado pelos censores do DSI (Departamento de Segurança e Informação) de comunista. Tinha seu trabalho vigiado de perto.

Como crítico, a situação era muito difícil. O salário em Opinião não dava para viver; era um "arrocho total". Ele não tinha onde morar porque não havia dinheiro suficiente. Nas pensões e albergues no Rio de Janeiro, Bernardet enfrentava riscos de todos os tipos. Eu vivi na "lama, em cubículos desse tamanho [de uma cama]. (...) Não tinha dinheiro nenhum". Nesses albergues, não havia um quarto propriamente. A cama ficava envolta por grades de ferro. Bernardet tinha de se trancar nesse pequeno espaço para não sofrer com violência e roubo. Júlio César Montenegro e sua esposa ficavam preocupados com Bernardet, especialmente após ocorrer um assassinato na frente da pensão onde o crítico morava. Foi então que decidiram convidá-lo para dividir o apartamento com eles. "Eu não me queixo disso, absolutamente, era um momento de luta", diz Bernardet. Até para receber os dividendos da função de Diretor de Coleções da Editora Paz e Terra era complicado. Ele tinha direito a uma pequena porcentagem sobre as vendas, mas o dono de Opinião, Fernando Gasparian, não pagava nunca os dividendos. Bernardet teve choques com ele. Um dia, sem aguentar mais, declarou que iria dormir no escritório de Gasparian até receber os valores. Muitas horas depois, sem saber como proceder, Gasparian resolveu assinar um cheque. Pediu em troca um recibo a Bernardet, mas o cheque não tinha fundos. Só dias depois o dinheiro apareceu.

A sobrevivência era garantida com o dinheiro dos seminários ministrados no Instituto Goethe em diversas cidades brasileiras. Foi nesses espaços que Bernardet ministrou os cursos sobre o cinema nazista, sobre Tiradentes, sobre Getúlio Vargas,

\footnotetext{
${ }^{5}$ Em 1973, Bernardet escreve com frequência até abril. Há um longo período sem matérias entre maio a outubro, quando ele passa a assinar Carlos Murao. Provavelmente esta ausência se deva ao período citado por Bernardet no qual todos os artigos dele eram vetados pelos censores. Em 1974, os textos recebem a assinatura de Murao até dezembro de 1974. O crítico só volta a publicar com seu nome em novembro daquele ano.
} 
sobre a representação turística das cidades feita pelos consulados. Os seminários foram o primeiro contato de muitos professores com os filmes enquanto documentos históricos. Eles caíam muitas vezes na "ingenuidade" de tomar os documentos como realidade certa, sem perceber que entre o discurso de Getúlio Vargas e a ovação do povo havia um corte e uma montagem. Uma parte do dinheiro recebido era reservada para os estudantes sem dinheiro participarem das aulas; era uma forma de poder aplicar verbas na militância estudantil. Os seminários eram organizados nos consulados e no Goethe por se tratar de um território neutro e difícil para a polícia entrar. Mesmo assim os cursos causaram não só uma enorme repercussão, mas também problemas policiais ao instituto. "A atitude deles foi extraordinária", relembra o crítico. "Tive o maior acolhimento do Instituto. Eles tiveram uma enorme importância na resistência contra a ditadura". Hans-Joachim Schwierskott e Roland Schaffner foram obrigados a ter "muito jogo de cintura" e "argumentação" porque o órgão internacional não estava de acordo com eles. "O Goethe fez a cultura de resistência, o que não era fácil". Tudo isso até 1978, quando o nome de Bernardet foi vetado pela embaixada alemã. A ordem era interromper todo o contato com ele. Schaffner achou que Bernardet tinha se excedido: "esse meio termo às vezes é difícil", mas a causa poderia ter sido o pequeno espaço dado à Alemanha no seminário sobre turismo.

Não foi com a Abertura Política que a situação de Bernardet melhorou. Isso só aconteceu com a Anistia em 1979, quando ele pôde, enfim, retornar à Universidade como docente. O trabalho em Opinião e no Goethe era visto como parte da resistência. "A gente estava trabalhando numa faixa de cultura de resistência dentro de limites viáveis, evitando provocações." A postura era militante e de defesa do cinema brasileiro pelo local de origem, com alguma semelhança com a fase jacobina de Paulo Emilio a partir do Jornal da Tarde ${ }^{6}$. Bernardet assistia a todos os filmes nacionais em cartaz. Poucos artigos em Opinião analisavam o discurso político da filmografia estrangeira. A grande maioria dos textos dele no jornal era sobre o cinema brasileiro A atitude de intervenção significava a defesa dos filmes que falassem sobre a realidade do país, como na época de surgimento do Cinema Novo. "Eu não fazia muita crítica de cinema em Opinião. Eu tentei através dos filmes abordar questões mais amplas de cinema. (...) Através disso eu abordava questões de política cultural e isso funcionou no Opinião.

\footnotetext{
${ }^{6}$ Sobre a crítica de cinema de Paulo Emilio Salles Gomes nesse período, ver a tese de Pedro Plaza Pinto (2008).
} 
Houve repercussão". O tom diante dos filmes era mais ensaístico. Segundo ele, o trabalho foi o de "tomar uma posição em relação a uma política cinematográfica". Nos textos, se vê que o crítico estava muito longe da pretensão de objetividade jornalística ou da tendência da crítica de dividir os filmes em partes separadas para analisar. Despreocupado com as provas de erudição, Bernardet revelava as contradições escondidas nos filmes. Há uma tonalidade confessional, jamais autoritária, para provocar os debates.

Em oposição à difícil situação financeira em Opinião, Bernardet escreveu vários artigos no jornal que se tornaram referência. Alguns desses comentários serviram de base para futuras publicações e para os cursos ministrados ao longo dos anos, por exemplo, a análise dos filmes históricos no livro Piranha no mar de rosas (1982) e o estudo sobre o cinema documentário moderno, que se revela enquanto discurso, para o livro Cineastas e imagens do povo (1985). As análises não eram feitas apenas em Opinião, mas em outros jornais também. Pondo em prática a crítica participativa, JeanClaude Bernardet não só escreve sobre cinema, mas age e influencia o campo cinematográfico. Publica entrevistas com muitos cinemanovistas e alguns cineastas marginais em Opinião. Organiza os diretores para debater e refletir sobre sua produção; escreve textos para gerar polêmica e solicita continuamente a intervenção e contraargumentação dos próprios cineastas envolvidos.

O ápice da crítica ensaística de Jean-Claude Bernardet em Opinião está no artigo sobre o filme Lição de amor (1975) de Eduardo Escorel. O texto é citado pelo próprio crítico como um dos melhores exemplos de seu trabalho na imprensa alternativa ${ }^{7}$. Ele permite compreender a complexidade da sua forma de escrita a partir do conceito de estrutura, uma das chaves de seu pensamento. Muito longe de querer traçar uma tipologia da crítica de Bernardet, procuramos fornecer neste tópico um olhar sobre algumas matrizes teóricas dele.

Durante os anos setenta, o regime militar incentivava a produção de adaptações literárias através de financiamentos e prêmios, como uma maneira de dar algum tipo de orientação temática à produção nacional. Necessitando de recursos para filmar, muitos cineastas realizaram adaptações de clássicos da literatura, sem que isso significasse uma

\footnotetext{
7 Pasta AJCB PI-1-18. Acervo Jean-Claude Bernardet. - Centro de Documentação e Pesquisa da Cinemateca Brasileira.
} 
cooperação com os planos do Estado. Ao utilizar o formato das adaptações literárias ou do filme histórico, os diretores aproveitaram a brecha para realizar uma produção crítica e cifrada sobre o momento político. Nesse período, Eduardo Escorel era conhecido como $o$ montador dos filmes do Cinema Novo. Em 1975, ele realizou seu primeiro longa-metragem, Lição de amor, uma adaptação do romance Amar, verbo intransitivo de Mário de Andrade. A história narra o envolvimento amoroso entre Carlos e Fräulein, a governanta alemã contratada para realizar a iniciação sexual do jovem, a pedido do pai rico. A expectativa da crítica de cinema era grande por causa do histórico cinemanovista do diretor.

Se os diretores do Cinema Novo tentaram desenvolver uma linguagem brasileira para dar conta de revelar a miséria do país, não só no conteúdo, mas também na forma, o debate encampa novos rumos em meados da década seguinte. Acusados de hermetismo e de utilizar uma linguagem autoral incompreensível ao povo, os veteranos do movimento buscaram o contato com o público, conscientes da necessidade de dialogar com o mercado. Nesse novo viés, Escorel opta em seu primeiro longametragem pela linguagem clássica como possibilidade de contato com o público.

$\mathrm{O}$ artigo Uma estética bem comportada? ${ }^{8}$ expõe algumas características marcantes da escrita de Bernardet. O texto é escrito num movimento oscilante, quase pendular. E são exatamente essas nuances da forma que conferem um dinamismo interno. Por motivos didáticos, separamos os principais argumentos em blocos para ressaltar suas oposições, mas procuramos manter a ordem geral de apresentação do texto original.

$\mathrm{O}$ artigo é escrito na primeira pessoa. Inicia com um resumo da saudação da crítica de cinema a Escorel porque Lição de amor conquistou prêmios e público, trazendo uma solução ao cinema brasileiro:

"Festejado com flores e pássaros metálicos, Lição de amor é um filme providencial. Ele se apresenta como a solução do impasse em que muitos vêem enfiada a produção cinematográfica brasileira, encurralada que estaria a vulgaridade popularesca das porno-chanchadas, e o perigo político que representariam filmes como aqueles produzidos na década de 60 pelo Cinema Novo."

\footnotetext{
${ }^{8}$ Opinião. n. 194, p. 32, 23 jul. 1976. O filme foi lançado em maio de 1976.
} 
Em seguida, Bernardet entra no quesito político. Ele evidencia como Lição de amor dialoga com a sugestão do governo de adaptar clássicos da literatura para o cinema:

"O governo vem há anos desenvolvendo uma política cultural que leva os cineastas a se voltar para os clássicos literários. (...) Esta política pode não ter dado até agora resultados considerados relevantes. Mas Lição de amor, com seu sucesso de crítica e de público, prova que ela pode dar bons frutos. Ou seja: pode resultar em obras que dêem a uma certa burguesia brasileira uma lisonjeira imagem de si mesma."

Ao citar no início do texto o perigo político do Cinema Novo, o segundo parágrafo indica a tendência de fuga do cinema político para a adaptação literária, sem explicitar com todas as letras a tentativa de orientação estatal. $\mathrm{O}$ autor toma cuidado com as palavras: o governo desenvolve uma política cultural que leva os cineastas a se voltar aos clássicos literários. Os verbos 'desenvolver', 'levar' e 'voltar-se a' atenuam o sentido do direcionamento estatal. A conclusão indireta é clara: o governo não beneficia obras políticas. O trecho coloca em evidência que a estrutura externa (leia-se condições políticas) interfere na temática e na forma do filme. O excerto não pára por aí, estabelecendo uma ligação entre o objetivo do Estado e o sucesso de público e de crítica colocado em prática por Lição de amor. Mais do que isso, neste caso, houve uma conformidade entre a orientação estatal e o conteúdo do filme, criando uma visão lisonjeira da burguesia.

O segundo parágrafo será concluído só com a última parte do artigo, compondo um retrato circular de argumentação. Bernardet deixa implícito nestas primeiras linhas, mas só conclui com todas as letras no final do texto que, sem dinheiro, os cineastas rendem-se ao projeto do governo de realizar adaptações de clássicos da literatura. Tratase de uma tentativa de contenção de temas políticos. No entanto, o parágrafo possibilita uma segunda leitura: existe uma estratégia de negar-se enquanto cinema político por causa do regime militar. É sobre esse percurso que Bernardet irá falar.

A continuação do artigo prova com a análise do enredo como o filme possui uma imagem lisonjeira da burguesia. Lição de amor traz uma visão positiva dos 'avós'burgueses: 
“Os burgueses do filme não são assim tão desmerecedores. É claro que eles são criticados: tudo é mercadoria para eles e os sentimentos do filho são manipulados como qualquer negócio que se faz para dar lucros. (...) O casal Souza Costa é visto com ironia, sem dúvida, mas também e principalmente com a ternura condescendente que se teria ao folhear um álbum de fotografias de avós ultrapassados e um pouco ridículos, mas a quem no fundo se quer bem. Eles fornecem uma imagem digna dos avós da burguesia brasileira.

O casal Souza Costa possui uma casa ampla e elegante, veste-se bem, tem bons modos, dá uma sensação de segurança e estabilidade: o casal Souza Costa dá dos avós da atual burguesia brasileira uma imagem digna. Estamos longe do retrato 'incompetente' e involuntariamente grotesco que às vezes a chanchada faz dos grãfinos. (...)

Mas estamos longe, e como! da ironia e do retrato quase burlesco que Mário de Andrade faz dos Souza Costa."

Até os parágrafos iniciais sobre o conteúdo ou sobre a apresentação da burguesia, a análise não vê uma contestação política. $\mathrm{O}$ artigo segue assim num movimento em espiral, adentrando em camadas de análise cada vez mais densas e reflexivas. Da discussão sobre o conteúdo lisonjeiro sobre os burgueses, Bernardet chega ao estudo da forma em dois trechos separados, que acompanham esse mesmo movimento de espiral. No primeiro trecho inicial, a forma é prova de qualidade; ao mesmo tempo ela não problematiza o presente. O segundo excerto no final do artigo é bem mais complexo. Vejamos:

"A feitura extremamente cuidada do trabalho, a sua harmonia e homogeneidade, a lógica imperturbável da construção dramática, abordando problemas "eternos" enfiados num passado que não corre o risco de arranhar o presente, sob os auspícios justificadores de um monumento literário: não é um ideal? Os bem pensantes podem extrair satisfação tanto ao nível da realização do filme, quanto daquilo que ele mostra.

(...)

E me pergunto se o estilo do filme, até mesmo o estilo de Eduardo Escorel (...) não tentaria responder a estas contradições e ambiguidades. $\mathrm{O}$ estilo do diretor é olímpico. A rigorosa racionalidade em todos os momentos de elaboração do filme, o perfeccionismo, que não excluem delicadeza, instauram um nível de expressão contido, sempre aquém da emoção tanto da dele como da dos personagens. Um olhar, a contração de um músculo facial são o suficiente, no estilo de Escorel (...) para sugerir grandes sentimentos. Essa polidez, esse recato, essa altivez com que Escorel elabora sua expressão dão certa densidade aos sentimentos não exteriorizados, mas são também uma maneira aristocrática de não entrar no mérito do assunto, é pairar acima das contradições."

Há uma sutil diferença entre os dois trechos descritos acima. Saindo de uma leitura mais externa do filme como prova de qualidade no primeiro excerto, o final do artigo explica Escorel indiretamente. Sua forma de pairar acima das contradições indica 
exatamente a riqueza da obra, que não pode avançar totalmente na problematização sobre a relação do cineasta com o Estado. Sua maneira aristocrática é parte dessa contradição e ambiguidade. Não se trata simplesmente de cooptação de Escorel, como poderia parecer nos primeiros parágrafos, mas de uma cumplicidade que envolve muitas contradições. Dando continuidade ao estudo sobre a forma do filme, o artigo relaciona Lição de amor com a discussão do uso da linguagem clássica. Bernardet condena esta mesma linguagem por não realçar os mecanismos ideológicos, isto é, a linguagem clássica não gera reflexão no espectador. Sua preferência é pelo cinema moderno que se revela enquanto discurso. Nesse sentido, Bernardet vê o filme como um retrocesso:

"Sem pensar que o filme pudesse retomar o mesmo questionamento do romance, pode-se notar que o romance indaga (até certo ponto) o seu instrumental, enquanto que o filme, não. $\mathrm{O}$ filme não questiona, diante do espectador o instrumental cinematográfico de que se vale. (...) É indiscutivelmente o retrocesso do filme em relação ao romance do ponto de vista crítico."

Para provar sua teoria, o crítico traz trechos do livro em que Mário de Andrade indaga seu próprio aparato instrumental, questionando a forma do romance. Havia uma inquietação, uma reflexão sobre a narrativa, inexistente no filme. Escorel não questiona seu instrumental cinematográfico; usa recursos narrativos para criar uma ilusão, como se assistíssemos a um pedaço da realidade. $\mathrm{O}$ diretor não revela ao espectador que se trata de ilusão narrativa, daí o sentimento de retrocesso ${ }^{9}$. A condenação à linguagem clássica tem dois motivos: ela oculta os mecanismos de produção, e principalmente não coloca em questão a relação com o Estado. Exige-se aqui do montador do Cinema Novo uma atitude política sobre a linguagem utilizada. Ao contrário, a forma impecável da produção e a construção favorável aos burgueses no conteúdo cabem perfeitamente no projeto governamental.

Se no início, o autor frisava mais a estrutura externa, leia-se política cinematográfica, como detonadora da forma e do conteúdo, os parágrafos finais desconstroem a argumentação do próprio texto. Num movimento pendular, Bernardet

\footnotetext{
${ }^{9} \mathrm{O}$ texto de Bernardet foi publicado dois meses depois do artigo de Marcos Ribas de Farias no mesmo jornal. A diferença é que Farias analisa o aspecto auto-referencial do filme, enquanto Bernardet afirma que Eduardo Escorel não indagou seu próprio instrumental. Ver análise de Marcos Ribas de Farias neste capítulo.
} 
defende uma afirmação, para em seguida negá-la, e depois voltar ao ponto inicial. Eis alguns dos contra-argumentos lançados no final do artigo:

"Fräulein como projeção de um certo tipo de intelectual. (...) Um desses intelectuais imprensados entre o projeto cultural e a remuneração é o diretor do filme. Como nos serviços prestados por Fräulein à família burguesa Souza Costa, a realização de Lição de amor supõe contradição, ambiguidade e cumplicidade entre o projeto cultural e a prestação de serviço.

Uma opção teria sido denunciar esta dimensão do filme, apresentar esta dimensão como geradora do filme (inserir no filme a revelação do processo de produção de que é fruto). $\mathrm{O}$ que fazia estourar personagens, linguagem ilusória, e então denunciava a prestação de serviços, portanto deixava de prestar serviços. Outra opção era deixar latente esta dimensão, uma suave filigrana: assim não se poderia dizer que esta dimensão não estava no filme, mas sem que ela chegue a alterar o papel social que o filme está desempenhando. Tudo leva a crer que é esta última opção que foi perfeita [grifo nosso].

O cineasta que descreveu o envolvimento emocional de Fräulein e que a fez repetir com tanta insistência que ela queria seus oito contos, não está absolutamente alheio nem às contradições da governanta, nem às próprias."

Os trechos acima recortados desviam os comentários sobre a forma e a representação da burguesia para incidir na composição da personagem de Fräulein. Bernardet demonstra que a maneira encontrada para contradizer a política cinematográfica em Lição de amor não estava na forma do cinema moderno. Não, a atitude do diretor foi mais sutil. Escorel trabalhou com filigranas. Por esse motivo a contestação foi feita na construção de Fräulein, isto é, nas relações sociais construídas pela personagem. Sem utilizar a linguagem moderna para questionar os mecanismos cinematográficos, a discordância foi ainda mais tênue. Quando Bernardet declara: "tudo leva a crer que é esta última opção que foi perfeita", a frase indica o quanto o trabalho estético traz uma dimensão política oculta em Fräulein. A partir desta personagem, a análise do filme atinge o diretor.

O comentário final encerra a argumentação do início do artigo. Ao apelo de adaptação literária solicitado pelo governo, Escorel acaba por aceitar seus oito contos, como Fräulein. Teve de render-se à forma aprovada pelo Estado para poder produzir cinema, mas contestou a orientação indiretamente através da composição de Fräulein. Os dois trechos não são só indicativos da relação de Escorel com o Estado autoritário, mas problematizam também a ligação dos cinemanovistas com o governo por causa da 
política cultural ${ }^{10}$. A forma do texto reproduz em sua organização o movimento contraditório e complexo desta relação.

Também estes contra-argumentos são sucedidos de uma ou duas críticas negativas ao filme, num enorme quebra-cabeças dialético destinado ao leitor. A linguagem cifrada serve para evitar dar informações aos censores; serve para transmitir sentidos políticos que seriam censurados num texto totalmente transparente e direto.

Não é só para evitar a interdição que o artigo é escrito desta maneira. A forma ensaística de Bernardet em Opinião foge de uma argumentação de autoridade. Num movimento de tese e antítese, em tom dialético, o raciocínio torna-se muito mais complexo. É como se ele escrevesse duas críticas antagônicas no mesmo texto. Parece uma marca recorrente do estilo dele afirmar algo para sugerir depois outra possibilidade de leitura, numa obra aberta. Talvez seja essa uma forma de ensinar aos leitores a refletir, sem aceitar argumentos prontos.

Por último, mas não menos importante, a crítica a Lição de amor não aborda somente os preceitos de crítica sociológica, conteudística e participativa já descritos no capítulo anterior. $\mathrm{Na}$ intersecção entre estética e política, encontramos a forma de análise que estrutura todo o movimento em espiral do texto: ele não é nada mais do que o próprio conceito de estrutura (Candido, 2011 a).

Bernardet poderia ter utilizado somente a crítica sociológica, como às vezes ocorria em Opinião. É legítimo que se faça uma análise apenas do elemento externo, como na sociologia; mas quando a ênfase recai somente na dimensão social, corre-se o risco de esquecer o fator estético. Por esse motivo o estudo de base sociológica mostrava-se uma ferramenta incompleta. A análise de Jean-Claude Bernardet sobre Lição de amor consegue tocar a complexidade entre a estrutura interna e o contexto social.

Sem separar o estudo da forma do ambiente repressivo, Bernardet enfrentou suas conexões. Ele não analisou a obra por si mesma; caso tivesse feito isso, pensaria o estilo de Escorel como detonador único de sua estrutura interna. Estaria somente ao lado da crítica à obra de arte pura, fora do contexto. Ao contrário, a dimensão social e o estilo não podem ser desconectados, porque os fatores externos e sociais são agentes da

\footnotetext{
${ }^{10}$ Retomaremos o debate sobre a função do intelectual em Lição de Amor no capítulo 5.
} 
estrutura interna, de tal forma que a realidade social transforma-se em componentes da estrutura cinematográfica.

Como aplicar o conceito de estrutura para explicar Lição de amor? A política cinematográfica do regime autoritário (estrutura externa) foi agente da forma (estrutura interna) do filme, afinal de contas esta política levou Escorel a ter de recorrer à adaptação literária para conseguir financiamento. Contudo esse fator não explica a obra por completo. O financiamento não significou adesão ao regime autoritário, nem uma visão apologética do passado; porque a forma do filme tem autonomia em relação à estrutura externa. Esta última pode influir ou não na mise en scène, mas provavelmente ela tenha se feito presente na adequação à adaptação literária por causa da censura. Do estilo de Escorel, analisado por Bernardet, apreende-se a singularidade da obra; e nessa singularidade o elemento social foi filtrado na concepção estética do autor; não obrigatoriamente do regime. Porém, a estrutura externa pode ter sido em parte responsável por Escorel ter colocado as críticas ao sistema na composição da personagem de Fräulein, e não na forma do filme. Por outro lado, essa opção pode também significar a preferência do diretor pela linguagem clássica. Temos de levar em conta outro fator: a defesa do cinema clássico na imprensa ${ }^{11}$ significava para os egressos do Cinema Novo uma forma política de conquistar o público através de uma linguagem convencional. Novamente teríamos uma influência do fator externo sob a mise en scène. O movimento do artigo passa pelas duas formulações ao ver Lição de amor como síntese da política cinematográfica e da resistência. Como vemos, a relação entre todos esses fatores não fecha uma equação simples de resolver. Assim a forma de escrita de Bernardet revela ao mesmo tempo a complexidade do conceito de estrutura e as ambiguidades na aproximação com o Estado. Forma e contexto estão tão imbricados que é impossível determinar fronteiras claras entre o projeto político e a criação autoral.

Quando o crítico articula num todo complexo a forma e estrutura interna de Lição de amor com o contexto da política cinematográfica, ele vai além de uma crítica sociológica; caminha em direção à crítica integral, que segundo Antonio Candido não deve desconectar os aspectos formais dos aspectos sociais. Afinal nenhuma obra se explica por si só:

\footnotetext{
${ }^{11}$ Indiretamente os cinemanovistas continuam a defender o cinema autoral (ver Capítulo 5).
} 
“(...) saímos dos aspectos periféricos da sociologia, ou da história sociologicamente orientada, para chegar a uma interpretação estética que assimilou a dimensão social como fator de arte. Quando isto se dá, ocorre o paradoxo assinalado inicialmente: o externo se torna interno e a crítica deixa de ser sociológica, para ser apenas crítica. (...) Neste nível de análise, em que a estrutura constitui o ponto de referência, as divisões pouco importam, pois tudo se transforma, para o crítico, em fermento orgânico de que resultou a diversidade coesa do todo" (Candido, 2011 a: 17).

O artigo revela que Bernardet em Opinião não tratava o cinema apenas pelo viés político, como uma forma de subordinação da arte. Fugia, portanto, da crítica sociológica orientada. Ao contrário, estética e política completam-se, porque uma é fator de composição da outra. O texto indica o quanto Bernardet desconstruiu, aglutinou e reelaborou diversas matrizes da crítica de cinema em sua passagem por Opinião. Por fim, num trecho de Trajetória Crítica, o autor explica como articula uma análise mais profunda: "É necessário atingir a sua estrutura e pesquisar a significação da estrutura enquanto tal e não enquanto veículo de conteúdo.” (Bernardet, 1978: 231).

Na aplicação deste conceito à Lição de amor, vemos o quanto ele não só deflagra as significações imediatas do filme, mas vai além deste estudo mais explícito, porque sozinho ele não daria conta nem de revelar a ligação com o presente, nem de compreender a imagem sobre a sociedade dos anos 1920. Quando o estudo incide sobre a forma estética, não só sobre o conteúdo do filme, a análise vai além de explicar as intenções da obra e de Escorel. Para tanto, Bernardet não exclui nenhum tipo de metodologia, numa proposta parecida com a da crítica integral de Antonio Candido. Atento à análise fílmica em detalhes, ele foge da crítica sociológica que vê a obra como ilustração dos conflitos sociais. Desta forma, preserva o fator estético através da observação concreta das cenas para investigar como o estético trabalha historicamente. Bernardet quer demonstrar como se dá a resistência cultural de Lição de amor no campo estético, ao invés de procurar as formas estéticas dos conflitos sociais, como a crítica mais terrena costumava fazer.

$* * * *$

Se o artigo sobre Lição de amor atinge o máximo da crítica integral ao conciliar estética e política, Eduardo Escorel tomou estes comentários como os mais desfavoráveis recebidos no lançamento. Em 2011, na revista Piauí, ele escreveu: 
"Desde a morte de Paulo Emilio, em 1977, as ideias dele [Jean-Claude Bernardet] se tornaram, acima de qualquer outras, as de maior interesse para quem faz, estuda ou se interessa por cinema no Brasil. Não há prêmio maior do que ter um filme comentado por ele, e as feridas provocadas por suas restrições ou desinteresse dificilmente cicatrizam.

Eu mesmo custei a me recuperar, em 1976, da decepção causada pela crítica de Jean-Claude Bernardet ao filme Lição de amor. Mais do que os prêmios, a recepção crítica favorável, e o relativo sucesso comercial, além da reação de Paulo Emilio, a de Jean-Claude era a que eu mais esperava. E diante do comentário implacável escrito por ele em página inteira do jornal Opinião, minha resposta foi fazer, em 1980, uma antítese de Lição de amor - o filme Ato de violência que, por ironia cruel, foi ignorado por JeanClaude, além de ter sido um fracasso comercial retumbante". ${ }^{12}$

Sobre a declaração de Escorel, Jean-Claude Bernardet comenta em entrevista que se tivesse achado Lição de amor ruim, não teria falado do filme em Opinião:

\begin{abstract}
"Eu não falei mal do Escorel. Foi a pior crítica [para ele], porque havia a lei ou portaria do Ministério da Educação e Cultura que favorecia filmes inspirados de romances de autores mortos; Os Condenados do Zelito [Viana] entrou nessa também. Isso é o cinema da ditadura. E fiz uma crítica com vários ângulos para abordar o filme, que inclusive foi elogiada por outras pessoas depois pela multiplicidade de ângulos, mas era cinema da ditadura. (...) Escorel nunca engoliu isso. Eu não tomava muito conhecimento dessas coisas. (...). Recentemente ele escreveu sobre isso (...). A questão não é que Lição de amor seja um filme ruim, não é um filme ruim. A questão é pegar o filme nessa conjuntura complexa. (...) Aí é sempre essa questão, você gostou ou não gostou? (...) Não é isso, eu sou certamente muito mais complicado do que gostar ou não gostar. Só que há uma atitude por parte dos realizadores de cinema e diretores de teatro que é o sim ou não, ou você gosta ou não gosta (...). Foi a mesma coisa com Viramundo. A mesma coisa foi com Geraldo Sarno que parou de falar comigo. Anos depois, ele voltou. Agora, se eu achasse Viramundo um filme ruim, porque teria passado rigorosamente anos, vários anos, trabalhando em cima do Viramundo? Não é questão de gosto."
\end{abstract}

O que está em foco no artigo de Bernardet não é a obra em si, mas as relações estabelecidas pelo crítico a partir dos filmes. Ainda nos anos setenta, ele pensava esse tipo de texto como uma busca por "significações móveis". Por ser a crítica uma atividade da vida social da obra, sua contribuição é deflagrar significações potenciais nela. O estudo inclui também: apontar as contradições e os aspectos inesperados do trabalho dos autores, desvendar elementos da dramaturgia ainda latentes, discutir esses

12 Escorel, Eduardo. Jean-Claude Bernardet. Piauí. n. 61, out. 2011. Disponível em:< htp://revistapiaui.estadao.com.br/edição-61/questões-cinematograficas/jean-claude-Bernardet>. Acesso em 13 nov. 2013. 
pontos e colaborar com o amadurecimento dos realizadores. Assim o crítico pode dar uma contribuição ao desenvolvimento da dramaturgia. Foi esse trabalho que Bernardet colocou em prática no artigo sobre Lição de amor. Diferente da conclusão de Escorel, essa metodologia está longe de querer avaliar o pretenso valor de uma obra ou julgá-la. A riqueza advém das relações propostas não só pelos filmes, mas também pelas significações que somos capazes de extrair destas relações. Afinal as significações dos filmes são sempre sociais. Por esse motivo, o processo analítico deflagrador nunca tem fim. Uma obra não constitui "um momento parado, mas (...) um elo num processo que ao se desenvolver transforma a obra, ou, mais exatamente, transforma o que fazemos com ela" (Bernardet, 1978: 244-6). Como só existem significações móveis, cabe ao leitor fazer uma opção pessoal diante do texto:

“(...) decorre que nunca se procura numa obra alguma verdade, alguma mensagem. Mas sim significações móveis que se estabelecem pela relação que se estabelece na obra entre seus vários elementos e particularmente pelas tensões que podem ocorrer entre estes elementos, entre os vários níveis da obra. A obra é tida como forma dinâmica (...), como um processo gerador de significações.

A tarefa de análise pode ser aqui propriamente criadora na medida em que consegue pôr à luz e enriquecer, ao nível das estruturas, o sistema de relações. E não só ao nível de uma obra: estabelecer relações entre várias obras (mais exatamente: estabelecer relações entre as relações internas de diversas obras), e desencadear significações múltiplas a partir destas relações. Estas relações serão sempre ambíguas e as significações sempre flutuantes" (Bernardet, 1978: 244-6).

Para Bernardet, são exatamente os filmes com caráter aberto os que favorecem uma transformação na maneira de escrever os textos. Tudo isso por causa da impossibilidade de afirmação sobre a significação da obra. O crítico não diz o que o filme é, pois ele é "movediço" ou o texto o faz movediço. Pouco importa se as significações estão certas, incertas ou contraditórias. A crítica só poderá evoluir na exclusiva medida em que se apegar à produção cinematográfica e lutar para analisá-la. "A crítica, no entanto, tem deixado passar a oportunidade de evoluir ao se desligar da produção" (Bernardet, 1978: 231).

A forma de espiral por antinomias deste texto encaixa-se perfeitamente na descrição de Adorno (2003: 29-30) do ensaio: [os conceitos] "não formam um continuum de operações, o pensamento não avança em um sentido único." Essa é a 
metodologia de Bernardet: ele não tenta unificar o pensamento, nem busca uma solução definitiva. O movimento é realmente o do ensaio: fragmentado, como se a qualquer momento pudesse ser interrompido. O texto orienta-se diante de uma ação recíproca de relativização:

"Escreve ensaisticamente quem compõe experimentando; quem vira e revira seu objeto, quem o questiona e o apalpa, quem o prova e o submete à reflexão; quem o ataca de diversos lados e reúne no olhar de seu espírito aquilo que vê, pondo em palavras o que o objeto permite vislumbrar sob as condições geradas pelo ato de escrever". (Adorno, 2003: 35-6)

O tom problematizante de encadeamento de dados vai contra a leitura linear e procura captar as contradições da obra. Assim acaba produzindo uma tese, uma antítese e uma síntese, sem que isso signifique jamais a construção de um sentido único. Afinal Bernardet vê a obra como processo. Exatamente por causa disso, o movimento analítico por oposições desse texto parece ser a forma de compreender o mundo que nos cerca, ligado à concepção da realidade histórica como contraditória. Além disso, as antinomias apresentadas aos leitores buscam superar as próprias contradições através de sua consciência. Esse movimento de opostos e a passagem da afirmação à negação e à negação da negação caracterizam um movimento dialético ${ }^{13}$, usado aqui, no sentido lato. Bernardet não tem a pretensão de eliminar nenhum dos lados, porque as duas faces contraditórias coexistem. Por esse motivo, ele não tira uma conclusão única sobre Lição de amor, e é também por causa dessa metodologia de trabalho que o texto constitui-se numa obra aberta.

\footnotetext{
13 Não afirmamos aqui que o texto é dialético dentro de uma determinada linha filosófica, porque incorreríamos em erro, afinal em cada autor é preciso primeiro entender o seu conceito de dialética e sua função para compreender sua filosofia. Acreditamos que por tratar as contradições da sociedade na obra dos cineastas, Bernardet procure utilizar uma metodologia problematizante, voltada não só à polissemia dos significados, mas à ideia de superar as contradições da sociedade. Assim ele estaria mais próximo da dialética marxista. Contudo deixamos esta suposição como hipótese de pesquisa para o futuro. De acordo com Norberto Bobbio (1998), a palavra dialética na linguagem cotidiana do marxismo esconde em suas dobras significados variados, dificilmente articuláveis entre si e que são fonte de grande confusão e polêmica. Por exemplo, atento à dialética gramsciana, Bobbio observa que Gramsci define a dialética da seguinte maneira: "Sente-se que a dialética é algo muito árduo e difícil, na medida em que o pensar dialeticamente vai contra o senso comum vulgar, o qual é dogmático, ávido de certezas peremptórias e tem a lógica formal como expressão". Enquanto isso o diletantismo filosófico tem "falta de senso histórico ao captar os diversos momentos de um processo de desenvolvimento cultural, ou seja, de uma concepção antidialética, dogmática, prisioneira dos esquemas abstratos da lógica formal”. Bobbio completa com suas palavras: "Basta dizer ainda, nessa parte da análise, puramente terminológica, que a dialética como concepção da história (...) está estreitamente ligada à ideia de que a realidade histórica (...) é contraditória; e que a dialética é o instrumento adequado para compreendê-la, compreendendo-a, superar suas contradições" (Bobbio, 1998: 30-33).
} 


\subsection{Sérgio Augusto e Os Boas Vidas}

A cinefilia chegou ainda na infância de Sérgio Augusto através das idas frequentes ao cinema no Rio de Janeiro, acompanhado da mãe. Desde a tenra idade, o futuro crítico já tomava nota dos filmes, indicando o ano de produção, o nome do diretor e das atrizes. Leitor de Cinelândia, a prática das listagens fazia parte do dia a dia dos fãs de cinema. Com catorze anos aconteceu uma guinada em sua vida. A família assinava vários jornais cariocas, exceto Correio da Manhã. Graças a uma campanha de entrega gratuita por uma semana, chegou às mãos de Augusto uma crítica de Antonio Moniz Vianna. "Eram duas colunas de alto a baixo". Ele leu "fascinado", sem entender nada, apesar da clareza absoluta do texto. Faltava, na verdade, repertório para a compreensão. Foi como uma "luz"; era aquilo que ele queria ser na vida. Assistir aos filmes e escrever sobre as coisas que ele não compreendia. A partir daquele momento, Sérgio Augusto passou a ler a coluna de Moniz Vianna todos os dias. A cada novo diretor citado, o adolescente colocava todas as informações disponíveis numa nova página. A lista tornava-se maior e cada vez mais completa. Foi um aprendizado longo. Os primeiros textos, ele publicou no jornal da escola.

Entre os dezesseis e dezessete anos, Sérgio Augusto frequentou o curso de jornalismo do jornal $O$ Metropolitano da UNE (União Nacional de Estudantes). Os cem primeiros inscritos assistiam às aulas práticas e teóricas, aprendiam a escrever o lead $\mathrm{e}$ faziam matérias. A turma do Cinema Novo fazia parte da equipe, entre eles Arnaldo Jabor e David Neves. Cacá Diegues era diretor de redação. Os três primeiros colocados nas provas foram aproveitados na equipe e assim Augusto transformou-se em "redatorrepórter". Em pouco tempo ele passou a escrever sobre cinema no jornal.

Nessa época, Ely Azeredo aproveitou para tirar férias acumuladas de três meses e convidou Augusto para ocupar seu lugar na Tribuna da Imprensa. Novo convite surgiu, pouco tempo depois, quando Moniz Vianna tornou-se diretor do Correio da Manhã. A passagem para o Jornal do Brasil (JB) ocorreu depois. Alberto Dines, responsável pela famosa reforma do $J B$, chamou Augusto para participar do projeto, quando os dois trabalhavam num programa musical na rádio da mesma instituição.

Acumulando experiências, inclusive a de editor do $J B$, Augusto estava na editora Bloch quando Mino Carta sugeriu que ele migrasse para a revista Veja. Durante os anos 
setenta, o jornalista trabalhava em três jornais censurados: Veja, O Pasquim e Opinião. Depois foi para a Isto é, de novo com Mino Carta, e teve uma breve passagem pelo Jornal de Brasília até chegar a Folha de S. Paulo nos anos oitenta e noventa. Em seguida, Augusto compôs a equipe do jornal O Estado de S.Paulo, onde permanece até hoje.

Diplomado pela Faculdade Nacional de Filosofia, Augusto achou que seria redundante fazer Jornalismo, porque já tinha experiência no assunto. A formação em cinema não veio apenas da leitura diária das críticas de Moniz Vianna, mas das retrospectivas realizadas na Cinemateca do Rio de Janeiro entre 1958-1963. Cada um desses anos foi dedicado à filmografia de um país. Os cursos propiciaram um contato denso com o cinema americano, o francês, o inglês, o italiano e o russo. As cópias vinham dos países de origem. O processo completo valeu por um curso de cinema universitário feito em três anos. Pouco tempo depois, ele integrou a equipe da Cinemateca ao lado de Walter Lima Jr., organizando retrospectivas.

Sérgio Augusto nunca teve filiação política, mas foi preso no dia 29 de fevereiro de 1972. Sem ter nada para fazer na redação, num belo dia de verão, ele decidiu acompanhar Miguel Paiva e Bruno Barreto numa entrevista para O Pasquim. A polícia procurava por um carro com o mesmo modelo, e por azar, eles foram parados pela blitz. O carro estava sem documento, assim como Bruno Barreto. A condição de Miguel Paiva era pior. Ele levava uma carteira de estudante visivelmente falsa para entrar de graça no cinema e tinha na ficha um histórico de passeatas e organização de diretórios acadêmicos. Assim os três permaneceram presos da uma da tarde até a meia noite. Foi quando Augusto resolveu reclamar, porque não havia nada contra ele. Então o policial citou um dossiê da época do Jornal do Brasil. Além disso, ele era acusado de assinar o manifesto pela libertação dos "Oito do Glória" ${ }^{14}$ e de organizar em 1967 um debate sobre Terra em transe (1967) de Glauber Rocha, quando o filme foi liberado.

Graças à prisão, toda vez que Augusto saia do país, ele tinha de pedir autorização no Deops. Anos depois a ficha aumentou, quando publicou a reportagem "Mar de Lama" para O Pasquim. O jornalista usava declarações já publicadas na

\footnotetext{
${ }^{14}$ Trata-se do protesto realizado na frente do Hotel Glória durante a Segunda Conferência da OEA (Organização dos Estados Americanos) quando o grupo composto por Glauber Rocha, Joaquim Pedro de Andrade, Flavio Rangel, Mário Carneiro, Carlos Heitor Cony, Antonio Callado, Márcio Moreira Alves e o embaixador Jaime Rodrigues estiraram uma faixa escrito "abaixo a ditadura".
} 
imprensa como estratégia para fazer comentários negativos a Delfim Neto. O resultado deixava o ministro com uma imagem nada positiva. $\mathrm{O}$ título era forte, mas a matéria conseguiu sair, mesmo com o jornal censurado. Ele e Jaguar foram enquadrados na Lei de Segurança Nacional por difamar o ministro. O processo foi parar na Aeronáutica e a dupla teve de prestar depoimento. Augusto foi anistiado em 1979. Ficou muito chateado com o resultado final, porque não cometeu crime algum e gostaria de ter sido inocentado da acusação.

Se Moniz Vianna foi para Augusto a primeira grande influência, entre 19591960, uma nova transformação iria acontecer. Foi quando ele viu pela primeira vez em suas mãos a famosa revista Cahiers du Cinéma, ao entrevistar José Sanchez na Cinemateca por causa de uma retrospectiva. O momento é descrito como o contato com a "Bíblia de Gutemberg", reunida numa grande pilha. Augusto passou a comprar não só Cahiers, mas também sua antecessora, a Revue du Cinéma. Certa vez, ele salvou do lixo uma pilha da revista Arts quando trabalhava na Cinemateca. O crítico recortava os artigos e organizava em pastas por diretores. Lia muito Positif ${ }^{15}$. De Cahiers, gostava especialmente de Jean Domarchi e Jean Douchet, além de André Bazin e Eric Rohmer. Entre os brasileiros, Paulo Emilio não foi uma influência, porque nunca assinou o jornal Estado de S. Paulo. Sérgio Augusto tinha certa ressalva com a frase de Paulo Emilio de que o 'pior filme brasileiro é melhor do que qualquer um estrangeiro' ${ }^{16}$. Para Augusto, não se pode considerar Como é boa nossa empregada melhor que A dama de Shangai. A formulação geral, segundo ele, cria uma certa ambiguidade ou permite uma leitura errônea, se interpretada ao pé da letra. Augusto achava a ideia meio xenófoba, porque é avesso a qualquer tipo de nacionalismo. Na verdade, "nunca me detive sobre esse tipo de problema", porque "cheguei” um pouco atrasado no debate, que já corria adiantado.

Augusto define seu método de trabalho como "intuitivo", porque nunca teve uma preocupação a priori. O processo de escrita começa no cinema. $\mathrm{O}$ crítico toma as

\footnotetext{
${ }^{15}$ Positif era uma revista de ancoragem à esquerda, marcada pelo domínio cultural da influência do partido comunista. A revista congregava várias tendências políticas de esquerda; havia trotskistas, rooseveltianos, comunistas não ortodoxos. Amante do cinema americano, a revista transbordava de posições ideológicas anti-colonialismo, condenando cineastas de direita. Por outro lado, comentava os filmes B, desprezados pelos intelectuais comunistas (Baecque, 2010).

${ }^{16}$ Em dez de abril de 1973 no Jornal da Tarde, Paulo Emilio escreve "por pior que seja o filme o diálogo com ele possui o mérito de existir e pode ter consequências (...). O filme ruim, pelo simples fato de emanar de nossa sociedade, tem a ver com todos nós, e adquire muitas vezes uma função reveladora. Abordar o cinema brasileiro de má qualidade implica numa luta tenaz contra o tédio mas é raro que o esforço não seja compensado. O subdesenvolvimento é fastidioso, mas sua consciência é criativa." (Calil, 1986: 262-4).
} 
notas para não esquecer os detalhes. Presta atenção em tudo, nos diálogos, nos planos e na abertura para poder começar o texto de forma diferente. "Uma coisa é certa, eu entendo muito mais do filme quando escrevo, do que quando gosto e só vejo". Muitas vezes ele só tem uma ideia mais concreta ao começar a elaborar e refletir a posteriori. Às vezes muda sua apreciação exatamente por causa da escrita. Nos anos setenta, só era possível rever a obra no máximo uma vez antes de publicar. Todo o processo era feito de memória. A crítica semanal permitia mais tempo, com dois a três dias para compor os artigos. Na época do Metropolitano, não era imprescindível escrever sobre um lançamento. Ele só o fazia se tivesse algo a dizer. Enquanto isso, no Correio da Manhã existia uma obrigação de comentar a produção em cartaz. Muitas vezes as melhores críticas são contra os filmes. "Tem filme que eu adoro, mas não quero escrever. Eu gosto tanto desse filme e vou sempre ficar devendo. Não vou conseguir expor em palavras aquilo que sinto em relação ao filme. Isso aconteceu várias vezes comigo." Augusto não quis escrever, por exemplo, sobre Lágrimas amargas (1952) de Stuart Heisler, mesmo quando o editor ofereceu duas páginas "Fiquei inibido, porque jamais darei conta da estima que eu tenho". Quando ele conhece bem um diretor ou gosta dele, a situação gera uma "certa paralisia".

Com os diretores brasileiros, a relação passava por outros filtros. Ele conheceu de perto a maior parte dos cinemanovistas, como Arnaldo Jabor, Paulo César Saraceni, Joaquim Pedro de Andrade, David Neves e Carlos Diegues através dos cineclubes, da cinemateca do MAM ou do grupo de estudos cinematográficos da UNE. Acompanhou o alvorecer do Cinema Novo porque todos eram amigos dele. Escrever sobre os cinemanovistas no Metropolitano era uma tarefa complicada: "Era uma coisa meio esquisita porque como eu era amigo deles, eu ficava às vezes muito sem jeito, porque quando eu não gostava, eu tentava não escrever". Não houve grandes problemas para redigir sobre o Cinema Novo porque na época do Metropolitano a produção deles só estava começando. No Correio, ele era obrigado a comentar os lançamentos: "eu devo ter magoado muitos. (...) Lá eu tinha que pegar o filme e escrever mesmo. Esse negócio de amizade, era à parte". Muitas vezes podia ser um pouco "compreensivo" ou até mesmo "condescendente" por conhecer de perto os problemas enfrentados na produção. A relação com o grupo variava, Paulo César Saraceni e Nelson Pereira dos Santos não faziam nenhum tipo de cobrança a ninguém, diferente de Gustavo Dahl. Carlos Diegues 
ficou uma época sem falar com ele, porque considerou a crítica de Augusto sobre Joanna, a francesa na Veja implacável. Com o tempo, tudo voltou ao normal.

Cinéfilo apaixonado pelo cinema clássico, Augusto não esconde a falta de apreço pelo Cinema Marginal. Gostava mesmo é dos realizadores. Num dos artigos de Opinião ${ }^{17}$, ele explicou que a "auto-agressão" do Cinema Marginal ao público é um dos gestos mais impotentes, apesar de ser considerada uma atitude política”. Como no Rio de Janeiro "não houve Boca do Lixo", a crítica "não ligava muito" para esse tipo de filme. Contudo, a paixão pelo cinema norte-americano não o impedia de dar uma força pessoal à produção fora de hollywoodiano. "Eu promovi vários diretores, fora do esquema de Hollywood, porque a gente via e achava ótimo. Tem que promover mesmo para o pessoal ver".

A cinefilia ficava de lado quando o assunto era a política cinematográfica, afinal o cinema americano sempre foi uma "praga" para o mercado brasileiro. Augusto preferia "ficar à margem" desse tipo de "discussão" e não comentar as leis de cinema. Afinal não era a "parte interessada" sobre o tema da ocupação do mercado. Ele preferia escrever sobre cinema estrangeiro em Opinião. Dos mais de 60 artigos publicados, 15 textos eram dedicados ao cinema brasileiro. Destes, apenas oito matérias comentam em algum trecho a política cinematográfica. Nestes casos, o tom é factual, nacionalista. Além disso, o mercado recebe o adjetivo de inimigo da cinematografia nacional. A postura é mais opinativa e sem concessões. Nos artigos, Augusto não perde a oportunidade para fazer críticas sem rodeios a algumas figuras governamentais, à política cinematográfica e às empresas norte-americanas ${ }^{18}$.

A predileção ao cinema americano não significava um desapreço pela crítica marxista. Para ele, a esquerda maoista tomou conta de Cahiers no pós-1968, levando a revista a uma fase politizada demais. A oposição dele não era só a esse novo viés da crítica de cinema, mas também a alguns filmes. Ele desaprovava a "velha crítica de esquerda partidária" com seu "método stalinista" de "apelação ao sentimentalismo", como foi Sacco e Vanzetti (1971) de Guiliano Montaldo. Para Augusto, esse filme era um muito "mentiroso", com apelação "sentimentalóide" que atropelava a história. Um “filme de esquerda tem que ser de esquerda mesmo. Não existe arte revolucionária sem

\footnotetext{
${ }^{17}$ Augusto, Sérgio. "Udigrudi” ou inseticida. Opinião. n. 16, p. 20, 19 a 26 fev. 1973.

${ }^{18}$ Ver capítulo 1.
} 
forma revolucionária". Essa do "coração batendo de perto, eu nunca engoli". Sacco e Vanzetti era "um pouco demais".

Entre os críticos marxistas preferidos em Cahiers estavam Jean Domarchi e Jean Douchet. Segundo ele, ambos mostravam que muitos filmes americanos chegavam a criticar mais a própria sociedade em comparação à produção russa. Em comum com estes dois críticos franceses havia a paixão pelos clássicos americanos. Augusto admirava também a "análise cirúrgica" de Louis Marcorelles, que pensava os filmes através do estudo do capitalismo. Diferente deles, Augusto achava Georges Sadoul muito stalinista e "preconceituoso" 19 . Ele dava "duas estrelas para Cidadão Kane" e quatro estrelas para qualquer filme soviético ou italiano "só por exaltar a resistência", relembra. Os críticos marxistas, como Alex Viany, mudaram muito. Os marxistas europeus perceberam depois o quanto "menosprezavam" os outros. Se o instrumental da crítica marxista é "precioso", há uma diferença em relação à linha ligada ao partidão. Esta faz uma má leitura de Marx. Para ele, é lamentável dizer que Balzac é pior ou melhor que Zola, porque esse tipo de comentário não leva a nada.

Muito distante da crítica de matriz sociológica que muitas vezes não chega ao filme, Augusto sempre colocava a análise interna em primeiro plano. Em muitos artigos, há também o estudo do contexto de produção. Há uma atenção jornalística às datas comemorativas, aos festivais, resenhas de livros, balanços, ciclos de debate, etc.

Como critério de organização textual, Sérgio Augusto avalia todos os pontos do filme. Dividindo para analisar, ele toma em separado a fotografia, o estilo, a atuação, o roteiro, etc. Existe uma preocupação jornalística em explicar ao público qual a produção em cartaz. Num dos artigos para Opinião, ele esclarece que a função do articulista não é recomendar uma obra, mas 'tentar explicar como o filme 'funciona', reproduzir em público a leitura que ele, crítico, fez do filme" ${ }^{20}$. No caso de $O$ fantasma da liberdade (1974) de Luis Buñuel, Augusto explica com primor os sentidos presentes da palavra

\footnotetext{
19 Antoine de Baecque (2010) estabelece algumas diferenças entre os três críticos. Sadoul teria uma escrita ditada ou corrigida pela consciência comunista. Por isso odiou o cinema hollywoodiano e amou o cinema stalinista. Enquanto isso, Jean Domarchi era um crítico comunista e escrevia não só em Cahiers, mas também em Les Temps Modernes. Era especialista em Vincente Minelli, Alfred Hitchcock e Anthony Mann. Já Louis Marcorelles conseguia ser comunista, stalinista e cinéfilo. Amava o cinema americano, mas sabia julgar o cinema stalinista, sem simplesmente aderir a ele. Os primeiros a contestar os jovens turcos de Cahiers foram exatamente os cinéfilos comunistas. Sadoul, por exemplo, os taxava de antivermelhos, neoformalistas e de direita.

${ }^{20}$ Augusto, Sérgio. A nova santa Bernadette. Opinião. n. 68, p. 18, 25 fev. 1974.
} 
liberdade do título através da análise das sequências ${ }^{21}$. O trabalho é feito na observação acurada da composição do filme, na relação entre atores e personagens, na análise da postura da câmera e nas formas escolhidas para representar a realidade. Nele, a marca do hic et nunc está sempre presente.

O toque de erudição o diferencia, assim como a memória enciclopédica de fazer inveja a qualquer um. Há centenas de citações enriquecedoras sobre diretores, atores ou detalhes de produção. No artigo sobre Noite americana (1973) de François Truffaut, ele descreve em detalhes todo o tipo de construção em abismo do filme ${ }^{22}$. Embora o discurso seja de especialista e de distinção, muitas vezes vem acompanhado de um toque de humildade, ao reconhecer que não domina o cinema soviético de Sergei Paradjanov ${ }^{23}$ por causa dos filmes "verbotten", isto é, censurados. Leitor ávido de publicações estrangeiras, muitas vezes os artigos fazem um cotejo com a opinião dos críticos internacionais, ora como estratégia de alinhamento, ora para criar franca oposição aos colegas renomados.

Augusto segue as etapas de formulação da crítica. Começa o texto a partir do isolamento dos traços característicos da obra. Depois os compara a outros filmes, visando estabelecer dados históricos em comum. Em seguida, revela os resultados obtidos para depois atingir a interpretação e o julgamento. Nunca traz esses dados como a verdade absoluta, mas como parte de sua construção, porque coloca sempre sua subjetividade no texto. A análise dos elementos da obra é precedida da reflexão crítica, do juízo e da análise da estrutura interna das obras. Seguindo a adequação da crítica voltada ao julgamento estético, Augusto centra seu estudo na mise en scène. A premissa básica parece respeitar a crítica aristotélica (Coutinho, 1975) que não tem um fim

\footnotetext{
${ }^{21}$ Augusto, Sérgio. Blasfêmia pasteurizada. Opinião. n. 148, p. 23, 05 set. 1975. "Buñuel não conta nenhuma história nem se preocupa em explicar com a clareza indispensável o que vem a ser o tal 'fantasma da liberdade'. Diante de sua câmera, proverbialmente serena, sucedem-se flagrantes estapafúrdios da sociedade francesa, safra Pompidou-Giscardiana: uma coleção de colunáveis (médicos prósperos, madames perfumadas) e seus mais representativos acólitos de inferior extração, que se acreditam proprietários, praticantes e protetores da liberdade). Qual liberdade? A de poderem, tranquilamente, preservar os preconceitos, as hipocrisias e as perversões que sustentam a ordem social que lhes garante a vigência do status quo. (...) Entre a cena de abertura, que reproduz Goya e o fuzilamento de três patriotas espanhóis em Toledo, em 1808 (...), até a carnificina no zoológico de Vincennes e as escaramuças que lembram maio de 68, uma sucessão de anedotas e paradoxos funciona como parênteses ao suposto tema básico da 'liberdade' e seus 'fantasmas' (ou suas ilusões), ligadas a um elemento comum que tanto pode ser um livro (elo entre a sequência do fuzilamento e a primeira cena da babá no parque) como um personagem. Resta ao espectador médio, no entanto, usufruir unicamente as relações estabelecidas dentro de cada parêntese. O que, se descoberto o truque dominante do contra-senso - seiva do humor dialético do cineasta - não é tarefa fácil."

${ }^{22}$ Augusto, Sérgio. "A noite americana”. Opinião. n. 73, p. 16, 01 abr. 1974.

${ }^{23}$ Augusto, Sérgio. Russo, barroco e dissidente. Opinião. n. 78, p. 24, 06 mai. 1974.
} 
elaborado, além de si mesma. Contudo a grande atenção dada a mise en scène estava em queda na crítica de cinema francesa dos anos setenta. No contexto francês, segundo Robert Stam (2003), em dez anos, a política dos autores tornava-se ferramenta conceitual ultrapassada. A mise en scène e sua política eram desmontadas na própria casa, a revista Cahiers du Cinéma. Enquanto isso, a semiologia de orientação linguística retirava o autorismo do centro das preocupações, vendo-o como uma construção de personalidade autoral baseada em pistas e sintomas superficiais. O autor ficava aprisionado nas relações impessoais estabelecidas pelo estruturalismo, frente ao papel da linguagem e da ideologia. Havia, de forma concomitante, um declínio da cinefilia. Os grandes autores não eram mais vistos como inovação, mas como tradição. As críticas vinham de todos os lados. Os partidários da vanguarda acusam o autorismo de uma exclusiva devoção ao cinema comercial, deixando pouco espaço para o cinema experimental. Já os ativistas cinematográficos de esquerda sublinhavam os preceitos hierárquicos e autoritários dos autores. Por último, os marxistas condenavam o pressuposto a-histórico do autorismo.

Longe das preocupações de ordem social do intelectual arauto, Augusto procurava manter-se no polo oposto ao engajamento: a cinefilia, com a atenção voltada ao específico do cinema. É assim que ele anuncia em Opinião, com absoluta "alegria", que vem estampada no título, o relançamento de Cantando na chuva (1952) de Gene Kelly e Stanley Donen ${ }^{24}$. Na reprise no Cinema I do Rio de Janeiro, Augusto escreve que o filme "foi sete vezes ovacionado por uma plateia composta em grande parte por pessoas sintonizadas com um tipo de música e cinema radicalmente diferente". A seleção dos depoimentos de cineastas renomados nesta matéria indiretamente prova a primazia do cinema clássico. Arnaldo Jabor, "visivelmente emocionado" teria declarado: "Eu sou um irresponsável por fazer cinema". Os comentários são precedidos em Opinião da confissão típica de cinéfilo de Sérgio Augusto:

"Mas a sensação de desânimo provocada por Cantando na chuva não é um 'privilégio' dos cineastas. Como crítico confesso sentir-me quase que inteiramente incapaz de expressar com palavras adequadas a arrebatadora alegria que me provoca a cada novo contato essa imortal obra-prima de charme, humor, poesia e elegância".

\footnotetext{
${ }^{24}$ Augusto, Sérgio. Alegria! "Cantando na chuva” está de volta. Opinião. n. 74, p. 24, 08 abr. 1974.
} 
A frase expressa a máxima da cinefilia, caracterizada pelo tom de confissão. Ela é extensão da mise en scène, do diário íntimo do diretor (Baecque, 2010). A definição de diário tenta explicar a impossibilidade de dizer algo acerca desse "arrebatamento". O sentimento pela sala escura é quase religioso. Trata-se de uma maneira de assistir aos filmes, de falar sobre eles e difundir seu discurso. Os jovens turcos ${ }^{25}$ de Cahiers a utilizavam como forma de legitimação artística para autores desprezados pelos intelectuais. Diferente deles, Sérgio Augusto não estende a cinefilia aos nãoconsagrados ou incompreendidos. De qualquer forma se mantém o papel de legitimação cultural aos já legítimos. Dotado de uma lista de diretores preferidos, o crítico os defende, mas jamais na base do "custe o que custar", como veremos.

Aqui a declaração de amor ao cinema hollywoodiano aponta para diversas similitudes entre Augusto e a primeira fase de Cahiers du Cinéma. A preferência pelo cinema autoral é perceptível ao comentar em Opinião a reexibição de alguns filmes de Jean Renoir ${ }^{26}$. Para provar a importância do cineasta, ele cita as diversas influências sobre os diretores modernos: Toni antecipou o neo-realismo em sete anos. $O$ crime de monsieur Lange antecedeu a Nouvelle Vague em duas décadas e meia. La règle du jeu "é a versão original de Sorrisos de uma noite de amor (de Bergman) e de L'eau à la bouche (de Jacques-Doniol Valcroze)", tudo isso sem contar ainda com a filmografia de Truffaut, "harmonioso amálgama de renoirismos e hitchcockices".

Para provar o caráter autoral de Renoir, Augusto cita nessa crítica o estudo de Peneloppe Gilliatt, baseado em André Bazin, sobre a utilização da profundidade de campo como possibilidade de libertação democrática aberta ao olhar do espectador. $\mathrm{O}$ interessante no comentário é o desvio, porque o exemplo não é tomado para provar como A regra do jogo (1939) antecipa o início do cinema moderno, sendo o precursor de Welles (Bazin, 1991). Nem para mostrar como a profundidade de campo altera a relação com o espectador, como fez Bazin (1991). O objetivo é frisar a autoria. O conjunto selecionado indiretamente tentava provar a tese da superioridade do cinema autoral.

\footnotetext{
${ }^{25}$ Recebem essa denominação os jovens críticos de Cahiers du Cinéma: Jean-Luc Godard, François Truffaut, Claude Chabrol, Eric Rohmer, Jacques Rivette e Jean-Doniol-Valcroze, que se tornaram expoentes da Nouvelle Vague.

${ }^{26}$ Augusto, Sérgio. A volta de Renoir. Opinião. n. 49, p. 29, 15 a 22 out. 1973.
} 
Para Augusto, Renoir é um incompreendido, que cabe ao crítico cinéfilo decifrar. Ele contesta nesta mesma matéria de Opinião a definição dos admiradores de Renoir como cineasta dotado de "sensibilidade humanística" e "amor à natureza", porque dela não se pode extrair a mise en scène do diretor. As provas usadas pelos admiradores foram retiradas do próprio diretor quando declarou: "a única coisa que posso dar a este mundo ilógico e cruel é meu amor". Para o crítico, a frase é somente abstrata e religiosa. Portanto, a mise en scène de Renoir deve ser procurada de forma mais densa, porque afirmações como esta são incapazes de captar a grandeza das "contradições" de Renoir, porque a obra dele é rica, variada e singular. Dentro e fora do culto ao autor, Augusto busca neste mesmo artigo sobre o cineasta francês uma metodologia de análise para chegar a sua definição intermediária da mise en scène de Renoir:

\footnotetext{
"Maravilhosas e conscientes. Os filmes de Renoir - graves e alegres, pesados e graciosos, frágeis e compactos, rigorosos e soltos - parecem, afinal, inconclusivos, deixados em aberto, mesmo os submetidos aos métodos de produção e criação considerados ideais pelo cineasta".
}

Essa seria parte da mise en scène de Renoir: a contradição e o caráter inconcluso da obra. A pergunta sem resposta para ele é: "porque num mundo tão vazio de malevolência como o dos filmes de Renoir as coisas terminam de maneira tão triste?" Em busca da mise en scène do autor, Augusto procura algumas pistas e as compartilha com o leitor. A unidade da obra estaria não só na ausência de vilões, mas também na construção que impede ao espectador odiar os personagens. Para encontrar mais respostas, Augusto aconselha estudar Renoir em suas motivações sociais e na "capacidade dele de revelar o conflito entre as classes sociais", e não só na abstração da obra. Este seria um elemento a mais da unidade artística. $\mathrm{O}$ crítico tenta transformar a visão de Renoir de hábil artesão para um verdadeiro autor. Ele teria a capacidade de revelar não só as exigências do indivíduo, mas as demandas da sociedade, numa variedade de formas. Eis a mise en scène de Renoir: conferir a todas essas formas "a marca de um estilo personalíssimo que sobreviveu milagrosamente ao tempo". A prova do estilo é a grande influência sobre outros autores. 
Textos como este são bastante comuns na trajetória de Augusto em Opinião. Trata-se de seu principal interesse no jornal: a busca pelo autor. Entre as acepções de autoria $^{27}$, como a de Alexandre Astruc ou de Andrew Sarris, a que mais coincide com Augusto é sem dúvida a política dos autores da Cahiers. Para os jovens turcos, o autor é um cineasta que expressa sua sensibilidade e sua visão de mundo. Se a primeira origem do termo em Astruc aponta para um significado literário, vendo o cineasta como escritor, a política é a apologia do sujeito. $\mathrm{O}$ filme é a expressão pessoal do cineasta. $\mathrm{O}$ sentido de autoria em Augusto parece bastante ligado à definição da Nouvelle Vague. O diretor é alguém que se expressa através da forma de diário íntimo. Uma das diferenças com Augusto é que os jovens turcos causaram polêmica ao utilizar a autoria para se referir aos cineastas americanos ligados ao espetáculo, como Alfred Hitchcock e Howard Hawks. Esses dois diretores estavam longe de traduzir imagens sobre a forma de diários íntimos. Faziam filmes de enredo com forma de espetáculo. Apaixonado pelo cinema americano como os jovens turcos, Augusto coloca em pauta o estudo da autoria para os diretores já consagrados de sua lista. Deixa de lado os novos realizadores conectados apenas ao espetáculo por causa da falta de um it autoral. Quantitativamente o crítico se concentra em localizar essa ausência de autores nos lançamentos. Trata-se de descobrir se o cineasta é um auteur ou um metteur en scène. A autoria é negada, por exemplo, a Sam Peckinpah em Implacáveis (1972) ${ }^{28}$ em Opinião:

"A intelligentsia meia bomba americana descobriu o talento de Peckinpah quando este, melancolicamente, já começava a demonstrar preguiça e cansaço. Os implacáveis é um filme de encomenda, o mais comercial de uma carreira superficialmente rebelde a concessões. Mesmo num gênero inédito em sua filmografia Peckinpah repete todo o receituário ideológico-formal de suas explosões anteriores.

As considerações negativas concentram-se não só nas repetições do diretor, mas especialmente na crítica de atuação e na psicologia dos personagens. O casal não combina: "não porque ele seja um bom ator e ela, talvez, a pior atriz lançada por

\footnotetext{
${ }^{27}$ O tema da autoria é complexo. Cahiers du Cinéma tornou célebre a autoria no cinema através da Política dos autores, mas os jovens críticos da revista não produziram nenhum texto definindo a noção. Jean-Claude Bernardet (1994) procura delimitar o termo tomando por base os artigos publicados na revista. Para Eduard Buscombe (Ramos, 2005), a teoria do autor nunca foi uma teoria específica do cinema. Andrew Sarris escreveu só em 1962 o texto Notes on the auteur theory, mas cronologicamente o grande marco para os críticos de Cahiers foi o artigo La camera-stylo de Alexandre Astruc publicado na L'Écran Français de 1948. Este último valorizou o ato de filmar como o de um artista criativo com pleno direito de utilizar o estatuto de escritor (Stam, 2003, Oliveira, 1999).

${ }^{28}$ Augusto, Sérgio. Quando o crime compensa. Opinião. n. 35, p. 22, 08 a 16 jul. 1973.
} 
Hollywood nos anos 60. Há um conflito evidente de temperamentos." Neste texto, existe quase um imperativo de compatibilidade entre a personalidade do ator e do papel interpretado. Procurando localizar a mise en scène de Peckinpah, ou melhor, negá-la, Augusto conclui em Opinião que há como em todos os filmes, "uma série de mortes violentas, sensualmente registradas pela câmera, além, claro, dos absurdos, das incongruências, das gratuidades e do machismo doentio (...)".

O "único argumento passível” para dotar um filme de Peckinpah como relevante é o seu amoral happy end. Fixando-se em falhas técnicas para gravar a violação da personagem, Augusto retira um dado importante para analisar a autoria. "Como qualificar, por exemplo, a cena da violação de Susan George, em Straw Dogs? No mínimo, de mentirosa, tecnicamente falando (...). É através de falhas desse tipo que se revela o fraco do cineasta por efeitos. E se confirma a falácia dos seus absurdos." Ou seja, os filmes têm uma incapacidade técnica em expressar a impressão de realidade. A conclusão não poderia ser outra: não se trata de um autor, mas de um técnico deficiente. A busca por efeitos especiais revela, no fundo, uma preocupação com o ornamento. Há apenas "uma" cena "criativa" em "122 minutos de colcha de retalhos". A autoria é negada a Peckinpah porque ele é um "artesão", e ainda mais, ineficiente. Os comentários negativos não são apenas sobre os efeitos técnicos e sobre o roteiro, porque a análise das partes comprova a inexistência de um autor. A divisão de mundo é maniqueísta, os vilões são gângsters decentes, a composição dos personagens é fraca e incongruente, assim como o roteiro e a impressão de realidade.

Os comentários aos Implacáveis revela um desinteresse pela técnica, o que é característico da política dos autores. Para os jovens turcos, ela só pode ser um instrumento a serviço de outra coisa. A técnica não tem valor ou significação própria em si. Não é um dado estético. Ela só importa se remete a algo que a ultrapassa (Bernardet, 1994: 56). Para Augusto, Peckinpah não passa de um metteur en scène. Este último, segundo Eduard Buscombe (Ramos, 2005), não tem um estilo verdadeiramente pessoal. Se ele consegue adaptar o material com habilidade, não consegue transformá-lo em algo genuinamente seu. A centelha divina separa o artista do mortal comum; distingue o gênio do artesão ${ }^{29}$. Enquanto o autor tem a capacidade de fazer uma obra

\footnotetext{
${ }^{29}$ Nem todos se renderam à diferenciação entre autor e metteur en scène. Paulo Emilio recusava a diferenciação simplista entre autor e artesão. Já Andrew Sarris não desprezava as condições de trabalho dos cineastas e fugia de uma ideia de autoria idealizada, porque levava em conta a pressão do sistema de
} 
verdadeiramente original, o metteur en scène oculta que a origem de seus filmes está em outra parte. Embora Augusto não use o termo, ele está na gênese de sua busca pela autoria. De qualquer forma, o cinema de gênero era sempre um empecilho para os que trabalhavam o conceito de autoria.

Peckinpah não é autor para Augusto porque o pensamento de um cineasta toma forma cinematográfica pela mise en scène ${ }^{30}$. Esse pensamento é o encarregado de instituir a beleza absoluta do filme. Tanto o conteúdo quanto a mensagem advêm da forma desdobrada por ela (Baecque, 2010: 216). Os jovens turcos prezavam a mise en scène porque enxergavam nela a própria matéria do filme, isto é, uma organização da obra com sentido em si mesma. Como na revista francesa, Augusto dedica-se mais ao estudo da forma do que ao do conteúdo, como se este fosse uma consequência da primeira. Desaprovando a forma e o conteúdo de $O$ casal (1975) de Daniel Filho, escreve Augusto ${ }^{31}$ :

\begin{abstract}
"o constrangedor superficialismo do drama encaixa-se à perfeição com a mise en scène: um mistifório de truques (zoom, câmera lenta, câmara rápida, planos fixos, tomadas com lente grande-angular, e até um beijo circularmente descrito como os que Hitchcock aprecia mostrar em melhores lábios e sem trinados de flauta ao fundo) para encher os olhos dos ingênuos. Ou a confluência exata entre a frescura de Lelouch, a comiseração de De Sica e o didatismo da revista Pais e filhos."
\end{abstract}

Apenas esta vez o crítico se referiu à mise en scène para um filme nacional. Embora o termo seja utilizado, a descrição não é de um autor, muito menos de um metteur en scène, mas de um ornamento. Para piorar $O$ casal é cosmopolita e falso: "é um filme tão brasileiro quanto as calças Levis fabricadas em São Paulo”. Não existe um artigo sequer de Augusto tratando o cinema brasileiro pelo viés da autoria. Geralmente o critério de escolha são os filmes nacionais em cartaz, geralmente atrelados à ideia de espetáculo. Há apenas entrevistas e comentários sobre os lançamentos brasileiros. Aos

produção sobre a criação. Para Sarris, todos os diretores estão aprisionados em condições técnicas e culturais; portanto esses valores devem ser integrados ao sistema de criação (Bernardet, 1994: 28).

${ }^{30} \mathrm{O}$ conceito de mise en scène carece de definição mais precisa, segundo Jean-Claude Bernardet (1994). Mais do que uma colocação em cena, trata-se de uma colocação em imagem. Pelos textos de Cahiers, depreende-se que ela envolve elementos auxiliares para a elaboração dos planos: quadro, movimento de câmera, iluminação, marcação e direção dos atores, aproveitamento da cenografia e dos objetos em cena. A Política dos Autores valorizava a mise en scène porque é através dela que o cinema poderia distanciarse da literatura.

${ }^{31}$ Augusto, Sérgio. O Love Story de Ipanema. Opinião. n. 151, p. 22-23, 26 set. 1975. 
filmes que caberia uma discussão sobre a mise en scène, como a produção dos cinemanovistas, Augusto só publica entrevistas, provavelmente porque Jean-Claude Bernardet já tivesse escrito sobre eles. Isto é, mise en scène, unidade da obra e autoria só para o cinema estrangeiro. Talvez o crítico não aponte sua análise para a mise en scène brasileira, porque partilhe da mesma ideia de Gustavo Dahl nos primeiros anos de Suplemento Literário. Para ele, jamais haverá um filme brasileiro enquanto seu diretor não tiver em relação à câmera as mesmas sensações e sentimentos tidos em relação a seu corpo (Bernardet, 1994). O conceito de cinema em pauta neste trecho é do cineasta como escritor em primeira pessoa, num registro autobiográfico da câmera como extensão de si, lembrando um diário íntimo. Isso porque para Dahl a câmera participa organicamente da personalidade do diretor, integrando-se fisicamente nela. Na origem de ambos estava a presença concomitante de Cahiers du Cinéma.

A ligação entre autoria e "diário sentimental" é a chave do artigo de Sérgio Augusto sobre Os Boas-Vidas (1953) de Federico Fellini ${ }^{32}$. Reexibido em nova cópia, o crítico procura distanciar o cineasta do cinema moderno. Prefere sublinhar o diálogo com o neo-realismo. Por isso declara que Oito e meio (1963) é um momento isolado e singular na produção do diretor, num "ato de exorcismo narcisista". As linhas de força já estariam traçadas nos Boas Vidas. Explicando um ingrediente despercebido, Augusto demonstra como Fellini foi precursor no Vitelloni. Há um "laivo" de "modernismo" porque os personagens definem-se através de gestos e ações marginais, não por emblemas e situações. Se os realizadores costumam ocultar esse tipo de informação, Fellini estava literalmente vinte anos adiantado. O paralelo é aberto com o neo-realismo, que substituiu a evolução dos personagens por "uma espécie de fenomenologia do comportamento mal passada". Para Augusto, o cineasta faz uma sátira de costumes e aborda os desocupados fora do viés marxista:

\footnotetext{
"Ao contrário do que disseram alguns críticos marxistas, Vitelloni não é 'uma sátira (ou uma crítica) de costumes' nem uma descrição da agonia de uma classe decadente. Os decadentes e nostálgicos desocupados de Fellini não são produtos de uma categoria, de uma classe social. Fellini é a negativa mais talentosa do ideal marxista de cinema. Em vez de desemprego e reforma agrária, ele discute problemas de caridade, amor e solidão".
}

\footnotetext{
${ }^{32}$ Augusto, Sérgio. A maioridade de Os Boas Vidas. Opinião. n. 76. p. 20, 22 abr. 1974.
} 
Fellini não discute, apenas mostra e contempla. "Sua concepção dos destinos do homem é profundamente cristã. Para ele, a angústia moral pesa mais do que as falhas sociais, a dialética não compensa as graças da anagogia."

O artigo é dedicado a localizar a mise en scène de Fellini. A produção é vista em meio à ideia de unidade. Cada um dos filmes surge como uma peça no quebra cabeça do estilo do diretor. A mise en scène aponta para uma ideia de "pureza", como se esta palavra traduzisse o conceito de unidade. É por meio da análise do conteúdo dos filmes que se localiza a unidade felliniana. Se o tratamento principal em Augusto é encontrar a mise en scène pela forma, em tantos outros momentos como este, os artigos iniciam com a análise da temática, do enredo e dos personagens. Para Baecque (2010), apesar da mise en scène ter sido uma bandeira dos jovens turcos, o método crítico da política dos autores foi a análise temática. Foi por isso que muitos filmes eram vistos primeiro pelo resumo do enredo e pela ordem cronológica para chegar à avaliação. Tudo porque nos primeiros anos não havia instrumental para pensar a mise en scène, enquanto a análise temática tinha uma tradição tanto na literatura quanto no teatro. Para Baecque, o enredo era ao mesmo tempo valorizado e desvalorizado, porque o método consiste em localizar as significações que estão por detrás. O enredo não é posto de lado, mas é interpretado como um suporte, um pretexto, como um cabide de outra coisa mais importante. Os temas expressam a visão de mundo do autor.

Neste texto, Augusto segue a ordem de raciocínio da análise temática: “(...) Vitelloni conta uma história - intransigência de que o antiintelectualista Fellini, apesar dos arroubos vanguardeiros de Oito e meio, jamais abriu mão - e possui o que a crítica arcádica chama de 'tema central'. No caso, o amaro far niente, a vagabundagem tediosa”. Da explicação do vitellonismo e da analogia entre vida e obra, Augusto chega à unidade da obra. As linhas de força estão traçadas n'Os boas vidas: "a rendição à distensão lírica e ao grotesco, a inclinação afetuosa por personagens cândidos, hiperbólicos, primitivos, marginais e gregários, o apelo a uma simbologia simplista (o mar como evasão impossível)." Essa é a mise em scène felliniana.

A análise detalhada de cada filme permite observar as provas de confissão mais ou menos diluídas da vida do autor. Pelas diversas "coincidências" entre trajetória 
pessoal e obra "não há como negar o espírito familiar-comunal de Vitelloni" ${ }^{33}$. Eis a unidade que toda obra precisa encontrar, porque sem ela não há autor. $\mathrm{O}$ crítico atento à autoria é motivado pela busca da integralidade da obra e do artista. Ele olha para o filme e para o diretor como um todo, mas as partes devem articular-se em um sentido coerente. Por esse motivo, a unidade participa de um paradigma mais amplo de universo e visão de mundo, sempre muito presentes nas críticas de cinema (Bernardet, 1994: 177).

Se cada filme compõe a unidade da obra, a continuidade do trabalho não significa a certeza de novos elogios. Um ano depois, quando Augusto toma contato com Amarcord (1973), as considerações sobre Fellini mudam radicalmente ${ }^{34}$. Se o cineasta é geralmente tratado como autor, o estudo da mise en scène fica em segundo plano porque Amarcord não traz nenhuma originalidade; apenas reminiscências do passado. Colocando de lado a busca pela unidade da obra, Augusto observa apenas uma repetição. "Os grandes mestres do cinema, fatigados, se repetem. (...) Não surpreende, portanto, que Federico Fellini (...) recomponha na tela, mais uma vez, os fantasmas de sua puberdade." Se a unidade pressupõe repetição, o exagero é condenado: "Do impressionismo jornalístico de Roma passamos à baffonata nostálgica de Amarcord. A memória comanda o espetáculo: no dialeto da Emilia, (...), amarcord significa 'eu me lembro'. Não poderia ser este o título de todos os filmes de Fellini?"

Os comentários negativos incidem sobre a galeria de tipos e sobre as inúmeras coincidências biográficas. "Do fundo do baú os ossos, lembranças acridoces, são remexidos: volumosos seios de fêmeas insatisfeitas, vitelloni errantes, loucos, velhos, crianças, (...).” A conclusão é que Fellini envelheceu e o filme não é original, apesar das qualidades: "a orquestração é impecável, apesar do claro fastígio do maestro". Amarcord "não é um prodígio de invenções e surpresas". Aqui o caráter autobiográfico das confissões não é mais visto como positivo. A função do crítico é evidenciar a matriz do cineasta através da unidade. Isso já tinha sido feito no artigo sobre Os Boas-Vidas. Afinal a matriz é uma virtualidade e uma abstração que se projeta com maior ou menor

\footnotetext{
33 "Em Vitelloni, Fellini trata de sua cidade natal (o filme foi rodado em Viareggio mas qualquer semelhança com Rimini não é mera coincidência), de seus vizinhos, parentes, em especial dos amigos. Dos cinco boas-vidas, três têm exatamente o mesmo prenome dos atores que os interpretam: (...). Acrescenta-se a esta coincidência mais duas: Ricardo é irmão de Federico, Moraldo (...) e Fausto (...) eram os nomes de dois companheiros do diretor. (...) Fausto se casa com a irmã de Moraldo. Este é o alter-ego de Fellini, o vagabundo que, num rasgo de consciência, abandonou a tempo o torpor da província." Augusto, Sérgio. A maioridade de Os Boas Vidas. Opinião. n. 76, p. 20, 22 abr. 1974.

${ }^{34}$ Augusto, Sérgio. Na jangada da medusa. Opinião. n. 130, p. 21, 02 mai. 1975.
} 
nitidez sobre as realizações concretas; como uma espécie de decantação de algo oculto. Cada filme possibilita o acesso a essa ideia, e o crítico precisa remontar a virtualidade das aparências. As realizações até podem ser múltiplas, mas a ideia é única. Por esse motivo, a produção concreta é valorizada e desvalorizada, porque nunca é a obra em si, mas um meio de alcançar a ideia (Bernardet, 1994: 55).

Se Augusto desgosta de Amarcord exatamente por causa das repetições, a peça essencial do trabalho do crítico geralmente é a redundância. As repetições e similitudes na diversidade das situações dramáticas ajudam o crítico a delinear a matriz, porque o autor é um cineasta que se repete. Quando esclarecida, a matriz ilumina os filmes anteriores e tem um efeito retrospectivo para o crítico (Bernardet, 1994: 29-31). No caso de Os Boas-Vidas, Augusto traçou a mise en scène felliniana no âmbito da temática comum e do passado do diretor, mas não gostou de vê-la repetida em Amarcord. Por outro lado, talvez o maior problema não seja a recorrência, que é um traço da autoria, mas a retomada sem acréscimo de nada novo. Naquele primeiro artigo, ele chegou à definição do específico de Fellini com a ideia de "confissões" e "pureza". "Talvez seja imprudência falar de pureza. Não tanto pelo fato de que, por tabela, se estaria comprometendo a genuinidade das demais 'confissões' fellinianas, mas por ser esta palavra, via de regra, tomada em vão por critério de qualidade. Mas ela é inevitável." Isto é, a pureza de um filme significa retratar de forma autêntica a experiência do diretor, como uma espécie de veracidade histórica. Para provar a tese, ele explica a ligação da vida de Fellini com cada filme. Portanto, a definição da mise en scène completa-se com a aplicação da psicologia ao diretor. Ela incide sobre a mensagem e sobre os temas. Trata-se de um deslocamento da análise imanente para a psicologia, que propicia uma coincidência científica entre o objeto e seu olhar. Esse tipo de metodologia era utilizada por Andrew Sarris, segundo Eduard Buscombe (Ramos, 2005). Para o crítico americano, a personalidade confere à obra uma unidade orgânica. Um diretor deve exibir certas características recorrentes de estilo que servem como assinatura (Bernardet, 1994). A atenção à psicologia pode estar na base do sentido de autor como expressão pessoal.

É como se a crítica de cinema tivesse de captar a alma do diretor e sua personalidade para entender o sentido da obra, calcado na crença da existência de uma verdade revelada e incutida em cada filme. Os artigos são assim dotados de uma transcendência explicativa sobre os diretores. O método possibilita atingir a criação 
autoral. É através do crítico que o leitor pode encontrar a verdade revelada sobre o autor. Por esse motivo, o texto está cheio de longas declarações do cineasta ligando os filmes às suas experiências.

Augusto não foi o único a traçar um paralelo entre a biografia de Fellini e sua mise en scène. Paulo Emilio valorizou no cineasta a coincidência entre a experiência existencial dele e seu processo criador. Procurava na biografia do realizador os elementos de compreensão da obra. Esse tipo de comentário também era comum em Moniz Vianna (Bernardet, 1994). É curioso que a fonte primária da comparação aponte para o próprio cineasta. Em Opinião, publica-se um depoimento do diretor para explicar Amarcord ${ }^{35}$. Fellini recorria, segundo Bernardet (1994), à ideia de magma em seus filmes: "Tudo ocorre como se já houvesse, desde o início, um acordo entre o filme a nascer e eu. Como se o filme acabado já existisse fora de mim. É necessário encontrar seu caminho pessoal neste magma, cavar até que se produza a faísca”. Após a filmagem, o filme toma a sua forma na mesa de montagem. Diz Fellini: "a mim me parece que todos os projetos que depois acabo por realizar não surgem num instante, mas sempre existiram, para depois ganharem um destaque." Nessa perspectiva, a obra já existia antes da sua concretização, fechando-se sobre si mesma como num círculo. $\mathrm{O}$ comentário de Fellini baseia-se no efeito retrospectivo da matriz acabada. Esta faz da obra um sistema fechado e o reinado da redundância, repetindo-se incessantemente até a máxima depuração da matriz. (Bernardet, 1994: 33-34)

Uma implicação que aparece pouco nos textos é a junção entre a autoria e o estilo de diversos cineastas. Dada a preocupação de Augusto com a unidade temática dos diretores, algumas vezes ele monta um verdadeiro quebra-cabeças de influências, como foi o caso de Noite americana (1973) de François Truffaut ${ }^{36}$ e Imagens (1972) de Robert Altman ${ }^{37}$. Nestes casos, o estudo do específico autoral rende-se a uma tendência mais globalizante que vem do contexto social. Alguns paralelos com críticos brasileiros podem ser tomados. Para Paulo Emilio Salles Gomes (Bernardet, 1994), o estilo é coletivo, nacional e histórico. Em Antonio Moniz Vianna, a noção de estilo era de peso e não excluía o diálogo com outros cineastas, sem que isso despersonalizasse o autor em questão.

\footnotetext{
${ }^{35}$ Fellini, Federico. Fellini: a luz sob controle. Depoimento concedido a Jean-Paul Mont-Servan e Gideon Bachman. Opinião. n. 130, p. 22, 02 mai. 1975.

${ }^{36}$ Augusto, Sérgio. "A noite americana". Opinião. n. 73, p. 16, 01 a 11 abr. 1974.

${ }^{37}$ Augusto, Sérgio. A ambígua realidade. Opinião. n. 41, p. 20, 20 a 27 ago. 1973.
} 
Portanto, três características definem o trabalho de Augusto em Opinião: a cinefilia, a preferência pelo cinema clássico e o estudo sobre a mise en scène. $\mathrm{O}$ foco principal é definir se um filme faz parte da autoria ou se é mero entretenimento. A atenção de Augusto se divide em duas partes. Na primeira delas é preponderante e presente do ponto de vista qualitativo. Crítica de cinema se atém às obras de arte. Caso um lançamento seja apenas repetição de uma estratégia já adotada, não será recomendado. A segunda preocupação é mais presente na quantidade de artigos. $\mathrm{O}$ crítico sempre condena o esquematismo dos filmes, a tentativa de comover e os finais felizes óbvios. Afasta-se gradualmente da perspectiva do gosto popular, mas não impõe uma opinião ao público. É possível ao leitor tirar suas próprias conclusões, através do que busca no cinema: arte ou entretenimento. Afinal o processo jamais esconde a subjetividade de suas preferências.

Às vezes Augusto faz esse tipo de comentário através de features, como foi o caso do artigo sobre Gilles Carle, A verdadeira natureza de uma mulher chamada Bernardette (1972) ${ }^{38}$. Este texto percorre vários caminhos críticos de análise: de ordem psicológica, sobre o décor e o ornamento, sobre as coincidências onomásticas e simbologias óbvias adotadas, sobre a análise da fraqueza do roteiro, sobre a concepção individualista da história, que não chega a tocar temas mais profundos do presente. Se Augusto sempre se preza em declarar que o espetáculo por si só já vale, na prática, ele sempre encontra algum defeito. Assim a maior parte dos lançamentos não são bem vistos porque algo lhes falta, isto é, não são arte. Espetáculo ou arte, eis uma questão para o crítico.

O estudo de gênero também incide sobre as conclusões tomadas. Após a análise detalhada, autores mesmo são poucos, por volta de treze, enquanto o número de lançamentos é bem maior. O conceito de autoria nele é complexo; reúne uma lista dos diretores preferidos. Nos casos de cinema de gênero, Augusto aplica a análise da ideologia e da representação sociológica. Critica o esquematismo e os aspectos ideológicos para estabelecer uma corrente entre o filme e os valores sociais norte americanos presentes.

Para Augusto, os melhores textos de Opinião são sobre os filmes que ele não gostou. Observamos que nestes casos, o arsenal utilizado é o da análise do discurso das

\footnotetext{
${ }^{38}$ Augusto, Sérgio. A nova santa Bernadette. Opinião. n. 68, p. 18, 25 fev. 1974.
} 
obras, a partir da racionalidade do crítico. São os textos em que o crítico não localiza um autor. Contudo, parece-nos que nos casos de preferência por determinados autores, Augusto coloca em prática de maneira plena seu ato crítico (Milliet, 1981; Candido, 2011). Isto é, há o instante de racionalidade e o momento intuitivo de sensibilidade estética. São estes os artigos que o aproximam da criação autoral. Nestes casos, ele sintetiza a matriz da crítica atenta à psicologia e o impressionismo estético de cinéfilo.

A crítica impressionista estava em pauta como principal critério de análise no Brasil até os anos sessenta. Enquanto Bernardet (1978) abandonou esse modelo por causa do Cinema Novo, Augusto ainda o tomava como padrão. Movendo-se com sensibilidade pelo mundo da arte, na crítica impressionista, o crítico proporciona uma maior penetração no universo artístico. Do contato com a obra, as impressões despertadas nele possibilitam ao leitor reviver a experiência do artista. O texto é o encarregado de verbalizar emoções para reconstituir o sentimento provocado pela obra. Portanto, as reações do crítico são a forma de atingir a criação autoral e de captar a sensibilidade do diretor.

Este critério é sempre subjetivo e os textos aparecem na primeira pessoa. $\mathrm{O}$ trabalho é feito através de cânones e no confronto entre a obra e as normas modelares. A crítica impressionista deriva da crítica platônica, de natureza psicológica, mas também tem inspiração no movimento estético. Ela é realizada por homens de sensibilidade refinada, como Saint-Beuve, Anatole France e Sérgio Milliet (Coutinho, 1968, 1975, Candido, 2011). Aqui a arte é vista como um estado de transe quase místico da alma do autor.

Nos casos em que Augusto tem um élan com o filme, ele atinge a plenitude do ato crítico. Quando há identificação com grandes obras, há uma forma de atitude apologética que se aproxima da definição de impressionismo autêntico de Sérgio Milliet (1981). Neste caso, o ato crítico pressupõe empenhar a personalidade, inteligência e sensibilidade para interpretar as obras. Não há um método ou doutrina de abordagem, mas uma gravação de percepções subjetivas, convertidas em juízo estético. Para Milliet, a crítica mais autêntica se entrelaça com a atitude apologética. Ela é fruto natural da identificação do analista com as obras com as quais tem afinidade. Para dar conta do processo, Augusto reúne as características essenciais: o encontro entre o racional e o sensível, sem deixar de lado a sistematização teórica e a tentativa de entender os 
problemas artísticos de seu tempo. Ele disseca a obra racionalmente, mas não recusa a intuição. No momento criativo, ocorre o instante de revelação da obra com a participação afetiva do analista no texto. A descoberta do autor depende, portanto, da identificação afetiva e intelectual do crítico com o filme.

Não se trata jamais do erro de insistir na impressão subjetiva, deixando o objeto de lado, porque o trabalho é feito através do estudo dos elementos intrínsecos da obra: a análise imanente e o estudo da autoria. O processo de Augusto permite revelar ao leitor no que consiste a obra; sua qualidade, estrutura, forma e essência. Portanto, no caso de Augusto, a utilização da psicologia para captar a alma do diretor concilia-se com a busca do específico do cinema pela crítica impressionista, focada na mise en scène. 


\subsection{Gustavo Dahl: política e emoção em Uirá}

Nascido em Buenos Aires, as primeiras lembranças cinematográficas de Gustavo Dahl vinham dos cinejornais ${ }^{39}$. Na época com quatro a cinco anos de idade, ele se empolgava com as cenas de batalha do noticiário da Segunda Guerra Mundial. Mas a curtição durava pouco. A mãe o obrigava a abaixar a cabeça até o joelho para não ver as imagens "impressionantes". Com a separação dos pais, a mãe trotskista veio para o Brasil com o filho. Em São Paulo, Gustavo Dahl tornou-se aluno do colégio Paes Lemes, quando começou sua maior aproximação com o cinema. O colégio oferecia quatro sessões de cinema semanais, geralmente de clássicos americanos. A localização era estratégica para um cinéfilo, por causa da proximidade geográfica com as salas de exibição da avenida Paulista. Já naquela época, Dahl escrevia sobre cinema para o jornal da escola.

Foi num piquenique, entre onze ou doze anos, que ele viu pela primeira vez a Revista de Cinema, de Minas Gerais. Percebeu um novo tratamento dado ao assunto: ao invés da paixão infantil e da diversão, o cinema era tratado como coisa séria e ocupava os adultos. Cinema era cultura. Depois disso, Dahl passou a acompanhar a Filmoteca do Museu de Arte Moderna com a mãe, frequentadora de exposições artísticas. As maiores transformações de interesse começaram por volta dos treze a catorze anos, quando teve contato com "figuras míticas" como Paulo Emilio Salles Gomes e Walter Hugo Khouri. Foi um colega de escola quem o apresentou ao grupo de Rubem Biáfora e de Khouri. O curso na Filmoteca do MAM significou a ponte para o ingresso no Cineclube Dom Vital, ainda no final dos anos cinquenta. Dahl cursava direito no Mackenzie e trabalhava no Departamento de Propaganda da Sears-Roebuck. O sonho era seguir a carreira diplomática. Como presidente do Dom Vital, ele foi fazer o Curso para Dirigentes de Cineclube da Cinemateca Brasileira. Aproximou-se de Paulo Emilio Salles Gomes, de Rudá de Andrade e de Francisco Luiz de Almeida Salles.

O ingresso na crítica de cinema aconteceu graças a Paulo Emilio Salles Gomes, que o convidou para escrever um artigo sobre Elia Kazan em sua coluna no Suplemento

\footnotetext{
${ }^{39}$ Falecido em 2011, as informações biográficas de Gustavo Dahl foram colhidas do livro de José Inácio de Melo Souza (2002), de uma entrevista datilografada da Cinemateca Brasileira Pasta D 159/52 e da edição especial sobre ele na Filme Cultura (n. 55, dez. 2011).
} 
Literário do Estado de S.Paulo. O texto demorou nove meses para ser gestado e Dahl continuou a publicar artigos para o jornal, a partir de $1959^{40}$. Este não foi o único ponta pé inicial; Paulo Emilio conseguiu também uma vaga para ele na Cinemateca Brasileira, onde preparava catálogos de festivais.

Nova mudança aconteceu quando Dahl viu um anúncio de jornal do governo italiano oferecendo bolsas de estudo em 1960. Ele ficou logo interessado e pediu a intersecção de Paulo Emilio. Com a carta de recomendação, ele pôde ingressar no Centro Experimental de Cinematografia em Roma. No curso, conheceu Bernardo Bertolucci e Marco Bellocchio. Tornou-se amigo de Paulo César Saraceni, com quem dividia apartamento. Como o principal articulador e divulgador do Cinema Novo, Gustavo Dahl garantiu o acesso dos estreantes aos festivais europeus. De aluno de cinema transformou-se em porta voz do movimento. Por meio dos festivais, ele sedimentou amizades, não só com os cinemanovistas, mas com críticos franceses, especialmente com Louis Marcorelles da Cahiers du Cinéma. Este último lhe abriu as portas da revista para escrever e para difundir o Cinema Novo, quando Dahl já tinha se tornado uma espécie de porta-voz do movimento.

A estreia como diretor de longa metragem ocorreu em 1968 com O Bravo Guerreiro. Ele publicou também artigos na Revista Civilização Brasileira ${ }^{41}$. Entre 1972- 1973, Dahl realiza Uirá, mas o filme só é lançado em 1974, após retenção pela censura. É exatamente nesse período de liberação e estreia que Dahl começa a escrever para Opinião. O primeiro artigo publicado é exatamente sobre Uirá. Talvez o ingresso no jornal tenha relação com esse processo, porque o editor de cultura, Júlio César Montenegro, o recebeu como diretor censurado e perseguido pela ditadura militar. Ele não se lembra claramente se Dahl foi até a redação porque queria participar do semanário ou se alguém da direção sugeriu seu nome. O crítico permanece em Opinião um mês após a demissão de Raimundo Pereira em 1975. A época coincide com a transição para a equipe Argemiro/Augusto e com o seu ingresso na Embrafilme, onde vai dirigir a Sucom (Superintendência de Comercialização).

\footnotetext{
${ }^{40} \mathrm{O}$ artigo sobre Kazan foi publicado em 1959. Dahl, Gustavo. Atualidade de Elia Kazan. Suplemento Literário. O Estado de S.Paulo. 10 jan. 1959, p. 41.

${ }^{41}$ No currículo de Gustavo Dahl, consta também a publicação de artigos no Jornal do Brasil, Correio Braziliense, Movimento e Folha de S. Paulo.
} 
Em Opinião, Dahl não se ocupa muito dos lançamentos, mas sim dos clássicos. Dos 16 artigos publicados entre junho de 1974 a março de 1975, algumas temáticas são recorrentes: a autoria, o cinema político e o filme musical. A maior parte dos textos é dedicada ao cinema estrangeiro, com foco na análise fílmica.

Se Dahl dedicava-se à questão da autoria quando era crítico de Suplemento (Bernardet, 1994), em Opinião o tema tem relevo, mas sofre alterações em relação ao tratamento dado pelos críticos atentos ao mesmo assunto no bloco Sérgio Augusto/Marcos Ribas de Farias/Clóvis Marques. Bernardet esclarece que na época de Suplemento, Dahl apoiava-se na crítica francesa dos Cahiers, na valorização do autor e no estudo do estilo. O colega crítico não se interessava pela repetição de si mesmo como marca da autoria. Da Política dos Autores, Dahl ainda pensava o autor como dotado de uma visão própria de sentimento do mundo (Costa, 1966). Um pouco dessas ideias aparecem no artigo sobre Gritos e Sussurros (1972) de Ingmar Bergman ${ }^{42}$. O lado poético dele se manifesta no conjunto de textos de Opinião, fazendo lembrar o comentário de Paulo Emilio Salles Gomes afirmando que Dahl era quem melhor escrevia entre os críticos da nova geração ${ }^{43}$. A sensibilidade é aguçadíssima e os textos sempre atraem pela construção elegante. Ele tem estilo: uma mera sinopse se engrandece em suas mãos pelas comparações históricas e teóricas. Dahl consegue ir além, procurando nos filmes um sentido filosófico para os sentimentos mais banais. Retira sínteses importantes de minúcias. Os comentários passam sempre pela linguagem cinematográfica e explicam conceitos aos leitores. Os dados estéticos estão sempre presentes com tom humanista e poético. Eis um trecho da crítica a Gritos e Sussuros:

"Este mundo arquetípico no qual os personagens são 'sistemas de comportamento' tipificados, monolíticos, tem um sabor acremente provinciano. Mas é partindo desta simplicidade forte do desenho psicológico, que este mesmo mundo transcende, se universaliza. (...)

No momento em que o cinema volta a aceitar que a arte imita a vida, Bergman filma uma montagem teatral hiper-realista. A cenografia é inteiramente artificializada, o vermelho usado como cor única, já que o branco é a soma de todas as cores, o preto, a ausência delas e o cinza, a mistura destas duas. Mesmo com o chão vermelho marcando esta teatralidade cenográfica, surpreendentemente a casa do filme é possível, ou como

\footnotetext{
${ }^{42}$ Dahl, Gustavo. A morte loura. Opinião. n. 108, p. 19, 29 nov. 1974.

${ }^{43}$ Paulo Emilio define o método de trabalho de Dahl calcado na noção de identificação pela simpatia. Gomes, Paulo Emilio Salles. Uma nova crítica? Suplemento Literário. O Estado de S.Paulo. 16 jan. 1960, p. 11.
} 
tal se apresenta numa leitura puramente realista. As cores mais vivas, o azul, o amarelo, o verde, o rosa, que aparecem nos planos iniciais do filme em que se vê a natureza, dentro da casa vão se refugiar nos detalhes mais sutis, a suave decoração de uma bacia de porcelana, as flores de um vaso. O dourado do outono rima com o brilho dos relógios cujos pêndulos e carrilhões marcam o tempo no mesmo balanço em que se balança a infância, suavemente impulsionado pela ama de seio farto e terno. Eterno? O vermelho que se interpõe entre os clareamentos e escurecimentos que pontuam a narração, deixa entrever sua significação, quando Ingrid Thulin, auto-flagelada com violência inaudita, esfrega o sangue que escorre, em sua própria cara. A convenção levada aos limites extremos aparenta a realidade. Como gostava de dizer Godard: 'Não é sangue, é vermelho'.

A zoom, objetiva artificiosa, permite a Bergman colar a câmera em seus personagens, acompanhando-os nas elaboradas marcações, preciosas de tão precisas. Nos planos gerais com vários atores em cena, aparece o gosto de Bergman, pela plasticidade das marcações teatrais, no qual ele, alinhando-se com Welles, Kazan, Visconti, não está em má companhia. Se uma atriz sai por uma porta enquanto outra entra, a terceira dorme e a quarta espreita, os deslocamentos não se fazem somente em profundidade dentro do plano tridimensional, mas sobretudo no plano bi-dimensional da gradual ocupação de toda a superfície da tela, num tempo musical. A insistente intimidade dos closes, devora porém o vermelho da teatralidade e devolve o romance, a narração intimista, o fluído fluxo dos sentimentos".

Dahl procura encontrar nos filmes não uma descrição da forma ou do contraponto com a sociedade, mas uma explicação para o comportamento humano. Para ele, a morte em Bergman é uma experiência que ilumina as verdades interiores; que põe a nu o ser. Para provar a tese, Dahl decifra as ligações estabelecidas entre psicologia, arquétipos e a linha teatral naturalista, através da descrição das cenas. O artigo não procura uma matriz em Bergman, mas se engrandece nos pequenos detalhes sobre as cores da paisagem e do décor para mostrar como os temas se universalizam e transcendem.

Contudo, a influência de Cahiers dos primeiros tempos se faz uma entre outras; indo contra o início de sua trajetória. O tratamento dado a Bergman muda quando o diretor é Roman Polanski ${ }^{44}$. Com outro foco, o artigo destrincha o processo de construção do suspense em Faca na água (1962) e Chinatown (1974). Dahl estabelece um continuum entre a postura dos personagens e a do diretor, porque ambos procuram dominar todas as etapas da engrenagem cinematográfica, sem permitir ao espectador acompanhar de perto sua trajetória. De observações banais à primeira vista, ele resume a questão da ausência de autoria em Polanski pela ordem de apresentação dos fatos na montagem. O resultado é sempre pegar o público desprevenido, diferente da construção

\footnotetext{
${ }^{44}$ Dahl, Gustavo. Polanski - A linguagem inútil. Opinião. n. 116, p. 24, 24 jan. 1975.
} 
mais democrática de Alfred Hitchcock, que permanece no artigo como referência oculta. "O que há de mais irritante em Chinatown não é o fato dele ser convencionalmente bem feito, lambido mesmo, com a fotografia tão bonita e certinha quanto a reconstrução de época, mas a falta de originalidade de suas surpresas". Tudo isso é sinal de um "aluno" de cinema "aplicado", mas não de um gênio. Se Polanski não tem estilo próprio, a autoria lhe é negada porque ele não passa de um hábil artesão, desprovido de calor humano e de sensibilidade. É nestes momentos que aparece sutilmente a presença de uma cultura política engajada, que evita se manifestar claramente.

A postura em relação ao cineasta Roman Polanski não é uma expansão da política dos autores. Ao contrário, ela revela outras presenças. Se o autor personaliza seu sentimento de mundo, os parâmetros de análise de Dahl tinham mudado bastante desde a época de Suplemento. Dizia ele ainda em 1966: "não era mais o caso de julgar o artista pela agudeza ou justeza de sua percepção da realidade, mas pela agudeza ou justeza de seu juízo sobre esta mesma realidade. Sem deixar de ser físico o cinema tornou-se moral, sem deixar de ser estético o cinema tornou-se ético" (Costa, 1966: 23). Foi para Dahl o avançar do cinema moderno o responsável por trazer a responsabilidade do artista por sua criação. Não só com sua arte, mas também com a vida, com a sociedade e com a história. Portanto, a diferença quando Dahl estuda a autoria é passar pelo fator político. A finalidade do processo cinematográfico é transformar em arte uma visão de mundo. A questão central da autoria em Dahl significa saber se o artista sentese ou não responsável pelo mundo em que vive. Quando o crítico já no final dos anos cinquenta partia de um conceito político para definir a autoria, Bernardet (1994) considera a postura original, porque a conexão entre política e responsabilidade social era algo inédito e impensável para o conceito de Cahiers. Se o cinema de autor significa revolução para Glauber Rocha, a mise en scène desloca-se para a política e para a ética.

Quando a autoria encontra o fator político, Gustavo Dahl reelabora um sentido muito peculiar, que o caracteriza. Ele corresponde à mescla de dois momentos históricos de Cahiers. O cruzamento de parâmetros aparece no artigo sobre Gilda (1946) de Charles Vidor ${ }^{45}$. Diferente do texto padrão de Opinião para analisar o discurso ideológico da produção, o estudo de Dahl sobre a presença política do cinema

\footnotetext{
${ }^{45}$ Dahl, Gustavo. Gilda: bolero erótico ou filme político? Opinião. n. 111, p. 21, 20 dez. 1974.
} 
hollywoodiano está muito longe do enredo e da ideologia como dado único. Das nuances, ele encontra uma teoria que se compõe nas bordas, nas fronteiras. Começa o artigo com a fascinação da estrela enquanto ícone erótico para relacionar com a postura da câmera. Gilda é um filme político por sua visão de mundo, mas este percurso não exclui a teorização sobre a autoria. Porque Charles Vidor é um artesão habilidoso, a composição de planos e a montagem são banais. Para ele, a mensagem é simplista e a heroína é frígida. Se o filme tivesse sido entregue a Orson Welles, teríamos uma obra prima. Contudo, Vidor pertence aos que não tem nada a dizer, mas a fazer. Seu único objetivo é a absorção emocional do público. Para Dahl, Vidor não é autor porque não tem uma visão de mundo particular. Seu objetivo é a emoção do espectador. Apesar de taxar Vidor de artesão, Dahl consegue ver nele peculiaridades: há uma excepcional capacidade de realizar uma concepção musicalmente harmônica na manipulação do ritmo do cinema americano clássico. Mas o estilo é acadêmico, anônimo e acessível. O sentido político trilhado é o de evitar que o desespero dilacere os corações por meio do happy end. Essa construção enviesada, a partir de informações multifacetadas, caracteriza Dahl e o sobrepõe aos estudos sobre ideologia de Opinião. Os paralelos não são diretos e essa construção amplia o entendimento do político no cinema. Sem tentar provar como numa cartilha o quanto há de ideológico na produção, Dahl esmiúça os mecanismos com os quais o filme americano consegue hipnotizar, seja pela estrela ou pelo uso dos arquétipos. Foge da análise do enredo e chega ao político através do star system:

"O rosto de Gilda, o corpo de Rita, as roupas elegantes de Rita, sua voz, seu ritmo, são todas peças de um mito cientificamente construído. Seus gestos, seu jogo dramático, são a cristalização distanciada do óbvio. A expressão de seus sentimentos, constantemente mantida por uma técnica de representação, faz pensar a um Kabuki Kitsch. Uma estrela é uma máquina tão elaborada quanto um carro de corridas e bem administrada é capaz de grandes performances. É nos momentos melodramáticos ou sedutores que melhor se manifesta esta metalinguagem da convenção. (...) Mas a homogeneidade do artifício, a manutenção do mesmo diapasão interpretativo, o igual peso das sequências, nenhuma mais importante que a outra, a continuidade da luz, a simplicidade da decupagem vão criando uma fascinação cumulativa, hipnótica, subliminal, que leva o espectador a esquecer-se de si mesmo. O único objetivo é a absorção emocional do espectador pelo filme, e o único valor, a eficiência."

O trecho decompõe o que os demais artigos deixam em aberto: os mecanismos de construção do cinema e da estrela que levam à fascinação. Dahl explica como um 
filme melodramático torna-se político através da absorção emocional da reiteração. Esta constatação não é feita com dados óbvios do enredo, mas por meio dos mecanismos cinematográficos. Ao invés de se concentrar no que acontece, Dahl destrincha como acontece. Essa brecha não era levada em conta em Opinião.

Um segundo filme político analisado por Dahl criou polêmica no jornal. No texto, ele compara a reação de medo do povo em Delito Matteoti (1973) de Florestano Vancini ${ }^{46}$ com as imagens das multidões aclamando Mussolini. Observando que o fascismo alcançou a maioria da população, ele se pergunta se há dentro de nós uma parcela de culpa:

"No final do filme explode de novo o tema do medo, presente no início, no discurso e no rapto de Matteoti. Quando a violência fascista se desencadeia agredindo, prendendo, exilando, matando aqueles que lhe oferecem resistência, é impressionante ver o medo estampado na face da população que assiste ao massacre. Os olhares se desviam, os passantes fogem, ninguém tem nada a ver com isso. E assim é lançado o grande tema político que fica sempre oculto neste e noutros filmes que se ocupam do fenômeno fascista, que é o apoio efetivo e maciço da população que tanto Mussolini quanto Hitler obtiveram. Ou seja, a imposição do fascismo ou do nazismo pela cumplicidade ou fraqueza das elites financeiras ou políticas diante de sua violência, entende-se. O que não se entende, e seria interessante fazê-lo, é como poucos anos depois, por toda a Itália, multidões entusiasmadas gritavam: Duce, Duce, Duce... É cômodo atribuir à violência e ao medo que ela provoca, a indiferença da população. Mas a ideia de que o fascismo em determinado momento, foi expressão e desejo da maioria, é inquietante. Necessita-se para abordá-la um arsenal mais amplo e moderno do que o habitualmente usado para encarar a questão".

Citando um trecho muito parecido com este, Jean-Claude Bernardet escreve uma carta a Paulo Emilio Salles Gomes para relatar um episódio de censura interna envolvendo Gustavo Dahl e Delito Matteoti ${ }^{47}$. A introdução da crítica de Dahl teria sido cortada por mostrar como a ideologia fascista pode penetrar o povo, que a assumiria subjetivamente. "Não li o texto, mas é mais ou menos isso", explica o crítico. Em seguida, Bernardet aproveita para comentar outras formas de censura interna e um possível desfecho da história:

\footnotetext{
${ }^{46}$ Dahl, Gustavo. O delito Matteoti. Opinião. n. 117, p. 21, 31 jan. 1975.

${ }^{47}$ Correspondência de Jean-Claude Bernardet a Paulo Emilio Salles Gomes. Rio de Janeiro, 07 fev. 1975. Pasta PE/CP 1085 a 1088. Arquivo Paulo Emilio Salles Gomes - Centro de Documentação e Pesquisa da Cinemateca Brasileira.
} 
"Comigo, parece não haver problemas, mas por motivos circunstanciais fiz alguns artigos que tiveram repercussão, o que é bom para o jornal, sou uma 'autoridade no assunto', então em princípio o que escrevo é o centro, parece que tenho um certo apoio do Gasparian. Mas assim mesmo me foi dito ontem que tendo muito para o ensaio (o que é pejorativo) e muito pouco para o jornalismo. E eu soube que a editoria geral não gostou do Sérgio Augusto ter-me demitido do jornal (o que ocorreu por pressão nossa e para deixar a Gustavo a possibilidade de trabalhar como entende) e fez uma ofensiva no sentido de contratar Geraldo Mayrink. Este Geraldo é editor ou ex-editor de cinema de Veja. (...) Ele sacaneia sistematicamente o cinema brasileiro. Penso que já conseguimos barrar o Geraldo, mas me parece que a seção cultural de Opinião não terá um futuro glorioso. Em todo caso, não conseguimos colocar na cabeça deles que cultura não é perfumaria, que cultura e estética são tão política quanto economia, que (...) os artigos de maior repercussão são justamente os ensaísticos."

Exatamente a parte "censurada" parece ter sido publicada, talvez pela pressão interna relatada na carta. Infelizmente nenhum dos entrevistados conseguiu se lembrar do episódio; portanto nosso desfecho permanece inconcluso. De qualquer maneira, o evento revela importantes disputas na esquerda sobre como abordar regimes ditatoriais, sejam eles estrangeiros ou brasileiros. O tema aponta para um diálogo com a Cahiers $d u$ Cinéma onde o tema gerou diversas controversas.

Estava em alta o debate sobre a moda "retro", uma nova safra de filmes franceses que abordava o nazismo. A revista considerou a onda um perigo do ponto de vista ideológico, porque viu na produção daquele período uma certa fascinação com o nazi-fascismo. A tensão girava em torno da participação da população. Segundo a revista, quando um filme mostra o apoio do povo ao nazismo, parece natural existir um pouco de monstro ou de nazista em cada um de nós. Como consequência, o nazismo seria naturalizado, constituindo uma fuga do político para a irracionalidade e o mal da humanidade.

Portanto, quando uma ala de Opinião não aceita a argumentação de Gustavo Dahl e tenta censurar o tema, indiretamente a argumentação estaria mais próxima dos debates de Cahiers. Do outro lado, Dahl estaria em sintonia com a opinião de Michel Foucault, publicada um ano antes na mesma revista francesa ${ }^{48}$. Foucault discordava veementemente dos entrevistadores e declarou que o fascismo só existiu graças a uma população, co-responsável pelas atividades de repressão, controle e ordem. Contra essa linha, o leitor Luiz Teodoro Barreto vê uma postura idealista de Gustavo Dahl, porque a

\footnotetext{
${ }^{48}$ Toubiana, Serge; Bonitzer, Pascal. Anti-retro: entretien avec Michel Foucault. Cahiers du Cinéma. n. 251-2, jun. ago. 1974.
} 
base do fascismo estaria nos marginais, nos desocupados e na pequena burguesia impotente e manipulada ${ }^{49}$.

Se Delito Matteoti causou um problema interno na redação ainda na gestão de Raimundo Pereira, pouco tempo antes da demissão do editor chefe e da demissão coletiva, a política pode ter sido a causadora da saída de Dahl do jornal. Os dois últimos artigos de Gustavo Dahl em Opinião ${ }^{50}$ versam sobre a relação entre censura e cultura (ver Capítulo 1). No mesmo ano, ele publicou a primeira parte deste material na Mostra Internazionale del Nuovo Cinema na Itália ${ }^{51}$, junto aos textos clássicos do Cinema Novo. À primeira vista poderia ter havido algum tipo de represália da censura por causa do tema. Mas o que aconteceu foi muito diferente. Pouco tempo depois, Dahl assumiu um cargo na Embrafilme. Na mesma época, o controle do jornal saia das mãos de Raimundo Pereira/Júlio César Montenegro e ia para Argemiro Ferreira/Sérgio Augusto. Quem relata os bastidores do processo é o próprio Augusto: “eu, de alguma forma, o censurei, a palavra é um pouco forte”. Gustavo Dahl teria sugerido escrever uma série de artigos sobre cinema e cultura. Augusto aconselhou que ele tomasse cuidado porque a censura era forte. Havia um procedimento padrão para esses casos. O editor lê o texto antes. Quando há censura, o jornal paga ao colaborador porque ele não tem culpa pela interdição. "Mas há determinados artigos que a gente sabe que não vão passar". Nestes casos, o jornal não paga o autor. Continuou "Isso aqui é quase provocação para o censor". Se eles cortarem, "você não vai receber", mas se o artigo passar, "será maravilhoso porque o artigo sai e você ainda ganha". O material foi enviado à censura e veio a surpresa: não houve nenhum corte. Não só no primeiro texto, mas no segundo também. Segundo Sérgio Augusto, Dahl começou a mandar uma série de artigos do tipo “chove mas não molha". Ele foi conversar com Dahl. A sensação era de que os artigos remoíam, falavam as mesmas coisas, mas não iam adiante. Enrolavam, em síntese. Como os textos não diziam nada, Augusto decidiu parar de publicar a série, afinal ela estava ocupando espaço. A crítica incidia sobre a qualidade dos textos. $\mathrm{O}$ ex-editor de Opinião esclarece que faria esse tipo de crítica de objeção a qualquer artigo, de qualquer área do jornal, seja de artes plásticas ou culinária.

\footnotetext{
${ }^{49}$ Barreto, Luiz Teodoro. Opinião do leitor - O Delito Matteoti: o (falso?) apoio popular ao fascismo. Opinião. n. 119, p. 24, 14 fev. 1975.

${ }^{50}$ Dahl, Gustavo. Censura e Cultura I. Opinião. n. 124, p. 22, 21 mar. 1975; Dahl, Gustavo. Censura e cultura II. Opinião. n. 125, p. 24, 28 mar. 1975.

${ }^{51}$ Dahl, Gustavo. Censura e Cultura. In: Mostra Internazionale del Nuovo Cinema, 11, 1975. Il Cinema Novo Brasiliani. $1^{\circ}$ Testi e documenti. Pesaro, 1975. Quaderno Informativo, 64. p. 211-116. Trata-se da primeira parte do artigo Censura e Cultura I (n. 124).
} 
Para Augusto, os artigos não eram censurados, porque não diziam nada de maneira contundente. $\mathrm{O}$ ex-editor não lembra se o texto motivou a saída de Gustavo Dahl. Logo depois, ele foi trabalhar na área cultural do governo. Segundo ele, a série em Opinião contém uma plataforma com todo o raciocínio de uma política de estado para o cinema brasileiro.

Uma plataforma para o cinema brasileiro aparece lentamente nos artigos de Dahl em Opinião quando o assunto é discutir o filme musical hollywoodiano. Aqui o sentido do político segue por vias intricadas e indiretas. Trata-se de uma coletânea de cinco artigos que fogem da linha habitual de frisar os aspectos negativos do cinema americano. Começando com ares cinéfilos, a direção muda bem devagar, sem se anunciar logo de princípio. Se o estudo da ideologia era quase uma obrigação para um jornal de resistência, Dahl vai além do próprio meio. O primeiro deles tem um ar muito idílico e cinéfilo que vai se dissolvendo. É como se os textos fizessem uma síntese cronológica do percurso de Gustavo Dahl ao longo dos anos. Se no artigo inicial ele fala do cinema americano entre a primeira e a segunda guerra mundiais como dotado de uma função profundamente liberadora no plano do comportamento ${ }^{52}$, no texto seguinte o autor corrige o percurso e faz menção ao american way of life. Em todos eles, Dahl frisa o lado positivo do irreprimível otimismo e da alegria contagiante da função absolutamente terapêutica da higiene mental (Ver Capítulo 5). Contudo a argumentação está longe do óbvio, porque Dahl estabelece um ponto de contato entre esse momento de ócio e de sonho da população com as origens remotas do homem, como as danças, as festas religiosas e as representações teatrais. Todas elas agem como os mitos, revitalizando a população para a luta pela vida. Aqui se revela mais o propósito de Dahl frente à função de higiene da população. Trata-se de um eufemismo para mobilizar e incentivar as pessoas. Desviando e alterando as significações, Dahl compara essa função com a do teatro moderno, com a do Living Theatre ou do teatro praticado por José Celso Martinez Corrêa. Estes últimos recuperam o aspecto lúdico mágico-terapêutico da arte de representar. Por diferentes vias, o cinema clássico e o moderno atingem a mesma função. A originalidade da argumentação não é o desvio conceitual sobre o teatro de agressão e sobre uma aparente incorporação positiva do cinema hollywoodiano. Tratase, ao contrário, de um aspecto desprezado no período e realçado por Dahl: a função dos

\footnotetext{
${ }^{52}$ Dahl, Gustavo. Era uma vez em Hollywood. Opinião - alegria e eternidade (I). Opinião. n. 113, p. 22, 03 jan. 1975. A manchete retoma o título do filme Era uma vez em Hollywood (1974) de Jack Haley Jr., lançado naquela época no Brasil.
} 
meios de comunicação como válvula de escape. Aqui ele entrelaça esta função como estímulo pela vida e conscientização.

Para entender o trecho é preciso abrir uma brecha para o Dahl dos anos sessenta (Costa, 1966), quando o crítico discorre sobre os mecanismos que vai colocar em prática dez anos depois. Segundo ele, por causa das injunções econômicas, os artistas camuflam suas mensagens sob a forma de divertimento. Como elas afastam o cinema do público, há duas alternativas: escolher o povo ou exprimir seu mundo recôndito fazendo arte de luxo para a elite. Ao preferir o povo e colocar em questão o meio social onde vive, o autor "tenta subverter o sistema que dele o afasta, pela ação e por filmes que incitem à ação". Outra opção é aceitar o diálogo com as elites para mostrar como elas são ao mesmo tempo carrasco e vítima do mundo dominado. Os diretores que se sentem responsáveis pelo mundo e têm consciência de que podem transformá-lo, irão colocar essa consciência a serviço da transformação. Os verdadeiros artistas são os interessados na miséria, na guerra e na ameaça de liberdade. Trabalham para que o homem conquiste outro paraíso perdido, do qual não será mais expulso. Este é o argumento por detrás de Uirá, como veremos.

Esse mesmo raciocínio é colocado em prática para analisar os filmes musicais hollywoodianos. Assim Dahl não vê a produção americana como um fator alienante por si só, ou por causa do mecanismo de produção, mas frisa o conteúdo por detrás do enredo. No segundo artigo ${ }^{53}$, ele cita o número musical Faça-os rir com Judy Garland. É possível ver na atuação uma pitada de tragédia brilhando no fundo da atriz. Enquanto ela diz "esqueça os problemas, venha, seja feliz!" há uma sensação de verdade "do que é dito por causa da convicção com que é dito”. Garland faz com que acreditemos nela, mesmo sabendo que naquele momento "talvez ela estivesse corroída por crises sentimentais, financeiras, álcool, narcóticos, e problemas psíquicos", muitas vezes sem condições de pagar a conta do hotel, tudo isso no auge da fama. Parece existir no trecho uma crença na verdade da imagem, não de modo naturalista, mas enquanto representação. "Sente-se que no meio de tantos disfarces o número se refere de maneira muito clara à condição do artista dentro de sua sociedade", completa o crítico.

\footnotetext{
${ }^{53}$ Dahl, Gustavo. Era uma vez em Hollywood - a alegria não é reacionária. Opinião. n. 115, p. 24, 17 jan. 1975.
} 
É então que Dahl expõe discretamente sua argumentação: “depois de ter sido visto como diversão colorida para débeis mentais ou como lavagem cerebral alienante em escala mundial, o filme musical mostra hoje em dia sua modernidade pelo seu compromisso inabalável com o instinto de vida". O intuito do artigo é reabilitar o cinema hollywoodiano como forma de subversão daquele próprio sistema, em lacunas bastante instáveis, baseadas na ideia de veracidade. Portanto, o número musical de Gene Kelly em Cantando na chuva é uma forma de demonstrar a fabricação da magia do filme musical. A cena desvenda o segredo de suas ferramentas. Assim, o filme mistifica desmistificando, poetiza despoetizando, sentimentaliza zombando. O processo revela a modernidade por excelência. $O$ trecho quase chega numa crença baziniana na autenticidade da vida revelada na imagem, como a única forma de dar conta do real. A conclusão não podia ser outra: a alegria não é reacionária e o musical suberve a ordem.

É em trechos como este sobre Cantando na chuva (1952) de Gene Kelly e Stanley Donen que Dahl tenta provar o musical como cinema moderno. Se para David Bordwell (1996) o gênero tem aspectos modernos por causa da auto-consciência dos personagens e pela quebra da quarta parede, quando os atores se dirigem diretamente à plateia, Gustavo Dahl vai em outra direção. Observa o conteúdo dos filmes e a performance dos atores como forma de crítica ao sistema econômico. Indiretamente ele faz referência ao funcionamento deste mecanismo. Dizemos empiricamente, porque o crítico não explicita os aspectos da construção da narração e da linguagem cinematográfica. Prefere se concentrar no teor das canções e na ligação entre a vida do ator e do personagem. Ele tenta demonstrar que Hollywood também produz alguns musicais com conteúdo subversivo, marca do pensamento inovador dele em relação a um jornal que geralmente frisava o lado negativo do cinema americano.

Dahl chega a esta conclusão pelas brechas e lacunas na produção. Esta linha de pensamento também era colocada em prática na segunda fase de Cahiers, quando a revista recuperava filmes feitos no mecanismo de produção hollywoodiano para mostrar como cineastas como John Ford fazem uma desmontagem do sistema ideológico dentro do qual estavam inseridos. Entre os que disseminam a ideologia ou os que se opõem a ela através de evidente desconstrução do sistema de representação, Cahiers procura identificar de que forma o estético não corrobora o projeto político. Um dos exemplos é o da produção aparentemente representativa da cadeia ideológica, cujo trabalho verdadeiro instala uma distorção e ruptura. Nestes casos, a ideologia não estaria 
transposta tal e qual nas intenções dos autores. Ela se denunciaria na trama fílmica, mostrando seus limites e transgredindo. Este trabalho crítico é feito em leitura obliqua. Portanto, haveria graus variados de fissura: os de ataque frontal ao sistema até uma subversão dissimulada a partir de disjunções fílmicas que expõem limites da ideologia oficial sob uma aparente coerência formal ${ }^{54}$.

A nova linha era inaugurada em 1969 com uma série de editoriais denominados "Cinema, ideologia, crítica" (Xavier, 2005). A dupla Jean-Louis Comolli e Jean Narboni considerava que o cinema era atravessado ao mesmo tempo por correntes dominantes e subversivas. Ao assinalar as lacunas (Stam, 2003), seria possível mostrar como os filmes operam. Segundo Robert Stam, o esquema de Comolli e Narboni gerou uma onda de análises de 'fissuras e lacunas' um tanto derivativas e previsíveis, mas teve ao menos o mérito de expor os filmes à noção de contradição (Stam, 2003). Portanto, nesse sentido Dahl estava mais próximo de Cahiers do que de Opinião, que era incapaz de elogiar um filme hollywoodiano, num conceito monolítico de ideologia dominante.

A originalidade da argumentação dahliana não é somente defender em primeira mão o musical como narrativa moderna, mas estender esse conceito ao cinema brasileiro. O comentário chega até Alô alô carnaval (1936) de Adhemar Gonzaga ${ }^{55}$. Ante a eleição de Humberto Mauro como autor por Glauber Rocha, Gustavo Dahl escolhe Gonzaga como patrono do cinema brasileiro nos anos setenta, numa época de aliança com o mercado. O ponto nevrálgico é conseguir demonstrar Adhemar Gonzaga como autor moderno, porque a modernidade não cai nele exatamente como uma luva. $\mathrm{O}$ viés é indicativo da tentativa de Dahl inserir o cinema brasileiro no mercado, afinal em 1975 ele se torna diretor do setor de distribuição da Embrafilme.

Dahl foge de uma linha apologética para esta defesa. Constrói camadas de significação invertendo as linhas tradicionais da crítica de cinema. O estudo começa pela forma do filme de Gonzaga e pela narrativa. Nossos musicais parecem mais um homem de "Neanderthal num salão renascentista" porque há muitos defeitos: a técnica é rústica, há ignorância da sintaxe cinematográfica, a câmera quase sempre está colada de frente, os cortes sucedem-se aos trancos, os travellings são raros e absurdos, a continuidade é constantemente violentada, a montagem é aleatória, os intérpretes são fixos como o microfone, a integração dos números musicais com a trama é arbitrária e,

\footnotetext{
${ }^{54}$ Cinéma/idéologie/critique. Cahiers du Cinéma. n. 216, p. 11-15, out. 1969.

${ }^{55}$ Dahl, Gustavo. Banana da terra vale ouro. Opinião. n. 119, p. 21, 14 fev. 1975.
} 
por último, a trama está prestes a se romper. Quando a defesa parece difícil de engolir e pensamos estar de frente do sucessor de Ely Azeredo, Dahl inverte os mecanismos de análise:

\begin{abstract}
"mas tudo isso não tem importância, ao contrário do que sustenta a antiquada ideologia que reduz o cinema a uma arte visual, sobrevivência de uma estética do cinema mudo. Ou então aquela outra vinda do cinema clássico, que reduz o filme a uma narrativa. São ideologias cinematográficas igualmente reacionárias, e a prova consiste na perspectiva política geralmente sustentada por aqueles que as professam. $\mathrm{O}$ uso da plasticidade ou adequação sintética como critério de julgamento de um filme é apanágio da crítica rasgadamente conservadora e corresponde à tradicional ótica dos regimes ditatoriais sobre o cinema. Paradoxalmente todos se aproximam nesta obsessão do quadro bem composto e do filme bem narrado. Não é impunemente aliás, que os módulos do cinema clássico foram forjados dentro do capitalístico cinema americano, que nunca se furtou à sua função política de propagador do american way of life. Cada país tem o Busby Berkeley que merece, o nosso é Adhemar. (...) A verdadeira obsessão com o dinheiro em Alô alô carnaval combinada com a manifesta zombaria sobre tudo que é estrangeiro (...) resulta numa tomada de posição anti-imperialista, numa manifestação concreta, quotidiana e alegre da superioridade de nossa cultura tropical sobre a cultura importada. Oswaldianamente aliás, a revista que é montada se chama Banana da terra e vale ouro. (...) É preciso pensar no onirismo do musical americano (...) para ver como este compromisso com o real do musical subdesenvolvido, herança do teatro de revista, é profundamente original, moderno e brasileiro. Nesse sentido, a não alienação de Alô alô carnaval vem combinada com uma ironia sobre as próprias mazelas, como uma despretensão, com uma alegria de viver. Há ironia, e não alienação neste filme.”
\end{abstract}

Dahl aproxima-se neste artigo da argumentação pauloemiliana. Em comparação aos musicais americanos, é possível entender o idioma e o sentido das canções nas chanchadas. Isto muda tudo. Podemos chorar não só em Era uma vez em Hollywood (1974) de Jack Haley Jr., mas também em Alô alô carnaval. Se a linha argumentativa de Paulo Emilio está presente nestes artigos, ela só é explicitada no último deles ${ }^{56}$. Sintonizado com os comentários do mestre em Cinema: Trajetória no subdesenvolvimento (1980) ${ }^{57}$, Dahl fecha o artigo com a seguinte frase: "cada filme brasileiro, por pior que seja, é digno do nosso interesse porque contém uma parcela de nós mesmos, isto é, somos nós que somos dignos do interesse.” A conclusão não poderia ser outra. Neste sentido, Alô alô Carnaval é um grande filme porque revela uma grande parcela de nós mesmos. Acima de tudo, revela a essência do brasileiro. A brasilidade está presente, segundo ele, nos planos de Carmem Miranda e Aurora que revelam a alma da gente brasileira.

\footnotetext{
${ }^{56}$ Dahl, Gustavo. Alô alô carnaval - ingênuo mas não otário. Opinião. n. 120, p. 24, 21 fev. 1975.

${ }^{57}$ Publicado pela primeira vez na Revista Argumento. n. 1, out. 1973.
} 
Se Alô alô carnaval nos "convida a curtir nossos musicais", Dahl assume para si a função de publicista do cinema brasileiro. Tenta recriar do ponto de vista historiográfico uma nova significação, pela adaptação de Paulo Emilio. No final ele reproduz o mesmo esquema descrito para Judy Garland, mas agora centrado no diretor. Alô alô carnaval é um filme moderno porque Gonzaga conseguiu zombar de tudo que vinha de fora, caçoando das trapaças das companhias de revista estrangeiras. Para Dahl, Adhemar revelou sua originalidade pela subversão da ordem do colonialismo. No fundo a tese contém a premissa da incapacidade criativa de copiar de Paulo Emilio, tese esta longe do horizonte de Opinião. Sem ser possível frisar a modernidade com intenção na forma descrita antes, sobrou provar a modernidade explodindo na proposta em relação ao subdesenvolvimento. Gonzaga trata o Brasil moderno com deboche e ironia, afinal os personagens não têm dinheiro. É por essas e outras que o filme subverte o colonialismo e o subdesenvolvimento, revelando sua originalidade. Moderno aqui é a intenção crítica do autor, como a de Judy Garland. Dahl é o único crítico de Opinião que incorpora sem atraso o texto Trajetória no subdesenvolvimento de Paulo Emilio Salles Gomes ${ }^{58}$. Sem citar nominalmente a incapacidade criativa de imitar, ele prova o quanto há extrema criatividade na sofisticada beleza do papel crepom, da purpurina, do papel dourado e dos jardins artificiais. Tenta criar uma tradição ad regretio ao cinema brasileiro e urge pela realização de filmes musicais modernos, trazendo a popularidade da chanchada para tentar conquistar o público.

Se para falar do passado é permitido frisar o aspecto político, a postura muda de tom quando o assunto é o tempo presente. Ao escrever sobre seu filme, Dahl coloca de lado os fatores políticos. Uirá (1973) conta a trajetória do índio com o mesmo nome que perdeu o filho mais velho por causa das doenças trazidas pelos brancos. Inconformado com a morte, e sem gosto pela vida, ele sai em busca de Maíra, entidade mítica, para encontrar na terra o paraíso perdido para onde vão os mortos. Baseado numa história real ocorrida no Maranhão em 1939, o caso foi relatado por Darcy Ribeiro (1974). Em contato com os brancos, Uirá sofre todo tipo de agressão, tanto física quanto moral. Quando finalmente vai regressar a sua tribo, ele decide encontrar Maíra pelo jeito comum, suicidando-se num rio.

\footnotetext{
${ }^{58}$ Nesse mesmo viés de reelaboração do artigo de Paulo Emilio, Jean-Claude Bernardet irá publicar alguns meses depois o texto "Nós, os invasores" no jornal Movimento. n. 25, p. 14, 22. nov. 1975.
} 
Uirá ganhou a capa de Opinião. A cobertura inclui três artigos. Uma nota informativa sobre o lançamento ${ }^{59}$, um texto de Glauber Rocha ${ }^{60}$ e uma (auto) crítica de Gustavo Dahl ${ }^{61}$. As três matérias transformam o trabalho de Dahl numa quase unanimidade à esquerda e à direita, porque o coro de elogios vem de fontes antagônicas: dos militares e de um cineasta exilado. Sob o pretexto de comentar os elogios dos membros das forças armadas a Uirá, o primeiro texto informa ao público a censura ao filme. A obra foi exibida em Brasília para autoridades do governo, para antropólogos, indigenistas e para censores. Ao término da sessão, todos foram consultar o "mais ilustre espectador presente", o general Ismarth de Araujo Oliveira, presidente da Funai, que recomendou a liberação de Uirá.

Gustavo Dahl analisa seu filme na primeira pessoa. A frase inicial é bem indicativa da mensagem oblíqua: "De Uirá o que eu gostaria que se dissesse é que é um filme do seu tempo". Ou seja, do tempo presente. O cineasta define a obra como um cinema experimental e sujo, diferente de O Bravo Guerreiro (1968). Na verdade, Uirá foi feito com extremo cuidado nas imagens. É bem montado, limpo, asséptico e de narração lenta. Observa-se que Dahl adapta os conceitos ao veículo no qual fala. Para a revista da Cinemateca ${ }^{62}$, ele não esconde que se trata de um filme de arte. Em Opinião ele parece querer ampliar seu público e se distanciar discursivamente do passado do Cinema Novo.

Dahl tenta vender a imagem ao público de que o filme fala por si próprio: “descobrir o estilo, fazendo-o". Teria deixado de lado o estilo para contar uma história. A frase está bem sintonizada com as exigências dos anos setenta. Se Bravo Guerreiro foi feito para encaixar a história dentro de um "estilo predeterminado", em Uirá, o método teria sido: "vamos ver depois o que vai dar". Já pronto, Dahl declara que percebeu certo ritmo e uma severidade no tratamento das imagens com o uso de planos fixos. Mas mesmo assim ele insiste em declarar Uirá como filme heterogêneo, ante a unicidade de Bravo. Durante todo o artigo, Dahl elogia o cinema clássico e o comentário vem acompanhado de críticas ao Cinema Novo:

\footnotetext{
${ }^{59}$ Dahl, Gustavo. Os índios como profetas do mundo. Opinião. n. 82, p. 12, 03 de junho de 1974.

${ }^{60}$ Rocha, Glauber. "Enfim, o bicho-homem". Opinião. n. 82, p. 12, 03 de junho de 1974.

61 Dahl, Gustavo. Gustavo Dahl, aprendendo a filmar o Brasil. Opinião. n. 82, p. 12, 03 de junho de 1974.

${ }^{62}$ Uirá (Depoimento de Gustavo Dahl). Cinema - Revista da Cinemateca Brasileira. n. 3, p. 5-11, jan. 1974.
} 
"De O Bravo Guerreiro a única frustração que ficou foi aquela de tendo conformado o filme a um estilo preexistente in abstracto, ver (viver!) o produto acabado como um pré-conceito. $\mathrm{O}$ uso da câmera era orgulhoso e autoritário, embora sensual. Os atores hieráticos, o quadro fixo, os sentimentos dissimulados em ideias, um filme rigoroso. De impor respeito ao próprio Straub. Cada um faz o filme que precisa. Quatro anos depois, o que eu tinha vontade era de fazer exatamente o contrário: deixar correr frouxo, descobrir o estilo fazendo-o: aliás, esquecer do estilo, narrar uma história e basta. A simplicidade figurativa do cinema clássico americano continua eficiente ao decorrer das décadas, enquanto que as audácias de montagem e fotografia da década de 60 já sabem a vinho azedo".

A diferença entre cinema moderno e clássico norteia o texto, para sintetizar o percurso das audácias na montagem e do "vinho azedo" em direção à simplicidade narrativa. Há uma clara tentativa no artigo de se distanciar em nível discursivo do Cinema Novo enquanto forma e linguagem, negando os comentários políticos explícitos. Contudo a argumentação deixa intacta a discussão política e o engajamento. Dahl busca criar uma crença na veracidade da imagem, negando a intervenção do diretor sobre o aparato cinematográfico, como outros cinemanovistas o farão (ver Capítulo 5 e 6).

A parte mais interessante das três matérias sobre Uirá é sua composição por antinomias. Como uma obra pode ser elogiada ao mesmo tempo por militares e por Glauber Rocha? A explicação passa pela estratégia política da obra e seu viés nacionalista. Ao ler o artigo, fica a impressão de que Gustavo Dahl e Glauber Rocha não viram o mesmo filme. Glauber evita a linha laudatória e começa com comparações entre diretores renomados: "Cinantropologia - linguagem moderna por excelência Uirá estória de um índio que sai em busca de Deus, é um filme estruturado em planos médios, na cadência de uma síntese produzida pela montagem dialética de humanistas como Rossellini e Bresson a materialistas históricos como Brecht”.

Se Dahl se esforça para forçar a comparação com o cinema clássico, Glauber faz o caminho inverso. Frisa o lado moderno de Uirá e não esconde as origens de Dahl. Para ele, o filme mobiliza com maestria as teorias do Cinema Novo. O colega cineasta fecha com chave de ouro a argumentação: trata-se do único ensaio brasileiro sobre as contradições entre ideologia e história. Se os artigos parecem apontar para dois filmes diferentes, eles possibilitam uma leitura crítica do público. Abrem uma curiosidade para saber qual das duas versões é a "verdadeira". 
Neste ponto é necessário passar pelo Dahl cineasta para observar se o material fílmico coincide com as chaves-mestra de pensamento do Dahl crítico. Não nos dedicamos aqui a decompor a recepção crítica de Uirá. Sintetizamos apenas os críticos que pensaram as declarações do diretor. Esta recepção se atém a dois aspectos: o mecanismo de identificação e o uso da emoção no cinema. Entre a estética e a política, em que ponto estaria o chamado "ideólogo do mercado"?, termo com o qual Dahl ficou conhecido anos mais tarde. Em algumas entrevistas, Dahl tentava provar que Uirá fazia parte do cinema clássico por usar bastante o processo de identificação e emoção, mas o funcionamento desse mecanismo no filme é bem mais complexo.

Para provar a aproximação com o cinema clássico, Dahl discorre na Revista de Cinema ${ }^{63}$ sobre sua tentativa de sair da área conceitual e se dirigir ao concreto, à emoção, a identificação e ao melodrama. Aqui é possível adentrar mais em seu discurso. A proposta de Dahl é revitalizar as formas da "máquina de origem popular", calcada no melodrama e na identificação, tornando-as dinâmicas. Se Uirá fala em tupi, o público não pode compreender o que ele diz. A consequência é a necessidade de sair do entendimento racional e sentir o drama através da emoção. Em síntese, colocar-se na pele do índio. Por isso o cineasta declara ter atenuado as cenas de violência para evitar o interesse do público por uma espécie de calvário físico, presa na brutalidade visual e externa. Se Dahl comenta muito nas entrevistas seu novo interesse pela emoção, o dado não era nada novo. Em 1966 (Costa, 1966), ele definia o cinema como a arte que revela e transmite as emoções e sentimentos latentes em nós mesmos. Nesse papel, o diretor agia como responsável pela operação de simpatia e de decifração da realidade.

Três críticos dedicaram-se a destrinchar o funcionamento da emoção e da identificação em Uirá: Sérgio Augusto, José Carlos Avellar e Maria Rita Galvão. Relembrando a declaração de Dahl sobre o lado clássico e a simplicidade narrativa hollywoodiana de Uirá, Sérgio Augusto ${ }^{64}$ relembra que sentiu exatamente o oposto. O filme é simples, mas não segue a linha figurativista do cinema clássico. Se há falta de dramaticidade, porque estamos longe da língua nativa, a emoção vaza do filme "nos momentos em que os índios ocupam sozinhos o campo visual (toda a primeira parte e trechos esporádicos da segunda)". Nesses momentos, “jorra em Uirá o fluxo emocional sonhado pelo autor", que possibilita o envolvimento com o público por causa da aura e

\footnotetext{
${ }^{63}$ Dahl, Gustavo. Depoimento de Gustavo Dahl. Revista de Cinema. Cinemateca Brasileira. n.3, p. 05-11, jan 1974.

${ }^{64}$ Augusto, Sérgio. Luz, câmera, abstração. Pasquim. 15 jun. 1974.
} 
autenticidade absolutas. "Aí, sim, prevalece uma lição do cinema clássico: só se pode fazer bom figurativismo com bom artificialismo". Por fim, Augusto escreve: "Gostei de Uirá com todas as suas emoções $a b$ abstractio. Ou, melhor dizendo, por tudo aquilo que seu autor dizia não haver em seu filme. Como dizia o outro é discordando que a gente se entende".

Pensando um conjunto de filmes com temática indígena entre 1972-1977, José Carlos Avellar ${ }^{65}$ vê o conflito entre índio e branco como forma de representar o mecanismo injusto da sociedade daquela década. Assim os filmes agem como uma forma de resistência à ditadura, quando mostram personagens perseguidos até a morte ou impedidos de agir, traduzindo o som do silêncio e o cerceamento. Em seu caderno de anotações de filme, Jean-Claude Bernardet ${ }^{66}$ tomou a mesma direção, assim como Claúdio Bujunga ${ }^{67}$.

Avellar (1986) completa o mecanismo de identificação descrito por Dahl. O espectador sente mesmo na pele as agressões ao índio. A estratégia possibilita uma forma de viver outra dimensão do mesmo mecanismo de opressão social ao qual o espectador se encontra submetido fora da sala de projeção. A identificação criada é de um pedaço da história (durante o Estado Novo), tomado para encenar o agora. Portanto, a manifestação da violência ao índio funciona como representante do oprimido. A identificação surge porque há um sentimento de violência e humilhação no dia a dia dos personagens e da população, que não se consegue traduzir em gestos ou palavras. Esse tipo de sentimento foi convertido em imagens de cinema em Uirá. Contudo, todo o envolvimento depende da escolha do público adentrar ou não no mecanismo: "para o espectador que adere à proposta do realizador, que se deixa levar pela emoção e entra na veracidade da ficção, o desfecho da história de Uirá ganha um significado especial" (Avellar, 1986: 164-5). O processo de aprofundamento sensorial começa porque o espectador só consegue apreender os significados através dos gestos. Enquanto a cena se passa na tela, só há uma relação afetiva com o personagem. Surge só depois uma narração em português na voz off da esposa de Uirá, Katai. Portanto os diálogos em tupi funcionam como um som musical e como gestos de um balé. É por isso que a plateia sente a imagem e o sentimento primeiro.

\footnotetext{
${ }^{65}$ Avellar, José Carlos. O espectador na pele de um índio. Jornal do Brasil. 12 out. 1977. O texto serviu como a primeira versão para um capítulo do livro $O$ cinema dilacerado (1986).

${ }^{66}$ Caderno de anotações de Jean-Claude Bernardet. Pasta PI 18 o. Caderno V. Arquivo Jean-Claude Bernardet. Centro de Documentação e Pesquisa da Cinemateca Brasileira.

${ }^{67}$ Bojunga, Carlos. Dahl - o papel de tirar conclusões. Jornal da Tarde. 23 out. 1974.
} 
Se Dahl queria construir um filme através do processo de identificação, teria sido mais fácil elaborar os diálogos em português, mas daí se perderia toda a originalidade da proposta e a bela descrição de Avellar do par sentimentoracionalidade. Nos momentos de utilização do tupi, a forma de significação parece próxima a do cinema silencioso. Em alguma medida, ela nos afasta de Uirá. O processo é diferente com Katai. Sua voz off fala conosco em português. Ela ri, interage com nosso mundo. É possível senti-la perto de nós pela gargalhada, no gosto pela música, no flerte com os brancos. Ao contrário dela, Uirá permanece como enigma, traduzido por Katai. Ele parou no tempo, não se adapta e não se encaixa. Pertence ao passado. Além da raiva e tristeza, não sabemos mais nada dele, a não ser a narração da esposa. Uirá sinaliza, portanto, uma presença-ausência no filme. Fechado em si mesmo, não sofremos com sua morte, porque a humanização passa mais pelo lado racional e porque a cena é gravada em planos gerais distanciados. Só conseguimos chegar até ele através de Katai. É ela a ponte para o processo de humanização do filme.

Nossas observações têm alguma simetria com as de Carlos Alberto Mattos para a revista Filme Cultura ${ }^{68}$. Segundo ele, a voz off de Katai funciona como uma consciência instalada dentro do filme. Ela fala por si mesma, por Darcy Ribeiro e por Gustavo Dahl. Katai é a personagem ativa, enquanto Uirá se move impelido pela crise. Cabe a mulher preparar o corpo dele para a viagem, gritar quando a família está em perigo ou é agredida. É ela quem tem os olhos curiosos para a hilariedade das situações. Katai ri e chora, enquanto Uirá se retrai ao peso de seu drama íntimo. A vulnerabilidade dela faz um contrapeso vital à obsessão mítica dele.

Um ano após o lançamento, Maria Rita Galvão ${ }^{69}$ explica que o uso da emoção não é novidade em Dahl. Existia desde O Bravo Guerreiro. O filme se dirigia a um público de nível intelectual elevado, capaz de acompanhar a procura quase científica dos fenômenos tratados. O objetivo era decifrar mecanismos complexos, "em que a própria procura do conhecimento, mediada pelo personagem central, é a fonte essencial da emoção dramática". Há um estudo rigoroso do momento político e dos personagens, no qual o método discursivo e racional da exposição pode atingir um alto nível de

\footnotetext{
${ }^{68}$ Mattos, Carlos Alberto. Uma cultura à deriva. Filme Cultura. n. 55, dez. 2011.

${ }^{69}$ Galvão, Maria Rita. Uirá, em busca do cinema brasileiro. Debate e Crítica. Revista Quadrimestral de Ciências Sociais. n. 5, p. 105-117, mar. 1975.
} 
intensidade emocional. Se o conhecimento recusa a emoção, ele a priori se apoia sobre as qualidades emocionais das ideias.

$\mathrm{O}$ processo mudou de método em Uirá. Para a autora, o filme se dirige à sensibilidade do espectador. Se a emoção vem antes das imagens e dos sons, o filme nunca descamba para o sentimentalismo, porque o processo é apreendido pela sensibilidade. Galvão observa um intenso lirismo em alguns momentos, nostálgico e contido, porque o mundo no qual as pessoas se movem é o do sentimento.

Lirismo e não melodrama. Lirismo e não emoção pura. Se nos anos sessenta os cinemanovistas viam na emoção uma grande inimiga por causa do diálogo com o sentimentalismo e o melodrama, a proposta de Dahl estava também distante do sentido dado pelo Teatro de Arena. Elaborado pela ala comunista do grupo, a linha não despreza a emoção, nem a catarse. Tratava-se de uma construção dramática em estética marxista para facilitar o diálogo com o grande público através da narrativa convencional. $\mathrm{O}$ ideário estaria próximo do nacional popular. O objetivo era mostrar as contradições da sociedade, criando um viés crítico. O processo causaria emoção e identificação com o fim de gerar uma consciência nacional emancipadora depois do desentorpecimento. As peças tinham forte investimento criativo entre emoção e consciência política, mediadas pelo desenvolvimento psicológico dos personagens, mas sem se dissolver no melodrama (Napolitano, 2011). Essa proposta não tem relação com Uirá porque Dahl trabalha a emoção em sentido poético.

Se o Cinema Novo se opunha à emoção nos primeiros anos, Leon Hirzsman fará uma primeira tentativa de incorporá-la em Garota de Ipanema (1967). Muito antes disso, no artigo Stella: a força do melodrama, publicado no Última Hora em 31 de agosto de 1963, Bernardet (1978: 100-2) já discorria sobre a necessidade de se comunicar com outros públicos em formatos conhecidos e apreciados. A proposta pretendia utilizar as formas do melodrama ou da chanchada, elaboradas com fins entorpecentes e de fácil compreensão, em novo sentido de luta. "Se essa ideia pode parecer inicialmente absurda, é provável que não o seja, porque as formas utilizadas pela máquina são de origem popular”. Revitalizar tais formatos significaria reencontrar seu significado popular, tornando-os dinâmicos. A simetria desta frase em relação ao pensamento de Dahl aqui exposto é grande. Quando analisa Garota de Ipanema em 
$1968^{70}$, Bernardet (1978: 204-207) vê uma proposta que não conseguiu atingir o público, porque a segunda parte do filme desmistifica o mito e a empatia criada no início. Depois dessa época, a utilização da emoção voltou à cena nos anos setenta como uma possibilidade de relacionamento com o público (Galvão; Bernardet, 1983). Contudo Uirá foi feito para o espectador do cinema de arte. Dialogava, acima de tudo, com a sensibilidade artística.

A proposta de Dahl sobre o melodrama sofria alguns ajustes de percurso no período. Dois anos antes da estreia de Uirá, no artigo sobre Lola Monthès (1955) de Max Ophüs, publicado na Filme Cultura ${ }^{71}$, ele defendia este filme como modelo para o cinema brasileiro alcançar o público. A grandeza estaria na narrativa moderna e no reencontro entre Eisenstein e Brecht. Assim se fazia ao mesmo tempo a associação e o desmonte da narrativa e da relação espaço/tempo no espetáculo das massas. Para Dahl, Ophüs assumiu o cinema como representação, mas o transformou em circo, flertando com uma fruição de espetáculo. A história da ascensão e queda de Lola Monthès e sua tentativa de alcançar sucesso e dinheiro pelo casamento e dança evitava ao máximo o processo de identificação. Ophüs usa muito pouco o primeiro plano e o close. Lola Monthès é feito quase inteiramente em planos gerais e médios. Desta teorização, Dahl só manteve o uso dos planos gerais e médios que já o caracterizava. Só em alguns momentos, o cineasta usou closes para nos aproximar da beleza de Katai. A proposta é diferente porque os flashbacks de Lola Monthès não atingem o público em sua emoção. As cenas são cortadas para o palco, revelando muitas vezes que a versão narrada ao público não aconteceu realmente. A consequência, segundo Dahl, é ativar no espectador o distanciamento brechtiano em relação ao que é mostrado. Portanto, com uma diferença de dois anos, Dahl defendia num veículo o cinema moderno, e em outro, o cinema clássico. Uirá não tem a quebra do procedimento do melodrama e tenta se aproximar do processo de identificação. Contudo, há um certo distanciamento em relação ao que é apresentado, tornando impossível uma fruição voltada ao espetáculo.

A mudança de perspectiva de Dahl em relação ao melodrama acompanha o percurso dos anos setenta, quando os que mantinham uma crítica ao sistema não mais assumiam uma recusa radical da decupagem clássica. Não se tratava mais de ressaltar o

\footnotetext{
${ }^{70}$ Bernardet, Jean-Claude. Garota de dois gumes. Aparte. n. 2, 05 jun. 1968.

${ }^{71}$ Dahl, Gustavo. Premissas a um projeto de cinema brasileiro. Filme Cultura. n. 20, p. 50-2, mai./jun. 1972.
} 
divórcio entre o gênero popular e o cinema crítico. Segundo Ismail Xavier (2005), a década trouxe revisões de repercussão inegável, reabrindo o processo do melodrama. Houve uma revalorização do diálogo com os produtores da indústria como estratégia de sobrevivência de um novo cinema político, que se queria mais estável na comunicação com o público. Se há uma exploração ao potencial do gênero, o jogo é invertido, colocando em xeque uma anatomia das lutas pelo poder.

O discurso de Dahl na imprensa é flutuante. Para a Revista de Cinema ${ }^{72}$, ele não nega que Uirá faça parte de uma linha de continuação do Bravo Guerreiro. Trata-se de um esquema cultural do qual ele estaria "em transição de saída”. Ele tampouco esconde o caráter "de arte" do filme. Os pressupostos do nacional popular e do Cinema Novo voltavam sutilmente quando Dahl afirma: o que torna um filme popular é ser útil em termos de consciência ao povo no momento atual. O conceito implica numa identificação existencial e ideológica (do intelectual, mas isso nunca é dito) com o povo. Nesse sentido, Dahl explica que explorar a emoção é mergulhar fundo na realidade brasileira. Nesta entrevista, ele não oculta seus objetivos políticos. O cinema americano torna-se político através da empatia. Em Opinião, este conteúdo está mascarado pela ideia de ultrapassar a política, quando se escolhe como tema algo maior: a cultura. A proposta aqui é mais uma variante do cinema antropológico, sintonizado à época com o discurso de Carlos Diegues e de Nelson Pereira dos Santos (ver Capítulo 5 e 6). Naquele momento, os cinemanovistas enveredavam por uma defesa das raízes da cultura popular, supostamente opondo-se aos temas políticos. A negação do político e a defesa do lado "inofensivo" da emoção cumprem o papel de evitar a interdição dos filmes e respondem às críticas feitas ao grupo anteriormente.

Só muitas edições depois, Dahl admite em Opinião que Uirá é um filme político, mas de forma indireta. O comentário vaza pela oposição ao Anjo da noite (1974) de Walter Hugo Khouri ${ }^{73}$. Dahl perdeu para ele o prêmio de melhor diretor no Festival de Gramado, porque a "visão cosmopolita" de Khouri "tranquiliza as esferas oficiais". De maneira indireta fica claro que Uirá tem um tema político e não acalma o Estado. A condenação a Khouri está calcada não só na noção de ornamento, mas na falta de um viés político. Se no primeiro artigo sobre seu filme, Dahl procurava se distanciar do Cinema Novo discursivamente, a estratégia é a mesma de minar o sistema por dentro.

\footnotetext{
${ }^{72}$ Dahl, Gustavo. Depoimento de Gustavo Dahl. Revista de Cinema (Cinemateca Brasileira). n. 3, p. 0511, jan 1974 .

${ }^{73}$ Dahl, Gustavo. Coisas de festival... e de filme de índio. Opinião. n. 117, p. 20, 31 jan. 1975.
} 
Condena-se a linguagem moderna do Cinema Novo por dificultar o entendimento do público, mas não por sua manifestação política. Portanto, quando ele defende ao mesmo tempo o fator político na entrelinha e o musical não há uma incoerência, porque ambos têm a modernidade a seu favor, não no sentido da linguagem, mas na função social de subverter o sistema. Por detrás do discurso sobre a função de higiene da população reside o engajamento, porque se possibilita a Frente Cultural ${ }^{74}$ : conquistar o público e o mercado pela linguagem clássica e conscientizar sobre a situação do país. Daí o retorno sobre os filmes que tenham algo a dizer sobre a sociedade, diferente de Khouri.

A proposta também não era novidade para os anos de 1974. Em 1966, ele já defendia o conceito de modernidade enquanto responsabilidade social. Nesse sentido de modernidade, Uirá se encaixa como uma luva. Com esta definição, Dahl fará um corte na modernidade. Segundo ele, a simples escolha do tema já significa um estilo e uma opção do autor moderno. Bergman e Fellini não são modernos, enquanto Visconti e Saraceni o são. É a responsabilidade social, no caso em relação aos índios, que diferencia um autor moderno de um clássico para Gustavo Dahl. Do outro lado só há "delírios formais", caso não haja uma severa disciplina e responsabilidade do artista em relação a sua criação. A escolha em Uirá é a da responsabilidade ética de transformar a sociedade; jamais é um mero exercício formal. Portanto o conceito de modernidade é muito mais do que um procedimento técnico, narrativo ou estilístico. O cineasta "não tem somente um compromisso com sua arte, mas também com a vida, com a sociedade e com a história" (Costa, 1966: 28). O artista não mais constata apenas a realidade, mas dela toma partido "sobre o que dentro dela é falso e o que é verdadeiro, segundo uma concepção evolutiva da história" (Costa, 1966: 29-30). Para Dahl, a linguagem tem uma responsabilidade perante o mundo. Portanto, seja ela clássica ou moderna, o discurso político emerge. Embora o crítico defenda o cinema clássico em Opinião, sua definição de modernidade não passa pela linguagem, e é por isso que sobra essa fissura discursiva nos textos.

O tema dos dois filmes de Dahl é ainda a "estória de uma queda", como ele próprio definiu ${ }^{75}$. Tanto Bravo Guerreiro quanto Uirá significam a marcha de dois guerreiros em direção à própria morte. O sentido foi ampliado do tema da participação política para a repressão da civilização branca. Nos dois momentos, há a crise de mal

\footnotetext{
${ }^{74}$ Sobre as Frentes de Opinião ver introdução.

${ }^{75}$ Dahl, Gustavo. Depoimento de Gustavo Dahl. Revista de Cinema (Cinemateca Brasileira). n.3, p. 0511 , jan 1974.
} 
estar de uma cultura e a derrota da função social dentro da sociedade, seja ela a do intelectual clássico ou a do intelectual orgânico em Uirá. Ambos estão em crise de sentido da vida pelo contato com a política ou com a civilização branca. Sobre Bravo Guerreiro, o cineasta declarava: "Em relação ao Cinema Novo, eu pessoalmente botei o meu revólver na boca em 1968, dizendo que realmente falar não serve para nada". O período antecede o vazio cultural com o processo de fechamento do sistema e a promulgação do AI-5. Uirá foi feito nesse período de transição do discurso do vazio cultural ${ }^{76}$, nos idos dos anos 1972, em direção à tentativa de revitalização frente ao otimismo da possibilidade de abertura política já em 1974. Sintonizado com este novo discurso, Dahl dizia: "Acho que é chegado o momento de dizer: parem de chorar, de reclamar, como a choradeira do intelectual de esquerda brasileira lamentando sua impotência. Impotência de sua ideologia de transformar o real."

Contudo, Uirá aponta para outra direção. Aponta para o vazio cultural porque é a história de uma lamúria e da destruição de uma cultura. Há uma linha de continuidade entre os dois filmes. A repressão leva o intelectual ao suicídio. A civilização branca arrasta o índio à morte, progressiva e paulatina. Ela não mata somente os índios pela doença, mas gera um desgosto pela vida, cuja consequência é o suicídio. É nesse sentido que a corrida de Uirá em direção ao mar em busca de Maíra resignifica um vazio. Numa clara citação ao final de Deus e o diabo na terra do sol (1964) de Glauber Rocha, o índio corre para o mar, mas no sentido inverso: da direita para a esquerda. Sem encontrar Maíra, a cena representa um retrocesso da utopia dos anos sessenta. Não há libertação, porque ele é retirado do mar à força pelos policiais. O suicídio retoma o plano final de Macunaíma. Mas não se trata nem de um suicídio em transe hipnótico pelos encantos da sereia imaginária. Trata-se de um suicídio ainda mais amargo e consciente do que a da cena do revólver congelado na boca no final de Bravo Guerreiro. Não há em Uirá a jaqueta verde oliva de Macunaíma boiando como sinônimo da morte pelo regime militar, mas o cocar do índio em tons vermelhos na água. Se Dahl aponta discursivamente para uma saída do vazio cultural, o filme revela a temática comum do suicídio. Vazio e revitalização. Ética e política. Todos esses dados exigem uma leitura indireta porque Dahl escreve sob a forma de um quebra-cabeça e faz dessa trajetória um lugar para tematizar a própria contradição.

\footnotetext{
${ }^{76}$ O termo foi cunhado por Zuenir Ventura na revista Visão em julho de 1971. Naquele momento, ele observou uma decadência cultural na produção do momento, causada tanto pelas perseguições da ditadura, quanto pela cultura de massa. Ver Capítulo 5.
} 


\subsection{Marcos Ribas de Farias e Clóvis Marques: a meio campo entre a cinefilia e a política}

A cinefilia começou na infância e levou Marcos Ribas de Farias e Clóvis Marques ao jornalismo. Os dois entraram para a redação na gestão de Argemiro Ferreira. Clóvis Marques era ainda um novato e estreou na carreia exatamente em Opinião, enquanto Marcos Ribas de Farias foi convidado por Argemiro, porque os dois trabalhavam juntos no Jornal do Brasil. Farias era amigo também do editor de cultura, Sérgio Augusto, desde a época do $J B$. A aproximação entre os dois nasceu exatamente por causa do amor ao cinema.

Bacharel em direito sem nunca ter exercido a profissão, Ribas de Farias começou na carreira através do Curso de Jornalismo do Jornal do Brasil no início dos anos sessenta. Este ponta pé inicial se transformou logo em seguida num convite para continuar no mesmo $J B$. Naquela época, ele estreou como crítico de cinema e de teatro na Tribuna da Imprensa. Passou pela redação de outros tantos jornais, como o Última Hora, O Globo e O Estado de S.Paulo.

Entrar para a imprensa alternativa para Marcos Ribas de Farias não significava lutar contra o regime militar. Como para Augusto, tratava-se de um projeto interessante de jornalismo. Em Opinião, ele teve o ponto alto da carreira como crítico de cinema e podia escrever longamente, às vezes até duas páginas. Montenegro dava total autonomia para escolher os temas. Ninguém determinava qual filme assistir, o que não acontecia nos demais jornais. Foram anos muito "interessantes" e "provocadores", resume Marcos Ribas. Ele começou na seção de Internacional de Opinião e passou de sub-editor a editor. Ao mesmo tempo fazia crítica de literatura, cinema e teatro para Tendências \& Cultura. Saiu oficialmente do jornal no início de 1976, quando Gasparian avisou a equipe de Argemiro que não dispunha mais de recursos para manter os jornalistas. Farias continuou na redação como "colaborador permanente" de Júlio César Montenegro.

A entrada de Clóvis Marques ocorreu através do espaço aberto aos leitores. Ele era colaborador do programa Falando Cinema da Rádio $M E C$, organizado por Alberto Shatovsky, e terminava o curso de Jornalismo no Rio de Janeiro. Depois de ler a crítica de Sérgio Augusto sobre Lacombe Lucien (1974) de Louis Malle, ele decidiu enviar 
uma carta à redação de Opinião. Se Augusto gostou do filme, Marques tinha ressalvas e achava Lacombe equivocado. Relembrando o episódio, Sérgio Augusto conta que resolveu publicar o texto na íntegra porque o artigo era ótimo. Tratava-se de uma crítica ao ponto de vista do próprio editor. Depois da publicação, Marques foi procurar Augusto na redação, constrangido por causa da carta. Ele já tinha entrevistado Augusto para um trabalho de final de curso. No meio da conversa, surgiu o convite para estrear como crítico de cinema do jornal. Foi seu primeiro trabalho como "jornalistacolaborador". Além disso, ele era tradutor em Opinião. Não se tratava de um emprego fixo. Por isso, durante a troca da equipe Argemiro-Augusto, ele foi trabalhar no Jornal do Brasil.

A metodologia crítica utilizada por eles significa um casamento entre a política e a mise en scène. Neste tópico nosso corpus de trabalho é bem menor. Cada um deles escreveu por volta de dez artigos num período de um ano, enquanto Jean-Claude Bernardet e Sérgio Augusto passaram da casa dos sessenta artigos publicados. Marcos Ribas de Farias ficou até a morte do jornal. Depois voltou para o Jornal do Brasil.

Clóvis Marques define seu método de trabalho como o de um auto-didata espontâneo. Ele lia de tudo e se mantinha bem informado. Marcos Ribas de Farias assistia aos filmes uma ou duas vezes sem fazer anotações. Quando saia da sala de cinema já tinha todas as ideias na cabeça. Então começava o processo da escrita. Tentava ir "burilando" os textos, "mas não como Flaubert", sintetiza. Não havia uma predisposição para escrever sobre os filmes preferidos ou não. Segundo Ribas, os critérios teóricos até o norteavam, mas geralmente de forma inconsciente. Havia ao mesmo tempo um lado científico e de paixão. “Às vezes o resultado tinha um certo charme francês", explica.

A trajetória dos dois se confunde na cinefilia, que era um amor desde a infância. Dois filmes marcaram a trajetória de Farias: Cantando na chuva (1952) de Gene Kelly e Stanley Donen e Scaramouche (1952) de George Sidney, este último por causa dos duelos. Morando sempre no Rio de Janeiro, Marcos Ribas de Farias falava francês desde pequeno em casa. A formação cultural seguiu a mesma influência. "Sou um produto de Cahiers", explica, fazendo referência à primeira fase da revista. O crítico mais brilhante para Farias era Eric Rohmer. Além deste, os preferidos eram Jean Domarchi e Jean Douchet. Eles eram descobridores, instigantes e não tinham medo de 
ousar. Ribas define-se como seguidor de Cahiers na disputa com Positif. Ele até lia outras revistas como Sight and Sound, mas elas não o tocavam. Portanto, formação mesmo veio da fase do "auteur" de Cahiers, "que é maravilhosa" e de seguir de perto o Festival de Cinema Americano e Francês no Rio de Janeiro.

Para Farias, a fase seguinte de Cahiers, "aquela com Mao Tse Tung" é uma fase "chata", "mas eu não deixava de ler". Os textos eram "unicamente políticos". A leitura buscava "decodificar" para revelar o que era dito. Raramente a revista falava de um filme, conta Farias. Quando o fazia, era com leitmotiv para os comentários políticos. Esta fase o marcou muito também, influenciando-o politicamente, assim como a leitura de Leon Trotsky, Louis Althusser e Roland Barthes. Ele admite que às vezes via alguns filmes como uma pré-disposição para não gostar. Achava todo mundo reacionário. As influências teriam vindo tanto da primeira, quanto da segunda fase de Cahiers. O "ar dogmático" da revista em ambos os momentos tornava mais fácil para críticos, como ele, se posicionarem diante da produção.

Clóvis Marques define-se como um "cinéfilo" "que se levava a sério" desde a infância. Ele via entre 250 a 300 filmes por ano. Fazia anotações e assinava várias revistas estrangeiras. "Marxista livresco de biblioteca", lia na época Lucien Goldman, Georg Lukács, Nelson Werneck Sodré e Caio Prado Jr. Era de esquerda, mas “alienado" e sem engajamento, admite. Do cinema só lhe interessavam os filmes, não a política. "Estava na atividade alienada da vida de cinema; por acaso eu era de esquerda", completa. Ele esclarece que o grupo Augusto-Farias-Marques era influenciado pela crítica francesa, mas nele o fator político aparece mais no discurso como forma de metodologia crítica. Clóvis Marques estava interessado na análise do texto feita pela crítica de esquerda francesa. Ele procurava ir atrás do significado do filme. Neste estudo, importava também o contexto político brasileiro e a análise de fundo crítico da ideologia. Havia uma "impregnação estética" com fundo ideológico, explica. A frase de Marques resume bem o entrelaçamento entre estética e política dos dois críticos.

Marcos Ribas de Farias também faz parte desta dualidade em relação ao engajamento. Logo após o golpe militar, ele teve uma rápida passagem de três meses pela Ação Popular (AP). O movimento chamou sua atenção pelo viés mais radical. Marcos Ribas desistiu rápido porque achou tudo muito militarizado. "Detesto tudo que envolve militar". A entrada para o partido significava uma posição contra a família; 
"algo romântico de garoto". "Nunca fui atuante político", mas sabia que ao trabalhar em Opinião "entraria para o índex". O engajamento também o separava dos colegas de redação. Enquanto estes reclamavam de Gasparian, Ribas de Farias causava espanto quando respondia que a oposição contra a ditadura não era a luta dele. Na época, ele dizia coisas do tipo "tanto faz ter um patrão do capital nacional ou internacional, porque os dois exploram o jornalista do mesmo jeito". A resposta chocava a equipe.

As diferenças entre eles aparecem quando o assunto é a influência do livro Brasil em tempo de cinema. Clóvis Marques admite empolgado o quanto Jean-Claude Bernardet foi uma referência para sua geração. Mas para Ribas de Farias, o autor não teve efeitos sobre ele, porque não o estimulava à discussão. De acordo com Clóvis Marques, "nós, intelectuais pensávamos que podíamos ajudar o leitor a ter consciência da realidade social brasileira e mundial". Era como uma "camada de arrogância da juventude" de ajudar o leigo a entender o mundo. Influência mesmo para Farias só a dos críticos franceses. Rubem Biáfora e Khouri "nunca me disseram nada". Ribas de Farias lia os críticos mais próximos a sua geração, como Sérgio Augusto, Ronald Monteiro e José Carlos Avellar. "Não tive influência de nenhum crítico brasileiro", resume. Nem de Paulo Emilio, com quem teve uma relação pessoal muito próxima e de grande afeto. A oposição ao pensamento de Paulo Emilio passava pelo nacionalismo, que para Ribas "é uma coisa perversa". Farias se opunha também à frase de Paulo Emilio sobre o pior filme brasileiro ser melhor do que qualquer filme estrangeiro, "porque ela está errada". $\mathrm{O}$ argumento o incomodava por causa da impossibilidade de comparar a qualidade do cinema brasileiro com o estrangeiro. Diferente de Gustavo Dahl em Opinião, Farias não estava interessado na possibilidade de o filme ruim revelar uma parcela de nós mesmos enquanto brasileiros.

A questão do cinema nacional também os divide. O foco de Clóvis Marques era a questão da classe média urbana, talvez pela relação com sua trajetória pessoal ${ }^{77}$. Não se vê uma empolgação grande com a cinematografia brasileira, mas Marques admite que em Opinião era importante valorizar o cinema nacional. Como novato, Marques não decidia os assuntos para escrever; apenas atendia às solicitações. Ribas de Farias completa que existia uma pressão para falar dos filmes brasileiros. Quando se optava

\footnotetext{
${ }^{77} \mathrm{Na}$ entrevista, Clóvis Marques afirmou que o interesse dele pela questão da classe média urbana no cinema não teve relação com o livro de Jean-Claude Bernardet, Brasil em Tempo de Cinema.
} 
pelo cinema estrangeiro, a postura gerava uma crítica, "como se você estivesse dando força às produções estrangeiras. Acho isso uma bobagem”, explica.

Farias preferia escrever sobre o cinema estrangeiro, mas o motivo passa longe da cinefilia. A opção servia para diminuir "aborrecimentos" e atritos com os realizadores. Ele evitava os filmes brasileiros porque os diretores cortavam o contato com os críticos em caso de comentários negativos. Por exemplo, depois de escrever uma crítica a Ruy Guerra, o diretor nunca mais falou com ele. Esse tipo de problema continua a existir na crítica teatral, segundo Farias. Falar do cinema brasileiro cria sempre uma relação muito pessoal, o que inexiste com o cinema estrangeiro.

Se o cinema brasileiro parece dividir as opções dos dois, Ribas de Farias não deixou de escrever sobre Lição de amor (1975) de Eduardo Escorel ${ }^{78}$. Sem partir da sinopse do filme, ele coloca em prática a crítica sociológica para analisar a sociedade brasileira:

"Rigor rosseliniano - A maneira que Eduardo Escorel procurou ler cinematograficamente a novela de Mário de Andrade, Amar, verbo intransitivo, esboça e fornece mais uma resposta, ou melhor, oferece a um leitor atento um certo número de dados para uma compreensão precisa sobre a instauração e o entronamento da burguesia nacional. Mas, ao contrário das outras tentativas neste sentido, ele recusa a facilidade da crítica óbvia e do brilhantismo oco da demagogia populista, prefere, corajosamente, enfrentar a(s) ideologia(s) cultural(is) (...) e, com um rigor rosseliniano exemplar registrar os mecanismos que impulsionam um determinado momento histórico."

Farias procura em Lição de amor as marcas do tempo histórico, de um projeto cultural para o cinema brasileiro. Trata-se de uma possibilidade de acesso à estrutura da sociedade. Portanto, a forma do filme proporciona adentrar em camadas densas sobre a formação da burguesia nacional. Se o objetivo de localizar a presença da ideologia parece realçado em primeiro plano, na verdade, Ribas de Farias procura articular no texto como a forma do filme traz a dimensão social da realidade:

"Registro eficaz - A este caminho muitas portas são oferecidas. A primeira delas, e a mais marcante, é a maneira como Eduardo trabalha sobre a aparência e como ele demonstra friamente (apesar de uma certa sublimação estética) a íntima relação entre

\footnotetext{
${ }^{78}$ Farias, Marcos Ribas. Os cristais da velha classe. Opinião. n. 183, p. 20, 07 mai. 1976.
} 
esta aparência (a limpeza, a ordem, o branco, o amarelo, as cores claras, o décor preciosamente armado por Anísio Medeiros, as escovas, os pentes, as panelas brilhando, as rendas, as toalhas, as pratarias, o chá elegantemente bem cuidado, o conforto, as roupas engomadas) e a perpetuação da burguesia enquanto classe e prática ideológica. Isto é, ao mesmo tempo que constrói impecavelmente esta aparência e arma os elementos necessários para a sua existência (a mise en scène do filme é a mais perfeita que se fez no Brasil), ele, em um segundo nível de leitura, registra e demonstra que esta aparência não existe por acaso mas que ela é um fator preponderante para esta perpetuação da burguesia enquanto classe. Ao contradizer a ideologia burguesa enquanto estatuto mas não enquanto linguagem, os seus analistas apenas ajudam para que ela sobreviva porque no campo da aparência (que é o seu habitat natural) ela é invencível)."

Aqui o autor demonstra que as normas e formas da burguesia, como o branco, a higiene e o décor frio, não são somente os elementos formais de Lição de amor, mas explicam a maneira desta classe social se perpetuar. Porque são amplamente aceitas, estas práticas transformam-se numa linguagem de poder. Portanto, a estrutura interna do filme e a estrutura da sociedade misturam-se, tal como foi descrito por Antonio Candido (Candido, 2011 a). Eis mais um exemplo da utilização do conceito de estrutura no jornal. Primeiro, os elementos formais da burguesia aparecem na mise en scène. Quando a estrutura do pensamento burguês revela-se na forma do filme, Escorel estaria destrinchando este mecanismo aos espectadores. Daí a riqueza de Lição de amor. Com esta estratégia, o diretor confere à imagem uma significação ideológica via linguagem. Assim há uma inversão das significações: o tom positivo do excesso de branco e de higiene ganha contornos negativos, quando é desnudado pelo cineasta.

O foco do artigo é "enfrentar os códigos visuais", no caso o uso da cor branca nos objetos. Assim ele disseca, na verdade, um pouco de sua metodologia de trabalho procurar como a forma do filme revela os mecanismos de poder:

"Lição de amor é, exatamente, o estudo dessa aparência e, através de seu registro eficaz, a dissecação dos modos de operação desta aparência. Com esta dissecação, ele mostra os seus preciosos significados e consequentemente as infrutíferas tentativas de criticar e analisar a burguesia na aparência. Na verdade, qualquer projeto cultural neste aspecto deve tomar uma outra variante superficialmente sutil mas profundamente diversa. Em vez de ficar na aparência, este projeto cultural deve trabalhar sobre a aparência e demonstrar como ela é vital para a vitória ou a simples existência da burguesia." 
Citando indiretamente Roland Barthes neste trecho, Farias demonstra que não adianta criticar a burguesia na aparência, com suas leis e estatutos. $\mathrm{O}$ cineasta deve ir além, desnudando a representação da aparência na linguagem. Isto é, deve expor o processo de realização do filme. O crítico quase descreve as características do cinema moderno, mas sem utilizar essa palavra:

"Sendo, então, os seus mecanismos de defesa rigorosa e estrategicamente elaborados, o que deve ser feito é trazer estes mecanismos à luz, mostrar como eles agem. Por esta razão, os elementos episódicos que fazem a história evoluir, têm, afinal, pouca importância. O que realmente importa é a rigorosa e a refletida descrição deste meio onde acontecem estes elementos. (...) Esta descrição, porém, não deve ficar simplesmente no campo do documental e nem ser organizada em termos naturalistas ou realistas, mas sim em termos de representação desta naturalidade ou desta representação.

Construção cristalina - A escritura que é oferecida ao espectador fornece exatamente esta possibilidade de leitura. Ela trabalha, como já foi dito, sobre a aparência, mas também (e por consequência) desnuda a representação desta aparência. Com isto, o seu processo de construção torna-se cristalino e o rigor com que é trabalhado perfeitamente compreensível. Todo o magnífico ritual de planos e movimentos de câmera que escreve Lição de amor e a perfeição com que ele é elaborado, não se tornam, dessa maneira, estéreis. Muito pelo contrário."

Este artigo, como os demais, fornece uma atenção à análise interna da obra para demonstrar uma tese a priori. A atenção transita, portanto, entre a crítica de matriz sociológica e os comentários sobre a forma do filme. Observando a produção em cartaz, Farias não atenta para qualquer lançamento, mas para os autores que possibilitam ao público a reflexão sobre o ato de filmar. Entre os textos publicados, um tipo específico de cinema interessa Farias. Eis um exemplo:

“Olhar moderno. A partir desta riquíssima postura, este voluntário nível de representação possibilita uma espécie de retorno sobre si mesmo. Isto é, Antonioni termina por refletir sobre o próprio cinema oferecendo, a um leitor atento das variantes estruturais de seus procedimentos, o próprio processo de construção desta representação que ele perfaz. Ele nunca mascara seus procedimentos. Pelo contrário, ele os desnuda tranquilamente. E o (s) espaço (s) passa (m) a ser um dos interesses essenciais de Profissão: Repórter porque neles, ou sobre eles, é que acontecerão as reflexões e as rupturas do olhar moderno de Antonioni. ${ }^{79}$

\footnotetext{
${ }^{79}$ Farias, Marcos Ribas. O opaco transparente. Opinião. n. 180, p. 18, 16 abr. 1976.
} 
O trecho acima compõe um corpus significativo do interesse de Farias pelos aspectos modernos presentes na produção. Dos oito filmes analisados, seis são tomados como modernos nos termos apresentados acima: Profissão: Repórter (1975) de Michelangelo Antonioni, Lição de amor (1975) de Eduardo Escorel, A história de Adèle $H$ (1975) de François Truffaut, Stavisky (1974) de Alain Resnais, Trama Macabra (1976) de Alfred Hitchcock e a obra completa de Rainer Werner Fassbinder. As exceções são $O$ casamento (1975) de Arnaldo Jabor e $O$ homem que queria ser rei (1975) de John Huston. Há aqui um conceito estendido de cinema moderno concentrado num ponto. $\mathrm{O}$ crítico defende os filmes que se mostram como discurso e possibilitam ao espectador obter um papel ativo na construção de sentido. Trata-se de uma preocupação da crítica dos anos setenta, tal qual foi demonstrado por Robert Stam (2003): a defesa da auto-reflexão no cinema e a atenção dada ao dispositivo cinematográfico como produtor de sentido. Portanto, Farias liga-se muito mais na prática aos preceitos da moderna crítica de cinema do que ao estudo da autoria.

Atento à descrição minuciosa dos diversos procedimentos do cinema moderno, David Bordwell (1996) aproxima-se mais da proposta de Farias numa das acepções. Trata-se do cinema de arte e ensaio que destaca os procedimentos narrativos e exige do público um esforço de relativismo para compreender a verdade e ambiguidade da história. O caráter reflexivo do cinema moderno foi sublinhado por diversos teóricos e críticos. Para Luc Moullet (Xavier, 2005), O acossado (1960) de Jean-Luc Godard possibilitava repensar a narração cinematográfica por causa da existência de um discurso que se apresenta explicitamente enquanto tal. Observando as diversas características do cinema moderno como improvisação em cena, desdramatização, uso do plano-sequência, etc., Christian Metz (1972) conclui que nenhum dos procedimentos representa uma novidade, porque já foram utilizados antes. No livro A significação do cinema (Metz, 1972: 197, Xavier, 2005), ele explica o cinema moderno como enriquecimento das possibilidades narrativas. $\mathrm{O}$ importante é a modernidade chamar a atenção do espectador para o filme enquanto objeto. O objetivo é criar a consciência de que se trata de uma narração, cujo trabalho começa a se confessar à plateia. Ao colocar em questão o discurso, o cineasta afasta a noção de espetáculo transparente porque denuncia seu artificialismo. Talvez o sentido mais próximo à proposta de Farias esteja na noção de modernidade de Roland Barthes, porque ela conecta a discussão da forma à 
ideologia ${ }^{80}$. Para o teórico, o cinema deve desnaturalizar a linguagem. Assim o filme sabota a visão burguesa de espelhamento linguagem-mundo. Barthes é o principal autor citado por Farias e se opõe à linguagem mítica, porque ela permite à burguesia apegarse a uma estética da expressão natural do real como forma de se mascarar. A proposta de Barthes (2003: 238) é a destruição do mito, quando o homem fala para transformar o real. A linguagem revolucionária não pode ser mítica porque "a revolução se define como método catártico, destinado a revelar a carga política do mundo”. Quando produz uma fala plena de política, a revolução exclui o mito.

A arte revolucionária deve menos exprimir o real do que significá-lo. Esse é o sentido mais semiológico dado por Barthes em Crítica e verdade. "É pois necessário que haja uma certa distância entre o significado e o significante: a arte revolucionária deve admitir um certo arbítrio dos signos, deve dar vez a certo 'formalismo', no sentido de que deve tratar a forma segundo um método próprio, que é o método semiológico." (Barthes, 2003 a: 137). A possibilidade de proposta radical contra a falsa natureza burguesa de Barthes é encontrada em Bertold Brecht porque ela corta toda ilusão ao criar signos arbitrários.

Um ponto nevrálgico na proposta de Farias é a participação "ativa" do espectador na construção de sentido. Embora atrelada à concepção moderna do cinema, é possível demarcar um parentesco mais longínquo com a noção de modernidade de André Bazin. Segundo André Labarthe (Bazin, 2005), Bazin teria sido o primeiro a dar nome a esse despertar do espectador de sua passividade para o status de produtor de sentido. Ao se referir a Cidadão Kane (1941) de Orson Welles, o crítico francês pensou a profundidade de campo como modificadora do sentido de espetáculo. Bazin (1991: 77) não fala explicitamente em participação "ativa", mas numa "atividade mental mais ativa e até mesmo uma contribuição positiva do espectador à mise en scène." De qualquer forma, a crença baziniana na possibilidade de acesso ao real foi deslocada nos anos setenta para uma defesa materialista do cinema. Da possibilidade democrática de construção de um sentido polissêmico pelo público passamos à certeza de que a forma moderna altera a fruição artística.

Jacques Aumont (2012) concorda com Bazin ao definir Cidadão Kane como a passagem para o cinema moderno. Segundo ele, entre Acossado e o imediato pós-68

\footnotetext{
${ }^{80}$ Sobre os paralelos entre a metodologia de Roland Barthes e de Opinião, ver o capítulo 2.
} 
houve o momento mais rico em possibilidades modernistas no cinema. $\mathrm{O}$ modernismo europeu dos anos sessenta seria heteróclito em Bergman, Antonioni, Resnais, Fellini, Pasolini ou Godard. Uma das propostas de modernidade apresentada por Aumont coincide com a de Farias: a de ruptura e inovação, na qual a obra de arte expressa seu tempo e apreende contradições contra a arte dominante. O objetivo é fazer coincidir a invenção de uma solução formal e a resolução de uma questão ideológica. Welles poderia ser tratado aqui como norte do conceito de modernidade proposto: ele encontra uma linguagem própria, manifesta a liberdade do artista, é um experimentador, tem originalidade e seu cinema é reflexivo. Esta última característica é a mais importante para Aumont porque uma obra moderna é sempre uma declaração a propósito da arte.

No caso de Alfred Hitchcock, a inclusão como cineasta moderno é mais peculiar e se autentica no livro Le cinéma selon Hitchcock de François Truffaut, reproduzido no texto ${ }^{81}$ de Marcos Ribas de Farias:

““(...) O suspense, no fundo, é o próprio espetáculo. O suspense é antes de tudo a dramatização de material narrativo do filme ou ainda a apresentação mais intensa possível das situações dramáticas.'

(...) Neste sentido, a escritura hitchcockiana talvez seja a mais inventiva e cristalina que se tem conhecimento pois os mecanismos de sua construção são ofertados aos espectadores mais atentos (...). Ao se ver um filme de Alfred Hitchcock, tem-se a sensação de se estar assistindo a sua filmagem. A obra parece estar sendo construída na nossa frente, na tela".

A argumentação está centrada nesta frase-síntese do livro Hitchcock-Truffaut, que localiza o específico de Hitchcock na ideia de cinema puro (Truffaut, 2004: 25). A grandeza do diretor seria exprimir-se de modo puramente visual. É esse percurso que Farias vai analisar, seguindo os passos de Truffaut. O sentido de modernidade do artigo está centrado na forma como a câmera constrói a narrativa. Ao enumerar dezenas de coincidências e citações da obra do mestre do suspense, Farias observa uma estratégia que nunca é camuflada pelo cineasta. A modernidade estaria, segundo ele, nessa exposição a olho nu. Nesse sentido, o principal astro do filme é o movimento da câmera:

\footnotetext{
${ }^{81}$ Farias, Marcos Ribas. Hitchcock - evidente, perverso, lúdico. Opinião. n. 202, p. 24, 17 set. 1976.
} 
"Os artifícios que Hitchcock usa (e eles são inúmeros) são sempre mostrados como artifícios, eles nunca são mascarados. Os artifícios estão diante do espectador e os significados que eles recobrem também. Da mesma maneira, o espetáculo também não é mascarado, é trazido à baila e seus mecanismos (não simplesmente os seus resultados finais mas também o seu processo de construção e criação também o cinema-enquantoestá-sendo-feito) colocados à olho nu."

Truffaut teria encontrado, segundo Ismail Xavier (Truffaut, 2004: 18), a reflexividade programada, conceito comum a Farias. Isto é, a ideia de que o cinema enquanto se faz, discute o próprio cinema em alguns filmes. Xavier aponta que Truffaut projetou uma teoria do cinema de Hitchcock no espaço da modernidade estética, confirmando o cineasta como figura que compõe a passagem entre o clássico e o moderno, tão fundamental quanto Orson Welles. O trecho acima exposto de Farias recoloca em cena a participação do público, argumento utilizado também por Truffaut (2004: 26). O cineasta francês pensava em Hitchcock como "a arte de criar o suspense é ao mesmo tempo a de botar o público 'por dentro da jogada', fazendo-o participar do filme. Nesse terreno do espetáculo, um filme não é mais um jogo que se joga a dois (o diretor + seu filme) e sim a três (o diretor + seu filme + o público)." Jacques Aumont (2012) partilha da mesma ideia de Farias, observando a importância a priori da imagem na teoria de Hitchcock. Para dar a primazia ao visual sobre o diálogo, o cineasta recorreu a uma gama teórica visual, composta pela enfatização e metonímia. São esses meios formais os encarregados de encarnar a significação de Hitchcock e agir sobre o espectador. É por esse motivo que a câmera é o primeiro instrumento para materializar não só um ponto de vista, mas ser submetida ao efeito do espectador.

Um comentário em especial afasta os críticos: o sentido da produção de Hitchcock nos anos setenta. Se Farias compõe suas ideias na concepção de modernidade, ele integra Trama macabra (1976) ao estudo da autoria. Esse é seu viés teórico: constatar o quanto a matriz de Hitchcock está presente nas formas apresentadas e na noção de perversidade e culpa cristã. Utilizando o arcabouço teórico da mise en scène, posteriormente Truffaut deslocou o debate sobre a noção de unidade da obra e repetição de temas e inscreveu Trama Macabra no rol de "grandes filmes doentes" 82.

\footnotetext{
${ }^{82}$ Truffaut esclarece que o filme foi bem recebido pela crítica, mas não pelo público. "Logo se percebeu que Trama Macabra não era um bom filme. (...) foi preciso cortar, nas cópias em circulação nos Estados
} 
Se a defesa da modernidade de Hitchcock incide no estudo sobre a forma, em outros momentos a discussão de Ribas de Farias passa pelo papel social do cineasta, como foi o caso de Rainer Werner Fassbinder ${ }^{83}$. O artigo de Farias apresenta as declarações do diretor, indiretamente endossadas pelo ponto de vista comum entre ambos. O cineasta se opõe ao realismo por ser uma forma de falseamento da realidade. Desta recusa, Fassbinder fornece a possibilidade ao espectador de alterar a relação de dominação com a imagem apresentada: "O cineasta alemão força o seu espectador a tomar uma atitude, a sair de sua posição passiva (...) de uma visão realista, e por razão direta, a assumir uma postura ativa, a ser, no fundo, um co-autor do filme que está vendo na tela".

O ponto de vista de Farias está em sintonia com Jacques Aumont (2012). Para ele, o cineasta deixa uma possibilidade real de liberdade ao espectador como participação ativa, quando fornece ao mesmo tempo os meios de distanciamento em sentido brechtiano e o material para a identificação com os personagens. Assim o espectador podia se desviar da história contada e se voltar à própria realidade, reconvertendo o exagerado otimismo de alguns filmes como espaço para pensar sobre si mesmo como sujeito social. Portanto, essa reivindicação de subjetividade é a de um sujeito moderno (Aumont, 2012: 154).

Neste artigo, Farias foi além de ver o melodrama como algo negativo. Ele percebe, assim como Xavier (2005) e Aumont (2012), que a concepção de melodrama de Fassbinder é orientada para a tomada de consciência. Neste caso não foi dada maior atenção à análise interna. Assim a argumentação se encaminha mais para uma discussão do papel do intelectual, indo em direção à crítica de matriz política. Como no caso de Lição de amor, Farias sublinha o quanto Fassbinder coloca em xeque a linguagem burguesa. Para ele, a forma cinematográfica do diretor possibilita discutir a produção

Unidos, um pequeno trecho de suspense que fazia o público americano rir. Creio que as cópias europeias são mais fieis à montagem original" (Truffaut, 2004: 337). O encantamento em relação a estas obras em Truffaut se dá por outra chave. $\mathrm{O}$ grande filme doente é uma obra abortada e um empreendimento que sofreu erros de percurso. A noção só pode ser empregada, segundo Truffaut, a excelentes cineastas que demonstraram em outras circunstâncias ser capazes de atingir a perfeição. Ela interessa aos cinéfilos porque sofre com um processo de sinceridade e vibração que a torna mais clara, enquanto para o público a autoria fica mais obscura. Enquanto isso, Thomas Schatz (1991) viu a produção de Hitchcock nos anos setenta como o declínio do diretor, porque ele já não mais dispunha do studio system que lhe conferia a completude do trabalho.

${ }^{83}$ Farias, Marcos Ribas. Fassbinder, o cinema anti fetichista. Opinião. n. 187, p. 23, 04 jun. 1976. 
cultural da dependência. Aqui ele pensa Fassbinder como arma da revolução. Frisa o papel engajado do intelectual que ensina o povo a agir:

"Para que possa haver qualquer ação, é absolutamente necessário que os mais cultos (a noção de uma ideologia positiva resta aqui sem importância) ensinem aos menos cultos como agir. Uma dominação, portanto, é seguida por outra, por mais 'bem intencionada' que esta nova dominação 'positiva' procure se revestir".

O foco do artigo não é o filme em si, mas expor pela forma artística o mecanismo de dominação no cinema. A argumentação traz alguns traços da cultura política engajada. Comparativamente há uma mudança metodológica em relação ao papel do intelectual brasileiro. Se Jabor foi criticado por pertencer à burguesia, quando fez $O$ casamento (1975), Fassbinder tem o mesmo critério a seu favor. A diferença é expor ou não a fabricação dos mecanismos cinematográficos e relacionar as obras à classe social do artista por causa dos condicionantes culturais. Por esse motivo Eduardo Escorel passou incólume de críticas, mesmo tratando da mesma burguesia. Jabor é condenado porque tem a mesma visão de sua classe social e não possibilita pela forma do filme conscientizar o público. Enquanto isso, o cineasta alemão pensa sua situação a partir de seu lugar de origem: a mesma classe média. Nestes dois casos, a análise interna fica em segundo plano, mas não há nada de aleatório nesse sentido. Afinal a atenção dada ao cinema moderno não pode ser desconectada do período histórico da crítica de cinema francesa. É possível traçar aqui mais de perto um paralelo não só com a cultura política engajada, mas com a segunda fase da revista Cahiers du Cinéma sob o signo do marxismo revisado. No caso de Jabor, a matriz de pensamento marxista (Eagleton, 2011) pensa a forma artística do cineasta como determinada por sua classe social e pelos fatores ideológicos e políticos que dela advém. Procura-se o valor da obra não em si mesma, mas na junção junto ao público (Coutinho, 1968, 1975). Não se trata somente de entender a ideologia, mas de construir uma teoria da sociedade para transformá-la. A abordagem vai além do tratamento histórico, porque procura um entendimento revolucionário da história.

Naquele mesmo período, autores da vanguarda e da semiologia clássica estruturalista, segundo Ismail Xavier, (2005: 146), realizavam um ataque direto às ilusões do espelhamento artístico e da mensagem de sentido claro. $\mathrm{O}$ alvo era a noção 
burguesa de representação. Se o realismo é criticado como falso princípio, se abre uma frente contra a decupagem clássica e contra o projeto ilusionista, promovendo um retorno ao cinema de montagem, por exemplo, em Cahiers du Cinéma ${ }^{84}$. Quando o solo do bazinismo é sacudido, há uma afirmação da ciência da linguagem, juntamente com a valorização de um cinema revolucionário. A empreitada combinava semiologia, psicanálise e marxismo para defender um "cinema que incorpora a si um discurso sobre suas condições materiais e sociais de produção." Xavier pensa a mudança como a passagem da fascinação pela imagem e do reinado da continuidade para a defesa da manipulação do material sonoro e visual. O autor vê a perspectiva de Cahiers nesse período como reflexo direto das formulações de Louis Althusser e de sua revisão de Marx. Nessa época, a revista assume a crítica da representação como horizonte, denunciando o idealismo do cinema mimético representativo. Assim nega-se também a impressão de realidade e o mecanismo de identificação, porque o cinema deve trazer a marca do processo de produção.

A presença desse universo cultural em Farias transforma seu texto em direção à teoria, sintonizado com as características da segunda fase de Cahiers. Marques, ao contrário, hesita entre duas posturas. Geralmente ele utiliza os critérios da crítica jornalística, mas em alguns momentos muito significativos adentra nos padrões conceituais da crítica de cinema voltada à ciência da linguagem (ver Capítulo 4). A metodologia de Marques é mais difícil de destrinchar, porque a maior parte dos artigos é composta por notícias e entrevistas. Ele tem uma tendência maior em analisar os aspectos internos da autoria e está menos preocupado em fazer considerações sobre a burguesia. Contudo, Marques toma uma postura bem mais política quando o assunto é a aproximação dos cinemanovistas com o Estado (ver Capítulo 5). Uma atenção maior é dada à mise en scène, dialogando também com a primeira fase de Cahiers. Para se referir a Cenas de um casamento (1973), Marques faz referência à temática e ao conceito de matriz da obra de Ingmar Bergman e traça algumas fases do diretor ${ }^{85}$. Se

\footnotetext{
${ }^{84}$ Do interesse específico sobre a mise en scène na primeira fase da revista (1951-1959) coordenada por André Bazin, a redação passa por mudanças progressivas nos anos sessenta, tornando-se cada vez mais teórica. Segundo Hilliers (1996), a mudança maior do período pós-68 não foi repentina porque a publicação movia-se nessa direção desde o início daquela década. Na virada, os textos apontam para uma polarização. O conceito de autoria vai mudando com a entrada em cena do cinema moderno e pela inovação formal, que trouxe consigo o despertar de uma intensa preocupação política, que se torna maior após o maio de 1968. (Wilson, 2000).

${ }^{85}$ Marques, Clóvis. O inferno a dois. Opinião. n. 171, p. 19, 13 set. 1976.
} 
discursivamente ele apontou na entrevista seu maior interesse pelo conjunto estética versus política, as análises fílmicas parecem tender mais ao primeiro núcleo.

Portanto, de comum entre Clóvis Marques e Ribas de Farias, existe um interesse sobre a mise en scène nos artigos. Contudo, a segunda fase de Cahiers com atenção ao discurso dos filmes é mais evidenciada. Em sintonia com a revista francesa, há também as formulações baseadas na ciência da linguagem ou a presença de autores como Roland Barthes. Marcos Ribas de Farias faz menção a Nöel Burch (1992) mais de uma vez, citando a edição francesa de Praxis do Cinéma que é de 1969. Ele cita o trabalho "exaustivo com o significante" em $O$ casamento (1975) de Arnaldo Jabor ${ }^{86}$. Enquanto isso, Clóvis Marques tem uma preocupação com a linguística ainda maior. Por exemplo, sobre $O$ rei da noite (1975) de Hector Babenco ${ }^{87}$, ele escreve:

“(...) O rei da noite corre menos risco de deslumbrar as consciências, menos atentas, ou mais blasées em relação ao tartamudear sintagmático de nossos filmes que deixou de constituir estigma incontornável para ser encarado como licença poética, ainda que nem sempre com plena consciência de causa por parte de quem estava atrás das câmeras ou na frente delas".

Como no caso de Sérgio Augusto, a psicologia é utilizada por Clóvis Marques para caracterizar os personagens em Cenas de um casamento. Contudo ela é desprezada como critério estético quando se fala de Lacombe Lucien (1974) de Louis Malle, porque o crítico considera o referencial político de Cahiers muito superior ao da psicologia. Isto é, ele não parte sempre de uma metodologia a priori, porque esta varia conforme o filme em questão. Para a produção não apreciada, Marques utiliza a análise do discurso político, como fez com $O$ Flagrante (1975) de Reginaldo Farias, tratado como mero ornamento $^{88}$.

A quantidade maior de análises de filmes possibilita refazer mais o percurso crítico de Marcos Ribas de Farias. Como metodologia de trabalho, ele parte da teoria para chegar às obras. O interesse dado aos elementos internos não é pela trama em si, mas pelos recursos estilísticos das obras. Dados como o movimento de câmera e a

\footnotetext{
${ }^{86}$ Farias, Marcos Ribas. O casamento, fracassado. Opinião. n. 169, p. 18, 30 jan. 1976.

${ }^{87}$ Marques, Clóvis. Um prato (bem) feito. Opinião. n. 184, p. 21, 14 mai. 1976.

${ }^{88}$ Marques, Clóvis. Pornô de butique. Opinião. n. 185, p. 19, 21 mai. 1976.
} 
relação espaço-temporal obtêm grande espaço, mas nem sempre a trama é articulada com o estilo para elucidar as teorias apresentadas. Algumas vezes os filmes servem de ilustração para comentários políticos, como era feito na segunda fase de Cahiers. Do lado oposto, surgem elementos de uma recusa ao falseamento da realidade do cinema clássico e um elogio discreto a Bertold Brecht, numa oposição ao realismo. Antes dos filmes, Farias se norteia pelo ideal do cinema moderno pela possibilidade da forma gerar uma postura ativa no público. Ela teria grande poder em relação à fruição alcançada. Farias é o único a defender explicitamente o cinema moderno, embora uma argumentação parecida esteja presente em Jean-Claude Bernardet.

Da cinefilia francesa à política brasileira. Esse trajeto pode ser tomado como uma síntese da postura tanto de Marcos Ribas de Farias quanto da de Clóvis Marques, como forma de entrelaçamento flutuante entre a matriz estética e a política, porque ambos integram a discussão da mise en scène à política. Passam pela crítica sociológica e a crítica voltada ao específico do cinema. De comum, havia o fato de serem jornalistas, mais ligados a Sérgio Augusto. Se o interesse deles por Opinião foi pelo projeto jornalístico e não pela luta contra a ditadura, o componente político, menos presente em nível discursivo atualmente, emana dos textos, como uma forma de estrutura significativa (Löwy, 2008). Eles sintetizam a influência das duas fases de Cahiers, da estética e da semiologia, mas são confrontados continuamente com o ambiente político da resistência. Por isso são o retrato da dicotomia do intelectual, descrita por Bourdieu (1996), entre o engajamento e a exigência de autonomia estética. 


\subsection{José Carlos Avellar e a materialidade do cinema}

Uma passagem rápida pelo jornal. De fevereiro a abril de 1976, José Carlos Avellar publicou sete artigos em Opinião. Nem era um típico "crítico contribuinte" do semanário, porque sua trajetória foi ainda mais fronteiriça. Ele não combinava os temas através de conversas com o editor, como era de costume. Nem teve contato com a equipe. Só ia até o jornal entregar os textos solicitados por Sérgio Augusto. Se o trajeto foi curto, Avellar trouxe ao jornal uma metodologia peculiar para compor as gradações entre estética e política. Os artigos para Opinião fazem parte de um trabalho muito maior que ele desenvolveu no Jornal do Brasil em mais de vinte anos ${ }^{89}$.

Se Avellar passou por Opinião por causa de um desentendimento com a direção do $J B$, a participação no jornal alternativo significava apenas um espaço para escrever sobre cinema, não para fazer parte da resistência. Afinal, para ele, fazer a oposição ao Estado era um estado de espírito constante. Avellar teve muitas matérias censuradas, mas nunca foi preso. Como fotógrafo de Manhã Cinzenta (1968) de Olney São Paulo, ele foi processado e teve de prestar depoimento. Mas não foi preso como o diretor ${ }^{90}$.

A diferença de Avellar com o restante da equipe de Opinião já começa na formação e na relação estabelecida com o cinema. O sonho de garoto era se envolver com o cinema, mas naquele momento ele ainda não sabia exatamente em qual função. A vivência dele de menino já era eclética. No bairro onde morava no Rio de Janeiro, havia cinco salas de cinema. Era possível ver filmes todos os dias, porque os exibidores trocavam a programação no meio da semana. Avellar tinha contato não só com os filmes hollywoodianos, mas com os brasileiros, desde chanchadas até os dramas da Atlântida. Os filmes latino-americanos faziam grande sucesso entre os garotos, especialmente os mexicanos. A programação se completava com o neo-realismo italiano, que dava a Avellar a sensação de mostrar na tela uma realidade não muito distante da sua. E ele aproveitava a programação. Era um espectador “compulsivo”. Não era leitor de revistas, mas gostava mesmo é de acompanhar todo tipo de produção. Ver

\footnotetext{
${ }^{89}$ Nos anos setenta, José Carlos Avellar escrevia para o $J B(1962-1987 / 88)$ e para revistas especializadas de cinema como Filme Cultura, Guia de Filmes, Filme e Revelação. Depois do JB, escreveu para o Última Hora e para o Estado de S.Paulo, exatamente nos dois anos finais do Suplemento Cultural.

${ }^{90}$ Olney São Paulo foi o primeiro cineasta processado por um filme não exibido. Para contar a história fictícia de estudantes presos e torturados pela participação num comício, Manhã Cinzenta usou cenas reais de passeatas. Por causa de um boato de que o filme foi exibido a bordo de um avião desviado para Cuba, Olney São Paulo foi preso por dois meses, acusado de conivência. Ele saiu da prisão com grande debilidade física e com uma pneumonia (Simões, 1999).
} 
filmes não era uma "escolha", porque o garoto não estabelecia termos de comparação entre melhores e piores. Talvez esse contato com vários tipos de filmografia sem preconceitos contribuíram para Avellar passar longe das ressalvas de gosto. Ou talvez a falta de preconceitos só antecipasse uma qualidade e uma necessidade constante da atividade jornalística, que ele iria exercer no futuro. José Carlos Avellar não desprezava a produção popular só pelo seu lugar de origem, como acontecia muitas vezes em Opinião. Não havia queixa por parte dele para assistir aos filmes "menores" e discutilos. A postura não era comum. Na hierarquia dos jornais, os críticos mais velhos ficavam com os mais "significativos" e os novatos com o restante da produção. No $J B$, ninguém queria assistir às pornochanchadas, mas ele não tinha problemas em analisar o gênero. Se no $J B$ ele era o único a escrever sobre as comédias eróticas, Bernardet o acompanhava nesse trajeto no Opinião e depois em Movimento. Além é claro de Paulo Emilio que concedeu uma importante entrevista sobre o tema em Movimento.

A formação nascia de forma "não disciplinada", conta ele. Misturando filmes, vendo produções diferentes, atropeladas ou seguidas uma após a outra. Se os críticos de Opinião instruíram-se através das revistas de cinema ou de colegas renomados, o percurso de Avellar começou com um realizador. Através da leitura dos textos de Sergei Eisenstein, ele descobriu que escrever sobre cinema podia ser tão agradável quanto assistir ou fazer filmes. O cineasta russo fornecia a ele um instrumental para escrever sobre seu tema preferido. Eisenstein comentava os filmes para falar do cinema em geral, mas nunca dizia se eles eram bons ou ruins. Sem emitir um juízo de valores, o mais importante era a discussão entusiasmada do processo narrativo e expressivo dos filmes. Foi assim que nasceu nele a vontade de publicar textos para explicar como e porquê um filme o tocava. O algo a mais que ele sentia falta nas críticas de cinema, Avellar encontrava em Eisenstein.

Assim a oposição de Avellar aos muitos cânones da crítica ganhava um contraponto possível. Os críticos pareciam aborrecidos com a maior parte dos filmes, como se não tivessem prazer com o próprio trabalho. Além disso, o tom opinativo dos textos o desagradava. Nas listas de melhores e piores do ano nada se acrescentava de informação útil sobre o filme. O leitor ficava sem saber o que era exatamente a obra por causa da argumentação passional. Enquanto isso, Eisenstein gerava a compreensão do filme. Juntando sua experiência anterior de espectador compulsivo com as novas ideias, Avellar criava sua própria forma de pensar o cinema. "Não há filme ruim" é quase uma 
máxima. Afinal até mesmo um filme ruim “diverte e dá prazer". Se é possível adivinhar logo nas primeiras imagens como a história vai acabar, Avellar pensa no que vê e estabelece ligações com outras produções. Todo esse processo para ele é muito prazeroso e enriquecedor. Durante a sessão, ele se deixa levar pelo prazer de assistir ao filme. A escrita é o resultado do maior ou menor prazer de ter visto a obra. Portanto, o ato de escrever é um prolongamento do prazer de ver os filmes. Enfim, ele gosta mesmo é do cinema e de se "surpreender" com as obras numa "relação direta" com os filmes.

O olhar acurado na materialidade do filme vem da formação de fotógrafo e de diagramador, antes de ser jornalista. $\mathrm{O}$ dia a dia no trato com a imagem dentro do jornal fazia Avellar pensar sobre a diferença entre ver o mundo a olho nu e através das lentes, no que se coloca entre o sujeito e mundo. Além dos filmes, o contato com a fotografia foi uma forte influência na sua trajetória. Antes de se tornar crítico de cinema, ele fotografou muitos filmes. A experiência serviu como aprendizagem para compreender o processo de narração e a composição do cinema.

As conversas com os realizadores brasileiros da geração dele, especialmente os do Cinema Novo, também tiveram peso nos anos de formação. Avellar falava muito com Nelson Pereira dos Santos, quando os dois eram colegas de redação no Diário Carioca e no $J B$. Acompanhando as filmagens ou no bate papo com os diretores, ele construía uma série de argumentos para usar na composição dos textos. No início dos anos sessenta, Avellar já tinha definido sua preferência pelo cinema brasileiro como forma de desenvolver uma argumentação cinematográfica. O interesse maior era escrever sobre cinema de um modo geral, mas com ponto de vista brasileiro. Só com os filmes nacionais era possível estabelecer um comparativo entre o que aparecia na realidade ao vivo e na tela. Esse cruzamento de dados o ajudava a compor a argumentação para o cinema nacional e para o estrangeiro. Tomando como ponto inicial sua experiência com as imagens nacionais, Avellar estava criando seu repertório para escrever sobre filmes de outros países.

Se as conversas com os realizadores ajudaram na formação, a literatura gerou nele o interesse pela temática brasileira. Foi através dos livros de Mário de Andrade e Graciliano Ramos que Avellar sentiu a vontade de escrever de maneira leve e sem complicar, tudo é claro gerando prazer de leitura. A composição do processo de escrita dele se concretizou totalmente com o jornalismo, que influenciou sua forma de fazer 
análise. A consciência de escrever para o jornal diário está sempre nos textos. Daí a grande preocupação do crítico em não contar o final da história para não estragar o prazer dos espectadores. De todo esse processo, ele encontrou um formato de escrita para ser "fiel ao filme" e "fiel ao prazer do leitor".

Por causa da proximidade geográfica, Avellar lia mais os críticos cariocas, como Alex Viany. Com menor frequência tinha acesso a Paulo Emilio Salles Gomes no Suplemento Literário do Estado de S. Paulo. Enquanto os críticos de Opinião formaram-se invariavelmente pela leitura de Cahiers du Cinéma, Avellar traçou um percurso diferente. A revista não fez parte das suas leituras nos anos de formação. Ele passou a acompanhá-la quando já era detentor de uma maneira própria de trabalhar os filmes; como crítico formado. O interesse na leitura era enriquecer seu arsenal de argumentação e estabelecer um diálogo com outros críticos, que refletiam sobre a mesma produção. Não importava se existia consenso ou dissenso de opiniões. A leitura não era sem ressalvas para com as duas fases da revista. O sentimento descrito é de uma relação de "proximidade e de distância" ao mesmo tempo. A segunda fase tornava-se cada vez menos "interessante", quando entrava nos anos setenta. Ele gostava de ler os textos da primeira fase, mas não participava do fascínio pelas formas narrativas hollywoodianas. Não concordava também com algumas discussões teóricas, como ver o "plano longo" como mais realista. Para ele, a "fase amarela" estava atrasada com as conclusões sobre o cinema americano em relação aos críticos brasileiros, tudo por causa da falta de acesso aos filmes no pós-guerra.

Nos artigos para Opinião, o foco de Avellar é decompor o mecanismo do cinema. Por tabela, o espaço maior é para os filmes estrangeiros. Só um é brasileiro: Ovelha Negra (1974) de Haroldo Marinho Barbosa. Há desde filmes comerciais até uma pornochanchada italiana ${ }^{91}$, passando também por Ingmar Bergman. O recorte para comentar Cenas de um casamento (1973) do mesmo autor é a fotografia ${ }^{92}$. O gancho é a cena na qual o marido conta à esposa que tem uma amante e lhe mostra seu retrato:

"Mais ou menos na metade da terceira das Cenas de um casamento (aquela onde "cai a guilhotina e Johan comunica de forma brutal que está apaixonado por outra mulher e pretende uma separação'), Mariane pede para ver um retrato de Paula (...).

\footnotetext{
${ }^{91}$ Avellar, José Carlos. Lição de patriotismo. Opinião. n. 175, p. 22, 12 mar. 1976.

92 Avellar, José Carlos. O retrato de Paula. Opinião. n. 179, p. 23, 09 abr. 1976.
} 
Curiosidade do espectador - Todas estas referências despertam uma natural curiosidade em torno da figura de Paula, mas os dois retratos na mão de Mariane jamais são mostrados ao espectador. A câmera observa a cena de um mesmo ponto de vista, não se movimenta dentro do cenário nem mesmo para se aproximar do rosto de Johan ou de Marianne".

Se Bergman recusa-se a satisfazer o desejo do espectador, o procedimento vai contra a corrente das novas tendências da fotografia:

"Mais do que uma simples detalhe de encenação, esta recusa de satisfazer uma curiosidade do espectador, de atender a um natural desejo de querer saber como Paula é, tem uma importância especial. É antes mais um exemplo de concisão numa época em que o cinema se tornou escravo de suas novas possibilidades técnicas: a lente zoom, o filme em cor, os filtros para alterar o contraste das imagens, as câmeras leves e automáticas, os novos materiais de iluminação."

A fotografia de Cenas de um casamento é tomada como comparação para analisar o filme inglês Tensão no aeroporto ${ }^{93}$ (1974) de Caspar Wrede, que satisfaz inteiramente a curiosidade do espectador:

"Hoje, no cinema, a visão mais luxuosa é aquela que se confunde com o real. Parece mais verdadeira a câmera que se movimenta muito dentro da cena, a que pode estar em vários lugares ao mesmo tempo, a que tem uma visão mais dinâmica que a do olho humano. A impressão de realidade não resulta de uma eventual veracidade dos fatos narrados, mas da sofisticada maneira de olhar. Se a ação é rápida, câmera lenta, para não perder os detalhes. Se os personagens estão muito afastados, um movimento de zoom para vê-los mais de perto. Se alguém desvia o olhar para um objeto pequeno dentro ou fora do cenário, uma nova imagem para trazer este detalhe a primeiro plano. $\mathrm{O}$ espectador tem a impressão de ver melhor, de ver toda a realidade com seus próprios olhos, e de ver materializado até o que se passa na cabeça de um personagem. (...)

O que importa é a ideia de uma fotografia tecnicamente perfeita, e dotada de mil recursos especiais, porque isto corresponde com exatidão ao comportamento dos personagens: [em Tensão no aeroporto] os policiais, os pilotos, os sequestradores e os sequestrados são indivíduos tecnicamente perfeitos, muito pouco parecidos com gente de verdade."

A diferença técnica da fotografia entre Cenas de um casamento e Tensão no aeroporto serve de gancho para uma informação técnica: o fotógrafo dos dois filmes é o

\footnotetext{
${ }^{93}$ O filme também é conhecido como Decisão Amarga ou The Terrorists (EUA). Título original Ranson.
} 
mesmo. Sven Nykvist é o responsável por todos os filmes de Bergman. A presença dele é então tomada para compreender "quais as solicitações que determinado estilo narrativo faz de sua fotografia".

Para tornar mais clara a diferença, Avellar traz as declarações de Nykvist, contando detalhes simples de bastidores. O fotógrafo explica que Bergman usou um moderno equipamento: "Em alguns planos existem mais ou menos 20 diferentes movimentos de zoom". A diferença foi a utilização desses movimentos: "no filme quase nenhum movimento apareceu, tudo saiu da montagem, e a ação ficou mais rápida e tensa”. O oposto foi feito em Tensão no aeroporto, explica Avellar. No filme de Cásper Wrede, quem age mesmo é a fotografia e a sofisticação da imagem. Os personagens não parecem gente de verdade. São indivíduos perfeitos. O equipamento tem importância expressiva maior do que a dos atores e foi usado para aparecer na tela. Através dessas informações técnicas, Avellar conclui a diferença da fotografia de Cenas de um casamento. Bergman não está interessado em frisar mil recursos técnicos. O moderno equipamento é utilizado para deixar o ator mais à vontade na cena. Por esse motivo, a fotografia não se faz notar e não desgruda do rosto dos atores para mostrar detalhes menos importantes, como o retrato de Paula:

"A fotografia, em Cenas de um Casamento, não se faz notar porque o diretor reduz intencionalmente o sofisticado equipamento cinematográfico de hoje aos limites do olho humano: ver as situações como gente de verdade. Ele leva a câmera a ficar presa a Johan e Marianne. Não desvia o olhar para qualquer detalhe menos importante do casal - como o retrato de Paula, ou uma descrição mais detalhada do ambiente do casal - porque se envolve emocionalmente na tensão desta história de amor entre 'duas pessoas terrenas e imperfeitas, egoístas, limitadas, briguentas', que para ser inteiramente compreendida só poderia ser fotografada de um modo terreno, humano, imperfeito: luz irregular, muito grão na imagem tensa, imóvel, que não tira os olhos de Johan e Marianne".

$\mathrm{O}$ artigo traz indiretamente um debate intenso do período e de Opinião: as possibilidades democráticas ao espectador no cinema hollywoodiano e no cinema moderno. Avellar não toca em nenhum desses assuntos, mas eles estão lá. A descrição indiretamente traz alguns elementos da transparência e da opacidade (Xavier, 2005). Ele deixa de lado linhas delimitadoras claras entre um cinema clássico e moderno, como às vezes ocorria em Opinião, por exemplo, para afirmar a primazia da linguagem clássica na conquista do público. Também não estabelece nenhum tipo de comparação 
valorativa entre o "cinema de entretenimento" e o "cinema de arte". Esses dois termos jamais aparecem. Avellar não taxa os filmes com essas etiquetas. Não planifica. Ele não faz a defesa do cinema moderno, nem do clássico, porque as linhas divisórias entre os dois mostram-se porosas ao longo dos textos escritos para o jornal. O diferencial de Bergman aparece como informação técnica, não como opinião, possibilitando talvez ao leitor um caminho livre para escolher qualquer um dos filmes.

Há aqui a marca que caracteriza Avellar. Ele suprime meticulosamente a presença do gênero opinativo. Se crítica de cinema é juízo de valores, estéticos ou de orientação de consumo, Avellar coloca em seu lugar o padrão de excelência do jornalismo. Ele tira a opinião e coloca informações em todas as linhas. Além disso, suprime ao máximo sua presença nos artigos. Traz a neutralidade no lugar. As frases são curtas e concatenadas sem nenhum tipo de adjetivo. Buscando as coordenadas assindéticas, o texto é bem escrito, limpo, enxuto e sem digressões. Há uma grande preocupação com a forma da escrita. Não há repetições de palavras ou ideias. O pensamento é organizado como nos cortes secos da montagem cinematográfica. A marca do bom jornalismo é evidente para um conhecedor. Esse processo quase fotográfico de edição de texto dá um toque final que diferencia Avellar. É pela informação total, imanente que ele chega à construção dos significados. Avellar não precisa emitir um juízo de valor porque ele provou cientificamente do que se trata o filme. A conclusão sobre a obra surge da informação, sem que o crítico precise se colocar no texto. O processo confere a Avellar uma enorme credibilidade. Afinal os dados são técnicos e é difícil discordar, porque ele prova a maior complexidade dos mecanismos cinematográficos de determinados filmes. O crítico se baseia no concreto e através dele explica o abstrato. Pela descrição das cenas, Avellar diferencia um filme de entretenimento e de arte, sem afirmar que um seja melhor ou pior. A construção e a força do texto dependem do tipo de apresentação dos dados. Eles parecem surgir de si mesmos, como se não houvesse um sujeito, embora teoricamente falando as fronteiras entre informação e opinião são muito porosas ${ }^{94}$.

\footnotetext{
${ }^{94}$ Não há informação sem opinião. Na teoria contemporânea do jornalismo há uma tendência geral de utilizar o termo relato e comentário, ao invés de jornalismo informativo e opinativo. Não retomaremos a discussão sobre gêneros jornalísticos, já teorizada na livre-docência de Manuel Chaparro (1997) e no livro de Martinez Albertos (1983). Em termos de gênero, a crítica de cinema/gênero opinativo/comentário coexiste com o gênero informativo/notícia/relato porque os espaços de delimitação nunca possuíram fronteiras claras. Existe apenas primazia de um sobre o outro. É impossível opinar sem noticiar ou informar sobre fatos sem o componente opinativo.
} 
Ao destrinchar os procedimentos do cinema, o objetivo dele era "estimular" o espectador a desenvolver seu próprio "arsenal" de leitura. A primazia da informação sob a opinião poderia ser também uma forma de evitar atritos de gosto com os leitores e com os editores. Permitiria também ao público escolher um dos filmes, conforme suas preferências: o entretenimento ou o filme de arte.

Em todos os artigos, Avellar dá uma aula de cinema ao público com exemplos concretos. Ele sempre traz a descrição das cenas para facilitar o entendimento do leitor. Através dos exemplos, o crítico liga os filmes ao tipo de cinema que quer demonstrar. Nada passa despercebido ao olhar fotográfico de Avellar. Se a ideia é revelar os mecanismos de construção do filme, uma interpretação do discurso político pode até ser feita, mas o mais importante é a discussão do cinema. Seria possível colocar no texto $O$ retrato de Paula algumas etiquetas como cinema de espetáculo ou de arte, mas Avellar nunca faz isso. Se indiretamente o crítico passa por essas categorias, ele está preocupado é com o específico do cinema.

O próprio Avellar esclarece que não estava interessado no "entorno do cinema", mas no "corpo a corpo com os filmes". O instrumento de pesquisa "não é o ideológico", mas o "prazer proporcionado pelos filmes". Para ele, a preocupação com a ideologia "não levava a coisa alguma", no sentido mesmo do "entendimento" da obra. Ele usava os "dados externos à composição formal" como "acessórios" na formulação do texto, afinal esses fatores não o envolviam muito. Nesse sentido, ele define-se na entrevista como formalista pelo interesse na composição formal e no tecido concreto das obras:

"Não me parece muito que as questões externas à construção do filme tenham um papel fundamental. Eu não diria que eu tenho uma formação, mas eu tenho um comportamento mais próximo do construtivismo, do formalismo. A única coisa que você tem contato direto, concreto do filme é a forma do filme. A minha preocupação é lidar com essa coisa. Mesmo quando nós tivemos aqui um contexto politizado, como não poderia deixar de ser, durante a ditadura militar, o que me interessava era, claro que você tem uma opinião política, claro que você age politicamente, conscientemente ou não, mas a minha forma de ação é através da forma cinematográfica. Eu procuro é discutir como aquela forma se constrói em parte por interferência do realizador e em parte por alguma coisa que ele pode ter feito inconscientemente."

O modo de ação de Avellar [no caso brasileiro] não exclui a atitude política, porque o jeito de agir dele é a decomposição da forma dos filmes. E as formas do 
cinema brasileiro daquele período também têm relação com o contexto político. Nestes casos, Avellar (1986) utiliza o conceito de estrutura, porque ele observou que o contexto político da violência do AI-5 foi o horizonte geral de uma estrutura comum aos filmes. Essa estrutura se manifesta na dramaturgia cinematográfica nacional em dois momentos: a vontade de usar as formas da paisagem real e os problemas populares como indicadoras dos temas e do modo de filmar. Nestes casos o próprio horizonte político interfere na composição formal dos filmes, consciente ou inconscientemente. Ao abordar o quanto os temas e as forma das obras dialogam com estes aspectos, o recorte de análise é, por derivação, também político.

Ao se concentrar na construção do filme, Avellar traz um diferencial para abordar a matriz política e estética em Opinião. Ele tem uma independência em relação aos julgamentos de base ideológica. Nesse sentido foi um contraponto a muitos artigos do jornal. No $J B$, Avellar trata os assuntos relacionados à ideologia no cinema com independência. Falando diretamente de cinema político, ele não emite juízo de valor ao observar as diferenças entre o cinema de gênero e o autoral. Consegue, ao contrário, adequar o conteúdo e a estética à fruição de diversos espectadores (Ver Capítulo 4). Esse tipo de análise que prescinde da discussão política do cinema, longe dos preceitos da cultura política engajada, era raríssimo em Opinião.

Através da descrição acurada das cenas, Avellar traz dados concretos sobre a ideologia nos filmes. Talvez para um jornal de grande público como o $J B$, ele conseguisse esclarecer muito mais os leitores sobre esses aspectos, porque a falta de uma postura visivelmente "engajada" poderia significar a perda de parte do público. O crítico não imputa aos filmes o poder de impedir uma determinada leitura, mas observa quais são as obras mais abertas à fruição ativa do espectador. Ideologia aqui aparece como visão de mundo, não como ocultação da realidade. Não se trata obviamente de neutralidade ideológica, porque qualquer linguagem não é imune aos processos ideológicos. Trata-se de passar longe de relacionar o imperialismo americano, com a falta de consciência do público e o discurso dos filmes.

Se olharmos de perto os filmes analisados em Opinião, veremos uma tendência que talvez se confirme no trabalho de Avellar no $J B$ : uma defesa do cinema que gera uma reflexão crítica do espectador. Há diversas derivações dessa possibilidade, a tendência ao cinema moderno, a postura da câmera, a preferência pela fruição ativa do 
espectador, ou o cinema artístico ou autoral, mas todas elas exigem conclusões feitas através do $J B$. Todos os filmes podem realmente agradar como diversão e prazer, mas alguns são melhores do que os outros do ponto de vista da complexidade dos mecanismos cinematográficos. Contudo todo esse processo não é feito a priori, mas a partir do contato e da análise dos filmes.

Se nos artigos para Opinião, Avellar se concentra nos mecanismos do cinema de modo geral, esse é apenas um lado de seu trabalho como crítico no $J B$. Por exemplo, enquanto a crítica sobre Cenas de um casamento concentra-se nestes mecanismos, ao comentar Gritos e Sussurros (1972) em 1974, Avellar (1982) adiciona o estudo sobre os grandes temas de Bergman. Ele não procura de forma alguma a mise en scène no abstrato, mas encontra o estilo de Bergman na peculiaridade do trabalho concreto dele, na descrição dos planos, no tratamento da fotografia, na utilização da câmera, na montagem e até mesmo na repetição da forma de composição:

“(...) Bergman mergulha no mundo de seus filmes anteriores, reestuda um personagem, retoma em profundidade um problema apenas enunciado. Procuremos seguir também, pelo menos em parte, o exemplo (...) para examinar Gritos e Sussurros. Isolemos um trecho do filme para tentar numa análise mais detalhada identificar o processo de construção geral. Bem sei que o leitor que de quando bate os olhos por aqui deverá estar dizendo com seus botões que é exatamente isto o que costumo fazer com tudo quanto é filme, isolar uma cena e tentar identificar na parte os sinais do todo. É verdade. Faço aqui um pouco como Bergman, que repete sua forma de composição" (Avellar, 1982: 36-41).

A crítica é construída em torno da cena na qual o padre reza ao lado do corpo de Agnes. Primeiro o sacerdote reza como se falasse à morta. Depois as ações funcionam como uma preparação para um tom desesperado e agressivo, pedindo a intersecção da falecida para orar por eles aqui na terra. Depois Avellar comenta a fruição do público. Se ele se deixa levar pelo envolvimento com a trama, o conjunto da composição formal pode incidir na forma como ele vai ver. Então a dor do que se vê será maior. Mas tudo depende de uma escolha. Avellar frisa a cena não porque se trata da mais bela ou expressiva, mas porque "as palavras do personagem parecem uma tradução direta do sentimento comum" a todos os personagens dos filmes de Bergman. "O padre, nesta cena, pensa, sente e fala como o próprio realizador". Assim ele chega à própria temática do cineasta, que não estava presente no texto escrito para Opinião: 
"Não é simplesmente uma dor física, não é a dor que vem de uma doença sem cura. Não é sequer qualquer doença, é a própria vida. Viver dói. Estar vivo é sentir dor e sofrimento. A vida inteira é uma prolongada agonia, é carregar uma culpa, pagar um crime desconhecido e sem perdão. O texto em si mesmo, tal como pode ser visto aqui, talvez nem pareça tão amargo e agressivo assim. Esta sensação vem muito mais da maneira de dizer do que das coisas que se dizem. Vem muito mais do envolvimento do espectador com a imagem. Não é bem uma coisa para entender, mas uma coisa para sentir".

Por fim, Avellar conclui qual é o mecanismo do filme e chega ao estilo do diretor:

"Gritos e sussurros é uma nova visita a este universo desencantado. Aí encontramos de novo os personagens de sempre e o mecanismo de construção de sempre: a ação é pouca, é principalmente reflexiva. Os personagens são apanhados num momento em que se dão conta da extensão do sofrimento humano e começam a pensar em voz alta. Ou a pensar e não falar de todo. Ou a pensar e falar numa linguagem incompreensível. Às vezes conversam entre si. Às vezes falam para a câmera, como se ela fosse um personagem invisível, ou simplesmente um espelho. Às vezes se agridem, com palavras ou com atos. Tudo é igual, e ao mesmo tempo não é igual, porque de filme para filme Bergman depura o seu estilo de narração. Faz assim como fez com o cenário do quarto de Agnes para filmar a oração do padre: retira os enfeites, retira os sinais habitualmente usadas para dar à imagem uma atmosfera natural."

Quando Avellar explica "a dor de dente da alma” de Bergman, temos um exemplo de trabalho que não aparece em Opinião. De certa forma, apenas os artigos que frisam mais o mecanismo do cinema foram selecionados para o jornal alternativo. Nos próximos capítulos, Avellar estará presente no contraponto entre os artigos de Opinião e os do $J B^{95}$. Os textos dele na grande imprensa servem para ilustrar como Avellar acrescentava a análise imanente quando a tendência era a crítica sociológica. Ou como criava um maior distanciamento em relação ao discurso dos cineastas.

\footnotetext{
${ }^{95}$ Trazemos a análise comparativa do trabalho de José Carlos Avellar no Jornal do Brasil aos seguintes filmes: Toda nudez será castigada (Capítulo 2), Uirá (Capítulo 3), Sacco e Vanzetti (Capítulo 4), O Amuleto de Ogum (Capítulo 6).
} 


\section{Capítulo 4}

\section{Os Embates com os Leitores}

Não faz parte de nossa investigação uma análise do tecido social. Precisamos somente fixar na mente quão grande é a parte representada pelo marco social em que nosso contato espiritual com o mundo, como ele tende a fixar o que é admissível, e determinar como deve ser julgado. Cada marco determina para si próprio os assuntos dentro de sua competência imediata. Acima de tudo ele determina a administração detalhada dos juízos. Mas o próprio julgamento é estabelecido por padrões que podem ser herdados do passado, transmitido ou imitado de outros marcos sociais. $\mathrm{O}$ mais alto marco social consiste daqueles que corporificam a liderança da grande sociedade. E ao contrário de todos os outros marcos sociais onde o montante de opiniões é de primeira mão somente sobre assuntos locais, nesta alta sociedade as grandes decisões sobre a paz e a guerra, de estratégia social e a distribuição definitiva do poder político são experiências íntimas dentro de um círculo que, potencialmente ao menos, são de relações pessoais.

Uma vez que posição e contato têm um papel tão importante em determinar o que pode ser visto, ouvido, lido e experimentado, assim como o que é permissível se ver, ouvir, ler e conhecer, não surpreende que o julgamento moral seja muito mais comum que o pensamento construtivo. Ainda assim no verdadeiro pensamento efetivo a primeira necessidade é eliminar julgamentos, recuperar um olhar inocente, desembaraçar os sentimentos, ser curioso e de coração aberto. A história do homem sendo o que é, a opinião pública na escala da grande sociedade demanda um volume de abnegação equânime raramente atingível por alguém em qualquer período de tempo. Estamos preocupados com os assuntos políticos, mas imersos nos nossos privados. $\mathrm{O}$ tempo e a atenção são limitados para serem gastos no trabalho de não se considerar as opiniões como um fato dado, sendo ainda submetidos a constante interrupção.

Walter Lippmann in A Opinião Pública 



\section{Capítulo 4 - Os embates com os leitores}

Ao percurso sobre as formas de analisar um filme do capítulo anterior, acrescentamos nestes próximos tópicos exemplos das disputas entre estética e política na seção de cartas do jornal ${ }^{1}$. O espaço constitui uma verdadeira Tribuna da Opinião, na qual não só o público em geral, mas especialmente os cineastas, produtores e acadêmicos tomavam parte. Exercia-se a crítica participativa por excelência. A ideia da polêmica toma conta desta seção, num exercício constante de pluralidade, estimulado pela redação. Toda a equipe ficava encarregada de ajudar na edição das inúmeras cartas que chegavam semanalmente. Um adendo necessário: talvez alguns dos textos da seção dos leitores fossem escritos por membros da própria equipe. Os articulistas do jornal às vezes mandavam cartas anônimas para participar do debate, quando não podiam adentrar publicamente em certos temas ${ }^{2}$.

Não pretendemos abordar a seção de cartas através dos estudos sobre recepção, tampouco a partir da negociação de sentido feita pelo leitor. Vemos o espaço como parte das disputas internas do jornal. A coluna permite observar ainda que empiricamente o entendimento do público sobre os conceitos discutidos pelos críticos, especialmente o de cinema político e a preferência por determinadas linguagens cinematográficas. O objetivo é realçar as disputas e resignificações dos leitores. Nesse sentido, fazemos aqui somente um esboço de um projeto maior sobre a construção de significados pelo público, desenvolvido, por exemplo, por Marialva Barbosa (2007).

\footnotetext{
${ }^{1}$ Quando citamos as declarações de Júlio César Montenegro, Jean-Claude Bernardet, Sérgio Augusto, Marcos Ribas de Farias, José Carlos Avellar e Clóvis Marques, trata-se das entrevistas que realizamos com os autores. Nos casos de exceção, mencionamos as fontes.

${ }^{2}$ Ao ler uma crítica negativa de Fernando Peixoto a uma peça do Teatro Ipanema, Jean-Claude Bernardet pediu para se manifestar num texto. Júlio César Montenegro explicou que ele não poderia escrever sobre teatro, porque não era a área dele. Então Bernardet decidiu publicar uma carta com pseudônimo, mas ele não se lembra se chegou a enviar ou não o material e se o texto foi publicado. O próprio Júlio César Montenegro certa vez enviou um texto com um nome falso ao jornal Movimento. Discordando da imagem de um Cristo torturado com uma coroa de espinhos e uma suástica para ilustrar o artigo sobre cinema nazista de Jean-Claude Bernardet, ele questionou "o maniqueísmo religioso", quando há, na verdade, "complexas forças humanas". Assinou Robert Stuart Dantas e deu o que falar na redação contra o "reacionário", "elitista", "desmascarado pelo próprio nome". Para Montenegro, as pessoas eram tão fanáticas que não perceberam que o artigo era a favor de Bernardet. Por acaso, o próprio Bernardet foi conversar com ele e falar da carta do leitor. Achou que o missivista tinha razão, e diferente de todos, não viu um comentário negativo. Montenegro conta que usou o nome de rico para ficarem com raiva. Certa vez, numa reunião em sua casa, um colega olhou em volta do seu apartamento e disse com ares irônicos que ele morava "muito bem!". Montenegro relembra que se sentiu julgado naquele momento. O artigo foi publicado com o nome de Angel Robleado Cantuária. Cantuária, Angel Robleado. O cinema nazista. Movimento. n. 8, p. 33, 25 ago. 1975.
} 
Mais do que tirar conclusões, procuramos identificar as tensões entre as metodologias utilizadas por diversos atores sociais, sejam eles críticos, público ou especialistas do campo. Começamos pelos artigos dos críticos que deram origem ao debate e depois comparamos os argumentos com os textos dos leitores. Tomamos aqui os casos como recorte dos atores envolvidos: 1. a disputa sobre as formas de analisar um filme entre um crítico e um futuro colaborador a partir de Lacombe Lucien; 2. A polêmica sobre Sacco e Vanzetti (1971) de Guiliano Montaldo e sobre Ensina-me a viver (1971) de Hal Ashby com os leitores, tendo como foco o cinema político de esquerda; 3. o debate gerado pelos próprios missivistas sobre a função do cinema político em torno de Tempos Modernos (1936) de Charles Chaplin. Neste capítulo, o jogo entre a matriz estética e política ganha contornos mais definidos, quando se transfigura em exemplos práticos sobre os lançamentos. Trata-se do momento no qual as teorias encontram sua aplicação para os leitores.

\subsection{Lacombe Lucien e a polêmica sobre a metodologia da crítica de cinema francesa}

Lacombe Lucien (1974) de Louis Malle alcançou grande sucesso de público na França e causou um intenso debate na crítica de Cahiers du Cinéma. A revista passou o ano de 1974 e de 1975 discutindo diversos ângulos do filme e atacando em voz uníssona seu ex-crítico. No ápice da discussão havia questões de fundo teórico, como a construção da enunciação no cinema, a teorização do uso do estereótipo nos filmes, o papel da naturalização e da ideologia na representação do nazismo e as tendências do cinema francês, na chamada onda retrô.

De todos esses ângulos, os críticos de Opinião escolhem apenas um deles para o debate: a cena do esparadrapo. Se o foco de Cahiers é o cinema político e a forma estética adotada por Louis Malle, em Opinião, a discussão envereda pelas metodologias da crítica de cinema em pauta naquele momento. É nesse sentido que Lacombe possibilita repensar se existe apenas diálogo ou franca oposição entre o jornal alternativo brasileiro e a revista francesa. Saímos aqui da abordagem metodológica 
sobre cada crítico do capítulo anterior, para abordar as disputas pelas formas de analisar um filme em Lacombe.

No centro da discussão estava a política. E, consequentemente, a estética enquanto fuga do político. A polêmica nascia em torno do tema tabu: o papel dos franceses durante a ocupação nazista. Lacombe Lucien relata a trajetória do camponês apolítico e rústico que se torna colaborador nazista como forma de ascensão e conquista de poder. Ele se envolve com uma moça judia e explora não só ela, mas toda a família. O problema surgia em torno da erotização do personagem como forma de fascinação pelo nazismo numa relação tensa e contraditória entre vítima e carrasco.

Longe da voz uníssona de Cahiers, o editor de cultura, Sérgio Augusto, escolhe o único artigo que analisa uma cena de Lacombe ${ }^{3}$. O debate sobre a cena do esparadrapo de Pascal Bonitzer é o centro da representação política do filme. Trata-se da única sequência na qual Lucien está num ambiente de tortura. O preso procura estabelecer um contato com ele, apelando para os bons sentimentos franceses. Ao pedido de soltura, Lucien responde apenas que não gosta de ser tratado por "tu". Para encerrar de vez a conversa, ele coloca um esparadrapo na boca do resistente e depois preenche o contorno dos lábios com um batom.

Para entender a polêmica em torno de Cahiers em Opinião, é preciso abrir um parêntese para esclarecer a metodologia de Pascal Bonitzer. Antes de chegar ao filme, ele explica ao leitor sua ferramenta de trabalho: o mecanismo de enunciação no cinema aplicado à crítica. $\mathrm{O}$ procedimento garante ir além da denotação para não cair na cilada do conteúdo. É neste nível que se esconde a armadilha ideológica de Lacombe, porque o discurso de Malle permanece apenas no comportamento denotado de Lucien. O trabalho do crítico é acrescentar sentidos e exibir o conteúdo latente da cena através da conotação, porque esta não esconde que "a verdade é um processo de construção", explica o crítico francês.

Para Bonitzer, a cena tem um posicionamento político implícito e revela o procedimento narrativo do filme para comunicar sentido. Na sequência, o prisioneiro age como representante do espectador, preocupado com a inserção de Lucien na história. Ele pede para o personagem demarcar sua posição política. Mas Lucien não responde ao nível do enunciado da demanda (me solte), mas ao nível da enunciação

\footnotetext{
${ }^{3}$ (Foction critique). Histoire de sparadrap. Cahiers du Cinéma. n. 250, maio 1974.
} 
(porque você me chama por tu?). A transferência seria uma forma de Malle se esquivar do significado político ao se concentrar somente no significante e na preocupação neurótica de Lucien em ser uma autoridade.

A consequência é uma hesitação do público entre vários sentidos contraditórios para explicar o personagem, comenta Bonitzer. Seria uma forma de infantilismo, inconsistência política, inocência ou aborrecimento com a política? É por estas vias que Malle explica o comportamento de Lucien somente na denotação, no caso, na questão familiar. Ele está em busca de um pai e encontra a função no pai substituto judeu. Portanto, para Bonitzer, a história é simplista e a única ferramenta de análise histórica do cineasta é a psicologia.

Há um ponto em comum entre a conclusão de Cahiers com a metodologia geral de Opinião: a correlação entre o personagem e a postura do diretor, mais exatamente com sua classe social e visão de mundo. Malle seria um cineasta burguês que dissemina a ideologia dominante. Esse tipo de argumentação era muito comum no jornal brasileiro, como vimos anteriormente. Ao invés de denunciar os regimes fascistas, o cineasta na onda retrô teria, por exemplo, uma fascinação pelo nazismo quando aglutina política e erotização. Daí a inclusão do filme nesta tendência. Se parássemos por aqui, estaríamos realmente perto de Opinião. Contudo a diferença é que Cahiers explica o como. O percurso argumentativo para a resposta não é nada curto. Para Serge Daney, “as contradições de classe em Malle não são nada além de contradições, tornadas assim acidentais, particulares e ahistóricas" ${ }^{4}$. O tratamento dado à rivalidade entre as classes sociais, no caso o camponês e a família judia de classe média, é o da eterna ambiguidade do homem. Com essa estratégia o diretor anula a luta como dado pacífico. Para Daney, Malle se esforça para tratar Lucien como um bárbaro inconsciente, incapaz de pensar e agir sobre processos históricos. Assim, a postura esconderia o nazismo como um fator político. Ele seria visto como algo natural porque é parte da perversão e do instinto humano. Incomoda à revista que Louis Malle não explicite seu discurso sobre o tema político e adote a solução explicativa da psicologia. Se a naturalização inocenta Lucien e esconde a visão de mundo do diretor, ela gera também uma crença na possibilidade de encontrar toda a verdade do personagem.

\footnotetext{
${ }^{4}$ Fonction critique. Cahiers du Cinéma, n. 250, maio 1974.
} 
O que Cahiers exigia de Louis Malle, afinal? Primeiro desmontar o sistema de representação nazista. Depois realçar o questionamento da formação discursiva do personagem pelo ponto de vista do cineasta, afinal a luta política deve aparecer na enunciação, na escolha dos temas e na forma cinematográfica. Esperava-se por um nível maior de opacidade para os leitores poderem procurar pelos significados não revelados via conotação. Trata-se de uma defesa do cinema moderno que se revela enquanto discurso.

Sérgio Augusto toma o filme para discutir as metodologias da crítica de cinema e para atacar a nova fase política da revista, tudo isso num jornal de resistência ${ }^{5}$ :

"Por ser um filme feito de "complexo e radical humanismo fora das rotineiras bitolas ideológicas do nosso tempo', conforme o definiu com implacável lucidez Paulo Francis, Lacombe Lucien entortou a cabeça de muitos críticos, sobretudo daqueles excessivamente presos às tais bitolas ideológicas. Nos atuais Cahiers du Cinéma, fase semiomarxista, Pascal Bonitzer procurou desmontar e pulverizar os 'artifícios' do filme através da cena em que Lucien se diverte sadicamente colorindo o esparadrapo que colocou sobre a boca de um prisioneiro maquis sob sua vigilância. Pouco antes, o prisioneiro apelara para os eventuais bons sentimentos de Lucien (...), mas ao seu pedido de soltura, o jovem torturador a serviço da Gestapo responde com um desabafo: 'Não gosto que me tratam por tu'. Segundo Bonitzer, se Lucien tivesse respondido sim (ou não) à súplica do prisioneiro em vez de explicar sua repulsa às intimidades do tuteio, a cena ganharia um mínimo de sentido político, pois se teria dado mais importância ao significado (soltar ou não) do que ao significante (a necessidade neurótica de respeito).

Fatalismo burguês - A análise prossegue, nesse nível de discussão, atirando denotações contra conotações, numa hábil acrobacia semiológica, para concluir que o objetivo claro de Louis Malle é culpar a História (sair pela tangente, 'fatalismo burguês') dos irresponsáveis procedimentos de Lucien durante a Ocupação da França pelos nazistas."

Pensando na linha editorial política de Opinião, é digno de nota deixar de lado exatamente as preocupações políticas e ideológicas. Segundo Augusto, Louis Malle privilegiou a temática psicológica do personagem rústico, separada do aspecto político. Recebeu críticas porque abordou de "maneira apolítica" e psicológica a cumplicidade de alguns franceses durante a Ocupação. Augusto resume bem aos leitores os argumentos de Cahiers, mas exclui o motivo da publicação enveredar pelo estudo político e

\footnotetext{
${ }^{5}$ Augusto, Sérgio. Um filme perigoso. Opinião. n. 133, p. 21, 23 maio 1975.
} 
ideológico, por discordar dele ${ }^{6}$. Bonitzer não deixou de lado o viés psicológico, só foi além dele. Augusto procura desabilitar a metodologia da revista quando se refere às diversas matrizes utilizadas pela linguística na revista como a semiologia, a teoria da enunciação sob o manto de um "semiomarxismo". No fundo há uma fuga é da temática política. Se Sérgio Augusto deixava de lado o componente ideológico, a estratégia não passou despercebida por um leitor que graças ao episódio se tornou colaborador do jornal: Clóvis Marques.

Augusto posiciona-se ao lado dos "liberais", como Pauline Kael. Ambos frisam o infantilismo do personagem idiota e apolítico com sede de poder. A preferência é, na verdade, pela psicologia como critério de análise fílmica. Contudo, Pauline Kael (1994: 260) na New Yorker envereda por uma linha voltada a Stanislawsky. Elogia o uso do ator da roça para interpretar o camponês Lucien porque ele "reage aos fatos com sua própria inocência, apatia e argúcia animal”. Cahiers veria a argumentação como uma forma de acreditar na naturalização, porque a autora não está nem um pouco preocupada em separar o discurso do personagem da narração do filme.

A grandeza do filme, para Augusto, seria ir contra o imperativo político da onda de Cahiers. Como o advogado de defesa que Malle não teve em Cahiers, ele elogia a postura do cineasta de não historicizar a idiotice rural:

"Malle não pretendeu aproveitar a lavagem de roupa suja sobre o mau comportamento dos franceses durante a Ocupação (...) para fazer seu rol de culpas e traições. Seu objetivo era dar curso a um estudo etológico da comunidade rural francesa no segundo semestre de 1944, ajustando o foco na primitiva psiquê de um camponês de 17 anos. (...) E ao redor de suas nervuras psicológicas construiu esta heresia: um filme amoral, tão amoral e bonito quanto o desconcertante Le Souffle au Coeur (Sopro no coração) (...).

Malle abstêm-se de historicizar a 'idiotice rural' francesa e a culpa, em parte, não é dele mas da incompatibilidade de se juntar profundidade analítica e riqueza psicológica, em satisfatória convivência, num filme de duração e ambições comerciais canônicas, sem graves fissuras na sua estabilidade ficcional. (...).”

O argumento dá conta de uma brecha interessante: a escolha de Louis Malle. Afinal não é possível "juntar profundidade analítica e psicológica ao mesmo tempo".

\footnotetext{
${ }^{6}$ Relembrando o episódio, Augusto declara bem humorado que detestou na época o texto de Bonitzer, que faz uma análise que ele até acha interessante.
} 
Segundo Augusto, para evitar o problema em torno da identificação com o nazismo, Malle optou por utilizar atores desconhecidos. Contudo, o rosto desconhecido do ator não evita por si só a identificação, afinal a cena final humaniza Lucien.

Assim o artigo evita adentrar no processo de construção do discurso do filme. $\mathrm{O}$ crítico não esconde o risco e o desafio "perigoso" da chave psicológica com fuga do político num personagem amoral, que não recebe julgamento no final. Termina o texto com a declaração que gostou da bela heresia amoral, porque o personagem é apenas um idiota apolítico com sede de poder ${ }^{7}$.

Duas semanas depois, o então leitor Clóvis Marques decide enviar uma carta à redação de Opinião para discordar de Augusto ${ }^{8}$. A preocupação inicial era explicar aos leitores a metodologia de Cahiers:

\begin{abstract}
"a escolha da revista é a seguinte: avaliar a intervenção que o filme exerce no contexto social em que é produzido e consumido; nuances psicológicas, procedimentos dramáticos, recursos formais são elementos de que o discurso fílmico se vale, deliberada ou 'inconscientemente', para veicular uma ideologia, com repercussões sociais que se pretende apontar".
\end{abstract}

Dissecar a configuração política ideológica do filme, tais as palavras evitadas no texto anterior. O objetivo da carta é rebater a metodologia de Sérgio Augusto e se alinhar ao padrão de Cahiers. Para Clóvis Marques, trata-se de uma questão de escolha dos críticos. Augusto preferiu aproximar-se da psicologia. Kael até pode ter entendido bem a mensagem de Malle, mas Bonitzer foi além. Verificou como Malle disse e porque o amoralismo do personagem esconde uma armadilha ideológica. Marques explica aos leitores que Bonitzer não excluiu o determinante psicológico, mas o enquadrou num âmbito mais abrangente:

"A laudas tantas de sua brilhante review de Lacombe Lucien, Sérgio Augusto diz que, "por se tratar de um filme impecavelmente nuançado do ponto de vista psicológico (...), as melhores observações a seu respeito não vieram da ala ortodoxa dos

\footnotetext{
${ }^{7}$ Augusto declara que utilizou de Marx a análise do idiota rural, aquele que pode virar qualquer coisa, comunista, nazista, quando entra na onda.

${ }^{8}$ Marques, Clovis. Louis Malle, um amoral em questão. Opinião dos leitores. Opinião. n. 135, p. 24, 06 jun. 1975.
} 
semiomarxistas mas de críticos liberais como a americana Pauline Kael (...), que pegou a essência do que Malle, não importa se equivocadamente, pretendeu e conseguiu dizer". O grifo é meu e pretendo apontar o que julgo ser uma incoerência na colocação de Sérgio Augusto. (...)

O importante é que Sérgio Augusto não ignora que Pascal Bonitzer está se lixando para o "complexo e radical humanismo fora das rotineiras bitolas ideológicas do nosso tempo' (justamente porque ele, Bonitzer, sabe que nenhum discurso, e muito menos o cinematográfico, é imune à ganga ideológica) e para a 'riqueza psicológica' do filme. E apesar disso parece sugerir que o 'semiomarxista' não alcançou a 'complexa' proposta do filme, quando o que se deu foi uma escolha: a de um ponto de vista, que não se detém em considerações psicológicas.

Mas onde me parece que a incompreensão se patenteia é no trecho citado e grifado acima. Porque depois de passar todo o seu artigo tentando justificar a distanciada 'isenção' do cineasta, (...), Sérgio Augusto, em quatro palavras faz baquear sua argumentação. Reconhece que Malle pode, afinal de contas, ter assumido uma posição equivocada em sua criação, que é, nada mais nada menos, o que o crítico francês tentou provar. Pauline Kael pode ter compreendido muito bem $o$ que o cineasta quis dizer, ou mostrar: 'a bronca inconsciência ideológica do personagem, seu infantilismo', Bonitzer há de ter recebido também este recado, como todos nós, mas não parou aí. Ele foi verificar como Malle disse, ou seja, como e porque, entre outras coisas, o seu amoralismo poseur esconde uma armadilha ideológica.

(...) o articulista dos Cahiers não falhou em sua compreensão do filme. Apenas, passando por cima de determinantes (psicológicas) que pretende enquadrar num âmbito mais abrangente (político ideológico), ele vai mais longe. Sérgio Augusto prefere ou julga mais satisfatória, evidentemente, uma abordagem humanista-liberal. Ótimo. É seu direito. Mas tenho a impressão de que justifica mal sua escolha quando chama de bitolada, (...). É responder à acrobacia semiológica com o malabarismo retórico.”

Assim Marques fecha sua argumentação ao lado da nova fase de Cahiers. Há um elemento no artigo dele que conseguiu passar incólume tanto por Augusto quanto por Cahiers. Indo além da maneira de pensar de ambos, ele consegue ver uma discussão política através da utilização da psicologia e da ambiguidade:

(...) Mas me parece que abordar um tema político como a ocupação (...) e sair pela tangente do caso clínico é uma atitude de calculada provocação, comme pour épater le marxiste, sem a qual o seu filme seria apenas mais um entre tantos requintados produtos do melhor cinema de autor. E não causaria polêmica."

Este argumento não aparece em Cahiers. Marques explica que a utilização da psicologia é uma forma de provocação, porque o cineasta toma um tema político e sai pela tangente. Provocação no sentido de tratar um tema caro aos franceses, como a ocupação, sem o viés político mais comum. Trata-se de uma nova forma de ver 
Lacombe. Os dois críticos de Opinião não estavam preocupados com a onda retrô e o perigo de Malle como cineasta burguês. Ambas as publicações tinham no período uma postura militante e o desejo de intervir na sociedade. As discussões sobre Lacombe em Cahiers formam uma voz uníssona entre seus críticos, sem contradições e fissuras. Enquanto isso, Opinião abriu espaço para um pensamento divergente com destaque. Ao contrário, Cahiers manteve uma política editorial homogênea ao longo de um ano. Há um único precedente: a entrevista de Michel Foucault sobre a onda retrô ${ }^{9}$. A comparação entre as duas publicações mostra que os críticos de Opinião acompanhavam de perto os novos caminhos de Cahiers, mas só um deles concordava com a nova trajetória. Mas no geral as similitudes não significaram uma aliança enquanto postura editorial.

\footnotetext{
${ }^{9}$ Ver o item sobre Gustavo Dahl no capítulo 3.
} 


\subsection{Sacco e Vanzetti: cinema político ou melodrama de tribunal?}

Não foram poucas as polêmicas entre os críticos do jornal com o público ou com o meio cinematográfico. A comparação entre Ainda agarro essa vizinha (1974) de Pedro Rovai com Os Condenados (1973) de Zelito Viana rendeu a Jean-Claude Bernardet um artigo amargo do produtor Miguel Faria Junior ${ }^{10}$. E uma carta anônima de um certo D. Autumm contestando não só a comédia erótica, mas a defesa da dublagem dos filmes estrangeiros ${ }^{11}$. Umberto Dias reclamou que Jean-Claude Bernardet não deu mais espaço para seu filme, $O$ anjo negro (1972) ${ }^{12}$. Se as controversas com Bernardet envolviam geralmente o meio cinematográfico, Sérgio Augusto conseguiu atrair cartas não só dos especialistas, mas dos leitores. Jairo Ferreira reclamou da falta de espaço dada a seu filme, O guru e os guris (1972) ${ }^{13}$. Paulo Emilio Salles Gomes saiu em defesa de Paulo Duarte após um comentário de Augusto sobre seu livro, Humberto Mauro, Cataguases, Cinearte ${ }^{14}$.

De todas as polêmicas com os críticos, a maior em quantidade de cartas envolveu Sacco e Vanzetti (1971) de Guiliano Montaldo, porque Sérgio Augusto tomou a obra como um falso filme militante. O tema era por si só controverso desde os anos vinte. Trata-se do processo judicial verídico de dois imigrantes italianos, o sapateiro Nicola Sacco e o peixeiro Bartolomeu Vanzetti, condenados à cadeira elétrica nos Estados Unidos pela acusação de realizar um atentado anarquista no mesmo período. $\mathrm{O}$ caso suscitou muitas declarações de protesto da imprensa e de homens públicos em várias cidades ao redor do mundo. Durante o processo, a participação dos réus não foi comprovada, acendendo uma dúvida se a execução foi causada pelas ideias políticas anarquistas dos dois, e não pelo delito que culminou com a morte de duas pessoas. A produção era considerada um filme político de esquerda em todo o mundo e foi censurada logo após a estreia ${ }^{15}$. Sacco e Vanzetti é visto por Sérgio Augusto como um filme "didático" 16.

\footnotetext{
${ }^{10}$ Murao, Carlos. A pornochanchada contra a cultura culta. Opinião. n. 99, p. 23, 27 set. 1974. Faria Junior, Miguel. Cultura culta x pornochanchada. Opinião. n. 101, p. 24, 11. out. 1974.

${ }^{11}$ Autumm, D. O cinema e a máquina de lavar. Opinião dos leitores. Opinião. n. 118, p. 24, 07 fev. 1975.

${ }^{12}$ Dias, Humberto. Exu, cão, gente, sete trovões. Opinião dos leitores. Opinião. n. 14, p. 22, 05 a 12 fev. 1973.

${ }^{13}$ Ferreira, Jairo. - 'Por que não ver melhor?'. Opinião dos leitores. Opinião. n. 59, p. 23, 21 dez. 1973

${ }^{14}$ Gomes, Paulo Emilio Salles. Em defesa de Paulo Duarte. Opinião dos leitores. Opinião. n. 82, p. 11, 03 jun. 1974.

${ }^{15} \mathrm{O}$ artigo de Sérgio Augusto é publicado durante a estreia no Brasil, mas naquela mesma semana, no dia 20 de junho de 1973, o general Antonio Bandeira baixou uma portaria proibindo a exibição de dez filmes,
} 
Esta afirmação de Augusto resume com uma frase uma série de procedimentos relacionados ao melodrama. Ele não entra em detalhes no texto, mas o tom didático do filme ajuda a excluir totalmente a culpa dos acusados. Com certeza, não se trata de uma produção aberta à reflexão do espectador, porque o diretor deixa de lado literalmente as incertezas sobre o caso. Sacco e Vanzetti é feito sob medida para humanizar e vitimizar os personagens. A divisão entre personagens é maniqueísta. Além disso, o filme abusa das cenas de comoção das esposas chorando e da trilha sonora em tom de ode sobreposta às imagens apresentadas como documentais. Por outro lado, seria possível pensar que esse tipo de produção tivesse maior efeito junto a um determinado público, já acostumado ao melodrama. Contudo, nenhum crítico de Opinião admitiria essa possibilidade, por causa da preferência conjunta pelo cinema autoral. Todos condenam as produções melodramáticas "esquemáticas" e fechadas a leituras diferentes. O motivo da polêmica foi o público tomar o comentário sobre a opção pelo melodrama como um ataque frontal ao cinema político.

Augusto começa o artigo com uma contextualização histórica para provar ao leitor a quantidade de dúvidas sobre a inocência ou responsabilidade dos acusados até a atualidade. Deixando de lado todas essas dúvidas, Montaldo partiu da "certeza" da inocência e utilizou o tom de documentário como prova de veracidade. Apelou ao sentimentalismo, a certeza de inocência dos anarquistas e ao maniqueísmo:

“(...) Guilano Montaldo começa a contar a sua versão do processo, com o falso ar de documentarista deformado pelas paixões do sectarismo. Sacco e Vanzetti não é como prometeu o cineasta, um filme didático sobre um caso complicado e sim uma defesa simplista e parcialíssima de dois anarquistas.

Montaldo parte da certeza de que, além de inocentes, Sacco e Vanzetti foram vítimas de um sistema diabólico disposto a apelar, se necessário, à corrupção de seus mais altos valores (no caso, a Justiça) para punir os seus inimigos. Um argumento de partisan (o que diminui bastante o interesse e o valor de sua obra) e insustentável quando se sabe que a inocência dos dois jamais foi provada de forma irrefutável."

que já tinham sido liberados pela Divisão de Censura. O de Montaldo integrava a lista, encabeçada por filmes de grande prestígio cultural e artístico. Sacco e Vanzetti permaneceu interditado por seis anos, até 1979, embora dois censores tenham votado pela sua liberação, porque a revolta contra o julgamento injusto, segundo eles, não fazia paralelo algum com o Brasil (Simões, 1999).

${ }^{16}$ Um melodrama de tribunal. Opinião. n. 20, p. 21, 19 a 26 mar.1973. 
Na continuação do artigo, Augusto explica como Montaldo manteve intacta a impressão de veracidade histórica. Ao invés de tentar produzir uma obra aberta com ambiguidades, o diretor preferiu criar heróis planificados num mundo corrupto com certezas falsas:

(...) Entre as 'certezas' de Montaldo está o crime de Braintree: ele o reconstitui com o requinte de uma testemunha ocular, ao passo que coloca fora de foco a visão do mesmo crime oferecida pelas personagens identificadas como as verdadeiras testemunhas oculares. A honestidade exigia do diretor, no mínimo, uma posição pirandelliana. Com uma retórica semelhante à dos suspenses-políticos de Costa Gravas - gênio da moda e que não passa de um subproduto de velhos policiais de Hollywood, liberalóides ou não - Sacco e Vanzetti é tão comprometido com a verdade histórica, ou com os autos dos processos, quanto as biografias romanceadas de heróis da pátria. As aparências não enganam: as cenas 'fingindo documentário' do começo e do fim não chegam para fazer o espectador mais atento se esquecer de que o resto foi rodado a cores exatamente por razões de glamour. E descamba-se para o mais deslavado melodrama de tribunal, em que tudo é permitido, desde excessos de "coincidências" (...) ao maniqueísmo gagá: quem está ao lado dos réus é bom; quem está contra é desumano ou imbecil."

Não podemos afirmar que Sérgio Augusto busque a veracidade histórica como os críticos faziam com esse tipo de produção. Ao contrário, ele condena indiretamente a utilização da impressão de realidade com o próprio parâmetro da veracidade histórica. Ele enfatiza as provas documentais porque toda a discussão sobre Sacco e Vanzetti se baseia nestes termos. $\mathrm{O}$ arcabouço foi necessário porque o debate sobre a veracidade histórica emerge como tema central sobre a construção fílmica.

Observando a recepção do público, talvez tenha faltado explicar mais uma vez aos leitores o motivo da condenação ao melodrama para esclarecer quais eram os parâmetros estéticos em pauta. Apesar do tom maniqueísta, o filme não provoca um sentimento total de passividade, porque não existe uma justiça poética que pune os vilões no final, como há na filmografia de Costa-Gravas.

Montaldo tenta causar indignação no espectador. No cinema clássico ou no melodrama deve-se partir de um tipo de identificação primária do espectador com os personagens para gerar indignação ou espanto. Todavia, Sacco e Vanzetti inverte o procedimento padrão entre personagem, plateia e indivíduo. José Carlos Avellar (Prudenzi, 2006) disseca a dualidade entre a complexidade da estrutura de identificação 
e a estrutura dramática simples entre heróis e bandidos do filme. O espectador é colocado num esquema de identificação com os personagens, porque ambos são forçados a permanecer sentados, imóveis e calados no meio da cena, sem poder participar do júri. Também Sacco e Vanzetti são reduzidos a meros observadores de seu julgamento, compartilhando o sofrimento com o público. Ao tornar mais complexa a identificação entre personagem e espectador, a projeção muda de sentido. Não parte dos personagens diretamente para o espectador, como é comum. Ao contrário, ela passa pela intermediação com a plateia do tribunal, permitindo assim a identificação do público que também está numa posição imóvel.

Avellar observa no filme de Montaldo uma estratégia que permite a participação do público. Segundo ele, o espectador é o centro e protagonista da narrativa durante todo o tempo do júri. Esse processo permitiria ao indivíduo analisar sua própria condição. O mecanismo de funcionamento parte da composição da imagem sobre o ponto de onde o espectador vê a cena. Dessa forma, a construção fílmica apresenta-se como dependente do olhar do espectador.

A crítica de Sérgio Augusto a um filme considerado de esquerda acendeu uma polêmica na Coluna dos Leitores de Opinião. Havia um clima hostil até mesmo na redação de Opinião. Certo dia, Augusto encontrou um tradutor do jornal no caminho para o trabalho. Após os cumprimentos, ele disse sem meias palavras que não tinha gostado nada do texto. Se ele fosse o diretor do jornal, o teria demitido. "Era a esquerda raivosa dogmática", explica o crítico. Augusto considerou este episódio um dos mais importantes de sua passagem pelo veículo. Por causa da censura, a resposta foi escrita "pisando em ovos", mas foi publicada, como veremos. O ex-editor lamenta porque não pôde dar uma merecida resposta aos leitores, porque a censura prévia baixou de novo naquela semana. O segundo texto dele sequer foi publicado. O conteúdo era mais abrangente, desconstruindo não só o cinema de esquerda, mas a estética da direita.

A base de contestação dos leitores baseou-se na comparação entre a bibliografia sobre o caso original e o filme de Montaldo ${ }^{17}$, ou seja, na ideia de que o cinema deve ser fiel à literatura e à história. Três leitores o condenam com esse critério, enquanto um quarto foge do esquema e consegue admitir o tom açucarado do filme ${ }^{18}$. O leitor José

\footnotetext{
${ }^{17}$ Sacco e Vanzetti, um debate. Opinião. n. 23, p. 2; 23, 9 a 16 abr. 1973.

${ }^{18}$ Veloso, Carlos Alberto. "Vanzetti inocente e Sacco culpado? Opinião dos leitores. Opinião. n. 22, p. 2, 02 a 09 abr. 1973.
} 
Luiz A. da Silva chama Sérgio Augusto de "minicrítico ahistórico e apolítico", e o condena por seu envelhecimento político. Julga conhecer o "espírito do jornal" que não condiz com o tratamento dado pelo crítico: “(Opinião) não tem o direito de nos impor, já que não nos dá outra opção, (...) alguém que coloque o cinema acima de suas implicações sociais". A frase destacada no subtítulo indica uma determinada visão sobre a arte. Ele não aceita a presença de um crítico que passe por cima dos cânones da esquerda e pense o cinema fora da política num jornal da resistência. No texto, a política está acima das questões estéticas e o cinema é apreendido na dependência do fator social; não como arte autônoma.

Qual o problema do filme para o leitor José Luiz da Silva? Uma "violência" porque "todo o sentido foi deturpado. Sacco e Vanzetti merecia uma análise "mais adequada, ou seja, profunda". Indiretamente há a defesa de um determinado tipo de cinema. O leitor elogia o tom didático na exposição dos assuntos do jornal, vendo quase uma obrigação nessa continuidade com o filme. Portanto, ao invés de abrir indagações, o missivista quer certezas, exatamente como Montaldo. Por isso ele elogia o lado didático e a "clareza" na "ligação entre a Justiça e 'os princípios do (classe dominante) Estado". Aqui o cinema serve de ilustração política esquematizada: Sacco e Vanzetti é "a própria história do capitalismo". A ideia de deturpar o sentido parte do pressuposto de que a crítica deve revelar uma verdade na narrativa, iluminando o leitor. Exigir um artigo mais adequado ou profundo é uma clara tentativa do público de influenciar o gosto do crítico numa coincidência de preferências, como ocorre nas resenhas vinculadas à propaganda. $\mathrm{O}$ que muda aqui é o tipo de propaganda, no caso, a política de esquerda.

José Luiz da Silva não aceita que o crítico não leve em conta a cultura política engajada e não estenda os elogios a Montaldo por ter seguido essa temática. É como se Augusto sofresse com esse texto um processo de retaliação dentro da própria imprensa alternativa. Ele teria tido a "honra" de entrar para a resistência, mas não fez por merecer: "tal crítico não honra a oportunidade que lhe é dada e destoa excessivamente dos demais articulistas". Isto é, prefere pensar o cinema alheio à "realidade", fora da cultura política de esquerda. O missivista vê o crítico como um peixe fora d'água na esquerda. Um dos trechos revela grande preconceito. Augusto comentou o suicídio de Andrea Salsedo como afirmação categórica, não como dúvida. Então, o leitor contesta a 
afirmação e vaticina: "Suicidou-se? Quem lhe dá tanta certeza? Talvez para você todo socialista seja um suicida em potencial".

A argumentação do leitor parte de duas linhas de raciocínio diferentes. Dependendo do argumento, o missivista questiona Sérgio Augusto por declarar ter certeza dos fatos, quando não há comprovação científica e histórica. Depois, tenta provar "outras" convicções, quando as afirmações lhe convêm. Ele descontextualiza e inverte as frases de Sérgio Augusto, partindo sempre, por incrível que possa parecer, do imperativo da veracidade histórica.

Semelhante é o raciocínio do leitor João Carlos Corriandre. Acusando Augusto de não ter lido o livro inteiro, recomenda sua leitura para ter "instrumental básico para analisar o filme" e conseguir "entrar com o pé direito na História e nas observações corretas". Ou seja, para ele o cinema é apenas uma ferramenta para o estudo da história, longe da ideia de que o cinema independe da fidelidade à literatura. $\mathrm{O}$ missivista apela também ao critério da veracidade histórica para comparar Sacco e Vanzetti ao filme $O s$ Inconfidentes (1972). O paralelo é feito através do uso da poesia de Cecília Meirelles e de sua adequação ao filme histórico. Segundo Corriandre, o filme de Joaquim Pedro "teve maior relevância" porque modificou "detalhes da história real". Contudo, o leitor expõe sua argumentação ao lado da veracidade histórica e acaba menos inclinado aos Inconfidentes. Para provar a superioridade de Montaldo, Corriandre recorre às próprias declarações do diretor:

"Meu filme está engajado numa realidade mais universal, na medida em que foi concebido como um discurso rigorosamente motivado no terreno histórico, onde nada se inventou e tudo se baseia numa documentação autêntica. Certamente o filme trata de sintetizar os dados e reelaborá-los à luz de um juízo ético-político que não se conforma em descrever os fatos de um modo impressionista.

Montaldo está coerente com a visão citada acima, a respeito da conotação histórica. Ele ainda foi mais puro não inventando nada que não tivesse base na documentação autêntica. Segundo ele, o filme reelabora os dados dentro de um critério ético-político, não se conformando na pura e simples descrição dos fatos."

A comparação é muito explícita. O filme de Montaldo é melhor porque parte de uma certeza histórica dada, enquanto Joaquim Pedro quer falar sobre o presente, usando como recurso o passado. A frase não oferece espaço para o espectador questionar e 
refletir sobre o passado representado. Vale pontuar também que num primeiro momento Sacco e Vanzetti é apresentado como "documentação autêntica" pelo diretor, mas na frase seguinte se fala em "reelaboração" com juízo "ético-político". Ou seja, a ficção se permite uma reinterpretação ou reconstrução, caso seja política e ética. Ao perceber a brecha na argumentação, o leitor explica que Montaldo foi "mais puro não inventando nada que não tivesse base em documentação autêntica". Numa contra-argumentação, ele tenta ocultar a ausência de fidelidade histórica dos fatos por causa do critério éticopolítico. Portanto, cai por terra a tese da veracidade histórica defendida antes. Trata-se de uma crença na possibilidade de acesso ao real e no documento histórico, oposta a que encontramos em Jacques le Goff (1998) ${ }^{19}$.

Essa não é a única incongruência argumentativa do texto. Para o leitor, Augusto não pode apontar erros históricos porque não estava presente no local do crime. Portanto, a argumentação poderia se estender a Guiliano Montaldo, que também não testemunhou os fatos. É como se o missivista tivesse assistido a outro filme, bem mais aberto às dúvidas. Observando o próprio filme, percebe-se que o diretor exagerou no uso dos flashbacks para inocentar os personagens. Quando Montaldo cola nos réus sem duvidar, há certo endossamento. Esse foi exatamente o motivo da condenação de Augusto.

Corriandre baseia-se até na lei dos tipos, quando comenta as proporções perfeitas entre o ator e o personagem. Uma das palavras utilizadas pode indicar um conhecimento da nova fase de Cahiers, quando ele se refere ao trabalho com a conotação histórica de Montaldo. Para ele, a função dos críticos é analisar o cinema política interditado porque esse tipo de produção fala sobre nossa realidade. Tudo é dito indiretamente. Segundo Corriandre, os críticos (leia-se Sérgio Augusto) só têm contato com o subproduto de Hollywood, não com os bons filmes. Assim eles assumem um "novo eu profissional" e modificam sua visão de mundo. Isto é, Corriandre acusa Augusto de sair da crítica política e retroceder à estética.

\footnotetext{
${ }^{19}$ Le Goff opõe o conceito de documento e monumento. Os monumentos são criados para transmitir uma determinada herança do passado. São, portanto, marca de poder com a intenção de edificação. Já os documentos eram vistos pelos historiadores no passado como uma escolha do historiador. Le Goff mostra que todo documento é um monumento, porque também foi fabricado para perpetrar uma determinada visão de si ao futuro. Ou seja, também envolve as relações de poder com a sociedade. Assim, cada documento é ao mesmo tempo verdadeiro e falso porque se trata de um instrumento de poder.
} 
Há uma segunda motivação por detrás da acusação dos leitores. A forma de apresentação dos dados. Na maior parte do texto, o crítico reconstrói os fatos a partir das provas, com ampla bibliografia e documentos históricos. Reveste-se como de costume pela imparcialidade da pesquisa. Traz todos os pontos de vista e enfatiza os contraditórios. O ponto de atrito parece ser o final do texto, quando Augusto indiretamente aponta para uma única certeza. Ele explica que se os acusados são inocentes, os anarquistas provavelmente têm alguma culpa. É esse argumento o ponto de atrito com os leitores. O dado parece irrefutável e se baseia na declaração do próprio advogado de defesa na vida real. Quando ele estava bem perto de descobrir os verdadeiros criminosos, o comitê anarquista mandou parar a pesquisa. A informação pesa bastante na argumentação do artigo. Além disso, o estudo de balística sobre Sacco feito na época também parece irrefutável. Quando desloca a argumentação para os especialistas e para essa documentação, o artigo fornece certezas, embora esteja totalmente de acordo com as normas do jornalismo de apresentar todas as versões disponíveis. A esquerda não engole Augusto quebrar um de seus mitos.

Para rebater as críticas, Sérgio Augusto utiliza a mesma linha de raciocínio dos leitores: a veracidade histórica e a falta de ambiguidades da história ${ }^{20}$. Cita as páginas de onde tirou suas frases e insiste em sua linha de argumentação. Muito irônico, afirma que dispensa as pretensiosas lições entre forma e conteúdo e pede desculpas por não parecer lukacsiano, afinal não é necessário ter conteúdo para um filme ser bom. Para ele, Sacco e Vanzetti é "uma produção política" para a "classe média". Atacando indiretamente esse público, declara que a polêmica "provinciana e estéril" não o espantou, porque só participaram dela pessoas devidamente instruídas sobre o caso. Realmente pelos comentários é possível observar o quanto os missivistas conheciam todos os detalhes da história, incluindo até a bibliografia em inglês. Por fim, Augusto completa sobre a questão da utilidade da arte:

\footnotetext{
"Meus críticos acreditam, com um fanatismo religioso, que toda arte é ou deve ser utilitária, ponto de vista discutível na medida em que faltam dados históricos para provar a eficácia desse utilitarismo. Eu, pessoalmente, gostaria que um filme tivesse a força de um contingente policial, mas ainda não tive a ventura de chegar ao Shangri-lá".
}

\footnotetext{
${ }^{20}$ Polêmica provinciana e estéril. Opinião. n. 25, p. 2, 23 a 29 abr. 1973.
} 
A declaração de Sérgio Augusto sintetiza o debate dos leitores à questão do utilitarismo da arte e sua dependência da política, mostrando a necessidade de explicar ao público a função estética do cinema e sua autonomia das demais produções culturais. Para ele, o valor e interesse de uma obra diminuem bastante por causa dos argumentos partidários.

A polêmica com os leitores foi motivada pela ideia de veracidade, naturalismo e impressão de realidade no cinema. Ela possibilita observar como e o quanto as ideias do próprio jornal repercutem na coluna. Por exemplo, os críticos de Opinião revelam muitas vezes aos leitores a fabricação da realidade nos filmes históricos, quebrando a noção de veracidade histórica ${ }^{21}$. Contudo, os missivistas não defendem somente a fidelidade à literatura, mas buscam no cinema clássico a "verdadeira" representação do processo histórico. Preocupados com a impressão de realidade, eles reinvertem os significados do artigo de Sérgio Augusto. O debate revela como alguns leitores preferiam ainda as estratégias do melodrama político.

Quando olhamos as seções de cartas, percebemos o longo caminho para o entendimento dos leitores. Antonio Gramsci (1968) já tinha feito referência à dificuldade de colocar em prática o Jornalismo Integral ${ }^{22}$ na área cultural. Sob o risco de ser muito técnico e pouco inteligível, o jornal deve fazer sempre retornos aos conceitos básicos, mesmo arriscando a repetição constante, porque sempre há um público não-proficiente. Neste caso, os leitores não conseguiram incorporar os novos conceitos explicados. Insistem na veracidade histórica, na defesa do cinema clássico e no imperativo político para o cinema. Preferem, mesmo, os filmes de esquerda mais melodramáticos e estendem esse critério a todo o jornal.

Finalizamos com a crítica de José Carlos Avellar sobre o lançamento de filmes políticos no Jornal do Brasil ${ }^{23}$. O objetivo do crítico é analisar o que dizem os filmes políticos pós década de sessenta. Ele considera Sacco e Vanzetti uma "reconstituição em estilo dramático tradicional do erro judicial e das pressões políticas que levaram a morte" dos dois anarquistas. O crítico não está preocupado em condenar a produção

\footnotetext{
${ }^{21}$ Para maiores detalhes sobre o filme histórico na imprensa alternativa, ver Adamatti, Margarida Maria. Crítica de cinema e política: o filme histórico nos jornais alternativos Opinião e Movimento. Anos 90. Porto Alegre. v. 19, n. 36, p. 173-198, dez. 2012.

${ }^{22}$ Sobre o jornalismo integral ver o item Crise ou reelaboração do intelectual? no capítulo 5. O Jornalismo Integral pressupõe a formação de uma consciência crítica ao leitor, através de exemplos concretos nos jornais.

${ }^{23}$ Avellar, José Carlos. Cinema Político. Jornal do Brasil. p. 36, 24 mar.1973.
} 
pela caracterização de melodrama ou elogiar algum outro que opte pelas regras do cinema moderno. Prefere tomar por ponto de partida as citações do livro Cinema $e$ Política de Leif Furhammar e Isaksson Folke (1976) para mostrar que o cinema não existe num estado de sublime inocência, porque o conteúdo político inconsciente está sempre presente. Assim qualquer filme sempre foi e sempre será político.

No artigo, Avellar explica a diferença entre Godard e Costa-Gravas, sem emitir um juízo de valor de forma explícita. Primeiro, esclarece que Godard foge do esquema de ilusão da realidade porque quer revelar a repressão social via linguagem cinematográfica tradicional. Esta costuma dificultar uma tomada crítica de posição do público, por isso o cineasta evita a estratégia. E insere o leitor na concepção de CostaGravas de cinema político que é:

"feito ao menos para influenciar os espectadores através da informação. É necessário usar o espetáculo de forma tradicional, construção dramática e utilização de atores para que as pessoas se sintam ligadas e sintam que o filme serve para alguma coisa. $\mathrm{O}$ público tem em geral interesse em sofrer com alguém na tela do que assistir às imagens comentadas e ser obrigado a refletir sobre uma situação real".

Sem condenar Costa-Gravas pela utilização do melodrama, da construção dramática e do sentimento de justiça poética presente na filmografia dele, Avellar procura adotar um tom neutro. Contudo, ele não se furta a fazer um breve comentário sobre a diferença entre os dois tipos de cinema, clássico e moderno, mas sem combater as bases destes dois. Ou seja, não censura o "hermetismo" de Godard, como se costumava fazer, nem considera Costa-Gravas um "subproduto" de Hollywood. Afirma que "boa parte dos filmes políticos ainda esbarra numa fórmula de espetáculo inadequado para a perfeita compreensão de seus temas". A maioria "se perde na procura desordenada por uma nova fórmula para ter um ponto de vista crítico”. Contudo, Avellar considera o saldo dos dois tipos positivo, porque até mesmo "os filmes parcialmente realizados" contribuem para "destruir a falsa ideia" de que política não é para as pessoas comuns. Ou seja, neste caso Avellar foi além da mera defesa do cinema moderno, adequando o conteúdo e estética ao tipo de público. Se o texto fosse publicado em Opinião, provavelmente a neutralidade política em relação ao cinema político também desse o que falar aos leitores. 


\subsection{Ensina-me a viver e o direito à autonomia da crítica de cinema}

Seis edições antes de publicar o artigo sobre Sacco e Vanzetti, Sérgio Augusto escreveu uma crítica a Ensina-me a viver (1971) de Hal Ashby ${ }^{24}$. Se os comentários passaram em branco pelos leitores, o mesmo missivista José Luiz A. da Silva não tardou a lembrar-se dos elogios ao filme de Ashby durante a polêmica envolvendo Sacco e Vanzetti. O objetivo era descredenciar Sérgio Augusto por suas preferências hollywoodianas ${ }^{25}$. A condenação do leitor revela muito sobre a presença de uma cultura política engajada. A história de amor entre uma idosa e um jovem com tendências mórbidas é tomada como "profundamente reacionária", porque o movimento hippie apresenta-se como forma de "combate" à sociedade americana, mas é apenas um "subproduto capitalista". Por detrás do argumento se vê a produção hollywoodiana como apolítica simplesmente por seu lugar de origem. $\mathrm{O}$ intuito de Ensina-me a viver seria ideológico: fazer o público esquecer a real situação de exploração dos homens. A realidade apresentada pela trama, segundo ele, é totalmente alheia à nossa. Mas José da Silva não aplica o mesmo critério para falar de Sacco e Vanzetti. No fundo, o leitor está comparando a ação individual e liberta dos personagens com o contexto de cerceamento à liberdade de expressão no Brasil. A prova do caráter reacionário está somente numa frase de Maud: "se você quiser cantar? Cante! Se você quiser gritar? Grite!". José da Silva explica que o filme esconde do público que a ação do indivíduo depende também do fator social. Ele quer dar um recado bem claro sobre a falta de liberdade política no Brasil, mas a argumentação não pode se completar.

Para esse tipo de filme, José Luiz da Silva não admite nenhum elogio da crítica de cinema brasileira, muito menos de um crítico da imprensa alternativa. Se Augusto defende uma produção sem conteúdo político, mais um pouco ele seria tachado de direita por não questionar o indivíduo à frente do social. Por vias bastante escorregadias, o missivista apresenta o crítico como um fascinado por Hollywood, que destoa do padrão do jornal.

\footnotetext{
${ }^{24}$ Augusto, Sérgio. O Love Story do Protesto. Opinião. n. 14, p. 20, 05 a 12 fev. 1973.

${ }^{25}$ Silva, José Luiz A. da. Sacco e Vanzetti - um debate Opinião dos leitores. Opinião. n. 23, p. 2; 23, 09 a 16 abr. 1973.
} 
José Luiz da Silva é mais um exemplo de leitor bem sintonizado com o vocabulário do momento. Ele fala em cinema contestatário (Amengual, 1975) e estabelece uma linha de continuidade entre o termo e o crítico brasileiro: "O movimento hippie é (...) subproduto da sociedade capitalista, não a melhor forma de combatê-la, apesar de contestatário (é provável que se o Sérgio Augusto lesse diria: 'mas quem disse em combatê-la'?)." Para ele, tanto o filme quanto o crítico brasileiro fingem contestar a cultura americana, para fortalecê-la. É inconcebível para José Luiz da Silva que Sérgio Augusto desconsidere o debate em torno da ideologia e aprecie Ensina-me a viver mesmo com todo o caráter contestatário.

Em resposta ao leitor, na mesma seção de cartas, Sérgio Augusto admite ter sido "excessivamente condescendente" no texto, porque o filme de Hal Ashby é mais "afetado" do que "significativo e politizado". Pede desculpas pela crítica "paternalista", mas considera Harold e Maud ${ }^{26}$ arte "para a classe média" ${ }^{27}$. Ele admitiu ter sido "implacável com as apelações sensacionalistas e as liberdades históricas tomadas por Montaldo", porque se trata de um "falso filme de esquerda" (Camargo, 2009). A revolta teria partido dos leitores "ideologicamente estreitos".

O comentário negativo de José Luiz da Silva tem como destino o tom encantado pelo cinema americano desengajado. Contudo, o artigo de Sérgio Augusto estrutura-se na oposição constante entre analisar a opção de engajamento e o encantamento cinéfilo. O movimento textual traz sempre dois argumentos em direções opostas. Ele faz ao mesmo tempo o papel do advogado de defesa e do promotor. Sem nunca retirar sua subjetividade, o texto deve ser lido nestas lacunas e nas diversas hesitações com ressalvas.

As palavras utilizadas dão conta dessa dualidade porque ele observa os dois lados. Portanto, a cada elogio dado, há uma crítica negativa embutida. Assim ele define Ensina-me a viver como um "filme de contestação romântica", o "Love Story da contracultura". Contestação romântica não significa louvor, porque é fuga da ação para dar conta do sentimento de evasão aos valores capitalistas. Para o padrão de Opinião, o correto não seria a palavra contestação, mas um filme contestatário. Em seguida, a comparação com Love Story (1970) de Arthur Hiller também não traz um sentido

\footnotetext{
${ }^{26}$ Augusto refere-se ao filme com o título original.

${ }^{27}$ Augusto, Sérgio. Polêmica provinciana e estéril. (Opinião dos leitores). Opinião. n. 25, p. 2, 23 a 29 abr. 1973.
} 
positivo, porque o filme é um melodrama daqueles de arrancar lágrimas do espectador. Um Love Story da contracultura é por si só uma antinomia. Se a contracultura subverte, como pode ser ao mesmo tempo um produto do próprio sistema? É na sutileza desse meio termo que a expressão define bem Harold e Maud.

Os comentários negativos veem logo em seguida: os cineastas da Nova Hollywood se imitam mutuamente com temas como conflitos de gerações, consumo, psicanálise, amor eletrônico, patriotismo, etc. Augusto denomina essa nova safra de "cinema de protesto sujeito à exploração comercial", incapaz de alterar as "consciências esclerosadas" com suas "fórmulas de empatia contaminadas pelos bacilos de Hopper \& Lelouch". O problema é "incontornável" e "insuportável". Os temas da Nova Hollywood seguem a linha a "juventude é quem manda". Os comentários apontam o quanto essa produção significa um retorno à direita. Assim Sérgio Augusto resignifica a palavra protesto. O sentido é irônico e aparece entre aspas: se todos os "cineastas de protesto" americano continuarem se imitando mutuamente por mais cinco filmes, "a ala esquerdista da primeira fila terá o direito de pedir de volta as colonizações comandadas por John Wayne. Elas, ao menos, não pediam para ser levadas à sério”.

A conclusão dele é que Ensina-me a viver "dá suas cutucadas discretamente". Contudo "alguns aspectos não acrescentam nada de novo à discussão, como a abordagem à psicanálise", explica. Então o crítico se pergunta: até quando "o cinema Estabelecido-que-combate-o-Estabelecimento ficará nos cutucando as nossas costelas como se dizendo 'olha só que plano poético?'”. Portanto, Augusto prova que se o filme critica as "formas dominantes", o objetivo é somente contemplativo. Há aqui quase uma descrição de um cinema contestatário que finge fazer críticas, mas não pode completálas porque depende do próprio sistema. Jamais essa produção irá alterar as estruturas ou as consciências, com ele mesmo diz. O artigo todo é regido pela ideia de apontar algo positivo, e logo em seguida, fazer diversas restrições.

Os dois elogios de Sérgio Augusto ao filme citados pelo leitor José da Silva realmente existem. Nesses momentos, o crítico procura se colocar fora da sociedade para julgar melhor, mas no movimento seguinte coloca em cena sua subjetividade. $O$ artigo é um bom exemplo da dualidade entre a busca de autonomia da arte em relação à política e a auto-colocação do crítico no texto. Augusto sempre coloca em debate suas próprias preferências. Portanto, ele constrói um artigo paradoxal sobre Ensina-me a 
viver. No primeiro elogio, ele aponta que naturalmente a "maioria dos espectadores sairá encantada com Harold and Maud”:

"o filme de Higgins-Ashby possui um feitiço especial, tão especial que a gente só descobre seus pontos frágeis depois. Na atual conjuntura me parece difícil e pouco recomendável deixar de estimar um manifesto tão apaixonado, eufórico e divertido em favor da vida, da liberdade, da generosidade e da espontaneidade como este".

Quando o crítico se refere ao "feitiço especial", a palavra tem dois desdobramentos. Feitiço pode ser tomado quase como fetiche, numa postura de ocultação da ideologia, ou seja, assistimos ao filme e só depois percebemos os pontos obscuros. Por outro lado, o termo pode revelar parte do encanto cinéfilo pelo cinema hollywoodiano. Atento à demanda do público, diferente do que faziam os críticos de Opinião, Augusto completa:

"Se minha bola de cristal ainda estiver regulando, prevejo para Harold e Maud (...) uma carreira excepcional por conta de seu romantismo revisto e atualizado às necessidades da atualidade, de seu humor negro (...), de sua insolente má vontade com as forças dominantes (da mamãe burguesa ao farisaísmo institucionalizado de nossa estimada sociedade cristã-ocidental - etc.) e, sobretudo, por conta de dois personagens encantadoramente estranhos e meia dúzia de outros deliciosamente odiosos."

O crítico observa no filme um jogo de forças contrárias entre uma crítica às formas dominantes e um produto feito e atualizado às necessidades do mercado. É neste ínterim entre mercado e cultura que Augusto analisa a obra. Ele sabe muito bem que Ensina-me a viver não se encaixa no projeto ideológico do jornal, na resistência ou no engajamento, mas ousa quebrar esse imperativo em nome do bom cinema. Augusto se permite num jornal da resistência fazer a defesa do conteúdo e do tom otimista pela vida. Exercita uma crítica paradoxal e irônica, é verdade. Por esses motivos a postura foi tomada pelo leitor como provocativa e indigna do jornal onde ele escrevia.

As polêmicas em torno de Lacombe Lucien, Sacco e Vanzetti e Ensina-me a viver, todas elas centradas em Sérgio Augusto, apontam ao mesmo tempo para dois debates sobre autonomia: a autonomia da arte frente à política e o direito de escolha do crítico de cinema. A tensão com o público é gerada porque Augusto cumpre a função de defender a autonomia da arte num jornal onde a cultura política engajada é muito forte. Geralmente, os missivistas veem qualquer manifestação contrária aos fins políticos 
como provas de alienação. Há, inclusive, uma quase exclusão do direito de subjetividade do crítico e quase um desprezo à polissemia da arte (Adorno, 1973). Se no início do século, Ricciotto Canudo lutava pela legitimação artística do cinema; no contexto da resistência, parecia aos missivistas da seção Opinião dos Leitores um retrocesso a reafirmação da autonomia da arte.

Sérgio Augusto firma-se em Opinião como o crítico que não se deixa subjugar ao imperativo político, exatamente num jornal da imprensa alternativa. O debate possibilita repensar o papel das vanguardas formalistas na tradição da arte engajada. Segundo Marcos Napolitano (2011), ele precisa ser revisto. Se a entrada no debate político pela intelectualidade significa uma luta pelo direito à discussão estética (Bourdieu, 1996), o problema começa quando essa luta ocorre dentro de um jornal de resistência. Sérgio Augusto não está interessado em debater a forma dos filmes como parte da política, porque seu critério metodológico é outro. Isso não significa um desprezo pela política como elemento criador, mas uma preferência pela discussão do próprio cinema.

Ao comentar os filmes, Sérgio Augusto exige o direito à subjetividade e se apoia na autoridade conquistada no campo artístico contra a moralidade do conteúdo político de esquerda. Ele sintetiza a descrição de Bourdieu (1996) sobre a dualidade entre arte e engajamento do intelectual. Entra na discussão política em nome da autonomia da arte (Ver Capítulo 5). O movimento destes três textos retoma um debate do século XIX, quando a arte afirmava sua autoridade contra o imperativo político e em oposição aos defensores da arte social ${ }^{28}$.

Portanto, quando os leitores de Opinião retornam ao imperativo político e moral da arte, eles indiretamente retomam essas premissas, talvez em sintonia com os ideais da Frente Ampla ${ }^{29}$. Com essas ideias na cabeça, recaía sobre Augusto quase um crime pela "audácia" de desafiar os preceitos da esquerda, majoritários no jornal. É como se nestes casos ele cumprisse em Opinião o papel de um phármakon, como o representante da matriz estética na resistência. A exigência tem relação com o lugar de origem do

\footnotetext{
${ }^{28}$ Pierre Bourdieu explica que nestes momentos, haveria uma libertação da arte de sua função social, moral ou política. Haveria também um desprezo em relação a qualquer tipo de serviço ou responsabilidade da arte à sociedade. Rompendo com convenções e utilitarismo, a luta era pelo direito à reação subjetiva e a invenção intelectual feita de maneira livre.

${ }^{29}$ Sobre as Frentes de Opinião ver introdução.
} 
debate: a imprensa alternativa. Assim Augusto converte-se num bode expiatório da esquerda quando ousa defender a arte acima do imperativo político.

O critério artístico por si só (Bourdieu, 1996) está calcado na noção de gratuidade, desinteresse, ausência de função e primado da forma. Há nas missivas uma quase oposição ao conceito de beleza definido somente pela satisfação estética. Para a matriz política dos leitores, a crítica estética tem uma concepção idealista e conservadora que mantém as estruturas de poder e ignora as condições de produção (Ginzburg, 2012). A postura deixaria de lado as tensões históricas e os conflitos sociais. Os leitores não aceitam a ideia de um conhecimento desinteressado do cinema americano, porque ele indicaria um afastamento das preocupações sociais. Contudo, Sérgio Augusto não caiu nesses pressupostos. Ele procurava os antagonismos da realidade na forma ou temática do filme, sem deixar de lado o contexto de produção.

Estamos aqui longe de querer afirmar a primazia de um dos núcleos, mas demonstrar suas metodologias. Se o polo engajado despreza a discussão da arte pela arte, há ainda uma preocupação de ordem moral com o destino dos homens, que é condenada pelo núcleo estético (Bourdieu, 1996). As formulações dos leitores de oposição à arte pela arte condenam a constituição de uma essência universal feita à custa de uma des-historicização da obra, porque ela ignora o contexto social e as condições de produção. No fundo, a ideia de valor remete a cânones nunca explicitados (Bourdieu, 2007). Com essas transferências, o valor aparece muito mais como substância, e não como atribuição ou construção social. Os missivistas procuravam historicizar o cinema feito em Ensina-me a viver, Lacombe Lucien ou Sacco e Vanzetti. Ao enfatizar o contexto social brasileiro, a consequência da historicização é deixar de ver a produção como contemplação desinteressada de objetos artísticos.

Contudo, esse núcleo também esqueceu em alguma medida de historicizar suas próprias referências. É mais fácil para a matriz política condenar o ornamento, a ausência de função, a procura pela forma, etc. Quando os leitores declaram a necessidade de uma função social ao cinema, a política torna-se uma essência, isto é, um valor em si mesmo que nunca é explicitado. Tudo sob o imperativo da resistência. Essa essência é definida pela busca de um conteúdo nacional, popular ou pela presença da realidade nas imagens. A mise en scène sai de cena e no seu lugar fica o nacional na forma de uma essência, nunca historicizada. Portanto o polo político faz um movimento pendular. Ele foge da arte pela arte, mas volta para outra essência: o cinema nacional. 
Há uma dificuldade para historicizar algumas preferências do jornal, não só na coluna dos leitores. Por exemplo, a predileção pelo Cinema Novo (ver Capítulo 5). Sua qualidade nunca é definida, quase compondo uma essência. Mesmo sem acreditar numa noção de cópia do real, a crença na possibilidade de acesso à estrutura da sociedade brasileira, mesmo feita com a noção de discurso, às vezes transforma-se numa essência. Uns conseguem tocá-la, outros a distorcem. No fundo, não se questiona que a preferência por alguns autores indique na verdade o cinema autoral. Existe também um desprezo pelo gosto popular e pelo conteúdo simplificado do cinema político de esquerda que esconde uma eleição da arte "superior". No fundo, o jornal quer mesmo é levar a arte ao público. Por todos esses motivos, Opinião defende o Cinema Novo como união entre estética e engajamento.

Para fugir da condenação feita ao polo oposto, a matriz política deveria historicizar mais suas preferências. O processo significaria deixar o leitor a par das lutas internas pelo poder de nomeação entre o Cinema Novo e o Cinema Marginal. Significaria também criar um debate auto-reflexivo sobre a constituição do campo cultural e da própria illusio (ver Capítulo 5). Nestes casos, haveria a possibilidade de explicitar a escolha por um ponto de vista político como projeto editorial. Esse ponto de vista quase se transforma num imperativo universal do jornal, se não fossem aparições como as de Sérgio Augusto, como indícios de pluralidade. Explicitar as preferências significaria explicar ao leitor as escolhas, não como cânones, sejam elas a do cinema clássico ou do cinema moderno, sem instituí-las como verdade em si. Em Opinião, o estudo sobre a historicidade só é feito para os inimigos. Parte desse processo começou no jornal, por exemplo, quando Júlio César Montenegro, Ronaldo Brito, Jean-Claude Bernardet e Luís Costa Lima discutem jornalismo cultural colocando em debate o próprio jornal (ver Capítulo 6). Contudo no geral, Opinião não coloca sob questão os valores culturais nos quais acredita. A luta interna só aparece até certo ponto, sem deixar de reproduzir a illusio. Afinal é mesmo difícil colocar em xeque a própria instituição cultural a qual se pertence. 


\subsection{Tempos Modernos e tempos de fissuras na esquerda}

O relançamento de Tempos Modernos (1936) de Charles Chaplin gerou o mais extenso debate sobre cinema na seção dos leitores. O primeiro comentário surgiu pelas mãos do futuro editor-chefe Argemiro Ferreira ${ }^{30}$. Se Chaplin era o artista rebelde que não se negava a falar das causas políticas nos anos trinta, agora ele é um "conformista", "envelhecido intelectualmente". Negou as motivações políticas do passado e declarou sem meias palavras que queria mesmo era ganhar dinheiro com os filmes. Para entender essa mudança, Argemiro narra a trajetória de Chaplin contra o establishement americano e absolve o artista do passado. Foi somente o octogenário que mudou de discurso, após receber um Oscar.

Três semanas depois, o cineasta João Batista de Andrade envia uma carta para a seção de leitores de Opinião para contestar a reputação de cinema político de Tempos Modernos ${ }^{31}$. Pecebista, na época ele trabalhava na televisão e colocava em prática a estratégia frentista de ocupar os espaços, como veremos. Anos depois, ele condenou o stalinismo no PCB. Contudo, na carta sobre Chaplin, o cineasta se desloca discursivamente para a outra ponta. Portanto, trazemos a carta para pensar no debate surgido no jornal, não para tirar maiores conclusões sobre o pensamento de Andrade.

Andrade acusa o filme de ser "extremamente reacionário" e refletir "uma visão ultra-alienada da realidade". Haveria também uma visão distorcida do progresso. As máquinas aparecem como as grandes culpadas pela opressão e deixam o sistema incólume. É como se João Batista não acreditasse no poder da metonímia e exigisse de Chaplin se concentrar apenas no conteúdo denotado para atingir o público. Portanto, as declarações do Chaplin octogenário contaminaram para ele a obra dos anos trinta.

A argumentação gira em torno do tratamento dado aos operários. Ele não aceita a cena na qual Carlitos joga óleo no rosto dos colegas de fábrica. Eles correm atrás dele e se transformam em vilões "para o nosso consumo de mito". A consequência é tratar os operários com imbecilidade, grossura e brutalidade. Eles não obtêm espaço na história e são reduzidos a uma função dramática. Ao brincar com operários e máquinas, os dois

\footnotetext{
${ }^{30}$ Ferreira, Argemiro. Lembranças de uma rebeldia. Opinião. n. 87, p. 18, 08 jul. 1974.

${ }^{31}$ Andrade, João Batista de. Opinião dos leitores - O mundo conservador de Charles Chaplin. Opinião. n. 90, p. 20, 29 jul. 1974.
} 
são convertidos apenas em brincadeiras. Seria possível ver em João Batista alguns traços de uma possível defesa do realismo, e quiçá de um realismo socialista (Rubim, 1987, 1988 a), mas em termos de estrutura significativa goldmaniana ${ }^{32}$. Eles estariam não só na defesa de uma temática social, mas no quase imperativo de engrandecer e dignificar os disciplinados personagens operários. João Batista de Andrade condena que o filme alimente a mitologia a respeito de Carlitos e deixe os proletários de lado: "Por exemplo, fortalecer o mito de Carlitos à custa da integralidade dos operários que ao lado de Carlitos, e sem micagens, fazem o trabalho acelerado e cáustico. Isso é preciso repetir". O correto seria o indivíduo carregar a carga do conflito coletivo. Por esse motivo, João Batista de Andrade não aceita a zombaria aos operários e a imagem de Paulette Godard encantada com casacos de pele numa loja. O argumento por detrás desse exemplo é simples: se a imagem é ambígua, ela não possibilita a quebra do mito. O ideal seria Paulette rejeitar vestir o casaco com seu orgulho de classe. Faltaria, nesse sentido, trazer o momento de politização dos personagens.

Estes últimos comentários sobre Chaplin apontam para direções contrárias em relação ao trabalho de João Batista de Andrade no período. Na maior parte do texto é possível traçar continuidades com as defesas da Frente para a área de cinema. Naquela época, ele trabalhava no noticiário da TV Cultura, A hora da notícia. O próprio trabalho na televisão, ao lado do também pecebista Vladimir Herzog, significava parte de uma proposta de ocupar o mercado com uma visão contrária ao discurso oficial. Segundo o próprio Andrade (Caetano, 2010), o projeto se baseava no reencontro e ocupação dos espaços perdidos pela intelligentsia numa proposta de ação política a longo prazo. Se Batista de Andrade defendia a proposta frentista de ocupação do mercado, o mesmo não acontecia com a defesa do realismo. Ele fazia parte do PCB, mas estava longe de colocar em prática o realismo no trabalho diário. Na televisão, Batista de Andrade usava constantemente a justaposição do ponto de vista oficial e popular para construir novas significações. A escolha das temáticas explicitamente políticas e sociais do noticiário eram parte de um embate político militante (Caetano, 2010). Anos antes, o cineasta tinha feito o filme marginal Gamal, delírio do sexo (1969), numa direção oposta a sua trajetória. Naquela época, João Batista de Andrade rejeitava Gamal - delírio do sexo (1969) em nome dos imperativos políticos do Partido e do Cinema Novo.

\footnotetext{
${ }^{32}$ A estrutura significativa goldmaniana é o resultado de um complexo esforço coletivo de grupos sociais, não de uma estrutura mecânica fixa. Ver capítulo 2.
} 
João Batista de Andrade condena Chaplin com uma premissa que já era velha conhecida do jornal: a necessidade de desmistificar o mito, politizando à esquerda seu conteúdo. Afinal, "todo mito tende a ser conservador", diz ele. A análise concentra-se no enredo do filme. Carlitos está entre os operários sem ser operário. Ele é preso sem ser criminoso. Depois prende os colegas da cadeia sem ser policial. Batista explica que convém ao mito estar acima de todas as coisas. A leitura chega até a última cena na qual o personagem relembra a necessidade de ser feliz e dar a volta por cima. João Batista vê a imagem como uma fuga do conteúdo coletivo para o individual. Ele não realça a ambiguidade e beleza na alegria triste da sequência, após a desilusão com a expectativa de melhora de vida. Sua leitura é outra: há uma "sublimação do mito". Os dois estão acima de todos e resolvem não mais brincar. Mandam o mundo às favas e dão às costas, tendo em vista as montanhas ao fundo, talvez um "paraíso onde o mito é soberano e pode ser mito em paz”. “Aqui, na terra, as coisas continuam como estavam”. Isto é, para João Batista, o filme não propõe uma solução para os problemas da classe operária.

$\mathrm{O}$ artigo procura encontrar um prolongamento entre a declaração do Chaplin octogenário da matéria de Argemiro Ferreira e o conteúdo do filme. Relaciona a classe social do diretor com o enredo e a composição dos personagens. Em síntese, Chaplin é visto como prolongamento de Carlitos. $\mathrm{O}$ argumento por detrás dessa linha de raciocínio é ver em Chaplin um cineasta contestatário, que finge atacar a ideologia, para ganhar dinheiro com o tema. Não se trata também da tentativa de localizar brechas e fissuras na produção hollywoodiana, como fizeram Jean Louis Comolli e Jean Narboni (ver Capítulo 3). Na verdade, o texto vê a produção americana determinada pela ideologia. Com uma ideia na cabeça, o missivista não olha para o material fílmico. Andrade vê Tempos modernos como a ilustração de uma visão política dada a priori.

Opinião publica ao longo de várias edições seis cartas de defesa a Chaplin, todas contrárias a João Batista de Andrade. Procuramos aqui relacionar o debate a algumas premissas da Frente Cinematográfica de Opinião que aparecem no texto, seja por via de uma estrutura significativa, de maneira consciente ou inconsciente. Chaplin é uma unanimidade como modelo de cinema político para os leitores. Se alguns textos do jornal (como vimos) tendem a ver o discurso hollywoodiano determinado pela ideologia, os leitores seguem o trajeto inverso quando o assunto é Chaplin. Eles procuram por fissuras porque observam que o conteúdo de Tempos Modernos não condiz com o referencial de análise do jornal para a produção norte-americana. 
Lembrando-se de diferentes cenas do filme, quase todos os leitores procuram explicar a metonímia da máquina como representante da "própria configuração material do capital”, como fez José Afonso Primo ${ }^{33}$. O debate explicitou matizes entre os leitores. É possível encontrar de tudo no jornal, até um possível encontro de uma brecha do pensamento de direita com a esquerda, no radicalismo do bancário Aristides Nogueira ${ }^{34}$. Ele sugere que Batista de Andrade deixe o cineasta inglês de lado e se ocupe do conservadorismo de Glauber Rocha e de Ruy Guerra. O motivo do desafeto é a declaração elogiosa de Glauber Rocha a Golbery e Geisel na revista Visão (Ver Capítulo 5). "O tão decantado papa do Cinema Novo, tido e havido como progressista, em nossa opinião é tão somente um notável contrabandista, que conseguiu passar ideias bem reacionárias como coisas até revolucionárias." A frase pode ser vista como uma ala da esquerda irada com a aproximação entre cinemanovistas e Estado (ver Capítulo 5). O leitor se ateve à superfície externa do personagem de Antonio das Mortes, do filme Deus e o diabo na terra do sol (1964) de Glauber Rocha, como "apologia da repressão". Anos depois, em 1983, Ismail Xavier (2007) abordaria a dualidade do matador de cangaceiros como motor para a revolução.

Dois leitores trazem um elemento importante da Frente Cultural: a defesa de uma linguagem acessível ao público. Para José Roberto da Silva ${ }^{35}$, João Batista de Andrade fechou os olhos para o poder de comunicação dos personagens. Para ele, o mais importante no filme é criar uma linguagem que todos os espectadores entendem. Acima de tudo, Chaplin é "didático" e por isso mesmo "irrita um público esquerdoso que se define bem". Retirando do contexto a própria frase de João Batista de Andrade, ele explica esse público "esquerdoso" como "nós, da classe média", numa crítica bem pejorativa. Na mesma linha, Manuel Pessoa ${ }^{36}$ defende a comédia como possibilidade de atrair o maior número de espectadores. O missivista não cai no pressuposto de Batista, porque não pensa o diretor como prolongamento explicativo do filme. Quase vendo em Tempos Modernos um filme moderno, ele defende a obra por "induzir" o espectador a uma determinada leitura, no caso, vislumbrar algo de errado quando o sistema

\footnotetext{
${ }^{33}$ Primo, José Afonso. Charles Chaplin - por trás das máquinas. Opinião dos leitores. Opinião. n. 94, p. 24, 19 ago. 1974.

${ }^{34}$ Nogueira, Aristides. Carlitos, o beato Manuel e Corisco. Opinião dos leitores. Opinião. n. 94, p. 24,19 ago. 1974.

35 Silva, José Roberto da Silva. Tempos modernos - Carlitos, Lulu Massa e Militina. Opinião dos Leitores. Opinião. n. 95, p. 23, 02 set. 1974.

${ }^{36}$ Pessoa, Manoel. Carlitos - um lumpen inconformista. Opinião dos leitores. Opinião. n. 98, p. 20, 20 set. 1974.
} 
transforma o operário em escravo. Para Manuel Pessoa, nem as limitações hollywoodianas conseguiram cercear as denúncias do inconformista Chaplin. João Batista de Andrade aparece no texto quase como um cineasta ornamental, cujo comportamento conservador rejeita a realidade e a deixa intacta. No fundo, os missivistas referem-se a João Batista de Andrade como sintoma do "desespero" do "intelectual” naquele momento. Curioso é que o próprio cineasta definia Gamal como parte desse desespero do período, indicando talvez uma reciprocidade com os comentários da crítica de cinema sobre seu filme (Caetano, 2010). Talvez exista na argumentação não só uma breve referência negativa a Gamal, mas ao Cinema Marginal.

O debate interno da esquerda se intensifica quando entra em cena Leandro Konder ${ }^{37}$. Para ele, Andrade defende a arte "progressista" com "critérios naturalistas", isto é, a representação do operário não deveria ser por tipos. Se Chaplin seguisse o raciocínio de João Batista, respeitaria o proletariado e o mostraria trabalhando com "disciplina”. Konder aponta uma divisão da esquerda e conclui por fim que João Batista "é um sintoma do avanço dos critérios antirealistas no interior do pensamento estético atualmente majoritário entre nós". Indiretamente ele tematiza que o realismo cede espaço para outras concepções de intervenção direta sobre o material fílmico. Konder termina como uma provocação ao trabalho de Batista: se Chaplin tivesse ouvido os conselhos do cineasta brasileiro, teria feito um documentário sociológico ou uma peça de jornalismo cinematográfico. Teria descrito melhor a vida dos operários e suas rudes condições de vida, ao invés de "plasmar" a "verdade humana e social dos trabalhadores" em alguns "vigorosos" momentos "narrativos". A conclusão: não haveria vantagem artística e o filme deixaria de ser uma comédia, isto é, não alcançaria o público.

O debate termina com o artigo de mais um especialista na área. José Teixeira Coelho Netto aponta para a necessidade de discutir a técnica de representação de Chaplin ${ }^{38}$. Há uma mudança forte da temática do realismo dos textos anteriores para a defesa da metodologia brechtiana como forma de atingir o público. Teixeira Coelho escreve um texto muito didático sobre o épico e o efeito de distanciamento. Ele explica que Brecht considerava Chaplin o maior ator do mundo. Para Teixeira Coelho, o filme não trabalha com a noção de conflito, mas de contradição. Por isso, Carlitos não é herói

\footnotetext{
${ }^{37}$ Konder, Leandro. Tempos modernos - Carlitos, Lulu Massa e Militina. Opinião dos Leitores. Opinião. n. 95 , p. 23, 02 set. 1974 .

${ }^{38}$ Coelho Neto, J. Teixeira. Nem herói, nem vítima. Opinião dos leitores. Opinião. n. 98, p. 20, 20 set. 1974. Na época, Teixeira Coelho fazia mestrado na Escola de Comunicações e Artes.
} 
nem vítima. Sua característica fundamental é a ambiguidade. Ela impede o espectador de estabelecer um estado de empatia absoluto. Assim o público consegue avaliar criticamente as cenas. Numa delas, Carlitos pode ser vítima, mas no momento seguinte será carrasco de outra pessoa. Então o público tenderá a repudiar a identificação, pelo menos "teoricamente". Pensará sobre a cena real remetida pela cena artística. Com essa análise, Teixeira Coelho encerra o debate. Não era para menos. Com sua leitura, ele desconstruiu o debate ao colocar em pauta o método de representação.

Aqui é possível traçar um paralelo entre a linha argumentativa do artigo com a análise de Roland Barthes (2003) sobre Tempos Modernos no livro Mitologias. O teórico francês preenche as lacunas sobre a falta de politização do personagem, ao frisar sua ambiguidade. A leitura de Barthes é também brechtiana. Para ele, a representação da fome no filme é sempre épica, daí o tamanho desmedido dos alimentos. Tolhido pela miséria, Carlitos está sempre um pouco abaixo da tomada de consciência. Ele faz aflorar incessantemente a temática do proletário, mas nunca a assume politicamente. Cego e mistificado, ele é incapaz de alcançar o conhecimento das causas políticas. Segundo Barthes, talvez Brecht tenha sido o único a entrever a necessidade de a arte socialista considerar o homem na véspera da revolução. Isto é, mostrar o homem ainda cego, quando o excesso da miséria é iluminado pela revolução. Carlitos ostenta essa cegueira ao público. O espectador pode ver todo o entorno, mas vê alguém que nada vê. Essa é a melhor maneira de ver intensamente o que está fora do horizonte do personagem.

Se o debate em Opinião foi feito a partir de uma única obra, os textos apontam parcial e empiricamente para os vários caminhos da esquerda naquele momento. É possível ver na polêmica alguns traços de análise que lembram o meio termo comum da Frente Cinematográfica de Opinião, especialmente sobre qual linguagem cinematográfica seguir. No horizonte está a certeza de que a clareza de Chaplin leva uma mensagem política ao maior número possível de espectadores. Uns planificam a sociologia das visões de mundo e veem o personagem como prolongamento do diretor. Nestes casos, o cinema serve de ilustração política. João Batista de Andrade defendia nessa época o que Jean-Claude Bernardet (2003) define como "dramaturgia de intervenção". Pelos choques entre os depoimentos oficiais e os do povo, ele queria conscientizar o público e quase exige de Chaplin uma atitude semelhante. Outros tomam o filme quase num ideal frentista para atingir o público e para conscientizá-lo da situação social. É nesse sentido que a linguagem clássica do filme, a utilização da 
comédia e a conquista do público são realçadas. De todas as formas de pensar Tempos Modernos, essa foi a única que conquistou um espaço um pouco maior. Outros ainda exigiram de Chaplin um trabalho de imposição da fruição do público para fins de conscientização. Trata-se de uma defesa do cinema moderno, que na outra ponta trouxe Bertold Brecht para o debate. Outras linhas também apareceram no tema do realismo.

Embora fragmentada, a polêmica sobre Tempos Modernos revela que no campo do cinema as formas de realizar a resistência e de afirmar um cinema político não chegavam a um consenso entre o público, diga-se de passagem, muito proficiente. Se alguns críticos de Opinião defendiam o cinema moderno como construção por antinomias, os leitores não são um prolongamento desses textos. Os missivistas em geral tendem mais ao cinema clássico do que à inovação estética, talvez por gosto ou porque se trate de uma proposta de entendimento mais fácil.

A polêmica em torno de Tempos modernos reflete a abertura de pensamento da própria esquerda sobre o cinema político e a arte naquele momento. Em primeiro lugar estavam em pauta alguns pontos da Frente cinematográfica de Opinião: a discussão sobre a linguagem clássica e a defesa de obras com conteúdo acessível ao público. Como no caso da defesa de Sacco e Vanzetti pelos missivistas, há uma sutil preferência por um cinema didático com mensagem clara e sem ambiguidades. Em todas as cartas, o cinema aparece como imperativo político. Ninguém ousa defender a estética por si só. $\mathrm{O}$ debate revela uma tendência maior dos leitores pelos pontos comuns da Frente Cinematográfica de Opinião. Na verdade, a seção de cartas é um dos melhores espaços para acompanhar as polêmicas entre os atores sociais da resistência.

Observando as metodologias utilizadas pelos críticos e o contraponto dos leitores, fica claro que não há uma linha de continuidade entre ambos. Se alguns críticos defendem o cinema político e o moderno, o leitor mantém sua preferência pelo cinema de linguagem convencional. Talvez parte do público tivesse dificuldade em assimilar os conceitos do jornal ou simplesmente discordasse das preferências dos articulistas. Se os colaboradores tentavam desmistificar os falsos filmes de esquerda ou a produção melodramática, o leitor parece não partilhar dos mesmos referenciais. De qualquer forma, o debate nas seções de carta revela uma disputa acirrada entre a função do cinema, como ilustração política ou como campo autônomo. 


\section{Parte II - Crítica de Cinema e Frente Cultural: concordâncias e conflitos no campo cinematográfico.}

Temos que criar a legitimidade da discórdia, construir pela persistência a democracia, não só no Estado mas em tudo, obrigando, literalmente obrigando, os que não têm essa visão democrática a engolir a pílula. Naturalmente não sou criança nem provocador e não estou com capa preta. Não tenho nada além do que tenho a dizer. Não vou fazer nenhuma imprudência, mas é uma atitude tranquila de não-conformidade, firme. Em grande parte a autocensura é fruto do medo. Isso é justificado. Quem de nós não teve medo ou não tem ainda? Mas a gente tem que ir marcando, tateando, as fronteiras do possível. É uma luta entre a imposição de fora e a nossa vontade. O intelectual tem que estar na fronteira do possível. Mesmo que esteja aquém daquilo que ele pretenda - e no momento está -, ele deve tentar ampliar essa fronteira. Não acredito muito nas posições que põem entre parênteses o mundo. $\mathrm{O}$ sujeito fica calmo com a sua consciência e diz: 'Não concordo com isso, logo dou as costas.' Diga: 'Não concordo, não dou as costas e tenho que mudar.' A maior restrição à liberdade de criação não é externa, é interna. Depende de sermos capazes, termos imaginação e coragem de ir propondo questões. Questões que têm de ser incômodas. O intelectual ou é incômodo ou não é nada: em qualquer circunstância, em qualquer regime.

O intelectual é, por definição, um ser incômodo: pergunta, chateia. E ninguém gosta de responder a certas perguntas. (...).

Temos de alargar as fronteiras do permitido e tentar ampliar o grau de consciência da situação brasileira.

Fernando Henrique Cardoso in Visão n. 6 - ago. 1973 

Capítulo 5

Por dentro do discurso do Cinema Novo: Conceitos Movediços sobre o intelectual em Opinião

Assim, o intelectual é o homem que toma consciência da oposição, nele e na sociedade, entre a pesquisa da verdade prática (com todas as normas que ela implica) e a ideologia dominante (com seu sistema de valores tradicionais). Essa tomada de consciência - ainda que, para ser real, deva se fazer, no intelectual, desde o início, no próprio nível de suas atividades profissionais e de sua função - nada mais é que o desvelamento das contradições fundamentais da sociedade, quer dizer, dos conflitos de classe e, no seio da própria classe dominante, de um conflito orgânico entre a verdade que ela reivindica para seu empreendimento e os mitos, valores e tradições que ela mantém e que quer transmitir às outras classes para garantir sua hegemonia.

Produto de sociedades despedaçadas, o intelectual é sua testemunha porque interiorizou seu despedaçamento. É, portanto, um produto histórico. Nesse sentido, nenhuma sociedade pode se queixar de seus intelectuais sem acusar a si mesma, pois ela só tem os que faz. (...)

Não é, portanto, dizendo 'não sou mais um pequeno burguês, movimentome livremente no universal' que o intelectual pode se unir aos trabalhadores. É, justamente ao contrário, pensando: 'sou um pequeno-burguês; se, para tentar resolver a minha contradição, alinhei-me ao lado da classe operária e camponesa, não deixei por isso de ser um pequeno burguês'.

Jean-Paul Sartre in Defesa dos Intelectuais 



\section{Capítulo 5 - Por dentro do discurso do Cinema Novo: Conceitos Movediços sobre o Intelectual em Opinião}

O intelectual como arauto e o intelectual como intermediário neutro do processo cultural. Esses dois conceitos sintetizam os dois polos de pensamento sobre a função do cineasta brasileiro em Opinião. O capítulo 5 analisa as gradações entre os dois modelos e as motivações por detrás desse discurso. Este capítulo revela qual era o pensamento sobre a intelectualidade cinematográfica no jornal. Logo após o golpe militar, o conceito do intelectual à frente do processo cultural era central. Naquele contexto político, a intelectualidade enxergava para si mesma um papel central na resistência. A partir da revisão da cultura do nacional popular no final dos anos sessenta, começava o questionamento do papel do arauto como vanguarda de pensamento no campo cultural. A década de setenta corresponde a um período de crise sobre a concepção do intelectual. De porta-voz autorizado do povo, ele passava a ser cada vez mais questionado no interior do campo cultural. A própria ideia do intelectual que vai ao povo para conscientizá-lo entrava em crise. Na nova configuração, o intelectual apresentava-se como mero mediador das classes populares. O capítulo é dedicado à história da trajetória dos intelectuais-cineastas em Opinião. Avaliamos se o semanário acompanhou este debate da esquerda, abordando a crise do intelectual-crítico de cinema ou se permaneceu atrelado aos valores dos anos sessenta. O jornal está literalmente no meio do processo de questionamento do arauto e de transição para um novo modelo. Se o papel do intelectual era um dos pilares da Frente Cinematográfica de Opinião ${ }^{1}$, essas amarras são difíceis de desfazer porque a função do intelectual na resistência é central para o semanário. Algumas perguntas norteiam a questão. Qual a função que os críticos davam ao seu trabalho? O semanário colocava em xeque o intelectual arauto, sintonizado com os questionamentos internos da esquerda? Os cineastas e críticos abandonaram a postura de dirigente da cultura e de gerador de consciência?

O capítulo é dividido em cinco tópicos. Começamos pela mudança teórica sobre a função da intelligentsia. Abrimos o debate a partir do conceito de intelectual enquanto arauto da resistência (Napolitano, 2011, Aggio, 1998) que evoluiu no contexto político para o conceito do intelectual mediador neutro ou intelectual antropológico observado

\footnotetext{
${ }^{1}$ Sobre as Frentes de Opinião ver introdução.
} 
por Ortiz Ramos (1983). O estudo é feito pelo grupo cinematográfico que debate sua própria função na sociedade dentro de Opinião: os cinemanovistas. Observamos se o grupo do Cinema Novo alterava seu discurso às exigências dos novos tempos ou se permanecia atrelado ao ideal da década anterior. Nos depoimentos, os cinemanovistas refletem sobre as razões do declínio do movimento e sobre os pontos de conflito da resistência. Os envolvidos reconstroem não só a memória sobre o passado, mas também as significações políticas do movimento.

No segundo tópico, analisamos uma importante coletânea do jornal Dez anos de cinema nacional, que é sempre citada pela historiografia, mas nunca analisada de forma aprofundada. As declarações dos cinemanovistas em Opinião permitem observar os pontos de convergência e as fissuras entre o grupo sobre alguns pontos centrais da Frente Cinematográfica: o cinema comercial, o Cinema Novo, o Cinema Marginal, a ocupação do mercado, etc. Os cinemanovistas realizam um balanço autocrítico sobre o movimento à luz do momento de crise do papel do intelectual, num contexto muito importante, o ano de 1973 quando se saia do vazio cultural $^{2}$.

Se ainda em 1969, Cacá Diegues declarou pela primeira vez que o Cinema Novo tinha morrido, os cinemanovistas como um todo não chegavam a um consenso sobre o assunto. Tratamos desse assunto no terceiro tópico deste capítulo. O próprio jornal Opinião abriu uma discussão para analisar se o movimento tinha mesmo morrido ou se tinha ressuscitado. A discussão de Opinião estava sintonizada com um momento no qual toda a imprensa discutia o papel do Cinema Novo na resistência. A inquietação constante do semanário para descobrir se o movimento tinha mesmo acabado revela uma preocupação muito forte com o papel do intelectual e com a existência de um projeto cinematográfico. Trata-se, na verdade, de uma disputa sobre como fazer a resistência. Durante os anos setenta, o grupo deu diversas afirmações conflitantes sobre a continuidade ou não do Cinema Novo. Essas assertivas possuem um significado político importante, porque o grupo detém um projeto para o cinema brasileiro.

\footnotetext{
${ }^{2}$ O termo foi cunhado por Zuenir Ventura na revista Visão em 1971. Naquele momento, ele observou uma decadência cultural na produção do momento, causada tanto pelas perseguições da ditadura, quanto pela cultura de massa. A solução para superar o vazio cultural seria a cultura crítica, de produções como as do Cinema Novo. No mesmo ano dos depoimentos dos cinemanovistas em Opinião, em agosto de 1973, Zuenir Ventura observou algumas tentativas de enfrentar o dilema do vazio. Nesse sentido, as matérias em Opinião são indicativas desta transição. Ventura, Zuenir. A crise da cultura brasileira. Visão. v. 39, n. 1, p. 52-58, 05 jul. 1971. Ventura, Zuenir. Os impasses da cultura. Visão. v. 49, n. 6, p. 101- 130, ago. 1973.
} 
O pano de fundo dessa questão era pensar o Cinema Novo num novo contexto político de aproximação com o Estado autoritário via Embrafilme. Analisamos a relação entre os intelectuais e o Estado autoritário no quarto tópico. Por causa da aproximação entre cinemanovistas e o governo por causa da política cultural, teria recaído sobre este grupo a acusação de cooptação na imprensa. Para provar a adesão ao Estado, os pesquisadores utilizaram as declarações dadas ao Opinião. Destrinchamos as afirmações dos cinemanovistas a partir da especificidade do texto jornalístico.

Como se trata de um assunto daquela atualidade, a forma escolhida por Opinião para falar do papel dos intelectuais-cinemanovistas é a entrevista. $O$ formato proporciona um contato maior dos leitores com os realizadores, indicando um tema em construção. Se a entrevista geralmente é associada ao gênero informativo, o opinativo está presente mais ainda na introdução, servindo de crítica ou comentário. No geral, a entrevista permite que as opiniões apareçam como dados indiscutíveis; como fatos. É interessante observar o quanto Opinião desloca indiretamente o debate sobre a função do intelectual para as entrevistas dos cinemanovistas. Portanto, o estudo sobre a intelectualidade cinematográfica é feita por ela mesma. O jornal entrega a palavra aos próprios cinemanovistas para o debate sobre sua função na resistência. Essa lacuna opinativa de Opinião para escrever sobre a intelectualidade é muito significativa. A repassagem do espaço a determinados grupos indica uma possibilidade de preferências estéticas e políticas do próprio jornal. Portanto, o mais importante aqui é analisar se há uma incorporação das declarações dos cinemanovistas nos críticos. Se os críticos evitam analisar a função dos cineastas na sociedade como tema principal, o estudo deve ser feito na tensão entre o gênero informativo e o opinativo. Porque se trata de um jornal censurado, a função da intelectualidade na resistência está nesta lacuna entre os gêneros.

Fechamos o capítulo com as questões teóricas sobre a função da intelectualidade em Opinião à luz dos teóricos que se debruçaram sobre esse tema. Por fim, retomamos o caso do artigo de Jean-Claude Bernardet sobre Lição de amor para discutir a função do intelectual e observar como a tensão entre estética e política aparece no debate. $\mathrm{O}$ objetivo é concluir como a intelectualidade reunida em torno de Opinião na seção de cinema pensa um projeto estético e cinematográfico para o cinema brasileiro. 


\subsection{A função dos cinemanovistas na resistência: entre o arauto e o mediador neutro}

A tradição do intelectual como arauto da liberdade política e crítico do sistema dialoga com a tradição socialista (Napolitano, 2011). Milton Lahuerta (Aggio, 1998) recompôs parte do percurso histórico mundial em direção ao arauto em alguns marcos importantes como a Primeira Guerra Mundial, a Revolução Russa e a ascensão dos regimes fascistas. O contexto político levou a intelectualidade a refletir sobre o sentido de sua atividade. O conceito trazia junto a ideia de missão e uma chave para a identidade social do grupo através do imperativo ético. Na adesão às classes populares, o intelectual ambicionava formar a consciência popular como seu intérprete e mediador.

No contexto brasileiro dos anos sessenta, o conceito do intelectual como arauto era hegemônico entre a esquerda. A intelectualidade isebiana estava empenhada em se converter em arauto da consciência nacional (Mota, 2008) e essa leitura disseminou-se por todo o campo cultural. Com essa mudança, tanto os cineastas quanto os críticos de cinema encontraram uma missão social. Eles acreditavam em seu papel de instrumento de conscientização da sociedade, vendo a arte como forma ativa nas transformações sociais; não mais desvinculada do contexto. No campo específico do cinema nos anos sessenta, ampliou-se o processo do intelectual abandonar a postura de neutralidade e interesse somente sobre a mise en scène para pensar sua função dentro do debate político. Muitos deles acreditavam ter uma responsabilidade na construção da nação. Jean-Claude Bernardet (1978: 47-51) pensava "a transformação da crítica em arma e em instrumento de análise do cinema e da cultura brasileira”. Mais do que isso, o trabalho do crítico torna-se "uma verdadeira arma de combate que contribuirá para a evolução da cultura brasileira". Aqui a crítica é espaço de intervenção sobre a realidade. Enquanto isso, Glauber Rocha em Estética da Fome (Rocha, 2004: 65-67) definia em 1965 o Cinema Novo como um conjunto de filmes que "dará, por fim, ao público a consciência [grifo nosso] de sua própria existência”.

Esse conceito entrou em crise logo após o golpe militar na produção cinematográfica, quando os intelectuais do campo do cinema questionaram a própria postura, produzindo filmes como O desafio (1965) de Paulo Cesar Saraceni, Terra em Transe (1967) de Glauber Rocha e O Bravo Guerreiro (1968) de Gustavo Dahl. 
Naquele momento, a pretensão intelectual de aderir às classes populares e de levar à conscientização ao público entrava em crise.

Ainda em maio de 1965, Ortiz Ramos (1983) observou numa declaração de Carlos Diegues uma mudança discursiva sobre o papel do intelectual. Por causa do golpe militar, o cineasta sairia de uma postura de puro "intervencionismo social" e "crônica paternalista da sociedade" para uma "faixa antropológica" de "aprofundamento" da realidade. Nesse texto, Carlos Diegues fazia uma releitura do Cinema Novo muito diferente da proposta de Estética da Fome:

"O que sei é o seguinte: o golpe de abril correspondeu a um momento em que o cinema brasileiro se aprofundava, a uma faixa antropológica [grifo nosso] de aprofundamento na própria cultura do homem brasileiro, atrás de um absoluto que não é Deus mas é o absoluto das divindades da morte, da felicidade, da vida, etc., numa pesquisa que deixou de ser simplesmente descritiva, ou de representação, e passou a ser interpretação." 3

Diegues defendia no texto que o cineasta passava a agir como um antropólogo com profundo respeito pela cultura popular. Para Ortiz Ramos, a tese de Diegues foi deglutida lentamente nos anos seguintes. Tomamos a afirmação como parâmetro do início da mudança discursiva dos cinemanovistas sobre seu papel. Queremos observar se em Opinião o modelo de arauto realmente evoluiu na fala cinemanovista em direção ao intelectual mediador. Mais do que isso, procuramos analisar como o grupo faz para sustentar esta formulação. Fazemos o estudo a partir da coletânea Dez anos de cinema nacional ${ }^{4}$. Os depoimentos dos cinemanovistas nesses textos possibilitam observar: 1. qual a função que o grupo confere a si mesmo; 2. se há consenso entre eles; 3. se os cineastas ainda se portam como os intelectuais que vão ao povo para ajudar no processo de elaboração da consciência popular (Napolitano, 2001, 2001 a, 2011); 4. se o discurso do Cinema Novo estava sintonizado com a crise da cultura nacional popular.

\footnotetext{
${ }^{3}$ Vitória do Cinema Novo. Debate realizado com Alex Viany, Gustavo Dahl, Carlos Diegues, David Neves, Paulo César Saraceni. Revista Civilização Brasileira. n. 2, p. 227-248, mai. 1965. O artigo pode ser encontrado também em Viany (1999: 101-123).

${ }^{4}$ Hollanda, Heloisa B. de; Brito, Antonio Carlos de. Dez anos de cinema nacional. Opinião. n. 32, p. 1719, 11 a 18 jun. 1973. Os depoimentos de Carlos Diegues, de Arnaldo Jabor e de Joaquim Pedro de Andrade estão na página 18. O de Joaquim Pedro de Andrade na página 19. Hollanda, Heloisa; Brito, Antonio Carlos de. Dez anos de cinema nacional. Opinião. n. 40, p. 16-17, 13 a 20 ago. 1973. O depoimento de Eduardo Escorel está na página 16. O de Gustavo Dahl na página 16 e 17.
} 
Uma constância caracteriza o discurso dos cinemanovistas entrevistados em Opinião nessa coletânea: a mea culpa. A título de exemplo, trazemos o depoimento de Gustavo Dahl: “o Cinema Novo tinha um lado extremamente ingênuo, bom moço, um lado de se levar a sério que tinha um sabor acadêmico que irritava os jovens". Aqui, Dahl apresenta a postura política dos cinemanovistas como ingenuidade, não como intenção política consciente, isto é, temos um apagamento bastante expressivo em tempos de repressão. A reprovação da linguagem hermética do Cinema Novo tinha por objetivo maior condenar o papel dos cinemanovistas no passado. Mais do que isso, a revisão sobre a linguagem do movimento feita em meados dos anos sessenta já significava a porta de entrada do questionamento sobre a função do intelectual. A ideia de intelectual engajado tem sentido negativo na declaração de Gustavo Dahl ${ }^{5}$ :

"O grande bode da arte começou quando o artista se sentiu politicamente responsável pelo mundo, o que, na minha cabeça, é romantismo. O artista começou a identificar arte como ação política e esse mal-entendido de confundir representação com ação foi levando-o a uma culpabilidade e que é demonstrada pela destruição da própria arte que é o próprio sentido da arte moderna."

O "bode da arte" significa para Dahl exatamente o artista sentir-se responsável pelo mundo, partilhando de uma missão a cumprir. Assim o cineasta recusa o cinema como ação política, porque o descreve somente como representação. Como consequência, Dahl questiona o tema do engajamento e desloca o debate para a questão estética. A frase indica a correção do projeto cinemanovista, quando se percebe que os filmes não tornaram possível a ação política. Levando o pensamento do diretor em diante, se o cinema não gera ação política, a atitude de engajamento dos cinemanovistas foi um "mal-entendido" ou uma "confusão", isto é, não teve intenção consciente. As palavras "mal-entendido" e "confundir-se" servem para eximir o grupo. Para Dahl, o "sentir-se responsável" pelo mundo gera a culpa no intelectual e a destruição da arte. Ao submeter-se à ação política, a arte engajada deixa de ser arte, porque perde a autonomia. O trecho revela um desvio da definição de cinema moderno e de arte política em direção à arte militante ${ }^{6}$, condenando-a. A declaração de Dahl pode ser vista como sintomática

\footnotetext{
${ }^{5}$ Hollanda, Heloisa; Brito, Antonio Carlos de. Dez anos de cinema nacional. Opinião. n. 40, p. 16-17, 13 a 20 ago. 1973.

${ }^{6}$ Enquanto a função da arte engajada é criticar o poder, a arte militante costuma ser vista como uma forma de mobilizar a consciência pela paixão, incitando à luta política. Ver Napolitano (2011 a).
} 
de um período pós-golpe militar, quando os intelectuais do campo do cinema questionam a própria postura na produção. Para Bernardet (Schwarz, Sosnowski, 1994: 10) a intelligenstsia "caiu de seu pedestal" porque "a situação inverte-se: não é mais o intelectual superior e consciente que pode provocar a consciência popular".

Por causa do novo contexto, os cinemanovistas em Opinião não falam em nenhum momento na palavra conscientização, mas em aprofundamento da cultura nacional e investigação antropológica do homem brasileiro, sintonizadas com o depoimento de Carlos Diegues de 1965. Diferente do que declara Gustavo Dahl, a intelectualidade ganha sim uma nova função no regime militar. Para reformular a realidade brasileira, a cultura surge como foco da luta contra a ditadura. Assim o intelectual torna-se um ator político essencial. Atendendo a um imperativo ético e político, ele se vê não só como personagem central da resistência, mas também como a voz dos que não tem voz. (Napolitano, 2011, Pécaut, 1990, Czajka, 2005). Ao ganhar este novo encargo, a intelectualidade repensa seu papel, mas a auto-avaliação é seguida de uma crise sobre sua função, gerada em grande parte pelo autoritarismo e pela repressão. A ideia de construir uma temática popular pela aproximação da perspectiva entre povo e intelectual não tinha o mesmo consenso de antes do golpe. A postura não conseguia resolver a distância com o povo. Ao falar em nome da população, o intelectual tendia a desconsiderar as contradições reais. Depois do golpe, esta aproximação forjada entre artista e povo não desfrutava do mesmo consenso. Naquele período, o debate cultural colocava sob suspeita o intelectual que falasse em nome do povo ou se representasse como porta-voz das classes populares e dos interesses nacionais, mesmo quando engajado e bem intencionado (Napolitano, 2011). Por este motivo, os cinemanovistas declaram só "dar vazão" à cultura popular "sem preconceitos" ou intervenção, sintonizados com o discurso do intelectual porta-voz das classes populares. Portanto, a condenação ao intelectual arauto está presente não só na declaração de Gustavo Dahl, mas, por exemplo, na fala de Jabor: "Então esse mito de liberar [grifo nosso] a sociedade através da câmera de Super-8 acho mais utópico do que liberar a sociedade através da câmera de 35". O cineasta desvia o debate sobre a função do intelectual engajado - que faz a resistência contra a ditadura - para o intelectual porta-voz, que "libera" o público. Atentemos para o verbo utilizado. Não se fala mais em conscientizar o público, nem em libertar, longe dos ideais do Cinema Novo e do ISEB. A palavra de ordem era "liberar" o público, quase um eufemismo para 
a 'liberdade'. Tanto Jabor quanto Carlos Diegues comentam indiretamente o papel político do intelectual, mas sem fazer referência a este termo. Explica Carlos Diegues ${ }^{7}$ :

"Acho que tem que ser feitos filmes sobre o Brasil de hoje. Você tem que dar o seu testemunho através da criação cultural. (...) Quero ajudar a transformar o cinema em forma de conhecimento e essa é uma das razões morais que me leva a fazer cinema: a de me relacionar com o outro, através de uma possibilidade de conhecimento que lhe dou".

Existe nesta frase ainda a missão do intelectual, mas se denega o papel de conscientizar e dirigir, porque o cinema seria apenas uma "forma" de "conhecimento" do outro. Indiretamente cabe ao cineasta "possibilitar" este "conhecimento" a um terceiro. As frases de Diegues em nível discursivo mais superficial aproximam-se mais do sentido de cineasta porta-voz ou neutro. Mas no fundo o "relacionar-se" ao público esconde a ação do intelectual enquanto organizador da cultura, porque a função de dirigente ainda está lá. Portanto, não se fala mais em "consciência", mas em "conhecimento". Percebe-se como Diegues não declara a motivação política, mas a razão "moral". Assim o discurso antropológico encontra a moralidade como forma de eufemismo político. Nesse movimento paradoxal, a função política aparece de forma subentendida, atrelada à resistência ou ao objetivo ético. Afinal é como se a palavra "gerar conscientização" estivesse vetada.

A argumentação sobre o papel do intelectual dos entrevistados é baseada numa antinomia de avaliar criticamente o passado cinemanovista, mas elogiá-lo indiretamente, como se a discussão fugisse ao cinema político. Deste modo, Carlos Diegues relembra que o Cinema Novo estabeleceu certos princípios universais ao cinema político, mas eles "faltam" ao cinema "de hoje". São eles: a defesa e preservação de nossa identidade. Diegues declara que cabe a ele "só" "transmitir", "preservar" e "proteger” a identidade do país. Esse é mais uma nuance da ação política, deslocada para o tema da identidade. Observa-se como há uma zona intermediária calcada em eufemismos sobre o papel do cineasta e do cinema político. Portanto o sentimento de nostalgia de Diegues esbarra "sem querer" no sentido político através dos imperativos: "Acho que tem que ser feitos filmes sobre o Brasil de hoje. Você tem que dar seu testemunho através da criação cultural". Em síntese, a função do cineasta passa

\footnotetext{
${ }^{7}$ Hollanda, Heloisa B. de; Brito, Antonio Carlos de. Dez anos de cinema nacional. Opinião. n. 32, p. 1719,11 a 18 jun. 1973 .
} 
pelo conceito de resistência, trazendo de volta indiretamente o intelectual dirigente. Como era uma tendência no período, também Arnaldo Jabor evita posicionar-se como intelectual dirigente de mudanças sociais:

"Comparando a visão de cinema que eu tenho agora, depois de Toda nudez será castigada, com a que eu tinha antes, o que sinto é que diminuiu em mim aquela sensação messiânica, de 'dirigente' da cultura brasileira, de responsável por seus rumos para que chegue a um bom porto. Ficou menos onipotente a minha relação com o cinema e sinto que o mesmo aconteceu com meus colegas.

(...) Agora, acho que a única posição possível de um artista consciente é a de aceitar que é brasileiro, que mora no Brasil, esteja como estiver a situação.

(...) Acho que os caminhos estão mais intrincados e o artista realista, e que tenta ter uma visão clara da realidade, tem que aceitar esse intrincamento sem medo de nele se perder. A realidade ficou muito labiríntica, mas se você tiver medo de se jogar nela vai, no máximo, salvaguardar uma virgindade que de fato não significa muito para a realidade brasileira nem para a cultura mundial". 8

Jabor traz neste trecho a morte do intelectual messiânico que significaria o fim do projeto de engajamento dos cinemanovistas e a crise discursiva da intelectualidade como dirigente e formadora da cultura. A frase revela o sentido da ideia de missão e o peso da responsabilidade do intelectual arauto. Ele assinala o encerramento do sonho cinemanovista de gerar a ação política através do cinema. O adjetivo "messiânico" sintetiza bem a mudança conjunta no discurso dos entrevistados. Se a relação com o cinema ficou menos onipotente, como diz Jabor, a frase é bastante reveladora da morte temporária de um projeto explícito de engajamento do Cinema Novo, num período no qual o grupo declarava-se mediador "neutro" da cultura popular, sem intervir nos filmes.

Para ser analisado, o trecho deve ser dividido em dois. Num nível mais imediato de significações, Jabor não pensa mais sua função como artífice da nação. Indiretamente, ele nega também a opção pelos desfavorecidos, o caráter educativo do cinema e a função de conscientização. Contudo, nas idas e vindas retóricas de Jabor ainda se defende na entrelinha uma missão do intelectual, quando ele declara que o cinema deve relacionar-se à realidade brasileira. Seguindo o raciocínio de Jabor, a arte não tem a obrigação de relacionar-se à realidade; portanto a frase revela a preferência

\footnotetext{
${ }^{8}$ Hollanda, Heloisa B. de; Brito, Antonio Carlos de. Dez anos de cinema nacional. Opinião. n. 32, p. 1719,11 a 18 jun. 1973.
} 
dele pela política. Assim, o caráter missionário ressurge por causa da resistência à ditadura. Depois da "fuga geográfica", leia-se exílio, o "artista consciente" deve aceitar que é brasileiro, "esteja como estiver a situação", declara o cineasta.

A leitura deste trecho pressupõe algumas lacunas. A ideia de intelectual como dirigente divide-se aqui em duas partes: o dirigente do povo e o dirigente da cultura. Enquanto a primeira é negada no depoimento, porque não se fala em conscientizar o público, a segunda é mais complexa. Há ainda um resquício deste segundo papel, porque o debate sobre a forma de dirigir a cultura incide sob a ideia de missão contra o regime. O conceito de resistência do período tinha no intelectual sua máxima e significava ter um papel perante o povo e o país, levando ou a consciência (no caso do intelectual arauto) ou o conhecimento do outro (intelectual mediador). Portanto esse trecho significa um posicionamento do tipo "tão perto e tão longe". A intelectualidade a partir de meados de cinquenta não se vê mais como formadora da identidade nacional, como ocorria nas décadas anteriores (Pécaut, 1990). Porém, ainda permanece em Jabor um resquício desta função, quando ele cita a necessidade de preservar a cultura brasileira. Se o cineasta não fala em dirigir, mas em preservar a cultura já existente, há no trecho uma espécie de eufemismo. Vendo o povo como uma entidade já constituída, o papel do cineasta é a defesa dos valores nacionais contra as ameaças externas, assegurando a unidade da cultura. De alguma forma se mantém ainda a função de comandar o povo, nem que seja através da cultura. A autoridade é, então, extraída da vocação nacional. Quando Jabor declara a função de exprimir a sociedade para si mesma, sua intervenção ainda existe. Aqui ele se vê muito mais como guardião da democracia, como missionário e dirigente da "verdadeira" cultura brasileira do que como arauto. No fundo a declaração não está tão distante do intelectual gramsciano (1968). Como organizador da cultura, ele tem papel central para elaborar uma teoria de transformação social, formando a vontade nacional. Sem sua direção, a cultura carece de organização.

Jean-Claude Bernardet (1978: 175-77) analisou estes depoimentos dos cinemanovistas em Opinião na revista Argumento ainda em 1973. Ele observou uma crise do status dos cineastas porque o grupo perde o prestígio de interpretar a sociedade e não se sente mais levado pelo povo. Eles sentem-se "destituídos" de um certo poder de decisão. A solução encontrada era tentar encontrar o público para readquirir uma posição atuante na sociedade. Bernardet analisa in loco que os cineastas afirmam que os 
tempos eram outros, mas a forma de pensar a relação com o público ainda vinha dos parâmetros do Cinema Novo.

Marcelo Ridenti (2000) observa que setores da intelligentsia tornavam-se uma espécie de porta-voz do povo entre 1960-80 por causa das dificuldades de expressão das classes subalternas e da crescente influência dos meios de comunicação de massa. A ideia de porta-voz descrita por ele coincide bastante com os depoimentos dos cinemanovistas nesta coletânea, quando o grupo descreve o distanciamento em relação ao arauto. Aqui a palavra porta-voz significa um cinema voltado a "traduzir" os valores populares, "sem" a intenção crítica e a intervenção do cineasta, tal qual declarava Nelson Pereira dos Santos (Ver Capítulo 6) no lançamento de O Amuleto de Ogum (1974). Poderíamos utilizar outros termos para descrever este discurso: o intelectual "suplente" (Adorno, 2003) ou "representante do sujeito social", o intelectual "mediador", "neutro", "invisível" ou o intelectual "correia de transmissão" dos anseios populares.

Tal insistência na função do intelectual cinemanovista ocorria porque o tema passava por questionamentos dentro da própria esquerda. Provavelmente o grupo percebia a impossibilidade naquele contexto de se declarar formador da consciência. Assim os cinemanovistas faziam um malabarismo para construir um discurso socialmente aceito, adaptando-se aos novos tempos, sem alterar suas crenças mais importantes. O questionamento do intelectual arauto se aprofundou ainda mais no contexto da abertura política quando as tensões da esquerda ficaram mais expostas. Essa série de entrevistas é um pouco anterior, mas o processo já estava em curso. Nestes depoimentos de 1973, vemos um processo transitório desta crise, mas que mantém no papel do intelectual na resistência um dos pilares centrais da Frente Cultural. O arauto mantinha-se de pé entre os cinemanovistas por causa do imperativo da resistência. Porque o conceito de arauto estava sob questão no período, o grupo nega-se como dirigente, mas se mantém como vanguarda à frente do povo.

As fronteiras entre o intelectual arauto e o porta-voz destes depoimentos são, por definição, bastante porosas. Os dois conceitos estão bastante imbricados. Tanto a palavra porta-voz quanto o mediador não estão distantes do arauto. Daí a dificuldade prática para separar totalmente os dois modelos. Afinal, o sentido primeiro de arauto pressupõe a mediação indispensável e neutra do intelectual ao povo. A diferença é que o 
discurso cinemanovista nos anos setenta procura apagar totalmente o sujeito que realiza a mediação, a partir da ideia de não-intervenção do cineasta na cultura.

Ao dar espaço para os intelectuais cinemanovistas discutirem a função social do cineasta, Opinião não busca produções em separado, mas um cinema com a preocupação política de analisar a estrutura da sociedade. Daí o vazio sentido pela dispersão do Cinema Novo. A motivação do jornal não é pelo sucesso comercial, ou pelo desenvolvimento da indústria cinematográfica desagregada de qualidades estéticas. O que se depreende destes depoimentos? A necessidade de reavaliação do projeto do Cinema Novo aos novos tempos. Na triste constatação do declínio do ideal de intelectual do Cinema Novo fica a impressão da inexistência de uma nova função, num eterno retorno a um tipo de arauto amenizado que não se mostra por completo. A derrocada do Cinema Novo não representa o desaparecimento da produção dos veteranos, mas o fracasso gradativo de um projeto político dos anos sessenta. Ao mesmo tempo, constata-se naquele momento a inexistência de um novo programa conjunto, que não seja o do Cinema Novo aliado ao Estado.

Através da ideia de missão e resistência, os cinemanovistas podiam ver o próprio trabalho dentro da esfera da luta contra a ditadura. O conceito de arauto evitava que os cineastas debatessem criticamente a própria contradição. Trata-se do pressuposto básico da resistência, invertendo o percurso da ação: o cineasta age porque a sociedade solicita. Uma visão particular de antropologia serviu de eufemismo para provar a nãointervenção do cineasta. O conceito do mediador invisível significou uma nova forma discursiva dos anos setenta, quando os cinemanovistas defendem a liberação do público pelo intelectual porta-voz, dizendo o mesmo com outras palavras. Afinal, não houve uma mudança real no discurso deles sobre sua função, porque o grupo ainda se considerava soberano das ideias. Ao não questionar a ideia de preservação da cultura nacional, eles podiam se ver como entidade a serviço do povo. Se o pensamento cinemanovista ainda estava atrelado ao ideal do intelectual dos anos sessenta, as alterações discursivas não fazem parte de uma falta de consciência dos cineastas, mas de uma estratégia para evitar debater as próprias contradições, na qual a mudança discursiva serve de anteparo às críticas recebidas na década anterior. Assim o grupo conseguiu manter uma validade e uma função social ao próprio ato de filmar. 


\subsection{Dez anos de cinema nacional: o discurso cinemanovista nos novos tempos}

Entre junho a agosto de 1973, Opinião prepara uma coletânea de entrevistas ${ }^{9}$ em duas edições sobre a situação do cinema brasileiro nos últimos dez anos. A proposta era debater o que tinha acontecido com o Cinema Novo e quais eram as possibilidades para o futuro. O Cinema Marginal, o Super-8 e a política cinematográfica perpassam os depoimentos.

Logo no início, o jornal esclarece que procurou reunir "não os melhores" cineastas do país, mas "figuras relevantes" e de "todas as correntes do processo cinematográfico brasileiro", embora o Cinema Marginal não tenha um único representante escolhido. Participaram do balanço dez cineastas: Carlos Diegues, Arnaldo Jabor, Joaquim Pedro de Andrade, David Neves, Leon Hirszman, Gustavo Dahl, Geraldo Sarno, Zelito Viana, Eduardo Escorel e Carlos Vergara. Glauber Rocha, Nelson Pereira dos Santos, Rogério Sganzerla e Júlio Bressane "recusaram-se" a participar.

Opinião anuncia entre os entrevistados o nome de Leon Hirszman, mas seu depoimento não consta na matéria de junho, nem na continuação, publicada em agosto. Há apenas uma frase do diretor destacada no corpo do texto na edição número 40, o que é um claro indício da censura. O leitor não sente falta somente do depoimento de Hirszman, mas também da paginação correta. O número da página difere da numeração indicada pelo jornal como "continuação do artigo". Essa era uma das formas de transmitir aos leitores a interdição. A coletânea Dez anos de cinema nacional demorou para ser publicada ${ }^{10}$. O material foi enviado à censura para a edição de 30 de abril a 07 de maio (n. 26), mas só foi publicado a partir de junho (n. 32). A informação é importante porque mesmo com a restrição, a matéria foi liberada com muitas críticas ao

\footnotetext{
${ }^{9}$ Hollanda, Heloisa B. de; Brito, Antonio Carlos de. Dez anos de cinema nacional. Opinião. n. 32, p. $17-$ 19, 11 a 18 jun. 1973. A entrevista com Geraldo Sarno localiza-se na página 17. Os depoimentos de Carlos Diegues, de Arnaldo Jabor e de Joaquim Pedro de Andrade estão na página 18. As entrevistas com Joaquim Pedro de Andrade, David Neves e de Zelito Vianna seguem na página 19. Hollanda, Heloisa; Brito, Antonio Carlos de. Dez anos de cinema nacional. Opinião. n. 40, p. 16-17, 13 a 20 ago. 1973. O depoimento de Eduardo Escorel está na página 16. O de Gustavo Dahl está localizado entre as páginas 16 e 17. Por fim a entrevista com Carlos Vergara foi publicada na página 17.

${ }^{10} \mathrm{O}$ artigo faz parte do DSI (Divisão de Segurança e Informações) do Ministério da Justiça "Artigos do Jornal Opinião enviados para a censura. IX”. Disponível em:

$<$ http://www.an.gov.br/sian/Multinivel/Exibe_Pesquisa.asp?v_CodReferencia_ID=1033633|> Acesso em 09 set. 2013.

Código de Referência BR RJANRIO, XX TT.0. MCP, AVU. 26.
} 
Estado autoritário. Por causa do contexto político, o conteúdo do texto não é evidente à primeira vista. Portanto analisamos aqui o discurso cinemanovista na entrelinha.

A primeira parte do artigo ganha a capa do jornal com um cangaceiro ao fundo e a manchete Dez anos de cinema nacional. No subtítulo da matéria, há uma homenagem sutil aos dez anos das filmagens de Deus e o diabo na terra do sol (1964) de Glauber Rocha, isto é, não se trata da imagem de um cangaceiro qualquer.

A introdução escrita por Heloisa Buarque de Hollanda e Antonio Carlos de Brito abre o texto exatamente com Deus e o Diabo para declarar que dez anos após o início de suas filmagens, a "grande aventura" do cinema moderno brasileiro "parece no fim", levando consigo os esquemas coletivos dos anos sessenta:

'O sonho de 'uma ideia na cabeça e uma câmera na mão' acabou. O Cinema Novo - glória da cultura brasileira e excelente produto de exportação dos anos 60 expirou com esparsas orações fúnebres e um vago atestado de óbito que apontava como causa mortis 'a falta de comunicação de seus filmes com o grande publico"” ${ }^{11}$.

Embora o verbo "parecer" não signifique uma certeza do fim da "aventura" do Cinema Novo, todos os entrevistados atestam sua morte. Pelo menos uma convicção se abre: o fim dos esquemas coletivos do movimento, porque o cinema dos anos setenta está calcado em bases individuais. Uma primeira conclusão surge logo nas primeiras linhas, em tom de contextualização. É a diferença entre a postura dos cineastas no passado e nos anos setenta:

"São 10 depoimentos ao todo. Alguns confluentes em certos pontos, a maioria, porém, ao contrário do que ocorria nos áureos tempos do Cinema Novo, heterogênea, prova de que o processo cultural brasileiro atualmente se desenvolve fora dos antigos, úteis e funcionais esquemas de ação coletiva."

Para o jornal, o tom individual dos cinemanovistas nos anos setenta sinaliza a perda do caráter coletivo e homogêneo do Cinema Novo. A condenação à falta de comunicação com o grande público não é somente apresentada como um ponto indiscutível, mas como um consenso até entre os cineastas:

"De modo geral, todos aceitam como suicida a empostação elitista de fazer filmes que, nos anos 60, deu substância e força ao movimento. David Neves chega,

\footnotetext{
${ }^{11}$ Hollanda, Heloisa B. de; Brito, Antonio Carlos de. Dez anos de cinema nacional. Opinião. n. 32, p. 1719, 11 a 18 jun. 1973.
} 
inclusive, a tocar numa questão melindrosa mas profundamente realista: a influência negativa de Glauber Rocha em maus copiadores de sua barroca objetividade".

Condenar a ausência de comunicação do Cinema Novo com o público não era um argumento original nos anos setenta. $\mathrm{O}$ balanço do movimento começou a ser feito por volta de 1964-65 e teve como argumento fundamental a distância em relação ao público (Bernardet, 1978: 174).

Heloisa Buarque de Hollanda e Antonio Brito escolheram colocar a discussão sobre a linguagem "hermética" do Cinema Novo e as influências "negativas" de Glauber Rocha como ponto principal da introdução. Se o título fala em balanço do cinema nacional, a discussão desloca-se para o Cinema Novo. Os dois endossam a informação de que o tempo do "fechar-se em si mesmo", do "elitismo" e das "elocubrações teóricas" e "estetizantes" já passou. Depois concluem que estas palavras são o "bode expiatório" do grupo para todos os problemas do Cinema Novo.

O cineasta-símbolo de todas estas críticas é Gustavo Dahl, "autor de um dos filmes mais impenetráveis do $\mathrm{CN}$ (O Bravo Guerreiro)" ${ }^{12}$. Curiosamente Dahl não é apresentado no seu depoimento como cinemanovista. Ele só foi escolhido para aglutinar todas as reprovações ao cinema autoral moderno. Ao eleger o Gustavo Dahl de 1968 como síntese do "hermetismo", os entrevistadores ocultam a existência dos diversos caminhos do cinema autoral na virada para os anos setenta ${ }^{13}$. Se o objetivo era condenar o hermetismo, os articulistas poderiam ter escolhido os filmes alegóricos fragmentados, que são mais indicativos do caráter "impenetrável” descrito acima.

Diferente do que diz o trecho acima, ainda no final da década de sessenta, parte da produção cinemanovista estava atenta à comunicação com o grande público, ao lado de filmes marcados por uma narrativa moderna. Assim o modelo alegórico fragmentado convivia com alegorias de cunho didático ou com uma produção voltada à comunicação com o público através de linguagem convencional. Macunaíma (1969) de Joaquim Pedro de Andrade e Garota de Ipanema (1967) de Leon Hirzsman convivem com Fome de Amor (1967) de Nelson Pereira dos Santos e Pindorama (1971) de Arnaldo Jabor. De acordo com Ismail Xavier, houve uma demanda de comunicação ao lado de um impulso

\footnotetext{
12 Ismail Xavier (2001) define $O$ bravo guerreiro como um filme asceta, rigoroso, com fala política no centro da encenação, intriga reduzida a discursos e confinamento do intelectual-político. Ele está longe da fácil comunicação porque assume a via autoral sem concessão, seguindo a linha de Terra em Transe.

13 Alguns dos caminhos do Cinema Novo: o cinema ajustado à linguagem narrativa convencional, o cinema atento à comunicação com o público, o balanço da ilusão do intelectual, o cinema alegórico totalizador ou com fragmentação do discurso (Xavier, 2001; 1993).
} 
de modernidade autoral que marca uma oscilação na postura do Cinema Novo. (Xavier, 2001, Ramos, 1987). Portanto, tratar o Cinema Novo como um todo "hermético" ou como bloco homogêneo por natureza, como faz esse texto, significa selecionar um conjunto parcial como representante do todo. Assim a matéria de Opinião endossa parte da visão da historiografia sobre o fechamento do público naquele período.

Um novo apagamento é criado nesta matéria. Ao apontar as críticas à forma moderna do cinema, nem os cineastas, nem Opinião mencionam os filmes autorais cinemanovistas com linguagem mais acessível ao público, como Barravento (1961) de Glauber Rocha, Os fuzis (1963) de Ruy Guerra, Vidas Secas (1963) de Nelson Pereira dos Santos, A grande cidade (1965) de Carlos Diegues, A falecida (1965) de Leon Hirzsman, O Desafio (1965) de Paulo César Saraceni, Garota de Ipanema (1967) de Leon Hirzsman, etc. Dentre estes, Vidas secas ${ }^{14}$ é sempre lembrado pelo jornal, mas se oculta que ele faça parte do Cinema Novo.

Ao excluir os filmes atentos à comunicação com o público e definir o Cinema Novo só com o lado "hermético" e "impenetrável", os entrevistadores fizeram uma escolha. As inúmeras condenações à linguagem moderna expostas nesta entrevista fazem parte do discurso contrário ao Cinema Novo feito a partir do final dos anos sessenta. Esse ponto de vista é incorporado pelos entrevistadores. Desde o balanço do movimento em meados de sessenta, o grupo defendia a ocupação de mercado e a necessidade de diálogo com o público, através da linguagem acessível do cinema narrativo convencional. Essa visão era hegemônica no campo e é endossada aqui como a correta. Contudo, ao longo da década houve um debate cada vez maior em relação a esses valores. A defesa deste lado do pêndulo indica uma disputa interna pelo poder de percepção legítima, da qual o núcleo favorável à conquista do mercado é escolhido como o caminho certo. Indiretamente se tem uma pré-disposição contra qualquer tipo de vanguarda. Em menos de dez anos, entre o final de 1960 e o de 1970, a corrente hegemônica do nacional popular perdia cada vez mais espaço. Napolitano (2011) explica que no início dos anos setenta coexistia na resistência a massificação e o experimentalismo, solicitando uma "revisão na crítica político-cultural" e na expressão estética. Essa mudança de perspectiva pode ser vista no posicionamento de Heloisa Buarque de Hollanda nesta matéria e, depois em 1979, quando a autora defende a tese que virou livro no ano seguinte, Impressões de Viagem. No final da década, Hollanda

\footnotetext{
${ }^{14}$ Ismail Xavier (2001) refere-se a Vidas secas como um proto-Cinema Novo.
} 
Buarque encaminha-se para a valorização da contracultura jovem, como herdeira da tradição da vanguarda. De acordo com Marcos Napolitano (2011: 143-144), o livro valorizava o experimentalismo e recolocava a contracultura e a vanguarda como "tradição de crítica cultural consequente, politizada e inovadora".

O argumento sobre o hermetismo da arte não era usado só para acusar o Cinema Novo. Ampliando este debate para o campo da arte engajada, tanto Heloisa Buarque de Hollanda em Impressões de Viagem, quanto Roberto Schwarz em Cultura e Política (2009) ${ }^{15}$ defendiam na época a tese de que a cultura nos quatro primeiros anos da ditadura esteve marcada por um círculo fechado e estéril de comunicação (Napolitano, 2011). Eles pensavam o artista engajado como alguém isolado das massas e longe do circuito artístico. Essa série de reportagens é marca daquele momento. Comunicação mesmo, o autor só conseguiria com sua classe social; a classe média consumidora de cultura. Portanto, o argumento de Heloisa Buarque de Hollanda já estava presente nesta entrevista de Opinião, coordenada por ela.

Se os cinemanovistas condenam o hermetismo em nome da ocupação do mercado nesta matéria, a estratégia também não era inédita do cinema, porque o debate aponta para os circuitos da arte engajada. Segundo Napolitano, a partir de 1967-68 coloca-se em xeque a relação entre arte engajada e seu público, visando encontrar os circuitos mais adequados. Isso acontece com a fragmentação da esquerda, antes homogeneizada pelo PCB. Para os intelectuais do partido, preocupados com a ocupação do mercado, a popularidade era um caminho para chegar ao público. Os cinemanovistas como grupo estavam mais alinhados com a cultura do nacional popular. Como vemos, o debate de Opinião tinha sintonia com estas questões, nas quais o mercado parecia a solução para a arte engajada conquistar popularidade. O grande desafio daquele momento era construir um circuito de mercado sem cair nas armadilhas do entretenimento.

Se essas questões já apareciam no final da década de sessenta, elas se delineiam fortemente nos anos setenta, quando a produção cultural é obrigada a enfrentar o tenso vínculo entre o cinema autoral e as pressões políticas e de mercado (Ramos, 1987). Condenando a estética alegórica do Cinema Novo, Opinião não aprofunda nesta série a polêmica dos anos setenta, que grosso modo, se dividia entre uma estética atenta ao aceitável no mercado, e de outro lado, uma estética voltada à experimentação. Como

\footnotetext{
${ }^{15}$ A primeira versão do ensaio foi escrita entre 1969 e 1970.
} 
resultado, apenas o último bloco aparece como culpado pelo insucesso do cinema autoral brasileiro.

Assim a escolha de Gustavo Dahl como "bode expiatório" permite observar a construção sobre os "eleitos do Cinema Novo" nos idos dos anos setenta. Como vimos, estas categorias variavam ao longo dos anos, e os apagamentos sinalizam quais tipos de filmes são recusados pelo discurso da época. Num período em que o mercado e a aliança com o Estado são vistos como fatores imprescindíveis, a exclusão de $O$ bravo guerreiro em 1973 indica a preferência pelo cinema de fácil comunicação com o público, em prol da conquista do mercado. A argumentação talvez tenha um cunho valorativo, deixando intocados os filmes autorais de diretores ainda mais consagrados como Glauber Rocha e Nelson Pereira dos Santos.

Este não foi o único apagamento do texto. É curioso que Carlos Diegues seja apresentado como um dos fundadores do movimento, porque Opinião sempre o exclui do rol de cineastas autores e cinemanovistas. Arnaldo Jabor também não é apresentado como cinemanovista, o que é indicativo das críticas feitas a Toda nudez será castigada (1972) em Opinião. Apenas dois de seus filmes são mencionados neste depoimento, os já referidos Toda nudez e Pindorama (1971). O jornal cita também A Opinião Pública (1966), mas não discute se este seria parte do Cinema Novo. A escolha de Pindorama é uma crítica sutil aos filmes alegóricos do grupo, endossada por Jabor quando ele condena a narrativa incompreensível daquela fase.

$$
* * *
$$

\section{A exclusão da dissonância no debate}

A palavra cinema político é quase proibida nesta coletânea. Contudo o tratamento é paradoxal. Se o sentido parece negativo por inibir o público, internamente a significação é positiva porque é uma forma artística excluída do circuito exibidor por seu conteúdo. Se a discussão política fica em segundo plano por causa da discussão da forma, mais condenado que o Cinema Novo só mesmo o Cinema Marginal. Heloisa Buarque de Hollanda e Antonio Carlos de Brito resumem o consenso entre os entrevistados sobre o tema: "a marginalidade e suas formas de comunicação - o cinema em Super 8 - são irreais e reacionários". A sentença negativa ao Cinema Novo e ao Cinema Marginal é feita em nome da ocupação do mercado e é consensual entre entrevistadores e entrevistados. Os entrevistadores só esquecem de explicar ao leitor que 
todos falam mal do Cinema Marginal e do Super-8 porque os cineastas selecionados ou são do Cinema Novo ou estão mais inclinados ao cinema político, exceto Carlos Vergara, o único representante superoitista. Enquanto todos entrevistados dão por encerrado o Cinema Marginal, até o ano de 1973 a produção do Cinema Marginal e o grupo estavam relativamente coesos (Ramos, 1987 a).

Se as declarações sobre o Cinema Novo o culpam pelo caráter hermético, os adjetivos para o "concorrente" Cinema Marginal não são nada elogiosos. Arnaldo Jabor refere-se ao cinema underground como "uma bobagem do fim da década que não vale nada"; porque foi simplesmente uma paródia do Cinema Novo. As condenações ao underground são as mesmas do Cinema Novo: o formato não consegue atingir o público, dada sua inaptidão para ocupar o mercado.

Opinião escolheu para entrevistar apenas diretores identificados ao Cinema Novo e ao cinema político. O semanário excluiu cineastas de outras tendências para entrevistar. Do ponto de vista jornalístico, o jornal não explica claramente a ausência dos realizadores marginais no debate, nem oferece a eles o direito de resposta às críticas feitas. Sem trazer opiniões dissonantes, o periódico acaba por incorporar o discurso contrário à experimentação. Portanto, essa coletânea não foi pluralista, porque excluiu da discussão não só os marginais, mas também outros grupos, como os cineastas de mercado. A ausência dessas tendências de pensamento reflete as preferências do próprio veículo por um cinema político. O periódico nem se dá ao trabalho de lidar com as opiniões dissonantes; escolhe só as consonantes. Quando foge do díssono, Opinião aponta sem rodeios para seu próprio projeto de cinema brasileiro.

Quando os cinemanovistas fazem sua mea culpa, eles apagam da discussão os questionamentos sobre a produção atual deles. Os defeitos do Cinema Novo passam a ser uma questão do passado. Sem a condenação atualizada do jornal ao grupo, percebese que o Cinema Novo desfruta de um grande poder de refração ${ }^{16}$, interceptando comentários negativos. Assim mostram-se coesos e legítimos (Bourdieu, 2011). Quando os cinemanovistas colocam as críticas apenas no passado, escondem do leitor o acesso às lutas travadas no interior do campo entre os concorrentes. A atitude consegue

\footnotetext{
${ }^{16}$ Quanto mais um campo tem autonomia, ele sofre menos com as influências externas, escapando das limitações de outros campos. Nestes casos não se tem acesso às lutas travadas no interior do campo (como a concorrência entre os agentes), que sempre existem. Já o campo como menor poder de refração sofre com maiores influências dos demais campos. Nestes casos, as imposições externas são facilmente reconhecidas. (Bourdieu, 2001)
} 
minimizar as imposições externas na imprensa. $\mathrm{O}$ mesmo não ocorre com o Cinema Marginal, que tem baixo poder de refração no jornal ${ }^{17}$.

Credita-se o fim do underground a uma questão estética; não política. Provavelmente por causa da censura, não se expõe ao leitor que os filmes marginais são também políticos. Não se relaciona a forma alegórica do Cinema Novo e do Cinema Marginal como opção adotada por causa da interdição dos filmes. Opinião não comenta os berros, atrocidades e desespero como sintomas dos cineastas marginais frente ao regime militar (Ramos, 1987). Como consequência a forma é apresentada como uma opção de vanguarda e formalismo por si só; que ao desprezar o conteúdo, prefere ser apolítica.

Opinião exclui os cineastas marginais, quando manifesta sua preferência pela ocupação de mercado a qualquer preço. Repensando o trabalho diário nos jornais, JeanClaude Bernardet (1978) explicou que os críticos deixavam de lado os filmes marginais porque não tinham instrumental metodológico adequado para analisar a aparente irracionalidade. Eles não sabiam onde apreender os mecanismos de significação. Presos ao realismo, a maior parte deles não podia prescindir do enredo, personagens e dramaturgia para apreender o sentido dos filmes. Por outro lado, a denúncia do irracionalismo era uma forma de evitar os temas polêmicos. Havia entre os críticos uma preferência pelo Cinema Novo, pela crítica politizada e pela valorização da mensagem nos níveis mais explícitos da obra (Bernardet, 1978). Enquanto isso, os filmes sem sustentação verbal eram considerados alienados e despolitizados. Esse critério parece prevalecer em Opinião na maior parte das matérias.

\section{$* * *$}

Morte por elitismo ou assassinato do Cinema Novo?

Se a coletânea de entrevistas busca entender as razões do declínio do Cinema Novo, os motivos reais são apontados no meio dos depoimentos. Eis alguns dos exemplos:

"Hoje as pessoas [do Cinema Novo] estão entregues a caminhos e soluções individuais, estão praticamente sem contato umas com as outras. (...) Quem fazia cinema sentia-se participante de algo que estava acontecendo no Brasil. Na medida em

\footnotetext{
${ }^{17}$ Segundo Fernão Ramos (1987 a), a revista Cine-Olho no final dos anos setenta constituiu um local privilegiado para o debate dos filmes marginais, que não tiveram repercussão no auge de sua produção. Existiu, de acordo com ele, uma nítida aproximação da linha dos artigos da revista com alguns aspectos da produção marginal. Bárbara Viera Neto (2012) fez uma iniciação científica sobre a Cine-Olho.
} 
que isso não existe mais, me parece que há uma espécie de enclausuramento progressivo dos indivíduos". (Eduardo Escorel)

"Talvez os problemas existentes no país nos tivessem levado, num primeiro momento a uma tentativa de sair pela tangente. Primeiro um movimento meio escapista, uma tentativa de fuga direta, sair geograficamente ou sair formalmente do Brasil. Uma recusa da realidade brasileira, a recusa de você ter que se inserir como brasileiro na sua área geográfica. Agora, acho que a única posição possível de um artista consciente é a de aceitar que é brasileiro, que mora no Brasil, esteja como estiver a situação. A outra saída foi de querer chegar à Europa ou por vias linguísticas ou pela solução alegórica: a manutenção dos pontos de vista anteriores, dos temas básicos anteriores só que narrados obliquamente. E essa narrativa ia se obliquizando de tal maneira que se tornou cada vez mais incompreensível, inexibível, inexistente.”(Arnaldo Jabor)

"A dificuldade leva o artista a formar (sic) de protestos cada vez mais subjetivos, individualistas, 'marginais'. (...) O que observamos é o surgimento de uma espécie de hipocrisia, isto é, as pessoas em cinema estão proibidas de tratar com verdade uma série de temas". (Joaquim Pedro)

Se os cineastas insistem que o fracasso do Cinema Novo foi causado pela ausência de contato com o público, por causa da forma elitista, na entrelinha a motivação política aparece como causadora da linguagem "hermética" em todos os depoimentos. A mensagem dos cinemanovistas é clara: foi o regime militar quem impediu uma linguagem mais clara, levando aos protestos alegóricos, cifrados e subjetivos. Esta série de depoimentos exige do espectador uma postura analítica e de decifração de significados. O artigo relembra os dez anos de "coação" do Cinema Novo pelo regime militar, daí a "comemoração" do aniversário das filmagens de Deus e Diabo na terra do sol.

Ao frisar a opção "elitista” do Cinema Novo, a condenação permanece na forma utilizada, incapaz de atingir o público. Assim o conteúdo e o caráter autoral do grupo permanecem intactos tanto para os entrevistados quanto para os entrevistadores. Porém esse argumento não se estende ao Cinema Marginal. Afinal todos continuam a defender de forma implícita a conexão entre o conteúdo capaz de "captar" a realidade brasileira e a forma original (desde que não "hermética"). Não é a intenção política que está em jogo, mas a forma utilizada nos filmes para conquistar o público e o mercado.

$* * *$

\section{A sintonia discursiva do Cinema Novo}

Os testemunhos da matéria Dez anos de cinema nacional demonstram que os cinemanovistas continuavam a compartilhar muitas ideias. Se nesses depoimentos, os 
egressos do movimento não se veem como grupo unido, eles permanecem como grupo coeso na maior parte da entrevista. Mas, afinal, qual era a proposta cinemanovista para o cinema brasileiro desta matéria? Um pouco dessas ideias se depreende dos discursos de Gustavo Dahl, Carlos Diegues, Joaquim Pedro de Andrade e Arnaldo Jabor. Os testemunhos parecem se articular numa grande lamúria pela perda do Cinema Novo:

"O chamado ciclo do Cinema Novo, que é considerado enterrado e morto por todo mundo, mas ao mesmo tempo não surgiu nenhuma proposta cultural equivalente ou melhor". (Gustavo Dahl)

"Não estou propondo soluções individuais, mas acho que como está tudo começando de novo devemos experimentar profundamente. Acho que, por exemplo, no ano passado surgiram três filmes (Como era gostoso o meu francês, Os inconfidentes e Quando o carnaval chegar) totalmente diferentes entre si, cada um correspondendo a um caminho próprio, mas que começam a desmontar e criticar toda essa mitologia dos anos 60, que naquele momento era real, fazia parte de um processo." (Carlos Diegues)

"No momento vivemos uma profunda crise de criação, estão faltando as propostas fortes e consequentes, originais, que formam uma escola. As pessoas ficam abstratamente em busca de caminhos, enquanto que essa força detonadora, que é uma força criativa, não existe mais. Nós estamos em crise de importância: nós perdemos a importância que um dia chegamos a ter num determinado momento, porque fizemos uma coisa que correspondia a uma necessidade histórica e artística, que desempenhava uma função relevante, e hoje estamos atomizados, em busca de soluções individuais." (Joaquim Pedro)

"Acho que o cinema olímpico acabou, que a arte olímpica é uma arte que não interessa mais. E considero isso um pensamento de vanguarda, pois acho que o desafio da conquista de uma linguagem pública é uma busca de vanguarda. Confunde-se muito vanguarda com esoterismo, mas a vanguarda não tem que obrigatoriamente levar a um hermetismo." (Arnaldo Jabor)

Quase todos eles deixam aberto um caminho para os filmes com inovações. Reclama-se aqui não só a falta de um cinema de vanguarda, experimental e que atinja o público, mas também de um cinema engajado. Portanto, os depoimentos iniciaram com uma crítica à forma do Cinema Novo, ocasionada pela ditadura militar, mas todos terminaram justamente com a defesa da experimentação. Carlos Diegues observa uma continuidade nas recentes produções dos egressos do Cinema Novo e cita indiretamente o cinema autoral através dos lançamentos. É nestes momentos que Diegues defende o retorno de um projeto muito próximo ao do Cinema Novo, como fez Dahl. Já Joaquim Pedro comenta com pesar a falta do Cinema Novo, quando observa uma crise de propostas estéticas e políticas. Se todos não sentem falta do "hermetismo" do Cinema 
Novo, não se pode dizer o mesmo sobre a função política do intelectual cinemanovista de Joaquim Pedro: "fizemos uma coisa que correspondia a uma necessidade histórica". Depreende-se aqui que o cinema voltado ao mercado não vai conseguir sozinho realizar o sonho de manter a originalidade e atingir o mercado e o público. Para realizar esse projeto é preciso ressuscitar o Cinema Novo. Essa é a proposta indireta dos textos.

Nessa acrobacia linguística, Jabor defende o cinema de vanguarda que atinja o público, mas procura dissociar a vanguarda do "hermetismo da forma". Se todos condenam o hermetismo em nome da ocupação de mercado, indiretamente Jabor também defende o cinema autoral para conquistar o público. A frase relembra um pouco Maiakovski: "sem forma revolucionária, não há arte revolucionária". É como se a ocupação do mercado precisasse de uma forma original, retornando indiretamente ao Cinema Novo. Nesse sentido procurar a comunicação é o verdadeiro desafio da linguagem e deve orientar a pesquisa estética.

Existe nos depoimentos uma tensão entre ocupação do mercado e as possibilidades de linguagem. Joaquim Pedro chega a misturar as bases da linguagem moderna e clássica, quando declara que "assumir o lado moderno do cinema, que é justamente a possibilidade de se comunicar com a massa”. Longe da visão consensual, Joaquim Pedro não vê o cinema moderno como experimentação, que gera distanciamento crítico, mas como possibilidade de comunicar-se com a massa. Quando observamos de perto estes depoimentos, vemos uma defesa do cinema autoral engajado, não exatamente a defesa da linguagem clássica. Já entre os críticos de Opinião, a linguagem convencional para atingir a ocupação do mercado era um tema controverso por si só (Ver Conclusão). Aqui não se elogia simplesmente a captação da "realidade brasileira”, o cinema voltado ao mercado ou os interesses do público. A preferência é pelo cinema autoral, com forma e conteúdo originais, sem interesse em lucro. Trata-se de uma missão em relação ao Brasil.

Em entrevista, Jean-Claude Bernardet concorda que havia um paradoxo entre a defesa da ocupação do mercado pelos críticos e uma reação da mesma crítica contra os filmes de mercado. "Isso existe até hoje. Acho que quanto mais $O$ som ao redor está chegando aos cem mil espectadores, menos as pessoas estão gostando. É um vício estrutural de uma questão de preservação da cultura de um grupo que se quer hegemônico e muito restrito". 
A missão do intelectual na matéria Dez anos de cinema nacional desdobra-se na ideia de ocupação do mercado, que segundo Jabor, é por si só uma atitude política. Na conclusão desse raciocínio, Jabor defende que Toda nudez será castigada (1972) é um “filme político" porque conquistou o mercado. [Ele é] "o meu melhor filme. E o mais importante politicamente, pois está sendo exibido no Roxy e em grande circuito".

Aqui a atitude política denota a ocupação do circuito exibidor. Decorre daí que a função política do cinema é desviada para a conquista do mercado, através do cinema comercial. Contudo não se trata de uma simples defesa do cinema voltado ao mercado, tão criticado por Jabor no depoimento, porque a conquista do público significa “(...) se apoiar nos mitos da indústria cinematográfica para poder ir contra ela". O sentido da mensagem é construído indiretamente, quando Jabor explica que a [doutrina de "segurança nacional" da] televisão não mostra um par de coisas reveladas por ele:

"A TV é um problema político, não é um problema cultural, é um problema de segurança nacional. A TV é a arma mais importante da integração nacional (...). E eu estou interessado em mostrar uma série de coisas que estão sendo proteladas, esquecidas e marcadamente soterradas pela TV, tais como liberdade, vida, verdade e uma série de valores que se você fugir com uma Super-8 debaixo do braço estará ajudando a que fiquem esquecidas."

Vemos nesta coletânea que os cinemanovistas declaram a intenção de realizar a resistência dentro do circuito exibidor, mas negam a possibilidade de "contaminação" porque fazem um trabalho crítico, contrário ao cinema voltado ao lucro. Zuenir Ventura sintetizou ainda em 1971 o receio dos intelectuais do período em atender aos interesses comerciais: "Tendo que atender mais ao requerido pelo consumo, (...) esses intelectuais se considerariam produtores e não criadores, fabricantes de produtos em série e não criadores de objetos únicos" 18 .

Bernardet problematizou a relação entre ocupação do mercado, Cinema Novo e Cinema Marginal nos textos Indagações sobre as significações políticas do Cinema Novo (Bernardet, 1978: 125-139) e Uma crise de importância (Bernardet, 1978: 174177). O primeiro foi publicado no livro Kino und Kampf in Latinamerika em 1974 e o segundo na revista Argumento em 1973. Diferente da defesa da ocupação a qualquer

\footnotetext{
${ }^{18}$ A crise da cultura brasileira. Visão. v. 39, n. 1, p. 52-58, 05 jul. 1971.
} 
preço de Opinião, o crítico coloca em xeque este conceito nos dois textos. Bernardet explica que se a preocupação dos cinemanovistas era ocupar o mercado, a preferência deveria ter recaído nos filmes comerciais. Isso porque as intenções políticas dos filmes não são o produto mais indicado para atingir o público. Mas se o objetivo era fazer um cinema crítico, o grande circuito não era a única opção, porque as discussões importantes estão fadadas ao esquecimento no circuito exibidor. Além disso, o público das grandes salas exibidoras não é a melhor escolha para promover uma discussão política sobre a sociedade.

No texto Uma crise de importância, Bernardet (1978) tomou os depoimentos dos cinemanovistas nessa coletânea de Opinião como síntese da aproximação dos cinemanovistas com o Estado e de suas contradições. Se eles queriam atingir o público, deveriam trabalhar na televisão; proposta que geralmente era rejeitada. Entre os depoentes, só Geraldo Sarno elogiou a experiência que teve na TV. Questionando as declarações, Bernardet pergunta: os cinemanovistas estavam "minando" o "sistema" "por dentro", ou faziam parte dele? Até onde ia a atitude de justificação? Se o simples ato de passar um filme no circuito exibidor como disse Jabor é suficiente como ato político não é mais necessário fazer nenhuma forma de resistência? A contradição que os cinemanovistas não querem enfrentar, segundo ele, é a da necessidade de entrar no sistema para poder atingir o público das salas comerciais. Arthur Autran (2013) observa um curto-circuito ideológico no meio cinematográfico dos anos setenta, porque se afirmava o domínio do mercado interno como o principal objetivo, mas a justificativa vinha através da motivação cultural.

No fundo, o questionamento do cinema voltado ao mercado indica a preocupação com a função política do cinema. A problemática do cineasta que quer ocupar o mercado, mas despreza o cinema comercial é um assunto tabu no jornal, porque não se quer adentrar nesta contradição, que eles não conseguem, nem querem resolver. Trata-se do paradoxo do período ${ }^{19}$.

Se a ocupação do mercado é o ponto consensual entre os cinemanovistas entrevistados, os testemunhos revelam dois pontos dissonantes para conquistar o mercado: a linguagem utilizada e cinema comercial.

\footnotetext{
${ }^{19} \mathrm{~A}$ crítica à produção comercial indica o questionamento interno da esquerda e do intelectual frente à indústria cultural. Ver o livro Seguindo a canção de Marcos Napolitano (2001) que aprofunda a relação entre os artistas da MPB e o imperativo da indústria cultural. Há uma luta entre a busca da autonomia da MPB enquanto instituição cultural e a heteronomia por causa da articulação com a indústria cultural, sujeitando-se às leis exteriores e a reordenação comercial. Essa disputa é a mesma do Cinema Novo que luta entre sua autonomia e a sujeição ao mercado.
} 
A defesa inicial da linguagem clássica não é sinônimo de ocupação do mercado. Um pequeno foco de discordância diz respeito ao papel da emoção no cinema. Eduardo Escorel prefere a linguagem clássica e reprova a supressão do prazer cinematográfico. Enquanto isso Geraldo Sarno e Gustavo Dahl foram os únicos a defender o uso da emoção no cinema. Eles adentram num campo minado em Opinião ao defender a "sensibilização" num jornal que relaciona a emoção com interesse comercial e melodrama de baixa qualidade artística. Nessa direção vai Gustavo Dahl:

"O que a indústria pede do cineasta é que ele se dirija ao máximo denominador comum, que chegue aos sentimentos mais elementares que são comuns a grandes camadas da população - de usar como matéria bruta a emoção do espectador. Do ponto de vista do cinema mágico terapêutico, isso não é mau. Porque se vai trabalhar, como no cinema americano, na área dos grandes sentimentos. O problema das relações entre vida e arte é uma coisa que está sendo vivida muito intensamente no momento (...)".

Aqui, Dahl defende a emoção no cinema, justamente num jornal que se preza a condenar a visão política e ideológica dos filmes hollywoodianos (ver Capítulo 2). Num primeiro olhar, ele parece defender o ponto de vista da indústria, porque não questiona sua visão de mundo. Porém a ideia de emoção era a base para atingir a capacidade de mobilização e conscientização. Dahl tentou colocar isso em prática quando fez Uirá (1973) trazendo a emoção em sentido político (ver Capítulo 3).

As discordâncias em torno da ocupação do mercado neste texto aparecem a partir da comédia erótica. Gustavo Dahl é o único a elogiar a política cinematográfica. Dois anos depois, em 1975, ele assumirá a direção da Sucom (Superintendência de Comercialização) da Embrafilme.

Não se pode esquecer que a defesa da conquista do mercado deste depoimento já estava presente nos artigos do cineasta para a Revista Civilização Brasileira em $1966{ }^{20}$. Nesta entrevista, Dahl vê a comédia erótica como elemento positivo em direção à conquista do mercado, visão única nos depoimentos. Num jornal de intelectuais de esquerda, o cineasta enxerga este gênero como forma de se liberar sexualmente. Esse

\footnotetext{
${ }^{20}$ Para maiores detalhes ver Bernardet e Galvão (1983) que analisam as mudanças do discurso de Dahl no início dos anos sessenta e em 1966 na Revista Civilização Brasileira. De acordo com eles, o radicalismo de Dahl no começo daquela década atenuou-se, quando ele tomou ciência da realidade do mercado, vendo a associação entre indústria e desenvolvimento como algo inescapável. Foi quando Dahl questionou os postulados do Cinema Novo, distante do público e do mercado. Para Galvão e Bernardet, houve uma guinada quando Dahl renegou o seu princípio básico de antiindustrialismo, trazendo o ideário do cinema industrial. Eles consideram que a evolução do pensamento de Dahl é extremamente coerente. Portanto não procederia a acusação de virada ideológica posterior, porque as inflexões ocorreram em períodos muito anteriores. Ver também a análise de Arthur Autran (2013) sobre os artigos de Dahl na Revista Cvilização Brasileira.
} 
argumento é sempre contestado em Opinião como um subterfúgio do mercado para lucrar mais. Ninguém naqueles anos discutia o mercado sem prescindir dos argumentos de fundo moral ou ideológico, diferente do que Dahl fez aqui.

Quando Dahl justifica a ocupação a qualquer preço via comédia erótica, ele retira de pauta a preocupação ideológica sobre o conteúdo dos filmes. O cineasta incorpora a defesa do cinema só como mercado, sem questionar a lógica do lucro, postura que ficará famosa com a publicação do seu artigo Mercado é cultura ${ }^{21}$. Dahl parece encaminhar-se pouco a pouco para o reconhecimento da superioridade da lógica do mercado na organização das relações sociais e naturalização das relações econômicas, aceitas como princípios incontestáveis e universais. Só que o argumento dele em Opinião possui um movimento problematizante, porque é acompanhado da função política do intelectual.

Se a ocupação cinematográfica é válida para Gustavo Dahl a qualquer preço, Joaquim Pedro tem uma postura mais complexa, preocupado com a "prostituição" que busca assegurar a audiência. A postura é típica dos anos setenta. Ao mesmo tempo, ele considera fundamental a exploração crítica junto às massas. Os dissensos sobre os limites da ocupação revelam no fundo as disputas em torno do cinema comercial, que é o maior adensador de discórdias. Exceto Gustavo Dahl e Joaquim Pedro, todos condenam muito o cinema voltado ao lucro fácil. Carlos Diegues tem a postura mais negativa. Para ele, cinema comercial significa a cópia dos modelos estrangeiros e o subdesenvolvimento industrial. Isto é, não há originalidade nele. Os cinemanovistas veem o filme comercial como parte da engrenagem capitalista. Portanto, o interesse deles pelo formato é apenas uma forma de atingir o público, como se estivessem acima da contaminação pelo sistema porque realizam filmes comerciais "críticos". Os cinemanovistas e Opinião fazem tábula rasa do cinema de gênero. A contradição desse argumento é ocupar o mercado mas prescindir desse tipo de filme.

A solução encontrada para o embate entre comércio e arte é citar Macunaíma (1969) de Joaquim Pedro de Andrade como filme autoral de proposta original que conseguiu obter grande sucesso de bilheteria. Portanto, a defesa da ocupação do mercado em Opinião não significa obrigatoriamente cinema voltado ao mercado, nem linguagem clássica; mas segue o modelo autoral de Macunaíma.

\footnotetext{
${ }^{21}$ Mercado é cultura. Cultura. Brasília. v. VI, n. 24, jan. mar. 1977.
} 
A polêmica de Gustavo Dahl - o cinema como higiene mental

As discordâncias dos cinemanovistas apontadas acima não chegam a desestruturar a união entre eles. Porém, há um afastamento gradual de Gustavo Dahl do restante do grupo. O ponto de discórdia só poderia ser mesmo o cinema comercial, pois ele é o único a defender o mercado, desvinculando a conquista econômica da discussão ideológica. O depoimento de Dahl para Opinião nesta mesma série de entrevistas tornou-se polêmico pela seguinte declaração:

"Pode parecer radical mas estou absolutamente convencido que a função social do cinema é a higiene mental da população. E isso coloca a necessidade de uma visão de mundo um pouco mais globalizante que a política. Pode ser a mudança de valores, de uma civilização. No meu primeiro filme, $O$ Bravo Guerreiro, eu criticava as possibilidades da democracia parlamentar. Hoje, no Uirá, o que estou colocando em questão é a cultura branca, a civilização ocidental."

Dahl usa aqui outra palavra proibida num jornal de intelectuais de esquerda: a defesa da "higiene da população", numa referência positiva à função de entretenimento do cinema americano. Naquele contexto político não era costume admitir a função do cinema como válvula de escape. Essa declaração foi considerada uma mudança de discurso por Ortiz Ramos (1983). A frase foi entendida como apologia ao entretenimento e como oposição ao engajamento. Pensar o cinema como válvula de escape denotava para a esquerda apatia "ideológica" infringida pelo ato de diversão. Significava a impossibilidade de atingir a emancipação crítica por causa do conteúdo da produção industrial. Ortiz Ramos vê as formulações de Dahl como um endossamento acrítico da industrialização e como consequência da política cultural do Estado.

Já Renato Ortiz (2006) inclui esta declaração de Dahl como exemplo dos que questionaram o Cinema Novo. Não se trata de um oponente qualquer. É quase como se ele visse Dahl como parte do aparelho ideológico de Estado. Para explicar a argumentação, Ortiz esclarece a forma encontrada pelo Estado autoritário para condenar o caráter político do cinema: o regime criticava o Cinema Novo e o cinema político em nome do público. Dessa maneira, a ditadura escondia que suas preferências tinham caráter ideológico. Em nível discursivo, o Estado não condenava o conteúdo de esquerda dos filmes, mas seu viés "elitista" e desinteressado pelo público. Para Ortiz, tanto o Instituto Nacional de Cinema (INC), quanto os cinemanovistas estavam em 
sintonia quando o assunto era criticar o Cinema Novo dos anos sessenta. O problema era desviado da questão política, para centrar-se nos interesses do público consumidor, com viés de entretenimento. Dessa forma o Estado mostrava-se como espaço da neutralidade.

Se a análise de Renato Ortiz explica o funcionamento do discurso do regime militar, ela não dá conta de entender o discurso dos cinemanovistas em sua totalidade. Primeiro, nos parece salutar compartilhar uma informação que coloca a frase de Dahl num contexto mais amplo. Quase concomitante a essa declaração, o cineasta tocou no assunto da função do cinema na revista Filme Cultura $^{22}$ :

"Os meios de comunicação de massa se encontram na encruzilhada de uma função higiênica (diversão), com uma função social (informação, isto é, formação). É esta segunda, moderna e misteriosa, que supera a passividade limitada da primeira e confere ao filme, que pode ser um simples produto, a categoria de ato social e civilizatório".

Neste texto Dahl explica melhor a declaração dada ao jornal Opinião, porque a frase pressupõe uma tensão no cinema entre a função de diversão (higiene) e de formação. Assim o pensamento dele deve ser analisado em termos gerais, não numa afirmação pinçada do texto. Afinal a análise do discurso dos cinemanovistas nesse período não é simples, porque pressupõe mudanças, hesitações, contradições e mensagens na entrelinha, mas tudo isso não é sinônimo direto de adesão ao regime. Gostaríamos de trazer uma segunda possibilidade de leitura.

Seguindo a linha de raciocínio exposta acima, as ressalvas de Opinião ao Cinema Novo por causa de seu conteúdo elitista significam uma condenação ao cinema político em nome da conquista do público? Não. Num periódico censurado como Opinião, as declarações dos cinemanovistas devem ser lidas implicitamente, afinal ninguém pode colocar em xeque a preocupação do jornal com o cunho político do cinema. Devemos ler Opinião no que é preciso não dizer para poder dizer. O semanário não defende o gosto do público; geralmente até o despreza. Sua luta pelo cinema político visa à conscientização. Exatamente por esse motivo, o jornal condena o hermetismo da linguagem, por impedir a conscientização do público. O signo é trocado com a ideia de entretenimento proposta por Renato Ortiz. Neste novo sentido, a defesa da emoção e o uso da linguagem clássica também podem ser armas para a

\footnotetext{
${ }^{22}$ Premissas a um projeto de cinema brasileiro. Filme Cultura. 6 (20): mai. jun. 1972, p. 50-2.
} 
conscientização. Essa declaração de Dahl difere dos demais comentários em Opinião, que desprezam o papel da emoção no cinema. Se ele defende num primeiro momento a função do cinema em divertir, interpretada erradamente como negação da função política do cinema, a frase seguinte muda tudo. Dahl declara em Opinião que se o cineasta:

"está a fim de transar com o povo, a massa, tem que usar a linguagem dessa massa e tem que se usar as necessidades dela. Em vez de uma visão aristocrática, intelectual, falsamente cultural, acho que bastaria que a gente descobrisse dentro da gente o que é povo. Povo naquele sentido mais amplo, de um grupo humano que transa dentro de uma mesma fronteira e na qual nós também estamos incluídos.

No momento em que os artistas se descobrirem participantes [grifo nosso], eu acho que eles terão resolvido uma porção de problemas, como artistas, da arte, da arte brasileira, e, sendo um pouco mais utopista, estarão também ajudando o povo brasileiro a evoluir em todos os sentidos, material e espiritualmente."

Se Dahl falasse somente em prol do cinema comercial, na frase seguinte ele não faria referência ao conceito de intelectual participante da época do Cinema Novo. A grande novidade aqui é que Dahl está a meio caminho entre Opinião e o conceito de intelectual participante (ver Capítulo 2) de Antonio Candido (2011). Ele quase teoriza o caminho para o intelectual comunitário da AP (Ação Popular), quando fala em "transar" como forma de trabalho conjunto com o povo, incluindo-se nele (ver Capítulo 6). Porém, no meio da declaração, o cineasta volta ao ideal do arauto ou dirigente da cultura que "ajuda o povo a evoluir". Há uma tensão entre ser dirigente, fazer parte da comunidade e participar de uma ação coletiva. Literalmente no meio do caminho, Dahl procura se encaminhar para o polo do intelectual que age na comunidade junto ao povo. Ele hesita e não consegue se integrar totalmente ao conceito de Gramsci (1968) e de Florestan Fernandes (1976) de imiscuir-se com o povo, nem com o conceito sartriano (1994) do intelectual que deve se integrar, participar e se deixar "penetrar" pelas classes desfavorecidas ${ }^{23}$. A hesitação revela o quanto ele ainda se via como ser à parte do povo, como dirigente.

Gustavo Dahl falou mais de uma vez sobre a função do cinema como higiene da população, com mais de uma variação de sentido. No Manifesto Luz \& Ação (Ver Capítulo 5), texto conjunto dos cinemanovistas sem a participação de Dahl, nega-se a função do intelectual como dirigente da cultura, e para isso o artigo cita o autor de $O$

\footnotetext{
23 Aprofundaremos a análise teórica desses autores no item Crise ou reelaboração do papel do intelectual?
} 
Bravo Guerreiro: "Gustavo Dahl: '... porque só o orgulho, o pior dos pecados, é que nos pode fazer crer que temos algo a ensinar aos outros em vez de simplesmente dizer algo ao outro - acredito que a principal função do cinema é a higiene mental da população"”.

É inegável a tensão em Dahl entre a defesa do cinema feito para o mercado como uma forma universal e naturalizada e a preferência pelo conteúdo político do cinema indiretamente. Essa discussão não era só de Gustavo Dahl, mas do período. Esse discurso antagônico criava variações. No testemunho para Opinião, num nível superficial em relação ao contexto, ele parece tomar partido do cinema comercial. Mas, ao contrário, no texto para Filme Cultura, Dahl defende explicitamente o cinema crítico, contra o cinema voltado ao mercado. Este último artigo também gerou polêmicas. Ortiz Ramos (1983) viu o texto como "síntese que situa-se num nível de despolitização da cultura superior até mesmo ao da PNC" (Política Nacional de Cultura). Isso porque Dahl envereda pelo argumento de preservação da cultura, mas enquanto a PNC é de 1975, o texto da revista Filme Cultura é de 1972. Só que muito antes da PNC, o Cinema Novo já defendia a busca da cultura brasileira autêntica. Ortiz Ramos não aceita que Dahl veja o cinema industrial como uma "fôrma" sem ideologia, onde se pode encaixar qualquer conteúdo. Para o período, uma declaração como esta facilmente geraria um mal entendido. Defender o cinema comercial naquele contexto significava "vender-se" ao sistema. A discussão do mercado não podia prescindir do argumento ideológico, condenando justamente a visão liberal. Mas como vimos no Capítulo 3, Gustavo Dahl estava mais próximo da busca de lacunas e fissuras defendida na revista Cahiers $d u$ Cinéma por Jean Narboni e Jean-Louis Comolli, sem ver obrigatoriamente o cinema americano como fator negativo.

Se algumas frases realmente indicam o quanto Dahl caminhava para uma defesa do mercado, as declarações seguintes negam as primeiras afirmações. O tom é problematizante. É preciso tentar separar o discurso de Dahl enquanto crítico, antes e depois de sua passagem pela Embrafilme. Ortiz Ramos constrói sua argumentação a partir de uma frase de Dahl, mas na continuação do artigo, o cineasta toma outro rumo.

Uma diferença precisa ficar clara. Em Opinião, o argumento sobre a função de higiene é cortado pela metade. Neste texto, Dahl não comenta a função crítica do cinema. Talvez o restante da frase tenha sido excluído pela edição ou o entrevistado não tenha concluído mesmo o pensamento. Ele também pode ter alterado a forma de pensar, voltando-se cada vez mais ao argumento mercadológico, porque entre os dois textos há uma diferença de quase um ano. Um ano antes, em 1972, na revista Filme Cultura, Dahl 
defende o cinema crítico e a função de formação, não a higiene mental da população. No fundo, Dahl elogia mesmo o cinema autoral, mas sem demonstrar essa equação publicamente. É essa a função misteriosa e moderna que "confere ao filme a categoria de ato social civilizatório". Se a palavra "civilizatório" parece carregada de sentido negativo, talvez ela traga a função do intelectual de conscientizar o público. Afinal Dahl utilizava esse termo para falar de Uirá, lançado naquele ano. De qualquer forma, concordamos com a inadequação da terminologia, que parece trazer a ideia de correção dos costumes populares em prol da superioridade dos valores ocidentais civilizados. Ao falar para Opinião que tinha mais leitores, Dahl defendia Uirá quase como uma produção voltada ao grande público. Quando escreve para a revista da Cinemateca, ele comenta a obra como um filme de arte (Ver Capítulo 3).

O que os pesquisadores não comentaram é que até o título do artigo de Dahl em Filme Cultura sinaliza que o projeto político do Cinema Novo estava de pé: "Premissas a um projeto de cinema brasileiro". Esta é a defesa de Dahl do mercado. Muito longe de uma incorporação dos valores do mercado, o cinema que tem como "função" a "formação" não é ninguém menos que o Cinema Novo. Entretanto, Dahl não cita o nome do movimento:

"Atualmente existe no Brasil uma indústria cinematográfica em processo de implantação (...), mas desprovida de uma ideologia, isto é, indiferente à missão de descobrir os valores de sua civilização. E existe também um movimento culturalcinematográfico que esgotou na prática as tendências elitistas, enquanto recuperava 0 atraso que o cinema brasileiro mantinha em relação ao cinema mundial. Tudo leva a imaginar um encontro destas duas realidades e a prever que o cinema, como arte, como meio de comunicação de massas, conhecerá em nosso país a sua ressurreição."

É como se ele quisesse unir o sonho do cinema independente com o cinema industrial e o autoral. Numa leitura sintonizada com as demandas do período, incomodava Dahl negar a presença de conteúdo ideológico do cinema industrial. Talvez ele estivesse um pouco além do jornal Opinião, separando a discussão do conteúdo da forma. Ou talvez estivesse sintonizado com a teoria de Patrick Lebel (Xavier, 2005) ${ }^{24}$. Para o contexto brasileiro, a frase podia indicar ingenuidade ou incorporação pelo

\footnotetext{
${ }^{24}$ Para Lebel, a forma não tem sentido ideológico em si. A câmera é neutra do ponto de vista ideológico. Portanto, pensar um tipo de narração como uma narrativa burguesa significa para o teórico assumir uma posição idealista. O autor atacava os redatores de Cahiers du Cinéma, acusando-os de transformar a ideologia numa essência. Para Ismail Xavier (2005), as colocações de Lebel atingiram o que há de problemático e discutível nas formulações dos defensores da desconstrução, mas ele caiu em simplificações vagas. Afinal a noção de forma de Lebel transforma a linguagem em mero instrumento inocente e à disposição do usuário.
} 
mercado. Dahl vê o cinema como uma "fôrma" onde se pode acrescentar qualquer conteúdo. O trecho revela, assim, um deslocamento do sentido de ideologia para a missão do intelectual de descobrir os valores sociais. Portanto a ideologia ausente na indústria é a "contra-ideologia" do Cinema Novo. É este movimento quem irá descobrir os valores da "civilização".

Essa é a defesa de Gustavo Dahl do cinema comercial: a industrialização do cinema "como arte", isto é, a industrialização do Cinema Novo. Com esse segundo trecho, a citação anterior adquire outro significado. A oposição entre função de diversão e função de formação é a divisão entre o cinema industrial e o cinema crítico. Para ele, a diversão do cinema industrial precisa reencontrar-se com a função de formação do cinema crítico. A ideia de ressurreição exposta por Dahl é a do renascimento do Cinema Novo, após a correção do problema da linguagem hermética, que impede a comunicação com o público.

É preciso compreender as contradições de Dahl como parte das contradições do próprio intelectual (Sartre, 1994) e como parte do pensamento da intelectualidade que faz uma aliança com o Estado autoritário em prol do cinema. Para entender Gustavo Dahl num jornal censurado como Opinião, ou em qualquer outro veículo da imprensa do período, é preciso seguir a forma problematizante do seu texto e entender seu discurso dentro dos projetos políticos de sua área. A frase polêmica de Dahl não significa uma negação do caráter político dos filmes, afinal ele saia da discussão sobre a democracia partidária em $O$ bravo guerreiro para atingir um debate sobre $\mathrm{o}$ cerceamento à liberdade de expressão em Uirá. Talvez a forma de escrita de Dahl por antinomias revele um viés ensaístico dialético. Talvez Dahl seja o maior indício do discurso contraditório dos cinemanovistas em relação ao Estado. 


\subsection{O Novo Cinema Novo: as mortes e ressurreições do movimento na imprensa}

Logo nas primeiras edições de Opinião, Jean-Claude Bernardet se questiona se o Cinema Novo tinha mesmo morrido ${ }^{25}$. O ano é 1972, período em que a historiografia ainda considera vivo o movimento ${ }^{26}$. A indagação surge por conta de um primeiro contato com São Bernardo (1972) de Leon Hirzsman. Para o autor, nenhum outro movimento cinematográfico, após o Cinema Novo e o Cinema Marginal, "se viu em condições de promover uma análise e uma reflexão crítica sobre a sociedade, nem de pesquisar formas dramáticas de apreensão da realidade". A frase revela parte do projeto Bernardet de dar atenção aos filmes que fazem a análise da sociedade. Qualquer semelhança com o Cinema Novo não é coincidência. No fundo, defende-se o cinema moderno e político, responsável por promover uma reflexão crítica ao espectador.

A aposta crítica em tom de hesitação ou hipótese de Jean-Claude Bernardet é a de que "agora parece que o Cinema Novo" não morreu porque surge um "bloco homogêneo" de filmes:

"No vazio criado pelo silêncio compulsório dos estreantes de 68-70, os filmes de alguns 'veteranos' constituem o esforço básico para sustentar essa reflexão crítica no cinema: Como era bom (sic) o meu francês, Os inconfidentes, A casa assassinada. Agora São Bernardo. Todos de 1971-72. Seus autores, Nelson Pereira dos Santos, Joaquim Pedro, Saraceni e Hirszman foram figuras de destaque do cinema novo, movimento que, pelos idos de 68-70 se dizia morto, mas que talvez não esteja tanto assim, se se considerar que os filmes citados, produzidos quase simultaneamente formam um bloco homogêneo.

Passando por cima das formas inovadas pelo 'cinema marginal', do seu desespero, dos seus gritos, do seu frequente irracionalismo, da dissolução do enredo, da composição fragmentária dos personagens, e até do esforço de apreensão e expressão da realidade que estavam germinando em alguns filmes, estes quatro filmes retomam a linha dramatúrgica que sustentou o cinema novo: o realismo crítico. Uma ponte: Vidas secas/64 - São Bernardo/72.

\footnotetext{
${ }^{25}$ Bernardet, Jean-Claude. Uma voz inesperada. Opinião. n. 7, p. 22, 18 a 25 dez. 1972.

${ }^{26}$ Há um consenso historiográfico sobre o final do Cinema Novo. A partir de 1970, segundo Ismail Xavier (2001), existem apenas trajetórias individuais. Depois disso não se pode mais falar de Cinema Novo, por causa da fragmentação do grupo. O cinema brasileiro posterior a 1972-73 não facilitaria a tarefa de mapeamento, nem de encontrar estéticas conjuntas. Para Paulo Paranaguá (Ramos, 1987) nos anos setenta estavam presentes só os cinemanovistas, sem o movimento conjunto que caracterizou o Cinema Novo. Johnson e Stam (1982) colocam como data limite para o Cinema Novo o ano de 1972 como o último ano de existência do grupo. Para Paranaguá (Ramos; Miranda, 2000), a presença dos cinemanovistas nos anos setenta dificulta estabelecer períodos claros. Portanto, a filmografia precisa entre Cinema Novo e não Cinema Novo não é fácil de definir. Filmes como São Bernardo de Leon Hirszman e Toda nudez será castigada de Arnaldo Jabor, ambos de 1972, ainda são considerados pela historiografia como pertencentes ao Cinema Novo.
} 
O enredo nasce de uma análise da sociedade. E o conjunto das situações apresentadas pelo filme, bem como pelas contradições vividas pelos personagens centrais são uma síntese das contradições sociais globais num determinado momento."

O crítico não toma São Bernardo como indicativo do cinema brasileiro no ano de 1972, mas como obra de exceção, porque ele não vê na filmografia nacional um viés crítico ${ }^{27}$. A dramaturgia utilizada parece ser a mais adequada para a análise de uma problemática social. Afinal, a produção importante para o crítico aborda o passado e o presente. Ela revela a realidade econômica e política. A base metodológica para Opinião pensar a continuidade do trabalho cinemanovista ao longo dos anos está nesse texto. Aqui o Cinema Novo é um conjunto homogêneo que faz a análise da sociedade.

Depois desse texto, a pergunta latente que Opinião a cada lançamento cinemanovista é $O$ Cinema Novo está morto? Da inexistência de um marco final consensual do movimento, surge uma suspeita sobre sua continuidade. Especialmente entre 1972 a 1975, o semanário abriu debates, não só para suscitar polêmicas, mas para procurar um caminho e um projeto político para o cinema brasileiro. A continuidade ou não do Cinema Novo no semanário não significa a procura por um conjunto homogêneo do ponto de vista estético, mas indica a busca por uma ética de transformação da sociedade e por um projeto político de conscientização. Os cinemanovistas obtêm bastante espaço no jornal porque há entre eles uma convergência de propostas estéticas e políticas.

A indagação de Bernardet sobre a continuidade ou não do Cinema Novo não era estanque e dependia do enfoque dado. Por exemplo, em 1974, Bernardet (1978: 136) escreveu um capítulo para o livro Kino und Kampf in Latinamerika e declarou: "Tem-se falado muito na morte do Cinema Novo. Se morte houve, é provável que tenha havido, ela é a ruptura povo/cinema". Neste texto, o crítico se refere ao Cinema Novo como se ele continuasse a existir, observando suas principais dificuldades. Bernardet, inclusive, toca em pontos vetados em Opinião por causa da censura, como a necessidade de produzir sob intensa repressão. A postura indica que os sentidos da continuidade do Cinema Novo variavam no período. Não se considerava somente a postura estética ou a coesão entre eles. O critério já passava pela existência conjunta frente à política cultural ou pela proposta dos filmes de analisar a sociedade. Depois disso, Bernardet desiste de

\footnotetext{
${ }^{27}$ Bernardet, Jean-Claude. Zezero e o fantasma da castração. Opinião. n. 9, p. 6, 01 a 08 jan. 1973.
} 
procurar um todo homogêneo no Cinema Novo, mas nos artigos escritos em Opinião o movimento continua a existir como um grupo detentor de um projeto político.

O interesse de Opinião sobre a sobrevida do Cinema Novo começa em 1972 e estende-se até 1975. Não se trata de um enfoque original do jornal. No mesmo período, a imprensa se ocupou bastante do mesmo tema. A dúvida não era gerada só porque os cinemanovistas continuam a produzir, mas porque o grupo estava articulado politicamente em torno do Estado (ver Capítulo 5).

Por exemplo, o Jornal do Brasil em 1975 realiza três grandes reportagens sobre o assunto ${ }^{28}$. O primeiro destes artigos constrói o mito de uma virada no Cinema Novo e reavalia suas teses mediante a aproximação com a Embrafilme. Para o conjunto de entrevistadores do Jornal do Brasil, o grupo ainda desempenha um "inegável” e "extraordinário" papel na vida cultural do país. O periódico, então, abre suas páginas para os cinemanovistas discutirem a política cinematográfica. Nesta matéria Arnaldo Jabor, Glauber Rocha, Nelson Pereira dos Santos e Paulo César Saraceni afirmam em coro que o Cinema Novo continuava vivo. Nelson Pereira dos Santos chega a insistir que a morte do Cinema Novo é repetida pelos seus adversários na esperança de "finalmente matá-lo". Os cinemanovistas defendem a existência do Cinema Novo com as seguintes provas: 1. o grupo se adapta à realidade, 2. o Cinema Novo acompanha a dinâmica da "consciência da realidade", 3. o movimento "é uma das poucas árvores ainda em pé" se pensando, 4. o Cinema Novo esteve sempre morrendo e ressuscitando, 5. os cineastas continuam a produzir, 6. o movimento é voltado à realidade brasileira e seu diferencial é um processo dialético de constante construção, 7. o grupo encontrou novas formas de se manifestar e apresenta o novo no plano formal. Só Paulo César Saraceni discorda dos entrevistados e vaticina uma morte em 1968, quando o grupo deixou de existir. O movimento é apresentado por eles como uma "tática" e "estratégia" para alcançar a distribuição e a comercialização. A frase revela uma definição do Cinema Novo como grupo atuante junto à política cinematográfica. Para variar, a declaração de Glauber Rocha termina com uma provocação:

\footnotetext{
${ }^{28}$ Pontes, M.; Cabrol, Arlette; Silveira, Emilia; Alencar, Miriam; Couri, Norma; Gropper, Symona. As muitas mortes e ressurreições do Cinema Novo. Jornal do Brasil. Caderno B. 10 dez. 1975, p. 8. O segundo artigo é Um órfão de público (e um público órfão de cinema). Jornal do Brasil. Caderno B. 11 dez. 1975. E o terceiro Um doente à espera do remédio milagroso. Jornal do Brasil. Caderno B. 12 dez. 1975 , p. 8.
} 
"O Cinema Novo existe porque estou dando essa entrevista, porque ele está sendo discutido, como é que um processo pode estar morto, se a imprensa se ocupa dele, e muito, como tem acontecido nos últimos tempos? O Cinema Novo existirá sempre que existir algum cineasta filmando dentro do processo criativo revolucionário."

O segundo artigo do Jornal do Brasil ${ }^{29}$ procura justificar a necessidade de participação dos cinemanovistas na política cultural. Coloca-se mais uma vez em debate a existência do movimento:

"A questão de saber se o documento que hoje se espera do Cinema Novo é um atestado de óbito ou uma carteira de trabalho não é tão bizantina quanto à primeira vista parece. Se ele é declarado morto, isto significa, na prática, que a seus integrantes, enquanto tal será negado o direito, a voz e voto na condução dos negócios cinematográficos do país. Batendo o pé, gritando que está vivo, acenando com os seus atestados de residência e de sanidade, o Cinema Novo está reclamando esse direito. E valorizando o seu papel na vida cultural da nação, está não apenas reclamando a sua participação, mas também querendo provar a sua autoridade para intervir nas decisões."

Aqui há a percepção de que a afirmação do grupo é mais uma estratégia de pressão e de articulação política do que uma questão estética. $\mathrm{O}$ artigo é informativo e adere às declarações dos cinemanovistas. Afinal elas não são criticadas nem contrabalançadas. $\mathrm{O}$ atestado de morte do movimento não foi só criado pela imprensa. Em grande parte, ele se baseou nos depoimentos dos cinemanovistas. Por exemplo, Carlos Diegues (Johnson, Stam, 1982) se auto-proclamou o primeiro a decretar a morte do Cinema Novo, num depoimento publicado em Cahiers du Cinéma em $1970{ }^{30}$. Os cinemanovistas usavam as declarações sobre a morte e vida do movimento como estratégia para provar sua presença junto à política cultural.

É interessante observar também como as matérias sobre a morte e ressurreição do Cinema Novo não comentam as mudanças de argumentação do grupo. Nas reviravoltas discursivas deles na imprensa é possível identificar o significado político do grupo. Afinal suas declarações sempre aparecem em conjunto em alguns momentos importantes, como veremos. Muitas vezes o grupo toma como dado comum a continuidade do trabalho dos cineastas para provar a existência do movimento. Por

\footnotetext{
${ }^{29}$ Um órfão de público (e um público órfão de cinema). Jornal do Brasil. Caderno B. 11 dez. 1975.

${ }^{30}$ Diegues, Carlos. Entretien avec Carlos Diegues. Entrevista concedida a Jacques Aumont, Eduardo de Gregório e Sylvie Pierre. Cahiers du Cinéma. n. 225, p. 44-55, nov./dez. 1970.
} 
exemplo, Glauber Rocha ${ }^{31}$ no artigo "Xyka da Silva" define o Cinema Novo como conquista do mercado, sintonizado com a postura dos colegas naquele momento. Por causa disso, ele integra alguns diretores antes excluídos do grupo, como Bruno Barreto. Quando Glauber Rocha chega a esta constatação, cai por terra a argumentação da continuidade do grupo, porque se revela a falta de homogeneidade entre eles. Existe, na verdade, apenas um "germe" do Cinema Novo. A ideia é a mesma da entrevista do cineasta ao Jornal do Brasil descrita acima. Cinema Novo aqui é grupo de pressão política, tal qual foi definido por Ismail Xavier (2001) décadas depois ${ }^{32}$. A ideia da existência do movimento passava, portanto, pelo conceito de grupo de representação política, vendo os cinemanovistas como detentores de um projeto cinematográfico.

O termo Cinema Novo na imprensa do período resvala em diferentes significações: descreve ao mesmo tempo continuidade do movimento, uma forma homogênea de análise da sociedade e a presença conjunta dos cinemanovistas ou dos filmes no quadro de produção. Tanto a imprensa quanto os cinemanovistas compartilham a construção de um discurso sobre a continuidade e morte do Cinema Novo. Provavelmente uma das grandes motivações para esse debate na imprensa tenha sido a publicação em 1973 do Manifesto Luz \& Ação, assinado em conjunto pelo grupo 33. O objetivo era convocar a participação dos produtores de cultura para criar novas ideias e um diálogo aberto. Este texto traz também a ideia de união e continuidade do Cinema Novo. Eles apresentam-se como um grupo político, detentor de um projeto para o cinema brasileiro enquanto arte. Os cinemanovistas reafirmam a importância do cinema como "invenção permanente" e como solução para enfrentar a produção de “baixo nível”, voltada para o mercado. Além disso, o Manifesto constrói a ideia de que alguma coisa está para acontecer, frase que será retomada no lançamento de $O$ Amuleto de Ogum (1974) de Nelson Pereira dos Santos (ver Capítulo 6). O documento constrói a

\footnotetext{
${ }^{31}$ Por exemplo, o livro Revolução do cinema novo publicado em 1981 por Glauber Rocha (2004) está cheio de tentativas de ressuscitar o Cinema Novo ao longo dos anos.

${ }^{32}$ Para Ismail Xavier (2001: 80), o movimento dos cinemanovistas durante o governo Médici, era "antes uma sigla para identificar um grupo de pressão, aliás hegemônico junto a Embrafilme, do que uma estética", enfatiza o autor.

${ }^{33}$ Assinaram o manifesto Carlos Diegues, Glauber Rocha, Joaquim Pedro de Andrade, Leon Hirszman, Miguel Farias, Nelson Pereira dos Santos e Walter Lima Jr. A primeira parte do manifesto foi publicada num jornal em 1973, mas na documentação da Cinemateca Brasileira não há a indicação do nome do periódico. Ver Pasta 89-30. Carlos Diegues (1988) publicou no seu livro uma pequena parte do Manifesto como de sua autoria. O Manifesto integral está disponível em Autran, Arthur. Documentos para a história do cinema brasileiro. 2006. Cinemateca Brasileira. Uma parte do artigo foi transcrita também por Johnson e Stam (1982). Depois o texto foi publicado na Arte em Revista. n. 1, p. 5-9 jan./mar. 1979. Publicação do Centro de Estudos de Arte Contemporânea.
} 
ideia de continuidade da ação cinemanovista, através da conquista do mercado e pela utilização de recursos estatais. Mas esse viés não deixa de lado a estética, nem a função do intelectual. O texto defende que o cinema só tem sentido como "invenção permanente" em todos os níveis: busca por novos modos de produção, novos temas e experimentação linguística. A missão do cineasta também é lembrada no texto: "O prazer da forma, as grandes utopias e o sentimento do mundo são direitos e deveres do artista”. Segundo Ismail Xavier (2001: 12), em pouco tempo essas ideias estariam traduzidas na gestão da Embrafilme.

Isso não significa que a fabricação da morte e ressurreição do Cinema Novo seja uma criação exclusiva dos cinemanovistas, engendrada pelo Manifesto Luz \& Ação e na imprensa. A crítica de cinema também tem o papel de gerar a crença reprodutiva não só nos artistas, mas também no sistema cultural. Os críticos de cinema auxiliam nesse processo de construção discursiva. Porém, todo o campo cultural age em conjunto. Se o projeto político dos cinemanovistas conseguia um amplo espaço dentro da cobertura dos jornais através do viés da resistência e da política cinematográfica, em Opinião repensar o Cinema Novo trazia para a crítica o debate sobre a função do intelectual e o papel político do cinema brasileiro. Estava em pauta o engajamento do intelectual, daí a importância de resignificar o Cinema Novo. O Novo Cinema Novo significava uma proposta de projeto político para o cinema brasileiro.

Observando as diversas declarações dos cinemanovistas na imprensa e no Manifesto, comprovamos que eles estavam articulados num discurso conjunto. Quando o grupo declara que o Cinema Novo tinha morrido, todos concordam. Quando ressuscitam o movimento, a trupe segue junto. Isso aconteceu mais de uma vez naqueles anos. Há uma estratégia bastante coesa que revela a existência deles não só como grupo de pressão junto à Embrafilme, mas como conjunto uníssono nos principais pontos além do ano de 1972. A estratégia de forjar a morte e sobrevida do Cinema Novo não é mera propaganda, mas uma estratégia de resistência ao regime. Por outro lado, talvez por causa da aproximação com o Estado autoritário, os veteranos do movimento tentem se balizar perante o público. Daí se explica a tão grande repetição de ressurreições cinemanovistas como forma de provar a existência de uma produção crítica ao sistema. A estratégia é útil também para negar a união com o Estado autoritário e revelar a existência de um grupo unido. 


\subsection{Intelectuais Cinemanovistas e o Estado autoritário - a tensão entre os gêneros jornalísticos}

A partir de 1974, os cinemanovistas aproximam-se do Estado autoritário tendo em vista sedimentar uma política cinematográfica de base nacionalista e protecionista na Embrafilme. Esse envolvimento gerou algumas acusações de cooptação na década de setenta e de oitenta. Algumas dessas acusações teriam sido feitas pela imprensa, especialmente pela imprensa alternativa. Analisamos neste tópico como a questão aparecia em Opinião para observar se realmente havia um entrelaçamento entre os dois discursos e se o jornal aderiu à acusação contra o grupo.

$\mathrm{O}$ ápice desse debate parece ter sido a declaração de Glauber Rocha à revista

Visão. Transcrevemos na íntegra o texto:

"Visão me pede para responder alguma coisa, eu também estou procurando uma resposta, a rainha Tomíris que matou Ciro era de um povo que costumava sacrificar aos deuses mais potentes os mais velozes seres humanos. Quando saí do Brasil, em 1971, deixei nas mãos do Tarso e do Maciel um artigo pra Já, onde anunciava que em 1974 baixava uma luz e as sete cabeças da besta se desintegrariam: depois, em outras ilhas, Marcos berrou no meio da viagem: Petróleo! E sabíamos que não era nosso na matéria mas Ideia; quem me encontrou nesses anos em vários continentes se lembra do que estava anunciando.

Visão me pede para responder sobre arte no Brasil de 1964-74: são dez anos de Bode, daquele Demoz que crava fundo as patas no dorso da plebe. Reagimos, o sangue correu em Jardim das Piranhas, Antonio das Mortes falou ao terceiro mundo, esperamos agora, sobretudo $\mathrm{Eu}$, que sou protestante, Luz e Ação.

Acho que Geisel tem tudo na mão para fazer do Brasil um país forte, justo e livre. Estou certo inclusive que os militares são os legítimos representantes do povo. Chegou a hora de reconhecer sem mistificações, moralismos bobocas, a evidência: Costa era quente, frias eram as consciências em transe que não viram pintar as contradições no espelho da história.

Em 1968, eu era albuquerquista e Antonio das Mortes é o profeta de Alvarado e Khadafi. Vejam as coisas: agora a história recomeça. Os fatos de Geisel ser luterano e de meu aniversário ser 14 de março, quando completo 35 , me deixam absolutamente seguro de que cabe a ele responder às perguntas do Brasil falando para o mundo. Não existe arte revolucionária sem poder revolucionário. Não interessa discutir as flores do estilo: quero ver o tutano da raiz. Comecemos por economia política e vejamos como se articula o desenvolvimento da superestrutura sobre o subdesenvolvimento da infraestrutura, etc. Acho Delfim Netto burro, idem Roberto Campos. Chega de mistificação.

Para surpresa geral, li, entendi e acho o general Golbery um gênio - o mais alto da raça ao lado do professor Darci. Que Celso Furtado é a metáfora do terceiro mundo dragado pela Wall Street Scout. Que Fernando Henrique é o príncipe de nossa sociologia. Que leio e curto a revista Argumento. Que Chico Buarque é o nosso Errol Flynn. Que entre a burguesia nacionalinternacional e o militarismo nacionalista eu fico, sem outra possibilidade de papo, com o segundo. De cinema novo? O novo é sempre viveterno e São Bernardo ainda surpreendeu incrédulos da geração de 50. Não tenho nada de pessoal contra tropicanalhistas: detesto a finura sutil dos machadianos, o 
revisionismo time-life da moçada abrilhantada. Sou um homem do povo, intermediário do cujo, e a serviço.

Força total pra Embrafilme,

Ordem e progresso." ${ }^{34}$

Esta declaração é o ponto de partida para pensar como Opinião lida com o tema. O texto causou espanto, vindo de um cineasta exilado. Ele deve ser visto como parte da estratégia de minar por dentro? Como parte da verve polêmica de Glauber Rocha? Como ironia pura através de signos trocados? Como prova de cooptação? Ismail Xavier (2001: 136) explica que "Glauber põe a nu o caráter elitista e excludente da política brasileira mas sua dialética de apatia e participação muitas vezes implica uma solicitação de ordem que se apoia na solução messiânica (...)". Nos anos setenta, o cineasta deu entrevistas sobre o poder nos anos 1970 que causaram estranhamento pelo tratamento da questão militar. Explica Xavier: "Na sua visão, o civilismo e a democracia liberal não estão no centro da crítica à ordem vigente, pois sua ideia de libertação nacional não exclui uma via militar e despótica, desde que carismática e antiimperialista, nacional e popular".

Como de costume, esta declaração de Glauber Rocha pressupõe mais de uma possibilidade de leitura ${ }^{35}$. Quem cita o artigo de Visão, costuma selecionar apenas alguns trechos, mas o sentido advém exatamente da leitura completa. Algumas partes são bastante óbvias, como referir-se ao regime como "dez anos" de "bode" que "crava fundo as patas no dorso" do povo. Ou quando Glauber cita a besta de sete cabeças, que vai se desintegrar em 1974 (leia-se abertura política). A comparação com Antonio das Mortes é irônica e ambígua. Em Deus e o Diabo na Terra do Sol (1964), Antonio das Mortes é o matador de cangaceiros, a mando dos fazendeiros. Por outro lado, o personagem é o agente catalisador das mudanças. Pela violência, ele vai levar à revolução do povo no futuro. Isto é, pela repressão do regime militar, pela adversidade, virá a revolução popular. O cineasta utiliza ainda outros recursos neste texto. Ele coloca em xeque a própria linha de argumentação para transmitir mensagens. Torna suas premissas frágeis para desconstruir os sentidos da conclusão. Por exemplo, "porque"

\footnotetext{
${ }^{34}$ Rocha, Glauber. Abaixo a Mistificação. Visão. n. 5, p. 154-155, 11 mar. 1974.

35 Zuenir Ventura (2005: 65-73) conta os bastidores dessa "entrevista- bomba" de Glauber Rocha. O cineasta respondeu a um longo questionário por carta da Itália. Quando recebeu a carta, o primeiro impulso de Zuenir Ventura foi jogar fora o papel. Quando ele releu a carta que "era mesmo obscura, continha mensagens que pareciam cifradas", chamou a sua atenção um bilhete escrito a mão: "Deduza o que quiser e publique". Sem conseguir localizar Glauber, entendeu que o bilhete significava uma autorização, quase uma ordem. Ele saiba que a publicação iria atrair a ira de toda a esquerda. Havia também o temor de que o "elogio" a Golbery fosse interpretado como uma "provocação".
} 
Geisel é luterano como ele, e porque o aniversário dele é 14 de março, os fatos "me deixam absolutamente seguro de que cabe a ele responder às perguntas do Brasil". Portanto, os fatos não dão a ele nenhuma segurança sobre a possibilidade de abertura. As ironias são muitas: ao falar em sacrifício dos deuses mais velozes e depois emendar informações sobre o seu exílio, o cineasta parece apontar para si mesmo, como resultado da guerra que se abateu sobre o país. Não há só elogios no texto. Há críticas, por exemplo, a Delfim Netto e Roberto Campos.

Para entender a declaração é preciso pensar como o discurso oficial e o cinemanovista eram compreendidos na imprensa. O que possibilitava essa aliança? Houve uma mudança de rumo do regime militar, quando ele adotou uma perspectiva nacionalista na área cultural, incentivando o cinema brasileiro ${ }^{36}$. Esse novo discurso possibilitava uma coalizão com o projeto cinematográfico nacionalista do Cinema Novo. Os interesses eram logicamente invertidos, mas a união se dava em torno da defesa da cinematografia nacional e do caráter protecionista e nacionalista da política cultural. Os militares procuravam construir uma anuência entre os intelectuais de oposição, mas não aceitavam a radicalidade da posição dos artistas de esquerda (Napolitano, 2011). Portanto, o código do diálogo foi o nacionalismo cultural sob signos ideológicos trocados. Do outro lado, os comunistas aproximavam-se de alguns setores estatais para esboçar uma política de cultura.

A política cinematográfica deu bons resultados na produção e bilheteria dos filmes brasileiros, conquistando faixas cada vez maiores do mercado. Tudo era feito com o auxílio da Embrafilme e de medidas protecionistas. A partir de 1975, o Estado articulou transformações amplas no campo da cultura, a partir da publicação da Política Nacional da Cultural (PNC). No final de 1974, Roberto Farias assumiu a presidência da Embrafilme, indicado pelo setor cinematográfico. Ele levou junto Gustavo Dahl, colunista de Opinião, que se tornou depois diretor do setor de distribuição, a famosa Superintendência de Comercialização (Sucom). Preparando este terreno, Nelson Pereira dos Santos tinha participado de comissão do Ministério de Educação e Cultura (MEC) para reformular os órgãos de cinema em 1974. A época é vista como um divisor de

\footnotetext{
${ }^{36}$ Se no início do regime militar, o Estado não tinha propostas abrangentes no plano cultural, esse perfil mudou nos anos setenta. No pós-AI-5, tenta-se redefinir o setor cultural (Ortiz Ramos, 1983). No governo Médici delineia-se de forma substancial a política cultural do Estado, que assume o papel de organizador da cultura. Enquanto o regime internacionalizava cada vez mais a economia, ele apropriava-se das antigas proposições nacionalista na área cultural. Graças ao viés econômico-nacionalista do governo Geisel, o Estado abriu um diálogo com a intelectualidade cultural.
} 
águas em relação ao papel do intelectual e do artista em relação ao Estado autoritário, concretizando a união do grupo do Cinema Novo em torno da Embrafilme.

Os cinemanovistas ainda viam o Estado como o grande responsável pelo desenvolvimento do cinema brasileiro (Ortiz Ramos, 1983). Era exatamente este viés nacionalista deles que permitia uma associação com o governo. Aceitava-se o Estado como protetor e interventor da cultura, restaurando o equilíbrio da concorrência desleal estrangeira. Para Wolney Malafaia (2012), a associação dos cinemanovistas com o regime era feita em torno de interesses em comum, que passavam a ser mais importantes do que a contradição com o Estado autoritário. Eles eram o grupo mais articulado e detentor de um projeto cultural constituído nos anos sessenta. Portanto, no pós 1974 , as mudanças na área cultural não foram um fato isolado e criado somente pelo governo. Ao contrário, elas tiveram a participação de intelectuais não identificados ao Estado, mas que viam nesta proximidade uma abertura à democratização.

Analisando o discurso contido nos documentos oficiais da política cultural, Sérgio Miceli (1984) aponta que graças a um ministro forte como Ney Braga se conseguiu trazer porta-vozes legítimos da classe intelectual e artística para a direção dos órgãos estatais. Com estas medidas, o governo Geisel conseguiu trazer setores intelectuais arredios ao regime. O sentimento de poder contribuir para a fixação de diretrizes da política cultural e o direito de escolher seu representante para a Embrafilme teria contribuído para a "adesão ostensiva do pessoal" do Cinema Novo, porque alguns setores culturais não encontravam uma colocação segura no mercado.

De acordo com Marcos Napolitano (2011), entre a resistência e a colaboração havia projetos ideológicos e diversos graus de combatividade e crítica na esquerda. $\mathrm{O}$ Cinema Novo lutava pelo cinema politizado, mas não recusou a política cultural. Exatamente os artistas em torno do PCB foram os que mais aderiram ao mecenato estatal. Enquanto isso, a opinião pública de esquerda via esse processo como cooptação de seus quadros pela indústria cultural e pela burocracia estatal. Mas convenhamos que se a associação dos cinemanovistas era feita em nome da democratização, de qualquer forma é preciso voltar ao ambiente político e repensar os sentidos possíveis das declarações dos cinemanovistas. Como elas eram entendidas pelos críticos de cinema?

\section{Opinião e a polêmica cinemanovista}

A postura da historiografia em relação à aproximação entre cinemanovistas e Estado já nasceu polarizada. Ortiz Ramos (1983) realçava que a imprensa frisava muito 
a cooptação que realmente existiu dos cinemanovistas. Enquanto isso, Randal Johnson (1987) viu as relações entre cinema e Estado muito mais complexas do que a ideia de cooptação. A associação é descrita por ele como uma convergência de interesses e um casamento de conveniência entre cinemanovistas e Estado, sob a vigilância dos órgãos censores. Os trabalhos mais recentes, tanto a tese de Wolney Malafaia (2012) sobre o projeto político dos cinemanovistas, quanto a iniciação científica de Giuliana Almeida (2009) sobre a PNC em Opinião, deslocam esta polêmica para a imprensa alternativa.

Os trabalhos explicam esta aliança do ponto de vista ideológico. Longe de um viés de cooptação, Malafaia, inclusive, revela os pontos de convergência do projeto político dos cinemanovistas com o do Estado autoritário. Antes dele, Ortiz Ramos viu o discurso estatal como uma forma de desarticular a oposição através da incorporação do projeto nacionalista de esquerda. Segundo ele, alguns cinemanovistas adesistas adotaram uma perspectiva do popular totalmente despolitizada, em "total convergência" com a PNC (Ortiz Ramos, 1983: 125).

A terminologia "cooptação" e "adesão" dos cinemanovistas é típica dos anos setenta e oitenta. Segundo Napolitano (2011), ela precisa ser revista, porque a compreensão crítica das lutas culturais não deve ficar refém da dicotomia entre resistência e cooptação. Afinal em ambos os casos trata-se de processos complexos e contraditórios. Havia, na época, uma dificuldade real em analisar as contradições do regime, que matava comunistas e financiava filmes de artistas do mesmo partido.

A historiografia dos anos oitenta prova a condenação da imprensa aos cinemanovistas com as matérias de Opinião. Portanto, nosso objetivo é verificar se o semanário realmente endossou o coro de críticas ao grupo, ou se aderiu ao seu ponto de vista. Analisamos os artigos em sua totalidade, desmembrando as significações não imediatas do discurso dos cineastas. Ao mesmo tempo, tomamos cada crítico como sintoma das disputas internas do jornal e da Frente Cultural, ao invés de pinçar algumas declarações do corpo geral dos textos.

Para tanto, é preciso pensar se estes textos são entrevistas "neutras" ou “opinativas"; se são artigos de Opinião ou dos cinemanovistas, porque a forma dos textos constrói significações. Não se deve planificar os gêneros jornalísticos; e esta é uma das contribuições da análise interna feita aqui. É preciso levar em conta que o entendimento dos textos da imprensa alternativa deve extrapolar o sentido linear de leitura por causa da censura (ver Capítulo 1). 
Um sinal de fissura: a radicalidade do jornal

Antes de falar de Opinião, devemos retomar uma nota muito importante publicada em Movimento. Isso porque o primeiro comentário de Opinião sobre o assunto é um comentário sobre esta nota. Foi Maurício Azedo, ligado ao PCB, ${ }^{37} \mathrm{em}$ Movimento quem realmente fez uma condenação direta aos cinemanovistas no trecho que se segue ${ }^{38}$ :

"Os 68 milhões de cruzeiros atribuídos pelo governo federal à Embrafilme para a produção de fitas no País subiram à cabeça de alguns cineastas brasileiros, que na ânsia de pôr a mão nesses recursos, para fazer os roteiros que se acumularam por falta de financiamento, estão justificando uma adesão incondicional ao poder. Longe do senso do ridículo, eles chegam a se atribuir à condição de porta-vozes de autoridades do governo, como fez há dias o cineasta Paulo César Saraceni (...) ao declarar em entrevista à Imprensa que o 'presidente Geisel e o ministro Reis Velloso estão interessados, realmente, em uma revolução cultural'. (...)

O pretexto para a apaixonada adesão de Saraceni ao poder foi uma entrevista de Glauber Rocha (...) que, repetindo a posição que expusera por ocasião da posse do atual governo ('O General Golbery é um gênio da raça', disse ele em controvertido depoimento à revista Visão), pregou a 'distensão entre o Cinema Novo e o governo', como forma de assegurar recursos para a produção de filmes pelos diretores que participaram do Cinema Novo.

O açodamento com que certos cineastas do Cinema Novo oferecem adesão ao governo reflete as dificuldades em que se encontram os produtores e diretores de cinema, que perderam as perspectivas profissionais, diante da inoperância e da burocracia que dominam a atividade da Empresa Brasileira de Filmes (Embrafilme) e do Instituto Nacional de Cinema, e no esforço de recuperá-las acabam perdendo também as perspectivas políticas - e também um pouco do pudor. (...)

De olho na verba, (...) Saraceni faz a apologia do governo ('Não tem mais sentido recusar um diálogo com o governo, porque foram exatamente eles', Geisel e Reis Velloso, a quem ele se referira antes -, 'mais o ministro Nei Braga, mais o Golbery que pediram a quebra da burocracia') e passa a misturar alhos com bugalhos, com a auto-suficiência de quem se arroga o papel de mentor político e ideológico do cinema brasileiro e com uma confusão mental que mostra precisamente a sua inadequação para a tarefa de tal porte. Ele sustenta, em síntese, que é preciso 'fazer filme revolucionário no Brasil', (...) e sustenta que tal cinema será possível com o diálogo cineasta-governo.

Ao contrário de Glauber, que está fazendo filmes no exterior com recursos de produtores dos países que percorre (....), Saraceni procura apenas sustentação política para obter os Cr\$ 3 milhões necessários à realização de seu filme Anchieta, José do Brasil. (...)."

\footnotetext{
37 Oscar Maurício de Lima Azedo era jornalista e foi presidente da ABI (Associação Brasileira de Imprensa). Comunista filiado ao PCB, colaborou em jornais do partido e da imprensa alternativa. Foi preso e torturado em 1976. Ver histórico do jornalista no site da ABI e no site do PCB: Disponível em: <http://www.abi.org.br/morre-no-rio-o-jornalista-mauricio-azedo-presidente-da-abi>. Acesso em 12. fev. 2014.Disponível: $<$ http://www.pcb.org/portal/índex.php?option=com_content\&view=article\&id=6773:oPCB-não-se-esquecera-de-mauricio-azedo>. Acesso em 12. Fev. 2014. Ver também Azevedo (2011: 113) que comenta quais jornalistas de Movimento vinham de laços com o PCB, como Maurício Azedo. ${ }^{38}$ Azedo, Maurício. O grito de Glauber e alguns vagidos. Movimento. n. 12, p. 2, 21 set. 1975.
} 
No caso de Glauber, o depoimento sobre Geisel não significou para Maurício Azedo um desmerecimento ao seu trabalho. Separa-se aqui o conteúdo do filme das declarações. Afinal os filmes dele nem sequer chegavam ao Brasil. Essa atitude não se estende a Saraceni. Ao usar o dinheiro do Estado ${ }^{39}$, a atitude significava um comentário negativo sobre o cineasta A condenação de Azedo indica um questionamento de um membro do próprio PCB à aproximação com o regime militar, quando foi exatamente essa ala quem se aproximou mais da política cultural.

Opinião escreve um texto sobre o caso e reproduz alguns trechos da matéria de Maurício Azedo em Movimento:

"Parece que a adesão de Glauber Rocha ao governo ganhou mais um seguidor: Paulo César Saraceni. (...) Bajular o governo seria uma maneira de Saraceni conseguir os Cr\$ 3 milhões necessários para filmar Anchieta, José do Brasil, que, segundo o cineasta, é uma 'figura santa, mágica, histórica na defesa dos índios e na defesa da alma do povo brasileiro'. Essa tese já foi refutada por muitos historiadores, mas como 'nacionalismo', é um tema que agrada.

'À parte o angu ideológico que sua entrevista constitui, à parte também a presunção que a perpassa de ponta a ponta (...) se deduz que Saraceni poderia ter sido bem mais objetivo, direto, claro. Na verdade, ele quer saber apenas se o cheque já está pronto e se já pode passar na caixa', termina Maurício Azedo." 40

Este tom ríspido e planificado sobre as relações entre cineastas e Estado só aparece esta única vez em Opinião, incorporando o texto de Maurício Azedo no jornal concorrente. A condenação não versa sobre um comprometimento ideológico, nem sobre ingenuidade ou passividade, mas sobre o auxílio financeiro do Estado. A discussão é sobre a autonomia financeira dos cineastas. O tom presente nesta matéria coincide com a ideia de cooptação a que Ortiz Ramos faz referência.

Há uma diferença importante na nota de Opinião: ela não está assinada. Assim o autor anônimo utiliza o recurso de citar o jornal de Raimundo Pereira para validar seus comentários. Uma nota não basta como prova do projeto editorial do jornal. É preciso ir além, porque Opinião não tem uma postura única para esse assunto. Uma nota não revela o projeto editorial de um jornal que é síntese das fissuras da esquerda. Essa nota extremamente opinativa foi um caso único. As demais matérias são bem mais complexas e interessantes do que esta diatribe.

É bom que se diga que há poucos artigos não assinados em Opinião. Mas quando o assunto é a política cinematográfica, podemos unir num mesmo conjunto os

\footnotetext{
${ }^{39}$ Um adendo: José Carlos Avellar explicou em entrevista que metade do dinheiro recebido por Saraceni para filmar Anchieta José do Brasil sumiu com a inflação, mas nenhum crítico comentou isso.

${ }_{40}$ A adesão de Saraceni. Opinião. n. 151, p. 23, 26 set. 1975.
} 
raros artigos não assinados com os textos de articulistas pouco conhecidos ou externos ao campo do cinema. Todos eles assemelham-se pela radicalidade política e destoam do tom geral dos críticos do jornal. Talvez esses textos fossem escritos por colaboradores de partidos políticos indagadores da ideia da Frente Ampla, pela vanguarda ou por opositores do Cinema Novo. Vemos esse tipo de nota como sinal da disputa interna que recebe pouco espaço na edição final. Como toda a equipe ficava encarregada das notas, isso dificulta descobrir os autores. Quando o assunto é a aliança cinemanovista com o Estado, o jornal caracterizava-se pela heterogeneidade, sem conclusões únicas. Portanto, não há artigos categóricos dos críticos acusando o Cinema Novo de adesão ao regime.

$* * *$

\section{As entrevistas dos cinemanovistas: o gênero informativo}

Nenhum crítico de cinema de Opinião dedica um artigo inteiro para analisar a Política Nacional de Cultura e a relação dos cinemanovistas com o Estado. Nesta mesma linha, o jornal apenas transcreve numa matéria alguns trechos deste documento ${ }^{41}$. O artigo não deve ser tomado como prova do alinhamento com a diretriz estatal por causa da inexistência de contestações ao seu conteúdo. Afinal, o comentário crítico está no título: "alma nacional para consumo". A matéria não tem contestações ao documento oficial, mas deve ser lida como estratégia da política do silêncio (Ver Capítulo 1).

Os textos de Opinião comentados pela historiografia são, na verdade, entrevistas, exceto o artigo de Carlos Diegues. Estes espaços críticos não são editoriais (espaço por excelência da opinião do jornal), como os pesquisadores parecem entender. Quando um jornal dá voz aos entrevistados, ou quando abre espaço para seu corpo de críticos, ou quando publica artigos de terceiros, esse discurso não corresponde necessariamente ao discurso editorial. Ao contrário, estes espaços podem representar as disputas internas presentes em qualquer campo.

As entrevistas esclarecem as opiniões dos cinemanovistas sobre a política cinematográfica, como se os cineastas falassem diretamente aos leitores, "supostamente" sem intermediários ${ }^{42}$. São entrevistados Eduardo Escorel, Arnaldo Jabor, Gustavo Dahl e Nelson Pereira dos Santos ${ }^{43}$. A relação com o Estado não é o

\footnotetext{
${ }^{41}$ Política Nacional de Cultura. A alma nacional para consumo. Opinião. n. 208, p. 20, 29 out. 1976.

${ }^{42}$ Obviamente há a mediação do jornalista na entrevista, através da seleção das pergunta e da edição do texto. Sobre os gêneros jornalísticos, ver José Marques de Melo (1985).

${ }^{43}$ A distância cronológica entre todos esses textos é grande: começa com a entrevista com Gustavo Dahl em 1974, passa por uma entrevista com Nelson Pereira dos Santos em fevereiro de 1975, para chegar ao
} 
tema principal de nenhuma delas. Entre as diversas perguntas, inclui-se a conexão com o regime. Propomos aqui analisar a tensão entre o discurso cinemanovista e o do entrevistador, que aparece em algum momento do texto, seja na introdução ou na forma de elaborar as perguntas. A partir destas disputas, pensamos as fissuras entre os dois discursos para concluir se o crítico endossa ou condena as declarações.

Ao dar espaço ao grupo do Cinema Novo para apresentar suas ideias, Opinião debatia um assunto do momento, mas não deixava isso claro aos leitores, exceto na nota não assinada citada acima. Num jornal atento ao gênero informativo, esse apagamento das notícias sobre cinemanovistas e Estado é significativo. De qualquer modo, ele indica um meio 'silêncio' destes críticos sobre o assunto, sem confrontar o grupo. Por esse motivo, a forma escolhida para tratar o tema da atualidade é a entrevista, não a crítica. Sob o discurso de neutralidade e urgência da questão, os articulistas não compõem artigos essencialmente opinativos. $\mathrm{O}$ uso da entrevista cria um élan de propiciar o acesso à informação "sem" a mediação. Só que o formato por sua gênese é circunstancial e sujeito à interpretação do jornalista.

\section{A entrevista de Gustavo Dahl}

Antes de assumir o cargo de diretor de distribuição da Embrafilme, Gustavo Dahl ${ }^{44}$ concede um depoimento a Jean-Claude Bernardet. O tom sobre a política cultural é otimista: "Estamos fazendo progressos", declara ele. Ao falar na primeira pessoa do plural em nível mais imediato, o texto parece quase anular a distância em relação ao discurso oficial. Só que olhando de perto, Dahl faz uma síntese crítica do vínculo dos cinemanovistas com o Estado. Como se falasse da relação entre os "artistas modernos" com o Estado Novo, ele comenta: "Tenho impressão de que houve uma espécie de reconciliação do setor oficial com a função social do cinema. No fundo é um compromisso entre a tentativa de impor um cinema oficial e a impossibilidade de ignorar o consenso." A relação para Dahl estava mais para negociação do que união.

A comparação com o Estado Novo não era só dele. Jean-Claude Bernardet faz uma introdução à entrevista, mostrando que apesar de antigo, o problema da relação com o Estado agora "está no centro do cinema brasileiro". A novidade é a participação dos cineastas na política cinematográfica através de Roberto Farias. Para Bernardet, a

artigo assinado por Carlos Diegues em setembro de 1975 e a entrevista de Jabor um mês depois. O conjunto fecha com a entrevista de Eduardo Escorel em 1976.

${ }^{44}$ Dahl, Gustavo. "O importante é conquistar terreno ao filme estrangeiro". Entrevista concedida a JeanClaude Bernardet. Opinião. n. 107, p. 20-1, 22 nov. 1974. 
postura do Estado como uma "poderosa máquina" não só incentiva, mas "pode orientar". Quando Dahl apela para o argumento da normalidade e naturalização das relações entre Estado e Cultura, ocultando as divergências, Bernardet interrompe: "você não acha o seu conceito de cultura um tanto monolítico e próprio da classe dominante?" Temos claramente uma tensão entre os dois discursos com o questionamento de Bernardet, mas ele não taxou Dahl de adesista.

\section{A política cinematográfica global de Nelson Pereira dos Santos}

Por conta do lançamento de $O$ Amuleto de Ogum, Nelson Pereira dos Santos concede uma entrevista ${ }^{45}$ a Jean-Claude Bernardet, cuja segunda parte inteira é dedicada à política cinematográfica. Nelson é apresentado como membro de uma comissão criada pelo Ministério da Educação e Cultura e como um dos "principais responsáveis pelas negociações em andamento entre governo e cineastas". A palavra utilizada é bastante indicativa do olhar de Bernardet. $\mathrm{O}$ trecho não fala em aliança, mas em negociação, sinalizando uma troca comercial na qual os interessados não têm exatamente os mesmos objetivos.

Bernardet mantém a estratégia de distanciar-se do discurso do diretor. Os comentários manifestam-se especialmente na introdução, mas os silêncios e indagações não respondidas podem incomodar o leitor. O crítico não adere ao discurso do entrevistado, nem tampouco o endossa. De qualquer forma, o entrevistador não bate de frente contra as declarações de Nelson Pereira sobre a política cinematográfica. Bernardet faz um contraponto entre o discurso do cineasta e a sua opinião na introdução, quando declara que:

"Nelson Pereira dos Santos acredita [grifo nosso] que se a Embrafilme tornarse, além de produtora, também distribuidora e exibidora - transformando-se assim numa espécie de centro da economia do cinema nacional - seria possível torná-lo mais forte e naturalmente mais apto a conquistar o público brasileiro. (...)

$O$ argumento imediatamente utilizado contra [grifo nosso] essa aproximação entre cinema e Estado é o possível aumento de controle por parte desse último sobre a produção e consequentemente a criação dos filmes brasileiros. A interferência efetiva da censura, atualmente restringida ao nível da exibição, poderia estender-se à própria escolha de temas e ao tratamento. Nelson Pereira dos Santos não acredita nisso [grifo nosso]. Partindo da premissa 'centralização dos meios econômicos, descentralização da criação', ele acha que [grifo nosso] não haveria interesse do governo em criar uma

\footnotetext{
${ }^{45}$ Santos, Nelson Pereira. "Caxias para mim, é a capital cultural do Brasil”. Entrevista concedida a JeanClaude Bernardet. Opinião. n. 119, p. 19-21, 14 fev. 1975.
} 
produção centralizada, do tipo oficial, uma vez que o objetivo comum é 'ganhar o público brasileiro'."

Vemos no trecho acima, que Bernardet coloca-se no texto para se distanciar do diretor quando afirma: "Nelson Pereira dos Santos não acredita nisso". Noutro trecho ele contesta o cineasta ao comentar que a censura poderia se estender à escolha de temas ${ }^{46}$, contestando o cineasta. Abre-se uma possibilidade de leitura irônica porque estamos falando de um Estado autoritário. Daí que a frase seguinte de Nelson Pereira sobre a centralização e descentralização da produção reveste-se de um cunho opinativo facilmente contestável.

O ponto alto desse artigo é quando Nelson Pereira dos Santos sinaliza que o projeto global não é do Estado autoritário:

"Os órgãos de classe, o sindicato da indústria, a associação dos produtores independentes, a associação de autores, têm trabalhado juntos na defesa da política cinematográfica brasileira e conseguiram por isso elaborar um programa para a implantação de novas bases no cinema brasileiro para dar esse salto, e esse programa foi aceito pelo atual governo e está sendo posto em execução."

Neste trecho final, o projeto global é definido como o programa elaborado pela classe cinematográfica e endossado pelo Estado. Nelson Pereira dos Santos tenta provar que a união com o governo é apenas uma etapa rumo à total independência econômica, quando o cinema irá se sustentar sozinho, sem o auxílio estatal. Inicialmente, trata-se da produção de filmes com auxílio estatal, sem intervenções da censura. Como Gustavo Dahl, ele parece falar em nome do Estado, ou da comissão da qual faz parte: "o que estou dizendo é que não vai haver protecionismo". O discurso construído para isso é a lógica neutra do capital, numa "política traçada cientificamente de mercadológica". Nelson Pereira constrói o argumento de que o Estado será somente um "parceiro" econômico. "Como empresário, ele não terá condições de controlar a criação, porque o empresário precisa da criação livre e cada vez mais forte”. Ortiz Ramos (1983: 131) viu essa declaração como prova do esvaziamento político de Nelson Pereira dos Santos. A evidência seria a proximidade cronológica entre o lançamento de Amuleto e a publicação da PNC, porque ambos falam em cultura autêntica. Contudo, tal crença é muito anterior ao ano de 1975.

\footnotetext{
${ }^{46}$ Aqui ele aborda a censura ao verossímil, explicada por Christian Metz (Amengal, 1975). O controle se dá na confecção do filme. Esse tipo de censura consegue fazer desaparecer muitos temas e formas de tratamento, porque apenas os possíveis serão autorizados pelo discurso.
} 
$\mathrm{O}$ argumento de Nelson Pereira dos Santos neste texto é o da neutralidade do Estado, chave explicativa para o discurso dos cinemanovistas. A visão era típica da esquerda, que tentava dissociar o Estado do governo. Bernardet (1979) vê essa perspectiva como a última esperança ingênua do bloco nacionalista. Pensar num Estado neutro e defensor desinteressado do cinema brasileiro justificava o ônus indesejável entre o Estado e a situação política. Quando o vínculo com o Estado poderia criar um compromisso ideológico indesejável com a situação política, reforça-se a ideia de neutralidade em relação a seus governos. Mário Brockmann Machado (Miceli, 1984) observou que alguns setores da sociedade, percebendo uma autonomia ampla nas agências do governo, viam esses órgãos como "agências de socialização política", isto é, como arenas políticas e espaços a serem democratizados. A postura parece se embasar nos termos de uma delegação da sociedade ao governo. Enquanto isso, também Bernardet viu a aproximação como uma forma de cooptar e desarticular os cinemanovistas (Bernardet, 1979: 46; 65). Por outro lado, ele comenta a dificuldade dos cineastas para realizar filmes críticos ao sistema com o auxílio oficial.

A tese da neutralidade do Estado não era uma novidade. Havia uma forte tradição política e intelectual brasileira que vê o Estado como sujeito da história e promotor de reformas e da redenção nacional. O próprio Daniel Pécaut (1990) mostra como a articulação dos intelectuais está constantemente ligada ao Estado. Os governantes geralmente tentaram apropriar-se das representações dos fenômenos políticos propostas pelos intelectuais, enquanto estes se inspiraram nas representações do Estado. Ao longo da história do cinema brasileiro (Ramos, 1987) não se concebe o desenvolvimento industrial sem o auxílio estatal.

$* * *$

\section{A tensão entre os gêneros jornalísticos na polêmica com Arnaldo Jabor}

No final de 1975, Jabor lançava O Casamento (1975), quando Clóvis Marques o entrevista para Opinião ${ }^{47}$. A época coincide também com a publicação da Política Nacional de Cultura. Se o filme parece ser o centro da discussão, as perguntas e respostas giram em torno da política cinematográfica, numa disputa acirrada entre cineasta e crítico. De todas as declarações, Jabor foi o cinemanovista que menos problematizou a união com os órgãos estatais de cinema. Nem Nelson Pereira como

\footnotetext{
47 Jabor, Arnaldo. Jabor não esconde o jogo. Entrevista concedida a Clóvis Marques. Opinião. n. 152, p. 20, 03 out. 1975 .
} 
entrevistado teve um tom tão favorável ao Estado como ele. Quando questionado, Jabor muda de assunto ou ataca a crítica de cinema. Para isso, ele cita a censura: "imaginar" que o governo vai "agrilhoar" os cineastas, obrigando-os a "fabricar epopeias dirigidas" é uma visão "liberalista e absurda". A declaração não está errada, porque mais de um filme crítico ao sistema foi feito com o apoio do Estado, geralmente sob o signo da alegoria. Por outro lado, o cineasta exclui a presença da censura.

Depois Jabor endossa os elogios de Glauber Rocha a Geisel e Golbery, porque os dois juntamente com Nei Braga "lutam" para "abrir caminhos ao cinema brasileiro" contra a "máfia" das distribuidoras estrangeiras. Assim a atitude "purista" em relação à intervenção estatal para ele é antiquada, reacionária, moralista, saudosista e pequeno burguesa. $\mathrm{O}$ argumento utilizado é a da necessidade econômica de enfrentar o cinema estrangeiro. Num discurso nacionalista, a neutralidade da Embrafilme é garantia de solução aos problemas do cinema brasileiro. Os elogios ao Estado não param por aí: "Existe em muitas áreas do governo uma compreensão perfeita deste e de outros problemas, uma compreensão mais profunda do que a de muito crítico esteticista". Sem eles, nosso setor "desapareceria". O discurso problematizante não está presente na edição final desta entrevista. Assim esta declaração otimista de Jabor deixa de questionar o Estado.

O tom de Clóvis Marques do começo ao fim em relação a Jabor é negativo ${ }^{48}$, ora direto, ora na entrelinha. A primeira condenação aparece logo no subtítulo: "O cineasta de Toda Nudez Será Castigada está contra a crítica e a favor do ministro Ney Braga". O que significava ser contra a crítica? Significa ser contra a resistência e sinaliza quase uma união indevida com o Estado. Logo na introdução, Clóvis Marques faz referência à difícil busca de Jabor pela bilheteria:

\footnotetext{
"Tanto quanto no filme, ele está apostando na injeção de ânimo econômico, financeiro e cultural que a nova Embrafilme, fortalecida, deverá trazer ao cinema brasileiro. 'Se dessa vez não der certo, eu sou capaz de procurar outra profissão', diz ele, com o amargurado realismo de quem está envolvido até a medula na estafante caça aos níqueis que, entre outras coisas, ainda impede a arrancada definitiva dessa 'arte que também é uma indústria' no Brasil. E responde àqueles que parecem desconhecer as contradições e dificuldades estruturais do nosso cinema, provavelmente por não viverem o seu dia-a-
}

\footnotetext{
${ }^{48}$ Um adendo. Todos os críticos não se recordam mais deste episódio. Em entrevista, Clóvis Marques relatou que na época não tinha interesse pelo lado político do cinema brasileiro. Era um novato que fazia as matérias solicitadas, com foco na estética do cinema. Marques considerava Jabor como um grande cineasta dotado de uma "centelha crítica". Infelizmente ele não se lembra mais dos detalhes da entrevista ou do contexto da realização. O mesmo ocorre com Jean-Claude Bernardet.
} 
dia, com a combatividade e a compulsão polêmica que a dura realidade ensinou aos cineastas da sua geração."

As frases sintetizam bem a postura de Clóvis Marques perante Jabor. Há uma tensão entre reprovar a proximidade com o Estado e desejar ocupar o mercado cinematográfico. Por outro lado, Marques não está alheio às dificuldades do trabalho do cineasta. Existe uma dualidade na utilização da palavra caça níquel. Ela serve de comentário sobre a difícil conquista de público e a necessidade de sobrevivência dos realizadores, mas pode indicar uma rejeição à aliança com o regime. Se o viés é desfavorável, o crítico não planifica seu discurso. Não há uma sentença simplificada porque o formato do texto não dá uma resposta única ao problema.

Depois Marques adentra no caso específico da liberdade de expressão do cineasta frente ao aparelho estatal. Ele pergunta se a associação com o Estado é uma garantia do final da censura. A frase tem fundo irônico, ao dizer indiretamente que os cineastas não terão mais coragem de fazer protestos; daí a censura nem precisará atuar. Clóvis Marques não afirma de maneira peremptória a "adesão" ao Estado por parte de Jabor, mas solicita sem sucesso que o cineasta abra esse debate.

Há uma disputa entre o crítico e o cineasta pelo sentido das palavras. Referindose ao elogio de Glauber Rocha a Golbery, Jabor contra ataca a crítica que tem uma “obsessão com um progressismo obrigatório”. Logo em seguida, Marques não demora para dotar a palavra de novo sentido. O crítico pergunta se Jabor cala sobre a proposta estética e cultural de $O$ Casamento, preferindo falar de temas polêmicos e conjunturais, como uma forma de ceder "justamente a esta compulsoriedade de progressismo intelectual que pressiona o artista brasileiro?". Aqui a palavra reveste-se de outro significado: a aliança com o Estado. Jabor também deu suas cutucadas. Segundo ele, a pergunta do entrevistador vinha "um pouco eivada" da apreciação "maniqueísta" da crítica "aparentemente mais esclarecida", ávida por distinguir filmes políticos, adesistas ou contra o sistema. A opressão maior ao intelectual está na própria “crítica”, vaticina o cineasta.

Não podemos afirmar que Opinião tenha tomado uma atitude hostil com Arnaldo Jabor por causa desta declaração favorável ao governo, afinal os comentários negativos ao cineasta datam de muito antes; da época do lançamento de Toda nudez. será castigada (1972). Clóvis Marques nem por um momento se furta a excluir as 
diversas tensões do corpo do texto. A riqueza do entrelaçamento entre texto informativo e opinativo desta entrevista deriva destas tensões.

Se Clóvis Marques não taxa Jabor de adesista como Maurício Azedo, ele não parece aprovar a ligação dos cinemanovistas com o regime. O crítico se opõe à aliança com o Estado um degrau acima do distanciamento de Bernardet. Portanto, esta entrevista-crítica é espaço de um conflito, não só entre o crítico e o entrevistado, mas entre os setores da esquerda. Pensando a ocupação do mercado, este artigo traz os questionamentos internos da esquerda sobre como fazer a resistência.

$* * *$

As esperanças de Carlos Diegues - o discurso cinemanovista sem mediação

Na mesma edição em que é publicado o texto A adesão de Saraceni, Opinião abre as páginas para um direito de resposta indireto dos cinemanovistas, através de Carlos Diegues ${ }^{49}$. Num texto publicado depois do lançamento da Política Nacional de Cultura, ele toma uma postura bem mais questionadora em relação à Embrafilme, mas faz isso em duas partes. Numa delas, ele elogia a empresa:

"Coisas a corrigir - Este Governo já mostrou que, ao contrário de todos os outros anteriores a ele e posteriores a Vargas, tem para o cinema um programa de infraestrutura. Isso é fundamental. Confio na missão da Embrafilme e nos propósitos de sua atual administração, embora saiba, como ela, que há ainda um mundo de coisas a corrigir ou criar.

Confio sobretudo em sua vocação de empresa democrática, aberta a todos, estimulando a imaginação criadora, praticando a renovação de ideias e quadros".

É interessante ver como Diegues aplica o verbo "confiar" na "missão" da Embrafilme. Aqui ele retoma a ideia de caráter missionário do cinema, dissociando-o do Estado autoritário. Afinal a Embrafilme, segundo ele, traz a marca da "vocação de empresa democrática". Fazendo uma menção indireta à PNC, ele considera o viés de preservar a "tradição" autêntica do povo brasileiro a "pior" das hipóteses.

Por outro lado, seria ingênuo acreditar que Diegues defenderia totalmente a política cinematográfica. A construção das frases revela ironia e exige uma leitura na entrelinha. Logo na abertura do texto, ele declara: "a única coisa realmente transformadora foi a lei 8x1". Só que a lei é de 1951 no governo de Getúlio Vargas. Ou seja, o governo militar não altera as regras do jogo, quesito fundamental para ele. O

\footnotetext{
${ }^{49}$ Diegues, Cacá. As esperanças do cinema brasileiro. Opinião. n. 151, p. 21, 26 set. 1975.
} 
papel da Embrafilme é descrito por Diegues como "o segundo momento potencialmente [grifo nosso] transformador", isto é, trata-se de uma possibilidade. A confiança na Embrafilme não se estende ao Estado. Segundo ele, seria trágico se o cinema brasileiro dependesse só dele por que:

"Nesse caso, se não nos transformássemos em funcionários públicos da criação, como nas piores cinematografias de certos países socialistas, acordaríamos um dia diante da descoberta de que o que o Governo nos dá com uma mão pode muito bem nos tirar com a outra: a da censura".

Numa equação de culpas pelos problemas do cinema brasileiro, a primeira da lista é a Embrafilme, que esquece os filmes nas prateleiras. Um único grupo fica imune à condenação: os cineastas. E obviamente isso não foi uma coincidência, porque é um discurso sintonizado com o de Nelson Pereira dos Santos. A ocupação do mercado não adianta sem a qualidade do cinema crítico autoral; essa é a tese de Diegues. Assim ele problematiza a ocupação a qualquer preço, uma raridade em Opinião. Busca-se convencer o público de que o projeto político do Cinema Novo é superior ao estatal. A solução para o problema do cinema nacional neste artigo não está na política cinematográfica, mas nos filmes dos cineastas autores: "Em suma, o mais importante mesmo (e sempre) é que os filmes sejam bons. Eles é que podem transformar o mercado, e realizar o programa que temos definido [grifo nosso] durante estes anos todos." A equação não é nada difícil de resolver. Os filmes bons são os dos cinemanovistas, e Diegues lembra que o grupo está "novamente junto".

A mensagem enviesada de Diegues é simples: o projeto cinematográfico não é do Estado, mas dos cinemanovistas. O poder transformador do cinema brasileiro, segundo ele, ainda está no programa político do Cinema Novo. Assim quem aderiu ao projeto foi o Estado, não os cineastas. Aqui há um retorno sutil à função política do intelectual. Portanto, o texto é indicativo de resistência, não de adesão.

$* * *$

A auto-análise de Escorel: a ambiguidade na resistência

Quando entrevista Eduardo Escorel ${ }^{50}$, Clóvis Marques deixa de lado as perguntas sobre a conexão dos cinemanovistas com o Estado e se dedica a fazer

\footnotetext{
${ }^{50}$ Escorel, Eduardo. 'Num país como o nosso, o fazer é uma forma de ação útil. Entrevista concedida a Clóvis Marques. Opinião. n. 183, p. 19-20, 07 mai. 1976.
} 
considerações descritivas sobre Lição de amor (1975). A postura não lembra em nada o tom em relação a Jabor. Diferente dele, Escorel traz uma visão desiludida em 1976. O texto inteiro deve ser lido dentro da estética do silêncio (Ver Capítulo 1). Juntando as partes aqui e acolá com algum conhecimento mínimo sobre o auxílio estatal às adaptações literárias, o leitor apreende que Escorel escolheu a adaptação cinematográfica como forma de conseguir recursos do Estado. Assim o trecho revela a própria situação do intelectual.

Problematizando a relação dos cineastas com os órgãos estatais, Escorel admite que o cinema brasileiro está se tornando muito dependente deles. "O produtor de cinema está sempre numa posição de inferioridade, dependente do seu eventual interesse e boa vontade. Assim ele é estruturalmente dependente". O trecho parece censurado, porque há uma frase em branco de uma linha e meia. Depois o cineasta comenta como o controle estatal incide no trabalho do realizador:

"Ele não trata de temas de atualidade polêmica, não se preocupa com a História (a não ser para fabricar certos confeitos comemorativos), [trecho em branco], não investiga, não documenta. Ele vive num limbo cujos limites parecem ser o moralismo boçal da comédia erótica e a artificiosa dignidade das adaptações literárias de autores consagrados".

Escorel aproveita o espaço para comentar a perda da autonomia dos cineastas, impedidos de tratar de assuntos polêmicos quando o Estado entra no jogo. Ele foi o único cinemanovista a admitir com um pouco mais de clareza essa possibilidade em Opinião. Sem o auxilio oficial, Lição de amor não sairia do papel, mas Escorel também comenta que seu interesse pela adaptação foi a possibilidade de tratar do presente. Entre a aproximação com o Estado por necessidade e a ideia de cooptação, as fronteiras com a resistência parecem flutuantes. De qualquer forma, ao invés de condenar o Cinema Novo, Clóvis Marques forneceu espaço para o diretor problematizar o vínculo com o regime. Se o crítico não conseguiu abrir a discussão com Jabor, conseguiu o que queria com Escorel.

Fissuras dos cinemanovistas e da crítica de Opinião

Se a chave explicativa para a associação entre cinemanovistas e órgãos estatais de cinema nos anos setenta e oitenta partia da ideia de "adesão" e "cooptação", procuramos aqui entender a lógica do primeiro grupo. Afinal nenhum cinemanovista 
apoiava o Estado autoritário, daí a necessidade discursiva de deslocar o debate para a "neutralidade" da Embrafilme, separada do "governo".

Um pouco além do discurso dos pesquisadores daquele período, Opinião como um todo não acusou os cinemanovistas de cooptação. Mesmo censurado, o jornal não atacou a aproximação com o regime, porque separava o Estado opressor da neutralidade das empresas estatais. Ao contrário, escrevia levando em conta as ambiguidades do jogo político. Contudo não questionava o interesse do governo em proteger o cinema brasileiro. O tom ríspido caracterizou somente a nota não assinada, e em alguma medida os comentários de Clóvis Marques sobre o discurso nada problematizante de Arnaldo Jabor. Porém, as condenações não se estenderam a todo o grupo do Cinema Novo. A linha do jornal é muito mais complexa, daí que tomar uma nota não assinada como prova de toda uma postura editorial incorre em erro. A utilização do gênero informativo como forma de escrita não pode ser tomada como prova de cooptação, mas era uma característica dos textos censurados de Opinião. Mostramos como esta nota não assinada e a crítica de Clóvis Marques a Arnaldo Jabor revelam as disputas das correntes políticas do semanário. Mais relevante ainda é pensar que num jornal de Frente Ampla, a condenação direta à união Cinema Novo-Estado só conseguiu “conquistar" o pequeno espaço de uma nota. Neste sentido, Opinião tendia muito mais para o lado cinemanovista, do que para seus opositores. Pelo menos, essa nota e a introdução de Clóvis Marques à entrevista de Jabor significam uma abertura para o dissenso da esquerda.

Jean-Claude Bernardet toma cuidado para se distanciar do discurso de Nelson Pereira dos Santos, mas não o contradiz. É certo que os questionamentos aparecem nos textos. Bernardet aponta os antagonismos, teme pela autonomia da produção cinematográfica em face da censura, mas vê a proximidade como “negociação". Há uma ambiguidade e um tempo de espera para tirar conclusões. O artigo de Bernardet que mais aprofunda a aproximação dos cinemanovistas com o Estado é sobre Lição de Amor (ver Capítulo 5). Neste caso ele foge de uma resposta única e vai muito além das categorias valorativas de cooptação e resistência, definindo as ambiguidades da relação. A própria análise de Bernardet sobre esse tema ao longo dos anos variava. Anos mais tarde em Cinema brasileiro - propostas para uma história (1979), ele tomará uma postura mais acirrada. As variações dependem do ângulo de abordagem.

Clóvis Marques adota uma postura a meio caminho, entre o lado combativo e as perguntas problematizantes, às vezes quase em tom afirmativo. Podemos pensar nele 
como sintoma de uma fissura se abrindo, num jornal que sempre "favorecia" o Cinema Novo do ponto de vista discursivo. Marques tomou a postura correta de um jornalista, que questiona os entrevistados. Afinal o ato de indagar e tocar nos pontos polêmicos faz parte do trabalho do jornalista. Seria condenável se Marques não tomasse esta postura.

Todavia, mais do que condenar, Opinião abre muito espaço para os cinemanovistas explicarem e debaterem suas ideias, indicando uma possível convergência, mais do que um acirramento. A preferência pelo Cinema Novo em Opinião fica clara se observarmos a falta de espaço para outras tendências de pensamento.

Sérgio Augusto comentou em entrevista que o Cinema Novo foi muito "mimado" pela imprensa ${ }^{51}$. Ganhava sempre capa dos principais cadernos culturais a cada lançamento. Houve certa "condescendência" e uma "discussão amiga" nos jornais, porque todos eram muito ligados. O que causava um mal estar na sociedade, segundo ele, era a proteção dada na Embrafilme aos cineastas brasileiros. Protegidos, financiados e "paparicados", muitos embolsavam metade do financiamento e não precisavam prestar contas, mesmo se os filmes não fossem recebidos bem pelos críticos e pelo público.

José Carlos Avellar não sentia uma preferência pelo Cinema Novo nas redações dos jornais. Metade gostava dos filmes, a outra metade não. Segundo ele, sequer existia um bloco de apoio ao cinema brasileiro. Avellar observa uma mudança de enfoque em relação ao Cinema Novo antes e depois do golpe militar. Antes da ditadura, o Cinema Novo gerou uma discussão intensa e democrática em escolas, universidades e na imprensa. $\mathrm{O}$ contexto mudou complemente com a entrada em cena do regime militar. A partir daquele momento, a defesa do Cinema Novo adquiria o sentido de oposição à ditadura. $\mathrm{O}$ interesse pelo cinema brasileiro era encontrar uma expressão democrática livre, porque as artes eram a grande força política de oposição ao regime. Não se tratava de uma defesa intransigente do Cinema Novo, mas de uma identificação com alguém que sentia a mesma coisa, isto é, a pressão da ditadura. O Cinema Novo se expressava publicamente contrário a esse estado de coisas nos filmes. Daí o espaço na imprensa.

O crítico explica que nunca sentiu nas redações uma posição contrária ao Cinema Novo por causa da aproximação com o Estado através da Embrafilme. Por outro lado, algumas produtoras paulistas sentiram-se menos atendidas pela empresa

\footnotetext{
${ }^{51}$ Quando citamos as declarações de Júlio César Montenegro, Jean-Claude Bernardet, Sérgio Augusto, Marcos Ribas de Farias, José Carlos Avellar e Clóvis Marques, trata-se das entrevistas que realizamos com os autores. Nos casos de exceção, mencionamos as fontes.
} 
estatal. Talvez, indiretamente, esse ressentimento possa ter propiciado um espaço de debate e um posicionamento contrário a essa aproximação na imprensa paulista. Não se trata de localizar aqui culpados, mas de compreender o sentimento de ser preterido no processo que pode ter influenciado de alguma forma os jornais.

Vemos o discurso cinemanovista como parte das disputas internas no campo cinematográfico e como estratégia de legitimação, quando a aliança com o Estado estava sobre questão. As declarações do grupo do Cinema Novo fazem parte de um discurso apologético, não ao Estado, mas a si mesmos. Ao apontar o cinema autoral como solução, os cinemanovistas querem demonstrar sua paternidade no projeto. Assim o Estado teria "aderido" às suas ideias de política de cinema. O governo entraria somente como mola de transmissão, daí a função do discurso de neutralidade também como estratégia para provar quem é o autor das ideias. Trata-se de uma disputa no campo cinematográfico pelo poder de nomeação e das categorias de percepção legítimas. Tanto estas entrevistas quanto o Manifesto Luz \& Ação são uma forma de afirmar publicamente que as ideias são do Cinema Novo.

Se Glauber e Saraceni são acusados na nota não assinada, Gustavo Dahl, Nelson Pereira dos Santos e Arnaldo Jabor são os que mais defendem a política cultural nas entrevistas. Num nível de significação mais imediata, nem sempre eles diferenciam, com clareza, os dois discursos. O que parece controverso é atacar Jabor e Saraceni, mas não contestar as afirmações de Nelson Pereira dos Santos. O critério não passa pelo teor das declarações, mas pela distinção simbólica. As declarações de Nelson Pereira são síntese da postura controversa da época de ver o Estado como mecenas e carrasco. Justo o maior defensor da política cultural foi o menos criticado em Opinião, provando que o jornal não via os cinemanovistas como um todo homogêneo.

Os depoimentos mais interessantes são os de Eduardo Escorel e de Carlos Diegues. O primeiro coloca em pauta a ameaça à autonomia do cineasta por causa da associação com o Estado. O segundo teve a chance de trazer seu ponto de vista, sem a "mediação" de nenhum jornalista. Ele fez críticas ao Estado através da estética do silêncio (Ver Capítulo 1). Nesse sentido parece-nos inocente acreditar na inocência do texto jornalístico informativo ou dos cinemanovistas em relação ao Estado.

O discurso dos cinemanovistas em Opinião presta-se a dois objetivos ao mesmo tempo. O primeiro é participar da resistência com os intelectuais, através de críticas ao Estado autoritário no teor dos textos. O segundo é conseguir a aprovação do regime, provando seu apoio através da imprensa. Nesse sentido o como o texto é construído é 
mais importante do que o texto diz em nível mais imediato. Pensamos esse discurso como parte da estratégia de minar por dentro o Estado autoritário. Afinal os depoimentos devem ser vistos como provas de um jogo político.

Onde estava nesse debate a "Crítica" aos cinemanovistas?

Para provar a condenação aos cinemanovistas na imprensa alternativa, não era preciso gastar as energias com Opinião, um jornal censurado, mutilado e escrito na entrelinha. Teria sido muito mais fácil olhar para Crítica ${ }^{52}$. Foi nesse jornal que Glauber Rocha ${ }^{53}$ publicou um artigo em 1975 perguntando se Geisel teria mesmo uma política cultural. Ele aproveitou o ensejo para criticar abertamente a Embrafilme e alguns cinemanovistas, que se aproximavam da empresa para conseguir verbas, usando o nome do Cinema Novo. Glauber critica a empresa por só produzir 'pornochanchadas', mas também por não dar oportunidades aos novatos. A condenação aos cinemanovistas tinha dois alvos fáceis de localizar: Gustavo Dahl e Paulo Cesar Saraceni. O primeiro porque era diretor da distribuição da Embrafilme, e o segundo porque realizava Anchieta, José do Brasil (1977) com a verba da mesma empresa. Em nenhum momento, Crítica fornece os nomes dos que "aderem" à "estatização", mas os "réus" são os primeiros "convidados" para responder a Glauber.

Tanto o tom de Gustavo Dahl quanto o de Saraceni são muito próximos das declarações de Jabor relatadas acima, defendendo o Estado e Geisel. Saraceni começa muito discretamente a problematizar a necessidade de aceitar as regras do jogo para poder produzir, tema que Eduardo Escorel vai aprofundar em Opinião um ano depois. Rebatendo as críticas, Saraceni não deixa Glauber incólume. Ele permaneceu no Brasil, enquanto Glauber foi para o exílio.

Nesta série de entrevistas com os cinemanovistas há uma grande diferença em relação à Opinião. Crítica optava pelo jornalismo opinativo no corpo das notícias, enquanto Opinião seguia à risca as lições de jornalismo informativo. As fronteiras entre estes dois gêneros se imbricam totalmente em Crítica em todas as matérias sobre política cinematográfica. O jornal questiona se a aproximação dos cinemanovistas com o Estado não visa ao enriquecimento e às gratificações. Um dos comentários mais

\footnotetext{
${ }^{52}$ O jornal alternativo Crítica só durou um ano (ago. 1974 - out. 1975), quando foi apreendido pela polícia. O periódico gostava de abrir uma polêmica de política, economia e cultura.

${ }_{53}^{53}$ Rocha, Glauber. Glauber por Glauber. Crítica. n. 55, p. 12-4, 25 a 31 ago. 1975.
} 
negativos foi o de Tânia Coelho sobre Gustavo Dahl, explicando que a entrevista só foi até certo ponto porque as declarações à imprensa não são aconselháveis na Embrafilme 54. Do jeito que a entrevista foi estruturada, não temos acesso às perguntas da entrevistadora, somente a alguns trechos selecionados. Tomando como modelo as entrevistas de Dahl a Opinião, temos a impressão que a complexidade das respostas dele foram desmembradas aqui em tópicos muito curtos. $\mathrm{O}$ texto tenta insinuar que o cineasta obtém lucros com a entrada dele na Embrafilme conseguindo verba para filmar.

O que Jean-Claude Bernardet falava por nuances em Opinião por meio da estética do silêncio para mostrar que talvez o Estado exercesse seu poder de censura na Embrafilme, Crítica afirmava sem titubear. Neste jornal, não há a tendência a problematizar; nem a enxergar alguma ambiguidade no processo, como fazia Bernardet. É digna de nota a liberdade consentida que Crítica tem para escrever sobre censura e condenar tanto o Estado, quanto a Embrafilme sem rodeios. Comparando-se Crítica a Opinião, percebe-se o grau aniquilador da censura ao jornal de Gasparian na seção de cinema. Foi também por esse motivo que muitos jornalistas deixavam Opinião para escrever com maior "liberdade" em outros jornais alternativos que não recebiam censura prévia. Salta aos olhos o quanto Opinião não podia ser claro no que dizia. Essa falta de clareza da mensagem cumpre o papel de evitar maiores interdições. De qualquer forma, Opinião não vilanizou os atores sociais, sejam eles o Estado ou os cinemanovistas. O semanário tinha a capacidade de entender que o processo é contraditório, longe de uma divisão maniqueísta.

\footnotetext{
${ }^{54}$ Coelho, Tânia. Pornochanchada é cultura popular? Crítica. n. 59, p. 12-13, 22 a 28 set. 1975.
} 


\subsection{Crise ou reelaboração do papel do intelectual?}

A função do cineasta na sociedade em tempos de repressão. Eis a síntese das discussões dos críticos de cinema de Opinião sobre o intelectual, traçadas neste capítulo. Ao deslocar o papel da intelectualidade cinematográfica para os cinemanovistas, os articulistas do jornal falam de si mesmos. Afinal eles se veem como participantes do processo de criação e responsáveis pelo cinema brasileiro. Os papéis são como espelhos deles; ao analisar os diretores de cinema, eles pensam sua função na resistência. Portanto, as observações sobre o papel do intelectual-cineasta revelam muito do pensamento deles sobre si mesmos.

Em Opinião, os cinemanovistas ficam a meio caminho entre duas balizas teóricas imbricadas constantemente. A primeira é a do projeto do intelectual arauto, responsável pela elaboração de uma consciência crítica, e a segunda a do cineasta porta voz, que "supostamente" não intervém na representação popular. Como um espelho da realidade, os cinemanovistas ainda apresentavam-se como tradutores das demandas sociais. No fundo, diziam o mesmo com outras palavras. O grande espaço dado aos cinemanovistas no jornal revela parte das lutas internas pelo poder de nomeação que conferem ao Cinema Novo sua distinção.

Os articulistas do semanário ajudam a gerar a crença no valor do Cinema Novo, tornando-o hegemônico. A alteração dos cinemanovistas em direção ao intelectual mediador neutro que supostamente "não intervém no processo" cultural cria uma ilusão retrospectiva, que só obtém êxito se apresentada como conversão a um novo paradigma 55 (Bourdieu, 2011: 82). Continuamente nas páginas de Opinião, os veteranos do Cinema Novo tentam convencer os leitores de sua conversão não só de estilo, mas de função. Pensamos as declarações como parte da estratégia de legitimação, consagração e distinção simbólica no jornal, lado a lado ao percurso histórico sobre a resistência. A empreitada garante que não se rompa com a illusio ${ }^{56}$ (Bourdieu, 1996). O valor do

\footnotetext{
55 Para o processo dar certo é necessário que os agentes não dominem complemente os mecanismos de distinção como condição para o seu êxito. Assim as conversões de um gênero ou estilo, ou de um "Novo Cinema Novo", são vividas pelos agentes, e devem sê-lo dessa forma, para poderem alcançar o êxito.

${ }^{56}$ A illusio é a ilusão da realidade coletivamente partilhada e comprovada. A illusio faz com que olhemos o objeto e esqueçamos de perguntar quem o criou. "Tendo assim trazido à luz o feito mais bem oculto desse conluio invisível, ou seja, a produção e a reprodução permanentes da illusio, adesão coletiva ao
} 
Cinema Novo criado no campo cultural não está somente nas obras em si, mas nas relações criadas e reconhecidas entre os agentes envolvidos, desde os produtores, críticos até o público. Portanto, a crença no movimento depende inclusive das reviravoltas do grupo, declarando-se morto ou ressuscitado, como vimos. Mais do que isso, o processo depende também das lutas internas no campo, por exemplo, com os adversários do Cinema Marginal ${ }^{57}$. Desta crença coletiva no jogo enquanto tal (illusio) depende a crença coletiva na arte e no Cinema Novo.

Se nos anos sessenta, os cinemanovistas podiam falar livremente sobre a função do cineasta de transformar a sociedade, em Opinião eles não vão conseguir resolver o debate sobre o papel do realizador. Numa época de questionamento sobre o Cinema Novo, o grupo prefere declarar-se simples intermediário da cultura popular. Por outro lado, negar esta função de arauto é uma forma de combate à ditadura através da estética do silêncio. Assim a suposta "neutralidade" do intelectual pode ser encarada como um ato eminentemente político, dando vazão indiretamente ao mesmo projeto de conscientização. Existe em Opinião uma dualidade entre o projeto do arauto cinemanovista e o intelectual "correia de transmissão"; entre o intelectual tradicional e o engajado. Isso caracteriza o intrínseco da atividade da intelectualidade. Essa tensão dá vazão às várias discussões de ordem política e estética entre os críticos do jornal, numa formulação de conceitos dialeticamente.

O projeto cinemanovista afundava lentamente para os críticos de Opinião, acompanhando o declínio do intelectual arauto. O questionamento gerou uma crise na função da crítica de cinema de Opinião? Afinal, a que serve a crítica num jornal de resistência, se não há preocupação em ser dirigente da cultura? A pergunta fica mais fácil se invertemos as proposições: Qual a função e missão da crítica em tempos de repressão? É por esse motivo que Opinião não condena os cineastas que se declaram arautos, porque o jornal mantém esse mesmo projeto na maior parte do tempo ${ }^{58}$. Afinal sem essa base, a própria crítica de Opinião perderia sua função política.

\footnotetext{
jogo que é a um só tempo causa e efeito da existência do jogo, pode-se colocar em suspensão a ideologia carismática da ‘criação’ que é a expressão visível dessa crença tática”. (Bourdieu, 1996: 193).

${ }^{57}$ As reviravoltas negativas são importantes para o sucesso do grupo, porque há um alto rendimento na polêmica. Esse processo é feito desacreditando ou expondo o princípio do discurso dos adversários (no caso o do Cinema Marginal). Ver Bourdieu (2011: 75-76).

${ }^{58}$ Há uma mudança na postura em relação à cultura do nacional popular em Opinião na última fase do jornal (ver Capítulo 6).
} 
O trabalho do crítico pressupõe sempre a distinção do intelectual, numa posição acima dos leitores. Daí o retorno à função de dirigente da cultura. Entre a missão de conscientizar a sociedade e a constatação de que o projeto do Cinema Novo dos anos sessenta fracassou, os críticos prendem-se aos conceitos antigos, porque não têm um cânone melhor para colocar no lugar. Para Opinião, nada preenche o espaço deixado pelo Cinema Novo enquanto estética e política. Portanto, o jornal é instante de formulação desta hesitação e dificuldade de construir um novo projeto de cinema brasileiro.

A última esperança de um projeto cinematográfico era a Embrafilme, mas incluir o Estado repressor na proposta significava uma possibilidade de perda da autonomia do cineasta. A aliança com o regime via órgãos estatais de cinema não é vista pelos cinemanovistas como um novo programa, mas como a continuidade do projeto deles, com algumas correções de percurso sobre a linguagem utilizada, sobre a distribuição e a exibição. Portanto, o ideal de um cinema que revela o Brasil ainda é forte no jornal. Seja como grupo de pressão na Embrafilme ou como projeto de transformação do Brasil.

As declarações do grupo fazem parte do momento de crise da cultura do nacional popular. Porém, esses questionamentos não incidem no papel do intelectual crítico de cinema de Opinião por causa de sua função na resistência. A proposta do Cinema Novo está presente no jornal em nova roupagem. Se o contexto pode entrar em divergência com a tese sobre o arauto ou com a utopia da conquista do mercado sem corromper-se pelo sistema, os críticos evitam o tema tabu. Afinal, pensar em produzir para o mercado ou fazer um cinema realmente comercial estava fora de cogitação para Opinião. Ocupação mesmo só a do Cinema Novo.

Se tudo é só mercado, fica difícil para o jornal encontrar uma nova proposta para o cinema brasileiro. No fundo, a própria ideia de projeto político do cinema traz o conceito de transformação da sociedade através da ação intelectual, num ideal próximo ao do Cinema Novo. Quando Opinião não consegue criar as novas bases de um projeto para o cinema brasileiro, o jornal também não questiona os pilares da Frente Cultural. Isso só foi feito na última fase do jornal. Da impossibilidade de poder apelar integralmente ao governo, as divergências internas da oposição significavam uma dificuldade em compor um projeto nacional. Assim as discordâncias sobre o significado político do Cinema Novo devem ser vistas neste contexto, quando o povo não é mais 
unidade a ser emancipada e quando a intelectualidade percebe seus próprios interesses, como a produção financiada pelo Estado (Pécaut, 1990, Lahuerta, 1999). Esse momento de debate sobre os cinemanovistas em Opinião relaciona-se com a fragmentação dos intelectuais, que se reforça na época da abertura política quando tudo era questionado (ver Capítulo 6). A aproximação da democracia significou o fim dos grandes mitos unificadores e dos projetos de formação do social. Já era impossível a qualquer categoria social monopolizar a representação da nação, como os intelectuais fizeram antes. Mas os cinemanovistas ainda tentavam fazer isso em Opinião e havia no jornal uma preferência pelos projetos globais. No novo contexto, a intelectualidade teria dificuldade para projetar-se acima da sociedade, ou de instalar-se na dianteira da história. O tempo das representações totalizantes, como a do Cinema Novo, tinha passado (Pécaut, 1990).

Roberto Schwarz (1994) situa a crise da intelectualidade na época da abertura, porque ela teria ficado sem mandato e sem papel. Naquele momento a intelligentsia se via obrigada a admitir os próprios interesses. Em Opinião o papel do intelectual face à resistência era maior do que o declínio do arauto. Portanto, o contínuo retorno do jornal ao dirigente da cultura significava naquele momento o encontro de uma função social. No geral, o semanário não consegue pôr de lado o papel de conscientizar o público, porque continua a se ver como vanguarda do pensamento num ambiente repressivo.

A inspiração teórica dos jornais alternativos ligados a partidos políticos, como é o caso de Opinião, está ligada a Antonio Gramsci (Kucinski, 1991). O livro Os intelectuais e a formação da cultura foi publicado no Brasil em 1968 pela Civilização Brasileira e aparece com frequência no projeto de Opinião através do Jornalismo Integral. Kucinski observou que Gramsci estava presente na intenção manifesta, nos pontos programáticos, nas plataformas de lançamento, no discurso elaborado para conquistar o apoio dos intelectuais e nos estudos da práxis jornalística. Através do Jornalismo Integral, Gramsci (1968) pensava os periódicos como entidades autônomas dos partidos políticos com o propósito de colaborar para a formação de uma consciência crítica nacional. Contudo, o projeto do jornalismo integral é muito mais complexo do que a proposta de localizar o discurso político dos filmes na análise do enredo. Se Gramsci pensa os leitores dos jornais como ductos ou elementos ideológicos maleáveis e "transformáveis filosoficamente", a base do Jornalismo Integral não é uma forma de imposição ideológica. O pressuposto da formação de uma consciência crítica não é algo 
que anula os leitores, porque o processo é longo e complexo. “(...) É pueril pensar que um 'conceito claro', oportunamente divulgado, se insira nas diversas consciências com os mesmos efeitos 'organizadores' de clareza divulgada: este é um erro 'iluminista"” (Gramsci, 1968: 173-4). Afinal cada camada social elabora sua consciência e sua cultura de maneiras diferentes. As modificações nos modos de pensar não ocorrem por "explosões rápidas, simultâneas e generalizadas", mas quase sempre através de "combinações sucessivas" de acordo com fórmulas de autoridades variadíssimas e incontroláveis. O trabalho do intelectual no jornalismo integral usa um método dialético e combina indução e dedução, adaptando conceitos. O objetivo é fazer o público pensar por casos concretos e desenvolver uma nova camada de intelectuais orgânicos. Não se trata de uma mera inculcação de consciência por osmose no leitor. De qualquer forma, mantém-se a função do intelectual como especialista da razão, que revela a verdade.

Da identificação com o povo e da vontade de expressar ideias, sentimentos e anseios populares, o intelectual rompe com tudo de conservador, retrógado, antidemocrático e antinacional. No trabalho diário, ele aponta as contradições históricas e faz crítica social. Esse viés do pensamento gramsciano é o mesmo de Opinião. Se o lado comum da crítica de cinema é analisar e desmistificar a ideologia presente nos filmes, o viés é parecido com o gramsciano. $\mathrm{O}$ mesmo vale para o intelectual engajado sartriano (1994), cujo principal trabalho é apontar as contradições de cunho ideológico. Sartre e Gramsci vêem a intelligentsia como alguém que auxilia o processo de democratização, rumo a uma sociedade mais justa. Para Sartre, por sua opção pelas classes desfavorecidas, o intelectual torna-se guardião da democracia. Esta parece ser uma das tarefas centrais de Opinião: desmistificar e contestar a ideologia e os princípios da classe dominante. A afinidade entre os pensamentos demonstra que não foi somente por causa do contexto repressivo que Opinião colocou a premissa da política na discussão cultural. A preocupação em revelar a ideologia latente na produção é uma das vertentes do intelectual engajado. Cabe a ele lutar contra o renascimento perpétuo da ideologia.

Uma diferença é clara. O intelectual sartriano admite continuamente sua condição contraditória e seus permanentes conflitos. Faz uma perpétua autocrítica de si mesmo. No geral, os intelectuais de Opinião não colocam em discussão aberta seu próprio papel, sem revelar suas contradições aos leitores. Ninguém deixa claro isso no jornal, porque em Opinião o intelectual não é só dirigente da cultura, mas figura 
primordial do processo de democratização. O povo como sujeito histórico ficava ainda em segundo plano no jornal. No caso específico de Opinião, a condenação à burguesia marcava o problema da contradição do intelectual com sua classe. Por exemplo, era consenso entre os críticos que Jabor fazia parte da burguesia, mas esse tipo de comentário nunca chegava à discussão reflexiva deles próprios. Assim só o lado oposto aparece: a escolha dos doutos pelo povo. O tema traz junto uma concepção de neutralidade da intelectualidade e uma crença na autonomia em relação aos demais grupos sociais. Se o processo ajuda a manter a crença reprodutiva no sistema, a noção é fundamental para o crítico acreditar em sua formação discursiva e em sua neutralidade. O mecanismo é importante para denegar o interesse. Jamais em Opinião alguém irá declarar como Sartre que o intelectual se une aos trabalhadores para tentar resolver suas próprias contradições e sentimento de culpa, mas mesmo assim ele nunca deixará de ser "pequeno-burguês" (Sartre, 1994: 47). Não estamos aqui dizendo que os articulistas não estivessem conscientes desta contradição, mas no geral eles preferem projetar fora de si a condição de classe média em alguns cineastas brasileiros.

Quando os críticos evitam colocar lentes de aumento na própria contradição compactuam em não romper uma parte importante da Frente Cultural. A posição permite, além disso, legitimar-se perante os leitores e perante seus pares. Nestes casos, os críticos de Opinião não usam o método dialético descrito por Sartre. Fato é que as duas posturas coexistem no semanário.

A opção sartriana incide não só na autocrítica do intelectual, mas no formato do texto. A descrição casa como uma luva nos artigos mais complexos de Opinião na seção de cinema. Não se trata de mera inculcação da consciência em seres desacordados ou incultos. O intelectual age através do método dialético do particular através das exigências universais. Neste movimento, ele prova o universal como singularidade. Para Sartre (1994), ao mostrar esse processo ao proletário, a intelectualidade auxilia na constituição da tomada de consciência, porque ela já tomou ciência de sua contradição (Sartre, 1994: 46-7). Em Sartre, o intelectual apenas ajuda a tomada de consciência do proletário, ele não a produz ${ }^{59}$. Nesse sentido, o intelectual sartriano, assim como

\footnotetext{
${ }^{59}$ Sartre descreve o imperativo do intelectual engajado. Foi ainda em outubro de 1945 que Sartre publicou o artigo "Présentation" no primeiro número de Les Temps Modernes defendendo o intelectual que se ocupa com a política.
} 
Florestan Fernandes (1976) não tem a pretensão de criar a vontade nacional popular, de ser um dirigente da cultura ou de "comandar-lhes os momentos" (Sartre, 1994: 48).

Pelo menos há aqui a intenção sartriana de participar dos valores das classes desfavorecidas, numa associação com ares concretos. Opinião não consegue estender o conceito do intelectual participativo na prática. O jornal ainda se vê muito mais como dirigente da cultura ou como vanguarda do pensamento.

Entre os críticos de Opinião, Bernardet é o que mais relativiza seus comentários, quando coloca em questão a dependência dos intelectuais ao poder, seja ele exercido pelo Estado, pelos donos do jornal, ou até mesmo pela imprensa alternativa. Ele parece seguir os passos do método sartriano de trabalho ao questionar a falta de autonomia completa do intelectual e sua contradição constitutiva.

O primeiro passo do método sartriano é a apropriação de si mesmo no texto. Portanto, o primeiro objeto de estudo do intelectual é ele mesmo, numa perpétua e radical auto-crítica. Como consequência, o estudioso não pode ser moralista, nem universalista, nem idealista. Seu trabalho está longe de transformar seu ser contraditório em totalidade harmoniosa, porque o intelectual está inserido na sociedade e conhece a impossibilidade de considerar o conjunto social objetivamente.

O intelectual sartriano não tem pretensão à universalidade, porque sabe que suas contradições influenciam a conclusão. Portanto, um passo importante para o trabalho é a forma do texto. O ensaio é o estilo comprometido com a reflexão. A busca de método deve coincidir com sua própria contradição para criticar a sociedade. A solução de Sartre é o método dialético que dá conta de analisar o ponto de vista externo e interno:

"o objeto de sua pesquisa exige uma especialização do método abstrato de que acabamos de falar: é preciso, na verdade, que nessa perpétua inversão de ponto de vista, exigida para vencer uma contradição precisa, os dois momentos - exterioridade interiorizada, reexteriorização da interioridade - estejam-lhe rigorosamente ligados. Essa ligação de termos contraditórios nada mais é que a dialética. (...) é seu objeto que o imporá pouco a pouco, pois ele tem dupla face e cada uma remete à outra. (...) A verdadeira pesquisa intelectual, se pretende livrar a verdade dos mitos que o obscurecem, implica uma passagem pela singularidade do pesquisador. Este precisa se situar no universo social para capturar e destruir nele e fora dele os limites que a ideologia impõe ao saber" (Sartre, 1994: 34-5). 
A descrição acima revela exatamente o percurso entre a análise da estrutura interna e externa tomada por Jean-Claude Bernardet no artigo sobre Lição de amor (Capítulo 3). O trecho sartriano ainda descreve o movimento do crítico de se colocar continuamente no texto, trabalhando com o movimento do particular e do singular. Toda a análise de Bernardet sobre o filme de Escorel não partiu num só momento da totalidade. Tendo consciência de viver imerso na sociedade, o crítico baseou-se na universalidade singular, sem jamais se fazer primeiro no abstrato. Assim a ambiguidade presente nos textos é uma forma do intelectual evitar acreditar na universalidade abstrata. Nesse sentido, Bernardet inicia suas análises pelo particular em constante confronto com o concreto, a partir do acontecimento.

Sartre não vê o método dialético como uma metodologia utilizada pelo crítico, mas como uma imposição do objeto. Assim como Sartre, Bernardet percebe a ambiguidade de Lição de amor. Começa pelo sentido oposto à universalidade, porque vê a sociedade como luta entre grupos. Afinal ele mesmo insere no texto sua condição de contradição. Como consequência, o crítico não afirma a dominação do Estado no filme, mas observa a disputa entre os atores sociais.

O artigo sobre Lição de Amor é o ápice do questionamento sobre a postura do intelectual no campo de cinema em Opinião. É também o artigo mais auto-reflexivo sobre a função do intelectual na seção de cinema do semanário, articulando as ligações com o poder instituído, seja ele o Estado ou os jornais. A abordagem do problema não foi categórica, porque inclui no movimento textual a própria contradição do intelectual. O sentido do que se diz depende muito do estilo e da forma ambígua do artigo. Fugindo da postura de juiz, Bernardet inclui-se no questionamento sobre as possibilidades de resistência dos cinemanovistas, face à aproximação com o Estado. $\mathrm{O}$ artigo é escrito a partir de antagonismos numa mesma região discursiva. Numa leitura superficial, alguns o leram como uma condenação aos cinemanovistas. Internamente, percebe-se que o debate pertence a uma região fronteiriça onde não é mais possível determinar de maneira definitiva o intelectual, mas apenas apontar indagações.

Num dos trechos, Bernardet compara seu papel de intelectual com o da protagonista do filme. Dessa forma, o crítico coloca-se como espelho dos cinemanovistas. Numa leitura alternativa do texto, é possível substituir Fräulein pelos cineastas que recebem o auxílio do Estado: 
"Num aspecto de Fräulein que o filme acentua, me encontrei bastante. Fräulein como professora de amor, assume uma posição profissional: exerce a profissão com a finalidade de obter rendimentos para se sustentar e executar projetos pessoais. Ao mesmo tempo, há um envolvimento emocional profundo que independe do simples exercício da profissão e das relações financeiras. As atitudes de Fräulein são ao mesmo tempo e contraditoriamente as de uma amante e de uma profissional. Sinto nesta personagem muito do intelectual (de um certo tipo de intelectual) cujo trabalho é remunerado, mas também cujo trabalho é vivido, como uma vontade/projeto cultural, sem comum medida com a remuneração. E todo o trabalho é constantemente marcado por estes dois aspectos vividos contraditoriamente. Esta situação vincula necessariamente Fräulein (e o dito intelectual) à classe que paga, da qual ela depende quanto à remuneração, que ela serve executando serviços contratados (....), mas como a qual ela entra em contradição (parcial), pois as ideias e sentimentos que ela põe em prática na execução dos serviços contratados não são totalmente aceitáveis pela classe que paga. Assim Fräulein é sempre usada e rejeitada, o que, salvo engano, o diálogo do filme acentua mais que o romance, e sempre a serviço dessa classe."

Trazendo como referência indireta para o debate o ideal do intelectual puro, os veteranos do Cinema Novo são como Fräulein, mas não se trata de uma prostituição por dinheiro ou sobrevivência, mas por amor e luta pelo cinema brasileiro. Bernardet não fala do intelectual somente enquanto razão, o que era raro em Opinião. O debate sai da racionalização total, porque o intelectual tem um "envolvimento emocional profundo" com a sociedade através da "professora de amor".

$\mathrm{O}$ artigo pode ser lido como uma forma de problematizar a aproximação entre cinemanovistas e Estado. Há a necessidade de trabalhar ou filmar para obter rendimentos, numa relação de "amante" e de técnico do saber ("profissional"). O argumento de aproximação com o Estado não foge do lado afetivo. O fato de tornar-se "amante" significa não só a paixão pelo cinema brasileiro, mas a necessidade de sobrevivência. A relação de entrega do cineasta não é nada pacífica. Na comparação com a família Souza Costa (Estado), o cineasta é sempre "usado" e "rejeitado", porque suas ideias não são totalmente aceitas pela classe que paga. Bernardet está longe de condenar os cinemanovistas por adesão ao Estado, mas aproveita o ensejo para pensar a contradição do intelectual.

Por causa da necessidade de diálogo com o Estado, entende-se o intelectual noutro regime de análise. Neste texto, nenhuma ação é desligada completamente da necessidade das relações de poder, um viés único em Opinião. Num regime de exceção, Fräulein como duplo de Escorel é possível e aceita. Aqui, o intelectual é obrigado a 
admitir a influência do contexto sobre si mesmo (Schwarz, 1994). Não está mais numa torre de marfim. Da necessidade de prestar serviços para poder sobreviver, perde-se parte da autonomia. Duas alterações importantes advêm dessa postura: há um distanciamento de uma visão idealista do intelectual de um lado, e de outro, há um questionamento sobre o desinteresse e sobre a denegação.

Avançando na problematização do funcionamento do campo cultural, sintonizado com Bourdieu, Bernardet mostra que a tão sonhada autonomia do campo intelectual é relativa por causa das disputas e sanções com o campo político. Ele foge de uma postura purista de condenar os cinemanovistas pela associação com o Estado. A relação entre contradição, cumplicidade e ambiguidade com o regime militar não é fundada na escolha, mas é imperativo intelectual da resistência. Está muito distante desse texto um olhar idealista que considera louvável o imperativo ético puro.

$\mathrm{O}$ artigo nos parece uma obra aberta e possibilita adentrar em camadas mais profundas de significações, mesmo que elas façam parte de uma leitura que corre paralela a outros sentidos. Em alguns momentos do texto, seria possível substituir a figura do mordomo japonês Tanaka tanto pelo Estado autoritário, quanto pelos mecanismos censórios ou coercitivos. Em cada momento, Tanaka pode representar tanto um sujeito da censura, como uma engrenagem do sistema. Seguindo esta linha, o casal Souza Costa estaria mais para os aparelhos ideológicos do Estado ou para o Estado neutro via Embrafilme, que age sem colocar a mão na massa:

"Destacar este aspecto de Fräulein talvez permita enriquecer as suas relações com Tanaka, o mordomo japonês que agride a governanta e se relaciona sexualmente com ela. Mário de Andrade vê entre Fräulein e Tanaka relações entre imigrados. A posição de Fräulein na família Souza Costa, (...), possibilita ver outras relações, além das entre imigradas. Tanaka agride (episódio das malas) Fräulein como um empregado, digamos, superior em relação à cozinheira e à criada (...). Quanto a Fräulein, no início de sua tarefa, ela tem certa disponibilidade para se relacionar com Tanaka; à medida que se desenvolve a tarefa, isto é, à medida que cresce o seu envolvimento emocional e, portanto, a sua participação na família, ela se afasta de Tanaka (sequência em que Tanaka vai procurar Fräulein no hall e se desaponta ao não encontrá-la). Pode-se ver assim no relacionamento cozinheira-criada/Tanaka/Fräulein/ casal Souza Costa uma discreta metáfora de uma sociedade de classe, e nessa metáfora, Fräulein é a peça que o filme mais destaca." 
Tanaka interioriza a violência simbólica. É imigrado, talvez oprimido, mas também agride. Tanaka e os Souza Costa são as duas faces do poder ou do Estado opressor. Ao relacionar-se com o mordomo, os cinemanovistas dividem os lençóis com quem bate neles. Fräulein como duplo de Escorel associa-se ao Estado, faz filmes em co-produção, mas seu grupo recebe a censura do governo. Por outro lado, os censores não criam as regras, só reproduzem as leis da "burguesia".

Não há coincidência em Fräulein ser a peça que o filme mais destaca. O intelectual é o protagonista da resistência ao poder instituído. Se nossa leitura faz um paralelo entre Fräulein/cineastas/cinemanovistas com o Estado, a comparação é explícita e aparece no parágrafo seguinte do texto:

"Fräulein como projeção de um certo tipo de intelectual. Um desses intelectuais imprensados entre o projeto cultural e a remuneração é o diretor do filme. Como nos serviços prestados por Fräulein à família burguesa Souza Costa, a realização de Lição de amor supõe contradição, ambiguidade e cumplicidade entre o projeto cultural e a prestação de serviços.

(...) O cineasta que descreveu o envolvimento emocional de Fräulein e que a fez repetir com tanta insistência que ela queria seus oito contos, não está absolutamente alheio nem às contradições da governanta, nem às próprias."

O trecho não poderia ser mais claro. Ao associar-se ao Estado, a ligação com o cineasta significa prestação de serviço e cumplicidade. Supõe também contradição manifestada no estilo "aristocrático" contido de Escorel. Chegamos a um paradoxo. O intelectual evoluiu para uma atitude mais ambígua. Ele pode até se corromper um pouco, ao se relacionar com o Estado, mas deve ser ainda um intelectual espião dentro do governo. A linguagem cifrada de Escorel, cabe a Bernardet decifrar.

Se Opinião não coloca em xeque totalmente o intelectual arauto é porque o imperativo de destruir a ditadura é ainda maior e faz necessária a ação da intelligentsia. É por isso que Bernardet solicita uma posição contestadora de Escorel como intelectual engajado e dirigente da cultura. No fundo, exige-se dele conscientizar o "público formador de opinião". Isto é, Escorel e Bernardet cumprem a função de formadores de intelectuais orgânicos. Da impossibilidade do cineasta explicar todo o percurso de resistência aos leitores, Bernardet toma para si a função de explicador. 
Jean-Claude Bernardet não via sua função como uma forma de orientar o público ou de se aproximar do ato de criação do realizador. Sua busca naquele momento era pelas significações móveis estabelecidas por ele. Assim a crítica torna-se atividade criadora, porque enriquece o sistema de relações entre vários filmes (ver Capítulo 3). Quando o articulista pensa em contribuir com os autores, desvendando aspectos inesperados e latentes do trabalho deles, o trabalho do crítico torna-se parte da obra dos cineastas. A leitura dos artigos de Bernardet revela o quanto as observações acuradas dele agendam os comentários e as respostas dos cineastas ao longo dos anos. Portanto, Opinião era um dos espaços para Bernardet agir no campo cinematográfico. Isto é, ele levou a cabo realmente a ideia de crítica participativa e de intervenção sobre o cinema brasileiro na prática do jornalismo. Desta forma, não há sombra de dúvida que Bernardet é o intelectual que lidera intelectuais em Opinião, especialmente os cineastas. Talvez Opinião tenha sido um jornal líder de intelectuais ${ }^{60}$, mas é preciso analisar cada caso, cada editoria. Por hora, deixamos aqui esta hipótese, confirmada no caso do cinema na figura de Jean-Claude Bernardet. Ele poderia estar inscrito no tipo de intelectual descrito por Karl Mannheim (1974: 82) que possui "maiores oportunidades de testar e aplicar as visões socialmente disponíveis e de experimentar suas incoerências". A descrição de Mannheim do intelectual moderno que se caracteriza pela "multipolaridade de visões" cai muito bem em Bernardet ${ }^{61}$.

Quando o artigo sobre Lição de Amor analisa a conexão entre a estrutura interna e externa da obra, Bernardet dá novo alento ao debate entre estética e política no cinema. A dualidade descrita ao longo do texto não é só característica de Eduardo Escorel, mas da gênese do intelectual descrito por Pierre Bourdieu na dicotomia entre a busca de autonomia estética e o engajamento. É através do prestígio junto ao campo artístico que o intelectual adentra no campo político. Para Bourdieu, o intelectual sempre está a meio caminho entre essas duas possibilidades. Afinal tanto o intelectual voltado à arte pura, quanto o engajado, completam-se porque a autonomia da arte é feita em função do debate político. Se a possibilidade de separar os críticos de cinema entre

\footnotetext{
${ }^{60}$ Bernardet não foi o único formador de opiniões da intelectualidade brasileira em Opinião. Milton Lahuerta (1999) considera a trajetória de Fernando Henrique Cardoso no semanário de Gasparian como sinônimo de liderança de intelectuais.

${ }^{61}$ Alguns pontos do processo intelectual de Mannheim explicam a metodologia do trabalho intelectual de Jean-Claude Bernardet. É possível também comparar a "multipolaridade de visões" de Mannheim ao método dialético proposto por Sartre. Enxergando além de sua subjetividade, a intelligentsia mannheiniana tem um alcance de visão mais amplo, aberta a múltiplos pontos de vista. É capaz até de experimentar concomitantemente várias abordagens conflitantes da mesma coisa.
} 
os polos da estética e da política poderia parecer muito sedutora do ponto de vista didático, os dois lados costumam se imbricar constantemente.

O que tornou possível o ato inaugural do intelectual intervindo no campo político foi a conquista da autonomia no campo cultural. Para Bourdieu, o intelectual constitui-se enquanto sujeito intervindo no campo político. Essa é a forma da intelectualidade ganhar legitimidade. Primeiro ele prova sua independência através de abnegação, competência e desinteresse para poder entrar na discussão política. A operação lhe garante um pressuposto ético, político e estético. A ação só é possível porque antes a intelectualidade havia conquistado sua liberdade dentro do campo artístico contra a política. Deste passado, alguns críticos de Opinião utilizam armas que não são as da política a serviço da causa pública. Eis por exemplo a aplicação do conceito de estrutura ao filme Lição de amor. Por outro lado, não havia simplesmente uma subordinação da arte à política por causa do contexto repressivo. Ao contrário, $a$ discussão política é feita em nome da arte. Tanto é verdade que os críticos de Opinião não apreciam o conteúdo político de filmes de esquerda de Costa Gravas, Guiliano Montaldo e Elio Petri. Em nome do cinema como arte, não só como forma de conscientização, é feita a crítica de cinema de Opinião.

Da impossibilidade de desconectar o campo político, Bourdieu possibilita pensar na autonomia do campo cinematográfico frente às sanções do campo político. Portanto a autonomia é sempre incompleta por causa das sanções internas de qualquer campo. É exatamente este caráter paradoxal do intelectual entre a arte pura e o engajamento que caracteriza o intelectual de Opinião. A partir da autonomia do campo, conquistada graças ao desinteresse e competência, o intelectual vai se firmar como tal no campo político e aumentar sua liberdade de crítica em relação aos poderes:

"o intelectual é um ser paradoxal, que não podemos pensar como tal enquanto não o apreendemos através da alternativa obrigatória da autonomia e do engajamento, da cultura pura e da política. Isso porque ele se constituiu, historicamente, na e pela superação dessa oposição.

(...) O intelectual é uma personagem bidimensional que não existe e não subsiste como tal a não ser que (e apenas se) esteja investido de uma autoridade específica, conferida por um mundo intelectual autônomo (ou seja, independente dos poderes religiosos, políticos e econômicos) do qual respeita as leis específicas, e que (e apenas se) empenhe essa autoridade específica em lutas políticas. Longe de haver, como se crê comumente, uma antinomia entre a busca de autonomia (que caracteriza a arte, a ciência ou a literatura ditas 'puras') e a busca de eficácia política, é aumentando sua 
autonomia (e, como isso, entre outras coisas, sua liberdade de crítica com relação aos poderes) que os intelectuais podem aumentar a eficácia de uma ação política cujos fins e meios encontram seu princípio na lógica específica dos campos de produção cultural". (Bourdieu, 1996: 370)

Havia um polo em Opinião voltado aos críticos formalistas, mais sintonizados com a concepção de intelectual tradicional. Interessados no enriquecimento do conhecimento e na sensibilidade, eles prezam em primeiro lugar sua autonomia. Contudo nenhum intelectual num regime autoritário pensa a si mesmo como alguém distante das causas políticas. Qualquer crítico em Opinião estava muito distante do intelectual alheio à política e aos conflitos sociais. Se a crítica de Opinião é formulada na tensão entre estética e política, Bourdieu mostra que esta dicotomia pertence a qualquer campo intelectual. Os debates políticos e as sanções de mercado fazem parte constituinte do campo cultural. As duas dimensões de identidade do intelectual - pureza e engajamento - geram uma combinação instável em Opinião, onde não encontramos uma postura exclusiva de um polo somente.

Os dissensos e ambiguidades entre os críticos de Opinião não são marca somente do Frentismo e da dificuldade daquele momento de formular um projeto coeso ao cinema brasileiro. Elas são também prova da evolução do pensamento intelectual, no qual as contradições devem ser incorporadas. Estas não devem ser vistas como um problema, afinal os dissensos fazem parte do intelectual. "O estatuto dos intelectuais é um pulular de contestações. Os que se chocam com isso, acreditam ainda no universal" (Sartre, 1994: 50). Portanto os casos de hesitações em torno de um projeto único ao cinema brasileiro significam também parte da consciência do intelectual de suas próprias contradições. Não se trata somente de uma incapacidade de formular um programa único, mas da habilidade do intelectual de fugir das generalizações e das universalizações, porque a dualidade e contradição o caracterizam. Percebendo as particularidades de cada caso, o crítico coloca-se como sujeito que interfere nas conclusões por causa de sua subjetividade. Ao invés de fechar os temas, ele abre mais questionamentos e debates para o público. Não age como um guia de soluções, mas como um constante indagador. 
A cultura popular em cena no cinema: entre atritos e silêncios

Se existe uma verdade, é que a verdade é uma aposta de lutas, e, se bem que as classificações ou julgamentos divergentes ou antagonistas dos agentes comprometidos no campo artístico sejam indiscutivelmente determinados ou orientados pelas disposições ou interesses específicos associados a posições no campo, a pontos de vista, o fato é que são formulados em nome de uma pretensão à universalização, ao julgamento absoluto, que é a própria negação da relatividade dos pontos de vista.

Pierre Bourdieu in As regras da arte 



\section{Capítulo 6 - A cultura popular em cena no cinema: entre atritos e silêncios}

Se o debate sobre a cultura popular no cinema é extenso ${ }^{1}$, um livro significou um divisor de águas para a geração dos anos sessenta no sentido da crítica ao nacional popular: Brasil em Tempo de Cinema de Jean-Claude Bernardet, publicado em 1967. Como já dissemos, a obra fazia parte da dissertação que o autor iria defender na Universidade de Brasília, onde lecionava. O trabalho foi feito sem recuo histórico e analisava a recente produção brasileira até meados de 1965. Com a invasão da universidade pelos militares, a defesa não foi feita. Só dois anos depois saiu a primeira edição do livro, com o título tomado de empréstimo de Cacá Diegues.

Antes mesmo da publicação, a obra já causou polêmica quando uma banca informal discutiu o trabalho durante o Festival de Brasília. O ponto de atrito era exatamente o cinema popular. Se alguns cineastas viam-se como sujeitos responsáveis por fazer aflorar a cultura popular, o livro encerrava o debate declarando a inexistência de qualquer cinema popular no Brasil até aquele momento. Indiretamente os comentários opunham-se ao papel de vanguarda do intelectual, seja o de gerar a cultura popular revolucionária do CPC (Centro Popular de Cultura) ou o de libertar o povo oprimido do Cinema Novo. Se não existia um cinema popular feito pelo povo, o livro gerava divergência ao inserir a produção do Cinema Novo como típica da classe média. Por causa desse perfil, os filmes hesitariam entre o povo e as classes dirigentes, enquanto a classe média tentava se firmar como diretriz das aspirações populares e encontrar para si mesma um projeto político.

O livro é pioneiro em realizar uma crítica ao nacional popular no campo do cinema (Xavier, 2009). Com esses comentários, Bernardet levava embora o sonho do intelectual cinemanovista de se ver como mediador autorizado do povo. Quase no mesmo período, Sebastião Uchôa Leite publicava na Revista Civilização Brasileira ${ }^{2}$ uma análise de peso. O texto saiu em 1965 e problematizava o conceito de cultura popular nas artes. $\mathrm{O}$ aspecto central era diferenciar a cultura feita pelo povo, para $\mathrm{o}$ povo e sobre o povo.

\footnotetext{
${ }^{1}$ Para um histórico e análise das propostas de cinema popular no Brasil, ver Bernardet; Galvão (1983).

2 Cultura Popular: Esboço de uma resenha crítica. Revista Civilização Brasileira. n. 4, set. 1965. O artigo também está disponível in Fávero (1983). Para uma análise do artigo de Uchôa Leite, ver Bernardet; Galvão (1983). Bernardo Kucinski (1991) vê a Revista Civilização Brasileira como o início da exegese da cultura de esquerda, fazendo a autocrítica de seus fracassos.
} 
Uchôa Leite encarava a arte popular como dinâmica, potencialmente crítica e conscientizadora por si só. Para o autor, a ala que vê a mutabilidade dos valores com desconfiança por causa de seus resultados negativos traz o risco de uma atitude de preservação estética e anti-histórica, ao ver o folclore como coisa cristalizada e indeformável. Jean-Claude Bernardet e Maria Rita Galvão (1983) sinalizaram que o viés de Uchôa Leite foi original para o período, porque ele apontava a necessidade de proporcionar ao povo as condições culturais de enriquecer seu próprio conteúdo. Uchôa Leite frisava que existia na cultura feita pelo povo a potencialidade crítica para essa abertura. Portanto, Jean-Claude Bernardet (Xavier, 2009) no campo do cinema e Sebastião Uchôa Leite (Bernardet, Galvão, 1983) na área cultural foram a marca de um pensamento inovador e progressista sobre a cultura popular naquele momento, porque fizeram a crítica ao nacional popular um pouco antes do final dos anos sessenta.

Se a tese de Bernardet não foi bem recebida num primeiro momento pelo meio cinematográfico, ela influenciou o discurso dos cinemanovistas na década seguinte, como vimos. Atendendo às indagações dos anos setenta de dar espaço à cultura popular, os cineastas respondiam também às afirmações de Brasil em Tempo de Cinema nas entrevistas para Opinião. Analisamos neste capítulo o posicionamento do semanário alternativo frente aos cineastas que se colocavam como mediadores ou como tradutores da cultura popular, tomando como parâmetro Brasil em Tempo de Cinema.

Algumas indagações iniciais norteiam esse capítulo: Opinião foi um marco de pensamento progressista sobre a cultura popular e sobre o nacional popular na área de cinema? O debate crítico de Brasil em Tempo de Cinema avançava em Opinião além desse marco? O jornal batia de frente contra o cinema voltado ao nacional popular? Não estamos atrás de uma periodização precisa, nem em busca de mitos fundadores. Não tratamos os textos sobre a cultura popular como totalidade ou área autônoma porque nos interessa o diálogo com o cinema e com Opinião. O capítulo contém quatro momentos cronológicos importantes que refletem os posicionamentos diante da cultura popular no cinema: a discussão em torno de O Amuleto de Ogum (1974) de Nelson Pereira dos Santos, o artigo de Jean-Claude Bernardet sobre Nordeste: cordel, repente, canção (1975) de Tânia Quaresma, a emergência de uma nova crítica de cinema no caso de Xica da Silva (1976) de Carlos Diegues e as polêmicas internas do jornal sobre o nacional popular. Buscamos realçar nos textos os contrapontos sobre o tema. 
O debate interno do jornal nestes quatro momentos dialoga com o percurso da cultura popular no campo artístico, indo em direção à crise do nacional popular. Por volta de 1964-65, começava o balanço do Cinema Novo (Bernardet, 1978). O debate antecipava outra crise, a da cultura do nacional popular um pouco antes da virada da década (Napolitano, 2011). Em todos esses questionamentos, a cultura popular estava no epicentro do debate e trazia junto a condenação à pretensão do intelectual em ser um porta voz do povo. Se a crítica ao nacional popular no cinema já estava presente em Brasil em Tempo de Cinema, ela se acirrava no final dos anos setenta e se tornaria inviável no começo da década de oitenta. Naquele momento, o nacional popular era visto como símbolo de uma ação autoritária, mistificadora, nacionalista e afeita às regras do mercado e do estado autoritário (Napolitano, 2011: 316). Pesava também a acusação contra o nacional popular de não deixar vazar o próprio povo como sujeito da história, sempre tutelado por um intelectual. A desconfiança em relação ao mercado e à massificação da cultura só aumentava. Os últimos anos de Opinião antecederam essa crise e retomaram em seu microcosmo a futura ruptura do frentismo. Alguns sinais de um movimento maior em direção à Nova Esquerda se anunciavam internamente em torno do debate de Xica da Silva.

A revisão da cultura nacional popular era realizada especialmente por alguns segmentos que compõem a Nova Esquerda: os trotskistas, a antiga Ação Popular (AP), a esquerda católica e os movimentos sociais e basistas (Napolitano, 2011). Algumas figuras relacionadas a esses núcleos estavam presentes em Opinião, como veremos. O segmento é heterogêneo e teve importância fundamental no desenvolvimento de uma revisão da cultura nacional popular. Esse movimento crítico à esquerda nacionalista $\mathrm{e}$ comunista ganhava o reforço da Nova Esquerda intelectual. Atentos à cultura popular, esses intelectuais procuravam novos atores na resistência e práticas democratizantes no interior dos movimentos sociais. Havia naquele período, uma crítica conjunta à mediação feita pelo mercado, ao elitismo e à massificação industrializada da cultura. De acordo com Marcos Napolitano (2011), surgiam novos temas que não pautavam a agenda dos intelectuais antes: a valorização da cultura popular urbana e a apropriação dos meios massivos. A cultura popular era vista como uma produção dinâmica e afastada do autenticamente popular. Esse viés transformador pautava uma nova visão sobre as classes populares, valorizando seus aspectos comunitários. Opondo-se ao intelectualismo e à mistificação da cultura popular, essa tendência seria reforçada 
quando emergiram os novos movimentos sociais como atores políticos importantes, por exemplo, o movimento operário. No final desse processo, o intelectual passaria a ser visto mais como alguém que apontava caminhos políticos e expunha tensões, sem a pretensão de trazer um único viés possível.

Autores como Marilena Chauí (Chauí, 1983; Queiroz; Valle, 1979) foram os responsáveis por rever conceitos importantes sobre a cultura popular e sobre o intelectual. Um dos primeiros textos reflexivos sobre a cultura popular dentro da Nova Esquerda intelectual teria surgido pelas mãos de Carlos Rodrigues Brandão no jornal alternativo Movimento (Napolitano, 2011). Em 1977, o professor da Unicamp condenava a concepção de cultura popular como algo estático e como objeto de preservação folclórica ${ }^{3}$. Brandão mantinha a tendência intelectual do período de ver a cultura popular como forma de resistência ao regime (Chauí, 1986) e aos valores conservadores da sociedade. Para ele, a cultura popular é uma produção ligada aos oprimidos e aos dominados. O artigo tem um viés crítico à indústria cultural e ao intelectual. Enquanto o povo ri, dança e se diverte, o intelectual procura ter "controle" sobre essas "bases" quando se debrua sobre esses temas. Marcos Napolitano vê o texto como sintomático das mudanças em curso. Elas teriam surgido em primeira mão na imprensa alternativa em 1977 apontando, segundo ele, para as novas tendências intelectuais da Nova Esquerda.

No campo específico do cinema, a revisão teórica do conceito de nacional popular concretizou-se no livro Cinema: repercussões em caixa de eco ideológica - as ideias de "nacional" e "popular" no pensamento cinematográfico brasileiro escrito por Jean-Claude Bernardet e Maria Rita Galvão (1983). A obra mostrava o quanto o conceito de nacional popular tornou-se fundamental para o pensamento do cinema brasileiro ao longo das décadas, porque os projetos de cultura nacional popular construíam uma identidade nacional. Os dois autores demonstravam o caráter autoritário e os limites estéticos e ideológicos dessa herança que, segundo eles, carecia de uma revisão. Se o livro foi publicado em 1983, alguns antecedentes desse debate estavam presentes anos antes em alguns artigos de Opinião.

\footnotetext{
${ }^{3}$ Brandão, Carlos Rodrigues. Um pouco de ordem nesse debate. Movimento. n. 119, p. 16,10 out. 1977. Antes de Brandão, Renato Ortiz também publicou um artigo no mesmo jornal mostrando que a cultura popular era algo caracterizado pela heterogeneidade, fugindo da perspectiva de um todo coerentemente integrado. Os dois textos faziam parte de um debate maior do jornal Movimento sobre a cultura popular. Ortiz, Renato. A sombra das multinacionais. Movimento. n. 114, p. 20, 05 set. 1977.
} 
Saindo do campo do cinema, chegamos a Marilena Chauí que coordenou a coleção da Brasiliense para discutir o conceito de nacional popular nas artes, da qual o livro de Bernardet e Galvão faz parte. No livro Seminários desta mesma coletânea, Marilena Chauí (1986) desmembrou o discurso do CPC como algo autoritário e populista. Ela fez também uma crítica ao autoritarismo em suas diversas facetas, tanto de esquerda quanto de direita. A autora renovou a discussão sobre o conceito de cultura popular enquanto estratégia de resistência ${ }^{4}$. Segundo Marcos Napolitano (2011), entre as vozes intelectuais mais influentes e críticas ao nacional popular estaria a de Marilena Chauí.

Não era só Marilena Chauí quem fazia a revisão do nacional popular e diluía a função do intelectual arauto. A Nova Esquerda católica também revisava o conceito, tanto na Ação Popular (AP) quanto nos Movimentos de Educação de Base através da figura precursora de Paulo Freire ${ }^{5}$. Nos dois casos, o pensamento sobre a cultura popular era pioneiro e diminuía o papel do intelectual como mensageiro da consciência popular. Da função de arauto, ele se transformava num mediador dentro das comunidades populares, provocando um processo de auto-descoberta. Paulo Freire não explica a relação entre o homem e o mundo como uma relação de passividade, porque cada pessoa guarda conotações de "pluralidade" e "criticidade". Assim, a captação dos dados da realidade é sempre crítica. Portanto, o viés do autor sobre a cultura popular é totalmente diferente. As soluções para os problemas devem ser procuradas com o povo, nunca sobre ele ou para ele. De acordo com Paulo Freire, “outra afirmação a ser colocada é a de que ninguém politiza ninguém. O conceito de politização tem uma conotação fortemente optativa". (Fávero, 1983: 99-100; 122). O papel do educador é o de auxiliar neste processo na forma de um debate entre todo o grupo, mas isso não significa que ele gere essa reflexão. Paulo Freire dava especial atenção aos problemas do cotidiano dos alunos. Ele estimulava a autonomia da comunidade na produção

\footnotetext{
${ }^{4}$ Nessa coletânea, Marilena Chauí (1986) explica que a noção de cultura popular é avessa à unificação. Como adjetivo, o termo busca uma unificação inexistente, uma vez que a noção de popular é composta tanto pelo popular, como pelo não-popular. Se o popular reivindica a ideia de divisão de classes e direitos ao cidadão, o Estado nacional tenta absorver o popular pelo nacionalismo e pelo populismo para dissimular a divisão entre o popular e o não popular. Chauí expõe que a expressão cultura popular é de difícil definição pelas variadas acepções dos dois termos. O termo nunca é utilizado pelo próprio povo, mas é empregado por membros de outras classes para definir as manifestações culturais das classes subalternas. Para um panorama do conceito de cultura popular ver Marilena Chaú (1986), Ecléa Bosi (2007), Alfredo Bosi (1992) e Sebastião Uchôa Leite (1965).

${ }^{5}$ Sobre a ligação entre a Nova Esquerda, Paulo Freire, a política cultural da esquerda católica e o Movimento de Cultura Popular do Recife, ver Napolitano (2011).
} 
cultural, respeitando os valores populares. Daí a conversão do povo em agente histórico, sem procurar alguém para colocar no papel de vanguarda.

Enquanto Paulo Freire desenvolvia seu método de alfabetização, a Ação Popular elaborava um documento em 1963 (Fávero, 1983) sobre a cultura popular que terá muitos pontos de contato com a visão de Opinião sobre o mesmo tema ${ }^{6}$. Porém há também alguns atritos. Neste documento, a cultura popular aparece como instrumento de resistência para a libertação dos homens, em oposição à cultura de classe, que é instrumento de dominação. Dois aspectos desse documento são semelhantes aos preceitos de Opinião: a autenticidade da cultura popular e a visão negativa sobre a cultura de massa. Os outros dois aspectos representam uma diferença em relação ao jornal: a diminuição do papel do intelectual e a elaboração da cultura popular como participação comunitária. O papel do intelectual como arauto da consciência popular fica quase em segundo plano no documento da AP, porque a cultura popular deve ser gerada na participação com a comunidade. Ela nasce da ação comunitária, não do intelectual. Para a AP, a cultura popular deve ser comunicável ao povo e responder às suas exigências, para realizar a consciência do homem. Ou seja, não se anula totalmente a ação do intelectual, mas se realça mais o papel do povo, enquanto sujeito de construção cultural. O viés era totalmente diferente das ideias de Carlos Estevam (Fávero, 1983), do CPC, que via a cultura popular como desprovida de dignidade artística pela falta de estética e de consciência. Se Estevam via o intelectual como sujeito da cultura popular revolucionária, a AP pensava a cultura popular elaborada com o povo, fazendo-o participante. Contudo, mesmo na AP, a alienação do povo é imputada aos meios de comunicação. Havia mais uma semelhança entre a AP e Opinião: ver o cinema como meio de conscientização política que deve ter posição crítica diante da realidade. Geralmente faltava Opinião pensar o intelectual como participante de uma cultura construída em conjunto com o povo. Esse viés comum a autores como Florestan Fernandes, Antonio Gramsci e Jean-Paul Sartre apareceu num dos textos de Gustavo Dahl, como vimos.

A ideia de autenticidade da cultura popular significava para a AP comunicar os valores humanos à consciência. Quando a cultura é transmitida a todas as consciências,

\footnotetext{
${ }^{6}$ Segundo Bernardo Kucinski (1991) haveria um comando secreto da AP em Opinião, mas as ideias do jornal na seção de cinema não seguem os preceitos do partido sobre a cultura popular e o papel do intelectual.
} 
ela é autêntica. Por uma argumentação enviesada, tenta-se combater uma cultura de um grupo, enquanto manifestação de dominação de classe. O conceito é um tanto frágil, porque exclui qualquer forma de cultura não universal ou regional, buscando uma essência da cultura nacional. No fundo a ideia de autenticidade da AP só quer dizer a oposição ao caráter alienante dos meios de comunicação. A autenticidade, como no CPC, também é uma essência.

Ainda dentro da Nova Esquerda católica, Alfredo Bosi $(1987,1992)$ auxiliou no processo de revisão da cultura popular. No final dos anos setenta, ele ainda via a cultura de massa como algo negativo por se apropriar do folclore, invadir lares e explorar a vida do povo como reportagem. Contudo há um sinal de esperança, porque a cultura para as massas seria incapaz de interromper o dinamismo da vida popular. Bosi frisava a necessidade de incorporar uma teoria da aculturação para levar em conta as imbricações entre a cultura de massa, a cultura popular, a cultura erudita e a cultura criadora dos artistas. Sem ver no intelectual um arauto, o autor mostrava que a visão do intelectual sobre a cultura popular variava da demagogia, do desprezo ou até como forma de inspiração para uma obra de arte. A proposta de cultura de Bosi (1987) é substituir a concepção ligada à tradição pela ideia de processo e fruto do trabalho a ser empreendido, com os agentes sociais sempre à frente. Vendo a cultura popular com vários aspectos contraditórios, ela é entendida como algo que se faz no dia a dia e nas condições possíveis pelo povo.

Se alguns dos trabalhos sobre a cultura popular tinham um viés mais teórico de análise, outros autores partiam dos dados empíricos para abordar a recepção do público aos meios de comunicação. Naquele momento, os intelectuais procuravam localizar as apropriações críticas dos trabalhadores resignificando o sentido das obras. Nesta linha, destacam-se dois trabalhos. O primeiro é de Ecléa Bosi (2007), ligada à Nova Esquerda. O segundo é de Carlos Eduardo Lins e Silva (1985) e faz parte do campo do jornalismo. Em 1972, Ecléa Bosi (2007) deu cabo a uma pesquisa sobre a leitura que as operárias fazem não só de livros, mas também dos meios de comunicação de massa. A autoria não insiste em ver a cultura popular como parte da resistência, porque identifica nela substratos conservadores, progressistas, retrógrados e criadores. Ela pensava a cultura popular como algo constantemente reelaborado, abrindo a possibilidade até de a cultura popular tomar de empréstimo alguns elementos da cultura de massa para transfigurar seu sentido em novas significações ou em formas artísticas. Ecléa Bosi (1982) também 
defendia a articulação necessária entre a cultura letrada erudita e a cultura oral dos pobres. Fugindo de um viés de folclorismo e massificação, o intelectual poderia mergulhar na condição de operário através do contato direto com a comunidade pobre.

Se Ecléa Bosi partia da psicologia para elaborar seu trabalho, Carlos Eduardo Lins e Silva fazia um estudo da recepção do Jornal Nacional pelos operários. A pesquisa de doutorado feita entre 1979-1984 era participativa e permitia depois de algum tempo incentivar os operários a observar criticamente os meios de comunicação. Lins e Silva concluiu que não existia uma recepção passiva do público operário à televisão. Ao contrário, havia uma negociação de sentido feita a partir do conhecimento de outras instituições sociais de informação, de filtros e de juízos de valores. A recepção ainda dependia do contato maior ou menor com os dados apresentados. Caso o espectador conhecesse menos a realidade apresentada, ele tendia a concordar com a visão apresentada pela TV. Segundo ele, as pessoas podem até ver as mesmas coisas, mas percebem significados diferentes, dependendo do contexto sócio cultural de cada um ${ }^{7}$. O olhar de Carlos Eduardo Lins e Silva em relação à indústria cultural é bem menos negativo, talvez pela aproximação com o trabalho jornalístico. Assim como JeanClaude Bernardet, Ecléa Bosi e Alfredo Bosi, ele frisava que os fenômenos sociais não são coerentes nem uniformes. Diferente dos demais pesquisadores, o autor apontava as ambiguidades, contradições e luta de classe no interior dos meios de comunicação, em vários atritos entre os jornalistas e a chefia.

Ainda no campo do jornalismo, Francisco Rüdiger (1981) trazia outra leitura do tema. O autor pensava o interesse dos intelectuais pela cultura popular como parte de uma nova conjuntura histórica. Haveria, segundo ele, um esgotamento de teorias que antes se bastavam denunciando os meios de comunicação como manipulação ideológica. Sem encontrar uma estratégia ofensiva e prática contra os meios de comunicação, os intelectuais teriam se voltado à estratégia de recuo: as manifestações das classes populares como parte da resistência cultural.

A evolução desses estudos mudava radicalmente quando surgiu um novo ator social em 1978: a eclosão das greves operárias, sem precisar de nenhum tipo de tutela intelectual. Foi nesse novo contexto que a crítica ao nacional popular se ampliou ainda

\footnotetext{
${ }^{7} \mathrm{O}$ início dos estudos de recepção dos meios de comunicação começou com os funcionalistas, sendo que Walter Lippmann (2008) constitui um marco importante sobre esse tema ainda em 1922. Uma síntese atualizada das teorias de recepção pode ser encontrada no livro de Clóvis de Barros Filho (1995).
} 
mais e alterou não só o quadro da esquerda, como o da própria imprensa alternativa, levando-a à chamada imprensa basista ${ }^{8}$. Os debates internos de Opinião acompanhavam a tendência de ruptura das frentes jornalísticas ${ }^{9}$ na imprensa alternativa. O semanário de Gasparian não participou da totalidade desse processo porque saiu de circulação um ano antes da eclosão das greves. Porém, algumas prerrogativas da futura Nova Esquerda estavam presentes no jornal. Trazemos nesse capítulo um primeiro lampejo dessa transição em algumas fissuras e aberturas de Opinião. O capítulo traz um momento inicial de contestação ao nacional popular e depois um acirramento da crítica a este modelo na fase do Jornalismo Cultural Reflexivo. O debate em torno da cultura popular em Opinião surgia em meio a três atores sociais: o núcleo do nacional popular que perdia espaço dentro da seção cultural; os opositores ao nacional popular e por último, os liberais na figura de Fernando Gasparian.

O debate sobre a cultura popular em Opinião ao longo dos anos tem alguns pontos em comum entre os críticos. Em geral, o povo surge como concepção genérica. É ao mesmo tempo destinatário e matéria prima dos filmes. O jogo cultural é descrito entre os amigos do povo e os inimigos da nação. As discussões abandonam a constatação da existência de uma porção popular e não popular da população brasileira e deixam de lado pensar se o popular é algo móvel ou eterno. As exceções estão nesse capítulo. No geral, os articulistas tratam a cultura popular como caminho de autenticidade. Afora um parágrafo de Jean-Claude Bernardet mostrando o quanto o povo é sinônimo de vulgo e outros adjetivos nada positivos ${ }^{10}$, a discussão teórica parava por aí. $\mathrm{O}$ apagamento é significativo porque revela um silêncio sobre a parte não-popular da população, para não atrapalhar a união em torno da identidade.

Quantitativamente, os críticos dedicam-se à ausência de autenticidade da cultura popular, seja a da produção norte-americana ou a do cinema de gênero brasileiro. Eles frisam o componente ideológico dos sucessos de bilheteria. Os filmes da indústria cultural são tema constante de represália. Se os críticos aguardam ardentemente a conquista do público, o mercado tem um papel paradoxal, mais atrelado ao lado do inimigo. A ele quase nenhum elogio era feito, seja em nome da arte ou da política. Para

\footnotetext{
${ }^{8}$ A imprensa basista nasce do trabalho cooperativo entre jornalistas e os movimentos sociais no final dos anos setenta. Sobre a imprensa basista, ver Kucinski (1991).

${ }^{9}$ Sobre as Frentes de Opinião ver introdução.

${ }^{10}$ Murao, Carlos (pseudônimo de Jean-Claude Bernardet). A pornochanchada contra a cultura culta. Opinião. n. 99, p. 23, 27 set. 1974.
} 
a produção da indústria cultural, os críticos não localizam os traços de nacionalidade, nem as marcas distintivas da forma e do conteúdo do cinema brasileiro. A necessidade de conquistar o público não significa de forma alguma aceitar totalmente os valores do cinema comercial. Além disso, as questões subjetivas do gosto do público são preteridas em nome do cinema artístico e da política. Indiretamente o debate se inclina para uma defesa da arte, dos imperativos políticos e da forma original. Se Opinião defende um cinema autoral com linguagem acessível ao público para ocupar o mercado, quando Toda nudez será castigada (1972) de Arnaldo Jabor atinge esse patamar, o filme é condenado por causa do flerte com o mercado. Em nome da política na forma da obra, o cineasta é tratado como alguém que tem objetivos comerciais e estéticos mais fortes. No fundo, os núcleos da arte e da defesa do mercado tornam-se em Opinião um tema de luta interna. A conciliação entre os dois tinha como modelo Macunaíma (1969) de Joaquim Pedro de Andrade, que possibilitava a união entre o público popular e o público culto. Portanto, a busca de um projeto cinematográfico para o Brasil passava mais pela produção feita sobre o povo com a marca distintiva do "autenticamente popular" do cinema autoral.

Quando o jornal vê a cultura para as massas como tosca, artificial, corrompida e sem dignidade artística, o viés está mais voltado a uma concepção aristocrática da cultura. Se Cahiers na primeira fase dava aos diretores considerados comerciais a distinção da autoria, esse caminho estava fechado em Opinião. Negava-se no jornal a possibilidade de conteúdo artístico à produção da indústria cultural. No fundo, um cineasta comercial não é considerado um verdadeiro artista no jornal. Trata-se de uma imposição no interior do campo do lugar da arte enquanto arte. O jornal procura deter o monopólio da legitimidade artística e se afastar da discussão sobre a luta pelas categorias legítimas de percepção no campo artístico. Daí a preferência pelo cinema que nada concede ao público, afinal sua força e seu prestígio derivam desse desinteresse e dessa denegação.

Se inexistiam formas de cinema feitas pelo povo, essa produção também não será pensada como possibilidade crítica e conscientizadora por si só. Já era um exercício deixar de ver o povo como código restrito e inferior. Desta ausência da produção do povo, a única possibilidade de acesso era a representação indireta feita pelo componente não-popular, seja a cultura de massa ou o cinema autoral. Nesses dois polos, o critério mudava radicalmente. 
Para a produção voltada ao consumo popular, os críticos oscilam entre a busca da invenção do povo ideal e um desprezo pela representação popular da indústria cultural. Ainda era mais comum pensar o crítico como vanguarda e dirigente do que como interlocução de igual para igual com o público. Lutava-se contra o espectador atrelar-se ao gosto estrangeiro por opção. No geral, tanto Jean-Claude Bernardet quanto Sérgio Augusto viam ou a pornochanchada ou a chanchada como imitação passiva do cinema estrangeiro. Uma exceção se encontra em Augusto quando ele elogiou a composição do malandro de Vai trabalhar vagabundo (1973) de Hugo Carvana ${ }^{11}$. Embora "esquemático", o estereótipo é "autêntico", porque compõe o tipo do "malandro real". Aqui, a cultura popular é ainda uma possibilidade de autenticidade.

Quando a produção é considerada cinema de gênero, o arsenal utilizado é o da análise de discurso. Ela se torna a principal ferramenta de trabalho para a ausência de autenticidade da cultura popular. Nestes casos, a cultura popular aparece como algo forjado, externo que revela parte do nacionalismo do jornal e do período. Com este mesmo ângulo de visão se vê a comédia erótica, alguns filmes históricos ${ }^{12} \mathrm{e}$ os filmes norte-americanos.

Algumas ausências são relevantes. Não há nenhuma linha sobre Mazzaroppi, talvez porque ele não representasse para o jornal um perigo na falsificação do nacional ou uma incorporação de padrões estrangeiros. O vazio indica uma falta de debate de Opinião para lidar com a preferência popular. A atitude não era somente de Opinião, mas da crítica de cinema em geral. Indo contra essa corrente, Paulo Emilio Salles Gomes comentou o silêncio da crítica ao comediante em 1973 no Jornal da Tarde. Fez também uma mea culpa sobre seu esquecimento (Calil, 1986). Os comentários de Paulo Emilio partiam não da obra em si, mas de uma metodologia pouco explicitada por Opinião: a observação sobre a recepção do público nas salas de cinema ${ }^{13}$.

A segunda ausência são os filmes dos Trapalhões, que estavam entre as maiores bilheterias brasileiras nos anos setenta. Neste caso, foi uma exceção bastante significativa, pois o cineasta marginal Carlos Frederico escreveu em Opinião que as

\footnotetext{
${ }_{11}^{11}$ Augusto, Sérgio. Saudades do carne frita. Opinião. n. 57, p. 23, 10 dez. 1973.

${ }^{12}$ Sobre os filmes históricos na imprensa alternativa, ver Adamatti, Margarida Maria. Crítica de cinema e política: o filme histórico nos jornais alternativos Opinião e Movimento. Revista Anos 90. v. 19, n. 36, p. 173-198, dez. 2012.Disponível em:< http://seer.ufrgs.br/anos90/article/view/30675>. Acesso em 05 jan. 2014.

${ }^{13}$ Alguns críticos estavam atentos à recepção do público, como Jean-Claude Bernardet e José Carlos Avellar, Aguinaldo Silva e Júlio César Montenegro.
} 
maiores bilheterias eram exatamente os Trapalhões e Mazzaroppi ${ }^{14}$. Foi quase a primeira entrada em cena da produção brasileira apreciada pelo público sem um viés negativo. Sérgio Augusto se esforçava para apreciar o entretenimento do cinema estrangeiro, mas gostava mesmo é do cinema autoral, como vimos. Foi preciso entrar na redação um crítico relacionado ao universo do Cinema Marginal para citar pela primeira vez Mazzaroppi e os Trapalhões. Se o gosto do público estava na gênese da maior parte das discussões sobre o cinema brasileiro, era muito difícil conhecer suas preferências no jornal. Talvez essa lacuna indique o mesmo caso de Mazzaropi: ambos não representam risco ao nacionalismo, nem uma incorporação da cultura estrangeira. Ao que tudo indica, eles são vistos num limbo entre cultura popular e a industrial, mas não se malha o público por sua preferência. Apenas o ignora.

Quando os críticos observam uma produção da indústria cultural, eles centramse no enredo e na análise do discurso político. Ora empregam o conceito de ornamento ou aplicam a sociologia das visões de mundo (ver Capítulo 2). Nos dois casos, o fator ideológico reside na análise das cenas. Assim alguns cineastas são tomados como representativos de uma classe social. A comparação é feita entre a estrutura da sociedade e as relações sociais presentes no filme. A produção é vista como reflexo distorcido da estrutura real. A condenação existe porque os filmes se apresentam como parte da cultura popular, como no caso da comédia erótica. Não se aceita sob hipótese alguma que a estrutura da pornochanchada possa ser igual em alguma medida à estrutura da sociedade. Afinal a comédia erótica é por síntese o polo da falta de autenticidade. Para os críticos era difícil aceitar uma possível preferência do público à comédia erótica ${ }^{15}$, atribuindo certos gostos a uma imposição da indústria cultural.

Se os críticos da grande imprensa tentavam vez por outra realçar algum aspecto positivo em separado das comédias eróticas, Opinião não tem nenhuma preocupação com o nível técnico ou com um possível viés autoral desta produção ${ }^{16}$. Há um ponto em comum com os críticos da grande imprensa: para todos eles a comédia erótica não tem nada de nacional, nem de genuína. A tese da incapacidade criativa de imitar de Paulo

\footnotetext{
${ }^{14}$ Frederico, Carlos. Um balanço da indústria cinematográfica. Opinião. n. 225, p. 24, 25 fev. 1977.

15 Jean-Claude Bernardet (Abreu, 2002) explicou que os críticos observavam atitudes moralistas e retrógradas na comédia erótica, mas o sentimento do público era totalmente outro; era de libertação. Ele percebeu isso ao acompanhar os filmes na exibição e em discussões com o público.

${ }^{16}$ Sobre a comédia erótica na imprensa alternativa, ver Adamatti, Margarida. "A comédia erótica na crítica de cinema dos jornais alternativos Opinião e Movimento". Revista Movimento. n.1, jun. 2012. Disponível em: <http://www.revistamovimento.net/edições-anteriores/primeira-edição-1>Acesso em 14 nov. 2014.
} 
Emilio (1978) sobre a chanchada não valia para a comédia erótica em Opinião, porque esta seria apenas uma cópia sem nenhum tipo de elaboração da cultura local.

A única exceção a essa regra foi o artigo de Jean-Claude Bernardet sobre Ainda agarro essa vizinha (1974) de Pedro Rovai, quando o crítico observou algo de real na estrutura brasileira retratada pelo cineasta ${ }^{17}$. Para Bernardet, o filme trazia situações reais vividas pelo público. Sem planificar o gênero, ele conseguiu ver algo de brasileiro na produção. Percebeu, inclusive, que a comédia erótica abria caminhos no contato com o público, diferente do viés de cultura decorativa de Os condenados (1973) de Zelito Vianna. O artigo levantou uma polêmica e causou indignação, encerrando o caso com a carta de Miguel Faria Júnior, produtor de Vianna ${ }^{18}$. Inicialmente Bernardet queria criar em Opinião um espaço de debate com o diretor de Os condenados e com Eduardo Escorel. Pela primeira (e única) vez em Opinião, afirmou-se a preferência por uma comédia erótica em face de uma produção de qualidade, considerada pelo autor como conservadora, vazia e sem apelo popular. Em carta a Paulo Emilio, Jean-Claude Bernardet comentou que houve grande repercussão do texto ${ }^{19}$. "O artigo estourou na redação, hoje de manhã recebi o apoio de todo mundo e estão me oferecendo guardacostas caso eu venha a sair de casa depois de publicado o artigo".

Em entrevista, Jean-Claude Bernardet lembra que a crítica dele sobre Ainda agarro essa vizinha causou muita repercussão no meio, mas repercussão negativa. "Sempre elogiei a cultura do povo (...). Eu me recuso a achar que a comédia erótica seja desprezível ou que não seja bom cinema. Não aceito isso." Bernardet esclareceu que quando defendeu o filme de Rovai tinha em mente duas coisas: os intelectuais não detêm a verdade da cultura e não se pode rejeitar o cinema de público. Se a cultura da elite pode fazer coisas ótimas e maravilhosas, ela não pode se considerar a "única cultura verdadeira". A questão não era o filme de Vianna em si, mas a postura em relação à política cultural. Se Os condenados fosse somente um filme ruim, não haveria motivo para comentar. Mas a produção abria a possibilidade de abordar questões de política cultural e esse viés dava muito certo no jornal.

\footnotetext{
${ }^{17}$ A pornochanchada contra a cultura culta. Opinião. n. 99, p. 23, 27 set. 1974.

${ }^{18}$ Cultura culta vs. pornochanchada. Opinião dos leitores. Opinião. n. 101, p. 24, 11 out. 1974.

${ }^{19}$ Pasta PE/CP 1406 a 1420 - Carta de Jean-Claude Bernardet. Rio de Janeiro. 24 set. 1974. Cinemateca Brasileira. Arquivo Paulo Emilio Salles Gomes - Centro de Documentação e Pesquisa da Cinemateca Brasileira.
} 
Através das anotações manuscritas de Bernardet, é possível observar o quanto os textos dele repercutiam no meio cinematográfico ${ }^{20}$. Ele recebeu uma quantidade considerável de telefonemas por causa do artigo sobre Ainda agarro essa vizinha. É possível perceber que o contato do crítico com os diretores era intenso. Os cineastas ligavam tanto para elogiar, quanto para criticar. Bernardet exercia com todas as letras a crítica participativa no seu dia a dia. Foi Ana Carolina quem telefonou para passar a ligação a Miguel Farias, produtor de Os condenados. Arthur Omar entrou em contato para apoiar inteiramente o artigo e usou palavras elogiosas, referindo-se à crítica independente. Ele teria comentado o texto com amigos que também se manifestaram favoravelmente. Oswaldo Caldeira ligou para discordar, mesmo sem ter visto Ainda agarro essa vizinha. Afinal, Pedro Rovai representa a direita e a CIC (Cinema International Corporation), que quer usufruir da lei de proteção dada ao cinema brasileiro. Para Caldeira, o artigo radicalizou muito, mas ele achou "boba" as declarações de Ana Cristina. Ela teria indisposto todo o Rio de Janeiro com suas declarações. Enquanto isso, Geraldo Sarno ficou "totalmente contra" o artigo, porque é "texto que divide". A postura dele é bem frentista. Para Sarno, o texto levava as pessoas a se estranharem, "afinal a questão é ocupar as telas" e a crítica de Bernardet poderia atrapalhar esses objetivos. Porém, o documentarista não se opôs à proposta de Bernardet de discutir a posição nacional popular, quando se falava em ocupar as telas. Observa-se nesses depoimentos o grande poder dado à crítica de cinema para atrapalhar a Frente de Oposição ao regime. Pode-se imaginar também o clima tenso, caso um crítico decidisse enfrentar os cânones do nacional popular do período ou tivesse uma opinião diferente da maioria dentro da Frente de oposição.

Fazer crítica participativa para Jean-Claude Bernardet era parte de seu trabalho diário. Significava não só um grande envolvimento com o sucesso do cinema brasileiro, mas também uma crítica que luta pelos filmes. No lançamento de Triste Trópico (1974), o exibidor prometeu a Arthur Omar uma semana a mais se a sessão da meia noite lotasse. Jean-Claude Bernardet decidiu ajudar e publicou um texto em Opinião com o pseudônimo de Carlos Murao. O texto era didático e dava sentido à dissonância entre

\footnotetext{
20 "Repercussão ao artigo a forma da chanchada vs. a cultura culta em Opinião". Cadernos de Anotações Manuscritos de Jean-Claude Bernardet. AJCB Pasta PI - 8 p. Caderno V. Arquivo Jean-Claude Bernardet. Centro de Documentação e Pesquisa da Cinemateca Brasileira. 30 set. 1974.
} 
som e imagem ${ }^{21}$. A sessão lotou e Omar conseguiu uma semana a mais de exibição, afinal Opinião era muito lido e tinha um peso grande com os intelectuais e com os universitários.

Se a cultura popular tem uma autenticidade que é negada à cultura de massa, algumas produções autorais escapam à regra, mesmo feitas para o povo. Nestes casos, grande parte dos artigos trata do cinema de perspectiva popular, geralmente pelas mãos de Jean-Claude Bernardet. Nestes casos o critério autoral ressurge indiretamente, não como algo negativo ou como ornamento. Este é o caso dos cinemanovistas que analisam a estrutura da sociedade, como vimos. São os filmes que unem as solicitações estéticas e políticas numa coincidência com a estrutura real da sociedade. Não se trata de cópia do real, mas de reelaboração factível da realidade. Nestes casos, o conceito de estrutura confere um tipo de autenticidade distante do sentido de apreensão simples do real, mas de construção da sociedade brasileira com todas suas contradições. No caso dos cineastas-autores, o debate sobre a cultura popular não parte de condenações diretas. Os artigos tentam averiguar se existe uma similitude entre o discurso do filme e a transformação da realidade brasileira. Muitas vezes os textos realçam mais o quanto a obra diz respeito à sociedade e diminuem o peso da análise interna. No fundo, há alguma busca de autenticidade da cultura popular, mesmo que em cada exame de caso ela não apareça. Nunca se admite no jornal que a produção do Cinema Novo seja de filmes feitos para o povo, porque com tal constatação o debate teria de ser feito em outros termos, como representação. O elogio parte do esforço de unir a autoria e o interesse social. Ele cabe aos cineastas que abdicam de sua visão de mundo para tentar incorporar a das classes populares. Esse conceito foi definido ainda no livro Brasil em Tempo de Cinema. Bernardet procurava por grandes obras, cujo valor estético é determinado na tensão superada entre a extrema unidade e a extrema riqueza, entre a coerência da estrutura e a multiplicidade do universo imaginário. Por exemplo, os elogios a São Bernardo (1972) de Leon Hirzsman referem-se a esta capacidade de relacionar as homologias e as estruturas. Em síntese, a forma do filme consegue captar a estrutura da sociedade e a coisificação do homem. Pouco importa neste caso que Leon Hirzsman seja da classe média, porque ele optou pelo ponto de vista das classes populares. É nesses casos que se abandona a comparação entre a classe social e a visão de mundo aplicada a Arnaldo Jabor e a Cacá Diegues. Os cineastas preferidos reúnem a

\footnotetext{
${ }^{21}$ Murao, Carlos. Uma cultura feita de cacos. Opinião. n. 111, p. 21, 20 dez. 1974.
} 
estética apurada, o apelo ao público e o engajamento pelo cinema brasileiro. São basicamente três: Nelson Pereira dos Santos, Leon Hirzsman e Joaquim Pedro de Andrade. Todos eles respondem às indagações de Brasil em Tempo de Cinema: o encontro entre um cinema de base estética e de apelo popular. Mesmo se Nelson Pereira dos Santos declarasse trazer a cultura popular em sua forma pura, ele não seria questionado porque não se vê Amuleto como reflexo da classe que o produziu. Era nesses casos que se procurava o popular: como tentativa de aumentar a audiência, comunicar-se com as massas e como fonte de inspiração artística. 


\subsection{Nelson Pereira dos Santos em "Amuleto de Ogum é a gente na tela"}

Em 1975, Nelson Pereira dos Santos lançava O Amuleto de Ogum (1974) e a crítica de cinema comentava com entusiasmo uma alteração no panorama cultural em direção a um cinema verdadeiramente popular. Amuleto é um divisor de águas em Opinião. Trata-se do filme brasileiro mais comentado no jornal; o único a receber seis artigos. Depois dele, nenhuma obra nacional obtém uma cobertura tão extensa. A análise interna dos artigos e a comparação com a crítica de época revelam o diálogo de Opinião com os pensamentos da esquerda sobre a cultura popular.

O tópico é dividido em duas partes. Na primeira, analisamos o Manifesto por um cinema popular (1975) e o release do filme como possibilidade de acesso ao discurso do diretor. Ambos documentos deram origem ao debate da crítica de cinema. Na sequência, a recepção de Amuleto na imprensa revela o diferencial crítico de Opinião sobre a cultura popular. O percurso permite observar as apropriações dos críticos sobre o discurso de Nelson Pereira dos Santos e o quanto eles se aproximaram ou distanciaram do conceito de cultura popular apresentado pelo diretor. Centramos nossa atenção no discurso de Nelson Pereira aos críticos, deixando de lado suas intenções enquanto cineasta e a proposta estética de Amuleto, que também está na raiz do interesse dos críticos.

O filme se inscreve num período no qual os cinemanovistas reveem a postura dos anos sessenta de ver a cultura popular como forma de alienação. Respondendo a esse debate, Nelson Pereira dos Santos tomou o mito do corpo fechado do deputado pistoleiro Tenório Cavalcanti ${ }^{22}$ para debater a cultura popular e a umbanda. Um dos objetivos era a aproximação com o público popular, quando esse tema parecia um impasse para estes cineastas. Nelson Pereira falava em captar a cultura popular sem preconceitos através da postura neutra do cineasta. A história era policial e retirada do livro do ex. motorista de Tenório, Francisco Santos. Na trama, Gabriel tem a proteção de Ogum contra balas e contra a morte, mas atrai a ira do chefe quando se envolve com sua amante.

\footnotetext{
${ }^{22}$ Sérgio Rezende fez O homem da capa preta (1986) sobre Tenório Cavalcanti.
} 
O lançamento de Amuleto em fevereiro de 1975 é acompanhado do release do filme e do Manifesto por um cinema popular ${ }^{23}$ (Stam, Johnson, 1982). A autoria do Manifesto cabe ao Cineclube Macunaíma, ao Cineclube Glauber Rocha e à Federação dos Cineclubes do Rio de Janeiro. Se a autoria não é de Nelson Pereira dos Santos, esse distanciamento lhe confere maior legitimidade e credibilidade. Afinal, os elogios são escritos na terceira pessoa, sem soar como propaganda ou release ${ }^{24}$. O Manifesto por um Cinema Popular é composto de entrevistas exclusivas com Nelson Pereira dos Santos e de três artigos: uma notícia-entrevista de Marcelo Beraba, publicada no jornal $O$ Globo, a entrevista-crítica de Jean-Claude Bernardet em Opinião e um ensaio exclusivo do mesmo autor. A análise desse material será feita ao longo desse tópico.

Tanto o Manifesto quanto as declarações do diretor são os responsáveis pela criação da ideia de uma virada no contexto cinematográfico. Logo na apresentação, o Manifesto afirma que Amuleto faz parte do "Novo Cinema Novo":

\begin{abstract}
“em 1955, Nelson Pereira dos Santos subia as favelas do Rio de Janeiro e antecipava o Cinema Novo com 'Rio 40 graus'. Agora, em 1975, 'O Amuleto de Ogum' é saudado como um novo Cinema Novo: um momento capaz de operar em nossa criação cinematográfica uma transformação tão importante quanto a que, sob influência de Nelson, marcou o fim dos anos 50 e toda a criação de 60. Estes vinte anos constituem a trajetória lúcida de um artista coerente e voltado para a busca de uma cultura verdadeiramente brasileira."
\end{abstract}

A divulgação do filme previa a integração do conceito de cultura popular até no release $^{25}$, apresentado pela Embrafilme. Neste espaço Nelson Pereira dos Santos

\footnotetext{
${ }^{23}$ O Manifesto é de 1975 e está disponível no acervo da Cinemateca Brasileira. Fol 145. Ele antecede a estreia do filme, por isso deve ter sido publicado antes de fevereiro daquele ano.

${ }^{24}$ Pierre Bourdieu explica que o poder de auto-celebração tem um efeito muito curto. O reconhecimento da legitimidade é mais completo quanto mais longo for o ciclo da consagração. A auto-celebração produz um rendimento de consagração muito fraco para um dispêndio de energia social igualmente fraco. "A legitimação só pode ser operada por procuração." (Bourdieu, 2001: 170). Assim o primeiro interessado é o menos indicado para a auto-celebração porque ele ganha com o interesse da celebração. O rendimento simbólico é maior, quanto menos aparente é a relação entre os parceiros. Por isso os elogios ao filme pesam mais se não houver relação entre Nelson Pereira dos Santos e o Cineclube. Pesam mais ainda se escritos por críticos renomados, como Jean-Claude Bernardet.

${ }^{25} \mathrm{O}$ release pode ser encontrado na Cinemateca Brasileira. Localização: D 560.
} 
fabrica a ideia de um filme ao mesmo tempo "popular comercial", tentando esconder as contradições a respeito da junção entre os dois momentos:

"é um filme popular, o que não quer dizer que não seja um filme comercial. A diferença entre os dois é que o popular não se preocupa com a oferta e a procura; tenta, principalmente, traduzir uma visão do povo, da realidade que o cerca. Meu filme não tem sociologia, não critica os personagens, não toma partido de ninguém. Para mim é como se fosse o primeiro filme".

A mesma ideia de Nelson Pereira dos Santos aparece sob a forma de poesia no release:

“(...) Nunca um filme esteve tão perto da verde! [?sic verdade]

Os deuses, a vida, corpo fechado, a morte.

O povo, o canto, o drama.

A traição, a fé, a gente.

Um canto de amor à crença do povo.

Inteiramente filmado em Caxias, com todo o respeito à umbanda e à crença do povo. A história de um homem com o corpo fechado.

'O amuleto de Ogum é a gente na tela.

O único filme lançado primeiro em Caxias".

Obviamente por causa dos objetivos propagandísticos, o release não problematiza a união de um cinema comercial e popular. $\mathrm{O}$ material procura criar uma identificação com o povo, ao frisar que o filme será lançado primeiro em Caxias, conhecido como um reduto popular no Rio de Janeiro. Segundo o diretor, o cinema comercial está interessado em bilheteria, enquanto o cinema popular se preocupa somente com o público. A diferença entre povo e público sequer é estabelecida. Além disso, o cineasta explica que o cinema popular traduz a visão do povo. Trata-se de uma visão de complementariedade idealizada do popular. O emprego do verbo traduzir oculta a ideia de representação. O que se tenta é forjar uma transmissão da cultura popular sem a intervenção do diretor, a partir da frase: "Meu filme não tem sociologia, não critica os personagens, não toma partido de ninguém”. Essa frase será reproduzida em mais de uma crítica na imprensa. O verbo esconde também a ação do realizador pela ideia de intermediação "neutra" e sem partido.

Segundo Robert Stam e Randall Johnson (1982), o Manifesto define a cultura popular como expressão espontânea de uma vasta maioria marginalizada da população brasileira. O filme tenta adotar a perspectiva popular, sugerindo que a visão do povo 
está sempre certa. Por outro lado, a celebração sem problematização da cultura popular é carregada de ambiguidades, realçam os autores, mas sem explicar como.

Ismail Xavier (Xavier et al., 1985) vê o manifesto como uma revisão do papel do cineasta face às representações populares. Cabe ao realizador ser um "mediador", abrindo espaço para a expressão de valores populares. Convém a ele respeitar as referências culturais, sem intenção crítica. Trata-se de dar-lhes expressão, não falar sobre elas. Xavier analisa como o período caracteriza-se por uma postura geral de "levantar a poeira", num desejo maior de empirismo.

Nelson Pereira dos Santos e Alex Viany já se interessavam pelo tema do cinema popular desde os anos cinquenta, quando defendiam um cinema conforme os interesses do povo, sem mistificação. A proposta de Nelson Pereira de apresentar um conteúdo popular e uma temática nacional para conquistar o público dos anos cinquenta é a mesma de Amuleto ${ }^{26}$. Ao longo dos anos sessenta, houve uma revalorização e reconciliação de alguns cineastas com os códigos de cultura popular, como o futebol, o carnaval, etc. Inserido nesse contexto de discussão, no lançamento de Amuleto, Nelson Pereira apresenta a umbanda como algo positivo. Contudo, quando o cineasta fala em "traduzir" a cultura popular de "forma autêntica", ele recorre à ideia de neutralidade do realizador, sintonizado com os debates do período. Naquele período, os artistas e intelectuais de esquerda solidarizam-se com as classes cujos interesses eles imaginavam representar os interesses (Ridenti, 2000). Nesse movimento, o grupo aparece como porta-voz ou substituto do povo, voluntária ou involuntariamente, porque a população não se faz representar na esfera social e política. É assim que setores da intelligentsia tornam-se tradutores das demandas sociais. Por causa das críticas ao intelectual que tem a pretensão de conscientizar sobre as condições de vida do povo, Nelson Pereira dos Santos define-se somente como um mediador da cultura popular.

\footnotetext{
${ }^{26}$ Nos anos cinquenta, tanto no I Congresso Paulista do Cinema Brasileiro em 1952, quanto na Revista Fundamentos, Nelson Pereira dos Santos defende o conteúdo popular e a temática nacional dos filmes brasileiros, ante o artificialismo da Vera Cruz. Já naquele período, ele estabelece uma ligação entre sucesso comercial, a conquista de mercado e o caráter popular dos filmes, tal como será restabelecido no lançamento de Amuleto. Segundo ele, para atingir o público e conquistar o mercado é preciso ter conteúdo nacional e popular. Retomando esse mesmo conceito, Nelson Pereira irá manter seu discurso e sua preocupação com um cinema de conteúdo popular, presente desde Rio 40 graus (1955). Ver Bernardet; Galvão (1983).
} 
Se o filme suscita uma polêmica na imprensa, não é só pelo tema do corpo fechado e da umbanda, tratados em viés policial. Os críticos observam uma mudança na forma como Nelson Pereira dos Santos apresenta a temática popular. O diretor não fala mais em nome do povo, mas permite ao povo aparecer na tela, retratado sem preconceitos em relação a suas crenças. Amuleto estaria muito longe do olhar cinemanovista dos anos sessenta, que via de maneira geral a cultura popular e as manifestações religiosas africanas como forma de alienação e atraso. Numa atitude de respeito à umbanda, Nelson Pereira declara que queria dar voz ao povo, trazendo a cultura popular sem intervenção crítica. Enfim, um prato cheio aos críticos. Ele promete lançar o filme primeiro no circuito popular, gerando uma expectativa muito grande de encontro com esse público. De qualquer forma, Amuleto não passa despercebido e os críticos devotam a ele um largo espaço.

Segundo Ortiz Ramos (Ramos, 1987), O Amuleto de Ogum abriu importantes discussões. O lançamento foi cercado de críticas e adesões, oscilando das acusações ao cineasta por incorporar acriticamente o universo da religião popular às louvações que viam surgir nele uma nova era no cinema brasileiro, longe do "sociologismo" do então Cinema Novo. As adesões tomaram maior volume e em tom mais alto, respondendo ao apelo de uma aproximação mais direta com a cultura popular. Ortiz Ramos não cita nominalmente os responsáveis pela "adesão" e pela acusação. Mesmo que o Manifesto por um cinema popular não tenha conseguido uma adesão total de todos os cronistas aos seus objetivos, ele conseguiu pautar os críticos no debate sobre a existência ou não de um cinema popular em Amuleto, como veremos a seguir.

\section{A hora da virada e a adesão global de Marcelo Beraba}

A polêmica na imprensa nasceu na entrevista de Nelson Pereira dos Santos ao jornalista Marcelo Beraba do jornal $O$ Globo ${ }^{27}$. Neste artigo constrói-se uma esperança de virada na produção brasileira, dando espaço para o cineasta narrar o quanto seu novo filme ia contra toda a trajetória preconceituosa até então feita à cultura popular. Além de jornalista do Globo, Beraba organizou o Manifesto por um cinema popular, onde esta mesma entrevista-artigo é reproduzida.

\footnotetext{
${ }^{27}$ Santos, N. P. A hora da virada. Entrevista concedida a Marcelo Beraba. O Globo. 29 jan. 1975.
} 
A entrevista do Globo foi convertida numa narrativa de Nelson Pereira dos Santos ao público. Este processo quase anula os espaços entre as declarações do cineasta e a do crítico, porque as informações não são questionadas. Em raros momentos, como o que vemos abaixo, Beraba utiliza a terceira pessoa para distanciar-se minimamente do texto:

“Em 'Rio 40 graus' ele já subiu os morros levado pela necessidade de um contato direto com a realidade marginal. A diferença de 'Rio, 40 graus' para 'O amuleto' está, segundo ele, num distanciamento sociológico que havia no primeiro, substituído agora por uma total identificação com a realidade cultural que filmou.

(...) A ideia era filmar junto com a prática religiosa. Não era o caso de usar figurantes para fazer de conta que estávamos numa sessão de Iemanjá. Era realmente a noite de Iemanjá e filmamos a festa, durante a cerimônia."

Aqui a narrativa cumpre a função de possibilitar um acesso mais vivo aos fatos. Ao utilizar a terceira pessoa, Beraba se distancia um pouco das declarações do diretor. Nos demais momentos, o artigo transmite declarações do cineasta sem separar seu discurso como jornalista, depois de abrir aspas como esta. Ele não escreve uma introdução para se separar da fala do entrevistado. Apenas reproduz suas ideias. O texto apresenta-se como uma narração de fatos, que "realmente" ocorreram. O mesmo é feito para a cultura popular. Ela é "espontânea", "natural", "reprimida", mas precisamos começar a vivê-la.

Na sequência, o artigo constrói o mito de uma grande virada, anunciada já na manchete e no subtítulo do artigo:

\footnotetext{
"O que acontece hoje com o cinema brasileiro acontece com toda a cultura brasileira. Está chegando o momento de uma virada. Na periferia das grandes cidades se formou um imenso público, que os Ibopes da vida identificam como classe $\mathrm{C}$ e $\mathrm{D}$, carentes de produção cultural. É o maior público, o mais necessitado e em relação a outros públicos, ainda não foi colonizado. O consumo dele ainda é a própria realidade".
}

Na sequência, uma afirmação de Nelson Pereira dos Santos chama a atenção nesta entrevista para o papel que o realizador ainda conferia a si mesmo como gerador de consciência do povo. Esse dado contradiz a informação anterior: 


\begin{abstract}
“A correção do povo - Com o crescimento urbano, não há mais desculpa para que os agentes culturais permaneçam marginalizados dentro do Brasil, vítimas acomodadas, incapazes de se realizarem. A gente fica querendo explicar as coisas e o problema é bem mais simples, embora exija um trabalho altamente violento: deixar de ser intelectual um pouco, e se esforçar para não manter essa repressão violenta que existe em cima do povo e em cima da gente também. (...) Em sua função social, o cinema pode ter um papel importante na liberação do comportamento humano, na medida em que através do filme reconheça a legitimidade desse comportamento."
\end{abstract}

É interessante observar como Nelson Pereira não aborda diretamente a função do intelectual de gerar a consciência crítica do povo. Mas isso permanece mitigado, em frases como a de gerar a "liberação do público" ou ver o povo como "vítima acomodada”. Ele seguia a onda dos cinemanovistas daquele momento que só falavam em "liberar" o público ao invés de "libertar" (Ver Capítulo 5). No fundo cabe ao intelectual gerar a "correção do povo", como frisa o subtópico. Corrigir o povo é bem diferente de traduzir a cultura popular, como foi dito antes. O verbo utilizado no subtópico foi um lapso de Beraba ou só uma forma para trazer o discurso do diretor? Se foi um lapso ou se foi intencional, foi o único do texto.

\title{
Amuleto como folclore - a condenação de Pola Vartuck
}

Ortiz Ramos não cita nominalmente os responsáveis pela “adesão" e pela acusação. Realizamos uma pesquisa das críticas de época e encontramos apenas um comentário que condena em parte a ligação que o filme estabelece com a religião. Pola Vartuck ${ }^{28}$ no jornal $O$ Estado de S.Paulo reprova Amuleto por tratar a religião ainda em termos folclóricos:

“Mas se 'O Amuleto' pode representar uma abertura tão importante para os novos
caminhos do cinema brasileiro, quanto o foi o primeiro longa metragem de Nelson
Pereira dos Santos, ainda vai uma grande distância entre as posições teóricas do cineasta
e a sua implicação prática. Pois 'O Amuleto', embora procure identificar-se com os
mitos populares, e embora evite explorar o lado puramente exótico ou coreográfico dos
ritos umbandistas, ainda se reveste de um inegável folclorismo. É verdade, como diz
Nelson, que o filme não critica os personagens e aceita como fatos reais as crenças por
eles professadas. (...). Mas teria o cineasta realmente captado o espírito da umbanda e os
seus preceitos morais (....)? Poderia um homem que teve o seu corpo fechado contra o
mal, segundo os ritos da umbanda, empregar-se como pistoleiro de um bandido como

${ }^{28}$ Uma visão folclórica dos mitos populares. O Estado de S.Paulo. 26 abr. 1975. 
dr. Severiano (Jofre Soares) e sair matando a torto e a direito sem perder a proteção de S. Jorge, Ogum?"

Depois de tecer esses comentários, a cronista defende que Nelson Pereira dos Santos deixou de ser "intelectual um pouco":

"o fato é que ao situar no mesmo plano de marginalidade a violência e o banditismo, a migração nordestina para os grandes centros urbanos e os elementos da umbanda, Nelson Pereira dos Santos ainda se vê involuntariamente traído por sua visão crítica e sociológica, que o impede de uma identificação total com a cultura popular."

Embora Pola procure a veracidade histórica num filme sobre mito ${ }^{29}$, ela consegue ver em Amuleto uma tentativa de se identificar com alguns desses mitos populares. Observa sem incorporar que a "visão sociológica" impede o cineasta de um contato mais íntimo com a realidade.

Os demais artigos encontrados sobre Amuleto o tratam com elogios, o que varia é o grau de adesão ou distanciamento do crítico em relação ao discurso de Nelson Pereira dos Santos. É sobre essa variação que gostaríamos de estabelecer uma comparação para analisar mais à frente como Opinião se coloca.

\section{Os personagens a Plenos Pulmões e o Recomeço do Cinema Novo por Ely Azeredo}

Na pré-estreia de Amuleto, Ely Azeredo usa a frase símbolo de Nelson Pereira dos Santos sobre seu filme não ter sociologia na abertura do texto ${ }^{30}$ para o JB. A diferença é que ele procura se separar da afirmação, creditando-a ao diretor. De qualquer forma, Azeredo não condena a declaração, provavelmente porque não teve contato com a obra. Desloca o texto para o cunho informativo e cita os elogios de

\footnotetext{
${ }^{29}$ Bernardet faz uma série de entrevistas com os umbandistas e eles também se concentram na veracidade das cenas. A maior parte deles só frisa o aspecto negativo do filme por causa da falta de veracidade das sequências e por revelar os segredos da umbanda. O principal ponto de atrito é a proteção contra balas do corpo fechado. Os umbandistas explicam que a proteção é contra as almas. Para eles, a visão do filme é totalmente fantasiosa e revela uma imagem negativa da religião para os não-iniciados. Bernardet, JeanClaude. Os babalaôs resistem aos sociólogos. Opinião. n. 121, p. 24, 28 fev. 1975.

${ }^{30}$ Azeredo, Ely. O Amuleto de Ogum. O corpo fechado no fundo do mar. Jornal do Brasil. Caderno B. 16 fev. 1975, p. 31 .
} 
terceiros. Dias depois, o distanciamento foi maior ${ }^{31}$. O cronista aproveita a chance para falar mal do seu desafeto: o Cinema Novo com sua atitude de "armação" e "leitura de tese". Segundo ele, a vertente "revolucionária" do Cinema Novo está cheia de "frustrações" e descaminhos. Apesar da crítica negativa, Azeredo não deixa passar em branco que Amuleto na verdade é a retomada do espírito do Cinema Novo:

"Ao contrário de tantos outros filmes do Cinema Novo, este não é uma 'armação' do autor-diretor contra os personagens, nem uma contestação formal, nem uma leitura de tese. Ausente a ideologia, os personagens respiram a plenos pulmões (...). Depois de tantos anos, Nelson nos dá um filme realmente livre. Sem dúvida não livre de preocupações: ao cineasta como indivíduo, com sua ideologia e com os espectadores. (...)".

Reatando com o mais autêntico de suas origens populares e propondo uma prospecção não-sectária da realidade brasileira, Nelson não pratica nenhuma heresia: sugere como capitalização da experiência dos anos 60 e 70 a retomada do legítimo espírito popular que estava à raiz da proposta inicial do Cinema Novo".

Se o artigo flerta com a possibilidade de Amuleto indicar um "recomeço" do Cinema Novo porque o filme não é uma "armação de tese", Azeredo não cai no discurso do cineasta. Mesmo uma obra de "características sem precedentes" como esta "pode não representar muita coisa" por causa da fragilidade econômica da produção brasileira. A postura em relação a Nelson Pereira dos Santos é paradoxal, cheia de elogios e ressalvas, mas Azeredo não incorpora a possibilidade de mudança no panorama brasileiro por causa de um único filme.

\section{A análise das cenas por José Carlos Avellar}

Nesta mesma página, José Carlos Avellar publica um artigo no Jornal do Brasil ${ }^{32}$ que seria uma primeira versão ou a base de sua análise de Amuleto, publicada no livro O cinema dilacerado (1986). Trata-se do único crítico que realiza uma análise das cenas do filme. Enquanto os demais articulistas pensaram a obra e sua significação no contexto do cinema brasileiro e de sua relação com o Cinema Novo, Avellar prova com exemplos as sínteses feitas pelos colegas.

\footnotetext{
${ }^{31}$ Azeredo, Ely. Como se fosse o primeiro filme. Jornal do Brasil. Caderno B. 19 fev. 1975, p. 31. O artigo está publicado também na coletânea de críticas de Ely Azeredo (2009: 173-5) com algumas alterações.

${ }^{32}$ Avellar, José Carlos. O bandido Severiano. Jornal do Brasil. Caderno B. 19 fev. 1975. P. 31.
} 
Avellar deixa literalmente de lado as declarações do diretor e os elogios à temática popular e faz a melhor análise publicada sobre Amuleto, não sobre seu entorno. Através da citação das cenas, ele revela o desinteresse de Nelson Pereira dos Santos por destrinchar a visão de mundo da umbanda como um sociólogo. O diretor está interessado em servir-se de sua poética como uma sugestão para a estrutura narrativa cinematográfica. A construção da umbanda não é estereotipada, e Severiano não é mostrado como vilão, fugindo do gênero policial. Da religião não se tenta tirar uma beleza coreografada nem material para uma reportagem. Amuleto é "meio solto e espontâneo" e se parece com um espetáculo cinematográfico "tal como nós estamos habituados a ver", mas às vezes é todo diferente. "E talvez exatamente por isto consiga documentar com perfeição as relações entre as pessoas comuns e a superestrutura social em que todos nos encontramos".

O ápice dessa postura espontânea e solta é a cena do almoço na casa de Eneida. A sequência lembra a apresentação do cego no prólogo: parece uma "história verdadeira que acabei de inventar agora", como diz o personagem-condutor da trama. A estratégia da cena não é de simples autenticidade, mas de improvisação na hora da filmagem, alcançada porque as pessoas não são dirigidas como atores. Graças à imprecisão da fala dos personagens e à presença de pessoas nos cantos da imagem se atinge uma atmosfera natural:

"Uma das sequências mais bonitas de $O$ Amuleto de Ogum é a visita de Eneida - ela e Gabriel - à família, num subúrbio de São Paulo. Dos abraços do irmão e dos pais à porta da casa ao almoço e o forró que se segue, a câmera muda a todo instante de ponto-de-vista para documentar um simples almoço de família, onde nada de excepcional acontece além da alegria de rever um parente há algum tempo distante.

Muitas vezes o cinema já usou uma situação semelhante para servir de apoio a uma ação dramática, para dar maior autenticidade, para facilitar o trabalho do ator, para aumentar o interesse visual da cena. (...)

Para sentir a diferença entre o almoço de Eneida com a família e as muitas cenas de apoio encontradas noutros filmes não é preciso muito esforço. É preciso apenas trazer à memória a ligeireza com que os atores tocam no prato, ou a nenhuma importância da comida na situação, ainda que ela possa ter sido destacada pela composição da imagem. Em geral as coisas importantes acontecem antes do almoço começar, ou na hora da sobremesa.

$\mathrm{E}$ as pessoas se comportam espontaneamente provavelmente porque não são atores, mas muito certamente porque não estão agindo como atores, nem dirigidos como atores. Não repetem os gestos convencionais. Quando um grupo de curiosos aparece na janela para ver a festa depois do almoço, trata-se seguramente de vizinhos que atraídos pela música (e pela filmagem) vieram até a janela ver de que se tratava. Uma reação natural, incorporada ao filme. (...)

A visita de Eneida e Gabriel a São Paulo (...) é certamente o momento onde se revela melhor e mais abertamente o objetivo de O Amuleto de Ogum." 
O tema é aprofundado por Avelar no livro Cinema Dilacerado. Segundo ele, a busca por um cinema popular no período não era a aceitação dos filmes pelo público, mas um desejo simples de usar as formas, cores e gestos da paisagem real como indicadores do modo de filmar. O objetivo seria discutir como as pessoas reelaboram as informações do sistema.

A ideia deste trecho contém a mesma proposta de cultura popular como estratégia de resistência contra o regime autoritário, analisada por Marilena Chauí (1986) ${ }^{33}$. Essa definição precisa e poética de cinema popular só foi utilizada por Avellar na crítica de cinema, mas esta conclusão em especial foi escrita muito tempo depois do lançamento de Amuleto, já nos anos oitenta, depois da reelaboração do conceito de cultura popular.

\section{A entrevista como desconstrução do discurso de Amuleto em Opinião}

Durante os anos de 1972-75, Opinião observou o surgimento de filmes de veteranos do Cinema Novo. Vislumbrou semelhanças e consensos entre eles, o que abriu uma dúvida se o Cinema Novo realmente tinha morrido (Ver Capítulo 5). O amplo espaço dado a Amuleto de Ogum é parte desse processo. É parte também da discussão sobre a possibilidade do filme representar uma mudança na postura dos cinemanovistas. Eles abandonariam uma visão intelectualizada do povo, para trazer às telas a "cultura popular" sem preconceito em relação a seus mitos e crenças.

O filme ganha a capa do jornal, com a manchete: Nasce um Novo Cinema Novo? A crítica de Jean-Claude Bernardet é acompanhada de uma entrevista com Nelson Pereira dos Santos ${ }^{34}$. Um ano antes da publicação dessa matéria, Nelson Pereira dos Santos tinha participado de uma comissão do Ministério da Educação e Cultura (MEC)

\footnotetext{
${ }^{33}$ Quando Avellar tematiza a cultura popular como forma de resistência, ele compartilha das ideias do período de questionar os conceitos mais tradicionais de cultura popular, especialmente os perpetuados pelo Estado autoritário. A concepção conservadora de cultura popular atrelava a produção cultural do povo ao atraso ou a um saber tradicional das classes subalternas. O popular teria uma autenticidade oposta à transformação da sociedade, conceito apropriado pela Política Nacional de Cultura de 1975, na ideia de preservação do patrimônio. No período de transição democrática, Chauí (1986) observava o conceito de cultura popular como uma estratégia de resistência dos dominados.

${ }^{34}$ Santos, Nelson Pereira. "Caxias para mim, é a capital cultural do Brasil. Entrevista concedida a JeanClaude Bernardet. Opinião. n. 119, p. 19-21, 14 fev. 1975.
} 
para reformular os órgãos de cinema ${ }^{35}$. Primeiro analisamos a entrevista, depois a crítica. A forma mais utilizada de abordagem ao Cinema Novo em Opinião é através das entrevistas, que possibilitam o contato com o discurso do diretor e a transmissão de mensagens através do gênero informativo, num jornal censurado. Além disso, as entrevistas têm uma peculiaridade em Opinião. Elas apresentam uma introdução que cumpre a função de uma crítica de cinema.

O gênero informativo na entrevista permite um afastamento em direção às declarações dos diretores. O texto não incorpora as explicações do cineasta. Vê-se claramente que Nelson Pereira dos Santos tenta forjar um mito de criação de um novo cinema, se colocando no papel de pioneiro. É dessa tentativa que Jean-Claude Bernardet tenta se distanciar criticamente logo nas primeiras linhas do artigo:

\begin{abstract}
"Segundo Nelson Pereira dos Santos, seu último filme $O$ amuleto de Ogum, é mais do que um filme: ele faz parte de um projeto global que definiria uma nova posição cinematográfica no Brasil. Um cinema popular, mas diferente das atuais chanchadas eróticas, parece ser a meta de alguns cineastas ligados ao chamado Cinema Novo e tradicionalmente identificados com filmes, por assim dizer, intelectuais e de pouco apelo popular.

Com $O$ amuleto de Ogum, depreende-se das palavras do cineasta, estaria começando uma nova fase para um setor importante do cinema nacional. Mergulhando um pouco mais fundo na realidade nacional, na cultura popular, os nossos autores cinematográficos deixariam de lado uma posição tão autoral e partiriam para uma 'observação mais aberta, menos facciosa' da vida do país. Sem abandonar uma visão crítica, mas esquecendo em parte os seus esquemas sociológicos, eles se colocariam uma tarefa básica e prioritária: conseguir um público brasileiro permanente para o cinema nacional".
\end{abstract}

Nesses trechos, o uso do jornalismo informativo permite um afastamento em relação ao discurso do diretor. Bernardet realça indiretamente que se trata das opiniões do diretor através das frases: como "segundo Nelson Pereira dos Santos", "depreende-se das palavras do cineasta". O recurso da introdução da entrevista proporciona uma distância entre os discursos, diferente da estratégia de Beraba. A proposta de Nelson Pereira dos Santos pressupõe que Amuleto seria o início de uma mudança no panorama cinematográfico brasileiro. Jean-Claude Bernardet não incorpora este discurso, mas o traz ao leitor. Afinal é a tese de Nelson Pereira a qual o jornal dá acesso. O crítico toma o cuidado de declarar que os cineastas autores do Cinema Novo mergulhariam "um

\footnotetext{
${ }^{35}$ Analisamos as declarações de Nelson Pereira dos Santos sobre a política cultural desta entrevista no capítulo 5 .
} 
pouco mais fundo" na realidade, ou seja, não houve uma mudança tão grande assim. Ele frisa também que eles esquecem "em parte" os esquemas sociológicos. Estas nuances trazem dentro do gênero informativo os comentários opinativos do crítico. Uma visão negativa em relação ao Cinema Novo se mantém nesse primeiro trecho: o olhar sociológico é visto como um obstáculo a uma aproximação com a realidade do país. O tom do crítico é de hesitação sobre as declarações do diretor: o filme "parece aceitar e acreditar nos valores de seus personagens".

Sintonizado com os debates da época, Nelson Pereira dos Santos faz uma mea culpa sobre seu comportamento em relação à cultura popular. Durante as filmagens de Rio 40 graus (1955), ele não estava interessado na umbanda, mas nas "relações sociais", porque achava que as cerimônias não faziam parte da realidade. Agora, a religião não é mais vista com preconceito, declara o cineasta. Ao contrário, Amuleto confere à umbanda o mesmo tratamento dado às demais religiões. $\mathrm{O}$ filme surge, então, como possibilidade de criticar a atitude "nossa" de intelectual:

"É preciso ter também uma atitude crítica dentro do filme. Embora usando temas populares ou colocando a imagem do povo no filme, a minha posição era de criticar uma atitude nossa dos intelectuais cineastas, de superioridade, de criticar a própria vida do povo. (...) Dizer que a vida do povo está fechada dentro de uma teia de acontecimentos, dizer que os personagens não tinham saída".

Tentando convencer o leitor de uma mudança radical do filme em relação ao povo, Nelson Pereira dos Santos envereda por um conceito de "neutralidade" do cineasta. Segundo ele, a atitude crítica do Cinema Novo não existe mais. Há um paradoxo ao tentar explicar como as críticas anteriores à realização cessam antes do processo de filmagem:

\footnotetext{
"A posição crítica é anterior ao filme. Acho que a partir do momento em que começa o filme, deixa de existir a minha atitude crítica, que existiu na seleção de valores do filme. Passam a existir os valores nos quais o filme acredita até as últimas consequências. A posição crítica está antes, na procura do filme, na procura da expressão, na parte da realidade que a gente quer analisar, na observação dessa realidade. A partir do momento em que o filme começa ele tem que usar a linguagem da emoção, estar ligado a estes valores populares, nunca mais criticar, pelo contrário: achar corretíssimos. Sou por um cinema que leve o público a pensar que ele está certo nas condições em que vive".
}

A visão de que a atitude crítica do diretor termina com o início do filme busca um discurso de neutralidade do aparato cinematográfico enquanto produtor de sentido. 
Esta postura de "neutralidade" tenta convencer o leitor de que a obra traz uma transparência total. Vende também a crença na verdade da imagem. No fundo, o diretor procura mostrar que Amuleto pode trazer a verdade dos valores populares à tela, "como ela é", sem a interferência dele.

Nelson Pereira dos Santos declara que o filme revela a inexistência de saída para os personagens ou para a população representada. "Em Amuleto, Gabriel não tem nada de sociólogo, ele tem superpoderes, mas é um joguete". Na sequência, Bernardet comenta as declarações do cineasta:

"Segundo Nelson, a crítica estaria no fato de que o filme mostra aos personagens - que o público reconhece como os seus representantes - que eles não têm saída na vida que levam. Mas, ainda assim, o filme estaria do lado do espectador, levando-o a pensar "que ele está certo nas condições em que vive"”.

O trecho revela boa parte das contradições presentes na entrevista. Se antes, Nelson Pereira dos Santos declarou que os filmes do Cinema Novo mostravam a falta de saída para a população, a nova postura não mudou em nada, porque Amuleto também indica a inexistência de soluções. A diferença é o tom otimista de mostrar que o povo está certo nas condições em que vive.

\section{A Crítica de Jean-Claude Bernardet}

No início do artigo O Novo Cinema Novo, Jean-Claude Bernardet ${ }^{36}$ não destoa do comentário geral da imprensa de ver em Amuleto um fato cinematográfico novo, mas depois credita esse fato a terceiros:

“Amuleto de Ogum (...) está certamente destinado a dar um enorme impulso ao atual cinema brasileiro, modificar profundamente as posições existentes, relançar discussões de há longo tempo omitidas. Para alguns, O Amuleto de Ogum é uma data histórica do cinema brasileiro".

De acordo com ele, a proposta de Nelson Pereira dos Santos é original porque o filme abre um relacionamento com uma faixa do povo, trazendo a visão que ele tem de si mesmo. Ao mesmo tempo, a produção foge da angulação intelectual necessária para a libertação do povo:

\footnotetext{
${ }^{36}$ Bernardet, Jean-Claude. O novo Cinema Novo. Opinião. n. 119, p. 20, 14 fev. 1975.
} 
"Apesar dos tiros, Amuleto não é filme policial nem de gang. O que Nelson tenta é se dirigir ao público fazendo uma proposta dramática e estética original. Neste sentido, $O$ amuleto de Ogum é um filme experimental. (...) Para tornar viável essa posição era necessário que Nelson Pereira dos Santos não pensasse no público como um amálgama indefinido e indiferenciado de compradores de ingressos. Era necessário que ele pensasse povo e não público. É a partir do relacionamento que ele estabelece com uma faixa da população e seus valores que o filme (...) foi elaborado, e não a partir da intenção de seduzir o público".

Depois, Bernardet vai revelar que Amuleto não é um cinema popular, em total oposição às declarações do diretor de Amuleto. Ou seja, ele desmonta o discurso de Nelson Pereira dos Santos de se ver como criador de uma cinematografia popular:

\begin{abstract}
"Evidentemente, nem Nelson nem ninguém possui a fórmula do cinema popular, ou melhor, do cinema de perspectiva popular [grifo nosso] para não confundir com o filme de simples sucesso de bilheteria. Inclusive porque este cinema não existe em si. Ele é um processo, ele é constantemente uma aposta estética e política. A aposta básica feita por Nelson neste filme, me parece, é de aceitação dos valores da realidade sócio-cultural que ele aborda e da faixa de público a que se dirige primordialmente. Não se trata de posição abstrata, mas do caso específico da umbanda."
\end{abstract}

O texto adentra num conceito que tinha permanecido aberto em Brasil em tempo de cinema: a cultura popular no Cinema Novo. O famoso livro demonstrou que a produção cinemanovista não era parte da cultura popular, mas uma produção típica da classe média. O elogio a Nelson Pereira dos Santos é romper com o paternalismo de um filme como Barravento (1961) de Glauber Rocha.

É importante frisar aqui uma alteração. Neste texto, ele deixa o questionamento de Brasil em tempo de cinema de lado. Continuamos a ter um cineasta com o mesmo desejo do Cinema Novo de "atingir" o público popular. Talvez a diferença seja uma tentativa a mais de se aproximar do espectador popular, que não deu certo, como veremos. Contudo, Nelson nunca é questionado por essa tentativa, como se fazia com Arnaldo Jabor em Opinião. A nova aspiração discursiva dos anos setenta é colocar o povo como personagem na tela, "sem questionar" seus valores. No fundo se trata do intelectual supostamente neutro que apenas dá vazão à cultura popular, como se não houvesse um caráter político em sua ação. Elogia-se Nelson Pereira dos Santos pela ausência de preconceitos à umbanda e por querer dialogar com as camadas populares na exibição. Mas no fundo temos o mesmo projeto do Cinema Novo de ocupar o mercado. 
Constrói-se, então, uma nova expectativa e um novo mito, porque o filme foi visto pela mesma classe média de sempre. Temos um avanço em constatar a inexistência da cultura popular nos filmes, mas não se polemiza um diretor alinhado a um projeto político para o cinema brasileiro. O elogio que fica implícito a Nelson Pereira é o de trazer a cultura popular como forma de resistência. O crítico não explicita as contradições do discurso do diretor, mas as frases estão lá para a análise do leitor.

\section{A recepção do público}

Três meses depois da publicação desses artigos em Opinião, Jean-Claude Bernardet comenta a recepção do público ${ }^{37}$. E a decepção é grande. Vê-se pelo texto a ansiedade geral pelo seu sucesso. Nenhum outro filme brasileiro ganhou uma cobertura específica sobre a recepção nas salas de cinema. Amuleto ficou dez semanas em cartaz, em salas destinadas a um público mais elitizado. O projeto original previa o lançamento em Caxias, onde o filme foi gravado, para marcá-lo como popular. Em seguida, a motivação para as classes mais abastadas seria a do "filme que vem do povo". Novamente vemos aqui a antiga tentativa cinemanovista de apresentar a obra como "cultura popular". Portanto, a intenção do autor de se dirigir às classes populares não se concretizou por causa do destino comercial dado à produção. De alguma forma, a crítica é uma resposta à divulgação que Opinião fez de Amuleto e à promessa de alteração em direção a um cinema popular. Bernardet pretende se afastar mais ainda das declarações de Nelson Pereira dos Santos com base em dados empíricos de bilheteria.

As intenções populares foram interpretadas pelas distribuidoras como motivações de consumo do público "classe A e B". De nada adianta realizar um produto popular se a distribuição e exibição determinam o público. "Por mais que os diretores queiram se dirigir ao povo, eles de fato se dirigem ao público". Portanto as possibilidades comerciais definem a carreira do filme: no caso de Amuleto o público alvo foi a classe abastada e os universitários. "Como mercadoria o filme procura as zonas de maior poder aquisitivo". Se ele é feito no regime de espetáculo, não há "como escapar ao sistema comercial" que determina "em grande parte a sua significação". Assim, a função de liberação dos espectadores populares prevista pelo diretor não ocorreu, porque esse público não foi atingido. Explica Bernardet:

\footnotetext{
${ }^{37}$ Os outros donos de Amuleto. Opinião. n. 134, p. 24, 30 mai. 1975.
} 
"Nelson Pereira dos Santos atribuía a seu filme uma função de liberação dos espectadores populares: 'Um cinema que leve o público a pensar que ele está certo nas condições em que vive'. Esta função o filme não cumpriu (...)”.

Amuleto acabou por atingir um público não citado por Nelson Pereira dos Santos. Não foi o espectador popular que viu o filme, mas a classe universitária, jovem e de alto poder aquisitivo. Esse público quer uma sociedade menos repressiva, e "provavelmente" projetou isso sobre Amuleto. "É exatamente aí que o filme acabou funcionando. Quer dizer, por bem ou por mal, uma imagem do povo para o uso das camadas cultas". Segundo o autor, o filme não impossibilitava a "identificação" com as classes populares, mas o sistema de distribuição impediu esse processo. Quando JeanClaude Bernardet faz essa constatação, é como se ele se voltasse à mesma conclusão de Brasil em tempo de cinema. O Cinema Novo continua sendo um produto que vende uma imagem do povo para a elite, sem atingir o povo. Neste caso o problema apontado foi o da distribuição; não o filme em si.

Esse tipo de pensamento traz uma matriz que vê o sistema comercial como determinante dos processos culturais. Assim, o filme é vítima desse sistema. Não adiantam as campanhas da imprensa ou o discurso sobre o caráter popular da obra, se ela é consumida como espetáculo. Portanto, os projetos de conscientização estariam fadados ao fracasso, caso não passassem pelo meio comercial. Afinal o mercado determina quais as classes terão acesso aos produtos. $\mathrm{O}$ que este artigo faz é responder do ponto de vista empírico às indagações de Brasil em tempo de cinema sobre a ligação entre o filme e o complexo de comercialização. O livro frisava o caráter popular de uma obra como determinante para a fruição do público, sem ampliar sua relação em termos concretos com o processo de comercialização. Esse tema foi debatido mais nos anos setenta. Aqui, se percebe que o problema da autoria e do caráter popular foge da perspectiva do filme em si, para chegar ao tipo de fruição determinada pela propaganda. O caráter popular não é garantia de conscientização, porque as forças do mercado determinam qual faixa do público terá acesso a sua significação. O tom é pessimista sobre as possibilidades do cinema brasileiro frente ao poder do mercado. 


\section{O Talismã sem Poder do Cinema Brasileiro}

Como último ponto a destacar, trazemos o ensaio de Jean-Claude Bernardet ${ }^{38}$ escrito para o Manifesto por um Cinema Popular, que antecipa algumas das questões levantadas pelos artigos de Opinião. Retomando Barravento (1961) de Glauber Rocha, Jean-Claude Bernardet vê uma alteração em relação ao popular. Em Amuleto, não há um personagem superior à vivência popular, como havia em Barravento. A religião não é mais sinal de opressão. O ensaio toma, portanto, Amuleto como um marco para o futuro e uma mudança em relação à produção anterior. Mas ao mesmo tempo, Bernardet observa a inexistência do sentido de cultura popular de Nelson Pereira dos Santos, porque a cultura popular mistura-se aos valores e à ideologia que a classe dominante tenta difundir ao povo como fonte de verdade. O objetivo da classe dominante é esvaziar e neutralizar o conteúdo da cultura popular, declara ele.

O texto vê Amuleto como um marco que tornou obsoleto uma série de filmes e posições: "O mínimo que se pode dizer de O Amuleto de Ogum é que reintroduz no cinema brasileiro uma discussão correta sobre alguns pontos fundamentais. Após $O$ Amuleto, uma série de filmes e de posições ficaram obsoletas”. Então, o crítico adentra num tema nunca abordado em Opinião, mas analisado depois em Trajetória crítica (1978). A luta pelo cinema brasileiro em termos exclusivamente de mercado fez com que qualquer outra discussão fosse tomada como estetizante, eliminando discussões políticas, culturais, estéticas e de problemática social.

Bernardet observa a inexistência do sentido de cultura popular de Nelson Pereira dos Santos, porque a cultura popular mistura-se com os valores e a ideologia que a classe dominante tenta difundir ao povo como fonte de verdade. O objetivo dela é esvaziar e neutralizar seu conteúdo. Contudo, a visão de Jean-Claude Bernardet não é de passividade do povo, como às vezes caracterizava Opinião. Segundo ele, o povo absorve alguns desses valores, mas também os transforma contra a própria fonte de origem, num conceito de resistência parecido com o de Marilena Chauí (1986) e de Carlos Rodrigues Brandão em Movimento. Portanto, “os valores populares não são, então, cristais límpidos, mas um processo contraditório.” Aqui, Bernardet não parte do pressuposto de que existe uma cultura popular autêntica, imóvel e verdadeira, como

\footnotetext{
${ }^{38}$ Ensaio - O Amuleto mudou tudo. Manifesto por um cinema popular. Cineclube Macunaíma, Cineclube Glauber Rocha e Federação dos Cineclubes do Rio de Janeiro. Cinemateca Brasileira. Fol 145.
} 
muitos acreditavam. Ou seja, Jean-Claude Bernardet fará a apreciação mais negativa que o filme recebeu, tudo isso no próprio Manifesto. Mas esses comentários foram filtrados em Opinião. Em seguida, neste ensaio, ele explicita que a tese de Nelson Pereira dos Santos é tão ingênua quanto a do Cinema Novo:

"A posição, então, é oposta e radical. E a longo prazo talvez tão ingênua quanto a tese da conscientização do início do Cinema Novo. De fato, os valores populares não constituem uma entidade autônoma. (...)

A longo prazo, o assumir acriticamente o que Nelson chama de valores populares leva a uma posição que, por muito diferente da sua posição inicial do Cinema Novo, não deixará de ser também romântica e populista."

Ao compararmos aqui as críticas da imprensa com o discurso do diretor, analisamos no fundo como se deu o processo de fabricação da crença no artista e nos bens culturais. A recepção de Amuleto prova o quanto a crítica de cinema articula-se de alguma forma às declarações do cineasta. Demonstramos o quanto os críticos tentaram afastar-se deste referencial; ou o quanto incorporaram de alguma forma as assertivas discursivas de Nelson Pereira dos Santos. Não se trata somente de um caso clássico das instituições culturais tentando pautar o discurso da imprensa. É verdade que os críticos não só predizem o sucesso dos filmes (Bourdieu, 2001), como também produzem, reproduzem e geram a crença no sistema cultural (Bourdieu, 1996). Afinal se a crítica de cinema participa da produção da crença ao filme Amuleto de Ogum e no diretor, o crítico não é o único responsável pelo processo, compartilhado por historiadores, pesquisadores, colecionadores, artistas, cineastas. A equação não é nada simples, afinal textos positivos não significam obrigatoriamente bons resultados de bilheteria. Tanto é verdade que há um limite na ação crítica para predizer o sucesso dos filmes. Mesmo fazendo a sessão de lançamento num reduto popular do Rio de Janeiro, Amuleto não conseguiu adentrar nas faixas populares. Bernardet conclui que a distribuição preferiu investir no público certo da classe média para garantir o lucro. Na verdade, a discussão aponta também para o sentido de popular que o público fez de Amuleto ${ }^{39}$.

É interessante demonstrar que o grande espaço dado a Amuleto diz respeito a um projeto político e cultural defendido em Opinião. Isso é visível pelas ausências. Por

\footnotetext{
39 Em Opinião, Bernardet observa a recepção dos espectadores de Caxias e conclui que as pessoas se identificaram, torceram e aplaudiram a cena final da ressurreição de Gabriel nas águas do mar. Bernardet, Jean-Claude. Os babalâ̂s resistem aos sociólogos. Opinião. n. 121, p. 24, 28 fev. 1975.
} 
exemplo, Quem é Beta (1973) do mesmo diretor só recebe uma menção no jornal como filme alegórico, porque não responde ao interesse dos críticos por um cinema político e de fácil entendimento popular.

O distanciamento criado pelos críticos em relação ao filme trouxe, na verdade, as disputas internas pelo monopólio do poder de nomeação. Pudemos observar as sutis lutas travadas entre o discurso de Nelson Pereira dos Santos - sobre o Cinema Novo, a cultura popular e o papel do cineasta - e as discordâncias expressas a estes mesmos conceitos especialmente em Jean-Claude Bernardet e em José Carlos Avellar.

Se o filme não foi um divisor de águas como se pretendia, a crítica a Amuleto de Ogum em Opinião gerou uma grande mudança nas esperanças sobre o cinema brasileiro. Antes de Amuleto, a crítica tentava conciliar um cinema popular, autoral e comercial, com a união entre um público culto e popular. Essa esperança parecia concretizada com o sucesso de Macunaíma (1969) de Joaquim Pedro de Andrade. Ela também aponta para a existência de certo projeto político para o cinema brasileiro que parece ruir com a constatação da impossibilidade de unir projetos tão díspares. O sonho de um filme autoral, de linguagem clássica e apelo de público, engajado na conscientização do povo fracassa em Opinião com Amuleto.

Trata-se do fracasso deste projeto, de mais uma expectativa para quem acreditava no cinema autoral, moderno e de apelo popular. Por isso depois da publicação dos artigos sobre Amuleto de Ogum nunca mais um filme será tão comentado com tantas expectativas em Opinião. Pelo menos no semanário, este sonho cinemanovista acaba com Amuleto por causa da constatação de que não é tão simples atingir o público popular. 


\subsection{Cultura Popular em Frasco: o Nordeste Congelado}

Uma crítica aos intelectuais, à política cinematográfica e à cultura do nacional popular. Por causa do lançamento de Nordeste: cordel, repente, canção (1975) de Tânia Quaresma ${ }^{40}$, Jean-Claude Bernardet observa o interesse de certo público urbano pela cultura popular brasileira. O texto explica que os filmes são sobre o nordeste e a cultura rural. Seu maior representante é Geraldo Sarno. Observando uma tendência no curta metragem, Bernardet sintetiza uma finalidade comum: o "registro das práticas culturais das classes dominadas rurais" e a divulgação do "seu valor cultural". O crítico sugere ainda deixar de lado a discussão sobre o assunto do filme para abordar a relação entre a produção, a cultura popular e o público. Ele lembra que essa ligação é sempre ocultada no produto final. Por isso, ninguém discute o porquê e para quem o filme é feito. A discussão fica só no fazer e como fazer, para não quebrar o clima de "autenticidade" dos filmes.

Analisando as tendências desse tipo de documentário de curta metragem brasileiro, Bernardet tira algumas conclusões: 1. os filmes não são de cultura popular, mas sobre; 2. os realizadores não fazem parte da cultura popular; 3. os produtores e consumidores da cultura popular não participam da realização dos filmes, nem têm acesso ao resultado final; 4. o público geralmente é o espectador culto. Portanto, a cultura popular serve apenas de matéria prima aos realizadores, compondo um retrato de uma "desapropriação cultural" de suas imagens e sons.

Bernardet observa que os filmes passam por três máximas: a ideia de "registro", de "preservação" e de "memória". As três juntas pretendem fazer uma frente à indústria cultural. A própria proposta de "registro" quer guardar a cultura popular antes de seu "desaparecimento", ou antes que ela seja "deturpada". O artigo traz uma provocação: por que preservar Lampião e deixar de lado Roberto Carlos? Por que o primeiro é mais genuíno do que o segundo? Isto é, por que a cultura do povo seria autêntica e a da cultura de massa artificial?

A resposta de Bernardet à própria pergunta não está nos filmes, muito menos na cultura popular. Ela se encontra no comportamento dos intelectuais, em meio a um

\footnotetext{
${ }^{40}$ O nordeste congelado pelo cinema. Opinião. n. 164, p. 20, 26 dez. 1975.
} 
ambiente cultural nacionalista. O crítico prova que a produção não foi feita para o povo. Ao contrário, a função desses filmes passa pela necessidade do público culto construir sua identidade e compensar os efeitos da descaracterização e despersonalização, provocados pelo consumo massivo:

"Mas como a crítica e a participação são reprimidas, como se tenta bloquear a inserção nossa no presente e no futuro, essa identidade é procurada no povo (em oposição aos dominadores), nas formas não industrializadas (em oposição à industrialização saqueadora e despersonalizadora), no passado estagnado (sendo bloqueada a dinâmica do presente e do futuro. (...)

Diante de uma despersonalização progressiva, apoderarmo-nos destas formas de cultura popular cinematograficamente elaboradas por nós é uma tentativa nossa para não desaparecer. Numa atitude de nacionalismo infantil e mágico (...), identificamo-nos com um museu criado por nós. Timidamente e sem alterar as regras do jogo as que nos são impostas, respondemos à alienação da despersonalização cultural como uma outra alienação: 'o museu popular'."

O trecho não poupa os intelectuais da auto-análise. O uso da cultura popular serve para a intelectualidade formar sua identidade como sujeito da resistência. Essa apropriação do componente popular pela intelligentsia acaba incidindo na imagem mostrada do povo. Ele aparece miserável na imagem, mas é sempre manso. Sofre "violência", mas devolve "artesanato" e poesia. Na última linha, Bernardet declara: "Não é pacato o povo de Nordeste: Cordel, Repente, Canção?"

O artigo contém uma série de críticas e pontos de atrito. Quando Bernardet questiona a indústria cultural e o conceito de preservação difundido pelo Estado, traz alguns argumentos da esquerda contrários à aproximação entre intelectuais e Estado. Alguns desses comentários tomarão mais força nos anos seguintes através da Nova Esquerda. O ano do artigo é significativo. Em 1975 foi promulgada a Política Nacional de Cultura (Ver Capítulo 5). Bernardet questiona no texto quem são os responsáveis por determinar quais práticas serão preservadas e o porquê do desprezo às formas culturais em evolução. Ele explica que esse trabalho de seleção, corte e montagem é feito tanto pelos produtores dos filmes, quanto por órgãos burocráticos como a Companhia de Proteção ao Folclore. Os dois grupos pertencem às "camadas sociais culturalmente dominantes", explica o autor. Provavelmente parte da contestação passe pela coincidência com o projeto político de preservação do regime. Nordeste: cordel, 
repente, canção foi patrocinado pela Embrafilme e distribuído pela mesma empresa, mas essa informação não está no texto. Bernardet condena, assim como Marilena Chauí (1986) e Alfredo Bosi (1992), a cultura popular vista como espontânea, deixando de lado a contradição social entre as classes. O questionamento feito nessas linhas incide diretamente no desejo do intelectual de auxiliar a resistência e localizar uma cultura de oposição nas obras. A intenção desta produção de chegar ao povo é colocada em xeque porque "estes filmes não atuam sobre a área cultural de que tratam". Os participantes das filmagens devem até "ignorar" o que é cinema. Se o público desses filmes é sempre culto, o quadro não teria mudado muito em relação aos anos sessenta. De cultura popular propriamente dita não existia nada; apenas o povo como matéria prima dos filmes. Por causa dessa falta de contato com o espectador popular, Bernardet coloca à prova uma produção que finge ser cultura popular.

Por detrás deste comentário está a certeza de que só os produtores da cultura popular são capazes de representá-la; quase dotados de uma autenticidade. Há aqui uma aspiração à participação do artesão no próprio processo de confecção do filme. Cinema popular seria entregar a câmera e o modo de produção ao povo. Esse é o tema indireto da matéria. No artigo, Bernardet antecipa um argumento que será usado depois no livro Cineastas e Imagens do povo (1985): a falta de acesso dos produtores culturais ao mecanismo de produção ${ }^{41}$.

Se os cineastas não entregam a câmera ao povo, o artigo realça o interesse dos intelectuais pela imagem do povo miserável, cujo objetivo é despertar compaixão. A ausência do cinema popular coloca para Bernardet a discussão sobre os intelectuais: eles acreditam trazer ao público a cultura popular com seu "nacionalismo infantil”. Quando Bernardet liga os filmes lançados à classe social de origem do cineasta, os comentários lembram Brasil em Tempo de Cinema por causa da pretensão da classe produtora de traduzir a cultura popular. Indiretamente se tenta mostrar que a cultura popular é impossível de ser apreendida por causa da classe social do cineasta. O livro de 1967 antecipava esses elementos críticos em relação ao tema. Talvez sintonizado com Sebastião Uchôa Leite (1965), Bernardet (2007) separava no livro a cultura popular feita pelo povo da cultura popular feita pela classe média para o povo. Para esconder sua

\footnotetext{
${ }^{41}$ Uma primeira versão das ideias foi publicada entre 1979-80 em A voz do outro (Bernardet, 1979-80).
} 
má consciência, a classe média eliminaria os conflitos entre a burguesia e os trabalhadores nos filmes.

Se o povo na obra de Tânia Quaresma é pacato e passivo, a visão não era muito diferente da exposta em Brasil em Tempo de Cinema, quando o autor observava a representação nos filmes de proletários sem defeitos e de camponeses esfomeados e injustiçados. No livro de 1967, Bernardet explicava com todas as letras que o sentido de popular estava só na inspiração da temática e das formas populares:

"assim, embora aspirando a ser popular por sua temática e pelo público que desejava alcançar, o recente cinema brasileiro, tanto o cinema de ideias como o artesanal e comercial, foi popular apenas na medida em que se inspirou em problemas e formas populares. Mas o que fez foi elaborar temática e forma que expressam a problemática da classe média. De Cinco vezes favela até $A$ falecida, São Paulo S.A. e $O$ desafio, passando por Deus e o diabo, divisor de águas do atual cinema brasileiro, elaborou-se em alguns anos uma temática que vai de uma alienação na qual a classe pretendia ilusoriamente identificar-se ao povo, a uma possibilidade concreta de afrontar os problemas dessa classe" (Bernardet, 2007: 183).

O autor decompôs no livro todas as possibilidades de cinema popular para mostrar sua inexistência: "Entre a constatação de que um filme é popular por ser baseado em problemas que dizem respeito ao povo, de que ele se vale de formas populares, e a conclusão de que ele é popular, ou seja, destinado a ser compreendido por um público popular, é um passo só, e uma confusão muito grande se estabelece." (Bernardet, 2007: 168). Para o crítico, "dizer que Deus e o Diabo é filme popular é idealismo e mistificação". Esse tipo de condenação clara ao cinema popular está ausente de Opinião quando se fala dos cinemanovistas.

Além desses comentários, o livro não deixava sem análise o papel do intelectual com o povo para chegar à revolução. Segundo ele, cabe ao "povo encontrar suas próprias soluções", e não ficar esperando o Antonio das Mortes glauberiano para "livrar Manoel da alienação". Bernardet demonstrava o quanto os cineastas tentavam se legitimar através da ideia de representantes legítimos da cultura popular. Em Opinião, os cinemanovistas canônicos só levavam alguns arranhões. A diferença é que os comentários negativos aos cânones do cinema brasileiro do livro não estarão mais presentes no semanário alternativo. Se em Opinião alguns desses temas não aparecem, Bernardet decompunha as contradições do discurso dos cinemanovistas em outros 
jornais (ver Capítulo 5). Por exemplo, num artigo de 1974 (Bernardet, 1978: 125-139) para o livro Kino und Kampf in Latinamerika, ele dizia claramente que o Cinema Novo não era revolucionário no sentido de orientação política concreta, mas ligado ao núcleo do nacional popular. Ao acreditar ser revolucionária, esta esquerda nacionalista estava vivendo mesmo era uma alienação.

Não era só em Brasil em Tempo de Cinema que Jean-Claude Bernardet participava de alguma maneira da crítica à intelectualidade. Como ator, ele aceitou interpretar um intelectual em Orgia, o homem que deu cria (1970) de João Silvério Trevisan. Sozinho e nu no meio do mato, o personagem é um típico intelectual à parte do mundo social. Prefere as letras e o conhecimento ao diálogo possível com os dois visitantes que se aproximam. O máximo de comunicação que há entre eles são alguns grunhidos sem sentido. Se ele literalmente engole as páginas dos livros, seus conhecimentos parecem inúteis porque o intelectual devora a informação só para si mesmo. O personagem nem sequer tem a pretensão de ser arauto. Carece até de uma função social. A paralisia e falta de sentido o levam ao suicídio. Depois de queimar quase todos os livros, ele se enforca numa árvore. Num misto de espanto e desdém risonho, os dois visitantes usam os livros que sobraram como papel higiênico. Nenhum detalhe desse ritual nos é poupado na imagem. A cena parece o ápice de um questionamento brutal do intelectual, sem nenhum tipo de eufemismo, muito distante da crise reflexiva poética do Cinema Novo em O desafio (1965) de Paulo César Saraceni, Terra em Transe (1967) de Glauber Rocha e O bravo guerreiro (1968) de Gustavo Dahl. Afinal Orgia pertence ao polo oposto e pode ser pensado como parte da postura anti-intelectual de muitos filmes marginais feitos na Boca do Lixo.

É como se Bernardet não voltasse mais em Opinião aos assuntos já concluídos no passado. Coincidência ou não, o autor contesta mais os aspectos do nacional popular do Cinema Novo em outros jornais, não em Opinião. Talvez ainda fosse uma prática conjunta aos críticos engajados conter certos comentários negativos ao cinema brasileiro para não atrapalhar a bilheteria dos filmes, como se fazia no Última Hora (Bernardet, 1978). Nos anos oitenta, Bernardet (1982: 29; 31) voltaria ao tema em Piranha no mar de rosas. Neste livro, ele comentou o desejo da época de construir um projeto mais extenso de cinema popular e do artista voltado ao público. A consequência disso era ocultar ao espectador a ausência de suas preferências na linguagem e na temática. Afinal a imagem precisa se considerar popular para se justificar perante si mesma. 
A teoria sobre a cultura popular de Nelson Pereira dos Santos sobre O Amuleto de Ogum (1974) era respeitada em Opinião, como vimos. A diferença em relação a Nordeste: cordel, repente, canção é de quase um ano. O artigo sobre Amuleto é de fevereiro e o sobre Tânia Quaresma foi escrito em dezembro. Se os cinemanovistas passaram quase incólumes pela maior parte do tempo no jornal, o filme de Quaresma retomava a ligação do popular como discurso de classe, do livro Brasil em Tempo de Cinema. Se provavelmente o critério é artístico, a diferença fica clara quando Bernardet comenta a produção de Leon Hirzsman. O crítico considerava todos os filmes do cineasta como uma busca de um cinema popular ${ }^{42}$. A utilização da palavra "busca" revela uma grande distância de objetivos em relação à Nordeste: cordel, repente, canção. Não se trata de encontrar a cultura popular, mas de uma tentativa, sem a pretensão de mostrar-se como acesso ao real. Portanto, havia os dois matizes de pensamento em Opinião. Existia espaço para os cinemanovistas colocarem suas ideias sobre a cultura popular, mas crescia uma crítica ao conceito de nacional popular. No geral, o jornal como um todo estava muito mais atrelado ao papel político do intelectual na resistência do que na sua crítica. Essas idas e vindas fortaleceram-se no final do jornal, como veremos. Trata-se do novo e do velho olhar dos anos setenta sobre a cultura do nacional popular em Opinião. O próprio Bernardet (1978) explicou um pouco desse clima político. A crítica de cinema temia atrapalhar a conquista do mercado com comentários negativos, porque lutava pelo cinema brasileiro. É por esse motivo que muitas discussões estéticas e políticas eram relegadas ao segundo plano. De acordo com Bernardet, falar mal do Cinema Marginal ou da comédia erótica não causava problema. A dificuldade era atacar o cinema crítico. A pergunta pode ter outra resposta. Ninguém afirmava a falta de popularidade do Cinema Novo dos anos setenta em Opinião por causa do marco fundador de Macunaíma (1969) de Joaquim Pedro de Andrade. O sucesso desse filme respondia à falta de popularidade do movimento e tornava possível a esperança de conquistar o mercado. Portanto, o ponto de atrito oculto do jornal é a preferência pelo cinema autoral ou crítico que geralmente não facilitava a conquista do mercado.

\footnotetext{
${ }^{42}$ Bernardet, Jean-Claude. Uma trajetória coerente. Opinião. n. 87, p. 16, 8 jul. 1974.
} 
O artigo sobre Tânia Quaresma rende um debate com os cineastas dentro e fora do jornal. Em Opinião, Geraldo Sarno escreve uma carta em retaliação a Jean-Claude Bernardet ${ }^{43}$. O ponto de atrito é colocar o nacional popular à prova no jornal e contestar sua produção pessoal como forma inautêntica de cultura popular. O cineasta acusa Bernardet de ter uma postura simplificadora e esquemática da realidade social. No texto, ele expõe a dificuldade de manter os produtos artesanais frente à investida do processo de industrialização. O realizador condena Bernardet de estar alheio à dificuldade de acesso dos produtores e comenta os obstáculos de comercialização para os documentários chegarem ao nordeste. Sarno endossa a importância da cultura nordestina na formação da cultura nacional. Depois se pergunta onde ficariam as obras de Glauber Rocha e de Guimarães Rocha que se "nutriram" da cultura popular. Trata-se de uma clássica defesa da cultura do nacional popular e de sua utilização pelo intelectual-cineasta, enquanto Bernardet questiona seu uso. O conceito de cultura popular de Sarno é o de expressão da resistência cultural às classes dominantes, típico daquele momento.

No fundo, Sarno defende a cultura popular como alicerce do nacionalismo para a afirmação da identidade nacional. Ligado ao PCB, o realizador está ao lado da cultura do nacional popular. Assim, toda cultura por ser do povo é libertadora. Há outro aspecto interessante na carta de Sarno em dissonância com o conceito apreendido por Bernardet. Segundo Michel Löwy e Robert Sayre (1995), o romantismo é uma crítica à modernidade e ao capitalismo. Por isso a nostalgia está no cerne da atitude romântica, e aparece na declaração de Sarno num conceito de povo amparado no passado, pelo folclore e pela volta a um tempo pré-capitalista. Não cabe ao jornal Opinião na área de cinema a caracterização de romântico, porque inexiste um sentimento anticapitalista. Ao contrário, o semanário toma o capitalismo por dado real, no qual a industrialização é necessária, e defendida. A constatação de que cinema é mercado aparece como imperativo, não como sensação de desencanto. O que se quer mudar no jornal é a forma de conquistar o mercado, através do cinema crítico. Ao contrário, Geraldo Sarno busca não só a cultura popular congelada, mas também uma comunidade brasileira autêntica.

\footnotetext{
${ }^{43}$ Sarno, Geraldo. A cultura apropriada. Carta dos leitores. Opinião. n. 166, p. 18, 9 jan. 1976.
} 
A opinião defendida por Geraldo Sarno era comum na época - e presente no projeto do Cinema Novo. Segundo Marcelo Ridenti (2000), trata-se de valorizar a tradição e a presença do passado, mas ao mesmo tempo se percebe o progresso como dessacralização da sabedoria popular. Sarno traz uma concepção de cultura atemporal e congelada no tempo para não gerar a perda de raízes. A visão traz um viés de autenticidade do popular, em oposição às transformações da realidade. Esse conceito mobilizou grande parte da literatura folclórica e os intelectuais tradicionais alinhados ao regime militar, defensores da volta ao passado porque a cultura brasileira seria um patrimônio a ser preservado. A finalidade era recrutar o Estado como guardião da memória frente à descaracterização das importações (Ortiz, 2006). A esta concepção cultural, Jean-Claude Bernardet se opõe constantemente.

Em oposição ao pensamento de Geraldo Sarno, Sebastião Uchôa Leite (1965) vê a cultura popular como algo vivo e em transformação. Quando pensa a cultura do povo como algo cristalizado, o cineasta traz o ponto de vista da preservação estética. Existe nessa atitude de Sarno um fundo ético de desconfiar da mutabilidade dos valores, porque eles só trazem resultados negativos. O realizador procura conservar os traços estáveis ou preservar a autenticidade da cultura de qualquer transformação. Este conceito tradicionalista para Uchôa Leite é uma falácia, se visto do ponto de vista extraestético e de integração histórica, porque pressupõe a ingenuidade dos produtores da arte popular. Sem analisar as causas, o fenômeno é visto de forma unilateral.

A carta do cineasta retoma o debate de Brasil em tempo de cinema com dez anos de atraso. O argumento de Geraldo Sarno nos remete ao artigo de Roberto Schwarz, Nacional por subtração (1987: 32-33), no qual o autor explica que a busca pelo caráter autêntico da cultura brasileira ocupava a ordem do dia da intelectualidade. Num espírito combativo prevalecia a ideia de preservar a cultura brasileira do comércio e da comunicação de massa, tal como Sarno. Assim, o progresso seria uma reconquista e a expulsão dos invasores imperialistas, que impediam o desabrochar da cultura autenticamente nacional, raciocínio usado com certa frequência em Opinião. Da "subtração" do que não era nacional, nem nativo, se acharia a essência da brasilidade. A ideia de essência do popular não era questionada em Opinião, exceto por Bernardet.

Essa não foi a única polêmica de Nordeste congelado pelo cinema. A repercussão continuou fora do espaço do jornal com alguns comentários de especialistas 
no assunto, nem sempre favoráveis ${ }^{44}$. Ivan Cavalcanti Proença contou a Bernardet que o artigo foi comentado em quatro debates sobre cultura popular. Se o texto foi o mais discutido, ele provocou "reprovação". Especialista no assunto, o professor universitário entrou em contato com Bernardet para dizer que estava "totalmente de acordo com o artigo", mas a publicação "foi inoportuna" e poderia ter servido a propósitos mais amplos. Provavelmente o lado inoportuno fosse colocar à prova o nacional popular, que era a semente comum da Frente Cultural. Se as observações de Proença tendiam mais para o negativo, Dieter Goebbels relatou que o artigo repercutiu a tal ponto num grupo, que Ivan Maurício e outros reformularam suas pesquisas.

Nesses relatos há uma pequena dimensão da dificuldade para o crítico de cinema se opor aos valores do nacional popular e à função do cineasta junto ao povo. A condenação não vinha só do núcleo do nacional popular na figura de Geraldo Sarno, mas do meio cultural. Provavelmente ao escrever, Jean-Claude Bernardet soubesse bem onde pisava ao comentar a cultura nacional popular. Em entrevista, ele afirmou que não havia problema algum em enfrentar o nacional popular em Opinião. Escolher publicar uma crítica aos cinemanovistas neste jornal ou em qualquer outro era questão de acaso. Por outro lado, os atritos internos do jornal no ano seguinte revelam a dificuldade de enfrentar de frente o tema do nacional popular em Opinião. Talvez pelo renome, Bernardet não sofresse nenhuma ressalva ao escrever sobre esses temas. De qualquer forma, ele é o grande pioneiro na crítica ao nacional popular tanto em Opinião quanto no debate do cinema.

O artigo Nordeste congelado pelo cinema não foi o único caso de desacordo de Bernardet com o tema da cultura popular na imprensa alternativa. Em suas anotações manuscritas, o crítico relatou a intervenção de um desconhecido durante o evento de lançamento de Movimento. A pessoa teria se levantado para dizer que não via diferença alguma entre Opinião e o novo jornal ${ }^{45}$. Para Bernardet, a frase foi colocada exclusivamente em termos de linguagem. Afinal não existia nenhum caráter popular no semanário. O interlocutor não explicou o que entendia por linguagem, nem qual

\footnotetext{
44 "Sobre o artigo de cultura popular, em Opinião". Cadernos de Anotações Manuscritos de Jean-Claude Bernardet. AJCB Pasta PI - 8 p. Arquivo Jean-Claude Bernardet. Centro de Documentação e Pesquisa da Cinemateca Brasileira.

${ }^{45}$ Cadernos de Anotações Manuscritos de Jean-Claude Bernardet. AJCB Pasta PI - 8 p. Caderno VII. P. 271. Data 13 jul. 1975. Arquivo Jean-Claude Bernardet. Centro de Documentação e Pesquisa da Cinemateca Brasileira.
} 
linguagem seria popular por definição. Nada teria sido dito sobre o preço do jornal, a perspectiva ideológica ou os temas abordados. Na opinião de Bernardet, a linguagem mais acessível seria a da ausência de posição política com uma perspectiva ideológica popular. Portanto, ele via o comentário como "farsante", porque seu objetivo seria o de transmitir uma determinada posição política de um grupo a uma camada de leitores populares. Escreve Bernardet: "Em última instância é a comunicação senão (...) ao ‘povo' de uma posição política e perspectiva ideológica que não sai do povo.” Para ele, um empreendimento popular tinha pouca relação com a acessibilidade à linguagem escrita. Além de tudo isso, para fazer uma imprensa popular seria preciso trabalhar com o feedback do povo, mas isso não existe. "O que estou escrevendo pode ser rapidamente taxado de espontaneista, cultuar o povo pelo povo (um pouco o que acho que foi $O$ amuleto de Ogum). Embora ache até saudável atualmente esta posição." Pensando em toda essa discussão, Bernardet fez uma sugestão "mais potencialista e dialética" numa reunião do jornal Movimento: fazer contatos com sindicatos que tenham jornais ou com associações de bairros, clubes de mulheres. A proposta seria colocar as matérias do jornal à disposição deles. O trabalho incluiria fazer pesquisas, reportagens e análises do interesse dos sindicatos a pedido desses movimentos. A descrição sintetiza a aproximação entre alguns sindicatos e cineastas, como Renato Tapajós, Sérgio Segall e Roberto Gervitz. Ou talvez antecipasse a ideia de imprensa basista. 


\subsection{Xica da Silva: a luta pelo poder}

A crítica de Opinião ao filme Xica da Silva (1976) de Carlos Diegues foi o mote para uma das maiores polêmicas culturais no final da década de setenta entre artistas e intelectuais de esquerda. Em 1978, Carlos Diegues cunhou o termo "patrulhas ideológicas" numa entrevista concedida a Pola Vartuck d'O Estado de S. Paulo ${ }^{46}$, durante o lançamento de Chuvas de verão (1977). Se o sentido inicial da palavra remete à polícia ideológica, Carlos Diegues aplicava o termo à esquerda radical por tentar submeter à arte aos imperativos políticos. A terminologia era entendida como conceito móvel, alargando o sentido de patrulha a múltiplos significados. Não demorou muito para vários artistas e intelectuais irem a público se declarar "patrulhados", seja por pessoas ou instituições, pela esquerda ou pela direita. Se os destinatários do debate eram muitos, como o próprio desenrolar provou, o cineasta tinha um alvo quando criou o termo. Os primeiros destinatários das condenações eram os críticos de Opinião e de Movimento ${ }^{47}$, que reprovaram Xica da Silva dois anos antes.

Sucesso de público, o filme foi bem recebido pela grande imprensa. A história da escrava alforriada que usava seus dotes sexuais para se tornar poderosa era a forma escolhida por Carlos Diegues para mostrar a subversão dos oprimidos em relação ao poder. O autor trazia a simbologia do modernismo e da carnavalização, quando os lados do oprimido e do opressor invertem-se bakhtianamente. Se o cineasta queria fazer uma crítica ao poder em múltiplas facetas, a imprensa alternativa não viu o filme do mesmo jeito. Três críticos de Opinião acusaram Diegues de se servir do apelo da comédia erótica para conquistar o público, trazendo de sola uma visão estereotipada e preconceituosa da mulher negra como objeto sexual.

Utilizamos um percurso metodológico semelhante ao de $O$ Amuleto de Ogum, isto é, cotejamos as declarações de Carlos Diegues com os comentários dos críticos de

\footnotetext{
46 Diegues, Carlos. Por um cinema popular sem ideologias. Entrevista concedida a Pola Vartuck. $O$ Estado de S. Paulo. p. 16, 31 ago. 1978.

${ }^{47}$ Roncari, Luís; Maar, Wolfgang. O novo samba enredo de Xica da Silva. Movimento. n. 65, p. 17, 27 set. 1976. Para os articulistas, o filme elogia a malandragem e o poder de sedução da escrava. Opera, portanto, uma ideologização pretensamente tropicalista que privilegia o conflito português e não o conflito entre senhor e escravo. O artigo sugere que Cacá Diegues é um instrumento ativo ou passivo do projeto do ISEB que fazia convergir nacionalismos de esquerda e de direita. O artigo foi publicado mais ou menos quinze dias antes do texto de Opinião.
} 
Opinião. Não procuramos por uma verdade dentro da materialidade do filme, afinal o objetivo de Diegues foi totalmente diferente da percepção dos críticos do jornal. Queremos entender as razões do posicionamento dos colaboradores do semanário, porque o lugar de onde eles falam altera a fruição e o entendimento do filme. Nossos comentários não são sobre a obra de Diegues, mas sobre a emergência de novos atores sociais em Opinião. A decomposição dos textos do semanário serve como a porta de entrada para acompanhar as mudanças em relação à cultura popular da seção Tendências e Cultura.

Indiretamente Opinião conseguiu criar uma polêmica que permaneceu por mais de um ano em pauta na imprensa. O caso das patrulhas ideológicas teria sido, segundo Marcos Napolitano (2006, 2011), um dos últimos debates da esquerda na área cultural daquele período. O tema surgiu como sintoma de uma crise maior na identidade da intelectualidade. Ela dava sinais de esgotamento em relação à proposta do intelectual se posicionar como porta voz dos interesses populares. Napolitano observa o episódio como um momento final da cultura engajada de esquerda e do estatuto do intelectual das décadas anteriores, já no contexto da abertura política.

Há em Opinião a emergência de um debate sobre o papel do intelectual-cineasta em relação à cultura popular. Entre os críticos convidados para participar da discussão, três não aceitaram um branco colocar-se como porta-voz das classes populares. O viés trazia o esgotamento da figura do intelectual engajado. Entre o lançamento de Xica e de Chuvas de verão, a discussão da esquerda tinha mudado bastante. Marcos Napolitano aponta que no final da década já era improvável encontrar um consenso mínimo em torno das tarefas culturais para uma luta democrática. Pensamos o debate de Opinião em torno de Xica como mais um componente da futura ruptura da frente oposicionista, cuja crise ficaria mais exposta tempos depois no sindicalismo e na organização partidária. $\mathrm{O}$ declínio da cultura engajada deixava nos atores sociais uma sensação de falta de rumo. Não havia mais uma visão homogênea do povo para emanar uma identidade nacional, nem uma crença numa linha evolutiva para chegar a uma estratégia política homogênea (Napolitano, 2011).

Ainda pensando no ambiente cultural do período, Carlos Diegues (2014) imaginou o enredo de Xica da Silva como uma fábula política. Ele queria romper com a melancolia de sua geração e proclamar o projeto de um cinema brasileiro nacional 
popular. Acreditava ainda na interpretação marxista de ver o imperialismo como inimigo principal e compôs os personagens com alguns atores sociais daquele período: o imperialismo brutal no conde português, a burguesia nacionalista e covarde no contratador, as classes médias serviçais no sargento, no tendente e no pároco, o intelectual revolucionário, e por último, o povo em Xica. Para Carlos Diegues (2014: 379) talvez não se tenha percebido "que não era de escravidão que o filme estava falando, mas do direito à felicidade em qualquer circunstância. Por que lamentar seria de esquerda e celebrar de direita?" O cineasta comentou que a carnavalização dos personagens permitia passar algumas ideias proibidas naquele momento. Se o filme celebrava a personagem que destrói relações sociais, a ideia era tratar um tema caro aos anos sessenta: o elogio ao sexo como forma superior das relações humanas. Numa nova fase, Diegues procuraria o "prazer" e a "alegria", porque para ele os dois não precisavam mais ficar sufocados por detrás das dores de um mundo que nunca será perfeito mesmo. Xica simbolizaria para o autor um exercício de preparação para a alegria de viver e para a democracia, já no contexto de abertura política.

Referindo-se em especial à crítica de Carlos Frederico em Opinião, que taxou Xica de pornochanchada, Carlos Diegues viu nessa atitude uma condenação ao sexo reprimido. A atitude seria de um conservadorismo moral, como se as relações sexuais na obra de arte só fossem respeitáveis se mostradas como dor, culpa, violência e metáfora do mal estar da sociedade. Ao contrário disso, ele queria "recuperar, contra a perversão moralista da pornochanchada, o sexo bem-humorado dos modernistas, uma brincadeira cheia de jogos e preguiça, circulação livre de corpos" (Diegues, 2014: 378).

O cineasta observa uma diferença entre os críticos da grande imprensa e da imprensa alternativa. A imprensa teria se esforçado para entender a novidade do filme. Enquanto isso, os críticos de Opinião teriam se chocado com a mudança que Xica representou para os "paradigmas do cinema brasileiro" e procuraram por clichês morais (Diegues, 2014: 393). Viria à tona o fantasma da instrumentalização política da obra de arte e a submissão aos interesses ideológicos de grupos e partidos. Para ele, o viés de Opinião foi autoritário e impôs um limite para a criação artística, quando defendeu a historiografia oficial e o tratamento convencional dos costumes.

Mas não foi só Opinião e Movimento que ficaram contra o filme. De acordo com o próprio autor, Alex Viany, Eduardo Escorel e Joaquim Pedro de Andrade deram 
declarações negativas sobre Xica. Para Diegues (2014: 395), o melhor texto publicado na imprensa foi o de Roberto Da Matta, porque o antropólogo explicou alguns mistérios da obra. O cineasta só não informou que o artigo de Da Mata foi publicado exatamente em Opinião, para não amenizar o peso das acusações ao semanário alternativo.

Se Xica da Silva provocou comentários negativos em Opinião, os filmes anteriores de Carlos Diegues quase não apareceram no jornal. Entre 1972 e a publicação do artigo sobre Xica em 1976, a equipe do semanário tinha mudado bastante. Trata-se da última fase do jornal. Jean-Claude Bernardet quase não escrevia mais, Sérgio Augusto também não. Contribuíam alguns críticos de maneira esporádica, como Carlos Frederico. Durante os anos de circulação do jornal, Carlos Diegues fez três filmes: Quando o carnaval chegar (1972), Joanna Francesa (1973) e Xica da Silva (1976). Somente este último recebeu uma crítica propriamente ${ }^{48}$ no jornal, mas com a nova equipe. Na fase anterior, Carlos Diegues também não recebeu elogios. Bernardet comentou Quando o carnaval chegar como uma chanchada ornamental, mas sequer fez referência ao nome do cineasta ${ }^{49}$. Enquanto isso, Joanna Francesa foi objeto apenas de uma entrevista, cheia de alfinetadas recíprocas entre Sérgio Augusto e o diretor ${ }^{50}$.

Xica da Silva ganha a capa de Opinião e um título que conta um pouco sobre os embates internos travados na seção, através das interrogações lançadas: Xica da Silva Genial? Racista? Pornochanchada? ${ }^{51}$ A disposição espacial das matérias não apresenta um crítico como representante do jornal, mas um conjunto de textos de segmentos de especialistas da sociedade: o cineasta Carlos Frederico, a historiadora Beatriz Nascimento, o sociólogo Carlos Hasenbalg, o escritor Antonio Callado e o antropólogo Roberto da Matta. Logo na apresentação, o jornal procura se eximir da responsabilidade em relação aos textos; tratando-os como "visões" dos convidados. O objetivo era "contribuir" para "aprofundar" e "ampliar" a polêmica, porque o filme provocou

\footnotetext{
${ }^{48} \mathrm{O}$ silêncio pode indicar duas coisas. Quando os críticos do Última Hora não gostavam de um filme brasileiro, ao invés de fazer um comentário negativo, não tocavam no assunto para não atrapalhar a produção (Bernardet, 1978). A segunda opção é que os críticos já tivessem escrito em outros locais sobre os filmes. Esse pode ter sido o caso de Joanna Francesa e de Quando o carnaval chegar. Augusto escreveu sobre os dois filmes em Veja, enquanto Jean-Claude Bernardet publicou um artigo sobre Joanna Francesa em Argumento (ver Bernardet, 1978).

${ }_{49}$ Bernardet, Jean-Claude. Chanchada, erotismo, cinema-empresa. Opinião. n. 25, p. 21, 23 a 29 abr. 1973.

${ }^{50}$ Augusto, Sérgio. O sol dos equívocos e dos acertos - entrevista com Cacá Diegues. Opinião. n. 40, p. 17, 13 a 20 ago. 1973. O texto é uma quase uma carta resposta de Diegues, que ficou chateado com os comentários nada elogiosos de Augusto sobre Joanna Francesa em Veja.

${ }^{51}$ Xica da Silva - genial? Racista? Digno do Oscar? Abacaxi? Opinião. n. 206, p. 18-21, 15 out. 1976.
} 
discussões desde o lançamento. Opinião não publicava na mesma edição tantos pontos de vista de diferentes críticos sobre um mesmo filme.

O cineasta marginal Carlos Frederico ${ }^{52}$ escolhe um título forte para sua crítica: Abacaxica. A palavra era comum na crítica de cinema das décadas anteriores quando o cinema brasileiro era tratado como um abacaxi. O texto dele é bem humorado e irônico ao extremo. Frederico chega a dar os parabéns pelo sucesso em meio a comentários bastante negativos. Ele começa o texto com uma comparação infundada entre Cinema Novo e pornochanchada:

"Xica da Silva, de Cacá Diegues, é o casamento oficial do cinema-novo com a pornochanchada, após o noivado (digno) de Guerra Conjugal, de Joaquim Pedro. Xica da Silva é também a primeira pornochanchada-'culturalista' (e 'histórica') do cinema brasileiro; a primeira a vestir embalagem de super-produção.

Por que pornochanchada? Porque, afinal, tudo gira em torno da cama e dos extraordinários dotes de Xica, queiram ou não os realizadores e incensadores do filme. Com as devidas proporções, a mesma história, as mesmas piadas, os mesmos traseiros e a mesma 'grossura' poderiam ser facilmente transplantadas pelo Mossy ou pelo Alcino Diniz para um motel da Barra, por exemplo...

Mas não há razão para muita surpresa diante de semelhante 'amigação'. Na realidade, existem muitos pontos de contato entre o cinema-novo e a pornochanchada sobretudo nos aspectos de linguagem e postura cinematográficas."

A comparação entre Cinema Novo e pornochanchada não se sustenta no texto. É mais uma provocação. Os comentários do autor podem ser lidos como parte da briga entre cinemanovistas e cineastas marginais. Contudo, para não desautorizá-lo em nenhum momento Frederico é apresentado como alguém do segundo grupo. Ele usa metade do texto só para explicar a comparação entre Cinema Novo e pornochanchada. Ela é vista como a "herdeira legítima" do Cinema Novo, onde encontra seus modelos e modismos. A argumentação parte de algumas inversões. Ignorando a preocupação estética do Cinema Novo, Carlos Frederico quer provar que os filmes têm falas em excesso. O objetivo é descaracterizar o Cinema Novo como linguagem cinematográfica. Segundo ele, o movimento foi copiado grosseiramente pelos fazedores de pornochanchadas porque tem a linguagem "mais falada" dos anos sessenta. Para provar

\footnotetext{
52 Frederico, Carlos. Abacaxica. Opinião. n. 206, p. 18-21, 15 out. 1976. Autor de A possuída dos mil demônios (1970) e de Lerfa-mu (1979), Carlos Frederico é autor de muitos curtas e média metragens. Foi produtor de Os homens que eu tive (1973) de Tereza Trautman e de alguns filmes da Boca do Lixo.
} 
a tese há um novo desvio na argumentação, que se volta à composição dos personagens e do enredo. Todas as ações seriam "explicadas" "verbalmente". Portanto, tanto os personagens do Cinema Novo quanto os da pornochanchada "são retilíneos, esquemáticos, estereotipados, superficiais, sem complexidade, sem 'vida"”.

No texto, o Cinema Marginal permanece como núcleo não citado dos que trabalham "a forma cinematográfica" sem roteiros "planificados". Enquanto isso, o Cinema Novo "era veículo para mensagens e ideias". Carlos Frederico explica que o movimento "é sempre o cinema como um veículo disto ou daquilo: nunca como um fenômeno em si”. A condenação à ligação entre arte e mercado era típica dos atores sociais contrários ao nacional popular. Para Frederico, o Cinema Novo aprende as lições de erotismo comercial, enquanto a pornochanchada procura aplicar os requintes estéticos cinemanovistas.

A questão central do artigo indiretamente gira em torno do espaço ocupado pelos cinemanovistas na Embrafilme e do auxílio dado pela empresa às pornochanchadas (Ver Capítulo 5). Vendo Xica como uma comédia erótica distribuída pela Embrafilme, Frederico traz a tona indiretamente o debate sobre a necessidade de apoio estatal a um grande lançamento comercial. Noutro artigo, ele irá retomar a questão com maior clareza ${ }^{53}$, reclamando dos benefícios dados às superproduções.

Se aqui Frederico ataca Xica por ser uma pornochanchada, depois ele irá defender Já não se faz mais amor como antigamente (1976) de Anselmo Duarte como comédia erótica sem piadas grosseiras e sem apelação à nudez ${ }^{54}$. Afinal a produção é de Anibal Massaini Neto. Neste caso, Frederico age como Jairo Ferreira, incentivando nas críticas a produção da Boca do Lixo da qual faz parte.

Carlos Frederico não se dedica à análise interna detalhada do filme. Ele não aceita o lado farsesco, visto como "equivocado", "teatral", "pretensioso", "ingênuo" e "acadêmico". "No máximo, acadêmico-tropicalista, para quem curte uma nostalgia". Frederico condena a complacência dos críticos com a "encenação tão escola-de-sambapra-turista-ver", parecida com a de Orfeu do carnaval (1959) de Marcel Camus. Analisando a recepção, o autor observa que o filme agradou a gregos e troianos,

\footnotetext{
${ }^{53}$ Frederico, Carlos. Festival de Gramado - guerras intestinas no cinema brasileiro. Opinião. n. 222, p. 20-1, 04 fev. 1977.

${ }^{54}$ Frederico, Carlos. Já não se faz mais amor como antigamente. Opinião. n. 228, p. 21, 18 mar. 1977.
} 
especialmente ao público "burguês", fascinado pela produção bem cuidada de época. Mas os elogios não vieram só da "classe média". O público "esclarecido" identificou Xica como produto cultural "posto que histórico". Contudo, o filme é tão "histórico" quanto "Independência ou morte" [1972 de Carlos Coimbra].

$\mathrm{Na}$ última parte do artigo, o autor procura a motivação de tantos elogios, vindos de todas as partes. Afinal, nem os clássicos do Cinema Novo receberam um coro de louvações e admirações tão rápido. Para Frederico, não há problema em realizar uma "super-produção bacana" como Xica. O que o incomodou foi ver a adesão dos críticos ao filme de Diegues como um marco e um caminho ao cinema brasileiro.

O texto tem outros dois alvos: o intelectual arauto e a massificação do mercado. Como representante da vanguarda, Frederico condena a "alienação massificada" que atingiu a "intelligentsia nativa". O último ponto de atrito do autor é a função dada à cultura popular. No papel "estúpido" da mulher negra, "Xica imita os ricos, os brancos, os déspotas, os poderosos, e curte adoidado ser como eles - e o filme aplaude, deslumbrado!" Nesse trecho é possível aproximar a crítica de Frederico com a de Cahiers du Cinéma em relação a Lacombe Lucien (1974) de Louis Malle (ver Capítulo 4). A publicação francesa criticava a lacuna entre a formação discursiva do personagem e do diretor, como se o realizador tivesse a obrigação de se separar da visão preconceituosa do personagem ou da trama. Nesse sentido, Carlos Diegues teria endossado as imagens da tela porque não criticou os personagens. Esse raciocínio fica claro na sequência, quando Frederico diz: "também não existe qualquer visão crítica sobre a personagem, embora ela seja extremamente dúbia, traidora, exibicionista, alienadora, e inconsequente". Se escrevesse sobre Lacombe, Frederico também iria destruir o filme de Malle, como fez Cahiers. Ele vê Xica e o cineasta como prolongamento um do outro "Mas, já que o próprio diretor do filme acredita que 'todo mundo tem obrigação de ser Xica da Silva; e tentar sê-lo' - o que dizer?"

Acompanhando o coro, o sociólogo Carlos Hasenbalg também condenou o filme 55. Mas o texto mais polêmico é o da historiadora e ativista do movimento negro Beatriz Nascimento, que também contesta Xica da Silva ${ }^{56}$. Duas afirmações desse artigo

\footnotetext{
55 Hasenbalg, Carlos. Copiando o senso comum. Opinião. n. 206, p. 19, 15 out. 1976. Segundo Napolitano (2011), na época Hasenbalg era doutorando em sociologia e ligado ao marxismo universitário. ${ }^{56}$ Nascimento, Beatriz. A senzala vista da casa grande. Opinião. n. 206, p. 20-21, 15 out. 1976.
} 
motivaram a declaração de Carlos Diegues sobre as patrulhas ideológicas ${ }^{57}$. O primeiro trecho em questão é realmente uma diatribe, bem ao gosto dos anos cinquenta: " $O$ senhor Carlos Diegues é senil em sua obra-prima (porque eu espero que ele não confeccione outra e já lhe concedo o fim da sua carreira cinematográfica)." $\mathrm{Na}$ sequência, Beatriz Nascimento declara: "Quanto a sua penetração enquanto discurso e comunicação o condenaríamos ao 'índex' das obras proibidas". Foi desta parte do artigo que Carlos Diegues tirou a comparação entre Beatriz Nascimento e a ação da censura, chamada de patrulha ideológica. Nem os textos mais radicais de Opinião chegaram a condenar a produção hollywoodiana ao índex. A diatribe se baseia num acirramento de posições, que tem relação com o lugar de origem. A autora do texto emerge como o próprio sujeito social; como a mulher negra ofendida pelo filme. Não se trata da opinião de um crítico de cinema. Esse é o principal motivo do atrito. Para Beatriz Nascimento, Xica da Silva tem um "humor barato e grosseiro em cima de estereótipos mais vulgares a respeito desse povo".

A argumentação de Nascimento gira em torno da veracidade histórica. A "Xica da História", segundo ela, não aparece em nenhum momento. Contudo não se trata de uma exigência de veracidade histórica na arte por parte de Beatriz Nascimento, porque ela reclama é da falta de conhecimento da cultura negra. Para a militante do movimento negro, Xica é um símbolo da raça negra. Ela não tinha o "comportamento infantil" mostrado no filme, mas era uma "mulher prepotente e dinâmica". O comportamento dela é típico da mulher africana e dos seus mitos religiosos. Carlos Diegues não entende desse assunto e achou "mais fácil" tratar Xica como "mito da sexualidade", declara.

A autora não fala em nome da veracidade histórica somente. Ela exige que o intelectual-cineasta respeite os mitos populares, tal como Nelson Pereira dos Santos dizia fazer. Ela quer a abolição dos estereótipos que prejudicam o dia a dia do seu povo. É como se parte da cultura popular surgisse na figura de Beatriz Nascimento para reclamar ao realizador a representação do povo negro. $\mathrm{O}$ debate dela não toma o ponto de vista da discussão artística, porque a motivação é a do movimento social: "Nesse momento", diz ela, "seu povo" procura se livrar exatamente desses estereótipos e Diegues atrapalha ao invés de ajudar. Este trecho implode a ideia do intelectual arauto

\footnotetext{
${ }^{57}$ Na entrevista a Vartuck, Diegues (2014: 422) conta que se referiu num dos momentos exatamente a esse trecho da crítica de Beatriz Nascimento: "Então qual é a diferença que existe entre o sujeito que te cassa os direitos políticos e outro que cassa os direitos profissionais de um cara fazer um filme?"
} 
como alguém capaz de transmitir a cultura popular. Diegues não deveria ter a pretensão de abordar tais temas porque não faz parte deste universo. Aqui há um limite muito tênue e polêmico entre a autonomia da arte e a recepção do público. Para Nascimento, colocar na tela um assunto tabu sem criticá-lo é endossar os preconceitos. Mais uma vez o imperativo político estava à frente da autonomia estética, num viés comum ao dos missivistas do jornal, como vimos.

Para provar a argumentação, Beatriz Nascimento vai até o enredo do filme. Ela coloca em prática a metodologia de Opinião de analisar o discurso político através do enredo das obras. Ao olhar somente para a trama do filme, a autora não analisa outras significações. Vê um reforço do "mito do senhor bondoso" com os escravos. Haveria "uma escravidão amena e divertida!", porque os portugueses são opressores e exploradores, mas são complacentes com os escravos. Seu ethos é de humanidade e reconhecimento dos negros. Do outro lado, os escravos são passivos, rebeldes, inconsequentes, mas são cheios de bondade e generosidade do Senhor. Com essa estratégia, segundo ela, o conflito racial fica escondido e só aparece nas pessoas insatisfeitas com o casamento ou com o emprego. Se é proibido a Xica ir ao mar ou entrar na igreja, é sempre o branco bondoso que resolve a situação. Nessa representação, o negro surge como alguém passivo, dócil e incapaz até de pensar. Continuando esse raciocínio, a autora observa um comportamento inconsequente em Xica. No único momento presencial de sexo, a personagem se apresenta "metálica" e "animalesca", "idiotizada na própria ação". Aparece somente a imagem do africano como "primitivo e selvagem". O argumento lembra de novo os textos de Cahiers sobre Lacombe Lucien. Para não ser acusado de compactuar com a imagem mostrada na tela, o cineasta deveria criticar explicitamente os personagens e a trama.

Dando continuidade a uma das formas de análise mais comuns em Opinião, Nascimento estabelece um prolongamento entre o diretor e o personagem. $\mathrm{O}$ personagem de Walmor Chagas vive angustiado no conflito entre o amor, o povo e a coroa, no papel de um intelectual burguês. "Será o imago do nosso cineasta em versão sec. XVIII?", se pergunta Nascimento. A conclusão não poderia ser outra. Pela comparação com Gilberto Freire, sutilmente Carlos Diegues é colocado ao lado da direita, num jornal de resistência. No prolongamento entre diretor e filme, Nascimento envereda pelo estudo psicológico do diretor: 
“(...) confesso que perdi as esperanças quanto à compreensão do intelectual branco brasileiro sobre a real história do negro. (...)

Talvez haja uma explicação para esse procedimento. Se o senhor Carlos Diegues descesse um pouco de sua onipotência e fizesse uma reflexão sobre si mesmo e a implicação da história do seu povo em si antes de confeccionar o filme, entenderia que, devido às relações sociais e culturais, ele como um homem branco brasileiro possui introjetado, de forma específica, o negro brasileiro, sua oposição em termos de homem e de raça. Mas ele, como a maioria dos seus iguais, deve ter um grande receio de descobrir esse ponto oculto. Deste modo, reprime-o dentro de si, e, ao se debruçar sobre um episódio da sua própria história, colocando o negro (Xica da Silva - Teodoro) como seu herói, tripudia profundamente sobre ele."

Nascimento acredita na inaptidão do intelectual arauto em representar com exatidão a cultura popular. Depois das muitas declarações de Nelson Pereira dos Santos sobre a possibilidade de colocar na tela a cultura popular sem preconceitos, um único comentário desmonta todas as teorias. Para Nascimento, o cineasta não está habilitado a falar pelo povo. Pela primeira vez em Opinião se ouve a voz de alguém atrelado à própria cultura popular. Ela evoca sua condição de mulher negra e militante do movimento para falar com mais autoridade do que Diegues. É como se fosse mais importante no debate seu lugar de origem do que a prática artística do diretor. A historiadora coloca-se como ator social legítimo, não como intermediária. Se os umbandistas entrevistados por Jean-Claude Bernardet só reclamaram da falta de veracidade histórica de algumas cenas de Amuleto ${ }^{58}$, Beatriz Nascimento coloca em xeque a própria representação do cinema. No fundo, ela queria um personagem positivo no filme, tal como se exigia nos anos cinquenta. Se Diegues tivesse "carinho" com os personagens e se identificasse com o herói, Xica da Silva apresentaria uma alternativa, por exemplo, na fuga para o quilombo.

Na sequência, ela se pergunta porquê Diegues "debocha" da cultura popular. Desta interrogação inicial, Beatriz Nascimento coloca em questão toda a intelectualidade: "Qual o impasse cultural em que está mergulhada a classe intelectual brasileira?" Se o debate retoma a falta de autenticidade do cineasta para tratar a cultura popular, o viés é de contestação: "Retira-se um episódio da História do Brasil, coloca-se acriticamente de forma que reforce todos os preconceitos e atira-se ao grande público,

\footnotetext{
${ }^{58}$ Bernardet, Jean-Claude. Os babalaôs resistem aos sociólogos. Opinião. n. 121, p. 24, 28 fev. 1975.
} 
entendendo-se que isto é forma de fazer 'cultura' popular, extraída da própria tradição e compreensão do fenômeno pelo povo".

Se o artigo tira o cineasta do pedestal de arauto, a própria cultural popular aparece com papel relativo. Nascimento foge completamente de uma perspectiva de autenticidade do povo em relação a si mesmo. Nem a ele cabe uma visão sem contradições: "mas quem disse, senhor Diegues, que a tradição e compreensão do fenômeno por esta entidade chamada povo é a mais justa, a mais honesta, a menos preconceituosa? Povo é monolítico e bom por essência?" Se o ensaio de Jean-Claude Bernardet sobre Amuleto abriu as alas ao explicar que a cultura popular não é composta de cristais límpidos, Beatriz Nascimento aprofunda mais a fenda, trazendo um argumento inovador ao jornal.

Se Beatriz Nascimento vê um desprezo do intelectual pela cultura popular, a historiadora traz a revanche do próprio povo na mesma chave: "o senhor me faz pensar que sua classe de acordo com a sua tradição está dentro da Casa Grande jogando restos de comida na Senzala. (...) Por favor, nos esqueça, a nós negros”. Isto é, o negro não precisa do intelectual porque pensa sozinho. Neste texto, Beatriz surge como um preâmbulo do povo como ator social na crítica de cinema. Ela é ao mesmo tempo historiadora e mulher negra. Reivindica sua autoridade para contestar um cineasta. Dois anos antes, ela fez o prelúdio de um debate que explodiu em 1978 com a eclosão dos movimentos sociais ${ }^{59}$. Naquele mesmo ano, houve, por exemplo, a unificação dos movimentos negros (Singer, Brant, 1982). Neste caso em especial, Opinião serviu como uma ponte para o início de uma discussão na opinião pública. Era em instituições sociais como esta, que muitas associações encontraram uma primeira acolhida para abrir seu espaço de atuação.

Algumas ideias apresentadas por Beatriz Nascimento e por Carlos Frederico encaminhavam-se para uma futura pauta comum à Nova Esquerda. Trata-se de um preâmbulo crítico ao nacional popular, que surge com força no final dos anos setenta. Há neste episódio um momento de encontro entre a ala de Opinião contrária ao nacional popular, a vanguarda e um movimento social emergente. Todos eles condenavam a

\footnotetext{
${ }^{59}$ Durante a maior parte do período ditatorial, os movimentos populares foram impedidos de vir à tona, pela repressão e pela censura. Reunidos num primeiro momento em associações comunitárias e em movimentos de base, as mobilizações de cunho mais nitidamente social aumentaram a partir de 1978, revelando a insatisfação com os salários e com as condições de vida (Singer, Brant, 1982).
} 
velha esquerda nacionalista e comunista. A política frentista de alianças não era vista como algo positivo, porque ela era usada pelo regime militar e pelo mercado. Havia uma sintonia maior entre esses três personagens na condenação à massificação da cultura e ao mercado. Nos dois casos se via uma forma autoritária de olhar o popular. Os críticos de Xica defendem o elogio à experiência cultural do povo e diluem o papel do intelectual como arauto da consciência popular.

Se Carlos Diegues achou que o tema da subversão da ordem estabelecida e da contracultura seria visto como algo positivo entre os críticos de cinema, os convidados do jornal não viram prazer algum no filme. Os três críticos de Opinião contrários a Xica não aceitavam nem um consenso mínimo para o debate. Havia neles uma oposição às regras do mercado, ao papel do intelectual, além de um desprezo ao prestígio dos diretores. A questão principal emergente era a representação da cultura popular.

Se os intelectuais e artistas dos anos setenta definiam as patrulhas ideológicas com os mais diversos sentidos, aqui é possível trazer mais uma nuance. Diegues declarava que havia nessa esquerda ortodoxa uma espécie de religiosidade, que preferia o sofrimento ao prazer. Mas a condenação de Opinião não partiu de nenhum núcleo ortodoxo da esquerda, mas de sua oposição, seja no Cinema Marginal ou no movimento social. Talvez a riqueza do filme tenha sido permitir essas duas leituras. Contudo, os atores sociais envolvidos no debate não são, de forma alguma, os “patrulheiros"-padrão. Ao contrário. Diegues enxergava um patrulheiro, mas eclodia na sua frente ao mesmo tempo uma mediadora do povo e uma representante legítima do movimento negro. Falando com suas próprias rédeas, Beatriz Nascimento não estava interessada em discutir a crítica de cinema enquanto arte, mas como forma de reivindicação política. Está aí mais uma forma de inversão de significados. A patrulheira de Diegues estava autorizada a falar e se investe desse papel, não do ponto de vista estético, mas do ponto de vista social.

Contudo, não era só esse lado que existia em Opinião. Tanto Antonio Callado ${ }^{60}$ quanto Roberto da Matta fizeram comentários positivos ao filme. Não nos concentramos nesses dois textos, porque apresentamos a razão da polêmica em torno do tema das patrulhas ideológicas. O primeiro artigo apresenta nuances laudatórias, concluindo que Zezé Mota e Xica da Silva são a mesma pessoa. Enquanto isso, a

\footnotetext{
${ }^{60}$ Callado, Antonio. Bem nascido e bem dotado. Opinião. Opinião. n. 206, p. 20, 15 out. 1976.
} 
argumentação de Da Matta é bakhtiniana ao ver o carnaval como momento de inversão do forte pelo fraco, que consegue subverter a ordem do mundo e do poder ${ }^{61}$. Mas sutilmente no final do artigo, o antropólogo apela para a entrada em cena do intelectual arauto. Segundo Da Matta, a força mágica de Xica não consegue consolidar uma inversão do mundo. Esse processo só é concretizado quando ela encontra no final do filme o rebelde revolucionário no convento: "É preciso que tal força esteja alijada aquela que emana do revolucionário, aquele que se rebela contra as regras do jogo social. A grande mensagem desse filme foi acasalar o poder dos fracos (poder místico da esperança) com o poder secular do teórico revoltado”. Estava selada assim no caso de Xica a briga interna entre o nacional popular e a arte do atrito em Opinião.

A disposição balanceada de textos contrários e a favor do filme criou em Opinião uma polêmica bem fundamentada. Portanto, tachar Opinião de patrulha não se sustenta, porque a equipe da seção de cultura estava exatamente no sentido contrário. Conseguir uma unanimidade ao tratar da cultura popular quase no alvorecer da entrada em cena dos movimentos sociais era uma utopia. No fundo, a reclamação de Carlos Diegues tem um endereço mais específico: as fissuras da esquerda dentro da redação do jornal, que é o tema do próximo tópico.

${ }^{61}$ Matta, Roberto da. A hierarquia e o poder dos fracos. Opinião. n. 206, p. 19, 15 out. 1976. 


\subsection{Júlio César Montenegro: a Frente do Atrito}

O episódio de Xica da Silva na redação de Opinião surgiu de forma espontânea. Beatriz Nascimento foi até o jornal revoltada com o último lançamento de Cacá Diegues. Para a militante do movimento negro, era mais um filme dizendo que a mulher negra subiu pela cama. O editor Júlio César Montenegro lembra que ficou "encantado" com a "revolta" dela. Na hora ele se indagou: "Como pensa o negro?" Sem saber responder à pergunta, o editor viu no episódio uma oportunidade para mostrar esse lado no jornal. Sem hesitar, Montenegro prometeu publicar o texto, se Beatriz escrevesse. A opinião dele era que Diegues recebeu para fazer um filme "vitrine". Se todos falavam bem de Xica, o editor de cultura de Opinião queria fazer o contraponto. Afinal, a ideia da seção cultural nessa época era abrir polêmicas e questionar.

Não foi só Beatriz Nascimento quem se dirigiu à redação de Opinião. O cineasta marginal Carlos Frederico viu Xica da Silva e detestou. Achou um cartão postal. Os dois vieram "feridos" ao jornal, relembra Montenegro. Depois desse episódio, Carlos Frederico passou a colaborar com a seção cultural de Opinião. Escreveu mais três artigos. Como havia poucos recursos para pagar os colaboradores, a saída era trazer os conhecidos para participar. Montenegro convidava quem ele tinha certeza que escreveria. Desse primeiro contato com o cineasta, surgiu anos depois o convite para o editor de Opinião fazer uma ponta como ator em Lerfa mú (1979) do mesmo Frederico.

Nessa época o jornal era "cheio de vida", explica Montenegro. As matérias incentivavam a participação do público por cartas. Ele fazia questão de reproduzir os textos dos leitores na íntegra, sem cortar nem alterar nada. Depois Montenegro passou a publicar o material da seção de cartas como artigos de colaboradores. O jornal "fervia" com a "garotada", mas ficava péssimo com os "medalhões da esquerda", resume o exeditor. Ele incorporou este termo do conto Teoria dos Medalhões de Machado de Assis (1994) ${ }^{62}$ para referir-se a Ferreira Gullar e Fernando Peixoto, que recebiam o apoio de Carlos Diegues e Nelson Werneck Sodré no jornal. O primeiro publicava em Opinião, mesmo exilado, graças à ideia de Sérgio Augusto de substituir seu prenome por Frederico e depois colocar o nome verdadeiro na gráfica. Fernando Peixoto não era

\footnotetext{
${ }^{62} \mathrm{O}$ conto é escrito na forma de um diálogo. Na história, o pai sugere ao filho tornar-se um medalhão. Ensinando a arte da política, ele explica como o filho deve lançar mão da publicidade, das amizades e da imprensa para se consagrar, nutrindo-se sempre de ideias alheias e de fórmulas consagradas.
} 
somente crítico de teatro de Opinião, mas também intelectual e membro do Partido Comunista Brasileiro.

O trotskista Júlio César Montenegro trazia "sangue novo" para o jornal. Na área de literatura, o núcleo da PUC do Rio de Janeiro se aproximava do semanário, trazendo líderes estudantis, líderes clandestinos, participantes de grupos de estudo, poetas marginais (Moriconi, 1996). A equipe de colaboradores externos era grande, enquanto a lista de pessoas que ajudavam diariamente e davam sustentação a Montenegro é menor: Wilson Nunes Coutinho, Katia Muricy, Heloisa Buarque de Hollanda, Cacaso, Heloisa Daddario, José Castelo, Laymert Garcia dos Santos. Dentro da redação, Ronaldo Brito, Heloisa Daddario e José Castelo. De Paris, Laymert Garcia contribuía. Montenegro contava com o escultor Zé Resende de São Paulo e Waltércio Caldas Jr. do Rio para discutir e fazer sugestões, além dos ilustradores Diter Stein, Rico Lins, Cassio Loredano e Leib. Nem sempre o dia a dia era feito só de elogios. As ilustrações eram obrigadas a lidar com a censura e causavam críticas internas porque eram consideradas de difícil entendimento ${ }^{63}$.

Montenegro conta que a figura dele crescia entre os colegas porque a equipe estava preocupada com o destino da cultura no dia a dia do jornal. Ronaldo Britto o elegeu como líder. As últimas reuniões do racha de 1975 aconteciam exatamente na casa do editor de cultura. Talvez esse afastamento progressivo da equipe de cultura tenha surgido antes da criação de Movimento, quando o coletivo negociava a saída de Raimundo Pereira de Opinião. Kucinski (1991) relembra que o conselho encarregado de representar todas as tendências do jornal rompeu exatamente por causa de uma divergência com o grupo da cultura sobre como gerir o novo jornal de propriedade coletiva de jornalistas. Tendências e Cultura defendia a independência total das seções e a ausência de um comando central. A outra ala queria uma estrutura centralizada. Para Raimundo Pereira (Azevedo, 2011), o editor deveria ter o poder de ler e vetar as matérias antes da publicação. Enquanto isso, Montenegro defendia que o editor-chefe só poderia ter acesso às matérias após a publicação. Pela pequena diferença de um voto, o grupo de cultura teria perdido a votação e abandonado o conselho (Azevedo, 2011).

\footnotetext{
${ }^{63}$ Vani Kenski (1990) analisou a criatividade e as estratégias de transmissão de sentido das ilustrações de Opinião.
} 
Essa disputa com a seção de cultura de Opinião cresceu especialmente na última fase do jornal. A redação tentava colocar em prática alguns elementos de uma política de auto-gestão. As pessoas julgavam-se donas do jornal, porque Gasparian pagava salários muito abaixo do mercado. Durante o pacto feito com Raimundo Pereira, Gasparian deu grande liberdade à equipe. Mas no período final essa linha de manobra se tornava mais difícil. Raramente o proprietário participava das reuniões de pauta. Marcos Ribas de Farias explica que Gasparian nunca se metia de frente, mas entrava por caminhos indiretos. Um dia, ele chamou o editor de cultura para dizer que Montenegro não deveria publicar os textos sobre Xica da Silva. O proprietário do jornal ficou irritadíssimo com a palavra abacaxica. Era o pior que se poderia dizer de um filme. Gasparian não queria divulgar os textos para não ofender Carlos Diegues. Mesmo assim, Montenegro publicou as críticas. Além disso, o editor de cultura escolheu imagens das edições com "os artigos encomendados" de Gasparian para a capa do jornal. Era uma clara provocação, mas provavelmente a primeira página tenha sido alterada, porque a edição nas bancas trouxe apenas o busto de Xica da Silva em tons de preto e branco com abacaxis e bananas desenhados. Em contrapartida, Gasparian solicitou dois artigos dos "amigos" Antonio Callado e Roberto da Matta para defender o filme e contrabalancear com as críticas contrárias à obra. O equilíbrio entre textos favoráveis e desfavoráveis decorre desse processo. Segundo Montenegro, as críticas sobre Xica da Silva geraram muita repercussão na época. Ele lembra que publicar um artigo em Opinião dava aos autores muita visibilidade na opinião pública e provavelmente isso tenha acontecido com Beatriz Nascimento.

A reação de Carlos Diegues foi forte. Montenegro relembra que ele mandou uma carta "irada", impublicável por causa dos palavrões. O editor queria publicar a resposta do cineasta, mas Gasparian não deixou ${ }^{64}$. Se Xica da Silva causou toda essa polêmica em outubro de 1976, este não foi o primeiro caso de desavença interna. Os entrevistados contam que meses antes houve um confronto por causa da peça de teatro Gota d'água de Chico Buarque e Paulo Pontes. O artigo teve péssima repercussão na redação e a matéria não foi publicada ${ }^{65}$. Em janeiro de 1976, saiu a crítica de Macksen Luís

\footnotetext{
${ }^{64}$ Glauber Rocha contou que a carta foi devolvida por Gasparian com um bilhete afirmando que a resposta não poderia ser publicada no jornal, nem ficar nos arquivos pessoais dele. A proposta da carta, segundo Glauber Rocha, seria criar um debate ideológico em outro nível (Hollanda; Pereira, 1980).

${ }^{65}$ Não há consenso entre os entrevistados sobre quem foi o autor do artigo vetado. Segundo Montenegro, o artigo de Opinião questionava a entrada de Bibi Ferreira no palco como estrela, quando a peça era para criticar a burguesia. Portanto, a trama não trabalhava a coletividade, mas trazia personagens excepcionais.
} 
elogiando ao máximo Gota d'água ${ }^{66}$. Se o texto sobre Gota d'água não foi publicado em Opinião, a seção de teatro também foi responsável por fazer uma oposição ao nacional popular na figura de José Arrabal. Nos artigos, o crítico de teatro fugia dos elogios aos autores consagrados Oduvaldo Vianna Filho e Gianfrancesco Guarnieri ${ }^{67}$ (Ver Anexo em anexo).

Naquela época, Júlio César Montenegro foi assistir ao espetáculo e detestou por causa do nacional popular. Tudo era "muito PCB" e "extremamente autoritário". Naquela noite, Montenegro foi o único a não se levantar quando a peça terminou. "Achei chato, esquerda babaca, era político. Não aplaudi. Achei que era político e não me levantei". O editor de cultura sabia que não adiantaria pedir um texto a Fernando Peixoto, porque o crítico era totalmente favorável ao nacional popular. Pediu para José Arrabal escrever, porque ele faria o texto como Montenegro queria. O texto foi publicado em abril de 1976 no Jornal de Debates de propriedade de Fernando Gasparian, quando Montenegro era redator-chefe [ver Anexo].

Criticar Chico Buarque criou "um problema”, relembra Montenegro. O dono do jornal o chamou para conversar, mas não o demitiu. Gasparian relatou a Vani Kenski (1990) que a equipe criticava pessoas ilustres e aliadas do jornal. Por isso, ele teria sido obrigado a interferir diretamente no dia a dia. Segundo Bernardo Kucinski (2003: 336), a redação decidia tudo por votação, e Gasparian não pôde recompor uma equipe alinhada ao seu lado. Os conflitos ressurgiam na cobertura de cultura por causa do apoio da corrente ligada ao $\mathrm{PCB}{ }^{68}$. O proprietário não conseguia substituir os “dissidentes da cultura", que insistiam na liberdade total para escrever. "Gasparian não admitia a crítica a seus amigos num jornal sob censura que do seu ponto de vista deveria priorizar a

José Arrabal contou em entrevista que escreveu o texto sobre Gota d'água especialmente para o Jornal de Debates. O artigo ocasionou muita repercussão após a publicação. Sobre as polêmicas internas da seção de teatro, ver o tópico sobre o crítico José Arrabal no Anexo. Nessa época, Montenegro estava numa fase de transição entre o Jornal de Debates e o retorno ao Opinião.

${ }^{66}$ Luiz, Macksen. A medeia da marginalia. Opinião. n. 167, p. 22, 16 jan. 1976.

${ }^{67}$ José Arrabal escreveu mais de um artigo contrário ao nacional popular no teatro. Por exemplo, a Longa noite de Oduvaldo, em referência à peça A longa noite de cristal (n. 202, p. 25) ou sobre Ponto de Partida de Gianfrancesco Guarnieri (n. 211, p. 21).

68 Segundo Bernardo Kucinski (1991), o jornal tinha contato com o PCB através da "Frente de Entendimento" comandada por Luís Maranhão. O objetivo era acompanhar e apoiar a imprensa, especialmente os jornais alternativos. Outros membros do partido declararam a Kucinski que não tinham contato com o jornal e não gostavam muitas vezes da visão esquerdista de Opinião. Na fase final do jornal, Gasparian teria se aproximado de alguns dirigentes do PCB para tentar exercer algum de controle na linha política do jornal. Desde os anos cinquenta, a ideia de frente jornalística estava presente em algumas publicações relacionadas ao PC, como Fundamentos, Para todos, Horizonte (Rubim, 1987). Essas publicações tornavam-se centro aglutinadores de intelectuais. 
crítica ao poder". Naquele momento, a redação "estava cansada da resistência pela resistência" e levantava novas bandeiras, como a crítica à complacência na área cultural.

A disputa entre a arte engajada e a crítica ao nacional popular também se polarizava no jornal. De acordo com Jean-Claude Bernardet, Fernando Peixoto estaria ao lado do violão e de Chico Buarque, enquanto Júlio César Montenegro preferia a guitarra elétrica e Caetano Veloso. Essa disputa foi crescendo na redação. Gasparian não queria enfrentar a ala dos "medalhões da esquerda" porque era um "jogo pesado", resume Montenegro. Segundo ele, "Foram para cima do Gasparian nos esculhambando", mas "essa não foi a minha primeira briga com a intelligentsia brasileira", nem foi a primeira vez que "esculhambei os intelectuais". A luta travada em Opinião não era uma questão pessoal contra algumas figuras, mas o acirramento político sobre as formas de realizar a resistência dentro do semanário.

Em meio ao clima de confronto nas últimas edições do jornal, Gasparian chamou Montenegro para conversar. Explicou que "eles" não continuariam a escrever, se o editor de cultura ficasse no jornal. Cheia de "apadrinhamentos", a cena cultural brasileira "preferiu acertar com o patrão a minha demissão", conta ele. Gasparian o demitiu, convidando-o a sair. Muitos colegas deixaram o semanário em "solidariedade à defenestração". Depois de duas ou três edições, o jornal fechou. Segundo Montenegro, o motivo não foi a censura, mas o "confronto com a redação". A briga final teria ocorrido em torno do problema de ter um "único comando" na seção Tendências \& Cultura. Num texto de maio de 2002, Montenegro expôs o que aconteceu nos bastidores da matéria sobre Xica da Silva ${ }^{69}$ :

\section{“Cacá no ventilador}

As recentes erupções de Cacá Diegues em defesa de seus negócios nas áreas de Cultura e Artes Ltda me lembram ataques semelhantes quando ele lançou o filme Xica da Silva e eu era editor de Tendências e Cultura do Opinião (seminário dos anos 70 financiado pelo milionário Fernando Gasparian, recém-chegado de exílio na Inglaterra, para lutar contra a ditadura e abrir novamente um caminho para ele na cena nacional. No Opinião escreveram estrelas como Fernando Henrique Cardoso e pessoas que mantiveram a integridade como Otto Maria Carpeaux, Jean-Claude Bernardet e outras).

Mal estreara Xica da Silva e apareceu no Opinião uma professora universitária negra e linda, Beatriz Nascimento, revoltada com o filme que, segundo ela, mais uma

\footnotetext{
${ }^{69} \mathrm{O}$ texto foi enviado e publicado numa revista de grande circulação nacional.
} 
vez mostrara uma negra usando o sexo para ascender socialmente. Veio também um cineasta, Carlos Frederico, com um artigo intitulado Abacaxica.

Preocupado com a frente-única-contra-a-ditadura o dono do Opinião, com intelectuais amigos dele, conseguiu artigos favoráveis ao filme que foram publicados junto com os desfavoráveis no mesmo número em que a capa era sobre a obra de Cacá.

Em resposta à tentativa salomônica de apaziguá-lo, Cacá mandou uma carta, segundo Gasparian, impublicável pelos vários palavrões. Cheia de compadrios, de apadrinhamentos, patotas, de curriolas, a cena-cultural-brasileira-que-aparece-mais-namídia se sentiu incomodada com os artigos polêmicos e descompromissados que publicávamos e, como Cacá, desacostumados/inseguros com a discussão PÚBLICA de diferentes visões \& concepções, preferiu um entendimento com o patrão, o dono do jornal, a uma discussão com os empregados, nós jornalistas.

Para evitar que Opinião continuasse incomodando aos senhores da cultura, Gasparian exigiu minha demissão. Frequentadora, senão dos salões, das bocas livres da Casa Grande, a esquerda que conta-e-faz-conta exigiu minha saída da editoria. A redação, que já sofria com a censura da ditadura, não aceitou a censura de nossos aliados e se demitiu solidariamente. Um ou dois números depois Opinião deixou de circular. Ganharam então os cacás da cultura. E agora?"

A demissão foi o resultado da "aliança de forças em torno de Gasparian". Montenegro explicou que a pressão era conjunta. Portanto, a ação não foi feita por uma pessoa em especial, porque sozinho cada um não tinha peso. A força vinha quando estavam juntos; seria como uma ameaça sob a forma de um "temor", não de uma "execução". As figuras importantes escreviam de graça, e Gasparian pedia muitos textos. Na verdade, o proprietário de Opinião respeitava seus aliados e não queria prescindir dessas relações. Isso não significava um controle partidário ou algo do tipo. O grupo queria que a imprensa falasse bem do nacional popular, porque eles produziam para a "burguesia". O objetivo era ter a imprensa favorável, sem colocar as ideias em xeque. Para Montenegro, eles "queriam repercussão, queriam acontecer". Enquanto isso, Gasparian sentia que perdia o controle porque "as pessoas estavam se juntando e formando uma corrente". A existência de uma esquerda crítica atrapalharia a luta comum contra a ditadura. Por isso, o intuito foi "matar uma semente que estava nascendo". Para Montenegro, eles não queriam dividir porque estavam no comando, mas o processo de divisão já estava em curso.

Xica da Silva e Gota d'água podem ter sido os maiores confrontos internos da seção cultural, mas não foram os únicos. Júlio César Montenegro organizou uma série sobre Jornalismo Cultural para analisar o esquema de artes e espetáculos em 
pormenores ${ }^{70}$. Os textos revelavam um pouco dos bastidores do próprio Opinião. Para esta coletânea, Montenegro solicitou um artigo a Jean-Claude Bernardet, que deixou Gasparian muito irritado. O texto explicava que o tom acadêmico dos jornais facilitava passar pontos de vista opostos aos da chefia ${ }^{71}$. Quando o texto era claro nas explicações, havia atritos. Quando as opiniões estavam diluídas, mesmo com divergência de opiniões, os artigos saiam. Portanto, toda essa série de confrontos contínuos culminou na demissão de Montenegro nas últimas edições.

Uma edição antes do artigo de Bernardet, Opinião publicou uma carta com um visível nome falso: Gregório Alves Guerra. O missivista expunha a disputa interna do jornal. Além disso, falava dos editores com intimidade e no final mandava beijos para a equipe $^{72}$. A autora da carta é, na verdade, Tânia Brandão da Silva ${ }^{73}$. Ela declara sua preferência pela "arte do atrito" de Júlio César Montenegro com "boas risadas", numa "tendência leve e brincalhona", em relação à arte "embolorada" do engajamento. Era mais um ataque ao nacional popular, agora endereçado pelos leitores. $\mathrm{O}$ artigo foge de uma dicotomia entre a arte engajada e a contracultura ${ }^{74}$, porque é necessário ter um esforço permanente de compreensão da existência das duas tendências. A missivista reconhece a necessidade de ambas existirem. Não se deve dividi-las entre "más e espúrias", "dignas e boas" porque a supressão de uma significaria uma "postura fascista". Se o artigo tenta equilibrar os dois lados da resistência, ao mesmo tempo não esconde as próprias preferências. Montenegro com sua "arte do atrito" e com seu trabalho transformador tem maior alcance crítico. Esse lado "permite hoje um trabalho mais denso, menos circular, mais transformador, numa escala bem restrita, do universo ideológico que a envolve.” A análise não vem à tona sem críticas. Para a missivista, o viés do atrito permite à pequena burguesia impotente uma forma de consolo nostálgico para exercitar seu poder. $\mathrm{O}$ artigo, inclusive, antecipa o choque entre as duas tendências

\footnotetext{
${ }^{70}$ Brito, Ronaldo. Jornalismo cultural - entre os spots e as academias. Opinião. n. 219, p, 20, 14 jan. 1977. Montenegro, Júlio César. O refresco da cultura. Opinião. n. 219, p, 21, 14 jan. 1977. Bernardet, Jean-Claude. Jornalismo cultural - de Bourdieu a Cid Moreira. Opinião. n. 223, p. 24, 11 fev. 1977.

${ }^{71}$ Bernardet, Jean-Claude. Jornalismo cultural - de Bourdieu a Cid Moreira. Opinião. n. 223, p. 24, 11 fev. 1977.

${ }^{72}$ Guerra, Gregório Alves (pseudônimo de Tânia Brandão da Silva). (Jornalismo Cultural) Acadêmico e mundano, embora crítico. Opinião. n. 222, p. 24, 04 fev. 1977.

${ }^{73} \mathrm{O}$ tom pessoal da carta, mandando beijos à equipe com grande intimidade, nos intrigou para descobrir a autoria. Relendo o texto, Júlio César Montenegro lembrou que se tratava de Tânia Brandão da Silva, docente da Universidade do Rio de Janeiro. Na época, ele também ficou intrigado com o pseudônimo. Só poderia ser alguém conhecido, porque o missivista o tratava pelo primeiro nome. Tempo depois, Tânia Brandão confessou-se a autora do artigo. Ela nos confirmou a autoria da carta.

${ }^{74}$ Essa necessidade de evitar as dicotomias entre nacional popular e contracultura é observada décadas depois por Marcos Napolitano (2011).
} 
que ocorreu semanas depois. Tentando minimizar as disputas internas, a carta explica que a arte do atrito não pode bater de frente, se o desejo é o debate. O modelo para o equilíbrio seria exatamente Opinião, que neutraliza as controversas. E termina: "Continuem, o Brasil conta com vocês". Triste ironia porque o jornal morreu edições depois por causa do choque entre as duas alas.

Nesta mesma edição, a ala contrária atacou com os elogios de Maria Elisabeth Viviane às peças: Gota d'água de Paulo Pontes e Chico Buarque, O último carro de João das Neves e Ponto de Partida de Gianfrancesco Guarnieri ${ }^{75}$. Elisabeth defendia os três dramaturgos em nome da união da esquerda. Criticar qualquer um deles seria uma postura "radical" e "nociva" para "o momento brasileiro". Respondendo às críticas internas, a autora condena os setores da esquerda que "engolidos na política das massas" acusavam peças progressistas de serem populistas, paternalistas e didáticas.

$\mathrm{Na}$ edição seguinte, mais um assunto polêmico surgia com o texto $O s$ intelectuais e o Estado ${ }^{76}$. Este único artigo revela mais disputas e fissuras sobre a aproximação entre intelectuais e Estado do que todos os artigos de cinema de Opinião. Há uma postura condenatória à aproximação dos intelectuais com o Estado, mas o tom é problematizante.

O nome de Montenegro permaneceu como editor até o número 228. Na edição seguinte, o quadro com a equipe desapareceu. Provavelmente a demissão tenha se dado entre essas duas semanas. No número seguinte (n. 230), a apresentação da equipe voltou, mas não há nem o nome de Montenegro, nem o dos demais editores ${ }^{77}$. Nessa época, Fernando Gasparian tentou colocar Ferreira Gullar como editor-chefe, quando ele retornava do exílio, mas o processo não deu certo (Kucinski, 1991).

Mesmo após a saída de Montenegro, a disputa interna surgia nas páginas do jornal. Mais uma vez o palco para a discussão seria a seção de cartas. Por causa do artigo de Maria Elisabeth Viviane, Jean-Claude Bernardet enviou uma carta ao jornal,

\footnotetext{
${ }^{75}$ Viviane, Maria Elisabeth. Paulo Pontes, João das Neves e Guarnieri. n. 226, p. 21, 04 mar. 1977

76 Coelho, Tânia; Fortes, Paulo; Penido, Stella, Branco, José Castello. Os intelectuais e o Estado. Opinião. n 227, p. 3-5, 11. mar. 1977.

${ }^{77}$ Provavelmente tenha existido uma segundo motivação para a demissão dos editores de outras seções. Segundo Kucinski (1991), se aproximava o mês de abril e a data do dissídio coletivo dos jornalistas do Rio de Janeiro. Gasparian decidiu não dar os aumentos e assinou a carta de demissão dos principais jornalistas. Após a saída de Montenegro, Gasparian teria começado a ler todas as matérias antes da publicação.
} 
porque foi citado para endossar ideias com as quais ele não concordava ${ }^{78}$. Maria Elisabeth Viviane se desculpou se a redação deu margem a uma interpretação equivocada, mas aproveitou o ensejo para criticar a seção Tendências e Cultura: "O meu artigo procurou criticar, de modo especial, uma determinada corrente de ideias sistematicamente veiculadas pela seção 'Tendências e Cultura' desse semanário”.

Marcos Penchel foi escolhido como o representante da equipe cultural para ficar na transição do jornal. Numa noite, ele ligou para Montenegro e contou que iria sair algo negativo contra o ex-editor naquela semana. Os dois foram até a gráfica e colocaram uma resposta no pequeno espaço disponível. A nota dava aos leitores o sinal de que Montenegro não estava mais no jornal. "Fui escondido antes da impressão e enfiei uma nota curta de resposta no final do 'ataque'. Por causa dessa nota o Marcos Penchel foi demitido", assim que o jornal saiu publicado.

O texto é escrito como se Montenegro fosse alguém externo ao jornal, endereçando uma carta "à direção do semanário Opinião". O autor explicava que na seção de cultura escrevem representantes das ideias mais diversas, inclusive Viviane. Por isso ele pedia definições sobre quais seriam as tendências citadas:

"facilitaria um eventual trabalho detetivesco definir qual é a citada 'corrente de ideias sistematicamente veiculadas pela seção Tendências e Cultura deste jornal'. E como esta seção já teve vários editores, seria também necessário marcar o nascedouro dessa 'corrente de ideias sistematicamente veiculadas'. Isto se se deseja uma discussão de ideias e não uma profissão de fé baseada em indiretas e alusões sem direção determinada. (Júlio César Montenegro)."

Duas edições depois, Fernando Peixoto criticava abertamente a seção cultural de Opinião ${ }^{79}$. Literalmente no último número do jornal, ele elogiou o nacional popular sob a forma de "teatro de responsabilidade social" por sua capacidade de problematizar e provocar uma reflexão transformadora no público, numa situação histórica adversa. Com a última palavra num jornal moribundo, essa edição sequer circulou, porque foi

\footnotetext{
${ }^{78}$ Carta de Jean-Claude Bernardet. Opinião. n. 229, p.21, 25 mar. 1977. "Onde e quando insinuei uma 'conveniência ou paralelismo entre a política oficial de cultura e os profissionais desse tipo de teatro? Onde e quando chamei João das Neves de 'oportunista', empresário ganancioso e coisas de igual quilate? O que além de má fé, pode levar M.E.V. a insinuar que fiz afirmações que nunca fiz, insinuações que chega a ser caluniosa".

${ }^{79}$ Peixoto, Fernando. A recusa da inércia. Opinião. n. 231, p. 16, 08 abr. 1977.
} 
apreendida pela polícia. Nela, o crítico atacava os oponentes: "No nível do pronunciamento da imprensa, nenhum dos espetáculos chegou a provocar, por insuficiência dos críticos (ou por censura dos jornais) uma discussão mais consequente." Havia uma condenação aberta a José Arrabal: "reflexos de radicalismo, por exemplo, surgiram num discutível ataque que José Arrabal desferiu com extrema violência, visando provocar reações através da inoportuna técnica de acirrar contradições existentes, contra o texto de Guarnieri."

Se a disputa interna aparecia no conteúdo do jornal, nas cartas e documentos de época, a polêmica passava pelo nome de Fernando Gasparian e era chamada de censura interna. No seu livro, Montenegro (1985) relatava o clima que gerou sua demissão:

"Trabalhei num jornal que se opunha à Ditadura. Foi onde tive pessoalmente a experiência de que a exploração e a opressão são fortes na medida em que não se concentram em torno de um só Ditador, antes se espalham por muitos (nem tanto...) exploradores e opressores.

No jornal, escrevíamos contra os patrões que, à sombra da Ditadura, exploravam seus empregados. Mas o nosso patrão, o dono do jornal, queria que nós nos deixássemos explorar por ele justamente porque estávamos lutando juntos contra a Ditadura.

Negávamos ao governo o direito de censurar, de esconder o que Eles achavam inconveniente que Outros soubessem. Mas raras eram as discussões dentro do jornal em torno do direito que Nós tínhamos de esconder o que não achávamos conveniente que Outros soubessem. E os que achavam que o jornal não devia censurar, eram censurados. (Montenegro, 1985: 25)."

A poetisa Ana Cristina César também comentava o mesmo tema em suas cartas:

[...] o Opinião fechou. O Gasparian demitiu todo mundo no culminar de uma crise. A princípio ele dava liberdade aos editores mas ninguém tinha carteira assinada. No momento que ele começou a pressionar as editorias e exercer censura interna (especialmente contra ataques a figuras "de esquerda" - Callado, Houaiss, Werneck etc.) (e assuntos considerados "irrelevantes" como: sexo, o pessoal chiou e chegou-se a um impasse com todo mundo exigindo carteira assinada e direitos trabalhistas ("Já que você quer se impor como PATRÃO, trate-nos então como um patrão"). Conclusão: demissão coletiva e fechamento do jornal (sob desculpa de censura)" (Freitas; Hollanda, 1999: 144). 
Deixando os relatos de época, é possível compreender em sentido ampliado as tensões entre as alas do jornal. Quase quarenta anos depois, Júlio César Montenegro comenta essas disputas da seguinte maneira:

\begin{abstract}
"Pelo que lembro, o opinião formou-se com 2 centros de poder:
1) o proprietário da operação, o dono da publicação que tinha como projeto a derrubada dos inimigos do derrubado presidente amigo dele;

2) os operadores, reunidos em torno do prestígio de adversário da ditadura escolhido editor-chefe
\end{abstract}

Esse poder negociado partiu-se quando rachaduras na ditadura foram permitindo novas infiltrações. O dono substituiu a redação de combate por uma outra profissional, quer dizer, apta a funcionar com superiores controles. Imagino que inclusive razões financeiras levaram ao fim da experiência com nomes firmados na mídia comercial (Sérgio Augusto, Argemiro Ferreira, Elice Munerato) e a volta dos, menos exigentes salarialmente, OPERADORES + engajados. O que distinguia o grupo reunido em tendências \& cultura era a tentativa de trazer a discussão das regras impostas de fora pela ameaça da força pelas etiquetas religiosamente absorvidas internamente via cultura. Em resumo, tratava-se mais de articulações ENTRE TENDÊNCIAS do que deliberações de eminentes saliências. Simbolicamente fios soltos podem ser desATADOS por poder concentrado. Tramas dando panos pras mangas vem de fios tecidos." 80

A tensão entre os lados ocorria porque um deles colocava como ordem do dia a luta contra a ditadura, sem dissolver a Frente. A outra ala preferia realçar a crítica cultural como forma de resistência e lutar pela autonomia da crítica. Se havia essa divisão, Montenegro explica que todos estavam unidos no "cimento" contra a ditadura: "não podia dividir, a ideia era juntar". Essa opção política ligava os dois lados. Havia “discussão de ideias", não uma hegemonia de partidos. Segundo os entrevistados, as acusações de censura interna teriam ocorrido somente no período final do jornal, em episódios como os de Gota d'água e Xica da Silva. "Não seria esta uma resposta sobre o projeto editorial?", nos indaga um deles.

Para Montenegro, o dono do jornal escolheu o nacional popular porque esse grupo tinha mais status no período. Por esse motivo, seria desgastante enfrentá-lo. Não se tratava de uma preferência pessoal, mas de um projeto político. Gasparian queria caracterizar o jornal somente por ser uma frente anti-ditatorial. Isto é, ele não queria

\footnotetext{
${ }^{80}$ Essa declaração em especial foi obtida via email em 22. jul. 2014. Os grifos são do autor.
} 
diluir a Frente de oposição. Montenegro relata que o proprietário do semanário tinha grande dificuldade de conviver com linhas diferentes na redação. Por isso, ele preferia entregar o comando para pessoas com peso na carreira sob o trilho do Partidão. Se o controle era indireto, ele garantia que os editores-chefes não iriam atacar Jorge Amado, por exemplo. Mas nem sempre Gasparian ficou ao lado do nacional popular. Mário Pamplona escreveu uma carta chamada "Jorge Amado cansado de glória" ${ }^{81}$ e Montenegro publicou "com carinho" 82. A carta desencadeou uma enxurrada de missivas ligadas ao Partidão. De acordo com Montenegro, Gasparian gostou porque o episódio aumentou muito o volume de cartas; não porque se criticava alguém dessa linha.

Percebe-se que as acusações de censura interna do passado apontam para algo maior: as disputas de poder entre os núcleos da resistência para evitar a fragmentação da esquerda e a eclosão de temáticas distantes da Frente Anti-Ditatorial (ver Conclusão). A dissolução gradual da Frente de Opinião não caminhou sozinha. Trata-se de um processo interno da esquerda. A relativa hegemonia da arte engajada nos primeiros anos após o golpe militar diluiu-se cada vez mais na virada para os anos setenta (Napolitano, 2011). Mas a corrente do nacional popular permanecia forte dentro do meio cultural e artístico, em torno de questões centrais para a resistência cultural como a ocupação do mercado, o intelectual arauto, a linguagem acessível ao público, etc. No decorrer desse processo, os artistas e intelectuais aprofundavam suas divergências sobre o como fazer. Se no final dos anos sessenta, o tropicalismo e a contracultura desencadearam o processo, nos últimos anos da década de setenta entrava em cena um novo ator social: a Nova Esquerda. Ela colaborou para a dissolução do nacional popular. Embora anteceda o surgimento desses novos atores sociais em 1978, Opinião é parte e reflexo constituinte desse processo. Em seu microcosmo, alguns desses atores sociais incidiram diretamente no episódio das patrulhas ideológicas. Júlio César Montenegro é o personagem oculto desse caso. Foi ele quem permitiu a eclosão na crítica de cinema de atores sociais atrelados ao movimento popular. Havia neste episódio um começo do

\footnotetext{
${ }^{81}$ Pamplona, Mauro. Jorge Amado, cansado de glória. Opinião. n. 7, p. 2, 25 dez. a 01 jan. 1973.

${ }^{82}$ Mário Pamplona era amigo de Montenegro do Ceará. Fez algumas traduções para Opinião e quando voltou para Fortaleza, leu o livro de Jorge Amado. Foi então que resolveu mandar a carta ao semanário. Segundo Montenegro, a equipe percebeu quantas pessoas eram contrárias ao escritor pela enorme quantidade de cartas.
} 
desatar dos nós das Frentes Jornalísticas ${ }^{83}$, que segundo Bernardo Kucinski (1991) romperam-se de vez nos sucessivos rachas de Movimento algum tempo depois.

Na polêmica em torno de Xica da Silva, três atores sociais aparecem com mais força: os liberais, os comunistas e a oposição ao nacional popular, num conjunto heterogêneo composto por traços do trotskismo, do cinema underground e dos movimentos sociais. O conjunto ruma em direção à Nova Esquerda, da qual temos aqui a prerrogativa de um processo cujo ápice ocorre em 1978.

Os atritos em torno de Gota d'água e Xica da Silva são alguns dos elementos de uma futura articulação da esquerda dentro da imprensa alternativa quase um ano depois. Foi Bernardo Kucinski quem observou in loco alguns traços desse movimento: "Como se adivinhassem a eclosão das primeiras grandes greves operárias, que só aconteceram um ano depois, as esquerdas articuladas nos jornais alternativos portadores de projetos nacionais começaram a se dividir em dois grandes campos já a partir de meados de 1977." (Kucinski, 1991: 161). O processo descrito aqui ocorreu um pouco antes desse limiar. Se em Opinião surgiu Beatriz Nascimento como parte do movimento negro, os rachas no interior dos jornais alternativos foram antecipados pela reaparição do operário. Kucinski explica que as tensões se acumulavam graças à ação das CEBs (Comunidades Eclesiais de Base) e dos movimentos populares. No interior desse processo, surgiram duas vertentes da esquerda com mais força dentro da imprensa alternativa. A primeira retomava o imaginário nacional-populista do PC e defendia a luta pelas liberdades democráticas, a revolução etapista e a aliança com os liberais e com os setores da burguesia. A segunda corrente tinha raízes nos antigos grupos antistalinistas da Nova Esquerda e era formada por quase todas as demais alas, desde a antiga Ação Popular (AP) até os novos e velhos grupos trotskistas. Essa última corrente negava as teses etapistas e defendia a organização das classes trabalhadoras como a única saída não ditatorial para a crise do autoritarismo. Desse horizonte formava-se no interior da imprensa alternativa a Nova Esquerda com forte presença trotskista. Em abril de 1977, aconteceu o racha em Movimento, quando a Nova Esquerda se rebelou contra o domínio do PCdoB (Kucinski, 1991). Por acaso, mês e ano coincidem com o final de Opinião.

\footnotetext{
${ }^{83}$ Ver definição na introdução.
} 
Dos rachas de Opinião e Movimento, surgiram desdobramentos na Nova Esquerda da imprensa alternativa em 1977. No jornal Em tempo dominavam os grupos trotskistas. Eles rejeitavam a Frente Democrática porque ela contribuiria com a hegemonia burguesa e deixaria de lado o movimento operário. A política da Frente era vista como algo remanescente de outros tempos, num momento em que surgia o trabalhador como agente político. A proposta de Em Tempo era subsidiar a organização dos trabalhadores. A edição experimental do jornal retomou um elemento do debate final de Opinião. Caetano Veloso, Gilberto Gil, Chico Buarque, Ferreira Gullar, Paulo Pontes, Jorge Amado foram os nomes escolhidos como depositário de críticas dos grandes mitos da cultura brasileira. O jornal os considerava totens criados conforme a necessidade dos mitos da intelectualidade: a cultura de resistência, a cultura nacional e a cultura popular (Kucinski, 1991).

Do racha da seção cultural de Opinião surgiu em 1977 não só Em Tempo, mas também Beijo, pelas mãos de Júlio César Montenegro, Ronaldo Brito e Genilson César ${ }^{84}$. De Opinião vieram também José Castelo, Wilson Coutinho, Rodrigo Naves, Ana Cristina César (Moriconi, 1996). A antiga equipe do jornal lançava o veículo como forma de reação ao autoritarismo nas relações internas de Opinião. Beijo surgiu como crítica ao dogmatismo dos grupos de esquerda com sua moral conservadora, com o culto ao sacrifício e a repressão sexual (Kucinski, 1991). A proposta do veículo era discutir comportamento, sociologia e cultura, pregando a importância do prazer e da sexualidade. As ideias faziam franca oposição aos jornais alternativos políticos, que tinham uma visão conservadora no campo pessoal e do prazer. O jornal trazia Michel Foucault como maior pensador e a esquerda como alvo das críticas. Beijo colocava em prática o que a equipe sonhou fazer em Opinião, mas não conseguiu. As diretrizes do periódico, escritas por Ana Cristina César, dizem muito sobre os pontos de atrito com a seção cultural de Opinião ${ }^{85}$.

Portanto, observar o pensamento de figuras-chave desses jornais possibilita entender melhor a dinâmica por detrás dos rachas da imprensa alternativa. Se a Nova Esquerda é o segmento menos estudado pela historiografia sobre a resistência cultural (Napolitano, 2011), conhecer de perto os personagens que coordenaram as mudanças

\footnotetext{
${ }^{84}$ Sobre os dois jornais, ver Kucinski (1991).

${ }^{85}$ Algumas das diretrizes de Beijo: a desmontagem da Frente Ampla, a descentralização da estrutura do poder e da intervenção autoritária do intelectual, os temas recalcados pela imprensa e o descompromisso com nomes e figuras sagradas ou aliadas com os temas em cartaz (Moriconi, 1996).
} 
nos jornais alternativos é parte desse trabalho. Nesse sentido traçamos o perfil de Júlio César Montenegro como o irradiador de grande parte das mudanças na seção cultural de Opinião. Se as alterações da seção foram um trabalho conjunto da equipe, Montenegro trouxe um contraponto à forma de pensar a cultura popular. Ele é o aglutinador das preocupações trotskistas e da Nova Esquerda no jornal. Montenegro trouxe para Tendências e Cultura a crítica ao nacional popular como ação autoritária e mistificadora, que cabia dentro das regras do mercado e do nacionalismo do regime. Ele é o personagem central da dissolução progressiva da Frente de Opinião porque abriu espaço na seção para questionar seus conceitos na fase do Jornalismo Cultural Reflexivo.

Júlio César Montenegro entrou para Opinião para fazer crítica: crítica da esquerda, da cultura, do jornalismo, da produção cultural, do sistema interno de espetáculo, dos deputados ${ }^{86}$. Como editor de cultura, ele não queria reproduzir ou noticiar os fatos. Se a imprensa não era colocada sob questão, Montenegro queria inverter esse padrão. Por ser trotskista, ele tentava fazer uma "crítica mais ampla" e daí surgiam os problemas. Muito do que praticava no jornal vinha das leituras de Leon Trotsky. Logo após o golpe militar, o Partidão ficou desmoralizado para ele como um partido conservador; como uma espécie de dogma, parecido com o da Igreja. O interesse por Trotsky surgiu nessa época, porque o Partido o colocou no Índex. Ele leu "Minha Vida" e se encantou com o autor.

Naquela época, era difícil encontrar livros de Trotsky no mercado, mas Montenegro conseguiu comprar Literatura e Revolução num sebo. A obra o influenciou bastante na sua concepção de cultura, porque o editor percebeu com o livro que a "cultura não pode ser compartimentalizada". Montenegro colocava em prática no jornal algumas das ideias do autor: a necessidade de fazer a crítica da cultura e a autonomia da arte em relação aos partidos políticos (Trotsky, 1980). O objetivo dele era trazer todas as alas internas da esquerda sem beneficiar nenhuma. Os primeiros atritos já surgiram dessa posição inicial, porque algumas pessoas viram nessas ideias uma tentativa de dissolução e um enfrentamento da política da esquerda.

\footnotetext{
86 Montenegro começou como correspondente político em Brasília. Desmascarava os deputados oposicionistas, mas logo foi acusado dentro do jornal de ser comprado pela ditadura, porque falava mal dos aliados. Os colegas aconselharam não escrever esse tipo de coisa para não enfraquecer a resistência e o congresso.
} 
Levando vida cultural intensa, Montenegro estava por dentro da produção artística da cidade do Rio de Janeiro para sugerir as pautas. Nesse processo, ele procurava o que ia contra a corrente. Empenhava-se especialmente em localizar algo que fosse contrário ao nacional popular, criando atritos com essa ala. Para Montenegro, a única coisa boa da ditadura foi romper a hegemonia da esquerda. "Foi bom quebrar o monopólio deles" ${ }^{87}$. Pessoalmente, o editor achava as polêmicas muito mais estimulantes, especialmente quando os autores respondem às críticas. É isso que ele gosta de fazer, "gerar polêmicas".

Querendo fazer a crítica da esquerda, Montenegro enfrentou a oposição da redação desde o início, porque a equipe estava unida contra a ditadura. Provavelmente o projeto editorial do jornal para a área cultural esteja na preferência pela luta contra o regime militar. Montenegro conta uma história para ilustrar um pouco o ambiente interno da esquerda no jornal. Certa vez numa palestra na PUC do Rio de Janeiro, Raimundo Pereira teria dito em tom negativo: "tem gente que quer discutir corpo". Ele teria ironizado Foucault e os que tomavam banho de sol enquanto o povo era explorado. $\mathrm{Na}$ vontade de fazer a crítica da esquerda, Montenegro só encontrou o apoio no jornal de Fernando Henrique Cardoso ${ }^{88}$. O contato surgiu através de Fernando Gasparian, que levou os principais editores do jornal até o Cebrap duas vezes ${ }^{89}$. Na segunda reunião, antes de assumir o comando da seção cultural de novo, Montenegro sugeriu fazer a crítica da esquerda. "Fernando Henrique foi o único que disse que dava para fazer". Para Montenegro, o sociólogo era a favor da crítica da esquerda pela esquerda porque ela já era praticada desde maio de 1968 na França.

Montenegro voltava da Europa, e tinha "consciência" de que fazia parte da "Nova Esquerda" 90 . Ele seria o único na redação a pensar assim. O restante dos colegas não era tão contrário ao nacional popular ${ }^{91}$. Montenegro estava interessado em trazer ao

\footnotetext{
${ }^{87}$ Foi após o golpe militar que Montenegro "percebeu que o Partidão era irresponsável”. A dinâmica é parecida com a descrição de Marcos Napolitano (2011). Num primeiro momento após o golpe militar, o PCB deteve a hegemonia no campo cultural, mas depois começou o processo de dissolução das alas da esquerda.

${ }^{88}$ Se Montenegro cita Fernando Henrique como o único aliado na ideia de fazer a crítica da esquerda, a lembrança de Jean-Claude Bernardet é diferente. Certa vez, o sociólogo foi chamado à redação como intermediário, porque os salários da equipe não davam nem para viver. Mas ele teria ficado ao lado do amigo Fernando Gasparian, porque o mais importante não era o salário, mas a luta contra a ditadura.

${ }^{89}$ Sobre a importância do CEBRAP e dos textos de Fernando Henrique Cardoso no Opinião, ver Lindoso (1997).

${ }^{90}$ Ele voltava de uma longa estadia da Europa no começo de 1970, além de uma viagem mais demorada em 1975.

${ }^{91}$ Segundo Montenegro, talvez Ronaldo Brito e Genilson César tivessem maior simpatia pela crítica ao nacional popular. Bernardet não se dedicava à crítica da esquerda de maneira explícita, mas o trabalho
} 
jornal o sentido da crítica de esquerda europeia. Nessa reunião, ele explicou que esse tipo de crítica era muito comum na Europa. Gasparian se opôs veementemente à ideia. Achava que não era a hora certa por causa do risco de desunião da esquerda.

Naquela época, todos acreditavam que primeiro o jornal deveria unir forças contra a ditadura, para depois pensar nas questões relativas à cultura, ao corpo, à etnia e ao homossexualismo. Explica Montenegro: "Mas no fundo eles iriam fazer como na Rússia; iriam nos esmagar. Vencia muito ser stalinista no jornal com a ideia de não quebrar a frente contra a ditadura". A mudança brutal nessa direção do jornal só veio mesmo após o "rompimento do pacto" com Raimundo Pereira.

Uma parte do trabalho diário de Montenegro como editor de cultura de Opinião está no artigo Imprensa: além da censura na Revista de Cultura Vozes (Montenegro, 1976). No texto, o autor explica como os mecanismos de censura interna dos jornais influenciam o trabalho da redação e evitam uma postura contrária aos interesses dos donos. Isso é feito especialmente através das técnicas jornalísticas, que ocultam o mecanismo de produção e os interesses do próprio jornalismo. Nesse processo, o editor tenta conciliar suas inclinações pessoais com o interesse do dono do jornal e dos anunciantes. $\mathrm{O}$ artigo resume um pouco do processo de censura interna de Opinião: o jornalista escreve pensando no editor e nos prováveis cortes e assim acaba interiorizando esse processo. Se a diretriz de Montenegro em Opinião era fazer a crítica da relação entre produção cultural e mercado, aqui ele sugere um argumento típico da futura imprensa alternativa basista: escrever com a cabeça voltada ao leitor.

Na segunda vez que dirigiu a seção Tendências e Cultura (1976-1977), Montenegro colocou essas ideias em prática. Ele criticava e quebrava cânones na fase do Jornalismo Cultural Reflexivo. Os artigos mais importantes dessa linha são a série sobre o Jornalismo Cultural de Ronaldo Brito, de Jean-Claude Bernardet e do próprio Júlio César Montenegro. No seu texto para essa coletânea, o editor explicava indiretamente o trabalho feito no jornal ${ }^{92}$. O título já resumia bastante o assunto: $O$ Refresco da Cultura. Segundo ele, os proprietários dos jornais orientam a seção cultural a agir como momento de relaxamento. Os textos devem ser leves porque as pessoas querem lazer e diversão, depois de um dia cansativo de trabalho. Além disso, as seções

dele era parte dessa renovação, fazendo a crítica do comportamento. Outros se aproximariam do viés crítico pelas ilustrações, como Cássio Loredano com seu desenho libertário ou Carlos Clémen.

${ }^{92}$ Montenegro, Júlio César. O refresco da cultura. Opinião. n. 219, p. 21, 14 jan. 1977. 
culturais auxiliam na promoção do circuito do mercado. No texto, Montenegro esclarece que "as polêmicas são incomparavelmente mais estimulantes quando o parecer do crítico é desfavorável à obra ou lhe faz severas restrições”. Isso porque as polêmicas desfazem "a falsa impressão de uma sapiência uniformemente distribuída". Nessa parte do texto, o intelectual aparece como alvo adicional do processo, porque se vê como um sábio acima dos mortais. Como desagregador da frente, Montenegro expõe tudo que não se fazia no interior do jornal:

"Mas primeiro, claro, isso que tem que ser considerado um assunto jornalisticamente relevante. Até que Foucault, Szasz, e outros nomes famosos da intelligentsia internacional discutissem a loucura não seria doidice pensar em fazer matérias sobre o tema? E o sexo cotidianamente praticado, ou pelo menos pensado, pela imensa maioria, quando é considerado digno de matérias sobre? Quando aparece nos filmes ou nos livros, por exemplo. Tais temas ainda não foram institucionalizados para discussão.

(...) Há aqui uma outra divisão que arbitra uma separação entre os assuntos considerados de interesse geral e os problemas pessoais. Não quer dizer que estes não atinjam a maioria esmagadora ou todas as pessoas. Em termos de imprensa, significa apenas que tais temas ainda não foram institucionalizados para discussão. Ou, em termos de seção de variedades, que só podem ser tratados como leve contrapeso às coisas sérias e relevantes que merecem ir para os espaços das outras seções."

Na sequência, ele esclarece que algumas temáticas eram colocadas de lado pela editoria de cultura porque "não foram institucionalizados para discussão". Uma delas foi uma matéria sobre o corpo, que não foi considerada por toda a equipe como digna de nota pela falta de interesse jornalístico e de seriedade do tema. A conclusão de Montenegro criava um atrito com o conceito do intelectual acima dos mortais: "Será que o maior problema não seria o tratamento de um assunto que interessa a todos que tem corpos (...) e sobre o qual todos podem participar com idêntico grau de especialização ou de ignorância? Não será um tanto incontrolável politizar um assunto tão próximo de todos?" A provocação era dupla. Ele defendia num jornal político que o sexo poderia ser tratado como elemento digno e questionava o intelectual arauto, porque no tema do corpo todas as pessoas são iguais em sabedoria.

A matéria sobre o corpo foi feita a partir do Nouvel Observateur. Montenegro decidiu aplicar o mesmo modelo no Brasil e mandou dois repórteres entrevistarem por telefone personalidades para saber o que elas faziam com seu corpo. O resultado é 
Tirando o corpo fora ${ }^{93}$, que consegue equilibrar profundidade de análise com muito humor. O tema do artigo causava grande surpresa nos entrevistados e o texto reproduz a conversa travada no telefone ${ }^{94}$. As pessoas não acreditavam que a matéria fosse de um jornal "sério" como Opinião. Enquanto Clarice Lispector disse "meu corpo sou eu", Nelson Werneck Sodré declarou que o corpo dele não importava. Para Montenegro, a declaração de Sodré mostrava mais um indício do desprezo do PCB pelas questões ligadas ao corpo e à sexualidade. A matéria trazia a diferença de pensamento das alas da esquerda e causou um constrangimento a Werneck Sodré. Ele foi reclamar com o dono do jornal porque não "apareceu bem" e "me botou numa situação difícil com Gasparian", conta Montenegro. A equipe teria uma "crítica danada" de Sodré por aplicar o conceito de feudalismo da Idade Média ao Brasil.

As mudanças feitas por Montenegro nessa segunda fase são muito evidentes. Michel Foucault era uma grande referência para o editor de cultura e está presente em várias matérias que explicam seu pensamento. Muitos textos abordam homossexualismo e divórcio. Outros tantos são bastante provocativos já na manchete: “A práxis e o êxtase, uma relação grilhada" 95 . O subtítulo dizia: "abaixo o sexual, viva o social! Essa é a palavra de ordem que comanda o ódio stalinista à sexualidade e o sucesso mundano da 'ala direita' psicanalítica. E os fascistas repudiam também o 'pansexualismo' o tal do sexo em tudo."

Se as matérias podiam causar espanto em quem esperava um jornal sério, Gasparian deve ter se surpreendido bem menos com o enfoque de Montenegro, porque o editor de cultura já tinha dado o mesmo enfoque quando dirigiu o Jornal de debates.

Na seção de cinema, esse processo era acompanhado numa velocidade bem mais lenta. A mudança na editoria cultural foi mais rica em outras rubricas. O ápice no cinema foi mesmo a crítica a Xica da Silva, mas alguns indícios apareceram antes. Por exemplo, a crítica de Jean-Claude Bernardet ao papel do intelectual em Lição de amor (ver Capítulo 3 e 5) coincide com o momento do debate interno do jornal sobre o papel do intelectual. Esse viés aparece também quando o crítico de cinema coloca em xeque Tânia Quaresma e a produção do nacional popular.

\footnotetext{
${ }^{93}$ Ethel, Leon; Branco, José Castelo. Tirando o corpo fora. Opinião. n. 216, p. 20, 24 dez. 1976.

${ }^{94}$ Teria sido $O$ Pasquim o primeiro a trazer uma entrevista sem a típica edição de texto, deixando fluir o texto como as pessoas falam normalmente.

${ }^{95}$ Vasconcelos, Gilberto. A práxis e o êxtase, uma relação grilhada. Opinião. n. 210, p. 22, 12 nov. 1976.
} 
Timidamente apareciam algumas matérias sobre o Cinema Marginal, mas em artigos de força diminuta, como no texto sobre Nenê Bandalho e (1970) de Emilio Fontana ${ }^{96}$. Uma mudança importante em relação à cultura popular na última fase aconteceu pelas mãos de Carlos Frederico, quando pela primeira vez se publicou a lista das maiores bilheterias, com as preferências do público ${ }^{97}$.

Quantitativamente a fase é curta. Pela cronologia exposta por Marquardt (2003), a segunda direção de Montenegro foi de junho de 1976 até abril de 1977. Isto é, do número 187 ao 231. Seriam, portanto, 44 números. No geral há menos artigos sobre cinema nesta última fase. Nem se pode dizer que existisse um crítico de cinema $d o$ jornal, como havia antes. Jean-Claude Bernardet publicou poucos artigos nessa época. Nessa fase escreveram mais Marcos Ribas de Farias, Carlos Frederico, Oscar Guilherme Lopes, Wilson Nunes Coutinho, Florestan Fernandes Filho. Mas cada um deles publicou entre dois a cinco artigos. O espaço imenso dado ao Cinema Novo não existia mais. O que vencia mesmo eram as análises do discurso político dos filmes, mas havia também artigos sobre estética do cinema.

Se em muitas das matérias da seção cultural apareciam temas ligados ao universo do comportamento, o interesse de Montenegro pelo tema não era novo. Para ele, o prazer é a coisa "mais subversiva do mundo" e faz a pessoa não aceitar nenhuma autoridade. É a melhor arma de combate, quiçá contra a ditadura. A postura não teve relação com o universo da contracultura. Naquela época, ele considerava os hippies alienados que usavam drogas. O editor só mudou de opinião, quando foi cobrir o Festival de Saquarema em $1976{ }^{98}$. Foi quando percebeu que "os hippies não eram a esquerda que eu imaginava". Montenegro achou incrível a partilha de todas as coisas, como uma forma de "comunismo cristão primitivo". A ideia do prazer dele surgiu ainda na infância, atrelada ao universo da natureza, dos animais, do instinto, do andar de pé descalço e de não ter vergonha do próprio corpo. O pensamento tinha relação com "um espírito crítico às regras de repressão social e familiar".

Montenegro era sempre o primeiro aluno da turma para tentar aliviar os gastos da família com o colégio caro. Garantia assim todo mês um bom desconto na

\footnotetext{
${ }^{96}$ Lopes, Oscar Guilherme. Um filme debochado? Opinião. n. 227, p. 21-22, 11 mar. 1977.

${ }^{97}$ Frederico, Carlos. Um balanço da indústria cinematográfica. Opinião. n. 225, p. 24, 25 fev. 1977.

${ }^{98}$ De acordo com Montenegro, não havia muitas pessoas ligadas ao universo da contracultura na seção cultural. José Castelo Branco tinha mais simpatia e foi cobrir o Festival de Saquarema. Uma "garotada" o convidou para ir junto, porque ele era o único que tinha carteira de motorista. Ele aproveitou o ensejo e fez uma matéria também. Ver: Branco, José Castelo. Um Oasis com som e surf. Opinião. n. 187, p. 3-4, 04 jun. 1976. Montenegro, Júlio César. A descoberta dos outros. Opinião. n. 187, p. 04, 04 jun. 1976.
} 
mensalidade. Por isso, sentia diariamente o peso desse tipo de responsabilidade e de repressão ao prazer. De uma família tradicional do Ceará, o sonho dele era ser diplomata. O tio era um dos fundadores do ITA e abriu as portas para o sobrinho estudar engenharia. Embora não gostasse da área, Montenegro fez o curso como possibilidade de adquirir independência financeira no futuro para poder realizar o sonho da diplomacia e o desejo de escrever. Durante esse período ocorreu a mudança em sua trajetória. Ele abandonou um pensamento de direita e trocou a religião pela crença no comunismo ${ }^{99}$. Conheceu Raimundo Pereira no ITA. Os dois colaboravam no jornal da turma. O pensamento militar ainda era forte nele. Quando Fidel Castro tomou o poder, Montenegro o atacou violentamente. Raimundo e os colegas decidiram fazer uma troça com ele. Escreveram uma carta em inglês e assinaram "Rainha da Inglaterra". A tal Rainha elogiava Montenegro porque as ideias dos dois eram muito parecidas.

Após uma estadia na Europa, ele decidiu emplacar a carreira de jornalista como parte da luta contra a ditadura. Morou no Rio de Janeiro entre 1971 a 1979. Zuenir Ventura ofereceu a ele o primeiro estágio na revista Visão. Um mês depois, Raimundo Pereira o levou para a revista Realidade para fazer o número especial Nossas Cidades. Ele começou como administrador e por causa das intervenções se tornou correspondente da edição do Rio de Janeiro e depois de São Paulo. Ele colaborou também na edição especial feita para o Nordeste. Montenegro fazia resenha de livros para $O$ Globo e para a Leia Livros da Brasiliense e atuava como tradutor de francês e inglês em jornais e livros. Por exemplo, a tradução de Cinema e política de Leif Furhammar (1976) é dele. A coleção foi dirigida por Jean-Claude Bernardet e Paulo Emilio Salles Gomes.

Provavelmente o jeito alegre, bem humorado e provocador de Júlio César Montenegro aproximasse muitos colaboradores de Opinião para seu lado. O crítico Marcos Ribas de Farias conta que Montenegro inspirou nele uma guinada total numa maneira livre de viver e de pensar. O editor teria "liderado a cabeça" dele até na relação com a revista Cahiers du Cinéma; sua formadora. Montenegro o "libertou" da "ditadura da esquerda e da direita". Influenciou a maneira de ver os filmes e a forma de escrever. "Foi a pessoa mais importante no jornalismo para mim". Se muitos da equipe orbitavam

\footnotetext{
99 "De qualquer maneira, na minha trajetória, o marxismo, o socialismo faz parte da passagem de uma visão mágico-religiosa do mundo para uma outra científico-experimental. A passagem da vivência religiosa, cristã, do mundo para uma outra, digamos, científica foi, me parece atualmente, ilusória. Abracei uma nova fé, o marxismo, com textos sagrados, missões a cumprir na terra, paraísos prometidos no futuro. Como também, e principalmente, o problema religioso em sua interpretação contemporânea, o problema da torre de Babel, edificada precisamente sem Deus - não para chegar da terra ao céu, mas para trazer o céu à terra (Montenegro, 1985: 25-26).
} 
em torno da questão cultural como ele, outros tantos não teriam "simpatia" pelo editor de Tendências e Cultura. Segundo Montenegro, essa ala seria a dos "stalinistas", que lutavam contra a ditadura. "Havia um pessoal ridículo em posição moral comunista, mas eram pequenos burgueses, intelectuais que no fundo tinham casa, família. Achavam que as questões de etnia ficariam numa segunda fase, depois da revolução proletária". Por isso essas questões eram abafadas. O atrito vinha porque ele era o mais "desbundado", isto é, não era engajado na luta de sacrifício contra a ditadura. Detestava o "mobral da esquerda", porque o povo odeia. Pior ainda era trazer embutida a ideia de educar o povo. Para Montenegro, essa "visão foi construída" pelo partido comunista e o Mobral da esquerda não é nada mais do que uma "empresa capitalista". Estabelecendo uma ponte, ele explica que por todos esses motivos um jornal responsável como Opinião não falava bem do Cinema Marginal.

Algumas portas teriam se fechado para Montenegro na imprensa alternativa por causa de seu jeito livre e "odara". Ele não foi chamado para Movimento porque "o jornal era bem mais stalinista que Opinião". Afinal não havia o contraponto a Raimundo na figura de Gasparian. "Nunca me convidaram, porque sabiam que eu não era do pessoal e que iria destoar do coro". O convidado para ser editor da seção cultural de Movimento foi exatamente Fernando Peixoto (Azevedo, 2011). Montenegro explica que os mais sérios foram para Movimento, enquanto as pessoas mais "críticas" me escolheram como "aglutinador e eu fui assumindo esse papel". Na época, "eu era considerado meio desbundado, foucaultiano", "um tanto alienado da necessária conscientização do nosso povo". Contrário aos partidos, quando alguém na redação dizia para ele "Lenin disse tal coisa", ele respondia: "e eu com isso?" "Eu era meio herege”, explica.

Montenegro sinaliza no jornal um processo de enfraquecimento do nacional popular, mas o processo foi de toda a esquerda. Se apenas na segunda gestão ele teve mais espaço para fazer a crítica interna da esquerda, a mudança de perspectiva acompanhava o trajeto do final dos anos setenta. Naquele período, a crise da cultura popular obrigava a oposição a fazer uma reavaliação, inclusive em relação às classes populares. No final do regime militar se via a impossibilidade de ter um projeto cultural global (Napolitano, 2011). A esquerda percebia que a ida ao mercado não era uma estratégia sem consequências políticas. Afinal as exigências da indústria cultural colidiam com as da arte engajada. 
Na última fase de Opinião temos uma parte desse processo em curso. A vontade de Montenegro era criticar e desmoralizar a intelligentsia, mas sem dizer isso. Por exemplo, em Beijo, ele resolveu aplicar o tom respeitoso e o tratamento literário e de "árvore genealógica" do intelectual para uma cozinheira imaginária. O título "Notas para uma biografia de Sebastiana Feitosa" foi retomado depois no filme de Carlos Frederico, Lerfa-mu (1979). Numa das cenas, Montenegro entrava e dizia "Eu que criei Sebastiana Feitosa”.

Se ele aproveitava as oportunidades para criticar os intelectuais na imprensa, Montenegro tinha uma visão diferente da cultura popular já de longa data. O processo significou um choque e uma ruptura desde o final dos anos cinquenta. Fascinado pela alta cultura por causa da família, ele teve um distanciamento da cultura patriarcal e um entrosamento com a cultura popular, "não com a cultura abençoada pela esquerda", mas a cultura popular "incontrolável". Pensou isso ao ver a montagem do livro de Ariano Suassuna Romance d'a Pedra do Reino e o Príncipe do Sangue do Vai-e-Volta. Quando assistiu à peça, percebeu o quanto ele mesmo era "reacionário". No começo, Montenegro ficou irritado porque achou que era TBC (Teatro Brasileiro de Comédia), mas não era. Pensou: "mais uma droga do nordeste, tipo 'o povinho que não é sério"”. Depois ficou fascinado e escreveu uma resenha que Zuenir Ventura publicou na revista Visão em meados de 1971. As mudanças foram assim um processo na vida dele. Sair do ITA e do viés de direita familiar e ir para a esquerda. O pensamento sobre a cultura popular é tão importante, que no final da década de setenta, ele decidiu tornar-se agricultor e viver próximo desse segmento. Aprendeu a cuidar da casa e cozinhar com o que havia disponível da colheita ${ }^{100}$.

Montenegro não valorizava o povo como figura mitológica: "Afinal nunca ninguém conseguiu me esclarecer quem vem a ser povo, tanto que, constantemente, autoridades diferentes atribuem desejos opostos à vontade do mesmo povo" (Montenegro, 1985: 27). A preferência dele era pela definição de Paulo Freire: "Cultura é tudo que é produzido/criado pelos seres humanos. Concordo." A visão do mercado não era mais amena: "Tenho a impressão de que esse negócio de valorizar como produção cultural só o que é feito por poetas, prosadores, filósofos, artistas plásticos,

\footnotetext{
${ }^{100}$ Tudo isso aconteceu depois de um episódio de depressão, quando ele trabalhava como jornalista, mas já tinha terminado a experiência na imprensa alternativa. Depois de alguns anos, Montenegro voltou a atuar como administrador de empresas até se aposentar. Continua morando no seu bosque no interior, intercalando suas poesias com a vida em Fortaleza.
} 
cientistas, arquitetos, atores, o escambau, é um golpe de publicidade, um artifício comercial para cobrar mais caro pelo que essa gente produz." (Montenegro, 1985: 30). Repensando no presente a diferença entre a cultura aristocrática e a popular, ele sintetiza:

\footnotetext{
"me ocorreu que a disputa cultural mais abrangente se dá no convívio DEMOCRÁTICO entre a produção cultural nascendo sem licença nem registro em ESTABELECIMENTOS cartoriais com TRADICIONAL PRESTÍGIO e a que é reciclada RESPEITOSAmente tipo culto aos ANCESTRAIS."101
}

Mas se Montenegro foi o principal editor de Tendências e Cultura, esse grau de pioneirismo e influência tinha limites sobre a crítica de cinema. O processo só mudou no final do jornal, um pouco antes do conceito ser questionado no interior da esquerda. O pensamento dele aproxima-se da definição de cultura popular comunitária e diária defendida pela Nova Esquerda. Trata-se da ideia de aceitar a cultura popular e se misturar com o povo, tal qual descrito por Florestan Fernandes (1976), por Antonio Gramsci (1968) e por Jean-Paul Sartre (1994).

${ }^{101}$ Declaração obtida via email em 02 ago 2014. Os grifos são do autor. 


\section{Conclusão}

Este é o último número de OPINIÃO a circular sob o regime de censura prévia. Só voltaremos a circular quando estivermos inteiramente livres de censura. Isto é, LIVRES.

Se chegamos, agora, ao fim desta etapa, se interrompemos, com este número, nosso contato com os leitores é que uma censura obstinada e destruidora já conseguia barrar-nos todos os caminhos: já nos vedava a própria transcrição de notícias amplamente divulgadas pela imprensa diária. (...)

E nem se diga que tal censura discriminatória abatia-se sobre OPINIÃO apenas em casos ligados à Segurança Nacional. Até uma frase do Presidente Geisel sobre as multinacionais, cuja existência o chefe do Governo disse não saber 'Se era para o bem ou para o mal', a censura impediu que a transcrevêssemos em nosso jornal.

Se mesmo o Presidente da República passou a ser alvo da censura em OPINIÃO que nos restaria, em breve, publicar?"(...)

Arcaríamos, ainda assim, com o prejuízo, faríamos todos os sacrifícios necessários para manter Opinião nas bancas, nas mãos dos leitores, dos congressistas, do povo, de todos aqueles que partilhavam da nossa reflexão sobre os problemas do Brasil. Mas que jornal estávamos nós passando a propor ao público? Que Opinião era essa que oferecíamos, mutilada, aviltada, desfigurada? Que matéria para meditação podíamos oferecer quando não mais podíamos oferecer quando não mais podíamos sequer transcrever notícias já publicadas, ou frases pronunciadas pelo Presidente da República? (...)

Aqui, portanto, fazemos nossas despedidas da censura. Dos leitores, não. Porque voltaremos um dia a ser LIVRES. Só encerraremos, temporariamente, esta primeira etapa à espera do direito de opinar. A pausa que nos impomos não é de resignação e sim de protesto. Não paramos nossas máquinas com melancolia e sim com indignação, esta boa e bela indignação que lavra entre tantos brasileiros inconformados como cerceamento de suas liberdades, a primeira das quais é a de pensar e a de dizer o que se pensa. Aguardamos, confiantes o retorno ao País do livre direito de Opinião. 



\section{Conclusão}

Um jornal de intelectuais e para intelectuais, marca de um pensamento progressista e original sobre a crítica cinematográfica. Um jornal aberto às diversas correntes da esquerda, desde os engajados até os independentes. Um jornal dividido entre a estética e a política, com diversas gradações. Um jornal que luta ao mesmo tempo pela autonomia estética e pelo imperativo político. Um jornal que segue a história dos rachas da esquerda. Um jornal censurado com múltiplas possibilidades de leitura. Um jornal que acompanha o nacional popular. Um jornal de oposição ao nacional popular. Um jornal de intelectuais arautos e um jornal crítico ao arauto. É dessas antinomias, desses meios termos e desses pêndulos com idas e vindas, que se pode caracterizar melhor a crítica de cinema de Opinião. Encontrar uma homogeneidade e linearidade em meio a tanta diversidade de opinião seria planificar a crítica de cinema. Portanto esta tese representa mais uma abertura de significações do que fechamento de temas.

A trajetória de Opinião na seção de cinema segue a dinâmica do frentismo cultural, mas com arestas bem polidas e desgastadas. A cada ano, novas camadas de cimento intercalavam-se a blocos maciços com reticências, adendos, ondulações e disputas. Pensando em periodizações de cunho didático, é possível falar em duas fases. A primeira delas (1972-1976) situa-se entre a gestão de Raimundo Pereira e a saída de Argemiro Ferreira e dialoga mais com a cultura do nacional popular. Nesse período, a seção Tendências e Cultura teve dois editores, Júlio César Montenegro e Sérgio Augusto. A segunda fase (1976-1977) estabelece um espaço de oposição ao nacional popular sob o comando novamente de Júlio César Montenegro. Constitui o que chamamos de Jornalismo Cultural Reflexivo ${ }^{1}$.

Na primeira fase, os valores frentistas são majoritários na crítica de cinema. A Frente Cinematográfica de Opinião ${ }^{2}$ defende a cultura do nacional popular, o intelectual arauto, a linguagem acessível ao público e a ocupação do mercado. O jornal confirma o sucesso da linha frentista no cinema porque a cultura do nacional popular transborda para vários segmentos da sociedade. Alguns desses valores tornam-se

\footnotetext{
${ }^{1}$ Ver capítulo 6.

${ }^{2}$ Sobre as Frentes de Opinião, ver introdução.
} 
bandeiras não só de críticos e cineastas engajados, mas também da política cultural, obviamente com signos invertidos.

Mais importante do que detectar continuidades, é encontrar pequenos atritos no jornal porque esses dissensos iriam crescer nos anos posteriores. Trata-se de entender como os valores são construídos e como se mantêm internamente. Neste percurso, encontramos algumas alterações nos conceitos, numa tensão constante entre estética e política dentro da crítica de cinema.

Desse estudo localizamos muitas aberturas na Frente Cinematográfica de Opinião. A primeira delas diz respeito ao uso de uma linguagem acessível para conquistar o público e o mercado. Ante o inimigo maior do imperialismo americano, críticos e cineastas apoiam uma linguagem cinematográfica de fácil entendimento. A defesa é acompanhada de um atestado de culpa: o hermetismo do Cinema Novo nos anos sessenta. Opinião segue a onda de condenar indiretamente o cinema moderno e elogiar a linguagem clássica. Mas desse consenso inicial sobre a linguagem surgem várias ressalvas por causa da preferência estética de cada crítico. No fundo, o desejo de ocupar o mercado não significa uma boa vontade em relação às produções sem apuro estético. O critério comum entre os críticos para analisar os filmes aponta para os valores estéticos e para o cinema autoral. As variações dependem do colaborador e do filme em questão. O tabu em Opinião é a impossibilidade de defender completamente a ocupação do mercado se os críticos desaprovam o cinema de gênero e as preferências do grande público.

Um dos principais temas de consenso no jornal é o papel do intelectual na resistência e na conscientização do público. A defesa frentista do arauto serve à missão do próprio jornal, à ideia de tradutor das demandas sociais e à função de explicador do país à própria intelectualidade. Assim, as alterações discursivas em direção ao intelectual mediador neutro no jornal geralmente retornam ao ideal do arauto. Essa discussão ocorre fora do gênero opinativo e significa uma outorga da palavra a terceiros no espaço da entrevista. Portanto, realçamos na tese o lugar de onde se fala. É muito significativo Opinião entregar a palavra aos cinemanovistas discutirem seu próprio papel na sociedade. A eleição desse grupo revela uma exclusão de outros atores sociais no debate, como os cineastas marginais. De maneira indireta, o pêndulo vai em direção aos cinemanovistas pela tentativa de aproximação com o público e com o povo. Dessa 
lacuna do espaço opinativo surge quase um alinhamento do jornal. Só na fase do Jornalismo Cultural Reflexivo, o seminário contesta o ideal do arauto pela ambição de se representar como porta voz das classes populares.

O elogio frentista do intelectual faz parte de algo maior: a defesa do nacional popular. Na primeira fase, não há grandes contestações a este conceito. No segundo período, os casos de condenação ao nacional popular captam a dinâmica do trajeto interno da esquerda, rumo a uma maior fragmentação. Essa força já estava latente no jornal, mas não conseguia bater de frente contra o nacional popular. Quando a crítica ao nacional popular surge com força em vários episódios, Júlio César Montenegro é demitido. Se a semente do atrito é cortada, nos anos seguintes ela vai crescer cada vez mais na esquerda.

No episódio da demissão coletiva da equipe se percebe o papel aglutinador e desagregador do nacional popular. Ele surge para alguns como a liga e a base de sustentação entre os atores sociais. Para os opositores do conceito, é apenas sinônimo de autoritarismo e contenção do povo no debate. Os defensores desses valores veem a implosão do nacional popular como a ruína da Frente Jornalística, porque a união da resistência era feita em seu nome.

Deixamos para o futuro uma hipótese sobre o nacional popular nas redações cariocas. Quando perguntamos se havia algum tipo de controle interno partidário do PCdoB (Partido Comunista do Brasil) e da AP (Ação Popular) em Opinião (Kucinski, 1991), dois entrevistados mudaram o foco e responderam sobre o controle do PCB, e não sobre o PCdoB. Em seguida, mencionaram um contexto ampliado nas redações cariocas. Era preciso "ter muito tato" para fazer a crítica ao nacional popular nas redações do Rio de Janeiro. "Havia um certo limite" e era possível ir "até certo ponto" nas discussões. Nestes casos, havia duas possibilidades: ou o artigo era cortado ou o jornalista se sentia culpado por criticar um aliado, "embora no limite não fosse". Afinal "você estava ao lado deles" [na luta contra a ditadura] ${ }^{3}$. Era complicado falar mal dos comunistas porque eles eram as "vítimas do regime". Além disso, graças ao esquema de proteção interno, muita coisa não era comentada. As "patotas" do PCB comandavam alguns cargos nas redações. Elas tinham o poder de colocar e tirar jornalistas. Quando não gostavam das preferências políticas dos candidatos, vetavam os nomes. De alguma

\footnotetext{
${ }^{3}$ Os termos utilizados foram retirados nas nossas entrevistas.
} 
forma, essa descrição permite um paralelo com alguns episódios da fase final de Opinião.

Se o nacional popular iria ruir anos depois, um item importante se mantém de pé no jornal: o nacionalismo. Ele é a base que une todas as alas de Opinião. A luta contra o imperialismo americano jamais seria tema de dissenso no jornal. Afinal o nacional ainda é definido pela negação do estrangeiro, tal como explica Roberto Schwartz (1987). Na seção de cinema, o combate à ideologia dos filmes americanos não é pensado como resquício indireto da cultura do nacional popular. O nacionalismo cumpre assim a função de uma chave explicativa para tudo. Dessa forma, Opinião não antecipa a discussão do campo intelectual sobre o tema. No mesmo ano em que o semanário acaba, Carlos Guilherme Mota (2008) condena o nacionalismo como forma de ideologia. Portanto, a crítica ao nacional popular não era absoluta, porque o nacionalismo funcionava como a liga comum do jornal contra a ditadura. $\mathrm{O}$ debate aponta para uma falta de questionamento da própria ideia de essência (Bourdieu, 2007).

O último ponto frentista do jornal a destacar é a conquista do público e do mercado. Trata-se de um consenso entre muitos críticos, cineastas, produtores e a política cinematográfica nacionalista. Mas mesmo nesse quesito, os textos de Opinião esbarram em algumas discordâncias internas, porque o mercado é visto cada vez mais como algo negativo por causa da indústria cultural. Além disso, existe também uma dualidade entre apoiar a industrialização do cinema e preferir o cinema autoral. A maior dificuldade interna do jornal é conciliar a escolha autoral com o gosto do espectador, sem abrir mão da responsabilidade social do cinema. Como conquistar um público culto e popular ao mesmo tempo? Se Macunaíma (1969) de Joaquim Pedro de Andrade parecia a melhor solução, esse sonho de alcançar os dois tipos de espectadores morre em Opinião com O Amuleto de Ogum (1974) de Nelson Pereira dos Santos, como discutimos no capítulo 6.

Essa relação dual com o mercado não era só do cinema, porque ele significava uma característica central entre a arte e a política no Brasil (Napolitano, 2011). Após o golpe militar, o artista de esquerda ainda tinha uma visão do mercado como canal de distribuição das suas ideias na forma de bens culturais. Essa relação começou a mudar a partir de 1967, quando se observava uma incompatibilidade entre as fórmulas da indústria cultural e a vontade de atuar politicamente. 
A primazia do mercado nas discussões culturais tinha relação com o contexto ditatorial. De acordo com Jean-Claude Bernardet (1978), os críticos faziam a defesa do cinema brasileiro pelo imperativo de mercado e pelo local de origem, porque as análises políticas eram censuradas. Para eleger o cinema brasileiro, esses dois argumentos eram suficientes. A consequência disso era polarizar a discussão entre a nacionalidade e o imperialismo americano. Teria sido o contexto político o responsável por criar uma crítica de caráter desenvolvimentista que misturava temas opostos como estética, política, indústria e mercado, sem se importar com as divergências. Na junção dessas temáticas, os críticos deixavam de lado alguns problemas do cinema brasileiro com receio de atrapalhar o mercado. Portanto, a defesa do cinema do ponto de vista econômico ficava encarregada também de impedir o florescimento de contradições internas, que levariam à desunião entre os cineastas (Bernardet, 1979). O tema comum da nacionalidade conseguiria criar um bloco de união entre todos os tipos de cinema brasileiro através da luta contra o imperialismo americano.

A ocupação do mercado servia como tema comum entre liberais e comunistas na oposição ao regime militar. Em Opinião, a temática se transformava na liga entre o proprietário do jornal e sua equipe. Os liberais que eram donos de meios de comunicação de massa tiveram papel fundamental na resistência quando abriram espaço para a manifestação da cultura do nacional popular trazida pelos agentes culturais da esquerda (Napolitano, 2011). A esquerda, principalmente a comunista, fornecia quadros importantes para a produção de conteúdo dos meios de comunicação de massa. Através dessa união, a indústria cultural assimilava vários projetos de ação da resistência. Fernando Gasparian cumpriu muito bem esse papel em Opinião. Ele abriu o espaço para a intelectualidade de esquerda expor suas ideias. Portanto, a relação dele com Raimundo Pereira pode ser vista como parte da aliança e dos dissensos na resistência entre liberais progressistas e a esquerda. No pacto com o editor-chefe, havia uma simbiose, uma troca de recursos e de ideias. A aproximação de Gasparian com a ala do nacional popular não acontecia somente pelo status dos "medalhões da esquerda", mas porque os valores compartilhados satisfaziam aos dois lados: a defesa do nacionalismo, da revolução etapista e da aliança entre amplos setores da sociedade.

Com a dissolução do acordo com Raimundo Pereira e o fim do contrato com Argemiro Ferreira, Gasparian também se unia ao grupo de oposição ao nacional popular na seção de cultura. Essa ala crescia no jornal e se delineava cada vez mais. A diferença 
é que a aliança entre o nacional popular e os liberais era menos conflituosa. O acordo entre o setor liberal e a oposição ao nacional popular na seção Tendências e Cultura era muito tênue, porque essa última ala não aceitava os valores da Frente e expunha a olho nu a própria instituição jornalística. A ideia de fazer a crítica ao nacional popular num jornal de Frente era uma tarefa delicada. O diálogo feito com Júlio César Montenegro vai além da dicotomia simplista entre engajamento e desbunde, porque há nele um tipo de resistência que explicita a diversidade da esquerda, como vimos no final do capítulo 6. No final, a vitória do nacional popular na última edição do semanário não cerceava só a pluralidade do jornal, mas significava uma derrota a médio prazo para a Frente. Portanto, na história das disputas internas de Opinião percebe-se o acompanhar dos rachas da esquerda.

Além de abrir a oposição ao nacional popular, a fase do Jornalismo Cultural Reflexivo traz uma grande inovação do ponto de vista jornalístico. Júlio César Montenegro antecipa alguns elementos da futura imprensa basista ${ }^{4}$, quando incorpora os leitores do jornal como colaboradores. Colocar o público a par da dinâmica do circuito cultural e fazer a crítica ao jornalismo dentro do próprio espaço da imprensa foi um projeto original de Montenegro. Mesmo com os atritos com Fernando Gasparian, fica a pergunta: qual dono de jornal permite a publicação de críticas ao próprio veículo? Nenhum. Portanto Opinião inovou nesse aspecto. Em nenhuma redação da grande imprensa daquele momento teria sido possível revelar os conflitos internos nas matérias, como aconteceu em Opinião. Só a aliança em torno da resistência entre atores sociais tão diversos permitiu concretizar essa experiência de autogestão.

Indiretamente, o Jornalismo Cultural Reflexivo expõe as disputas internas do jornal não só na etapa final, mas também na primeira fase. Desde o início Montenegro queria fazer a crítica da esquerda, mas só conseguiu colocar em prática seu plano nos dois últimos anos do semanário. De alguma forma, o período inicial sob o comando de Raimundo Pereira e Fernando Gasparian não abriu espaço para a crítica ao nacional popular. Afinal ao que tudo indica o projeto editorial estava mais voltado à luta contra a ditadura. A briga com a seção cultural não aconteceu porque Montenegro colocou em prática a Microfísica do poder através das ideias de Michel Foucault. O choque final veio quando a crítica ampliou-se para a política, atacando diretamente a cultura do

\footnotetext{
${ }^{4}$ Ver o capítulo 6 .
} 
nacional popular e seus principais cânones. Afinal a dissidência no jornal tinha seus "limites"; ela só podia ir até certo ponto. Quando a oposição interna da esquerda tenta se mostrar de corpo inteiro ao público, o nacional popular toma o poder de volta.

Ao longo dos capítulos, deixamos algumas indagações para o futuro. Além disso, quando há duas versões ou informações conflitantes, não apagamos com a borracha da objetividade as dúvidas. Nestes casos frisamos esses dados no corpo do texto ou em notas de rodapé para contribuir, quem sabe, com outras pesquisas. Afinal nosso recorte é a seção de cinema do jornal. Portanto não temos pretensão à universalidade e ao absoluto. Ao longo da tese, cotejamos a construção da memória dos entrevistados com a pesquisa documental, com o material publicado e com o percurso histórico daquele momento. Acreditamos que a pesquisa, seja ela acadêmica ou jornalística, deva trazer os sujeitos portadores dos pontos de vista, jamais os apagar ou homogeneizar. O percurso prevê ainda o espaço para o leitor tirar suas próprias conclusões e quem sabe construir outras significações.

Nos relatos dos colegas críticos de cinema, Montenegro surge como o grande personagem da seção cultural de Opinião. Há uma filiação em torno dele na memória dos críticos. Assim se reforçam também ao longo do trabalho alguns sentimentos de contraposição ao nacional popular. As referências ao passado centradas em Montenegro mantêm a coesão do grupo de críticos de cinema. Existe, inclusive, uma "comunidade afetiva" (Pollak, 1989) ou uma adesão afetiva do grupo centrada nele. Se estes comentários são sobre a construção da memória, deixamos de lado a subjetividade e a constatação do quanto Júlio César realmente encarna a afetividade em pessoa.

Montenegro falou abertamente sobre as disputas internas do jornal nas diversas entrevistas. Alguns críticos de cinema comentaram um ou outro episódio, mas a tendência geral foi relatar o desinteresse pelo debate interno da esquerda e pelas questões políticas do cinema. A exceção no quesito engajamento pelo cinema brasileiro é Jean-Claude Bernardet. Se todo relato individual tem um núcleo resistente, um fio condutor e um leitmotiv em cada história de vida, isso é válido para o tema do engajamento. Alguns entrevistados falaram da atuação política como questão central da esfera pessoal daqueles anos. Outros declararam sua preferência pelo cinema como arte, longe da esfera do engajamento. Afinal não se trata somente de relatos de fatos, mas de instrumentos de reconstrução de identidade in loco e a posteriori. 
Quando o assunto é a censura interna, a questão da memória é central. O tema causa nos críticos algumas pausas para pensar antes das respostas. Os entrevistados perderam o contato ao longo dessas décadas, mas há entre eles um discurso sintonizado que indica um consenso sobre os mesmos fatos e um processo de seletividade e negociação entre a memória individual e a coletiva. No tema da censura interna, o indivíduo define seu lugar social e suas relações com os outros. Às vezes o silêncio pode até significar uma condição necessária para a manutenção do diálogo com seu próprio meio (Pollak, 1989). A tendência dos entrevistados é reforçar a coesão social. Na média, ha um trabalho social de controlar as feridas, tensões ou quem sabe até mesmo as contradições da própria esquerda. $\mathrm{O}$ silêncio tem por função não se expor a maus entendidos pessoais. Nosso intuito é pensar a censura interna como exemplo das disputas entre as alas do jornal, mas para os entrevistados provavelmente o tema passe pelos nomes de quem estava no comando. Há nesse processo o mesmo relato de Michel Pollak das zonas de sombras, silêncios e não-ditos. Como o tema envolve também questões pessoais, no caso de Raimundo Pereira a tendência é minimizar os dados, até o desaparecimento completo do tema. Por outro lado, isso não é feito com a figura de Fernando Gasparian.

A palavra censura interna incorpora a marca de um censor do regime militar no jornalista encarregado de editar os textos. É como se o clima político causasse uma projeção do censor no colega de trabalho. O termo revela o quanto os colaboradores exigiam um tratamento em pé de igualdade entre todas as alas da esquerda, porque se tratava de um jornal de Frente Ampla. O sonho latente é a liberdade total de escrita, porque um veículo envolvido na luta contra a ditadura deveria ser democrático na edição do texto. Por outro lado, através dos depoimentos se percebe como a questão na grande imprensa provavelmente envolvesse uma autonomia menor de escrita.

É possível dividir o tema da censura interna em dois tipos. Uma conclusão definitiva precisa incorporar os relatos e documentos de outras editorias do jornal, especialmente a de política. Através da análise dos depoimentos e das cartas do passado, percebe-se que a maior parte dos relatos dizia respeito ao processo cotidiano de edição do jornalismo, resumindo ou alterando alguns trechos dos textos. Em nenhum dos relatos, Raimundo Pereira é citado por ter vetado artigos completos, como aconteceu com Gasparian na fase final de Opinião. Nesse sentido, provavelmente o silêncio dos entrevistados seja uma pausa de autoavaliação sobre as regras do jornalismo. É inegável 
que o contexto político gerou uma atmosfera de radicalidade. Há até relatos de leitores pedindo a demissão de colaboradores por causa de uma grafia escrita errada. A função de copydesk em meio a tantas solicitações de diferentes alas políticas no jornal não deveria ser tarefa fácil. Ao que tudo indica, Raimundo Pereira nem sempre solicitava a autorização dos autores para alterar os textos. Afinal ele editava os textos vírgula por vírgula até de madrugada. Diferente dele, Sérgio Augusto (2006) explica que cansou de tanto editar os artigos com linguagem empolada dos intelectuais de Opinião. Mas ele sempre pedia o consentimento dos colaboradores.

O segundo tipo de censura interna surge nos documentos de época e indiretamente nos relatos. Trata-se da tentativa de impedir o florescimento nos textos da crítica interna da esquerda. Nesses casos, o objetivo parece ser o de evitar a dissolução da união em torno da Frente Ampla. As acusações de época eram diversas: impedir o florescimento de críticas ao nacional popular e aos nomes renomados dessa cultura, diminuir o espaço de outras tendências de pensamento político ou tentar manter a qualquer custo a Frente Ampla. Embora a aplicação da palavra censura interna seja muito inadequada para os dirigentes de um jornal de resistência ao regime militar, ela dá uma boa dimensão do sentimento da equipe. Ao que tudo indica, a reclamação parece de cunho político.

Numa carta de época, Jean-Claude Bernardet deixava claro o quanto a censura interna tem como remetente a Frente Ampla ${ }^{5}$. O crítico expõe o clima de tensão entre o proprietário do jornal e as diversas editorias. Ele relaciona os conflitos de Opinião com a "coligação de forças heterogêneas de oposição", possível em 1972, mas que tende a estourar no governo Geisel e após as eleições. Para ele, Gasparian tem uma perspectiva totalmente "adesista" e totalmente MDB. Além disso, tende a colocar o jornal a serviço de seus interesses. Enquanto isso, a editoria geral ${ }^{6}$ busca iniciativas "à frente do MDB", gerando os conflitos ${ }^{7}$. A tendência da Editoria Geral é dar ao jornal uma "função clara e

\footnotetext{
${ }^{5}$ Correspondência de Jean-Claude Bernardet a Paulo Emilio Salles Gomes. Rio de Janeiro, 07 fev. 1975. Pasta PE/CP 1085 a 1088. Arquivo Paulo Emilio Salles Gomes - Centro de Documentação e Pesquisa da Cinemateca Brasileira.

${ }^{6} \mathrm{O}$ termo Editoria Geral carece de definição e ao pé da letra poderia apontar para um atrito com alguma seção do jornal ou com o comando geral. Os entrevistados não se lembram do seu significado. Um deles sugeriu que talvez a palavra indique uma maneira velada de se referir ao poder de Raimundo Pereira.

${ }^{7}$ Opinião elogiava o grupo dos autênticos do MDB (Movimento Democrático Brasileiro) e criticava os moderados, incluindo alguns amigos de Gasparian. Kucinski afirma que Opinião teve um posicionamento contrário ao MDB (Movimento Democrático Brasileiro) nas eleições de 1974 porque estava alheio às demandas dos leitores, que votaram em peso no partido. Ele vê o episódio como uma prova do envelhecimento e alienação do jornal, que transmitia uma visão irreal do processo político. Segundo ele, a
} 
definida no atual jogo político" para conquistar leitores. Contudo, esse viés cria uma tensão entre a Editoria Geral e a seção Tendências \& Cultura. As páginas finais deveriam ser mais leves porque cinema também é "divertimento", mas Jean-Claude Bernardet aponta que os críticos são mal humorados, "pixam" tudo. E termina "somos censurados internamente".

Ainda no próprio Opinião, Bernardet fazia a crítica à ideia de resistência como bloco homogêneo no artigo Jornalismo Cultural - De Cid Moreira a Bourdieu ${ }^{8} \mathrm{em}$ 1977. O texto problematizava as fissuras no campo dos intelectuais, revelando que a resistência não era um bloco homogêneo do ponto de vista ideológico. O campo intelectual, descrito pelo eufemismo do jornalismo, é "cheio de tensões e contradições", na verdade entre as formas de realizar a resistência.

Não era só Bernardet quem falava de censura interna e a relacionava à Frente Ampla. Uma carta de Ana Cristina César em dezembro de 1976 também comentava o impedimento de tocar no assunto da Frente Ampla. Portanto a censura interna na verdade não é pessoal, mas é uma tentativa de controle dos outros lados da Frente:

\begin{abstract}
"Acho muito legal discutir essa história de cultura nacional, esse conceito, e mais o nacionalismo e o populismo. Há como que uma briga se articulando, digamos, nas esquerdas - de um lado a "frente ampla", partidão, Movimento, nacionalismo, raízes populares, gota d'água, união contra o inimigo real do momento, vale tudo contra a ditadura, não vale falar mal nem criticar quem tá no mesmo saco. De outro lado (nem é um lado, estou sendo grossa, me entende, please) alguns grupos ou pessoas que não estão aceitando muito essa frente ampla e começam a criticar, Opinião, Montenegro, esse artigo do Renato da Silveira, o José Arrabal falando de teatro... Eu acho tão complicado isso, gostaria muito de discutir essas coisas. Em princípio, acho que não dá essa frente ampla dogmática ("a censura é o mal do teatro atualmente" é uma das frases lapidares); porra, não é só a censura; a censura vira desculpa, vira ponto de união de um saco de gatos onde entram inclusive os maiores filhos da puta. Mas, me argumentam os estrategistas - qual é afinal a diferença entre estratégia e tática? - mas é hora de união, não vale a pena atacar o inimigo errado no momento. Desconfio, desconfio. Nesse ponto acho o Adorno ótimo" (Hollanda; Freitas, 1999: 136-7)
\end{abstract}

redação achava que o MDB iria perder, por isso só no último momento o jornal propôs o voto no partido. Acreditamos que essa questão seja ainda mais complexa por causa dos dados obtidos com a leitura da tese de José Antonio Spinelli Lindoso (1997). Ao abordar as opiniões dos articulistas de Opinião sobre as eleições de 1974, se percebe claramente que o jornal colocava em xeque o papel de oposição do MDB, debatendo seus dilemas. Ou seja, não houve uma simples transposição de ideias do PC do B; longe disso, Opinião parece fazer a própria crítica interna da esquerda no jornal.

${ }^{8}$ Bernardet, Jean-Claude. Jornalismo Cultural - de Cid Moreira a Bourdieu. Opinião. n. 223, p. 24,11 fev. 1977. 
Do lado oposto, é possível entender a preocupação de Fernando Gasparian e Raimundo Pereira em não trazer as disputas internas da esquerda para não atrapalhar a Frente Ampla. De qualquer forma, o destino da Frente Jornalística era mesmo a separação com o processo de abertura política. Trata-se de duas maneiras diferentes de pensar a resistência cultural: a união em torno de objetivos comuns dos dirigentes do jornal ou a crítica interna da esquerda defendida pela seção Tendências e Cultura.

O movimento de rivalidade interna do jornal não faz parte somente da Frente Ampla, mas da própria dinâmica do campo cultural (Bourdieu, 2001). Todo campo é um campo de disputas em constante construção: "a história do campo é a história da luta pelo monopólio da imposição das categorias de percepção e apreciação legítimas; é a própria luta que faz a história do campo; é pela luta que ele se temporaliza" (Bourdieu, 2001: 88).

Pensar qualquer campo como parte de disputas internas evita sonhar a imprensa alternativa como bloco homogêneo e ligamento imune às infiltrações. A homogeneidade da resistência foi construída pela memória historiográfica (Napolitano, 2011). Afinal, nenhuma esfera de resistência estava imune às contradições. O esforço final é evitar ver os atritos da resistência na imprensa alternativa como um dado negativo só pela existência das lutas e tensões internas. Muito melhor é explicar a união e as rupturas da Frente Ampla de forma dialética e poética como fez Júlio César Montenegro: "Simbolicamente fios soltos podem ser desATADOS por poder concentrado. Tramas dando panos pra manga vem de fios tecidos" 9 .

\footnotetext{
${ }^{9}$ Essa declaração em especial foi obtida via email. 22. jul. 2014. Os grifos são do autor.
} 


\section{José Arrabal e a Crítica ao Nacional Popular na Seção de Teatro de Opinião}

Natural do Espírito Santo, a luta contra o autoritarismo na política estava no sangue. Ainda durante o Estado Novo, o pai de José Arrabal Fernandes Filho desafiou as leis da censura e interrompeu seu discurso de orador da Faculdade de Medicina para pedir a democratização do país a Getúlio Vargas ${ }^{1}$. A família de origem espanhola tinha na Guerra Civil Espanhola um dos assuntos preferidos ao longo das décadas. No mesmo ano do golpe militar, Arrabal entrou para a Faculdade de Direito da Universidade Federal do Rio de Janeiro. Era um estudioso do teatro. Em 1966, ele trabalhava como jornalista e crítico de teatro do Jornal do Commercio e dos Diários Associados. Ainda durante os primeiros anos da faculdade, sua carreira foi interrompida em decorrência da situação política. Da sua turma de faculdade, muitos foram para a guerrilha urbana. Ana Maria Palmeira lhe passou os primeiros livros sobre marxismo em 1966. Um ano depois Arrabal já era alguém assumidamente de esquerda. Ele começou dando apoio logístico a Vladimir Palmeira na DI - Dissidência Interna do Partido Comunista. Passou também pela Ação Libertadora Nacional (ALN). Na época era do tipo "boi de piranha", abrigando em sua casa várias tendências políticas, às vezes como espaço de reunião ou de acolhida aos que precisavam. Avesso à luta armada, José Arrabal começou como estrategista de segurança dos locais por onde passava Palmeira. O trabalho de infraestrutura e de compra de suprimentos o aproximava da guerrilha urbana. $\mathrm{Na}$ época, ele sabia de cor a Convocatória da Guerrilha Urbana de Carlos Marighella. Quando percebeu que a guerrilha era um barco furado, já era tarde. Ele foi preso com um grupo de jovens estudantes em 1972. Tinha 25 anos. Naquela época fazia parte da Fração da Política Operária (Polop), avessa à intervenção armada.

Naquele mesmo ano, surgia o jornal Opinião e Arrabal era leitor assíduo. Para todos eles, Opinião significava um apoio intelectual naqueles anos difíceis. Na prisão, Arrabal e sua esposa foram muito torturados. Ele ficou muito doente e teve uma infecção renal por causa da tortura. Demorou quatro anos para se curar. Depois da primeira prisão, José Arrabal foi detido mais quatro vezes, por causa do seu jeito "muito ousado" de ser. A postura dele não era aprovada pelos colegas, mas mesmo assim ele entrava nos ônibus do Rio de Janeiro e batia palmas. Depois pedia a atenção de todos e

\footnotetext{
${ }^{1}$ Ver Arrabal, José. A sociedade de todos os povos. Barueri/São Paulo: Editora Manole, 2010.
} 
contava que tinha sido preso e torturado. Passados alguns dias, vinham os telefonemas anônimos com promessas de novas prisões e sessões de tortura. Então Arrabal era novamente preso e apanhava muito. Segundo ele, as prisões tinham fundo "corretivo", para que Arrabal caísse na clandestinidade e pudesse ser perseguido mais ainda.

Por causa das prisões, José Arrabal não arranjava nenhum emprego. Quando ele conseguiu uma vaga de freelancer fixo num grande jornal, o editor voltou atrás no outro dia. Explicou que não poderia contratá-lo porque Arrabal seria preso no dia seguinte. No final de 1972, era impossível continuar a viver no Brasil. Com a carteira de correspondente internacional de Politika e da Tribuna da Imprensa ${ }^{2}$, ele foi para o exílio no Chile e na Argentina. Trabalhava como jornalista e enviava matérias contando a situação do Chile durante o governo de Salvador Allende com o pseudônimo de Marcos Prado. Foi no Chile que ele escreveu o primeiro artigo para Opinião. No começo de 1973, Arrabal entrevistou o senador Carlos Altamirano, líder do partido socialista, que defendia armar as favelas e impulsionar as formas de poder das organizações populares. Enquanto Arrabal pensava para qual jornal enviar a matéria, veio a sua mente Opinião ${ }^{3}$. A entrevista foi publicada com destaque no jornal ${ }^{4}$ e teve repercussão porque os temas não eram discutidos na opinião pública brasileira.

Graças ao sogro, Arrabal e a esposa puderam voltar ao Brasil. Ele foi até a redação de Opinião e se identificou para Raimundo Pereira. O editor-chefe pediu uma matéria sobre teatro e o primeiro texto foi publicado ainda no começo de 1975. Naquela época, Arrabal se aproximava do trotskismo e estava na Libelu (Liberdade e Luta). Muitos colegas dessa convergência foram com ele para Opinião. A preferência era pelo Trotsky enquanto crítico literário. A aproximação dele com a Libelu acontecia porque o

\footnotetext{
${ }^{2}$ Durante o regime militar, Arrabal trabalhou em diversos jornais da imprensa alternativa: Politika, Opinião, Movimento, Em tempo e em muitos outros veículos menores da imprensa alternativa em vários estados brasileiros. Escreveu para a Tribuna da Imprensa, Visão, Jornal do Commercio, Diários Associados e anos depois para a Revista Submarino. Nos anos oitenta, ele decidiu se tornar escritor e desde lá já escreveu mais de quarenta livros, além de exercer a docência em Jornalismo e Letras na PUC, na Metodista, na Faap, na Universidade de Mogi das Cruzes e na Unip.

${ }^{3}$ José Arrabal conta como era difícil transmitir as matérias para o Brasil. Geralmente ele recorria a um diplomata amigo ou enviava por carta os artigos para amigos da Argentina. Então os textos seguiam até o Brasil por correio. Antes disso, ele tentou despachar o material através da Varig, mas o funcionário não garantiu a entrega. Quando descia as escadas, Arrabal foi filmado por um policial como prova. A situação dos brasileiros no Chile também era insustentável e ele decidiu abandonar o país ao perceber que haveria um golpe militar.

${ }^{4}$ Altamirano, Carlos. O líder do PS Chileno: 'Avanzar sin tranzar'. Entrevista concedida a Marcos Prado (pseudônimo de José Arrabal) Opinião. n. 18, p. 16-17, 05 a 12 mar. 1973.
} 
partido discutia a questão comportamental, enquanto o PCB e o PCdoB não só negavam essa discussão, mas desprezavam o tema.

O trabalho na seção de teatro de Opinião era dividido pelas cidades. Fernando Peixoto escrevia de São Paulo, enquanto Arrabal cobria o Rio de Janeiro. Quando Peixoto não assinava, Arrabal publicava. Ele explica que a seção de teatro era muito censurada. A equipe mandava sempre textos em dobro porque o nome de Fernando Peixoto era constantemente vetado pelos censores. Por esse motivo, Peixoto muitas vezes assinava Andrea Sarti, pseudônimo retirado do livro A vida de Galileu de Bertold Brecht. Era comum a censura interditar um artigo de Peixoto numa semana e liberar na semana seguinte o mesmo texto assinado por Andrea Sarti.

Existia entre os dois críticos certa "divergência" de ideias, por causa da diferente de idade e de formação. Arrabal explica que tinha um profundo respeito pela trajetória de Peixoto como diretor e ator importante do Arena e do Show Opinião. Ele se definia como um estudioso de teatro, enquanto Peixoto tinha um compromisso profissional com o ramo. A relação era pautada por um debate de ideias, com alguma gozação do "jovem rebelde" que era. Arrabal gostava de falar para Fernando Peixoto: "O meu Brecht é comunista, o seu é liberal". Contudo, essa diferença de pensamento os afastava progressivamente.

De todos entrevistados, apenas Júlio César Montenegro e José Arrabal falaram abertamente sobre sua oposição direta ao nacional popular no jornal Opinião. Arrabal mudou sua postura sobre o nacional popular quando leu $O$ colapso do populismo no Brasil de Octavio Ianni, publicado em $1968^{5}$. Foi quando ele percebeu que o populismo levou ao fracasso da esquerda. Esse foi seu grande divisor de águas. Além dessa guinada, duas leituras foram importantes na sua trajetória de oposição ao nacional popular. A primeira foi o artigo de Sebastião Uchôa Leite sobre a cultura popular publicado em 1965 na Revista Civilização Brasileira ${ }^{6}$. Depois veio o livro de JeanClaude Bernardet, Brasil em Tempo de Cinema de $1967^{7}$. Desde aquela época, Arrabal não acreditava que o final da ditadura levaria o Brasil ao socialismo. Se o PCB se considerava um partido revolucionário, ele só via "conformismo".

\footnotetext{
${ }^{5}$ Ianni, Octavio. O colapso do populismo no Brasil. Rio de Janeiro: Civilização Brasileira, 1968.

${ }^{6}$ Cultura Popular: Esboço de uma resenha crítica. Revista Civilização Brasileira. n. 4, set. 1965.

${ }^{7}$ Sobre as duas obras, ver o capítulo 6.
} 
Se a mudança de pensamento de Arrabal veio nos anos sessenta, o ambiente cultural de Opinião possibilitava muitas trocas de ideias entre os críticos. Com os amigos Jean-Claude Bernardet e Ronaldo Brito, ele aprofundava ideias já sedimentadas. O jornal foi importante também na sua trajetória. Ele via Júlio César Montenegro e Bernardet como intelectuais sofisticadíssimos que conheciam muito bem diversos autores como Michel Foucault, Roland Barthes, Pierre Bourdieu, que ele passou a conhecer melhor através das leituras de Opinião.

José Arrabal conta que não era um colaborador constante no jornal, mas chamava muito a atenção porque falava "coisas que ninguém dizia". Assim ele ficou marcado como o "crítico ao nacional popular" ou como a pessoa "que abriu a ferida". Há nele uma autocrítica forte ao proferir essas palavras. Sua busca naquele momento era pelas obras de arte com uma reflexão na linguagem e pela capacidade de recolocar signos. Essa postura não repercutia só com os leitores, mas no próprio campo intelectual. Sebastião Uchôa Leite disse a Arrabal que tinha apreciado muitos os textos dele em Opinião, além de admirar sua coragem. Por volta de 1976-77, José Arrabal foi ouvir Carlos Guilherme Mota numa palestra na USP e decidiu fazer uma pergunta sobre populismo. Mota respondeu que não poderia responder, afinal o assunto era uma novidade trazida por Arrabal. A reação da plateia foi de risos e o crítico de Opinião teve que se identificar publicamente a todos.

Os artigos de Arrabal em Opinião têm um forte viés crítico ao nacional popular no teatro. O tema é vasto. Nosso viés aqui é introdutório e não aprofunda as questões específicas do campo teatral, nem tem a pretensão de relacionar os artigos com as peças em questão ou com os dramaturgos ligados ao nacional popular ${ }^{8}$. Nosso foco é traçar alguns paralelos entre a oposição ao nacional nos textos de Arrabal com a trajetória de Opinião. Procuramos esclarecer algumas das polêmicas da seção de teatro e observar algumas linhas de continuidade metodológica entre ele e o jornal.

O trabalho é feito com os dois artigos que causaram mais polêmica nos jornais de Fernando Gasparian. O primeiro texto é sobre Gota d'água de Chico Buarque e Paulo Pontes e foi publicado no Jornal de Debates, quando o redator-chefe era Júlio César Montenegro. O artigo antecipa algumas linhas de crítica ao nacional popular que serão colocadas em prática em Opinião por Montenegro. Meses depois, Arrabal

\footnotetext{
${ }^{8}$ No caso de Gota d'água, esse trabalho foi feito por Miriam Hermeto (2010).
} 
analisou a peça Ponto de Partida de Gianfrancesco Guarnieri no próprio Opinião, também sob o comando de Montenegro.

José Arrabal explica que o artigo vetado em Opinião sobre Gota d'água não foi escrito por ele. Seu texto sobre a mesma peça foi publicado sem nenhum problema interno no Jornal de Debates. Depois da publicação, o texto ocasionou muita "pedrada" em cima dele. O título escolhido já dá uma dimensão do tamanho da polêmica: Gota d'água: essa noviça rebelde ${ }^{9}$. O texto discutia se Gota d'água de Chico Buarque e Paulo Pontes representava alguma inovação no panorama cultural. Além disso, Arrabal trazia aos leitores um pouco do dia a dia interno da crítica de teatro. Ele observa um endeusamento dos dois autores que impedia uma troca de ideias, tornando as polêmicas um assunto proibido. Arrabal vai contra essa trajetória porque só com reflexão crítica o debate pode acrescentar algo sobre as formas de apropriação da realidade. $\mathrm{O}$ artigo antecipa a fase final de Opinião quando se vê a discordância e o questionamento das produções como prática enriquecedora do processo cultural. Parte da polêmica em torno de Gota parece passar pela questão da política cultural e da estratégia de ocupação dos mercados a qualquer custo ${ }^{10}$. Como membro da futura Nova Esquerda, Arrabal se contrapõe ao mercado e à totalidade desse processo, que gera peças de teatro para um público com feições conservadoras e com alto poder aquisitivo. Nesses casos, o modelo de construção é o do espetáculo comercial sofisticado e alienante, trazendo valores preconceituosos e uma visão de mundo passiva. Quando Arrabal entra no quesito da política cultural, ele analisa seus aspectos contraditórios, como o fortalecimento dos sindicatos de atores e o surgimento de um teatro não empresarial mais ativo. $\mathrm{O}$ polo elogiado pelas propostas originais é o de José Celso Martinez Corrêa e de Augusto Boal que questionam o processo de produção.

Os comentários de Arrabal sobre Gota passam mais pela visão de mundo da peça e pela análise da forma escolhida, isto é, a tragédia. Mantendo parte do específico da crítica de artes de Opinião (ver Capítulo 2), ele procura pelo discurso político da peça. Começa pela trama, provavelmente porque não localiza nada de verdadeiramente

\footnotetext{
${ }^{9}$ Arrabal, José. Gota d'água: Essa Noviça Rebelde. Jornal de Debates. n. 11, p. 9-10, 12 a 18 abr. 1976.

${ }^{10}$ Paulo Pontes era diretor da Associação Carioca de Empresas Teatrais, entidade da qual saiu o nome de Orlando Miranda para dirigir o SNT/Serviço Nacional de Teatro (Arrabal, 1983). Um documento desse órgão de 1973 solicitava o auxílio estatal através de financiamentos com juros módicos para incentivar o teatro. $\mathrm{O}$ artigo de Arrabal critica o viés liberal e comercial da política cultural, porque o dinheiro concedido só fortalece aos empresários e ao teatro empresarial, aumentando os custos de produção e o preço dos ingressos.
} 
inovador na forma cênica utilizada. Abrindo um paralelo com a seção de cinema de Opinião, os comentários poderiam ser incluídos nos casos onde os críticos não veem um autor e analisam uma produção de gênero, voltada ao mercado. Por esse motivo, o texto se concentra na história e na composição dos personagens. A Medeia tropical da resistência é vista como a história de interesses do jovem sambista Jasão que troca Joana por Alma, filha do poderoso Creonte. Jasão é visto como o duplo do intelectual que abandona suas raízes e seu compromisso com as classes populares em busca de poder. O texto explica que a história roga ao poderoso Creonte mais moderação e o abandono da violência, deixando as coisas como estão. Em entrevista, Arrabal contou que quando assistiu Gota viu uma obra com medo da ditadura. Mas a resistência não pode ter medo, porque com medo ela é derrotada. Ele sentiu que a peça almejava por uma revolução lenta, parecida com o projeto de um intelectual de esquerda aburguesado. Ele nem saberia dizer se ela era mesmo parte do projeto do PCB (Partido Comunista Brasileiro).

$\mathrm{O}$ artigo traça um paralelo entre a postura populista da peça e seu cunho moralista e liberal. A somatória desses elementos acabava por mascarar as relações de classe. Em sintonia com parte da forma típica de análise de Opinião (Ver Capítulo 2), Arrabal deixa de lado completamente a análise da qualidade da obra, a autoria do diretor ou o desempenho do ator. Ele não irá questionar em nenhum momento a boa intenção dos dramaturgos e dos diretores, mas as representações ideológicas do mundo que as obras transmitem indiretamente. Só há um único comentário interno onde Arrabal elogia o distanciamento (brechtiano) do intérprete de Creonte, fazendo o público pensar sobre o personagem e o distanciamento do tempo através de sua entonação.

$\mathrm{O}$ artigo possui mais de uma crítica direta à cultura do nacional popular, visto como forma do velho teatro ingênuo dos anos cinquenta que tenta ressuscitar de seu colapso. Primeiro ele problematiza o conceito de povo. Arrabal se pergunta se Paulo Pontes entende povo como "camada subalterna", ou se incluiria o catedrático e o estudante no grupo. O comentário estende-se à própria massa, mostrada como "massa de manobra", tanto dos personagens quanto no espetáculo. "Por que essa massa não pode pensar? Por que deve existir sempre quem pense por ela?" Como um desdobramento dessa questão, Arrabal chega ao receptor. Ele indaga a quem a peça vai libertar. Segundo ele, o público da peça não vai "implorar e aceitar que outros o libertem". Afinal o espectador não "engole" o recado e o "mundo continua como tal". 
Na sequência Arrabal questiona dois aspectos da cultura do nacional popular. O primeiro é o da cultura popular. "Fala-se em cultura de elite e em cultura popular: é preciso que esta última seja veiculada... através dos canais competentes da cultura de elite, é claro! E que fique tudo como dantes, no quartel de Arantes: santa ingenuidade!" Depois ele coloca em xeque a figura do intelectual arauto. "E em meio a esse clamor de protetores do povo, defensores de seus direitos, redentores de sua miséria, chancela de Chico, bandeira de Paulo". Reeditando o moralismo populista, se coloca "o dedo no nariz do público, ensinando com autoridade de cátedra, o que é libertação. A frase feita, a coisa dada como evidente, picadinha e mastigada, para o público engolir, sem pensar, de preferência." A consequência é "reproduz o velho populismo na crença elitista de que a nós, intelectuais, cabe o dever moral e a função redentora de manobrar a massa em favor de nossos ideais puros e inquestionáveis." Ao exigir de Jasão uma auto crítica, ele exige do teatro um tipo de questionamento como foi feito no Cinema Novo através de filmes como O desafio (1965) de Paulo César Saraceni, Terra em Transe (1967) de Glauber Rocha, O bravo guerreiro (1968) de Gustavo Dahl.

O terceiro ponto analisado é a opção pela visão trágica do mundo, sem espaço para os homens mudarem seu destino, porque tudo já está previamente determinado. Para Arrabal, a forma da tragédia é um discurso de autoridade que não aspira a transformar nada. Assim se mantém o status quo que interessa aos poderosos e veicula "a moderação, buscando um equilíbrio metafísico, de certo modo oportunista."

Arrabal inicia nesse artigo um debate sobre o funcionamento do processo de identificação e catarse no receptor. Segundo ele, o moralismo da peça é responsável por colocar o público numa postura de passividade, enquanto a tragédia funciona como uma advertência. Além disso, a tragédia gera no espectador um "sentimento de autopunição compensado que o fará sair com alívio da terapia cênica a que se submeteu". Essa questão será aprofundada nos artigos em Opinião, quando Arrabal observa um uso reincidente de personagens estereotipados, representando porta vozes ideológicos da sociedade, cujo processo de empatia entorpece as pessoas. O naturalismo ajuda bastante nessa construção e faz o público cair numa armadilha, a um passo da vocação autoritária. Após duas horas de catarse, a plateia consegue se sentir aliviada pelos problemas morais apresentados. Em mais de um artigo, Arrabal revela que no final das peças, a autopunição é recompensada com o alívio da culpa e a possibilidade de voltar para casa sem problemas de consciência. 
Sempre atento à inclusão das classes operárias na dramaturgia brasileira, Arrabal procura por um contraponto à mistificação popular em cena, mas só encontra nas obras analisadas em Opinião a transfiguração numa participação individual com cunho moralista. Assim o desejo dos autores de ir fundo nas relações sociais fica na aparência e o projeto deles não se concretiza. Arrabal questiona fortemente as peças que mostram os operários como figuras dignas de pena, sem enfoque crítico. Procura pela presença ativa em cena do operário sem a emoção. Se a identificação resulta em falácia, Arrabal procura pelo distanciamento brechtiano para questionar a naturalização do espetáculo.

Se os artigos de Arrabal em Opinião questionam o nacional popular mais de uma vez, um deles causou grande polêmica interna. Trata-se da peça Ponto de Partida de Gianfrancesco Guarnieri, sob a direção de Fernando Peixoto ${ }^{11}$. Nessa época, Peixoto já era editor de cultura de Movimento, mas continuava escrevendo para Opinião. O texto não ignora a contribuição de Guarnieri à história do teatro contemporâneo. Ele elogia a inclusão das classes oprimidas no palco, embora de um ponto de vista romântico. Os comentários negativos não são de cunho pessoal. Eles não incidem na direção, autoria nem no específico do teatro, mas na análise do discurso ideológico. Arrabal observa como o nacional popular e a ideologia surgem sutilmente em peças tidas como inovadoras e progressistas. O estudo começa pela trama e na forma autoritária e fechada de conduzir o espetáculo em relação ao público. A história gira em torno do inquérito pela morte de Birdo e a indagação se ele se suicidou ou foi assassinado. "Birdo é o herói morto, por todo o tempo na forca, pendendo do galho de uma árvore, diante da plateia compulsoriamente comprometida com o drama". Arrabal observa que essa mise en scène cria uma penalização do público diante do herói morto. Daí surge uma inatividade e um regime de adoração de deuses vencidos e de passividade ante os heróis.

Observando a obra de Guarnieri, Arrabal vê uma preferência por heróis trágicos que arrastam o público a um envolvimento quase catártico. É nesse sentido que ele fala em dirigismo, em atitude nostálgica e autoritária. Aqui é possível traçar um paralelo com a seção de cinema de Opinião. Uma peça como esta seria vista pelos críticos de cinema do semanário como filme de gênero ou como um melodrama hollywoodiano que arranca lágrimas. Provavelmente a forma escolhida para comentar a obra na seção de cinema também fosse a análise do discurso político (ver Capítulo 2 e 6).

\footnotetext{
${ }^{11}$ Arrabal, José. Partida para onde? Opinião. n. 211, p. 21, 19 nov. 1976.
} 
Como no artigo sobre Gota d'água, aqui a análise também incide na figura do intelectual, centrada no personagem do pastor de ovelhas, interpretado pelo próprio Guarnieri. Dodô conduz o público e cumpre a função de consciência popular. Ele sabe e pensa as coisas. Arrabal observa que o personagem sempre propõe um recuo diante da opressão, na postura típica de não-enfrentamento ao regime: "Sendo o condutor do público é um tanto também a expressão do ponto de vista último do próprio dramaturgo, no seu lamento envolvente da morte do herói e pelo fim dos tempos heroicos."

Arrabal questiona porque o lamento culposo e idealista pela morte do herói não se converte num espaço para discutir o porquê da falência do herói. "Assim Ponto de Partida parece chorar pelo que não existiu, chorando por nada. E na sua dialética, promovendo um lamento um tanto culposo". O propósito parece definido de antemão: "aliviar a culpa" do público. Novamente as classes trabalhadoras estão ausentes do palco dos conflitos, mas essa falta é suprimida pela plateia:

"As classes trabalhadoras estão ausentes do palco dos conflitos. No texto original, seriam interpretadas por bonecos, conforme a proposição de Guarnieri. No espetáculo, a ausência preenche-se por uma suposição convencional, projetando-se o desempenho dessas classes trabalhadoras por todo um processo de identificação com a plateia, que assim é traduzida ilusoriamente para o centro da ação dramática.

(...) O público é levado a uma postura de penalização diante do herói morto. Feição que o teatro hoje deve evitar, caso se pretenda enquanto canal renovador de mentalidades, veículo de novos comportamentos e promotor de ideologias críticas frente ao real."

Arrabal observa que nas peças o povo tem sempre alguém como intermediário para pensar por ele. Assim não é preciso fazer nada, porque o poder será esmagado internamente graças as suas contradições internas. Para o crítico, a visão economicista e o mundo moralista da peça escondem a possibilidade de ação concreta das classes trabalhadoras. O questionamento de Arrabal incide na forma do teatro. Como alguns críticos de cinema de Opinião, ele procurava as obras que revelassem o processo de produção das obras. É por isso que Arrabal se opõe as fórmulas do teatro convencional por sua insuficiência em termos críticos.

O texto sobre Ponto de Partida demorou para ser publicado, indicando uma maior contenção à crítica do nacional popular também na seção de teatro. O tipo de análise que Arrabal coloca em campo era comum para analisar os filmes estrangeiros 
hollywoodianos (ver Capítulo 2), mas criava problemas internos quando utilizado para autores engajados brasileiros. Essa matéria também deu muita repercussão e foi o último texto escrito por Arrabal em Opinião. Macksen Luís ficou em seu lugar porque ele ficou muito exposto no jornal. Arrabal conta que este foi seu único atrito em Opinião. Ele mesmo sugeriu que o semanário publicasse um texto favorável à peça para equilibrar o debate. $\mathrm{O}$ artigo só foi publicado depois que Fernando Gasparian pediu a opinião de duas pessoas, que aprovaram a publicação ${ }^{12}$. Um deles teria dito que Arrabal tinha feito uma leitura da luta de classe no teatro.

Arrabal analisa que na última fase de Opinião se colocou em prática o projeto cultural de Júlio César Montenegro. É possível observar um movimento semelhante na seção de cinema e na de teatro de Opinião. Se no Jornal de Debates se conseguiu espaço para criticar o nacional popular, a reincidência em Opinião foi punida. Os textos sobre Xica da Silva e Ponto de Partida conseguiram autorização para publicação, mas a semente foi logo cortada. No artigo sobre Gota d'água e nos artigos para Opinião, Arrabal bateu de frente contra os grandes nomes do nacional popular, procurando pela inserção do povo em cena. Jean-Claude Bernardet tinha feito a mesma coisa em Brasil em Tempo de Cinema nos anos sessenta, quando questionou a porção nacional popular do Cinema Novo. A consequência nos dois casos foi uma forte polêmica interna.

De comum com as críticas de cinema de Opinião, parece existir nos artigos de José Arrabal uma convicção de que a forma do espetáculo pode alterar a fruição do público. Por isso, ele defende a produção cultural que procura transformar a realidade. A metodologia desse trabalho na crítica de teatro foi apresentada por ele no texto Colunismo Social, publicado em Opinião ${ }^{13}$. Arrabal exige das peças uma lacuna discursiva entre a formação do dramaturgo e dos papéis interpretados (ver Capítulo 4). Os personagens não podem ser um prolongamento discursivo dos dramaturgos, sem nenhum questionamento do diretor. Há também uma variante da ideia de cinema contestatário. Embora em outro suporte, aqui é possível abrir um paralelo entre a aplicação da noção de tragédia em Gota com o sentido dado pelo jornal ao cinema

\footnotetext{
${ }^{12}$ Alguém contou a José Arrabal em off que os dois leitores foram José Arthur Giannotti e Mário Covas, este último era editor da sucursal de Opinião em São Paulo, mesmo cassado pelo regime.

${ }_{13}$ Arrabal, José. Colunismo teatral. Opinião. n. 195, p. 32, 30 jul. 1976. O artigo é o ápice da postura autocrítica do intelectual. Arrabal explica que não tem a intenção de depreciar os artigos dos colegas, porque até ele exerce o colunismo social, visto como um texto desligado da produção imediata sem capacidade de transforma a realidade. Além disso, é passível de uso pelo teatro comercial. Seu objetivo é localizar seu lugar histórico e apontar a crítica de teatro como ferramenta de mudanças sociais. Sobre a crítica participativa, ver o Capítulo 2.
} 
comercial contestatário. "No fundo a tragédia é bem sucedida, porque não se aspira transformar nada, ainda que finja ser a transformação o seu objetivo final. Daí a farsa”. Com esse comentário, Arrabal relacionava o estudo do enredo com a forma da obra.

Mais de uma vez há a presença de uma forte autocrítica de matriz sartriana que exige do intelectual repensar constantemente sua trajetória. Nesse sentido, busca-se localizar um personagem ativo em cena que seja capaz de criar a mesma postura no público. Vendo a gênese do espetáculo como incapaz de gerar a conscientização por causa das fórmulas, a solução apontada é a forma moderna da arte, como ocorreu no caso da crítica de cinema de Opinião (ver Capítulo 2). A matriz de pensamento aproxima-se nesses textos de Bertold Brecht e das propostas de José Celso Martinez Corrêa e Augusto Boal pela originalidade. A luta de Arrabal é pelo desenvolvimento crítico das mentalidades e do comportamento em direção a uma práxis de libertação, sem um moralismo libertário.

Opinião acabou sendo para Arrabal seu ponto de partida para continuar o trabalho de oposição ao nacional popular nos livros. Na coletânea Anos 70, ele organizou suas ideias como crítico (Novais, 2005). Depois o debate foi para a coleção $O$ nacional e o popular na cultura brasileira (Arrabal; Lima, 1983), organizada por Marilena Chauí. Arrabal comenta que provavelmente a origem dos semanários que deram origem aos livros organizados por Chauí estivesse no jornal Opinião. Afinal a maior parte dos autores convidados eram críticos do semanário de Fernando Gasparian.

José Arrabal passou por um longo processo de autocrítica desde os anos setenta. Na época do lançamento de O Amuleto de Ogum (1974) de Nelson Pereira dos Santos, Jean-Claude Bernardet perguntou a opinião de Arrabal sobre o filme. Ele respondeu que tinha gostado, mas condenaria Amuleto se fosse escrever. Afinal era obra nacional popular e reacionária. Foi então que Bernardet perguntou como ele podia ser uma pessoa tão "dividida" daquela maneira. A frase causou nele um "rebuliço" que durou anos. A partir daquele momento, ele passou a se pensar como alguém partido ao meio. Como podia gostar de um filme e escrever contra? Para resolver essa questão, Arrabal levou bastante tempo. Entre os entrevistados para esta tese, José Arrabal atinge o ápice da postura sartriana de autocrítica intelectual. Ele analisa abertamente até sua própria contradição e se vê nos anos setenta mais como rebelde do que como revolucionário. Arrabal observa no seu passado uma expressão sectária e doutrinarista, porque a discussão ideológica deixava de lado a observação da realidade. Certo era o discurso dele; a realidade é que estava errada. Se por um lado ele acredita ter sido "cruel" com 
certos autores, por outro lado conseguiu ser "politicamente correto" enquanto esquerda. De qualquer forma, a postura o levou ao sectarismo, explica. José Arrabal conclui hoje que era necessário na época ser mais fraterno. A esquerda tinha uma fraternidade. Nos textos, "eu os chamei de derrotados", mas eles não eram derrotados. "Eles foram combatentes que perderam a batalha", explica. Ele acha que os dois lados tiveram seus equívocos, mas centrar apenas na luta ideológica os levou a um sectarismo radical.

A revisão de conceitos de Arrabal chegou também a Gasparian e a Raimundo Pereira. Ele conta que a equipe tinha uma tendência a "demonizar" o proprietário do jornal. O crítico de teatro não queria nem estar na mesma sala com o dono do jornal. Gasparian deveria ser bem lembrado. Afinal não ganhou nada com Opinião, que foi um dos momentos mais altos da imprensa brasileira. O jornal foi "o mais importante" da imprensa alternativa. A intelectualidade do mundo inteiro escrevia no semanário. Apesar dos problemas internos com a equipe, Gasparian e a Paz e Terra deixaram um legado, publicando livros que ninguém lançava naqueles tempos. O mesmo vale para Raimundo Pereira que Arrabal chegou a chamar de ditador. Ele pode até ser ligado a um discurso autoritário, mas foi muito importante e continua a lutar por seu ideário político de construir um jornalismo decente.

Arrabal acabou por jogar luz na sutileza da censura interna de cunho político no jornal. O último parágrafo da entrevista dele publicada com Carlos Altamirano foi cortado, quando o senador chileno fazia uma crítica ao partido comunista. Raimundo Pereira alegou que não havia espaço suficiente. Além disso, o trecho aumentava muito a chance da censura vetar a entrevista completamente. Arrabal considerou correta a atitude. Raimundo Pereira não mentiu, mas havia também uma atitude política por detrás da motivação do texto. Afinal, havia os dois tipos de motivação para os cortes.

Como parte da futura Nova Esquerda (ver Capítulo 6), José Arrabal mudou mesmo sua postura em relação à classe trabalhadora ${ }^{14}$ no comício de Luís Inácio Lula da Silva na Vila Euclídes. Lula discursava sem microfone para 80 mil pessoas e os operários replicavam suas palavras para os companheiros de trás poderem ouvir. Ouvindo a fala deles todos juntos, Arrabal pensou: "Eu não sou vanguarda de nada. Nós intelectuais não somos vanguarda de nada. Eles é que são vanguarda”.

\footnotetext{
${ }^{14}$ No final dos anos setenta, Arrabal se aproximou da classe trabalhadora e passou a fazer trabalho voluntário no Capão Redondo, onde morou por vinte anos. Dava cursos de redação, organizou um cineclube e trabalhava nas associações de moradores.
} 


\section{Bibliografia}

AARÃO, Daniel; SÁ, Jair Ferreira de (orgs.). Imagens da revolução - documentos políticos das organizações clandestinas de esquerda dos anos 1961-1971. São Paulo: Editora Expressão Popular, 2006.

ABREU, João Batista de. As manobras da informação. Análise da cobertura jornalística da luta armada no Brasil (1965-1979). Rio de Janeiro: EdUFF/Mauad Editora, 2000.

ABREU, Nuno César. Boca do Lixo - cinema e classes populares. Campinas: Editora Unicamp, 2006.

ACERVO Jean-Claude Bernardet. Cinemateca Brasileira.

ACERVO Paulo Emilio Salles Gomes. Cinemateca Brasileira.

ADAMATTI, Margarida Maria. A comédia erótica na crítica de cinema dos jornais alternativos: Opinião e Movimento. Revista Movimento. n. 1, jun. 2012.

Crítica de cinema e política: o filme histórico nos jornais alternativos Opinião e Movimento. Anos 90. Porto Alegre. v. 19, n. 36, dez. 2012. . Jean-Claude Bernardet assiste aos Mansos (1973): anotações para estudo de filme. Rebeca. Ano 3, Edição 5, jan. jun. 2014.

ADORNO, Theodor. "Engagement." In: Notas sobre literatura III. Rio de Janeiro: Tempo Brasileiro, 1973. v. 3

. "O ensaio como forma". IN: Notas de literatura I. São Paulo: Editora 34/ Duas Cidades Editora, 2003.

ALMEIDA, Giuliana. Cinema Novo e Estado autoritário nas páginas do semanário Opinião. Iniciação Científica. São Paulo, Universidade de São Paulo, 2009.

ALMEIDA, Maria Hermínia Tavares de; WEIS, L. "Carro-zero e pau de arara: o cotidiano da oposição de classe média ao regime militar". In: SCHWARCZ, Lilia Moritz. História da vida privada no Brasil: contrastes da intimidade contemporânea. São Paulo: Cia das Letras, 1998. v. 4. 
ALMEIDA, Maria Hermínia Tavares de. Tomando partido, formando Opinião: cientistas sociais, imprensa e política. São Paulo: Editora Sumaré, 1992.

ALTHUSSER, Louis. Aparelhos Ideológicos de Estado: nota sobre os aparelhos ideológicos de Estado. Rio de Janeiro: Edições Graal, 1985.

ALVIM, Ricardo Cravo. Driblando a censura. Rio de Janeiro: Gryphus, 2002.

AMANCIO, Tunico. Artes e manhas da Embrafilme: cinema estatal em sua época de ouro (1977-1981). Niterói: EdUFF, 2000.

AMENGUAL, Barthélemy [et. al]. Cinema, arte e ideologia. Porto: Afrontamento, 1975.

ANDERSON, Benedict. Comunidades imaginadas - reflexões sobre a origem e a difusão do nacionalismo. São Paulo: Cia das letras, 2008.

ANDRADE, João Batista de; CAETANO, Maria do Rosário (org.). Alguma solidão e muitas histórias - um cineasta em busca da urgência e da reflexão. São Paulo: Imprensa Oficial, 2010.

AQUINO, Maria Aparecida de. Censura, Imprensa, Estado Autoritário (1968-78) - o exercício cotidiano da dominação e da resistência: O Estado de São Paulo e Movimento. Bauru: Edusc, 1999.

ARGAN, Giulio Carlo. Arte e crítica de arte. Lisboa: Editorial Estampa, 1988.

ARRABAL, José. A sociedade de todos os povos. Barueri/São Paulo: Editora Manole, 2010 .

ARRABAL, José; Estevão, José Carlos. Stalin. São Paulo: Moderna, 1986.

ARRABAL, José; LIMA, Mariangela Alves. Teatro, o seu demônio é beato. Coleção O Nacional e o Popular na cultura brasileira. São Paulo: Brasiliense, 1983.

ASSIS, Machado de. "Teoria do Medalhão". In: Papéis avulsos. Obra completa. Rio de Janeiro: Nova Aguilar, 1994 [1882]. v. II.

ASSOCIAÇÃO DOS DOCENTES DA USP. O controle ideológico na USP: 19641978. São Paulo: Adusp, 2004. Publicado originalmente com o título O livro negro da USP - o controle ideológico na Universidade [1978]. 
ASTRUC, Alexandre. "Nascimento de uma nova vanguarda: a "câmera-stylo". In: OLIVEIRA, Luís Miguel (org.). Nouvelle vague. Lisboa: Cinemateca Portuguesa, 1999. AUGUSTO, Sérgio. As penas do ofício - ensaios de jornalismo cultural. Rio de Janeiro: Agir, 2006.

. Lado B. Rio de Janeiro: Record, 2002.

. "Precisamos democratizar o elitismo". Entrevista concedida a Fabrício Marques. Suplemento Literário de Minas Gerais. Edição especial Reflexões sobre jornalismo cultural. Belo Horizonte, n. 698, 12 fev. 2012. Reproduzido no Observatório da Imprensa, ano 17, n. 785, 14 fev. 2014. Disponível em: <http:// http://www.observatoriodaimprensa.com.br/news/view/_ed698_precisamos_democratiz ar_o_elitismo>. Acesso em 14 fev. 2014.

AUMONT, Jacques; MARIE, Michel. A análise do filme. Lisboa: Edições Texto \& Grafia, 2009 [2004].

AUMONT, Jacques. As teorias dos cineastas. Campinas: Papirus, 2012.

Moderno? Por que o cinema se tornou a mais singular das artes. Campinas: Papirus, 2008.

AUTRAN, Arthur Franco de Sá Neto. O pensamento industrial cinematográfico brasileiro. São Paulo: Hucitec Editora, 2013.

AVELLAR, José Carlos. Imagem e som, imagem e ação, imaginação. São Paulo: Paz e Terra, 1982.

. O cinema dilacerado. Rio de Janeiro: Alhambra, 1986.

AZEREDO, Ely. Olhar crítico - 50 anos de cinema brasileiro. São Paulo: Instituto Moreira Salles, 2009.

AZEVEDO, Carlos. Jornal Movimento - uma reportagem. Belo Horizonte: Editora Manifesto, 2011.

BAECQUE, Antoine de. Cinefilia - invenção de um olhar, história de uma cultura 1944-1968. São Paulo: Cosac Naify, 2010 [2003]. 
BARBOSA, Mariava. História cultural da imprensa. Brasil - 1900-2000. Rio de Janeiro: Mauad X, 2007.

BARROS FILHO, Clóvis de. Ética na comunicação - da informação ao receptor. São Paulo: Moderna, 1995.

BARTHES, Roland. Crítica e verdade. São Paulo: Perspectiva, 2003 a. Mitologias. Rio de Janeiro: Difel, 2003 [1957].

BAZIN, André. O cinema: ensaios. São Paulo: Brasiliense, 1991. . Orson Welles. Rio de Janeiro: Jorge Zahar, 2005.

BERABA, Marcelo (org.). Manifesto por um cinema popular. Cineclube Macunaíma, Cineclube Glauber Rocha, Federação de Cineclubes do Rio de Janeiro, 1975.

BEREID, José Luís Bendicho. "A função social dos intelectuais". In: AGGIO, Alberto (org.). Gramsci, a vitalidade de um pensamento. São Paulo: Fundação Editora da Unesp, 1998.

BERNARDET, Jean Claude (org.) Anos setenta: cinema. Rio de Janeiro: Ed. Europa, 1979-1980.

. A questão do público. Revista Civilização Brasileira. n. 2, maio 1965.

BERNARDET, Jean-Claude. Brasil em tempo de cinema. São Paulo: Cia das Letras, 2007 [1967].

. Cineastas e imagens do povo. São Paulo: Editora Brasiliense, 1985.

Cinema Brasileiro: propostas para uma história. Rio de Janeiro: Paz e Terra, 1979.

. "Cinema Novo: anos 60-70: a questão religiosa". In SCHWARTZ, Jorge; SOSNOWSKI, Saúl (org.). Brasil: o trânsito da memória. São Paulo: Edusp, 1994. . "Entrevista”. Margem Esquerda: Ensaios Marxistas. São Paulo. n. 3, p. 931, abr. 2004. Entrevista concedida a Ricardo Musse, Marcelo Ridenti, Alfredo Catani. São Paulo: Boitempo Editorial, 2004. 
. Historiografia clássica do cinema brasileiro. São Paulo: Annablume, 2004 [1995].

. O autor no cinema: a política dos autores; França, Brasil anos 50 e 60 .

São Paulo: Brasiliense/Edusp, 1994.

. Piranha no Mar de Rosas. São Paulo: Nobel, 1982.

. "Resistência e Rebeldia". In: MELO, J. M. de. Pensamento comunicacional uspiano - impasses mundializadores na Escola de Comunicações e Artes (1973-2011). São Paulo: Escola de Comunicações e Artes da Universidade de São Paulo, 2011. v. 2.

. Trajetória Crítica. São Paulo: Polis, 1978.

BERNARDET, Jean-Claude; GALVÃO, Maria Rita. Cinema: repercussões em caixa de eco ideológica - as ideias de "nacional" e "popular" no pensamento cinematográfico brasileiro. São Paulo: Brasiliense, 1983.

BIÁFORA, Rubem; MOTTA, Carlos M. (org.). Rubem Biáfora: críticas. São Paulo: Imprensa Oficial do Estado de São Paulo/ Cultura: Fundação Padre Anchieta, 2006.

BOBBIO, Norberto (org.). Dicionário de política. Brasília: Editora Universidade de Brasília, 1998 [1983].

Os intelectuais e o poder: dúvidas e opções dos homens de cultura na sociedade contemporânea. São Paulo: Unesp, 1997.

BONITZER, Pascal. Film/Politique (Cinema/Ideologie/Critique). Cahiers du Cinéma. n. 222, jul. 1970 .

BORDWELL, David. La narración en el cine de ficción. Barcelona: Paidós, 1996. . Sobre a história do estilo cinematográfico. Campinas: Unicamp, 2013.

BOSI, Alfredo. A dialética da colonização. São Paulo: Cia das Letras, 1992.

BOSI, Alfredo (org). Cultura brasileira - temas e situações. São Paulo: Editora Ática, 2003. 
BOSI, Alfredo et alli (orgs.). "Cultura como tradição". In: Cultura Brasileira: tradição/contradição. Rio de Janeiro: Jorge Zahar/Funarte, 1987.

BOSI, Ecléa. Cultura de massa e cultura popular: leituras de operárias. Rio de Janeiro: Vozes, 2007 [1972].

- Memória e sociedade. Lembranças dos velhos. São Paulo: T.A. Queiroz/Editora da Universidade de São Paulo, 1987.

- "Problemas ligados à cultura das classes pobres". In: QUEIRÓS, José, VALLE, Edênio. A cultura do povo. São Paulo: Educ, 1982.

BOURDIEU, Pierre. A distinção - crítica social do julgamento. São Paulo: Edusp/ Porto Alegre: Zouk, 2007.

A produção da crença: contribuição para uma economia dos bens simbólicos. São Paulo: Zouk, 2001. . As regras da arte. São Paulo: Cia das Letras, 1996. . O poder simbólico. Rio de Janeiro: Bertrand Brasil, 2011 [1989].

BRECHT, Bertold. "Pequeno organon para o teatro". Estudos sobre teatro. Rio de Janeiro: Nova Fronteira, 2005.

BROWNE, Nick. Cahiers du Cinéma: 1969-1972: The politics of Representation. London: Routledge, 1996. v. 3.

BURCH, Noël. Práxis do cinema. São Paulo: Perspectiva, 1992 [1969].

BYWATER, Tim; SOBCHCK, Thomas. Introduction to film criticism. New York: Longman, 1989.

CALIL, Carlos Augusto; MACHADO, Maria Teresa (org.). Paulo Emilio, um intelectual na linha de frente. São Paulo: Brasiliense; Rio de Janeiro, Embrafilme, 1986.

CAMARGO, Maria Fernanda Ferrez de. A crítica de e a crítica sobre o cinema em Opinião. Trabalho de Conclusão de Curso - Escola de Comunicações e Artes, Universidade de São Paulo, São Paulo, 2009. 
CANDIDO, Antonio. A educação pela noite. Rio de Janeiro: Ouro sob Azul, 2011 [1986].

. Literatura e sociedade: estudos de teoria e história literária. Rio de Janeiro: Ouro sobre Azul, 2011 a. [1985].

. O estudo analítico do poema. São Paulo: Humanitas, 2004 [1963].

CAPARELLI, Sérgio. Comunicação de massa sem massa. São Paulo: Cortez, 1982.

CARDOSO, Célia Costa. Movimento: um jornal alternativo - 1975-1981. Mestrado. Pontifícia Universidade Católica, São Paulo, 1995.

CARNEIRO, Maria Luíza Tucci (org.). Minorias silenciadas. São Paulo: Edusp, 2002.

CASTRO, Rui; VIANNA, Antonio Moniz. Um filme por dia: crítica de choque (19461973). São Paulo: Companhia das Letras, 2004.

CESAR, Ana Cristina; FREITAS Filho, Armando; HOLLANDA, Heloisa Buarque de (orgs). Correspondência incompleta. Rio de Janeiro: Aeroplano, 1999.

CINÉMA/idéologie/critique. Cahiers du Cinéma. n. 216, p. 11-15, out. 1969.

CHAPARRO, Manuel Carlos da Conceição. Jornalismo, discurso em dois gêneros. Tese (Livre Docência em Ciência da Comunicação), Escola de Comunicações e Artes, Universidade de São Paulo, São Paulo, 1997.

. Linguagem de conflitos. Coimbra: Minerva Coimbra, 2001.

Pragmática do Jornalismo: buscas práticas para uma teoria da ação jornalística. São Paulo: Summus Editorial, 1994.

CHAUÍ, Marilena. Conformismo e resistência: aspectos da cultura popular no Brasil. São Paulo: Brasiliense, 1986.

. "Cultura do povo e autoritarismo das elites". In: Queiroz, José; VALLE, Edenio (orgs). A cultura do povo. São Paulo: Cortez e Moraes, 1979.

. Cultura e democracia: o discurso competente e outras falas. São Paulo:

Editora Moderna, 1981.

. O que é ideologia. São Paulo: Brasiliense, 1980. 
. Seminários. Coleção "O nacional e o popular na cultura brasileira”. São

Paulo: Brasiliense, 1983.

CHINEM, Rivaldo. Imprensa alternativa - jornalismo de oposição e inovação. São Paulo: Ática, 1995.

COSTA, Flávio Moreira da (org.). Cinema moderno, Cinema Novo. Rio de Janeiro: José Álvaro, 1966.

COSTELLA, Antonio F. O controle da informação no Brasil. Petrópolis: Vozes, 1970.

COUTINHO, Afrânio. Crítica e poética. Rio de Janeiro: Livraria Acadêmica, 1968. . Da crítica e da nova crítica. Rio de Janeiro: Civilização Brasileira, 1975.

CZAJKA, Rodrigo. Páginas de resistência: intelectuais e cultura na Revista Civilização Brasileira. Dissertação (Departamento de Sociologia do Instituto de Filosofia e Ciências Humanas), Universidade Estadual de Campinas, Campinas, 2005.

DAHL, Gustavo. Censura e Cultura. In: Mostra Internazionale del Nuovo Cinema, 11. Il Cinema Novo Brasiliani. $1^{\text {o }}$ Testi e documenti. Quaderno Informativo 64, Pesaro, 1975.

. Cinema novo e estruturas econômicas Tradicionais. Revista Civilização Brasileira. n.5/6, mar. 1966. . Cinema novo e seu público. Revista Civilização Brasileira. n. 11/12, dez. 1966. . Mercado é cultura. Cultura, Brasília, v. VI, n. 24, jan./mar. 1977.

DAHL, Gustavo. Premissas a um projeto de cinema brasileiro. Filme Cultura. n. 20, p. 50-2, mai./jun. 1972.

DIÁRIO DO CONGRESSO NACIONAL. Atas da comissão DCN 154. Comissão de Comunicação Simpósio Censura, histórico, situação e solução. Seção 1 da Câmara dos Deputados. Brasília. Ano XXXV Suplemento, n. 154.

DIEGUES, Carlos. Cinema brasileiro: ideias e imagens. Seleção de textos de Sérgio Roberto Silva. Porto Alegre: Editora da Universidade Federal do Rio Grande do Sul, 1988. 
- Vida de cinema - antes, durante e depois do Cinema Novo. Rio de Janeiro: Objetiva, 2014.

DOSSE, François. História do estruturalismo - campo do signo - 1945/1966. São Paulo: Ensaio; Campinas: Editora da Universidade Estadual de Campinas, 1993 [1991]. V. 1 .

História do estruturalismo - o canto do cisne, de 1967 a nossos dias.

São Paulo: Ensaio; Campinas: Editora da Universidade Estadual de Campinas, 1994 [1991]. v. 2.

DOUCHET, Jean. Nouvelle vague. Paris: Cinémathèque Française/Hazan, 1998.

DUCROT, Oswald. "Implícito e Pressuposto". In: Dizer e não dizer. Princípios de semântica linguística. São Paulo: Editora Cultrix, s.d. [1977].

EAGLETON, Terry. The function of criticism: from the Spectator to post-structuralism. London: Verso, 1984. Marxismo e crítica literária. São Paulo: Unesp, 2011 [1976].

ESCOREL, Eduardo. Jean-Claude Bernardet. Piauí. n. 61, out. 2011. Disponível em:< htp://revistapiaui.estadao.com.br/edição-61/questões-cinematograficas/jean-claudeBernardet>. Acesso em 13 nov. 2013.

ESPECIAL Gustavo Dahl. Filme Cultura. n. 55, dez. 2011.

FAGUNDES, Coriolano de Loiola. Censura e liberdade de expressão. São Paulo: Ditau, 1975.

FARO, José Salvador. Revista Realidade, 1966-1968: tempo de reportagem na imprensa brasileira. Porto Alegre: Editora da ULBRA, 1999.

FAUSTO, Boris. História concisa do Brasil. São Paulo: Edusp, 2010 [2001].

FÁVERO, Osmar et alli. Cultura popular e educação popular: memória dos anos 60. Rio de Janeiro: Graal, 1983.

FERNANDES, Florestan. A contestação necessária: retratos intelectuais de inconformistas e revolucionários. São Paulo: Editora Ática, 1995.

A sociologia numa era de revolução social. Rio de Janeiro: Zahar, 1976. 
FERREIRA, Jairo; GAMO, Alessandro (org.). Críticas de Jairo Ferreira: críticas de invenção: os anos do São Paulo Shimbun. São Paulo: Imprensa Oficial, 2006.

FERRO, Marc. Cinema e história. São Paulo: Paz e Terra, 2010 [1977].

FESTA, Regina; LINS DA SILVA, Carlos Eduardo. Comunicação popular $e$ alternativa no Brasil. São Paulo: Ed. Paulinas, 1986.

FIGUEIRÔA, Alexandre. Cinema Novo - a onda do jovem cinema e sua recepção na França. Campinas: Papirus, 2004.

FOUCAULT, Michel. A ordem do discurso. São Paulo: Martins Fontes, 1986. . Microfísica do poder. Rio de Janeiro: Graal, 1984.

FREDERICO, Celso. "A sociologia da literatura de Lucien Goldman." Estudos avançados. São Paulo. v. 19, n. 54, mai./ago. 2005. . "Presença de Lukács na política cultural do PCB e na universidade". In: MORAES, João Quartim de (org.). História do marxismo no Brasil - Os influxos teóricos. Campinas: Editora Unicamp, 2007. v. 2.

FREIRE, Paulo. "Conscientização e alfabetização: uma nova visão do processo”. In: FÁVERO, Osmar et alli. Cultura popular e educação popular: memória dos anos 60. Rio de Janeiro: Graal, 1983.

FREUD, Sigmund. "Psicologia de grupo e a análise do ego". [Além do princípio do prazer, psicologia de grupo e outros trabalhos]. In: Obras psicológicas completas de Sigmund Freud. Rio de Janeiro: Imago, 1974. v. XVIII.

FURHAMMAR, Leif; FOLKE, Isaksson. Cinema e política. Rio de Janeiro: Paz e Terra, 1976.

GALVÃO, Maria Rita. Uirá, em busca do cinema brasileiro. Debate e Crítica. Revista Quadrimestral de Ciências Sociais. n. 5, p. 105-117, mar. 1975.

GAMO, Alessandro. Vozes da Boca. Tese (doutorado em Multimeios). Universidade Estadual de Campinas, Campinas, 2006.

GARCIA, Miliandre. Do teatro militante à música engajada. A experiência do CPC da UNE (1958-1964). São Paulo: Perceu Abramo, 2007. 
GATTI, André Piero (org.). Embrafilme e o cinema brasileiro. Coleção Cadernos de Pesquisa. São Paulo: Centro Cultural São Paulo, 2008.

GERBER, Raquel. Cinema brasileiro e o processo político e cultural: de 1950-1978. Rio de Janeiro: Embrafilme, 1982.

O mito da civilização Atlântica: Glauber Rocha. Cinema, política e a estética do inconsciente. Petrópolis: Vozes, 1982.

GINZBURG, Jaime. Crítica em tempo de violência. São Paulo: Edusp/Fapesp, 2012.

GOFFMAN, Erving. "Estigma e identidade social". In: Estigma. Rio de Janeiro: Jorge Zahár, 1978.

GOLDMAN, Lucien. "La sociologie de la littérature: situation actuelle et problèmes de méthode. Revue Internationale des Sciences Sociales. v. XIX, n. 4, 1967.

GOMES, Paulo Emilio Salles. Crítica de cinema no suplemento literário. Rio de Janeiro: Paz e Terra, 1981. v. 2.

Cinema: trajetória no subdesenvolvimento. Rio de Janeiro: Paz e Terra, 1980. Publicado originalmente na revista Argumento. São Paulo, n. 1, out. 1973.

GRAMSCI, Antonio. Cadernos do Cárcere. Rio de Janeiro: Civilização Brasileira, 2010. v. 2

Os intelectuais e a organização da cultura. Rio de Janeiro: Civilização Brasileira, 1968.

GRUPPI, Luciano. Conceito de hegemonia em Gramsci. Rio de Janeiro: Edições Graal, 1978.

HADDAD, Vera; PUPPO, Eugênio. Cinema Marginal e suas fronteiras: filmes produzidos nas décadas de 60 e 70. Brasília: Centro Cultural Banco do Brasil, 2004.

HERMETO, Miriam de Sá Motta. 'Olha a gota que falta', Gota d'água: um evento no campo artístico intelectual brasileiro (1975-1980). Tese (doutorado em História), Universidade Federal de Minas Gerais, 2010. 
HERZOG, Clarice; HERZOG, Ivo (org.). "Resistir é preciso...” - Os protagonistas desta história - a imprensa alternativa, clandestina e no exílio, no período 1964-1979 (do golpe à Anistia). São Paulo: Imprensa Oficial, 2011. (DVD’S)

HILLIERS, Jim; BROWNE, Nick. Cahiers du Cinéma: The 1950s: neo realism, Hollywood, New Wave. London: Routledge, 1996 a. v. 1.

HILLIERS, Jim; BROWNE, Nick. Cahiers du Cinéma: 1960-1968: New Wave, New Cinema, Re-evaluating Hollywood. London: Routledge, 1996. v. 2.

HOLLANDA, Heloisa Buarque de. Impressões de viagem: CPC, vanguarda e desbunde - 1960-70. São Paulo: Brasiliense, 1981. São Paulo: Aeroplano, 2004 [1980].

HOLANDA, Heloisa B; MESSEDER, Carlos (orgs.). Patrulhas ideológicas. São Paulo: Brasiliense, 1980.

HUISMAN, Denis. A estética. Lisboa: Edições 70, 2013 [1994].

HUNT, Lynn. “Apresentação: história, cultura e texto". In: A nova história cultural. São Paulo: Martins Fontes, 1992.

IMPRENSA Alternativa \& Literatura - os anos de resistência. Rio de Janeiro: Centro de Imprensa Alternativa e Cultura Popular/RIOARTE, 1987.

JOHNSON, Randal; STAM, Robert. Brazilian Cinema. East Brunswick, London, Toronto: Associated University Presses, 1982.

Cinema Novo x 5 - Masters os contemporary Brazilian Film. Austin:

University of Texas Press, 1984.

JOHNSON, Randal. "Embrafilme, Concine, and a new direction in state policy, 19691980." In: The film industry in Brazil: culture and the State. Pittsburgh University of Pittsburgh Press, 1987.

JORGE, Fernando. Cale a boca, jornalista! São Paulo: Vozes, 1987.

KAEL, Pauline. Criando Kane e outros ensaios. Rio de Janeiro: Record, 2000. Talking it all in. New York: Holt, Rinehartand Winston, 1980.

KAEL, Pauline; AUGUSTO, Sérgio (org.). 1001 noites no cinema. São Paulo: Companhia das Letras, 1994. 
KENSKI, Vani Moreira. O fascínio de Opinião. Tese - Doutorado em Educação. Campinas, Faculdade de Educação da Universidade Estadual de Unicamp, Campinas, 1990.

KONDER, Leandro. Intelectuais brasileiros \& marxismo. Belo Horizonte: Oficina de Livros, 1991.

KRACAUER, Sigfried. Ornamento das massas. São Paulo: Cosac\&Naif, 2009.

KUCINSKI, Bernardo. Jornalistas e revolucionários - nos tempos da imprensa alternativa. São Paulo: Editora Página Aberta, 1991/São Paulo: Edusp, 2003.

LAHUERTA, Milton. "Gramsci e os intelectuais: entre clérigos, populistas e revolucionários (modernização e anticapitalismo). In: AGGIO, Alberto (org.). Gramsci, a vitalidade de um pensamento. São Paulo: Fundação Editora da Unesp, 1998.

. Intelectuais e transição: entre a política e a profissão. Tese Doutorado em Ciência Política. Faculdade de Filosofia Letras e Ciências Humanas, Universidade de São Paulo, São Paulo, 1999.

LE GOFF, Jacques. História e Memória: Campinas: Editora da Unicamp, 1998.

LEITE, Sebastião Uchôa. "Cultura Popular: Esboço de uma resenha crítica." Revista Civilização Brasileira. n. 4, set. 1965.

LIMA, Hamilton Garcia de. O ocaso do Comunismo Democrático - o PCB na última ilegalidade (1964-84). Dissertação (Mestrado em Ciência Política). Instituto de Filosofia e Ciências Humanas, Universidade Estadual de Campinas, Campinas, 1995. LIMA, Haroldo. História da Ação Popular: da JUC ao PC do B. São Paulo: AlfaÔmega, 1984.

LIPPMANN, Walter. A Opinião pública. Rio de Janeiro: Vozes, 2008 [1922].

LÖWY, Michel; NAÏR, Sami. Lucien Goldmann - ou a dialética da totalidade. São Paulo: Boitempo, 2008.

LÖWY, Michel; Sayre, Robert. Revolta e melancolia - o romantismo na contramão da modernidade. Petrópolis: Vozes, 1995. 
MACHADO, José Antonio Pinheiro. Opinião x Censura: momentos de luta de um jornal pela liberdade. Porto Alegre: L\&PM, 1978.

MALAFAIA, Wolney Vianna. Imagens do Brasil: o Cinema Novo e as metamorfoses da identidade nacional. Tese (Doutorado em História, Política e Bens Culturais). Centro de Pesquisa e Documentação de História Contemporânea do Brasil. Fundação Getúlio Vargas, Rio de Janeiro, 2012.

“MANIFESTO LUZ \& AÇÃO”. In: AUTRAN, Arthur Franco de Sá Neto. Documentos para a história do cinema brasileiro. 2006. Cinemateca Brasileira.

MANNHEIM, Karl. "O problema da 'intelligentsia: um estudo de seu papel no passado e no presente". Sociologia da cultura. São Paulo: Perspectiva/ Editora da Universidade de São Paulo, 1974.

MANTEGA, Guido (org.). Sexo e poder. São Paulo: Brasiliense, 1979.

MARCHI, Edivaldo Batista. Frente Ampla (1966- 1968) - alianças, contradições e limites. Dissertação (Mestrado em Ciências Sociais). Pontifícia Universidade Católica de São Paulo, São Paulo, 2001.

MARCONDES FILHO, Ciro. "Mediacriticism ou o dilema do espetáculo de massas". In: PRADO, José Luis Aidar (org.). Crítica das práticas midiáticas. São Paulo: Hacker, 2002.

. O capital da notícia. São Paulo: Ática. 1986.

MARCONDES FILHO, Ciro; RODRIGUES, Ciro Juvenal. O discurso sufocado. São Paulo: Loyola, 1982.

MARCONI, Paolo. A censura politica na imprensa brasileira: 1968-1978. São Paulo: Global Editora, 1980.

MARIE, Michel. A Nouvelle Vague e Godard. Campinas: Papirus, 2011.

MARQUARDT, Eduard. Cultura em Opinião - as páginas de Tendências Culturais (1972-1977). Dissertação (Mestrado em Literatura). Centro de Comunicação e Expressão, Universidade Federal de Santa Catarina, Florianópolis, 2003. 
MARTINEZ ALBERTOS, José Luis. Curso general de redaccion periodistica. Barcelona: Editorial Mitre, 1983.

MARX, Karl; ENGELS, Friedrich. A ideologia alemã. São Paulo: Centauro, 2002.

MASCARELLO, Fernando (org.). História do cinema mundial. Campinas: Papirus, 2006.

MAZZARA, Bruno. "Prejuicios y estereotipos en acción”. In: Estereotipos y prejuicios. Madri: Acento Editorial, 1999.

MELO, José Marques de. A opinião no Jornalismo brasileiro. Petrópolis: Vozes, 1985.

MELlO, Maria Amélia (org.). Vinte anos de resistência: alternativas da cultura no regime militar. São Paulo: Espaço e Tempo, 1986.

MEMÓRIA do Cinema Brasileiro: w.w.w.memoriacinebr.com.br

MEMÓRIAS Reveladas: www. memoriasreveladas.gov.br

METZ, Christian. A significação no cinema. São Paulo: Perspectiva, 1972.

MEYER, Marlyse. Folhetim, uma história. São Paulo: Companhia das Letras, 1996.

MICCOLIS, Leila (orgs.). Catálogo da imprensa alternativa. Rio de Janeiro: RioArte, 1986.

MICELI, Sérgio (org.). Estado e Cultura no Brasil. São Paulo: Difel, 1984.

MICELI, Sérgio. Intelectuais à brasileira. São Paulo: Companhia das Letras, 2001.

MILLIET, Sérgio. Diário Crítico de Sérgio Milliet. São Paulo: Livraria Martins Editora/Edusp, 1981. v. 2.

MONTENEGRO, Júlio César. A gente vai ficando velho. Fortaleza: Ed. do autor, 1985. . Imprensa: além da censura. Revista de Cultura Vozes. Petrópolis, ano 70, v. LXX, n. 4, mai. 1976.

MONTIEL, Rosane. Movimento: a janela de uma geração. Dissertação (Mestrado em Historia Social). Faculdade de Filosofia, Letras e Ciências Humanas. Universidade de São Paulo, São Paulo, 1996. 
MORAES, João Quartim de. "A influência do leninismo de Stálin no comunismo brasileiro" In: MORAES, João Quartim de (org.). História do marxismo no Brasil - O impacto das revoluções. Campinas: Editora Unicamp, 2007. v. 1.

MORAES, João Quartim de (org.). História do marxismo no Brasil - Teorias. Interpretações. Campinas: Editora Unicamp, 2007. v. 3.

MORETTIN, Eduardo Victorio. Os limites de um projeto de monumentalização cinematográfica. Uma análise do filme "Descobrimento do Brasil (1937)". Tese (Doutorado em Artes), Escola de Comunicações e Artes, Universidade de São Paulo, São Paulo, 2001.

MORETTIN, Eduardo; NAPOLITANO, Marcos (orgs.). História e Cinema. São Paulo: Alameda Editorial, 2007.

MORICONI, Ítalo. “O cenário. Políticas do sujeito”. Ana Cristina César: o sangue de uma poeta. Rio de Janeiro: Relume-Dumará, 1996.

MOTA, Carlos Guilherme. Ideologia da cultura brasileira (1933-1974). São Paulo: Editora Ática, 2008 [1977].

MOTTA, Rodrigo Patto Sá. "O PCB e a moral comunista”. Locus - Revista de História. Juiz de Fora NHR, UFJJ. v. 3, n. 1, 1997.

MOURÃO, Dora; CAETANO, Maria de Rosário; BACQUÉ, Laure. Jean-Claude Bernardet: uma homenagem. São Paulo: Imprensa Oficial do Estado de São Paulo/Cinemateca Brasileira, 2007.

NAPOLITANO, Marcos. "A relação entre arte e política: uma introdução teoriametodológica." Revista Temáticas. n. 37-8. Pós Graduação em Sociologia, IFCH/Unicamp, 2011 a.

Coração civil: arte, resistência e lutas culturais durante o regime militar brasileiro (1964-1980). Tese de Livre-Docência, Faculdade de Filosofia, Letras e Ciências Humanas, Universidade de São Paulo, São Paulo, 2011.

Cultura brasileira: utopia e massificação (1950-1980). São Paulo:

Contexto, 2001. 
. "O caso das patrulhas ideológicas na cena cultural brasileira do final dos anos 70”. In: FILHO, João Roberto Martins (org.). O golpe de 1964 e o regime militar novas perspectivas. São Carlos: Edufscar, 2006.

. Seguindo a canção - engajamento político e indústria cultural na MPB (1959-1969). São Paulo: Annablume/Fapesp, 2001.

NEVES, David. Cinema Novo no Brasil. Petrópolis: Vozes, 1966.

NEVES, David Eulálio, CALIL, Carlos Augusto (org.). Telégrafo visual: crítica amável de cinema. São Paulo: Editoral 34, 2004.

NOVAES, Adauto. Anos 70: ainda sob a tempestade. Rio de Janeiro: Aeroplano/Senac Rio, 2005.

NOVAES, Audálio (org.). Cultura Brasileira? tradição contradição. Rio de Janeiro: Jorge Zahar Editor, 1987.

OLIVEIRA, Luís Miguel (org.). Nouvelle vague. Lisboa: Cinemateca Portuguesa, 1999.

ORLANDI, Eni Puccinelli. As formas do silêncio - no movimento dos sentidos. Campinas: Editora da Unicamp, 2007.

ORTIZ, Renato. Cultura brasileira e identidade nacional. São Paulo: Editora Brasiliense, 2006 [1985].

A moderna tradição brasileira. Cultura brasileira e indústria cultural. São Paulo: Brasiliense, 1995.

PARANAGUÁ, Paulo (org.). Le Cinéma Bresilien. Paris: Editions du Centre Pompidou, 1987.

PASTAS da Cinemateca Brasileira. Recortes de jornais da época sobre filmes, diretores, movimentos cinematográficos, política cinematográfica, releases, etc.

PÉCAUT, Daniel. Os intelectuais e a política no Brasil: entre o povo e a nação. São Paulo: Editora Ática, 1990.

PENDERGAST, Tom; PENDERGAST, Sara. International Dictionary of Films and Filmmakers - Directors. v 2. London/New York: St. James Press, 2000. 
PEREIRA, Miguel Serpa. O Cinema Novo na Revista Civilização Brasileira. Tese (Doutorado em Ciência da Comunicação). São Paulo: Escola de Comunicações e Artes, Universidade de São Paulo, 2001.

PEREIRA, Moacir. A imprensa em debate. Florianópolis: Editora Lunardelli/ Assembléia Legislativa de Santa Catarina, 1981.

PINTO, Anna Maria do Amaral (org.). Catálogo da Imprensa Alternativa e Episódica do Brasil. Rio de Janeiro: Associação Brasileira de Imprensa, 1979.

PINTO, Pedro Plaza. Paulo Emilio e a emergência do Cinema Novo: débito, prudência e desajuste no dialogo com Glauber Rocha e David Neves. Tese (Doutorado em Ciência da Comunicação). Escola de Comunicações e Artes, Universidade de São Paulo, São Paulo, 2008.

POLLAK, Michel. "Memória, esquecimento, silêncio”. Estudos Históricos. Rio de Janeiro: CPDOC /FGV, v. 1, n. 3, 1989.

PONTES, Heloisa. Destinos Mistos- os críticos do grupo Clima em São Paulo (194068). São Paulo: Cia das Letras, 1998.

PRUDENZI, Ângela; RESEGOTTI, Elisa. Cinema político italiano - anos 60 e 70. São Paulo: Cosac Naify, 2006.

RAMOS, Alcides freire. Canibalismo dos fracos. Bauru: Edusc, 2002.

RAMOS, Alcides Freire; PATRIOTA, Rosangela. Fernando Peixoto: um artista engajado na luta contra a ditadura militar (1964-1985). Revista Fênix (Revista de História e Estudos Culturais). Ano III, v. 3, out./nov./dez. 2006.

RAMOS, Fernão. Cinema Marginal (1968-1973) - A representação em seu limite. São Paulo: Braziliense/Embrafilme, 1987 a.

RAMOS, Fernão; MIRANDA, Luis Felipe (Org.). Enciclopédia do cinema brasileiro. São Paulo: Editora do Senac, 2000.

RAMOS, Fernão. História do cinema brasileiro. São Paulo: Art Editores, 1987.

RAMOS, Fernão. Teoria Contemporânea do Cinema. São Paulo: Senac, 2005. v. 2 
RAMOS, José Mario Ortiz. Cinema, estado e lutas culturais (anos 50/60/70). Rio de Janeiro: Paz e Terra, 1983.

REIS, Daniel Aarão, RIDENTI, Marcelo (orgs.). O golpe e a ditadura militar - 40 anos depois (1964-2004). Bauru: Edusc, 2004.

REIS, Daniel Aarão. "O maoísmo e a trajetória dos marxismos brasileiros." In: MORAES, João Quartim de (org.). História do marxismo no Brasil - O impacto das revoluções. Campinas: Editora Unicamp, 2007. v.1.

RIBEIRO, Darcy. Uirá sai a procura de Deus: ensaio de etnologia e indigenismo. Rio de Janeiro: Paz e terra, 1974.

RIDENTI, Marcelo. Em busca do povo brasileiro: artistas da revolução, do CPC à era da TV. Rio de Janeiro: Editora Record, 2000.

ROCHA, Glauber. Revisão crítica do cinema brasileiro. São Paulo: Cosac \& Naify, 2003 [1963].

Revolução do Cinema Novo. São Paulo: Cosac \& Naif, 2004 [1981].

ROSENFELD, Anatol. O teatro épico. São Paulo: Perspectiva, 2008.

. Teatro moderno. São Paulo: Perspectiva, 2008.

RUBIM, Antonio Albino Canelas. Partido comunista, cultura e política cultural. Doutorado em Sociologia. Faculdade de Filosofia, Letras e Ciências Humanas, Universidade de São Paulo, São Paulo, 1987. "Partido Comunista e políticas culturais: uma tentativa de periodização". Ciências Sociais Hoje. São Paulo: Vértice/Editora Revista dos Tribunais, ANPOCS, 1988

. "Os comunistas e a questão da cultura contemporânea". Trabalho apresentado no XII Encontro Anual da Anpocs. Águas de São Pedro, 1988 a.

RÜDIGER, Francisco. "Da cultura popular como estratégia de recuo". Comunicação e Sociedade, ano III, n. 6, set. 1981. 
SALEM, Helena. Nelson Pereira dos Santos. O sonho possível do cinema brasileiro. São Paulo: Nova Fronteira, 1987.

SALLES, Francisco Luiz de Almeida. Cinema e verdade: Marylin, Buñuel, etc. por um escritor de cinema. São Paulo: Companhia das Letras, 1988.

SANDLIER, Darlene. Nelson Pereira dos Santos. Campinas: Papirus, 2012.

SANTOS, Pedro Henrique Simonard. A geração do Cinema Novo. Dissertação. Escola de Comunicações e Artes (ECA). Universidade de São Paulo, São Paulo, 1995.

SARTRE, Jean-Paul. Em defesa dos intelectuais. São Paulo: Ática, 1994.

Presentation. Les Temps Modernes. n. 1, p. 1-21, out. 1945.

SCHATZ, Thomas. O gênio do sistema: a era dos estúdios em Hollywood. São Paulo: Cia das Letras, 1991.

SCHWARZ, Roberto. Cultura e política. São Paulo: Paz e Terra, 2009.

. "Nunca fomos tão engajados" Folha de S. Paulo. (Editoria Mais). 26 jun. 1994, p. 5.

. Que horas são: Ensaios. São Paulo: Companhia das Letras, 1987.

SECCO, Lincoln. Gramsci e o Brasil. São Paulo: Cortez, 2002.

SEGATTO, José Antonio. Breve História do PCB. São Paulo: Livraria Editora Ciências Sociais, 1981.

SICLIER, Jacques. Nouvelle vague. Paris: Cerf, 1961.

SILVA, Carlos Eduardo Lins da. Muito além do jardim botânico. Um Estudo sobre a audiência do Jornal Nacional da Globo entre os trabalhadores. São Paulo: Summus, 1985.

SILVA, Tomaz Tadeu da. "A produção social da identidade e da diferença". In: Identidade de diferença. A perspectiva dos estudos culturais. Petrópolis: Vozes, 2000.

SIMIS, Anita. Estado e cinema no Brasil. São Paulo: Annablume/Fapesp, 1996. 
SIMÕES, Inimá Ferreira. Aspectos do cinema erótico paulista. Dissertação (Mestrado em Artes) - Escola de Comunicações e Artes, Universidade de São Paulo, São Paulo, 1984.

. O imaginário da Boca. São Paulo: Secretaria Municipal de Cultura, 1981.

SIMÕES, Inimá. Roteiro da intolerância: a censura cinematográfica no Brasil. São Paulo: Editora Senac, 1999.

SINGER, Paul; BRANT, Vinicius Caldeira. São Paulo: o povo em movimento. Petrópolis, Editora Vozes, 1982.

SMITH, Anne-Marie. Um acordo forçado: o consentimento da imprensa à censura no Brasil. Rio de Janeiro: Editora FGV, 2000.

SOARES, Rosana de Lima; SERELLE, Marcio. A crítica de TV no Brasil: valores e repertórios. Intexto. Porto Alegre, UFRGS, n. 28, p. 171-189, julho 2013 a.

SOARES, Rosana de Lima; SILVA, Gislene. Para pensar a crítica de mídias. XXII Encontro Anual da Compós, Universidade Federal da Bahia, Salvador, 04 a 07 de junho de 2013.

SODRÉ, Nelson Werneck. "O controle da imprensa". História da imprensa no Brasil. Rio de Janeiro: Mauad, 1998.

SOUZA, José Inácio de Melo. Carga da brigada ligeira: intelectuais e crítica cinematográfica 1941-45. Doutorado. Escola de Comunicações e Artes, Universidade de São Paulo, São Paulo, 1995. . Paulo Emilio no paraíso. São Paulo: Record, 2002.

STAM, Robert. Introdução à teoria do cinema. Campinas: Papirus, 2003 [2000].

TROTSKY, Leon. Literatura e revolução. Rio de Janeiro: Zahar, 1980.

TRUFFAUT, François; SCOTT, Hellen. Hitchcock/Truffaut: entrevistas. São Paulo: Cia das Letras, 2004.

VENTURA, Zuenir. A crise da cultura brasileira. Visão. v. 39, n. 1, p. 52-58, 05 jul. 1971. 
. Minhas histórias dos outros. São Paulo: Editora Planeta do Brasil, 2005.

. Os impasses da cultura. Visão. v. 49, n. 6, p. 101- 130, ago. 1973.

VENTURI, Lionello. História da Crítica de arte. Lisboa: Edições 70, 2013 [1984].

VIANY, Alex. O processo do Cinema Novo. Rio de Janeiro: Aeroplano, 1999.

VIEIRA NETO, Bárbara. Revista Cine-Olho: História e Crítica no Brasil (1976-1979).

Iniciação Científica. Escola de Comunicações e Artes da Universidade de São Paulo, São Paulo, 2012.

VIOTTI, Emilia. “A dialética invertida (1960-1990)”. Revista Brasileira de História. v. 14, n. 27, 1994.

VITÓRIA do Cinema Novo. Debate realizado com Alex Viany, Gustavo Dahl, Carlos Diegues, David Neves, Paulo César Saraceni. Revista Civilização Brasileira. n. 2, p. 227-248, mai. 1965.

WEBER, Max. "Ciência (e política) como vocação". In: Ciência e Política - duas vocações. São Paulo: Cultrix, 2007 [1967].

WILSON, David. Cahiers du Cinema: 1973-1978: History, Ideology, Cultural Struggle. London: Routledge, 2000.

XAVIER, Ismail (org). A experiência do cinema. Rio de Janeiro: Edições Graal/Embrafilmes, 1983.

XAVIER, Ismail. Alegorias de subdesenvolvimento: Cinema Novo, Tropicalismo, Cinema Marginal. São Paulo: Brasiliense, 1993/Cosac Naify, 2012.

Alegoria do desengano: a resposta do Cinema Novo à modernização conservadora. Tese (livre-docência). São Paulo, Escola de Comunicações e Artes, Universidade de São Paulo, São Paulo, 1989.

. Cinema brasileiro moderno. São Paulo: Paz e Terra, 2001.

."Em torno de São Bernardo". Argumento, n. 3, jan. 1974. 
. O discurso cinematográfico - a opacidade e a transparência. São Paulo:

Paz e Terra, 2005.

- O olhar e a cena - melodrama, Hollywood, Cinema Novo, Nelson Rodrigues. São Paulo: Cosac \& Naify, 2003.

. "O olhar e a voz - a narração multifocal do cinema e a cifra da História em São Bernardo". Literatura e Sociedade. Revista de Teoria Literária e Literatura Comparada. n. 2, 1997.

. Sertão Mar - Glauber Rocha e a estética da fome. São Paulo, Cosac \& Naif, 2007 (1983).

. Sétima arte: um culto moderno - o idealismo estético e o cinema. São Paulo: Perspectiva, 1978.

XAVIER, Ismail; BERNARDET, Jean Claude; PEREIRA, Miguel. O desafio do cinema - a Política do Estado e a Política dos Autores. Rio de Janeiro: Jorge Zahar Editor, 1985.

XAVIER, Ismail; MENDES, Adilson (org.). Ismail Xavier/Encontros. Rio de Janeiro: Beco do Azougue, 2009. 


\section{Filmes citados}

A casa assassinada (1971) de Paulo César Saraceni

A classe operária vai ao paraíso (1971) de Elio Petri

A dama de Shangai (1947) de Orson Welles

A doce vida (1960) de Federico Fellini

A estrela sobe (1974) de Bruno Barreto

A falecida (1965) de Leon Hirzsman

A grande cidade (1965) de Carlos Diegues

A história de Adèle H (1975) de François Truffaut

Ainda agarro essa vizinha (1974) de Pedro Rovai

Ali, o medo corrói a alma (1974) de Rainer Werner Herzog

Alô alô carnaval (1936) de Adhemar Gonzaga

Amarcord (1973) de Federico Fellini

Anchieta, José do Brasil (1977) de Paulo César Saraceni

Anjo da noite (1974) de Walter Hugo Khouri

A Opinião Pública (1966) de Arnaldo Jabor

A possuída dos mil demônios (1970) de Carlos Frederico

A queda (1978) de Ruy Guerra

A regra do jogo (1939) de Jean Renoir

Ato de violência (1980) de Eduardo Escorel

A verdadeira natureza de uma mulher chamada Bernardette (1972) de Gilles Carle 
Bahia de todos os santos (1960) de Trigueirinho Neto

Banana da terra (1939) de Ruy Costa

Barravento (1961) de Glauber Rocha

Barra 68 - sem perder a ternura (2000) de Vladimir Carvalho

Bonitinha mas ordinária (1963) de J. P. de Carvalho

Cantando na chuva (1952) de Gene Kelly e Stanley Donen

Cenas de um casamento (1973) de Ingmar Bergman

Chinatown (1974) de Roman Polanski

Chuvas de verão (1977) de Carlos Diegues

Cidadão Kane (1941) de Orson Welles

Como era gostoso o meu francês (1971) de Nelson Pereira dos Santos

Delito Matteoti (1973) de Florestano Vancini

Desejo de Matar (1974) de Michael Winner

Deus e o diabo na terra do sol (1964) de Glauber Rocha

Em busca do ouro (1965) de Gustavo Dahl

Emmanuelle (1974) de Just Jaeckin

Ensina-me a viver (1971) de Hal Ashby

Era uma vez em Hollywood (1974) de Jack Haley Jr.

Faca na água (1962) de Roman Polanski

Fome de Amor (1967) de Nelson Pereira dos Santos

Gamal, delírio do sexo (1969) de João Batista de Andrade

Garota de Ipanema (1967) de Leon Hirzsman

Gilda (1946) de Charles Vidor 
Gritos e Sussurros (1972) de Ingmar Bergman

Guerra Conjugal (1974) de Joaquim Pedro de Andrade

Imagens (1972) de Robert Altman

Joanna Francesa (1973) de Carlos Diegues

Lacombe Lucien (1974) de Louis Malle

Lágrimas amargas (1952) de Stuart Heisler

Lágrimas amargas de Petra Von Kant (1972) de Rainer Werner Fassbinder

L'eau à la bouche/Amor livre (1960) de Jacques Doniol-Vancroze

Lerfa-mu (1979) de Carlos Frederico

Lição de amor (1975) de Eduardo Escorel

Lola Monthès (1955) de Max Ophüs

Love Story (1970) de Arthur Hiller

Macunaíma (1969) de Joaquim Pedro de Andrade

Manhã Cinzenta (1968) de Olney São Paulo

Noite americana (1973) de François Truffaut

Nordeste: cordel, repente, canção (1975) de Tânia Quaresma

O acossado (1960) de Jean-Luc Godard

O Amuleto de Ogum (1974) de Nelson Pereira dos Santos

O Bravo Guerreiro (1968) de Gustavo Dahl

O casal (1975) de Daniel Filho

O casamento (1975) de Arnaldo Jabor

O crime de Monsieur Lange (1936) de Jean Renoir

O Desafio (1965) de Paulo Cesar Saraceni 
O Exorcista (1973) de William Friedkin

O fantasma da liberdade (1974) de Luis Buñuel

O Flagrante (1975) de Reginaldo Farias

O guru e os guris (1972) de Jairo Ferreira

O homem da capa preta (1986) de Sérgio Rezende

O homem que queria ser rei (1975) de John Huston

Oito e meio -8 1/2 (1963) de Federico Fellini

O processo (1962) de Orson Welles

O rei da noite (1975) de Hector Babenco

Orfeu do carnaval (1959) de Marcel Camus

Orgia, o homem que deu cria (1970) de João Silvério Trevisan

Os Boas-Vidas (1953) de Federico Fellini

Os Condenados (1973) de Zelito Vianna

Os fuzis (1963) de Ruy Guerra

Os Implacáveis (1972) de Sam Peckinpah

Os Inconfidentes (1972) de Joaquim Pedro de Andrade

O último tango em Paris (1972) de Bernardo Bertolucci

Ovelha Negra (1974) de Haroldo Marinho Barbosa

Pindorama (1971) de Arnaldo Jabor

Profissão: repórter (1975) de Michelangelo Antonioni

Quando o carnaval chegar (1972) de Carlos Diegues

Quem é Beta (1973) de Nelson Pereira dos Santos

Rio 40 graus (1955) de Nelson Pereira dos Santos 
Rollerball - Os gladiadores do futuro (1975) de Norman Jewison

Sacco e Vanzetti (1971) de Guiliano Montaldo

São Bernardo (1972) de Leon Hirszman

São Paulo S.A. (1965) de Luís Sérgio Person

Scaramouche (1952) de George Sidney

Sindicato de Ladrões (1954) de Elia Kazan

Sob o domínio do medo/ Straw Dog (1971) de Sam Peckinpah

Sol sob a lama (1963) de Alex Viany

Sonhos do Passado (1973) de John G. Avildsen

Sorrisos de uma noite de amor (1955) de Ingmar Bergman

Stavisky (1974) de Alain Resnais

Vai trabalhar vagabundo (1973) de Hugo Carvana

Vidas Secas (1963) de Nelson Pereira dos Santos

Viramundo (1964-65) de Geraldo Sarno

Tempos Modernos (1936) de Charles Chaplin

Tensão no aeroporto (1974) de Caspar Wrede

Terra em transe (1967) de Glauber Rocha

Toda nudez será castigada (1972) de Arnaldo Jabor

Toni (1935) de Jean Renoir

Trama Macabra (1976) de Alfred Hitchcock

Triste Trópico (1974) de Arthur Omar

Uirá (1973) de Gustavo Dahl

Xica da Silva (1976) de Carlos Diegues 
Z (1969) de Costa-Gravas

Periódicos do período consultados

Cahiers du Cinéma

Crítica

Filme Cultura

Folha de S. Paulo

Jornal de Debates

Jornal do Brasil

Movimento

O Estado de S.Paulo

Opinião

Pasquim

Revista Civilização Brasileira

Veja

Visão 